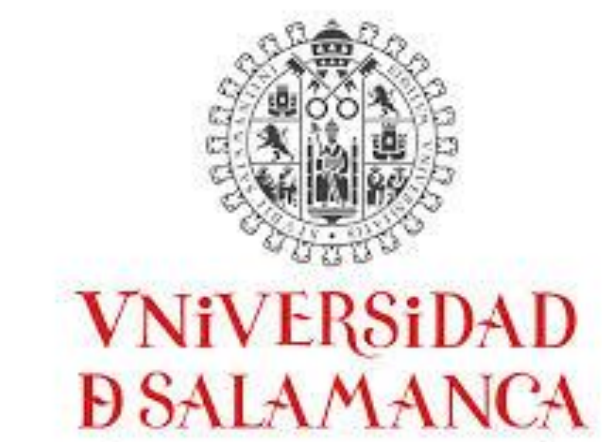

CAMPUS DE EXCELENCIA INTERNACIONAL

DOUTORADO EM ESTUDOS INTERDISCIPLINARES DE GÊNERO E POLÍTICAS DE IGUALDADE

\author{
LARISSA MARIA DE QUEIROZ
}

A PERCEPÇÃO DA IMPRENSA ESCRITA DE FORTALEZA - CE SOBRE O DISCURSO DE GÊNERO DOS POLÍTICOS E IGREJAS CRISTÃS

SALAMANCA - ESPANHA

2019-2020 



\title{
A PERCEPÇÃO DA IMPRENSA ESCRITA DE FORTALEZA- CE SOBRE O DISCURSO DE GÊNERO DOS POLÍTICOS E IGREJAS CRISTÃS
}

\author{
Tese apresentada ao programa de Doutorado em Estudos \\ Interdisciplinares de Gênero e Políticas de Igualdade da \\ Universidade de Salamanca, sob forma de Tese e requisito final \\ para obtenção de título de Doutora.
}

\section{Diretora:}

Profa. Dra. Mª Esther Martínez Quinteiro.

SALAMANCA - ESPANHA

2019-2020 


\section{A PERCEPÇÃO DA IMPRENSA ESCRITA DE FORTALEZA- CE SOBRE O DISCURSO DE GÊNERO DOS POLÍTICOS E IGREJAS CRISTÃS}

Tese apresentada ao programa de Doutorado em Estudos Interdisciplinares de Gênero e Políticas de Igualdade da Universidade de Salamanca, como requisito final para obtenção do título de doutora junto à comissão julgadora composta pelos seguintes membros:

Folha de aprovação 
Dedico este trabalho aos meus mentores espirituais pela missão que me foi confiada; aos meus pais e irmãs pelo amor e incentivo durante toda minha vida acadêmica; e ao meu esposo que sempre torceu por mim, estando ao meu lado como companheiro e amigo. 



\section{AGRADECIMENTOS}

Quero agradecer a todos meus familiares, por tudo, desde sempre.

À minha mãe, por seus princípios religiosos e valores morais tão fundamentais ao meu progresso espiritual e material.

A meu pai, pela honestidade, humildade e simplicidade: com ele aprendi que mesmo sendo grande, podemos ser pequenos (significando que, mesmo que tenhamos tudo ao nosso alcance, não necessitamos nos sentir superiores a ninguém);

À Nila, que além de ser minha irmã de sangue, é a amiga que aconselha, a mãe que orienta e conduz, a colega que comunga o exercício da advocacia. Grata por me presentear com uma afilhada linda e, principalmente, por me dar a certeza de que nunca estarei só.

À Milene, minha irmã mais velha, que desde que eu era criança sempre me orientou ao caminho correto, tanto na seara material quanto espiritual, Obrigada por me presentear com sobrinhos lindos!

Ao meu esposo, Vicente, que além de companheiro, é meu confidente e amigo - com sua simplicidade e humildade me deu forças para escrever esta tese.

À minha sogra, Ana, que sempre me apoiou nos meus projetos materiais, fazendo um papel de segunda mãe, para que assim eu tivesse tempo de concretizar meus objetivos.

À minha orientadora, Dra. Maria Esther, que se dispôs com afinco a me ajudar, motivandome à escolha do tema. E, com ética, responsabilidade e paciência, foi capaz de contribuir bastante para o meu amadurecimento como pesquisadora.

Agradeço à Instituição Centro Universitário Uniateneu por fazer parte deste sonho, pois somente por intermédio do incentivo ao corpo de docentes, pude me sentir apoiada para construir uma carreira acadêmica que, dentre outras realizações, envolve a concretização do Doutorado na Universidade de Salamanca.

Pela solicitude e solidariedade de todos os docentes que compartilharam comigo esta tarefa de renúncia em busca de uma realização profissional. Cibelli, Patrícia, Alexsandra, Luciana e Ismael que foram minha família, quando estive distante do meu país. Pessoas com quem sempre manterei contato, em virtude do grau de importância que alcançaram em minha vida.

A todos os meus amigos e alunos, que de uma forma ou de outra contribuíram para que eu pudesse encontrar este caminho, fazer trilhar este projeto e contribuir para a realização deste sonho. 

“O que não se pode é subordinar o auxílio espiritual a conceitos preestabelecidos da moral ou de como as coisas devem ser".

Tia Neiva. 


\section{Sumário}

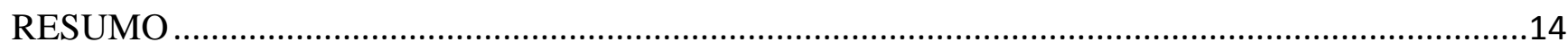

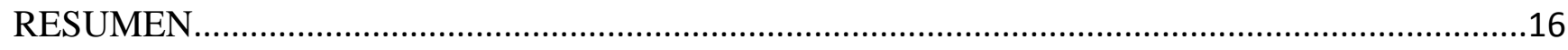

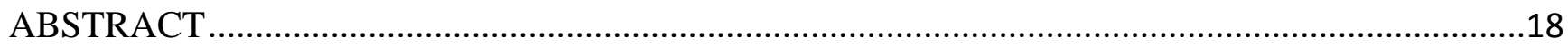

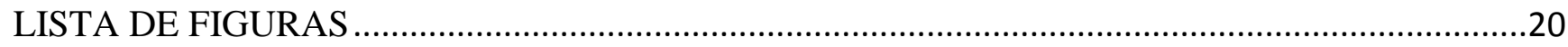

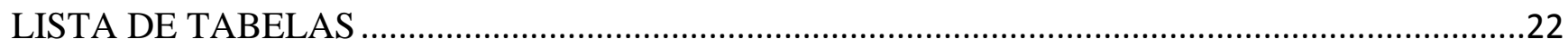

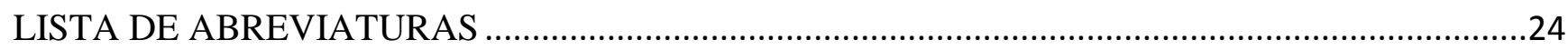

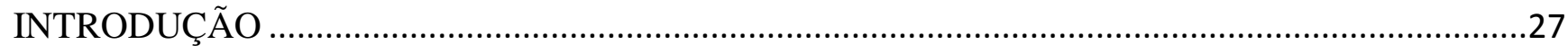

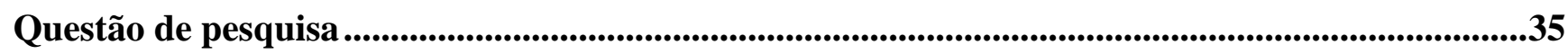

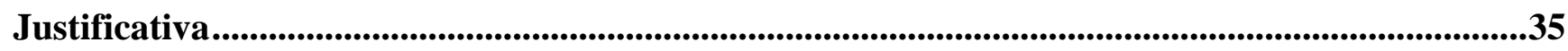

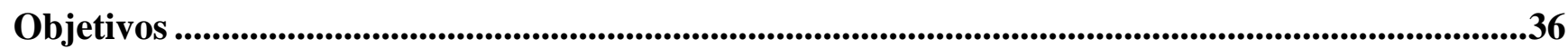

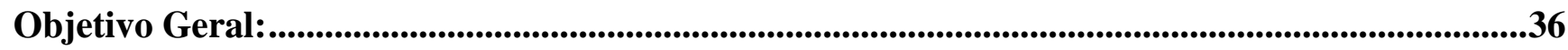

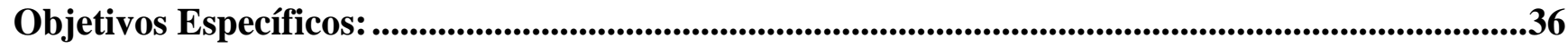

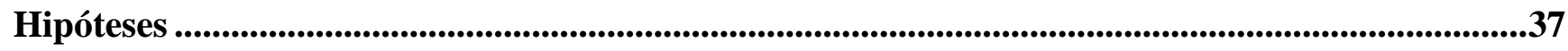

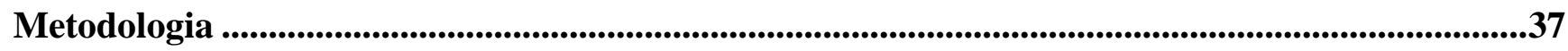

Apresentação da tese....................................................................................................................................41

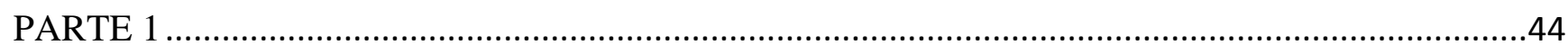

1 CONTEXTO HISTÓRICO DOS DIREITOS HUMANOS ........................................................45

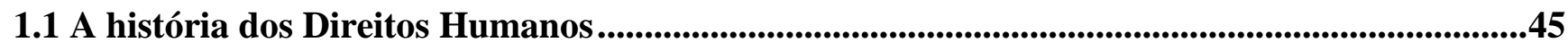

1.2 A contribuição da religião para a história dos direitos humanos.................................................45

$1.4 \mathrm{O}$ surgimento dos primeiros diplomas de direitos humanos .....................................................47

2 MORAL E DIREITO: CONSTRUÇÃO DA MORALIDADE CRISTÃ VERSUS A

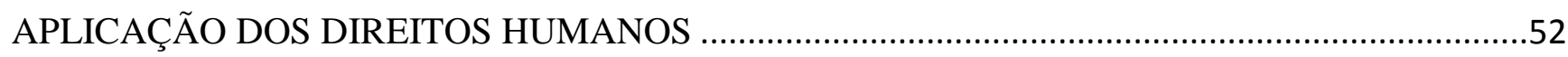

2.1 A história do Direito Constitucional brasileiro sobre as relações entre a Igreja e o

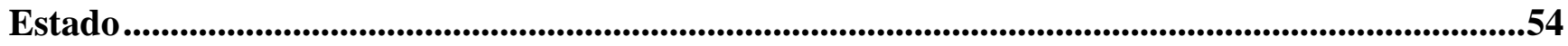

2.2 A igualdade de direitos das mulheres no Brasil, uma história nunca contada............................58 


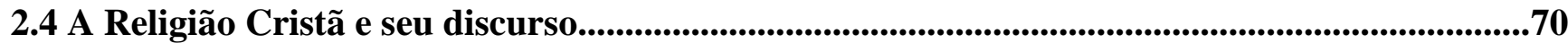

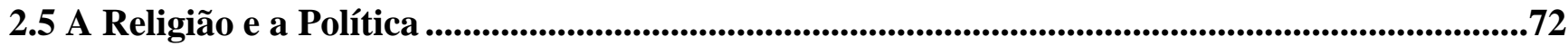

2.6 Uma questão de Gênero...........................................................................................................................79

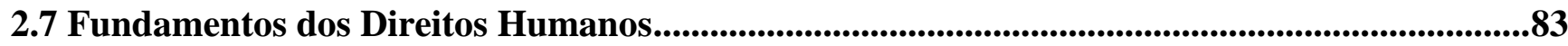

3 A VISÃO DO PARLAMENTO RELIGIOSO BRASILEIRO SOBRE O DISCURSO DA ONU .....85

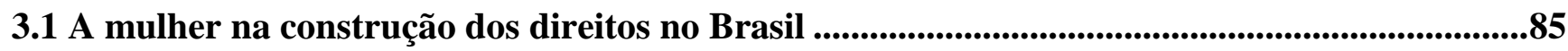

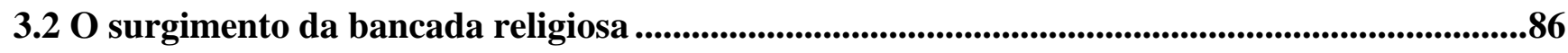

3.2.1 A bancada religiosa: da candidatura à eleição presidencial de 2018 ................... 89

3.3 Laicidade do Estado e Direitos Humanos .......................................................................................................91

4 A CONVENÇÃO SOBRE ELIMINAÇÃO DE TODAS AS FORMAS DE

DISCRIMINAÇÃO CONTRA AS MULHERES (CEDAW) SOB A ÓTICA BRASILEIRA..............94

4.1 A Convenção sobre a Eliminação de todas as formas de Discriminação Contra a Mulher

(CEDAW)

4.2 Violência de gênero e feminicídios............................................................................................................98

4.3 A importância do ensino a respeito da Convenção Sobre Eliminação de Todas as Formas de Discriminação Contra as Mulheres (CEDAW) para diminuir a violência de gênero e feminicídio no Brasil.

5 A EDUCAÇÃO DE GÊNERO E A IGREJA NO PLANO MUNICIPAL DE EDUCAÇÃO NA

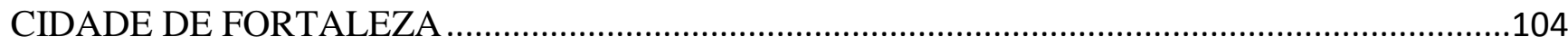

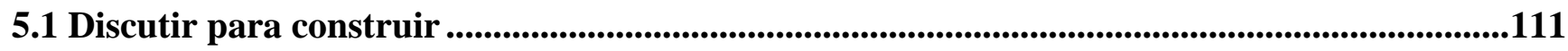

5.2 (DES) construir: um retrocesso considerável ..................................................................................113

6 O ABORTO COMO DIREITO DAS MULHERES EM DEBATE ............................................116

6.1 Dados e discussão do aborto no Brasil ..........................................................................................117

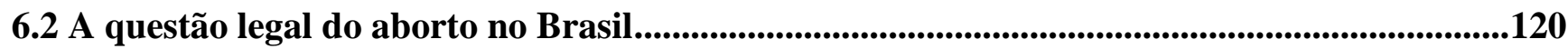

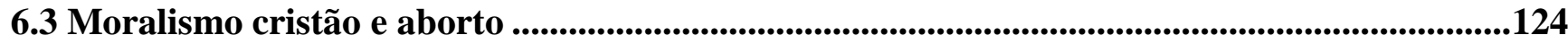

6.4 A posição da ONU .........................................................................................................................131

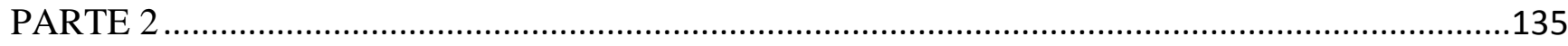

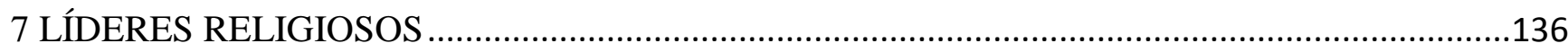


7.1 Líderes Cristãos das Igrejas Católicas e Evangélicas em Fortaleza.

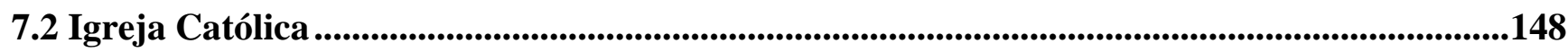

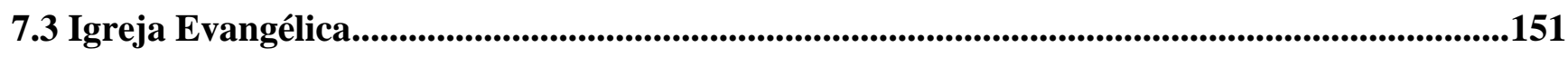

7.4 Igreja Católica e Evangélica.................................................................................................152

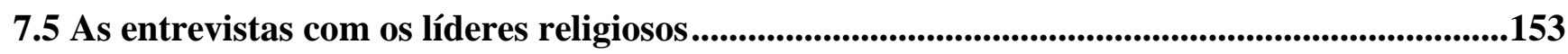

7.6 Líderes cristãos das igrejas católicas e evangélicas em Fortaleza ...........................................154

8 RESISTÊNCIA X CONSERVADORISMO SOBRE EDUCAÇÃO DE GÊNERO NO

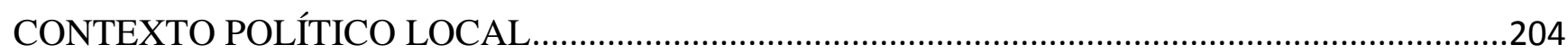

8.1 Veradora Larissa Gaspar, Fortaleza, Ceará ......................................................................204

8.2 Deputada Estadual Dra. Silvana, Ceará ................................................................................213

9 VIOLAÇÃO DOS DIREITOS DA MULHER: CASO MARIELLE NA IMPRENSA....................219

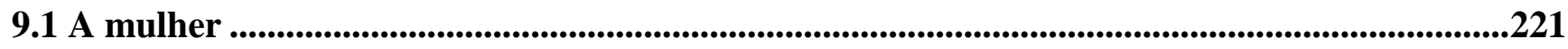

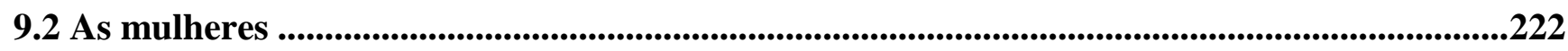

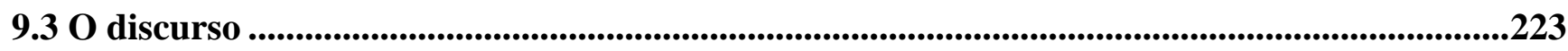

10 MOVIMENTOS PELA EDUCAÇÃO E CONSTRUÇÃO LEGAL DO TEMA NO BRASIL......230

10.1 Perspectivas legais para a educação nacional no Brasil: PNE e BNCC..................................230

10.1.1 O Plano Nacional de Educação ...............................................................231

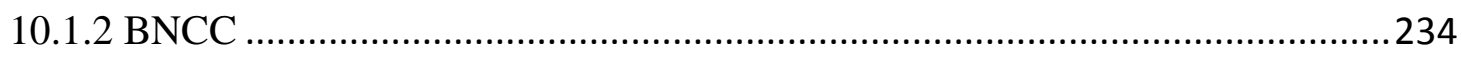

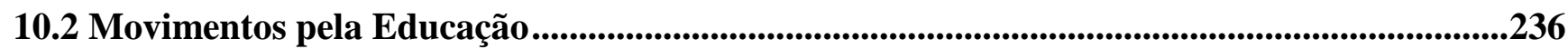

10.2.1 O movimento Escola sem Partido ............................................................238

10.2.2 Escola sem partido e gênero …...................................................................245

11 A “IDEOLOGIA DE GÊNERO” NA MÍDIA: USOS POLÍTICOS E MANIPULAÇÃO DA

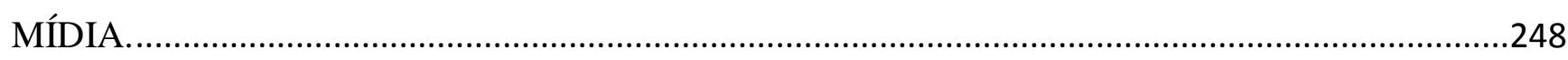

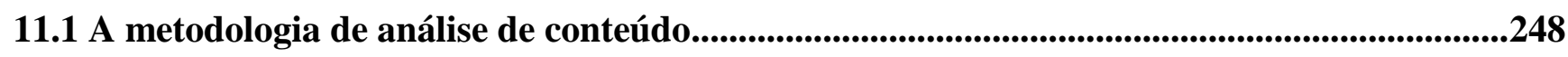

11.1.1 A análise proposta por Laurence Bardin ..................................................249

11.1.2 Método de coleta de dados .....................................................................251

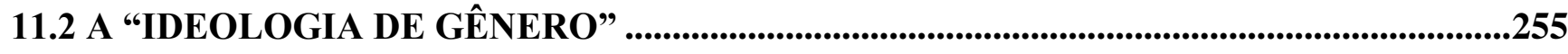

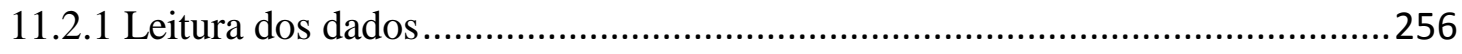

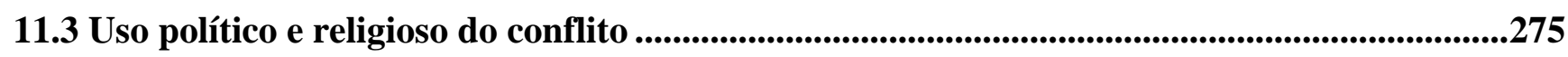


REFERÊNCIAS .299

APÊNDICE 1 - DADOS DIÁRIO DO NORDESTE

APÊNDICE 2 - DADOS DO JORNAL O POVO

APÊNDICE 3 - DADOS DA CARTA CAPITAL .373

APÊNDICE 4 - DADOS DA REVISTA FÓRUM .407

ANEXO 1 - PROJETOS MODELOS PARA A IMPLEMENTAÇÃO DO "ESCOLA SEM

PARTIDO” EM ÂMBITO FEDERAL, ESTADUAL E MUNICIPAL. .421

ANEXO 2 - QUESTIONÁRIO APLICADO AOS LÍDERES RELIGIOSOS .437 ANEXO 3 - PARECER DO COMITÊ DE ÉTICA 


\section{RESUMO}

A Constituição Brasileira de 1988 prevê a igualdade entre os cidadãos, sem discriminação de gênero, raça, etnia ou classe social. Mas, mesmo após 30 anos de sua aprovação, a Carta Magna ainda não alcançou seu objetivo essencial, para a existência de uma sociedade igualitária. Existem enormes dificuldades de diálogo sobre as ações que defendam os Direitos Humanos no Brasil. A agenda política sobre os direitos das mulheres incentivou um debate acirrado sobre leis e ações a serem tomadas no sentido de minimizar ou eliminar as violências chamadas "violências de gênero", cujos crimes são motivados unicamente pelo gênero da vítima. Para explorar a problemática abordada, foram escolhidos os seguintes métodos qualitativos dentro da metodologia de análise de discurso: entrevistas com alguns importantes líderes religiosos cristãos (evangélicos e católicos) da cidade de Fortaleza e análise da produção da mídia impressa do Estado do Ceará sobre o tema. Portanto, o trabalho teve como objeto de investigação a percepção das principais influências para a formação da opinião pública local. Tendo como foco a questão de gênero e a discussão do plano nacional de educação vigente, observou-se o impacto social sobre as várias questões políticas e religiosas em todas as perspectivas relacionadas a gênero, freando o veículo mais importante para a promoção dos direitos humanos que é a educação. Os planos de educação (municipais, estaduais e federal) e a Base Nacional Comum Curricular são um exemplo de política onde o impacto do conflito de forças, entre o pensamento conservador e o pensamento progressista, geram a inoperância do desenvolvimento social. Esse processo foi disseminado pela nada imparcial imprensa escrita que exerceu o papel de apoio, tomando partido para satisfazer a clientela religiosa cristã em Fortaleza, incentivando a perpetuação de uma cultura patriarcal, construída na sociedade fortalezense. Apesar de o Brasil ter ratificado entre outras convenções internacionais, a Convenção sobre a Eliminação de todas as Formas de Discriminação contra as Mulheres (CEDAW), igrejas cristãs através de seus líderes, militantes das grandes famílias cristãs, unem-se com um objetivo de influenciar e disseminar discursos conservadores. E em Fortaleza, através de entrevistas com dezenove líderes de diferentes igrejas, foi possível comparar tais discursos com a importante imprensa escrita atuante na cidade, que se congregam em neutralizar, distorcer, desprezar, e abertamente, o discurso internacional de direitos humanos e de gênero. A ignorância dos religiosos acerca das questões de gênero, alheios a qualquer debate sobre a igualdade entre homens e mulheres, aliada às mídias mais populares repletas de juízos de valor conservadores cristãos (visivelmente machista por se ausentarem do debate), criam uma sociedade distante das 
ideias de igualdade de gênero, nutrindo o conformismo pelo status quo e se esquivando do combate à violência contra a mulher.

PALAVRAS-CHAVE: VIOLÊNCIA DE GÊNERO, PLANO NACIONAL DE EDUCAÇÃO, DIREITOS HUMANOS, ANÁLISE DE DISCURSO. 


\section{RESUMEN}

La Constitución brasileña de 1988 establece la igualdad entre los ciudadanos, sin discriminación de género, raza, etnia o clase social, pero, incluso después de 30 años de su aprobación, la Carta Magna aún no ha alcanzado su objetivo esencial en lo que concierne a la existencia de una sociedad igualitaria. Hay enormes dificultades de entendimiento cuando se habla acerca de la implementación de los derechos humanos en Brasil. La agenda política sobre los derechos de las mujeres ha alentado un acalorado debate sobre las leyes y las acciones que deben tomarse para minimizar o eliminar la "violencia de género", esto es, aquella ejercida sobre las mujeres por el hecho de serlo.

Para explorar el tema abordado, se eligieron los siguientes métodos cualitativos: entrevistas, semi-estructuradas y abiertas, con diversos líderes religiosos cristianos (evangélicos y católicos), seleccionados por la importancia de su influencia en la población de la ciudad de Fortaleza; análisis cualitativo de lo publicado sobre la cuestión que nos ocupa en los medios impresos del Estado de Ceará y de lo recogido en otros documentos, analizados con las técnicas del análisis del discurso (AD), todo ello con "perspectiva de género" y enfoque de derechos humanos. Apelando a tales recursos analíticos tratamos de establecer la percepción de los más conspicuos portavoces y modeladores de la opinión pública local con amplia capacidad de impacto en el colectivo social.

Hemos podido establecer que una percepción mediatizada de la etiología de la violencia contra la mujer, orienta y lastra el Plan Nacional de Educación actual, dificultando la difusión y asunción por medio de la educación, tan importante, del paradigma internacional de los derechos humanos y la perspectiva de género en los diversos temas políticos y religiosos. Los Planes de Educación (municipal, estatal y federal) y la Base Curricular Común Nacional son un ejemplo de una política educativa que refleja el impacto del conflicto de fuerzas, entre el pensamiento conservador y el pensamiento progresista y que, a la postre, genera la inoperancia del desarrollo social de los derechos de la mujer. Son grandes las responsabilidades de la prensa escrita, no imparcial, que tomó partido para satisfacer a la clientela religiosa cristiana en Fortaleza, alentando la perpetuación de una cultura patriarcal de fuerte arraigo local.

Aunque Brasil ha ratificado, entre otras convenciones internacionales, la Convención sobre la Eliminación de todas las Formas de Discriminación Contra la Mujer (CEDAW), las 
iglesias cristianas a través de sus líderes, miembros de las grandes "familias" cristianas, se unen, olvidando en materia de las relaciones de género su competencia religiosa, con el objetivo de influir y diseminar valores conservadores al respecto.

Hemos comparado los discursos obtenidos de las entrevistas con diecinueve líderes de diferentes iglesias, con los de la influyente prensa escrita activa en la ciudad, comprobando así su acuerdo para neutralizar, distorsionar y despreciar abiertamente el discurso internacional sobre los derechos humanos y, por ende, los de las mujeres.

En suma: La ignorancia, hostilidad o desprecio de los líderes religiosos cristianos acerca de la perspectiva de género, su voluntad de mantenerse alejados de cualquier debate sobre la igualdad entre hombres y mujeres, recogida en el discurso los medios más populares repletos de juicios de valor conservadores (visiblemente machistas por ausentarse del debate), conforman una sociedad distante de las ideas de igualdad de género, alimentando el conformismo con el status quo y debilitando o simplemente orillando la lucha para erradicar la violencia contra la mujer.

PALABRAS CLAVE: VIOLENCIA DE GÉNERO, PLAN NACIONAL DE EDUCACIÓN, DERECHOS HUMANOS, ANÁLISIS DEL DISCURSO. 


\section{ABSTRACT}

The 1988 Brazilian Constitution provides for equality between citizens, without discrimination of gender, race, ethnicity or social class. But, even after 30 years of its approval, the Magna Carta has not yet reached its essential objective, for the existence of a society egalitarian. There are enormous difficulties in dialogue about actions that defend human rights in Brazil. The political agenda on women's rights has encouraged a heated debate about laws and actions to be taken in order to minimize or eliminate violence called "gender violence", whose crimes are motivated solely by the victim's gender. To explore the issue addressed, the following qualitative methods were chosen within the discourse analysis methodology: interviews with some important Christian religious leaders (evangelicals and Catholics) from the city of Fortaleza and analysis of the print media production of the State of Ceará on the subject. Therefore, the work had as object of investigation the perception of the main influences for the formation of the local public opinion. Focusing on the gender issue and the discussion of the current national education plan, the social impact on the various political and religious issues was observed in all perspectives related to gender, braking the most important vehicle for the promotion of human rights that is education. The education plans (municipal, state and federal) and the National Common Curricular Base are an example of a policy where the impact of the conflict of forces, between conservative thinking and progressive thinking, generates the inoperability of social development. This process was disseminated by the non-impartial written press that played the role of support, taking sides to satisfy the Christian religious clientele in Fortaleza, encouraging the perpetuation of a patriarchal culture, built in the 
fortress society. Although Brazil has ratified, among other international conventions, the Convention on the Elimination of All Forms of Discrimination against Women (CEDAW), Christian churches through their leaders, members of large Christian families, unite with the objective of influencing and disseminating conservative speeches. And in Fortaleza, through interviews with nineteen leaders from different churches, it was possible to compare such speeches with the important written press active in the city, which come together to neutralize, distort, and openly disregard the international human rights and gender discourse .The ignorance of religious about gender issues, unaware of any debate on equality between men and women, coupled with the most popular media full of conservative Christian value judgments (visibly chauvinistic as they are absent from the debate), create a society that is far from the ideas of gender equality, nourishing conformism for the status quo and shirking combat the violence against women.

KEY WORDS: GENDER VIOLENCE, NATIONAL EDUCATION PLAN, HUMAN RIGHTS, DISCOURSE ANALYSIS 


\section{LISTA DE FIGURAS}

Figura 1 - Sociedade Estamental na Idade Média

Figura 2 - Informativo do Mandato da Vereadora Larissa Gaspar,

Figura 3 - Ilustração da página da internet da Deputada Dra. Silvana.

Figura 4 - Capa da Revista Veja sobre o assassinato de Marielle Franco.

Figura 5 - Deveres do professor segundo o movimento Escola sem Partido.

Figura 6 - Debate perdido no tempo, Diário do Nordeste.

Figura 7 - Ilustração do livro didático que gerou conflito na Assembleia Legislativa.

Figura 8 - A sociedade perde ao não discutir gênero na escola. 


\section{LISTA DE TABELAS}

Tabela 1 - Projetos propostos pela vereadora Larissa Gaspar

Tabela 2 - Projetos propostos pela deputada Dra. Silvana

Tabela 3 - Metas do Plano Nacional de Educação

Tabela 4 - Competências da BNCC. 


\section{LISTA DE ABREVIATURAS}

ABA - Associação Brasileira de Antropologia

$\mathrm{AD}$ - Assembleia de Deus (igreja)

ADI - Ação Direta de Inconstitucionalidade

ALERJ - Assembleia Legislativa do Estado do Rio de Janeiro

Art - Artigo (Direito)

ADPF - Arguição de Descumprimento de Preceito Fundamental

AMIU - Aspiração Manual Intra-Uterina

BGC - Associação das Igrejas Batistas da Grande Curitiba

BNCC - Base Nacional Comum Curricular

CBB - Convenção Batista Brasileira

CCJ - Comissão de Constituição e Justiça (parlamentar)

CE - Ceará (estado brasileiro)

CEDAW - Convenção sobre Eliminação de Todas as Formas de Discriminação Contra as Mulheres (ONU)

CF - Constituição Federal

CGADB - Convenção Geral das Assembleias de Deus no Brasil

CNBB - Conferência Nacional dos Bispos do Brasil

CNE - Conselho Nacional de Educação

CNJ - Conselho Nacional de Justiça

CONAE - Confederação Nacional de Educação

CONFRADECE - Convenção Fraternal de Ministros das Assembleias de Deus do Estado do Ceará

CONFRADEME - Convenção Fraternal de Ministros das Assembleias de Deus de Montese

CONIC - Conselho Nacional das Igrejas Cristãs do Brasil

CONTEE - Confederação Nacional dos Trabalhadores em Estabelecimentos de Ensino

CREA-PB - Conselho Regional de Engenharia da Paraíba

DATASUS - Departamento de Informática do Sistema Único de Saúde

DF - Distrito Federal

E - Entrevistadora

ENEM - Exame Nacional do Ensino Médio

ES - Espírito Santo (estado brasileiro)

EUA - Estados Unidos da América 
FMI - Fundo Monetário Internacional

FPE - Frente Parlamentar Evangélica

GO - Goiás (estado brasieiro)

HPV - Papiloma vírus humano

HRW - Human Rights Watch

IBGE - Instituto Brasileiro de Geografia e Estatística

IBOPE - Instituto Brasileiro de Opinião Pública e Estatística

IBPT - Instituto Brasileiro de Planejamento Tributário

INEP - Instituto Nacional de Estudos e Pesquisas Educacionais Anísio Teixeira

IPEA - Instituto de Pesquisas Econômicas Aplicadas

IWHC - International Women's Health Coalition

LDB - Lei de Diretrizes e Bases da Educação

LGBT - Lésbicas, Gays, Bissexuais e Transexuais

LGBTFobia - Fobia ou preconceito ao público LGBT

MDB - Movimento Democrático do Brasil

MEC - Ministério da Educação e Cultura

MOVEC - Movimento Ecumênico de Curitiba

MP - Ministério Público (justiça)

MPF - Ministério Público Federal (justiça)

OIT - Organização Internacional do Trabalho

OMS - Organização Mundial da Saúde

ONU - Organização das Nações Unidas

ORMECE - Ordem dos Ministros Evangélicos do Ceará

PA - Pará (estado brasileiro)

PDC - Projeto de Decreto Legislativo

PDT - Partido Democrático Trabalhista

PE - Pastor entrevistado ou padre entrevistado

PEE - Plano Estadual de Educação

PEC - Proposta de Emenda Constitucional

PIB - Primeira Igreja Batista

PL - Projeto de Lei

PLS - Projeto de Lei do Senado

PMDB - Partido do Movimento Democrático Brasileiro

PME - Plano Municipal de Educação

PNAD - Pesquisa Nacional por Amostra de Domicílios 
PNE - Plano Nacional de Educação

PP - Partido Progressista

PPL - Partido Pátria Livre

PR - Partido Republicano

PRB - Partido Republicano Brasileiro

PROUNI - Programa Universidade Para Todos

PSC - Partido Social Cristão

PSDB - Partido da Social Democracia Brasileira

PSDC - Partido da Social Democracia Cristã

PSOL - Partido Socialismo e Liberdade

PT - Partido dos Trabalhadores

PTB - Partido Trabalhista Brasileiro

PUC - Pontifícia Universidade Católica

RJ - Rio de Janeiro (estado brasileiro)

RPC - Rede Paranaense de Comunicação (rede de televisão)

RS - Rio Grande do Sul (estado brasileiro)

SBT - Sistema Brasileiro de Televisão (rede de televisão)

SEPAL - Servindo aos Pastores e Líderes (organização religiosa)

Sinduscon-PA - Sindicato da Indústria da Construção do Estado do Pará

Sintricom -Sindicato dos Trabalhadores nas Indústrias da Construção Civil, Mobiliário e Montagem Industrial de São José dos Campos e Litoral Norte

SNI - Sistema Nacional de Inteligência

SP - São Paulo (estado brasileiro)

STF - Supremo Tribunal Federal

SUS - Sistema Único de Saúde

TJPA - Tribunal de Justiça do Pará

TJ - Tribunal de Justiça

UFABC - Universidade Federal do ABC

UFC - Universidade Federal do Ceará

UFF - Universidade Federal Fluminense

UNIFOR - Universidade de Fortaleza 


\section{INTRODUÇÃO}

\section{"O autoritarismo é alimentado pela paixão desesperada de acumular poder e silenciar o discurso político opositor antes que \\ ele tenha a chance de ser ouvido".}

Judith Butler

Os processos de modernização ocidental são caracterizados pela democratização, a industrialização, a secularização (ao promover uma separação do governo com a igreja ou com a religião considerada oficial), a mobilidade social e a globalização. Embora o esforço capitalista em legitimar a razão e a individualidade humanas e, nas sociedades ocidentais modernas, a igreja tenha perdido muito da sua força política, a sua influência está longe de se ter esgotado, pois em alguns países ainda é muito significativa, como é o caso do Brasil (Monteiro, 2003).

Apesar de esse país formalmente colaborar com a inserção da mulher, aderindo a pactos internacionais e criando leis de maior garantia e proteção às mulheres, famílias cristãs brasileiras ainda hoje apresentam tradicionais discursos machistas ou fundamentalistas. Não deve ser desprezada a ideia de que tais discursos podem ser reflexos de centros religiosos estrangeiros que, desenvolvidos com a colaboração local, transmitiram à sociedade sua forma tradicional de organização e militância em torno da sua própria moral baseada na bíblia, livro que dá suporte a todas as religiões cristãs e que está repleto de passagens que degeneram o papel da mulher na sociedade.

Na medida em que a Base Nacional Comum Curricular - BNCC (pautada nos direitos humanos) teve uma proposta mais inclusiva, cogitou-se a possibilidade de se acrescentar ao Plano Nacional de Educação (bem como aos Planos Municipais), a temática da igualdade de gênero. No entanto, tais dimensões discursivas, principalmente no que tange à imprensa, nos anos de 2016 a 2018, ganharam fervorosos posicionamentos contrários, sobretudo quando do surgimento de grupos religiosos na política, com um interesse sóciopolítico inquestionável. A pesquisa, ora apresentada, torna-se importante para se debater o papel desempenhado pelos periódicos, que servem como suporte na divulgação dos posicionamentos cristãos e cuja atuação está longe de ser tímida, aliás, muito pelo contrário, haja vista que se movimentam e se manifestam como instrumento para fomentar uma luta contra o diálogo acerca das questões de gênero. 
Este trabalho não poderia, dado o tamanho do Brasil e das diferenças na política e na religiosidade (e demais idiossincrasias dos diversos estados brasileiros), cobrir toda a realidade nacional. Portanto, com vistas à eficiência, o estudo fará um paralelo entre a percepção da principal imprensa escrita da cidade de Fortaleza, no estado do Ceará (tradicional e mais conservadora) e a percepção da imprensa nacional (mais progressista) sobre o discurso de gênero. Ademais serão ouvidos alguns líderes de igrejas cristãs também de Fortaleza-CE.

A necessidade de realização deste estudo surge da observância às estatísticas nacionais sobre a violência contra a mulher, dentro do conceito de violência de gênero (que é a violência sofrida pelo fato de se ser mulher, sem distinção de raça, classe social, religião, idade ou qualquer outra condição) produto de um sistema social que subordina o gênero feminino aos ditos morais cristãos. No ano de 2018, os números de feminicídios e de denúncias de violência da mesma natureza foram ainda maiores que os índices alarmantes registrados nos anos anteriores.

Os dados do canal Ligue 180, que agora pertence ao Ministério da Mulher, da Família e dos Direitos Humanos, apontam o registro de 92.323 denúncias, 25,3\% a mais do que no ano anterior, que apontou 73.669 denúncias em 2017 pelo 180. Esse canal começou a funcionar em julho de 2017 e já representa um avanço na proteção das mulheres (Batista, 2019).

No que concerne aos crimes contra a mulher, os agressores são frequentemente aqueles que coabitam/coabitaram com as vítimas, sendo seus companheiros, namorados, (ex)-maridos. A crueldade está sempre relacionada à ideia de que a mulher é propriedade do homem e que, por isso, deve-lhe obediência. Pensamentos fundamentados na cultura machista e cristã do brasileiro, que entende o papel da mulher como de submissa ao homem, conforme ensina a bíblia. A mudança deve ser cultural e educacional, para que os meninos e meninas comecem a entender a si mesmos e suas relações com o sexo oposto de maneira respeitosa e igualitária (Soares, 2006).

As dinâmicas sociais das práticas cotidianas são muitas vezes governadas e moldadas de várias maneiras pelas desigualdades de gênero e pelos contextos de micropoder, que permitem que várias formas de violência continuem a violar sistematicamente os direitos de certos grupos sociais. Os processos de violência simbólica são causados por procedimentos e discursos institucionais que permitem que várias formas de violência contra as mulheres sejam aceitas, padronizadas e reproduzidas com impunidade.

Diante desses dados, a sociedade se questiona o porquê da não existência de mais ações que combatam essa realidade. Quais são as forças que conflitam com a ideia de que a 
mulher deve ser protegida diante de números tão absurdos? Esta tese se motiva por esses questionamentos.

O Brasil tem vivido um cenário bastante conflituoso na política nacional. Após o ano de 2013 (no qual uma onda de protestos movimentou as metrópoles, em todas as regiões), estudantes de todo o país foram às ruas, na luta pela diminuição do valor do bilhete de transporte - pauta discutida desde o começo dos anos 2000 pelo movimento Passe Livre. Os protestos tiveram como consequência o impulsionamento de outras manifestações políticas dos cidadãos que estavam insatisfeitos com as políticas sociais dos Governos Lula (Luís Inácio Lula da Silva) e Dilma (Dilma Van Rousseff), políticos pertencentes ao Partido dos Trabalhadores - PT (Scherer-Warren, 2014).

As políticas públicas dos governos petistas foram desgastadas ao longo dos oito anos de Governo Lula (2002-2010) e do primeiro mandato de Dilma (2011-2013). A população é guiada por uma mídia ${ }^{1}$ pouco diversa que, no seu conjunto, não valoriza debates imparciais e começa a se posicionar publicamente. Uma parcela dos eleitores (notadamente, a classe média) passa a rechaçar as políticas sociais, iniciando-se uma campanha de deslegitimação do Partido dos Trabalhadores, criada pela mídia e grupos de elite conservadores - aliados a uma "blogosfera" repleta de novos influenciadores de extrema direita (Tatagiba, 2018).

O resultado se viu nas opiniões cada vez mais manifestas nas redes sociais e onde fosse possível se expressar. Estabeleceu-se um front de batalha entre a direita e a esquerda brasileiras. No resultado das eleições de 2014, o partido político que representava a oposição ao PT, Partido da Social Democracia Brasileira, declarou que a presidenta não teria governabilidade. A pressão política e a paralisia do governo federal, causada pelos embates no congresso, culminaram na falta de apoio da sociedade o que resultou, em 2015, na queda da Presidenta Dilma, através do processo de impeachment.

A partir de então, o Brasil estava repartido em dois: os progressistas e os conservadores, esquerda e direita, respectivamente. Tornou-se impossível não se posicionar politicamente e as discussões no âmbito privado se tornaram cada vez mais frequentes. O impeachment deu mais abertura para as falas dos conservadores, que passaram a entender o processo como a legitimação do pensamento político conservador.

As ações que visavam à defesa da mulher ou qualquer outra ação que tratasse da questão de gênero ou da sexualidade, que vinham em crescimento ascendente no que tange à importância - em termos de desenvolvimento das políticas públicas sociais de cidadania e

\footnotetext{
${ }^{1}$ Para entender a influência das mídias pelos discursos proferidos, ver também Charaudeau, Patrick (2007). Discurso das Mídias. In Charaudeau, Patrick (2007). Discurso político. São Paulo: Contexto.
} 
de respeito aos direitos humanos, passaram a ser desacreditadas. As igrejas tomaram uma maior fatia do poder sociopolítico, sendo substancialmente representadas no legislativo, nos canais de comunicação - na internet, principalmente. Centradas na visão conservadora da política tornaram-se ainda mais influenciadoras.

Nesse contexto, a tese aborda como problemática o discurso das lideranças religiosas tomadas de poder político e posicionamentos conservadores, que contam com apoio da mídia e embaraçam as possibilidades igualitárias das questões de gênero e da mulher no Brasil. Vê-se o conservadorismo nas escolas (com a proibição do ensino de qualquer conteúdo ligado a discutir gênero), na saúde, na mídia e na vida privada, com maior evidência. $\mathrm{O}$ embate entre as forças políticas é o ponto mais importante na análise de políticas públicas e ações que defendam os direitos humanos.

As religiões cristãs são as principais porta-vozes da visão política conservadora. Os deputados, vereadores e demais políticos identificados como "Bancada da Bíblia", são a força parlamentar do conservadorismo mais radical, apoiados pelos fiéis e fanáticos religiosos. Portanto, veem-se: as igrejas cristãs como criadoras de conteúdo e formadoras de opinião; os políticos, a elas ligados, como os executores políticos; a mídia, como a reforçadora do pensamento hegemônico conservador; e a população, como a massa de manobra e legitimadora do conservadorismo cristão.

Os conservadores criaram um novo termo para designar o debate, denominado "ideologia de gênero". A utilização de tal alcunha é uma falsa noção, haja vista que o conceito de gênero não tem uma estrutura ideológica, mas, sociológica. Gênero é uma palavra criada para lidar com as relações de poder e discriminação que sempre existiram em torno das identidades e papéis associados ao masculino e ao feminino (além do sexo biológico), com intuito de versar sobre segregação / preconceito no que concerne ao feminino. Essa nomenclatura foi uma construção de direitos humanos, discutida em várias conferências da ONU, nas quais o Brasil assinou compromissos (RIOS, 2006).

Ressalte-se que as relações de hierarquia e poder através das igrejas cristãs não estão instaladas de forma aleatória, e somente na realidade de Fortaleza, pelo contrário, além de serem passadas de geração para geração, vêm obedecendo a padrões hierárquicos de condutas subordinados a outras igrejas.

A igreja católica, por exemplo, é subordinada às decisões do Vaticano, que está sob o comando do Papa; as congregações evangélicas, aos Ministérios, Associações e Convenções, que por sua vez, também têm seus líderes. A aliança firmada entre fiéis e líderes é o que vai dando a força e poder a essas instituições. O Papa, tomando partido 
através de suas crenças sobre o que o mundo vive ou vivencia é o maior líder da igreja Católica (Scavone, 2008).

Por isso, torna-se preocupante quando crescem os discursos de líderes religiosos e que, independentemente de sua esfera de poder, unem-se em propósitos atentatórios à igualdade de gênero, justificando combater a "ideologia de gênero" ${ }^{2}$. Há que se destacar que o Papa Francisco vem emitindo opiniões contrárias à igualdade de gênero, fazendo diversas e objetivas advertências sobre tal "ideologia" - como se os termos "igualdade" e "ideologia" de gênero tivessem o mesmo significado. Na concepção do Papa, trabalhar igualdade de gênero dentro do âmbito escolar é o mesmo que promover uma espécie de colonização ideológica. Para ele, que defende o conceito de família tradicional, trabalhar tais questões é o mesmo que doutrinar crianças (o que seria, segundo ele, uma maldade com as mesmas). Tal discussão esvazia o conceito moral de família defendida pelo cristianismo, devendo os pais ser protagonista dos ensinamentos da igreja, acompanhando inclusive o que os filhos estão recebendo na educação.

Ademais, no Brasil do ano de 2016, nasceu uma aliança católica e evangélica, para erradicar a ideologia, sob a justificativa de preservar o conceito de família tradicional. Isso foi um movimento iniciado em Curitiba que já percorreu todo o país, o que aumentou ainda mais o poder das lideranças cristãs no Brasil em todas suas camadas sociais, e em suas esferas políticas e jurídicas (Rosado-Nunes, 2005).

O tema e suas associações acabam ganhando forças também nas Câmaras Municipais, com participação popular, atuando conjuntamente para não se discutir "ideologia de gênero" em

\footnotetext{
${ }^{2}$ No Dicionário de Política, no verbete "IDEOLOGIA", tem-se: "Tanto na linguagem política prática, como na linguagem filosófica, sociológica e político-científica, não existe talvez nenhuma outra palavra que possa ser comparada à Ideologia pela frequência com a qual é empregada e, sobretudo, pela gama de significados diferentes que lhe são atribuídos. No intrincado e múltiplo uso do termo, pode-se delinear, entretanto, duas tendências gerais ou dois tipos gerais de significado que Norberto Bobbio se propôs a chamar de "significado fraco" e de "significado forte" da Ideologia. No seu significado fraco, Ideologia designa o genus, ou a species diversamente definida, dos sistemas de crenças políticas: um conjunto de ideias e de valores respeitantes à ordem pública e tendo como função orientar os comportamentos políticos coletivos. O significado forte tem origem no conceito de Ideologia de Marx, entendido como falsa consciência das relações de domínio entre as classes, e se diferencia claramente do primeiro porque mantém, no próprio centro, diversamente modificada, corrigida ou alterada pelos vários autores, a noção da falsidade: a Ideologia é uma crença falsa. No significado fraco, Ideologia é um conceito neutro, que prescinde do caráter eventual e mistificante das crenças políticas. No significado forte, Ideologia é um conceito negativo que denota precisamente o caráter mistificante de falsa consciência de uma crença política”. STOPPINO, M., BOBBIO, N., \& MATTEUCCI, N. (2002). Verbete" Ideologia. BOBBIO, N. \& MATTEUCCI, N. Dicionário de Política, 1, 12.
} 
nenhum ambiente, públicos ou privado, sendo, portanto, considerado uma ameaça à sociedade e a família tradicional.

Comunidades evangélicas e católicas se uniram em 2017 através de um pacto contra a "ideologia de gênero". O conhecido "Movimento Gênesis - Homem e Mulher os Criou", criado para reforçar o conceito de família tradicional, baseada somente no casamento entre um homem e uma mulher. Nascido em Curitiba, o movimento já está se espalhando por todo o país (Favretto, 2017, on-line).

A adesão ao movimento foi tão expressiva, representando $80 \%$ dos cristãos da cidade Curitiba. Além de instituições como a Convenção Batista Brasileira (CBB), a Associação das Igrejas Batistas da Grande Curitiba (BGC) e o Movimento Ecumênico de Curitiba (MOVEC), a iniciativa teve o apoio das igrejas Presbiteriana, Luterana, Assembleia de Deus, Sara Nossa Terra, Metodista, Quadrangular, Menonita e as paróquias da Igreja Católica da Arquidiocese da cidade de Curitiba.

O movimento, por meio de materiais explicativos sobre o tema, foi divulgado nas redes sociais e em reuniões com membros da área médica, científica e jurídica em todo o território nacional que, dentre outros propósitos, objetivam instituir campanhas de reafirmação da importância da família e do papel e valor do homem e mulher, sob a justificativa de fundamentar a constituição do núcleo desse projeto nascido no coração de Deus: a família, destacando e enfatizando o valor dela e a importância dos papeis do homem e da mulher para o seu desenvolvimento (Favretto, 2017).

Foi criada uma agenda de ações e metas, a fim de atrair o interesse das mídias, gerando notícias nas TVs Globo, Band, Record, SBT, Rede Evangelizar, Canção Nova e jornais de circulação semanal, como RPC e Metro, para divulgação e disseminação do "Gênesis" (AÇÃO).

O movimento também já demonstrou sua insatisfação em relação à proposta da Base Nacional Curricular Comum (BNCC) e produziu um documento assinado por advogados da Primeira Igreja Batista de Curitiba (PIB) e da Arquidiocese de Curitiba, para ser enviado a Brasília. O material foi encaminhado ao Ministério da Educação, através do senador Magno Malta (PR-ES) (Favretto, 2017).

Em dezembro de 2017, em 14 (quatorze) municípios de nove estados do Brasil, já existiam leis que proibiam ou estavam prestes a proibir professores de discutir ou utilizar em sala de aula material didático que se referisse a questões de gênero e religiões. 
O Projeto de Lei do Senado (PLS) 193/2016, que inclui o programa Escola sem Partido dentro da Lei de Diretrizes e Bases da Educação Nacional (Lei 9.394/1996, havia recebido, até as $17 \mathrm{~h}$ desta terça-feira (26), mais de 173 mil votos favoráveis e cerca de 183 mil votos contrários. Qualquer cidadão pode opinar sobre os projetos em tramitação no Senado por meio da página Consulta Pública, uma das funcionalidades do Portal e-Cidadania. De autoria do senador Magno Malta (PR-ES), o projeto cria o programa Escola sem Partido para que sejam incluídos como princípios da educação nacional a neutralidade política, ideológica e religiosa; o pluralismo de ideias no ambiente acadêmico; a liberdade de aprender e de ensinar; a liberdade de consciência e de crença; o reconhecimento da vulnerabilidade do educando como parte mais fraca na relação de aprendizado; a educação e informação do estudante quanto aos direitos compreendidos em sua liberdade de consciência e de crença e o direito dos pais a que seus filhos recebam a educação religiosa e moral que esteja de acordo com as suas próprias convicções. O projeto proíbe os professores, no exercício de suas atividades, de: promover os seus próprios interesses, opiniões, concepções ou preferências ideológicas, religiosas, morais, políticas e partidárias; favorecer, prejudicar ou constranger os alunos em razão de suas convicções políticas, ideológicas, morais ou religiosas, ou da falta delas e fazer propaganda político-partidária em sala de aula ou incitar seus alunos a participar de manifestações, atos públicos e passeatas. $\mathrm{O}$ projeto estabelece ainda que "o poder público não se imiscuirá na opção sexual dos alunos nem permitirá qualquer prática capaz de comprometer, precipitar ou direcionar o natural amadurecimento e desenvolvimento de sua personalidade, em harmonia com a respectiva identidade biológica de sexo, sendo vedada, especialmente, a aplicação dos postulados da teoria ou ideologia de gênero". Além disso, a proposta determina que as instituições de educação básica deverão afixar nas salas de aula e nas salas de professores cartazes "com o conteúdo previsto no anexo desta Lei, com, no mínimo, 90 centímetros de altura por 70 centímetros de 
largura, e fonte com tamanho compatível com as dimensões adotadas". De acordo com Magno Malta, seu projeto de lei foi inspirado no Movimento Escola Sem Partido (Agência Senado, 2017, on-line).

Também há restrições a comentários políticos. No total, tais leis atingiram cerca de 270 mil alunos do ensino fundamental, com idade média entre 6 e 14 anos. Em outubro de 2016, a câmara do município de Crato (CE) aprovou lei que pró́be falar em "ideologia de gênero" e "toda orientação sexual" ao aluno que tente "extinguir o gênero masculino e/ou feminino do gênero humano".

Em alguns municípios, as leis parecem ser ainda mais atentatórias à dignidade da pessoa humana, impõem aos professores o papel de fiscais do comportamento dos alunos. Em Pedreira (SP), por exemplo, a lei aprovada no ano de 2017 dita que os professores não podem permitir que o estudante apresente "qualquer prática capaz de comprometer o desenvolvimento de sua personalidade em harmonia com a respectiva identidade biológica do sexo" (Agência Senado, 2017).

Em Barueri, na Grande São Paulo, o texto prevê que, mesmo fora dos colégios, os debates sobre questões de gênero, ainda que em ambientes públicos, não podem ocorrer com participação de adolescentes.

Em Fortaleza, a Câmara rejeitou incluir debate sobre sexismo no ano de 2017, nas escolas. A vereadora Larissa Gaspar tinha recorrido contra parecer negativo da Comissão de Constituição, Justiça e Legislação ao Projeto de Lei n ${ }^{\circ}$ 86/2017, de sua autoria, que incluía no Plano Municipal de Educação (PME) artigo contra "violências sexistas, raciais, religiosas e LGBTfóbicas” (Tomazela, 2018).

Cerca de 30 manifestantes contra e favoráveis ao PL estiveram presentes à sessão. Discussão que deveria ser sobre legalidade da matéria, que tramita na CCJ, tornou-se debate sobre "ideologia de gênero". Por 23 votos a sete, os vereadores contrários à proposta afirmaram que o PL é inconstitucional, visto que o PME “deve ser preservado, mantendo sua originalidade" pelo período de vigência, de dez anos da elaboração. Apoiadores da proposta, porém, alegam que o relator da CCJ, Jorge Pinheiro (PSDC), utilizou-se de argumentos contra "ideologia de gênero" para barrar a matéria, já que o termo surge no parecer do parlamentar.

Em defesa do recurso que apresentou, Larissa Gaspar disse que o conteúdo do projeto define que a escola traga "conteúdo para a pacificação de diálogos, cultura de paz contra violências sexistas, raciais, LGBTfóbicas e respeito à identidade de gênero". 
Em sua tese, a vereadora cita "decisão do Supremo Tribunal Federal (STF)", do ministro Luís Roberto Barroso, em Arguição de Descumprimento de Preceito Fundamental (ADPF), que declarou inconstitucionalidade de lei que "vista impedimento" de "adoção de políticas de ensino que tratem de gênero, de orientação sexual".

As consequências para o desenvolvimento de ações de direitos humanos e, como discutido neste trabalho especialmente, para a igualdade de gêneros pela defesa da mulher são inúmeras. Na tese apresentada será discutida essa problemática.

\section{Questão de pesquisa}

Tem-se como questão principal de pesquisa: "qual é a percepção das principais imprensas escritas de Fortaleza sobre o discurso de gênero e a sua relação com as igrejas cristãs?". Assim, é possível observar se a mídia impressa dissemina o conservadorismo cristão.

\section{Justificativa}

A escolha do tema foi feita na tentativa de se compreender a violência no cenário brasileiro, principalmente por existir, neste país, uma cultura excessivamente religiosa e, ao mesmo tempo, tão atentatória aos direitos humanos. $\mathrm{O}$ interesse no estudo adveio da escassez de publicações referentes a uma análise dos direitos humanos sob a ótica de uma predominante religião cristã, sobretudo, na existência de uma atuação tendenciosa da imprensa de Fortaleza, que vem proferindo um discurso contrário à "ideologia de gênero" o que, atualmente, fomenta uma discussão frequente, no âmbito sociopolítico, em frear projetos de lei que promovam questões igualitárias, desprezando, portanto, os direitos das minorias ${ }^{3}$. Ademais, em se comparando essa imprensa local com imprensas mais progressistas de abrangência nacional, pode-se denunciar seus discursos moralistas que tanto divergem dos discursos mais progressistas.

A amostragem que serviu para análise do discurso de percepção religiosa cristã foi coletada através de entrevistas realizadas com nove lideranças cristãs de igrejas católicas e dez, de igrejas evangélicas que, apesar de parecer uma quantidade mínima, traduz suficiente e plenamente a percepção de lideranças cristãs sobre igualdade de gênero em Fortaleza.

Além disso, motivou esta pesquisa o fato de não haver publicações científicas sobre o tratamento dado à temática das relações entre Igreja e Estado, cujo efeito é a violência e que não tem sido problematizado por constitucionalistas brasileiros. Desta forma, buscou-

\footnotetext{
${ }^{3}$ Sobre a história da imprensa no Brasil, ver Sodré, Nelson Werneck (1999). História da imprensa no Brasil. Rio de Janeiro: Mauad.
} 
se refletir sobre o discurso de uma cultura predominante e preexistente, que persiste em desprezar questões universais de direitos humanos e normas constitucionais que protegem, dentre outros, o princípio da dignidade da pessoa humana. Ademais, será analisada a cultura secular que se movimenta, agrega partidários (em segmentos de lutas e manifestações), para discutir suas ideias e seus valores conservadores e ainda patriarcais.

O presente trabalho contribuirá para a compreensão de aspectos relevantes a respeito da cultura cristã, no tocante às relações de gênero praticadas na cidade de Fortaleza que, por ser um reflexo da cultura presente no Brasil, permite a compreensão do papel exercido pela religião cristã na propaganda do discurso conservador da mídia brasileira, com o objetivo de interpretar como a violência contra a mulher e a violação de direitos humanos pode estar condicionada a este pensamento tradicional cristão contrário a direitos, liberdades e condições igualitárias dos seres humanos.

\section{Objetivos}

\section{Objetivo Geral:}

Compreender os discursos envolvendo as esferas do poder político, religioso e midiático, sobre a questão de gênero: como pode ser manipulada, construída e suas consequências sociais.

\section{Objetivos Específicos:}

a)Interpretar se a Base Nacional Comum Curricular - BNCC (pautada nos direitos humanos) por ter uma proposta mais inclusiva, e se o Plano Nacional de Educação (bem como aos Planos Municipais), aderiram à temática da igualdade de gênero nos anos de 2016-2018, após a aprovação do plano nacional de educação, 2014, em que tais debates se tornaram mais fervorosos na imprensa?!

a) Analisar e comparar os discursos das imprensas de âmbito local conservador e das nacionais progressistas, entre os anos de 2016 a 2018, para identificar e diferenciar o debate religioso cristão sobre igualdade de gênero na educação e, assim, sopesar quais são os valores que veem sendo manipulados pela mídia.

b) Avaliar se a percepção dos líderes católicos e evangélicos de Fortaleza se assemelha com o discurso político cristão sobre igualdade de gênero, e quais os efeitos deste discurso com relação à promoção dos direitos humanos.

c) Entender como as lideranças cristãs extremistas se articulam para propagar e defender seus interesses morais, em termos de manipulação e legitimação para o exercício do poder político. 


\section{Hipóteses}

Diante do exposto acima na justificativa e nos objetivos, apõem-se as hipóteses a serem testadas: há impedimento do avanço da igualdade entre os gêneros, causado pelo conservadorismo cristão; a mídia conservadora impressa endossa o tal posicionamento emitindo um discurso alheio à igualdade de gênero, principalmente se utilizando de expressões contra “ideologia de gênero", promovido por religiosos extremistas na política, que executam um debate contra a promoção destes direitos humanos na mídia impressa de Fortaleza. Assim, a violência contra a mulher ocorre livremente, embora haja ações para proibição.

\section{Metodologia}

Para melhor apreciação da hipótese proposta, resolveu-se utilizar não apenas um método de pesquisa, dependendo, portanto, do objeto da seção. Usaram-se entrevistas e análise de conteúdo documental.

A tese está pautada na análise qualitativa de dados, onde o olhar da autora e sua leitura sobre os fatos e impressões são imprescindíveis para o desenvolvimento da lógica metodológica. O fio condutor da tese é a Análise de Discurso, os quais são proferidos tanto pelos líderes religiosos quanto pelos periódicos consultados. A diferença está na prática de coleta de dados e em suas fontes.

Segundo Gil (2010), a pesquisa se faz pelo conhecimento acessível, com a execução da investigação através de métodos e técnicas que contemplam vários passos. De acordo com o autor, uma pesquisa deve ser entendida como um processo formal e sistemático de desenvolvimento de modo científico no qual serão descobertas ou provadas hipóteses ou repostas para as perguntas formuladas e os problemas apresentados. A metodologia deste estudo se baseia em conceitos que respondem à pesquisa com seu tema principal, de tal modo, o presente estudo terá enfoque qualitativo exploratório.

Segundo Spector (2001), a investigação qualitativa pode se tornar exploratória, descritiva e casual. O presente trabalho, como uma investigação exploratória qualitativa, tem a flexibilidade e a criatividade como base e trata de conhecer e se aprofundar no material recolhido. Portanto, ele é desenvolvido através de pesquisas bibliográficas e análises de matérias da imprensa nacional. A pesquisa relaciona os autores que fizeram estudos neste âmbito e que trazem luz à importância dos discursos da imprensa, com respeito à formação da ideologia que concerne às mulheres.

É importante e necessário investigar quais fatores foram primordiais para o desenvolvimento dos discursos sobre educação e gênero na imprensa escrita. O trabalho é 
uma reflexão sobre os principais obstáculos aos direitos das mulheres e todas aquelas pessoas que se identificam como tais, que deve igualmente ser valoradas na sociedade.

O planejamento da coleta de dados será feita na extração de informações por meio de uma análise de conteúdo dos periódicos mencionados. Essa análise será utilizada para decodificar, descrever, e interpretar o conteúdo de inúmeros tipos de documentos, já que os discursos enunciados pelos veículos de informação, além de todos os outros que se emitem ao largo dos tempos, estão cheios de ideais e de posicionamentos, ainda que não se assuma. Michel Foucault (1996), em A ordem do discurso descreveu as emissões de discursivas como uma construção de características sociais. A sociedade que promove o contexto do discurso analisado é a base de toda a estrutura do texto, ligando, desse modo, todo elemento que pode formar parte do sentido do discurso. O texto só pode se chamar assim se seu receptor é capaz de compreender seu sentido, e isto corresponde ao autor do texto e à atenção que dá ao contexto da construção de seu discurso. É a relação básica para a existência da comunicação verbal: emissão - recepção - compreensão.

A partir da análise de todos os aspectos do discurso, se chega ao mais importante: o sentido. O sentido do discurso não é fixo, por vários motivos. Pelo contexto, pela estética, pela ordem do discurso, pela sua forma de construção. O sentido do discurso se encontra sempre aberto para a possibilidade de interpretação de seu receptor. O efeito do discurso é, claramente, transmitir uma mensagem e alcançar um objetivo premeditado através da interpretação do indivíduo objetivo.

O discurso é um suporte abstrato que sustenta os diversos textos concretos que circulam em uma sociedade. É responsável pela concretização, em termos de figuras e temas, das estruturas semióticas e narrativas. Através da análise de discurso é possível realizar uma análise interna sobre o que diz o texto em um determinado contexto.

A análise busca relacionar-se com o campo da língua (susceptível de ser estudado pela Linguística) e o campo da sociedade (pautada pela história e pela ideologia).

A ideologia, de acordo com Pêcheux (1990) é um conjunto de representações dominantes em uma determinada classe dentro da sociedade. Devido ao fato de que há várias classes e várias ideologias, está presente constantemente o enfrentamento delas na sociedade. A ideologia é, pois, a visão de mundo de determinada classe, da maneira como ela representa a ordem social. Logo, a linguagem é determinada em última instância pela ideologia, já que não há uma relação direta entre as representações e a língua. A determinação em última instância é chamada por Pêcheux (1990) de formação ideológica ou condições de produção do discurso. 
Uma sociedade contém várias formações ideológicas e cada uma delas corresponde a uma formação discursiva que se relaciona com o que se pode e se deve dizer, em certa época. No caso da sociedade brasileira que, até o momento, é machista e patriarcal, a imagem da mulher projetada pelos meios de comunicação é ainda depreciativa e estimulada pelo preconceito e pela discriminação de gênero.

Segundo Althusser (2007), a ideologia é a representação imaginaria que interpela os sujeitos a tomar um determinado lugar na sociedade, mas que cria a "ilusão" de liberdade do sujeito. A reprodução da ideologia está resguardada pelos "aparelhos ideológicos" nos âmbitos religiosos, político e escolar, em cujos interiores das classes sociais se organizam em formações ideológicas, que são um conjunto complexo de atitudes e representações.

O discurso é um dos aspectos da materialidade ideológica: algo só tem sentido para um sujeito quando este o reconhece como pertencente à determinada formação discursiva. Os valores ideológicos de uma formação social estão representados no discurso por uma série de formações abstratas, que designam o lugar que o destinatário e o emissário se atribuem mutuamente (Pêcheux, 1990).

Segundo Fiorin (1990):

El discurso debe ser visto como objeto lingüístico y como objeto histórico. No se puede descartar la investigación sobre los mecanismos responsables de la producción del sentido y la estructuración del discurso ni sobre los elementos pulsionales y sociales que lo atraviesan. Estos dos puntos de vista no son excluyentes ni metodológicamente heterogéneos. La investigación hoy precisa profundizar el conocimiento de los mecanismos sintácticos y semánticos generadores de sentido; por otro lado, necesita comprender el discurso como objeto cultural, producido a partir de ciertas condicionantes históricas, en relación dialógica con otros textos $^{4}$ (Fiorin, 1990, 177).

De todo este conjunto de condições de produção e de análise do discurso saem as notícias na imprensa todos os dias. Isto é, as notícias são cheias de ideologias e assim buscam

\footnotetext{
4 "O discurso deve ser visto como um objeto linguístico e como um objeto histórico. A pesquisa não pode ser descartada sobre os mecanismos responsáveis pela produção do sentido e da estruturação do discurso, nem sobre os elementos instintivos e sociais que o permeiam. Esses dois pontos de vista não são mutuamente exclusivos ou metodologicamente heterogêneos. A pesquisa hoje precisa aprofundar o conhecimento dos mecanismos sintáticos e semânticos que geram significado; por outro lado, é preciso entender o discurso como um objeto cultural, produzido a partir de determinados condicionantes históricos, em uma relação dialógica com outros textos". Tradução livre da autora.
} 
parecer neutras para o seu público, mas não o são, o que é passível de análise pelas teorias e métodos da Análise de Discurso.

No Brasil existem leis que buscam manter a imprensa livre, porém, existem limites - uma vez que a carta constitucional preza por garantir o acesso à informação, pautada na imparcialidade e nos valores sociais, sempre respeitando a dignidade da pessoa humana, possibilitando, inclusive, o direito de resposta, quando houver lesão a esse direito.

No que tange à garantia legal, a tradição somada à ignorância da maioria dos socialmente excluídos não os permite fazer caso ao direito de resposta. No mais, os enunciados dos discursos não deixam visível o que pensam, assim não há quebra direta das regras e como resultado fica mais difícil exigir o direito de resposta ou ratificação.

Na seção "Líderes cristãos das igrejas católicas e evangélicas em Fortaleza" foram usadas entrevistas para a coleta de informações e posterior análise. Nove padres e dez pastores participaram desta pesquisa, com um roteiro comum entre todos os entrevistados ${ }^{5}$, que responderam às mesmas perguntas, em encontros presenciais. Mais detalhes sobre a aplicação das questões são dados na seção citada.

Os líderes foram visitados nos lugares de sua própria escolha, sem haver qualquer tipo de orientação da resposta. As respostas foram dadas de forma livre, sem o direcionamento da entrevistadora, senão o questionário comum a todas as entrevistas. As perguntas tinham como tema os direitos humanos, o papel da mulher e noções de resoluções internacionais de direitos humanos.

Na seção 12, “A ‘ideologia de gênero' na mídia: usos políticos e manipulação da mídia”, os dados foram coletados das plataformas online dos periódicos visitados. Foram escolhidos dois jornais locais de tiragem diária, do estado do Ceará, identificados posteriormente como conservadores, e duas revistas de tiragem nacional, semanais, identificadas como progressistas. A escolha dos periódicos se deve ao universo possível de agências disponíveis. Não há jornais identificados como progressistas de tiragem diária no Ceará. Para estabelecer o contraponto na abordagem, foram escolhidas as revistas nacionais.

Nesta pesquisa, o termo "ideologia de gênero" foi o ponto principal. A coleta foi feita em todo acervo disponível do período de 2016 a 2018, tendo o recorte do termo na temática de educação ${ }^{6} \cdot$. Selecionadas as matérias, foram sistematizadas em tabelas e as mais relevantes estão descritas na seção, no intuito de mostrar que a história dos fatos pode ser contada de maneiras diferentes e é essa manipulação que se evidencia na leitura dos dados.

\footnotetext{
${ }^{5} \mathrm{O}$ questionário que serviu de guia para as entrevistas está anexado ao final do texto da tese.

${ }^{6}$ Os resultados da amostragem da pesquisa sobre a mídia estão nos apêndices 1, 2, 3 e 4 deste trabalho.
} 
Unindo as seções no todo do trabalho, o resultado esperado é a compreensão dos discursos envolvendo as esferas do poder político, religioso e midiático, sobre a questão de gênero, como pode ser manipulada, construída e suas consequências sociais.

\section{Apresentação da tese}

O trabalho desta tese busca oferecer uma abordagem aprofundada sobre as opiniões acerca de políticas e ações positivas da defesa das mulheres no Brasil. Por isso, foi dividido em duas partes, senda a primeira focada na discussão mais teórica do tema e a segunda feita com pesquisas pragmáticas sobre o mesmo.

Inaugurando o texto, na seção 1, "Contexto histórico dos Direitos Humanos", é dada a abordagem generalista aos direitos humanos como base para toda discussão presente na tese. $\mathrm{O}$ entendimento dos direitos humanos como espaço de defesa dos grupos minoritários é essencial para compreender a linha lógica do pensamento da autora. A história da área é apresentada, desde a Idade Moderna, evidenciando sua construção e desenvolvimento até os dias atuais. Dessa forma, a discussão é engrandecida pela concepção da necessidade de se pensar os direitos individuais e a busca pela igualdade como base para uma sociedade justa.

Na seção 2, vemos que o estabelecimento da primeira constituição brasileira instituiu a religião católica como a oficial no país. Isso significou o impedimento de atuação de outras religiões e o cerceamento da liberdade individual daqueles que não comungavam da fé católica. Em seguida, é tratado sobre a igualdade dos direitos das mulheres no Brasil, as dificuldades da conquista da igualdade e como é a imagem da mulher no Cristianismo. O movimento feminista é retratado como um movimento que surge para combater a ideia da mulher submissa marcada pelo desígnio católico de ser a parte guiada pelo homem.

$\mathrm{Na}$ seção seguinte, a relação entre a política e religião é apreciada. Os direitos femininos são apresentados pela construção histórica, notadamente surgidos no século XX. Assim, a bancada religiosa toma força no final do século e é antagonista da luta das mulheres, incluindo nessa problemática os direitos da população LGBT. A ONU, como organização internacional que trabalha as questões de Direitos Humanos busca orientar o Estado a defender as minorias, sem grande resposta.

A dominação masculina é tratada na seção 4 , "A convenção sobre eliminação de todas as formas de discriminação contra as mulheres (CEDAW), sob a ótica brasileira". O feminicídio, os maus-tratos e outras questões são levantados no texto. O CEDAW - sigla inglesa da Convenção sobre a Eliminação de todas as formas de Discriminação Contra a Mulher - é apresentado como sendo uma atitude positiva na busca pela igualdade de 
gênero. $O$ Brasil, mesmo que signatário da convenção, não tem alcançado sucesso nas poucas ações tomadas na área.

Os conflitos das igrejas, contra a chamada "ideologia de gênero", são explicados na seção 5, "A relação de hierarquia e poder contra a 'ideologia de gênero"”. O termo usado para designar todo conteúdo referente às questões de gênero no Brasil é usado de forma errônea, uma vez que não existe ideologia nos movimentos sociais e elaborar um termo significa materializar uma ideia preconcebida como um inimigo da moral conservadora.

A continuação da questão de gênero na educação é dada na seção 6, "A educação de gênero e a igreja no plano municipal de educação na cidade de Fortaleza”. Nesta etapa, são relatadas as diferenças entre os gêneros na escola, os modelos familiares, o contexto brasileiro e as pesquisas no tema.

A reflexão sobre um direito da mulher é feita na sétima seção: "O aborto como direito das mulheres, em debate", onde é discutido o aborto como prática comum em todas as sociedades, com números estatísticos das ocorrências em diversos países. No Brasil, a discussão ocorre no Supremo Tribunal Federal e recebe contribuições de organizações, pesquisadores e militantes prós e contras esse direito feminino.

Na seção 8, "Líderes cristãos das igrejas católicas e evangélicas em Fortaleza", será dada atenção ao que os representantes, aqui chamados de líderes das igrejas evangélicas e católicas, pensam sobre questões de gênero, entendendo que nos cultos e missas os discursos são assimilados pelos fiéis como verdades. Com o uso de entrevistas, a autora explora o que pensam os líderes e identifica os ensinamentos cristãos como entraves para a mudança do paradigma religioso da submissão da mulher ao homem. A propagação destas ideias aos fiéis cria uma massa contrária aos direitos das mulheres.

Em seguida, a tese fala das parlamentares engajadas na temática de gênero. Na seção 9 , "Resistência x Conservadorismo, sobre educação de gênero no contexto político local”, a vereadora Larissa Gaspar é apresentada como uma vereadora do município de Fortaleza, que se preocupa com os Direitos Humanos e propõe projetos no sentido da defesa da mulher. Outra parlamentar apresentada é a Dra. Silvana, deputada estadual do Ceará contrária aos projetos direcionados às questões de gênero, realizando ações em favor da igreja evangélica dentro da Assembleia Legislativa e falas fervorosas contra ações positivas para o público LGBT e feminino.

Na mesma temática da seção anterior, a seção 10, "Violação dos direitos da mulher: caso Marielle na imprensa" trata do caso do assassinato da vereadora Marielle Franco, ocorrido em 2018. Essa parlamentar lutava pelos direitos humanos na cidade do Rio de Janeiro e, por isso, sofria perseguições políticas. Negra, mulher, lésbica e periférica, suas ações se 
voltavam para as minorias e também as mulheres e o público LGBT. O caso chocou o país e ainda não foi solucionado. Estuda-se, portanto, a abordagem da mídia para o caso, afirmando que houve a degradação da imagem da Marielle e o descaso com um evento tão importante que é a morte proposital de uma pessoa política.

Na seção 11 "Movimentos pela educação e construção legal do tema no Brasil”, é debatido um tema que se faz imprescindível para ilustrar os conflitos ideológicos. Os conservadores afirmam que a educação no país é usada para doutrinar as crianças para uma "ideologia de gênero", termo criado por eles próprios e que significa que os professores estariam incutindo nas cabeças dos alunos que eles devam ser "gays" ou "feministas", contra a "moral e os bons costumes". Na verdade, existe uma defesa da liberdade de ensino pelos professores que conflita com a regulação do Estado e a supervisão de parlamentares, religiosos e conservadores em geral. Há uma proposta do ensino de educação sexual e a inclusão de matérias que defendem a igualdade e os direitos humanos.

Na última seção, “A ‘ideologia de gênero' na mídia: usos políticos e manipulação da mídia”, foi examinada a abordagem da mídia sobre as políticas de gênero. Dessa forma, foi feita a análise de conteúdo de veículos de comunicação impressa, buscando o termo "ideologia de gênero" e interpretando a aparição das notícias de forma cronológica por periódico, somando quatro periódicos considerados de grande circulação no estado do Ceará, sendo dois mais conservadores (Diário do Nordeste e O Povo) e dois mais progressistas (Carta Capital e Revista Fórum), os dois últimos de circulação nacional porque não há mídia de esquerda no estado. Assim, foi feita uma pesquisa especial para esta seção, com amostragem disponível nos apêndices deste trabalho, que mostrou como pode ser manipulado politicamente o tema. O resultado é que as opiniões podem ter repercussões práticas na sociedade, fazendo com que a população tenha a tendência de interpretar fatos de acordo com as abordagens da mídia.

A seguir, a tese tem o desfecho com a conclusão deste trabalho. 
PARTE 1 


\section{CONTEXTO HISTÓRICO DOS DIREITOS HUMANOS}

Na busca por tentar desvendar os obstáculos para o cumprimento dos direitos das mulheres e a relação do direito com a religião, é importante estabelecer o que se entende nesse trabalho como Direitos Humanos, seus fundamentos e desenvolvimento até a era contemporânea. Assim, esclarecidas as bases de sua origem até o momento atual, pode-se debater a sua relação com a religião e os impactos profundos na sociedade, tendo em vista que toda discussão filosófica visa elucidar questões pragmáticas.

\subsection{A história dos Direitos Humanos}

Não há como delimitar em que momento se verificou na história o nascimento dos Direitos Humanos, pois adveio de uma construção normativa universal, que foi conquistada através de lutas contra a opressão, uma incessante busca do bem-estar do indivíduo, nesse sentido sua base ideológica foi pautada em valores referentes à justiça, igualdade e liberdade, cujo conteúdo impregnou a vida das primeiras comunidades humanas.

Ressalte-se que os primeiros escritos das comunidades humanas ocorreram ainda no século VIII a.C. e perduraram até o século XX d.C., totalizando mais de vinte e oito séculos rumo à afirmação universal dos direitos humanos, que tem como marco a Declaração Universal dos Direitos Humanos de 1948 (Comparato, 2017).

Pode-se afirmar que os direitos humanos são o reconhecimento universal da igualdade, em que nenhum indivíduo pode ser identificado como superior aos demais e toda essa crescente afirmação em que se sucedeu na história foi devido à defesa da dignidade humana.

Compreender tal conceito ainda é complexo, seja em relação aos contextos históricos (em que essa defesa pela dignidade humana foi se inserindo ou se afirmando), bem como diante das sucessivas respostas dadas pela religião, filosofia e ciência (Bobbio, 2004).

A contribuição da ciência sobreveio com a descoberta do processo de evolução dos seres vivos e com as explicações de Charles Darwin. Aos poucos, foi-se abrindo caminho no mundo científico, inclusive para se afirmar que a cadeia evolutiva se organiza em função do homem (Frezzatti Junior, 2011).

\subsection{A contribuição da religião para a história dos direitos humanos}

Torna-se oportuno enfatizar que a bíblia tradicional informa a figura de "Deus" como o modelo de pessoa para todos os homens. Que, sem dúvida, o cristianismo teve seu papel de importância, principalmente por ter proclamado o dogma da Santíssima Trindade, que é 
consubstanciar a figura de três pessoas em um único ser. E a pessoa Jesus de Nazaré, que concretizou um modelo ético de pessoa na história, levando sua figura humana aos demais humanos, tornando-o, portanto, um "Deus” mais acessível.

A contribuição da religião da preeminência do ser humano no mundo surgiu com a afirmação da fé monoteísta, ou seja, na crença da existência de apenas um Deus. Então, a bíblia levou para a humanidade a ideia de um Deus único e transcendente. Tendo a transcendência como característica por não estar limitado pelo espaço e pelo tempo, como ocorre no mundo real e, ao mesmo tempo, tendo atributo ou perfeição infinita (Comparato, 2006).

Ainda, destaca-se a importância da difusão cristã a todos os povos, principalmente com a pregação de Paulo Tarso, um legítimo fundador da religião cristã, e a ruptura do cristianismo com o judaísmo. Porém, essa igualdade universal dos filhos de Deus só valia, efetivamente, no plano sobrenatural.

O cristianismo continuou admitindo, durante muitos séculos, a legitimidade da escravidão, a inferioridade natural da mulher em relação ao homem, bem como a inferiorização dos povos americanos, africanos e asiáticos colonizados, em relação aos colonizadores europeus (Hunt, 2009).

Haja vista que, com a descoberta da América, houve uma colonização das terras americanas, por meio de lavradores e missionários. Por isso, um grande número de teólogos começou a disseminar a ideia de que os indígenas não podiam ser considerados iguais em dignidade aos homens brancos.

Um exemplo é o famoso caso de Bartolomeu de Las Casas, um frade dominicano espanhol, também teólogo. Apesar de ser diferente de muitos teólogos da época, com suas ideias humanistas, propôs ao imperador Carlos V, Juan Ginés de Sepúlveda, no concílio de Valladolid em 1550, um debate. Enquanto Bartolomeu defendeu a tese de que todos os homens são criados à imagem de Deus e, portanto, a escravidão deveria ser rejeitada, Sepúlveda defendeu a doutrina aristotélica da escravidão natural, afirmando que os índios americanos eram inferiores aos espanhóis, assim como as mulheres eram seres inferiores aos homens (Nascimento Filho, 2005).

Haja vista que a mensagem evangélica, na sua teoria, discursava, no plano divino, uma igualdade de todos os seres humanos, apesar de suas múltiplas diferenças individuais e grupais. Assim, é possível citar alguns exemplos da difusão destas mensagens cristãs, através de livros bíblicos ou até acervos doutrinários. Como se pode ver há diferenças estruturais quanto às concepções de seres humanos em cada um dos testamentos. No Antigo Testamento, estão expressas determinadas concepções dos seres humanos, assim 
como das relações entre os povos, em especial aos vulneráveis. Já no Novo Testamento, prega-se a igualdade e solidariedade com o semelhante e a preocupação com o bem-estar de todos.

Além disso, as ideias dos filósofos católicos também merecem ser citados, em especial São Tomas de Aquino, que defendeu a igualdade dos seres humanos e a aplicação justa da lei. Ressalte-se que ele foi o mais importante proponente clássico da teologia natural, contribuindo também no desenvolvimento da metafísica e teoria política (Boehner \& Gilson, 2012).

É oportuno destacar que mais tarde a Reforma Protestante do século XVI também colaborou para o fortalecimento dos direitos humanos, quando o poder da autoridade monárquica conseguiu enfraquecer o poder papal, colocando as igrejas nacionais sob o controle do soberano. E, somado a isso, com a evolução das leis, com base no estudo do direito romano, surgem teorias como as de Nicolau Maquiavel (1469-1527), Jean Bodin (1530-1595), Jacques Bossuet (1627-1704) e Thomas Hobbes (1588-1679) ${ }^{7}$.

\subsection{O surgimento dos primeiros diplomas de direitos humanos}

Na Idade Média Europeia, os poderes dos governantes estavam relacionados à vontade de Deus. Contudo, mesmo nessa época de autocracia, surgem os primeiros movimentos de reivindicações de liberdades a determinados estamentos ${ }^{8}$.

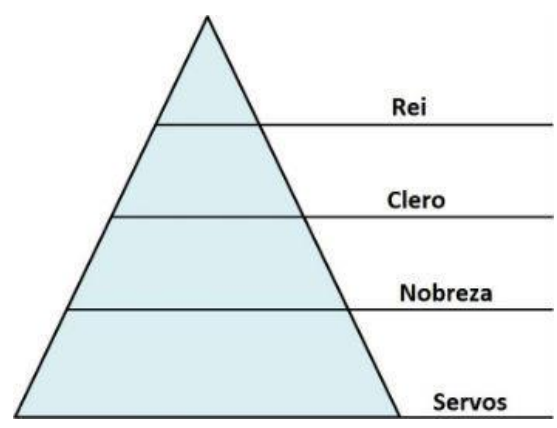

Figura 1: Sociedade Estamental na Idade Média.

Fonte: Figura disponível em https://www.todamateria.com.br/sociedade-estamental/.

\footnotetext{
${ }^{7}$ Esse conteúdo pode ser visto nas matérias de filosofia jurídica, assim como nos livros básicos acadêmicos sobre o tema e são conhecidos como teóricos da monarquia absolutista.

${ }^{8}$ Constitui uma forma de estratificação social com camadas mais fechadas do que as classes sociais, e mais abertas do que as castas, ou seja, possui maior mobilidade social que no sistema de castas, e menor mobilidade social do que no sistema de classes sociais.
} 
Neste período também iniciam os movimentos de reivindicação de liberdades, os quais impulsionaram a criação da Declaração das Cortes de Leão adotada na Península Ibérica em 1188 e a Magna Carta inglesa de 1215. A Magna Carta limitou o poder do Rei João da Inglaterra, que o assinou e seus sucessores, obstando o exercício de um poder pleno. Em consonância com os termos do instrumento, João, conhecido como "João sem terra", que deveria abdicar de alguns direitos, obedecendo aos ditames legais (Piovesan, 1997).

Com a queda da importância dos estamentos, nasce um ideal de igualdade de todos, sendo submetidos ao poder absoluto do Rei, o que não contribuiu para erradicar ou minimizar a opressão e a violência. Pelo contrário, a abrangência do ideal de igualdade não se consolidou e nem mesmo atingiria os domínios ultramarinos das colônias evidenciando-se, por exemplo, a continuidade do extermínio contra os indígenas da América.

Torna-se oportuno destacar que, em alguns momentos na história, o Estado Absolutista começou a ser questionado, em especial, a partir do Século XVII na Inglaterra. Elaboramse cartas e estatutos assecuratórios de direitos fundamentais, tais como: a Petition of Rights (1628), que requeria o reconhecimento de direitos e liberdades para os súditos do Rei; o Habeas Corpus Amendment Act (1769), que anulava as prisões arbitrárias; e o Bill of Rights (1688), o mais importante destas, pois submetia a monarquia à soberania popular; ainda o Act of Settlement (1707), que completa o conjunto de limitações ao poder monárquico do período (Piovesan, 1997).

A queda do absolutismo monárquico iniciou na Inglaterra com a Revolução Gloriosa, em 1688. Na época, Guilherme de Orange havia se tornado rei da Inglaterra, com o nome de Guilherme III, depois de assinar a Bill of Rights, "Declaração de Direitos", em 16 de dezembro de 1689, sendo, portanto, responsável por instituir um governo parlamentar inglês. Ressalta-se que nesta declaração foram impostos limites de atuação do monarca, sendo ele, inclusive, obrigado a se submeter ao que dizia o Parlamento (Ramos, 2017).

Em consequência dessa perda de poder do monarca somado ao crescente protestantismo foi impulsionado um sistema de idealismo baseado no anglicanismo, ou seja, foi introduzido e dialogado como religião oficial, ao ponto de se permitirem todos os credos, menos o católico na Inglaterra.

Com o fim do absolutismo, permitiu-se que as ideias iluministas se perpetuassem no século XVIII, em que se defendeu o predomínio da razão sobre a fé, para o progresso da 
humanidade. Alguns dos atores filósofos e idealistas da época foram John Locke (16321704), Montesquieu (1689-1755), Voltaire (1694-1778) e Rousseau (1712-1778) ${ }^{9}$.

O Iluminismo, que repercutiu na França, instituiu o lema: Liberdade, Igualdade e Fraternidade. Tais ideais fomentaram ainda mais a luta contra as injustiças sociais que eram relevantes na sociedade francesa, bem como em toda a Europa e suas colônias. É de bom alvitre elencar que este momento só foi possível na história pela corrente do liberalismo, que se baseia na defesa da liberdade individual, nos campos econômico, político, religioso e intelectual, contra as ingerências e atitudes coercitivas do poder estatal. Essa liberdade que parecia ser humanitária foi utilizada para se alcançar novos ideais em favor do homem e dos progressos burgueses.

Entretanto, foi na Inglaterra que os diplomas jurídicos começaram a fazer história em âmbito universal. Introduzindo novas interpretações sobre as normas que já existiam, criando novos direitos, como exemplo, a Petition of Right, que surgiu para a proteção dos direitos pessoais e patrimoniais, de 1628, e a Acta de Habeas Corpus, de 1679, que proibiu a detenção das pessoas na falta de um mandamento judicial sendo, portanto, consideradas prisões ilegais e, em 1689, a Declaration of Rights que reafirmou muitos direitos que já estavam consagrados em outros textos legais anteriores (Ramos, 2017).

Assim, outros direitos foram compondo um aspecto jurídico de universalidade, sendo introduzido como Declarações em seus estados. Em 12 de junho de 1776, por exemplo, surge a Declaração de Direitos da Virgínia, o Bill of Rights redigido por George Mason, especificando os direitos do homem e do cidadão. Também como resultado da Revolução Americana, é importante citar a Declaração de Independência de 4 de julho daquele mesmo ano, que considerou certos direitos inalienáveis e destacou expressamente os direitos relativos à vida, à liberdade e à busca da felicidade.

Ressalta-se que, até meados do século XX, o Direito Internacional possuía apenas normas internacionais esparsas, voltadas às questões humanitárias essenciais, sobretudo, referentes à criação da Organização Internacional do Trabalho (OIT), em 1919, que até hoje desempenha papel importante na proteção de direitos trabalhistas. Haja vista, a criação dos direitos humanos estar vinculada à nova organização da sociedade internacional, no pósSegunda Guerra Mundial (1984) ${ }^{10}$, marco dessa nova etapa do Direito Internacional, teve

\footnotetext{
9 As ideias dos autores pertencentes ao Iluminismo aparecem em diversas matérias dentro do tema da Filosofia do Direito.

${ }^{10}$ A ideia também é discutida em Lewandowski, Enrique Ricardo (1984). Proteção Internacional dos direitos humanos na ordem interna e internacional. Rio de Janeiro: Forense.
} 
sua gênese, na Conferência de São Francisco, em 1945, a Organização das Nações Unidas (ONU). O tratado institutivo da ONU foi denominado "Carta de São Francisco".

Um dos pontos que foi introduzido na Carta da ONU, devido à reação à barbárie nazista, foi a inserção do "respeito universal e efetivo dos direitos humanos e das liberdades fundamentais para todos, sem distinção de raça, sexo, língua ou religião”. Assim, foi inserido o compromisso de que todos os Estados-membros pudessem agir em cooperação com a Organização para a consecução dos propósitos enumerados na Carta, com intuito de ser evitada uma nova guerra.

Porém, a Carta da ONU não delimitou quais os direitos que seriam considerados essenciais. Então, foi necessário que, sob a forma de Resolução da Assembleia Geral da ONU, em 10 de dezembro de 1948, em Paris, fosse criada uma Declaração Universal de Direitos Humanos (também chamada de "Declaração de Paris"), que continha 30 artigos que explicitava o rol de direitos humanos que deveriam ser reconhecidos internacionalmente. Nos seus trinta artigos, são enumerados os chamados direitos políticos e liberdades civis (artigos I ao XXI), assim como os direitos econômicos, sociais e culturais (artigos XXII - XXVII).

Em resumo, podemos dizer que os direitos humanos percorreram longo caminho na história da humanidade para se encontrar como se convém conhecê-los nos dias atuais. No caminho percorrido até a consolidação dos direitos humanos ao longo do tempo é sempre tido como fundamental que todos os seres humanos devem ser respeitados e devem ter seu lugar na sociedade. Por isso, as lutas e contradições são importantes como motor da mudança em direção ao bem comum. Os movimentos envolvidos em questões de Direitos Humanos começam suas atividades com caráter combativo às desigualdades e, depois das conquistas desses grupos, tais direitos são normalizados e a sociedade considera o valor da contestação dos movimentos sociais.

Por isso, debater temas ligados à igualdade e direitos humanos deve ser um exercício frequente nas universidades e na sociedade. 


\section{MORAL E DIREITO: CONSTRUÇÃO DA MORALIDADE CRISTÃ VERSUS A APLICAÇÃO DOS DIREITOS HUMANOS}

No século XIX, à época do Império no Brasil, a Igreja Católica era considerada a religião oficial do Estado, de acordo com a Constituição de 1824. Conforme Freston (1994), a primeira Constituição impedia a participação política de não católicos, exigindo que o ocupante de cargos públicos jurasse "manter a religião católica". Porém, somente após o advento da República e o decreto promovido pelo intelectual e político republicano, Rui Barbosa de Oliveira, foi que, em 07 de janeiro de 1890, o Brasil optou pela separação da igreja e do estado e nasceu a Constituição de 1891, inspirada em grande parte por Rui Barbosa, assim como as demais constituições brasileiras do século XX. É o caso da Constituição de 1934, que, apesar da "confiança em Deus" (expresso no preâmbulo pela pressão dos componentes tradicionais católicos, proprietários de terras, padres católicos e homens de negócios conservadores), o art.114, $\S 5^{\circ}$, do seu texto constitucional, estabeleceu a liberdade religiosa.

Assim como ocorreu na Constituição de 1946, ao invocar "proteção divina", estipulou-se a separação da igreja e do estado no seu art. 31, inciso III, que, por conseguinte, tal estado não confessional também não foi renunciado pela então seguinte Constituição 1967$1969^{11}$.

A atual Constituição Brasileira de 1988, considerada a mais democrática que o Brasil já possuiu, ainda na sua promulgação, mencionava em seu preâmbulo "sob a proteção de Deus", repetindo a expressão tradicional no bojo, apesar de em seu texto constitucional proibir expressamente, conforme previsto no seu art.19, inciso I:

É vedado à União, aos Estados, ao Distrito Federal e aos Municípios: estabelecer cultos religiosos ou igrejas, subvencionálos, embaraçar-lhes o funcionamento ou manter com eles ou seus representantes, relações de dependência ou aliança, ressalvada, na forma da lei, a colaboração de interesse público (Brasil, 1988).

Tal como também foi previsto no Capítulo I, "os direitos e deveres individuais e coletivos" como a liberdade de consciência, crença e religião, a prestação de assistência religiosa nas entidades civis e militares de internação coletiva, proibindo privar qualquer dos direitos por causa de crença religiosa ou de convicção filosófica ou política (salvo se as invocar

\footnotetext{
${ }^{11}$ Essa discussão pode ser entendida em Vainer, B. Z. (2010). Breve histórico acerca das constituições do Brasil e do controle de constitucionalidade brasileiro. Revista Brasileira de Direito Constitucional, 16(1), 161-191.
} 
para se eximir obrigação legal a todos imposta ou se recusar-se a cumprir prestação alternativa, fixada em lei).

Assim, longe de acabar com as crenças religiosas, o laicismo estatal, consolidado no século $\mathrm{XX}$, favoreceu a liberdade religiosa e de cultos, e amparou o pluralismo religioso, no Brasil do século XXI. Apenas 7,4\% de cidadãos se declaram não religiosos, ateus ou agnósticos. No início da última década, um número impressionante de 123 milhões de brasileiros se declarava ainda católicos, porém, para a preocupação do Vaticano, está clara a diminuição do número de católicos e o crescimento de pentecostais.

Segundo o Instituto Brasileiro de Geografia e Estatística (IBGE) ${ }^{12}$, em 1970 os católicos constituíam 92\% da população, em 2000 eram 73,6\% e em 2010 haviam passado para 65\%. Ultimamente tem aumentado o número de espíritas, em 2010 tinha 3,8 milhões de adeptos no Brasil (1,9\% da população) e os seguidores das religiões afro-brasileiras do Candomblé e da Umbanda, que passam de seis milhões, e de crentes de 2000 a 10 milhões em 2010. Os crentes são os que têm crescido de forma mais visível, pertencem aos diferentes grupos de protestantes (antigos e recentes), principalmente os pentecostais e evangélicos, devido a influencia estadunidense, passando as diferentes famílias protestantes dos 26 milhões em 2000 a 42 milhões em 2010 (de Souza, 2012).

Vale ressaltar que, apesar de o Brasil viver um Estado democrático de direito regido por uma Constituição que traz em seu bojo um importante princípio como o da igualdade entre homens e mulheres $\left(\mathrm{CF} / 88\right.$, art. $\left.5^{\circ}, \mathrm{I}\right)$, ainda assim isso não é impeditivo para que uma grande maioria de religiosos permita, dentro de suas igrejas, uma estrutura hierárquica e patriarcal, sempre discriminatória com as mulheres.

As tradições religiosas sempre tiveram um grande impacto social e ideológico. Seus líderes, que estão cada vez mais presentes na política, ao entrarem em bancadas parlamentares costumam exercer uma influência ainda conservadora na construção de leis e medidas que se baseiam em seus ideais e princípios; ou na obstrução daquelas que não os contemplam.

O crescimento destas frentes legislativas resulta num declínio da igualdade nas relações de gênero, principais preocupações da ONU - que vem pactuando com o Brasil, dentre outras convenções internacionais, a Convenção sobre a Eliminação de todas as Formas de Discriminação contra as Mulheres (CEDAW).

A CEDAW foi adotada pela Assembleia Geral da ONU, em 18 de dezembro de 1979, e entrou em vigor em 3 de setembro de 1981. Ela dispunha, aos países participantes, sobre o

${ }^{12}$ Os censos do IBGE estão disponíveis em: http://www. ibge.gov.br. 
compromisso do combate a todas as formas de discriminação para com as mulheres. Em 06 de outubro de 1999, foi adotado, em Nova York, o Protocolo Facultativo à Convenção. Ele determina a atuação e define as competências do Comitê sobre a Eliminação da Discriminação Contra a Mulher, na recepção e análise das comunicações recebidas pelos países que fazem parte. O protocolo somente foi aprovado pelo Brasil em 06 de junho de 2002, por meio do decreto legislativo no. 107. Sua promulgação se deu em 30 de julho de 2002, por meio do decreto no. $4.316^{13}$.

\subsection{A história do Direito Constitucional brasileiro sobre as relações entre a Igreja e o Estado}

A etimologia da palavra 'direito' pode ser considerada uma forma de promover abertura de conhecimento e geração de amplitude terminológica. O termo 'direito' também significa 'direção' ou 'dirigibilidade', e a direção de uma sociedade pode ser 'vetorada' por uma elaboração de normas que determinam os rumos daquela (Cretella Junior, 1967).

Sob a égide da história do mundo (vide Roma Antiga e a Grécia de Aristóteles) e da formação dos Estados Nacionais (França de Luís XIV e a Inglaterra de Lancaster), o termo 'direito' estava relacionado ao surgimento de enunciados de ordem filosófica, econômica, social, militar e geográfica úteis à delimitação de liberdades e outras concessões a indivíduos que habitavam um determinado espaço (Pereira, 2004).

O Código de Hamurabi e a Lei de Talião (olho por olho, dente por dente) são passagens históricas da concessão de liberdades e instalação de punições a alguém (Cretella Junior, 1967). Assim, assumiu-se que o Direito, etimologicamente ligado às discussões presentes nas linhas anteriores, consistiu no estabelecimento de regras socialmente aceitas que outrora foram elaboradas por indivíduos dotados de profundo saber e socialmente aceitos para desempenharem tal labor (Telles Junior, 1986).

Assim, o Direito pode ser compreendido como uma elaboração de elementos que delimitam liberdades individuais e/ou coletivas, o que, de certo modo, termina como um controle do Estado sobre as ações promovidas pelas massas sociais ou por algum elemento que esteja contido em tal montante (Telles Junior, 1986).

\footnotetext{
${ }^{13}$ Observatório Brasil da igualdade de gênero. O Comitê CEDAW - Comitê para a Eliminação de todas as Formas de Discriminação contra a Mulher.

Disponível em: <http://www.observatoriodegenero.gov.br/eixo/internacional/instancias-regionais/o-comitecedaw-2013-comite-para-a-eliminacao-de-todas-as-formas-de-discriminacao-contra-a-mulher>. Acesso em 09 de agosto 2016.
} 
O direito brasileiro nasceu disciplinando as relações entre a Igreja e o Estado, notadamente, por meio da primeira Constituição Federal Brasileira de 1824, na qual apareceu patente o confessionalismo cristão da Religião Católica. Haja vista que havia uma intervenção excessiva do clero na política (Cifuentes, 1989). O Art. $5^{\circ}$ da primeira Constituição imperialista faz referência precisa quando menciona a uma religião considerada oficial: “A Religião Catholica Apostolica Romana continuará a ser a Religião do Império. Todas as outras Religiões serão permitidas com seu culto domestico, ou particular em casas para isso destinadas, sem forma alguma exterior do Templo" (Brasil, 1824).

Nessa época, os conflitos sociais eram superados com a ajuda da esfera religiosa, conforme traduz Oliveira Lima (1956), havia uma intromissão do Clero nos partidos políticos, fazendo com que a Igreja se distanciasse do lado espiritual. Ressalte-se que a autonomia religiosa estava em parte presa, ou seja, encarcerada aos ditames normativos jurídicos do Estado, o que, por consequência, permitiu que a Igreja perdesse seu poder de autonomia e o Estado tornasse cada vez mais confessional e menos laico.

Torna-se oportuno frisar que na Constituição imperialista - e nas fases iniciais de sua conquistada autonomia - a Igreja parecia um pouco tímida com as questões sociais como já anteriormente mencionado, o que dificultava seu engajamento para a promoção da cidadania, principalmente no que concerne a questões conservadoras e relações hierárquicas autoritárias (Alves, 1979).

Já a Constituição Republicana de 1891 não positivou o vínculo da Igreja e do Estado, pelo contrário, foi abortiva dessa possibilidade. Conforme previa o art. $72, \S 7^{\circ}$, no qual dizia "Nenhum culto ou igreja gozará de subvenção oficial, nem terá relações de dependência ou aliança com o Governo da União ou dos Estados” (Brasil, 1891). É válido frisar que tal separação partiu de uma luta eclesiástica e não da vontade do Estado e se deu em busca de autonomia - para a igreja não ter que se submeter uma autoridade civil, ou seja, para não manter a servidão em que vivera no Império (Athayde, 1931).

Apesar da Constituição de 1891 ter implantado um regime demasiadamente laico, o qual não faz qualquer menção a Deus (como é presente no preâmbulo na atual Constituição brasileira), tornou o Estado brasileiro laico somente do ponto de vista jurídicoconstitucional, do direito racionalmente legislado, desvinculando-se a realidade social da realidade jurídica. Um exemplo disso foi a eficácia somente do casamento civil no direito Constitucional, apesar da sociedade aceitar o casamento canônico como o verdadeiro matrimônio (Athayde, 1931). 
Não obstante a Constituição Republicana ter dificultado a intervenção religiosa, a Igreja Católica estava livre e com toda a autonomia, tanto para publicar os seus documentos quanto para diversificar o seu trabalho pastoral, inclusive no campo social, sem a ingerência do Estado.

Observa-se que as relações entre a Igreja e o Estado, no Brasil, foram historicamente incoerentes e tumultuosas por suas ideologias e pregações, cada um ardilosamente buscando a seus interesses. E, apesar de muitas vezes parecessem distantes por não pactuarem das mesmas concepções ou ideais, conseguiram sair do regime de separação da Constituição de 1891 para um processo de aliança teísta e religiosa na próxima Constituição a ser promulgada, que foi a de 1934, senão vejamos o que diz seu preâmbulo:

Nós, os representantes do povo brasileiro, pondo a nossa confiança em Deus, reunidos em Assembleia nacional constituinte para organizar um regime democrático que assegure à nação a unidade, a liberdade, a justiça e o bem-estar social e econômico, decretamos e promulgamos a seguinte constituição da república dos estados unidos do brasil, de 16 de julho de 1934 (Brasil, 1934).

Não obstante, seu preâmbulo impulsionador e ao mesmo tempo norteado pelas ideias predominantes da sociedade, aquela Constituição, em seu artigo 17, também trouxe, de maneira expressa e formal, a relação de colaboração recíproca entre ambas.

Assim mencionava:

Artigo 17 - É vedado à União, aos Estados, ao Distrito Federal e aos Municípios:

II - estabelecer, subvencionar ou embaraçar o exercício de cultos religiosos;

III - ter relação de aliança ou dependência com qualquer culto, ou igreja sem prejuízo da colaboração recíproca em prol do interesse coletivo. (Brasil, 1934).

Pode-se afirmar que esta mutação foi prejudicial em garantir o respeito às liberdades e igualdades dos cidadãos, quando se permitiu a ingerência e a consequente influência do religioso na política. A lutada e sonhada garantia do Estado Laico foi preterida, retrocedendo valores libertários em prol da atuação conjunta do religioso em assuntos públicos do Estado.

Destaca-se que até a primeira metade do século XX não houve mudanças significativas na Igreja, até que surgiu o questionamento da importância do "ser cristão", que foi tornando uma magnitude nas discussões sobre a importância de uma atuação social dos defensores 
do ser cristão. Líderes religiosos católicos se viram condicionados a ter um papel social (Bruneau, 1974).

Tais modificações constitucionais permitiram que a Igreja Católica crescesse como Instituição em relação às outras religiões ou crenças. Reavendo seu poder de decisão nos poderes públicos, oportunizou, assim, defender os seus interesses, sob a justificativa do “interesse social ou coletivo" (Bruneau, 1974).

A Constituição de 1937 foi mantenedora dos valores reverenciados pela Constituinte de 1934, vinculada politicamente ao Regime do Estado Novo e outorgada para manter as condições de poder do presidente Getúlio Vargas com a ajuda da Igreja Católica. As mudanças jurídico-constitucionais das relações entre a Igreja e o Estado foram praticamente inexistentes (Fragoso, 1992).

Apesar dessa reconquista do espaço público pela Igreja Católica, o Brasil começou a passar por um cenário de mudanças no campo social e político, convivendo - mais precisamente nos anos 30 e 40 do Século XX - com outras crenças religiosas, como as religiões evangélicas e espíritas, que começavam a ganhar espaço na sociedade brasileira. A Igreja Católica, consequentemente, passou a perder a sua hegemonia. (Emmerick, 2010).

O regime democrático nascido com a Constituição de 1946 não avançou normativamente para diminuir a força da Igreja perante o Estado, apesar de expor os direitos fundamentais de liberdade de consciência e liberdade religiosa, mencionava o casamento religioso com efeitos civis, reconhecia somente a família monogâmica e heterossexual, como autorizava a prática do ensino religioso nas escolas públicas (Sarlet, 2009).

Entretanto, as Constituições de 1964, 1967 e 1969 pouco alteraram o texto da Constituição de 1946, no que diz respeito às relações Igreja/Estado. Apesar de que a Igreja não conjugou ativamente com o Estado às arbitrariedades do poder ditatorial. Ao contrário, devido ao seu compromisso com a causa social e coletiva, foi patrona dos direitos humanos.

Si durante buena parte de la historia, la Iglesia cumplió el rol de unificar e integrar culturalmente a la población, en este periodo se prestaba a impulsar una transformación profunda de la estructura social brasileña. Ahora bien, una mayor o menor simpatía en los ejes pastorales prioritarios de la Iglesia no deberá distraer nuestra 
atención de la lógica que ha subyacido a su modus operandi ${ }^{14}$ (Esquivel, 2008, p.175).

Verifica-se que o discurso religioso com os temas como família, moral, educação, reprodução e planejamento familiar pouco foi alterado. Assim, também suas práticas foram sendo justificadas nos mandamentos morais e religiosos. E com sua participação atuante junto à coletividade, conseguiu aproximação com as camadas sociais mais carentes de proteção estatal, levando e orientando seus dogmas (Tavares, 2016).

Nessa conjuntura histórica nasceu a Constituição de 1988, instituindo tanto a redemocratização quanto um extenso rol de direitos e garantias constitucionais de proteção aos direitos humanos. No entanto, no que diz respeito à separação da Igreja em relação ao Estado, a atual Constituição ainda invocou a proteção de Deus em seu Preâmbulo; continuou colaborando com a religião sob a fundamentação do interesse público, concedendo, inclusive, imunidade tributária a templos de qualquer culto. Ademais, previu o ensino confessional nas escolas públicas, cuja constitucionalidade da educação religiosa (nas escolas públicas) foi reafirmada, no ano de 2017, pelo Supremo Tribunal Federal. Ressalte-se, também, que o casamento religioso se manteve com efeitos civis, resguardando ainda a proteção especial à família (Brasil, 1988).

Conclui-se, portanto, que não houve progresso do direito constitucional brasileiro que fosse capaz de separar as relações formadas entre a Igreja e o Estado, salvo na Constituição de 1891 que, devido aos interesses religiosos da Igreja na época serem mais voltados a lutar por sua autonomia - no que diz respeito ao Estado - do que se unir a ele (o que foi inédito nas demais constituintes brasileiras). No Estado constitucional moderno, as relações entre a Igreja e o Estado só são modificadas quando o interesse político, pautado também nos interesses das grandes religiões, assim almeje essa mudança, caso contrário, não haverá força política de reforma normativa.

\subsection{A igualdade de direitos das mulheres no Brasil, uma história nunca contada}

Escritos bíblicos explicam como nasceu a mulher: a primeira mulher nasceu da costela de Adão, do primeiro e único homem. O objetivo de sua criação era reproduzir, juntamente com Adão, toda a humanidade (Schmitt-Pantel, 2003). Nascida do seu companheiro e

\footnotetext{
14 “Se durante boa parte da história, a Igreja cumpriu o papel de unificar e integrar culturalmente a população, nesse período se prestou a promover uma profunda transformação da estrutura social brasileira. Agora, uma maior ou menor simpatia nos eixos pastorais prioritários da Igreja não deve desviar nossa atenção da lógica que sustentou seu modus operandi’. Tradução livre da autora.
} 
responsável por todas as mazelas e pecados do mundo, sua condição de ser existente estava fadada a ser subordinada e dependente daquele que a gerou.

No Brasil, não diferente das demais regiões, seja em âmbito nacional ou internacional, seguiu-se copiando e condicionando a submissão ao cotidiano feminino, cuja característica que definiu (e ainda define) o ser 'mulher' é a sua dependência à figura do homem, por ser o sexo frágil, emotiva, sensível e influenciada por paixões (Tabak, 2002). A primeira figura da mulher em território nacional é aquela que é considerada índia, observada pela cultura indígena predominante no momento descoberta do Brasil que se deu através da colonização (Souza, 2009).

Nesse momento de colonização existiram as catequeses. O europeu foi de encontro a índios e índias para convertê-los ao cristianismo, sendo, portanto, os índios considerados seres inferiores, diante da cultura europeia (Thomas, 1982). A mulher índia sofrera influência da religião tradicional ocidental, uma vez que os missionários viajantes, recém-chegados à América, entendiam que aqueles comportamentos indígenas (tais como a nudez, o canibalismo e as atitudes considerados erros demoníacos) estavam em processo degenerativo de evolução e que precisavam ser direcionados ao cristianismo.

Esse período na história brasileira foi marcado por uma ideia bíblica que já consagrava a mulher como fraca e suscetível às tentações da carne. Com as observações dos viajantes e missionários às índias brasileiras, acentuam suas perversões sexuais através da nudez e dos comportamentos lascivos que ultrapassavam a consciência trazida pelos europeus, pior ainda, quando praticavam o canibalismo ou uma espécie de ritual de canibalismo que pareciam trazer felicidades e desejos, principalmente pelas índias de mais idade (Priore \& Bassanezi, 2004).

A desigualdade na Colônia Brasileira continuava como forma de repressão à sexualidade feminina, que devia estar atrelada a um modelo de moral concebida pela bíblia e dialogada pela sociedade agora formada pelos estrangeiros que detinham o poder e as normas sociais. O comportamento que se esperava para ser aflorada a sexualidade feminina dependia do consentimento do pai, marido ou irmão que representavam o poder no lar. A Igreja era uma fonte de represália que legitimava esta inferioridade da mulher com relação ao homem. Em São Paulo, na Epístola aos Efésios se demonstra bem essa autoridade masculina no lar:

22 Vós, mulheres, sujeitai-vos a vosso próprio marido, como ao Senhor;

23 Porque o marido é a cabeça da mulher, como também Cristo, a cabeça da igreja; e ele é o salvador do corpo. 
24 De sorte que, assim como a igreja está sujeita a Cristo, assim também as mulheres estejam em tudo sujeitas a seu próprio marido (Carta de Paulo aos Efésios, cap. 5, vs. 21-33).

O Brasil do século XVIII começou a ganhar contornos diferentes. A descoberta do ouro e do diamante significou a manutenção da riqueza lusitana e da vida política. Porém as mulheres daquele século foram excluídas destas oportunidades em que a colônia demonstrava crescimento, como na política ou em qualquer cargo em que pudesse exercer um papel de social. Os ofícios determinavam os papéis dos homens e mulheres nas colônias (Priore \& Bassanezi, 2004).

O século XIX não trouxe significativas mudanças com relação às indiferenças sociais ou desigualdade de gênero, apenas idealizou a família burguesa com um modelo de família ideal, em que o papel ideal da mulher se destina a ser uma mãe dedicada aos filhos e ao marido (Souza, 2009).

O movimento feminista iniciado no século XIX tenta modificar uma história de desigualdades e repressões, recaindo sobre as mulheres uma árdua tarefa em lutar por melhores condições de igualdade (Pinto, 2003). A figura masculina sempre estaria por perto de uma mulher que lhe seria dependente, que decidiria por ela. Sempre o poder de decisão estaria concentrado nas mãos de um homem, seja ela filha ou esposa (Pinto, 2003). Isto seria o conceito de patriarcado, criado e organizado para comandar as mulheres que seriam dependentes e inferiores, devendo, portanto, serem comandadas por homens, inclusive pelos irmãos homens, que também teriam autoridades sobre as mulheres, quando a figura paterna não existisse ou ainda fossem solteiras (Aguiar, 1997).

Uma reconhecida luta global feminista foi contra a divisão sexual do trabalho. Isso porque o papel das mulheres estava atrelado a exercer funções que não eram reconhecidas socialmente ou não remuneradas, como o trabalho doméstico, ou então ocupar papéis sociais dentro da esfera privada, não tendo, portanto, qualificação para ocupar papéis públicos ou de caráter público (Hirata, 2010).

No Brasil, o movimento feminista nasceu no início do século XX, motivado pela busca do direito de escolher seus representantes eletivos. A atuação feminina motivou a criação de um Partido Republicano Feminino, que foi fundado em 1910, cujo objetivo era reivindicar o direito de voto da mulher (Pinski \& Pedro, 2010). O que se pretendia pelo movimento feminista era exercer o direito de cidadania, lutar em busca de ter os mesmos direitos que os homens, como o direito à educação e à sexualidade, combatendo as desigualdades de gênero. 
Um nome de peso nesta luta feminista foi da líder Bertha Lutz, bióloga, foi uma das pioneiras do movimento feminista no Brasil, responsável por ações que garantiram direito de voto às mulheres no início do século XX. Líder da Federação Brasileira pelo Progresso Feminino impulsionou vários Estados brasileiros a fazerem parte desta organização, cuja luta ganhou notoriedade no Brasil. E permitiu que a prerrogativa do voto fosse conquistada pela mulher brasileira (Alves, 1980).

Porém, em 1928, quando ocorreria a primeira eleição em que as mulheres iriam participar votando, a eleição fora anulada, pois não havia uma lei especifica que disciplinasse o direito de voto das mulheres. Para reverter o triste episódio, em 1929, o Rio Grande do Norte elegeu a primeira mulher a ser prefeita, na cidade de Lages, Alzira Soriano.

No ano de 1930, um projeto de lei começou a tramitar com o intuito de se regulamentar o direito de voto das mulheres, que não obteve qualquer sucesso, em razão da Revolução de 1930, movimento armado, liderado pelos estados de Minas Gerais, Paraíba e Rio Grande do Sul, que culminou no golpe de Estado: o Golpe de 1930, que depôs o presidente da república Washington Luís, em 24 de outubro de 1930, e impediu a posse do presidente eleito Júlio Prestes, fazendo com que a luta feminista ficasse estagnada, ou seja, a perda do mandato do presidente à época impulsionou o legislativo a deixar de lado a discussão. Após a instauração da nova república, o projeto voltou a ser visto e agora discutido por juristas encarregados de elaborar um novo código eleitoral, dentre eles, Bertha Lutz (Alves, 1980).

Portanto, somente em 1932, no governo de Getúlio Vargas, firmou-se a prerrogativa em que as mulheres teriam legalmente o direito ao voto - portanto, não obrigatório. Somente com a promulgação da Constituição de 1934 é que o voto feminino se tornou uma obrigação.

Apesar de o feminismo no Brasil ter se utilizado de modelos que estavam fora do Brasil, como o movimento latino-americano, ele ainda assim resistiu de forma diferente por nascer em meio à ditadura militar, cujo cenário de desigualdade ainda era pior, com várias restrições a direitos, num período que dificultava as atuações das organizações coletivas, principalmente se estas tivessem opostas à militarização (Simões, 1985).

A partir de 1975, mesmo no período de ditadura, iniciou no Brasil o movimento feminino pela anistia, para que as mulheres que tinham sido exiladas durante o período de ditadura militar retornassem ao seu país, o que colaborou para que suas formas de enxergarem o papel feminino na Europa e na visão norte-americana pudesse ser introduzida no Brasil (Simões, 1985). A partir daí se percebe que o cenário de timidez causado pela censura militar abre espaço para debates mais abertos. 
O feminismo acaba se perpetuando e, em 1980, torna-se ainda mais sedimentado em virtude da redemocratização, tornando-se um Estado Democrático de Direito. Possibilitando que os interesses políticos e sociais das mulheres pudessem ganhar mais força para lutarem em prol de seus direitos, criando inclusive laços partidários (Teles, 1993).

Com nova Constituição Federal de 1988, promulgada e democrática, elencou novos direitos que possibilitassem a igualdade e proteção da mulher, dando ela um conceito diferente no espaço social em que vivia.

Anos mais tarde, em 1994, o Brasil assinou o documento da Convenção Interamericana, visando prevenir, erradicar e punir a violência contra a mulher e, em 2006, nasceu a lei 11.340/06, chamada Lei Maria da Penha, nome dado em homenagem à Maria da Penha Maia Fernandes, mulher que lutou cerca de vinte anos para que seu agressor fosse preso, colaborou para que a violência contra a mulher passasse a ser tratada como um crime de potencial ofensivo. Mesmo tendo sido criadas leis para tal problema, a violência contra mulheres continua sendo um dos crimes de maior incidência no Brasil (Knippel \& Nogueira, 2010).

O direito das mulheres pode ter sido sedimentado na teoria política e na teoria jurídica, mas na realidade nua e crua no Brasil vão se reformulando novas teorias para se compreender a desigualdade ainda existente, o que requer uma atenção para as indagações que continuam existindo no cenário brasileiro, como a presença do patriarcado, a desigualdade de gênero e, por conseguinte a violência contra as mulheres.

Por se tratar de uma mazela arraigada na sociedade, o seu combate é lento, como se perceber quando Heleieth Saffioti (2004) inicia sua obra falando de teorias feministas, e explica que, por mais que se busque igualdade entre mulheres e homens, existe um domínio, uma exploração patriarcal ainda arraigada na sociedade brasileira. A mulher para conseguir mudar esse cenário precisaria aceitar que é dominada em detrimento do sistema capitalista.

Num trabalho realizado pela Fundação Perseu Abramo realizado por seus pesquisadores que entrevistaram entre $25 \%$ e $30 \%$ das mulheres, em cinco macrorregiões do Brasil e a mesorregião, realizando 2052 entrevistas em 24 estados brasileiros foi possível constatar que $57 \%$ das mulheres ainda vivem uma relação submissa considerando a proximidade familiar. A maioria não consegue perceber que estão submetidas diariamente à violência doméstica, bem como à de gênero e a intrafamiliar. E, mesmo que o Estado ofereça o aparato das Delegacias especializadas da mulher, poucas se utilizam desse serviço. 
Dentre os vários modos de fazer-se presente, a desigualdade no Brasil está no tratamento diferenciado entre trabalhadores e trabalhadoras e suas remunerações (Martinez, 2008). Lauretis (1987) explica que esta desigualdade é alimentada pelas tecnologias que reforçam as diferenças de gênero como cinema, discursos institucionais, epistemologias e práticas críticas.

No Brasil, são vários os tipos de violência que são praticadas contra mulheres. A violência de gênero, que consiste em qualquer ação ou conduta, baseada no gênero, que cause morte, dano ou sofrimento físico, sexual ou psicológico à mulher, seja no âmbito público ou privado. É uma manifestação de relações de poder, do homem sobre a mulher (Andrade \& Fonseca, 2008).

A violência intrafamiliar, que se caracteriza por todo tipo de ação ou omissão que afete de maneira negativa o bem-estar, a integridade física, psicológica ou a liberdade e o direito ao pleno desenvolvimento de outro membro familiar, podendo ser cometida dentro ou fora de casa por um membro da família, incluindo pessoas que passam a assumir função parental, mesmo que sem laços de consanguinidade, e relação de poder sobre a outra pessoa.

A violência doméstica que se difere da violência intrafamiliar, porque inclui outros membros do grupo, sem ter função parental, mas que convivem no mesmo espaço doméstico. Ressalta-se que no Brasil, apesar de milhares de mulheres e meninas sofrerem diariamente com esse problema, muitas não denunciam seus agressores. Mesmo assim, alguns dados da Central de Atendimento, o Ligue 180, que é número da Central de Atendimento à Mulher em Situação de Violência, registrou um aumento de $133 \%$ nos relatos envolvendo violência doméstica e familiar, isso só no primeiro semestre de 2016, em comparação ao mesmo período em 2015. Dentre todas as denúncias, 59,71\% das vítimas são mulheres são negras (Cristaldo, 2016).

A violência física contra a mulher é uma violência que ocorre comumente quando uma pessoa está em relação de poder (superioridade) contra a vítima e nesta situação tenta ou causa algum dano de natureza não acidental, através do uso da força física ou de algum tipo de arma que possa ou não provocar lesões externas, internas ou ambas. No Brasil, não só ocorre esse tipo de violência contra a mulher, mas várias outras, como é o caso da violência sexual, que compreende um leque de atos ou tentativas de relação sexual sob coação ou fisicamente forçada, tanto no casamento quanto em outras relações.

Além dessas, existem outras, que apesar de não ir para as vias de fato, conseguem diminuir, desvalorizar, prejudicar a autoestima da mulher, tal como a violência psicológica, sem descartar a violência patrimonial, que é ato destrutivo ou de omissão, afetando o bemestar e a sobrevivência da pessoa, causando danos de cunho patrimonial. 
A violência institucional, apesar de pouco discutida, é bastante presente no país, é aquela praticada pelas instituições públicas. Ocorre quando a mulher, ao ir em busca de ajuda junto às autoridades públicas, essas são omissas ou não preservam a intimidade daquela. Às vezes, sequer ajudam a resolver problema, tratando-a com descaso e até mesmo, preconceito $^{15}$.

Em 2014, foi realizada uma amostra da violência brasileira com 2.046 entrevistas, em 05 regiões, com mulheres e homens entre 16 a 24 anos. Segundo essa pesquisa, realizada pelo Instituto Avon em parceria com o Data Popular, 3 em cada 5 mulheres já foram vítimas da violência em relacionamentos, sendo, em sua maioria, relacionada à agressão física (Instituto Avon/Data Popular, 2013).

Haja vista que poucos admitiram existir ações violentas nos relacionamentos, somente $8 \%$ das mulheres responderam sofrerem violência do parceiro, enquanto $4 \%$, dos homens, apenas, admitiram que já praticaram violência contra a sua parceira. Entretanto, quando mudam as ações da violência, $66 \%$ das entrevistadas afirmaram já terem sofrido algum tipo de violência do parceiro e 55\% dos entrevistados assumiram haver praticado violência contra a parceira ${ }^{16}$.

Compreendendo os vários tipos de violência que são praticadas contra as mulheres, podese concluir que está presente em seus cotidianos um tratamento não só cruel, mas grave e atentatório às condições de igualdade das mesmas no Brasil.

\subsection{Estudos realizados sobre Direitos Humanos, Religião e Gênero}

No Brasil, tais temáticas têm sido abordadas em diversas dissertações e teses de doutorado. Trata-se de um estudo multidisciplinar, passível de ser estudado por vários campos do conhecimento, conforme apresentaremos a seguir.

Azevedo (2004), em sua obra intitulada “A Igreja Católica e seu papel político no Brasil”, analisa o papel político da Igreja Católica Apostólica Romana no país, por meio da CNBB, em seu relacionamento com o Estado e com a sociedade civil. Suas bases teóricas

\footnotetext{
${ }^{15}$ No dia 23 de novembro de 2016, uma jovem sofre abuso sexual em um cinema de Recife. A vítima ainda enfrentou descaso por parte de policiais e teve que relatar o caso para 05 homens. Jovem sofre abuso sexual em cinema de Recife. (2016, 30 de novembro) R7 Notícias (versão digital). Notícia na integra disponível em: http://noticias.r7.com/cidades/jovem-sofre-abuso-sexual-em-cinema-de-recife-30112016.

${ }^{16}$ Pesquisa Instituto Avon / Data Popular (2014). Violência contra a mulher: o jovem está ligado?.versao: 02.12.2014. Disponível em: http://agenciapatriciagalvao.org.br/wpcontent/uploads/2014/12/pesquisaAVONviolencia-jovens_versao 02-12-2014.pdf.
} 
inspiram-se na corrente renovadora da Igreja, legitimada pelo Concílio Vaticano II (19621965).

Ressalta que a Igreja, diferentemente do passado, não exerce o poder de forma direta, pois possivelmente não conseguiria, diante da consolidação do processo democrático e do pluralismo religioso. Acredita que em um primeiro momento, age de modo a influir na política (como um todo) e nas políticas públicas, com base em sua mensagem religiosa e sociopolítica. E, em segundo lugar, esse papel é resultante de todo um processo ideológico e histórico da construção de uma identidade específica e própria da Igreja.

Lafer (1995), em sua obra intitulada "A ONU e os direitos humanos", expõe a Carta da ONU que pretende preservar, das guerras, as futuras gerações. Fala sobre a evolução da teoria jurídica, que teve seu norte em dois planos: a) Plano Interno dos Estados, que era uma maneira nova de se pensar a política, cuja preocupação primordial era o bom governo e a figura principal eram os governantes; b) No plano internacional, a evolução foi mais lenta, porém gerou um tema global, no qual os direitos humanos passaram a ser encarados como a busca pela paz no mundo.

O mesmo autor explica os três paradigmas que surgiram no plano internacional: o pensamento hobbesiano-maquiavélico, caracterizado pelo estado de guerra de todos contra todos, em que as regras básicas da vida internacional são a prudência e o expediente, pois a política internacional é, tão somente, a política do poder; o pensamento grociano, que diz que a existência na sociedade internacional depende de "um jogo de toma-lá-dá-cá" e abrange um processo de interesse recíproco dos Estados e de suas populações; e o kantiano, que, além do modo grociano de ver a cooperação interessada, admite a inserção da razão abrangente do ponto-de-vista da humanidade, que afirma que o problema da paz não diz respeito somente aos países envolvidos em um conflito, mas a todos os membros da Liga das Nações ${ }^{17}$.

Lafer (1995) traduz o surgimento dos princípios como o direito dos Estados de exercerem proteção internacional com relação a seus estados nacionais. Buscou-se, nas ideias kantianas, o direito à hospitalidade universal, no qual nenhum ser humano pode gozar de dignidade, diante da soberania estatal. Elenca que a Declaração Universal dos Direitos

\footnotetext{
${ }^{17}$ Para saber mais sobre Kant nesta temática, ver Cabral, João Francisco Pereira (2017). Kant e o Idealismo Transcendental. Brasil Escola. Disponível em <http://brasilescola.uol.com.br/filosofia/kant-idealismotranscendental.htm>. Acesso em 23 de abril de 2017; e Krassuski, Jair Antônio (2005). Crítica da Religião e o sistema em Kant: um modelo de reconstrução racional do cristianismo. Porto Alegre: EPIPUCRS (Coleção Filosofia, 189).
} 
Humanos, adotada em 1948, além dos direitos civis e políticos, incorpora os direitos econômicos, sociais e culturais, que constituiu uma manifestação clara de repúdio aos regimes totalitários. Fala sobre a atuação da ONU que passa a controlar com manipulações políticas, algumas vezes, as situações que não eram vistas como metas para resolver as questões dos países em desenvolvimento.

Vale ressaltar que assuntos como fatores históricos e religiosos foram reconhecidos em caráter universal pelos direitos humanos. É mencionado que a Carta estabeleceu diretrizes mais precisas na área dos direitos humanos, para a construção de um sistema internacional, em que a política e a ética deixassem de ser esferas independentes. Em sua obra, explica que a globalização tem agravado as desigualdades sociais entre países ricos e pobres, aumentando o número de excluídos, por isso, a ONU atua fortemente na busca de ideais éticos (em geral) e dos direitos humanos (em particular). Essas características derivam dos princípios expressos em sua Declaração, porém o seu reconhecimento como legítimo na proteção dos direitos humanos, ainda é uma variável, que somente o tempo poderá dizer se acontecerá ou não.

Comparato (2017), em sua obra intitulada "A afirmação histórica dos direitos humanos", explica sobre a percepção da dignidade da pessoa humana. Fala sobre solidariedade humana em três dimensões, dentre essas, as sucessivas gerações na História, sobre surgimento dos direitos humanos, que teve seu início por volta do século VI a.C. Porém, mais tarde, tanto a democracia de Atenas quanto a república romana, foram aniquiladas pelo imperialismo que se instalou a partir século IV a.C. A Idade Média, que trouxe consigo várias transformações.

Como marco da História Moderna, o autor faz uma associação à Revolução Francesa e à Revolução Americana, como baliza do fim do absolutismo e dos privilégios da nobreza. Por intermédio da Constituição Mexicana e da Constituição de Weimar, é que foram positivados os direitos sociais e econômicos.

Nesta sequência histórica, Comparato (2017) fala sobre a efetivação dos direitos humanos no plano internacional, no campo humanitário. O primeiro documento a ser redigido foi a Convenção de Genebra, em 1864. Explica que em defesa dos direitos dos trabalhadores, em 1919, criou-se a Organização do Trabalho (OIT). O autor segue comentando sobre a evolução dos direitos humanos ao falar da Declaração dos Direitos Humanos, redigida em 1948 sob o impacto das atrocidades cometidas durante a Segunda Guerra Mundial. Traz uma reflexão acerca da existência de uma hierarquia entre direito internacional e direito interno, ao abordar a declaração de 1948, que proclamou os três princípios fundamentais de direitos humanos, como liberdade, igualdade e fraternidade. 
Em seu trabalho, apresenta o princípio de ordem estrutural dos direitos humanos, considerando que esse se dá em duas espécies: irrevogabilidade e complementariedade solidária; e enfatiza a importância dos processos históricos e seu significado na evolução das garantias de tais direitos, da amplitude das conquistas e da importância de permanecer em constante luta para tê-los respeitados.

Alves (2005), em sua obra intitulada “A declaração dos Direitos Humanos na PósModernidade", discute a paradoxal situação dos direitos humanos no tecido socioeconômico da contemporaneidade, e nos terrenos sempre movediços das relações mundiais. Tendo como horizonte os movimentos políticos, sociais, econômicos e culturais ocorridos nos últimos anos, penetra em seus meandros para distinguir os múltiplos fatores que ameaçam a legitimidade do que foi formalmente universalizado pela Conferência de Viena de 1993.

Sua análise traz à luz os eternos óbices à plena instauração e vigência dos direitos humanos, tais como os decorrentes de políticas do poder, do arbítrio autoritário, de preconceitos arraigados e da exploração econômica. Nesse exame, ganham particular destaque as novas tribulações que, na atualidade, são introduzidas pelas práticas da globalização, ao mesmo tempo, que são geradas no próprio seio dessa época de crise de valores e troca de paradigmas, tida como pós-moderna.

Alves (2005) insere o leitor no próprio âmago da controvertida problemática dos referidos direitos, ao colocar os acontecimentos cotidianos de impacto mundial, as consequências do viver com medo devido aos ataques terroristas e do viver sem dignidade e liberdade devido às xenofobias, aos dilemas das discriminações de todo tipo e aos efeitos corrosivos da globalização cega.

Trindade (1997), em sua obra intitulada "Dilemas e desafios da Proteção Internacional dos Direitos Humanos no limiar do século XXI", faz um balanço dos avanços conceituais e práticos e das limitações ainda existentes, de ordem legal ou política, à proteção universal dos direitos humanos, ressaltando a construção progressiva dos instrumentos disponíveis, como as convenções centrais, e o papel das conferências e das cortes regionais de defesa dos direitos humanos.

Comparato (2006), em sua obra intitulada "Ética: direito, moral e religião no mundo moderno", faz uma reflexão histórica desde os primórdios até o requintado capitalismo financeiro global de hoje. A humanidade experimentou um progresso notável. Mas, explica que, nesse caminhar da humanidade em direção ao futuro, calcado, sobretudo, no avanço tecnológico e científico, rompeu-se com valores do passado e se negligenciou as questões éticas. 
Globalizados e desiguais como nunca, é imperativo para a sobrevivência da humanidade que haja um pensar num programa de reconstrução ética do mundo: quem somos nós, afinal, e o que faremos com nossa capacidade crescente de interferir na biosfera e na evolução do gênero humano? Em busca de respostas para essas questões decisivas, a obra revisita o sistema ético do mundo antigo, bem como o nascimento da filosofia e do monoteísmo, responsáveis por sua transformação. Em seguida, dedica-se aos conflitos ideológicos e institucionais que tiveram início no século XVI, examinados à luz do pensamento filosófico de Hobbes, Locke, Rousseau, Hume, Kant, Hegel e Marx - dentre outros - não sem contemplar ainda a trajetória de vida de figuras modelares, como São Francisco de Assis e Gandhi.

Por fim, Comparato (2006) busca fixar os princípios e as instituições que deverão nortear a fundação do que chama de "sociedade universal do gênero humano", que é uma sociedade em que, aliada à técnica, a ética há de indicar o caminho da plenitude da vida e de uma igualdade maior entre os homens.

Dallari (2010), em sua obra intitulada "Direitos humanos e cidadania", oferece conceitos de cidadania e ordem democrática e suas origens históricas, os direitos humanos em geral e os direitos em espécie. Contempla a expressão "Direitos humanos" como uma forma abreviada de mencionar os direitos fundamentais da pessoa humana. Ensina que a afirmação da igualdade não quer dizer igualdade física nem intelectual ou psicológica. $\mathrm{O}$ autor justifica a afirmação primeira de que a pessoa humana é essencialmente a mesma em toda parte e representa um valor acima de qualquer outro.

Embora todas as pessoas sejam detentoras de direitos - que devem ser garantidos e preservados - nem sempre foi clara a consciência da amplitude desses conceitos, sobretudo nas sociedades que mantêm privilégios e excluem grande parte dos trabalhadores e mulheres dos benefícios da cidadania. Além de um histórico das conquistas essenciais para o convívio democrático, o autor descreve os direitos fundamentais de todo ser humano, tais como o direito à vida, à liberdade, à igualdade de oportunidades, à moradia, ao trabalho decente, à educação, à saúde, à participação do poder, entre outros. A consciência e a proteção desses direitos é condição para uma sociedade mais justa, constituída de indivíduos mais felizes.

Natividade (2006), em sua obra intitulada "Homossexualidade, gênero e cura em perspectivas pastorais evangélicas”, focaliza as formas de regulação da sexualidade do ponto de vista das pastorais evangélicas, a partir da análise de textos normativos. $\mathrm{O}$ autor discute ainda a noção de cura da homossexualidade. O material etnográfico é composto por livros e artigos brasileiros e estrangeiros, selecionados a partir do mapeamento do universo 
editorial evangélico e do monitoramento do conteúdo de sites que oferecem aconselhamento e tratamento a homossexuais, em uma perspectiva religiosa. Os dados foram coletados entre 2003 e 2004.

Rosado (2001), em sua obra intitulada "O impacto do feminismo sobre o estudo das religiões", analisa os diversos estudos de forma cronológica sobre a temática do feminismo e religião. Discute sobre a ausência do feminino dentro da temática religiosa e observa a produção acadêmica nesse campo.

Debate as posições que a mulher ocupa dentro do espaço religioso e como isso é reflexo do mundo social. Conclui que, também, a religião é uma forma de controlar a mulher. Por fim, a autora fala sobre a contribuição das feministas nesse campo de produção científica.

De Souza (2004), em sua obra intitulada "Gênero e religião nos estudos feministas", explica que gênero e religião compõem uma equação ainda pouco discutida e pouco admitida. No campo dos Estudos Feministas, essa relação ainda é abordada de forma muito acanhada. As iniciativas de estudo dessa temática são bastante escassas, especialmente no que tange à publicação de periódicos específicos a esse respeito.

Duas das revistas acadêmicas feministas mais expressivas do Brasil, como a Revista Estudos Feministas e Cadernos Pagu têm sido um espaço importante de discussão dessa temática. Outra publicação que se destaca nessa área é a própria Revista Mandrágora, uma revista específica sobre Estudos Feministas e Religião.

Natividade (2016), em sua obra intitulada "Uma homossexualidade santificada? Etnografia de uma comunidade inclusiva pentecostal", explica sobre as igrejas no país que se autodenominam "inclusivas", espécie de movimento noticiado pela mídia entre os anos 1990 e 2000, como "igrejas gays". Fala sobre o surgimento, no Brasil, da Igreja da Comunidade Metropolitana, uma famosa denominação ativista, criada em 1968, nos Estados Unidos, e sua transformação em Igreja Cristã Contemporânea.

O autor analisa como ela se consolidou a partir de influências locais e de um diálogo com ideias de sistemas religiosos do campo hegemônico. Argumenta que a implantação desse grupo compreende coloridos regionais, fornecidos por noções oriundas de passagens e mediações realizadas pelos sujeitos entre suas comunidades de origem e uma nova alternativa religiosa (Natividade, 2016).

Sarti (1988), em sua obra intitulada "Feminismo no Brasil: uma trajetória particular", busca trilhar os caminhos particulares do movimento de mulheres no Brasil (a partir dos anos 1970), do qual o feminismo é uma das facetas. A análise considera as características da sociedade brasileira, fundamentalmente desigual e o contexto de autoritarismo político, do qual emergiu o movimento. Ele adquire, assim, feição própria, tendo um caráter 
interclasse e uma forte tendência política, em relação às questões mais específicas da mulher. Essas ganham espaço posteriormente, nos anos 1980, início do processo de redemocratização.

Louis (2006), em sua obra intitulada "Diga-me: o que significa gênero?”, procurou definições da palavra gênero como esse vocábulo vem sendo usado atualmente, especialmente nas pesquisas em ciências sociais e no campo político, decifrando que as duas esferas, nesse caso, em particular, são indissociáveis. E, para maior precisão, concluiu que o feminismo não poderia ser um argumento para invalidar, legitimamente, o fundamento da crítica ao gênero. Ao contrário, o feminismo seria um convite para uma rigorosa redefinição dos termos empregados por feministas, por todos e todas que produzem no campo das múltiplas relações.

\subsection{A Religião Cristã e seu discurso}

A Religião Cristã sempre foi investigada por vários pesquisadores que tinham curiosidade de entender ou mesmo justificar seu poder de dominação, sejam pelas suas normas, ideologias, sua cultura ou até mesmo seu discurso. Alguns doutrinadores foram fazendo suas teorias com base nas interpretações advindas de várias óticas assimiladas, observando este direcionamento cristão que foi tomando um rumo perspicaz no decorrer da história, agregando valores e adeptos.

Alguns sociólogos, filósofos ou antropólogos, preocupados com as distintas formas de dominação simbólica que se manifestam nos diversos âmbitos que constituem o mundo social, dedicaram-se à análise das relações de poder. Dentre estes campos de estudo, pesquisaram a Religião.

Ressalte-se que o trabalho antropológico sobre religião foi iniciado a partir da II Guerra Mundial. Intelectuais como Durkheim, Weber, Freud ou Malinowski, ainda embasam os trabalhos científicos. Assim, explica Geertz (1989):
A discussão de Durkheim sobre a natureza do sagrado, a metodologia Verstehenden de Weber, o paralelo de Freud entre rituais pessoais e coletivos, e a exploração feita por Malinowski sobre a diferença entre religião e senso comum — parecem-me pontos de partida inevitáveis para qualquer teoria antropológica da religião que seja útil (Geertz, 1989, 66).

Campos e Gusmão (2010) analisam o conceito de religião proferido pelos clássicos das ciências humanas, como Marx e Émile Durkeim. Marx defendia que a religião era uma forma de falsa consciência para convencer as classes trabalhadoras a não se revoltarem em 
busca de seus próprios interesses contra a classe proprietária. Já para Émile Durkheim, a religião tinha o papel de exercer uma função conciliadora com os interesses da sociedade no bem-estar coletivo, pois, mais importante seria compreender a capacidade deste fenômeno religioso em se transformar e adaptar-se à nova época.

Destaca-se que o conceito de cultura religiosa se traduz mediante símbolos, que permitem a comunicação. Os símbolos sagrados servem para sintetizar o ethos $^{18}$ de um povo, sobretudo na crença e na prática religiosa. Tais crenças apoiam-se em sentimentos morais, que conseguem estabelecer uma congruência entre um estilo de vida particular e uma metafísica específica. Numa visão mais ampla Geertz (2008) afirma que "a religião ajusta as ações humanas a uma ordem cósmica imaginada e projeta imagens da ordem cósmica no plano da experiência humana não é uma novidade" (Geertz, 2008, 68).

Ainda segundo a mesma obra, a religião é, portanto, “uma operação em dois estágios: no primeiro, uma análise do sistema de significados incorporado nos símbolos que formam a religião propriamente dita e, no segundo, o relacionamento desses sistemas aos processos socioestruturais e psicológicos" (Geertz, 2008, 91). As palavras refletem bem o significado do discurso de um líder religioso. Elas traduzem uma realidade predominante para se manter uma ordem social de acordo com os seus ditames.

Esse "poder do símbolo" faz com que se mantenham estruturas e ideologias de pensamento. E, por conseguinte, o discurso está para além do que simplesmente 'se diz', a figura do líder assume um papel não só simbólico, mas também representativo. Bourdieu (2004) define que:

No estudo do campo em que se vê o poder por toda a parte, como em outros tempos não se queria reconhecê-lo nas situações em que ele entrava pelos olhos dentro, não é inútil lembrar que (...) é necessário saber descobri-lo onde ele se deixa ver menos, onde ele é mais completamente ignorado, portanto reconhecido: o poder simbólico é, com efeito, esse poder invisível, o qual só pode ser exercido com a cumplicidade daqueles que não querem saber que lhe estão sujeitos ou mesmo que o exercem (Bourdieu, 2004, 7-8).

Isso significa que, quando se profere um discurso pode existir por trás dele todo um arcabouço de símbolos que irão legitimar uma linguagem. Essa linguagem pode justificar e responder às questões sociais como das desigualdades, injustiças, privilégios, fazendo com

\footnotetext{
${ }^{18}$ Segundo Geertz $(2008,94)$ o "ethos de um povo é o tom, o caráter e a qualidade de vida, seu estilo moral e estético e sua disposição, é atitude subjacente em relação a ele mesmo e ao seu mundo que a vida reflete".
} 
que a sociedade possa incorporar inconscientemente tais ideias como verdades e, por repetição, terminam se adaptando às ideias daquela linguagem religiosa ao seu próprio modo de vida e a religião, por sua vez, utiliza-se de sua legitimidade para manter a realidade daquele mundo que foi socialmente construído por ela (Berger, 1985).

Daí a importância de se analisar ideologias que buscam reafirmar uma condição de sistema religioso hegemônico, como vem fazendo a religião cristã, quando ela se apresenta através de protótipos, como sendo os padrões ideais a serem seguidos. A religião legitima as instituições, infundindo-lhes um status de validade suprema (Berger, 1985).

\subsection{A Religião e a Política}

Para os cristãos, o livro da vida é a Bíblia Sagrada. Dividida em Antigo e Novo Testamento. É o guia do Cristianismo. Seu ser supremo, Deus, criou em seis dias o universo e a vida. No sétimo dia, descansou. A descrição da origem da vida encontra-se no Gênesis $^{19}$. Os primeiros seres, Adão e Eva, soprados à vida por Deus, foram postos a conviver no Jardim do Éden, sob a vigilância dele (Silva, 2014).

Ambos carnais, Adão e Eva estavam submetidos ao conflito entre a satisfação pessoal e os parâmetros divinos que regem o existencial. Nesse contexto, não há a presença de uma religião, pois, à época do Éden, não existia o Cristianismo, somente a presença da própria divindade. Não há que se falar em política nessa situação. Deus, permitindo a discricionariedade de conduta no paraíso, não submeteu o casal às suas leis, mas às consequências das transgressões.

Tomando a Bíblia Sagrada como referência, pode inferir-se que Deus dá liberdade de escolha ao homem, propondo a ideia de que a religião não pode encabrestar um indivíduo, ao contrário, guia-lo pelo melhor caminho, estratificando as consequências de decisões e escolhas.

\footnotetext{
${ }^{19}$ Gênesis é o primeiro livro da Bíblia cristã, que é uma coleção de textos religiosos de valor sagrado para o cristianismo, em que se narram interpretações religiosas do motivo da existência do homem na Terra. É considerada pelos cristãos como divinamente inspirada, tratando-se de importante documento doutrinário. A Bíblia é dividida em duas partes: o Antigo e o Novo Testamento. O primeiro, na versão aceita de forma geral por protestantes e judeus, apresenta a história do mundo desde sua criação até os acontecimentos após a volta dos judeus do exílio babilônico, no século IV a.C. O Novo Testamento apresenta a história de Jesus Cristo e a pregação de seus ensinamentos, durante sua vida e após sua morte e ressurreição, no século I. A Bíblia não era dividida em capítulos até 1227, quando o cardeal Sthepen Langton os criou, e não apresentava versículos até ser assim dividida em 1551 por Robert Stephanus. O primeiro Testamento tem 27 livros e o segundo possui 39.
} 
A igreja possui um poder de influência bastante difuso, tendo expressividade em todas as camadas sociais, independente do grau de instrução, salientando que há uma quantidade relativamente expressiva de intelectuais no mundo que optam pelo ceticismo. Tal detalhe acerca do ceticismo sempre existiu na história dos povos, pois quanto mais um homem não doutrinado por uma religião se mistura ao conhecimento, mais longe da 'polarização religiosa' desenvolvida em uma sociedade ele fica (Lopes, 2008).

Nas sociedades primitivas, o homem fazia uso da religião para preencher o vazio espiritual que lhe tomava o ser ou como medida protetiva às ameaças que atingiam o psíquico. Explica Geertz que só o homem dá significado às coisas, que busca interpretar o mundo em que vive e essa necessidade humana de dar sentido à experiência vivida é tão premente quanto suas necessidades biológicas. Então, ele é incapaz de viver em um mundo que não faça sentido (Geertz, 1989), por isso a religião se faz necessária nesta construção de percepções de si.

Para os povos mais primitivos, a religião não consistia em uma prática direcionada a um deus específico - o monoteísmo - mas, forças da natureza que 'demonstravam' poder, como as tempestades. Os gregos atribuíam vários fenômenos terrenos a diversos deuses, sendo Zeus o mais expressivo (Funari, 2012). ${ }^{20}$

As religiões possuem grande poder de polarização nas sociedades, uma vez que acabam ditando os valores e costumes locais em todas as sociedades. Um caso bastante visível é o Islamismo que é também um código de conduta de seus seguidores.

Na Mesopotâmia, que significa "terra entre rios", localizada entre os rios Tigres e Eufrates, no Egito Antigo, as populações promoviam cultos de adorações a deuses diversos e estranhos à nossa concepção moderna, sendo comum a prática do politeísmo. Osíris, um dos mais conhecidos, era cultuado pelos faraós, considerando ainda a presença de outras formas de adoração. Para aquele povo do Egito, a simbiose entre homens e animais gerava mitos e superstições como o fascínio dos egípcios pelo gato, esse tratado como objeto de veneração por ser uma 'proteção às pragas' (Funari, 2012).

Na Idade Média, o forte controle criado pela Igreja Católica estabelecia padrões de conduta e de pensamento, guiando a massa ignara medieval, influenciando fortemente em todos os segmentos da sociedade, inclusive na economia (Dreher, 1994). A ciência sofreu fortes influências da religião católica, bem como o ataque da Santa Inquisição, tornando, a

\footnotetext{
${ }^{20}$ Ver também Laqueur, Thomas (2001). Inventando o sexo: corpo e gênero dos gregos a Freud. Rio de Janeiro: Relume Dumará.
} 
exemplo, Giordano Bruno um mártir. Galileu Galilei sofreu perseguições da Inquisição Católica e, em certo momento, viu-se obrigado a ocultar seus trabalhos e, em até certo ponto, desmentir a si mesmo (Mariconda, 1997).

A difusão do pensamento filosófico e reflexivo, guiado por pensadores influentes como Jean Jacques Rosseau e Voltaire, serviu para embasar o Iluminismo, corrente de pensamento surgida entre os séculos XVII e XVIII, tornando-se forte contraponto à 'cegueira' sistêmica provocada pelos absurdos da Igreja Católica. Este Movimento caracterizou-se pela promoção do conhecimento, expansão das artes, abertura de pensamento frente às 'proibições' religiosas, direcionamento de críticas a práticas políticas constantes daqueles tempos e outros aspectos que merecem ser estratificados com mais rigor. Em suma, o Iluminismo foi uma abertura sobre a 'escuridão' imposta pela Religião (Falcon, 1994).

Nos tempos da Grécia antiga, a sociedade era dimensionada em cidades-estados, dotadas com as suas próprias leis e estruturas de escalas sociais e econômicas. A classificação dessas cidades-estados era a pólis, de onde se deriva o termo política (Bobbio, 1987). Assim, política pode ser definida como a ciência da governabilidade de um Estado ou País e também como sendo uma expertise em negociação para unificar interesses. O termo é originário no grego politiké, sendo então um substantivo derivado do termo polis (Bobbio, 1987). O significado do que vem a ser política possui uma conjuntura bastante abrangente, em sua generalidade, é relacionada àquilo que é de usufruto público. Deste modo, o termo política em sua natureza consistia no estudo e a aplicabilidade das melhores modalidades de se gerir uma pólis.

A aproximação entre política e religião pode derivar aspectos que estão intrinsicamente ligados como o ensino, costumes sociais, as leis, direitos e deveres etc. (Machado, 2013). Um exemplo pertinente de como a política pode se deixar ser influenciada pela religião é a não legalização do aborto, como ocorre no Brasil.

Uma religião local, por meio de seus representantes, poderá emitir, através de um discurso religioso, parecer opinativo com elevado grau de impacto social, promovendo ou depreciando por completo a autorização do aborto. Como a fundamentação do Cristianismo é a preservação pela vida, considerando-se os dogmas da religião católica, assim como a evangélica, os representantes clericais podem usar suas influências na mídia e em outros segmentos sociais para condenar a prática da descriminalização do aborto (Mariano, 2011).

A Igreja Católica, por muitos anos, exerceu controle político sobre a sociedade (Azevedo, 2004). No Brasil Colônia, os padres jesuítas - destaques para Lima e Silva, Manuel da 
Nóbrega e Antônio Vieira - promoveram, a exemplo, a catequização dos índios tupinambás no Alto Amazonas, sob o pretexto de que os aborígenes eram seres 'sem espiritualidade' (Fausto, 1996). Pode-se considerar que havia uma contradição frente ao pensamento dos jesuítas, uma vez que as populações indígenas possuem suas modalidades ecumênicas, adorando a diversos deuses, sempre vinculados à natureza e às suas forças (Melo 2010).

A influência do catolicismo no Brasil foi bastante expressiva até à Proclamação da República, quando o país deixou de ser oficialmente atrelado a uma religião. A presença de uma igreja física em uma sociedade correspondeu, por muito tempo, como uma representação da fé na terra (Fausto, 1996). Por parametrizar costumes e abominar culturas que não estivessem alinhadas a Roma, a Igreja Católica acabou exercendo um certo controle do pensamento individual e coletivo o que, de certo modo, foi bem usurpado pela classe política ao longo dos tempos.

O fluxo do tráfico negreiro ao Brasil, para abastecer os cafezais e canaviais com escravos, trazia a bordo uma população acorrentada fisicamente e psicologicamente. Ao chegar aqui, adicionavam-se os grilhões da religiosidade. Aqueles povos negros, em suas terras natais, promoviam atos ecumênicos estranhos à fé católica, como a umbanda e a quimbanda, bem como feitiçarias e outras adivinhações (Gomes, 1995).

Proibidos pelos senhores de engenhos, os quais eram guiados pelos parâmetros religiosos do catolicismo, de promoverem a cultura de suas religiões natais. Por isso os negros desenvolveram estratégias de 'mascaramento', atribuindo aos santos católicos os nomes e ritos das divindades correspondentes em força e em fé aos de sua religião (Gomes, 1995). Assim, pela falta de liberdade imposta, os cultos religiosos africanos eram realizados nas matas, longe dos olhos do "manso" senhoril.

Durante o Brasil Colônia, as relações entre o clero e a burguesia dominavam o cenário socioeconômico, influenciando diretamente na política. Assim, naqueles tempos, o poder da Igreja Católica estava aplicado no controle das relações humanas, compactuando, com a burguesia e a classe política, os aspectos que norteavam a sociedade colonial (Balmes, 1988).

A celebração de casamentos e de batizados foi e ainda é um aspecto da Igreja Católica, sob certo controle, discricionário nos dias atuais. Embora a Constituição Federal de 1988 possua em seu Preâmbulo o termo sagrado "Deus", o Brasil é formalmente um Estado laico, mas não nega a existência dele. Segundo o texto de Barbalho (1924), 
O preâmbulo enuncia por quem, em virtude de que autoridade e para que fim foi estabelecida tal Constituição. Não é uma peça inútil ou de mero ornato na construção dela: mas simples palavras que constituem, resumem e proclamam o pensamento primordial e os intuitos dos que o arquitetam (Barbalho, 1924, 3).

Isto não significa que toda a população brasileira acredite em Deus, mas pode-se correlacionar a escritura do Preâmbulo Constitucional com a influência centenária da religião cristã no País, devendo-se considerar que já fora proposto a remoção de crucifixos e/ou outros adornos de adoração religiosa das repartições públicas, o que sofreu um forte veto da opinião pública (Calado, 2010).

Em temos políticos, a manutenção da relação entre política e textos legais com religião se mostra como um objeto interessante, pois promove a homogeneidade dos povos e direciona o pensamento naturalista-filosófico humano. Se toda a população brasileira fosse católica, o pensamento político traçaria estratégias unicamente direcionadas a esta Religião.

Na cidade de Juazeiro do Norte, Estado do Ceará, a figura histórica do Padre Cícero Romão Batista por muito tempo dominou o pensamento político e social e até econômico daquele lugar. Os seguidores do Padre, denominados de romeiros, à época em vida do Beato, promoviam movimentos conhecidos como romarias e procissões, verdadeiros cultos de adoração à figura do Padre (Borges, 2013). A classe política local, inteligentemente, conseguia dialogar com o influente religioso e obter disto aspectos interessantes para promover o controle do pensamento local. Desde a morte do Beato até os dias atuais, a influência do Padre Cícero pouco diminuiu. Muitos creditam a ele milagres e alcances de livramentos.

Observa-se que o vínculo entre religião e política nunca se rompeu no Brasil. HervieuLéger (2008), ao discutir as mudanças com relação aos indivíduos e o transcendental, ou melhor, na relação entre os indivíduos e as instituições religiosas na contemporaneidade, a autora explica a perda de credibilidade na Modernidade, mas salienta que a secularização não pode ser confundida com a perda da religião na modernidade. Isto porque a religião não perdeu seu grau de importância na sociedade moderna. (Hervieu-Léger, 2008).

Casanova (1999) também refletiu sobre o assunto, que em muito contribuiu quando afirma que, no mundo moderno, a religião parece passar por um processo de "desprivatização":

'Desprivatización' de la religión moderna es el proceso por el cual la religión abandona su lugar asignado en la esfera privada y entra en la esfera pública indiferenciada de la sociedad civil, a los efectos 
de tomar parte en el proceso continuo de disputa, legitimación discursiva y retrasado de los limites ${ }^{21}$ (Casanova, 1999, 161).

O entendimento de Casanova sobre a desprivatização da religião é no sentido de que esta não abandona o espaço privado para entrar na esfera pública, mas sim, para entrar numa esfera pública indiferenciada, ou seja, na esfera da sociedade civil.

Para Burity (2005) o que se vê na sociedade contemporânea é a reconfiguração da prática religiosa subjetivada numa pluralidade de instituições religiosas. Ocasionando que, com a desprivatização, se tem como consequência a "repolitização" das esferas religiosas.

Burity ainda explica que a atuação do Poder Executivo conjuntamente com organismos religiosos se direciona para implementar programas sociais relacionados à educação, à saúde, à violência, que, por sua vez, reforça ou exprime, por exemplo, demandas por direitos humanos ou por identidade nacional, ocasionando contextos em que o que é público ou privado, propriamente político ou propriamente religioso, dificilmente poderá ser definido de forma categórica e estável.

Habermas (2007) explica a necessidade de transformar o debate público, tendo ele que ser discursado em uma linguagem acessível, suscetível de análise e avaliação por todos os sujeitos, ou seja, os argumentos que devem se pautados numa razão pública, e não particular, pois enfatiza que somente um discurso racional e fundado na razão pública poderá resultar em garantir direitos de liberdade e igualdade a todos os cidadãos indiscriminadamente, ou seja, indistintamente. Segundo o autor, apenas a "assunção de uma razão humana comum constitui a base epistêmica para a justificação de um poder do Estado secular que independe de legitimações religiosas" (Habermas, 2007, 135).

Mouffe (2006), diferentemente de Habermas, procurou fundamentar que a participação do religioso não deve ser ignorada, inclusive nas arenas políticas, contanto que respeite os limites constitucionais.

Faz-se oportuno ressaltar que, na sociedade brasileira, os discursos políticos dos religiosos costumam explanar suas concepções e dogmas meramente morais como verdades inquestionáveis, o que pode pôr em risco a garantia dos direitos de liberdade e igualdade de todos os brasileiros.

\footnotetext{
21 “'A 'desprivatização' da religião moderna é o processo pelo qual a religião abandona seu lugar atribuído na esfera privada e entra na esfera pública indiferenciada da sociedade civil, a fim de participar do processo contínuo de disputa, a legitimação discursiva e retardo dos limites”, tradução livre da autora.
} 
Vaggione (2005) explica que o grande desafio é compreender se as religiões e suas influências se apresentam para a sociedade como parte legitimada a discursar sobre democracia. Para este autor:

En vez de ubicar lo religioso en la periferia de lo democrático es preciso entender que, en ciertos casos, las religiones abren espacios políticos importantes. Insistir en la laicidad del estado o en la erradicación de los fundamentalismos son, sin dudas, actividades cruciales para la profundización democrática. Pero la religión sigue siendo una dimensión política más allá de estas dos narrativas; ignorarlo puede implicar, irónicamente, el fortalecimiento de los sectores religiosos más poderosos [...] Es necesario, por un lado, superar los marcos teóricos que asumen la religión como una dimensión esencialmente privada. Las religiones despliegan un importante número de roles políticos en las sociedades contemporáneas, particularmente frente a estados desguazados, sociedades políticas en crisis y sistemas económicos que excluyen. Simplificar estos roles, o considerarlos únicamente como antidemocráticos es no comprender la complejidad de lo religioso en las sociedades contemporáneas ${ }^{22}$ (Vaggione, 2005, 139-140).

Por fim, faz-se oportuno destacar que a construção histórica no Brasil sempre foi pautada na cooperação da Igreja Católica e depois também da protestante, atuando conjuntamente com o Estado e, contemporaneamente, atuando na esfera política. Ressalte-se que as crenças são divulgadas, discursadas coletivamente e que, por consequência, torna-se uma espécie de defesa dos preceitos religiosos no campo da política, independente do que se normatiza no texto constitucional e nas leis.

\footnotetext{
22 "Em vez de colocar os religiosos na periferia da democracia, é necessário entender que, em certos casos, as religiões abrem importantes espaços políticos. Insistir na natureza secular do Estado ou na erradicação dos fundamentalismos são, sem dúvida, atividades cruciais para o aprofundamento da democracia. Mas a religião continua sendo uma dimensão política além dessas duas narrativas; ignorá-lo pode, ironicamente, implicar o fortalecimento dos setores religiosos mais poderosos [...] É necessário, por um lado, superar os quadros teóricos que assumem a religião como uma dimensão essencialmente privada. As religiões implantam um importante número de papéis políticos nas sociedades contemporâneas, particularmente, contra estados desmantelados, sociedades políticas em crise e sistemas econômicos que excluem. Simplificar esses papéis, ou considerá-los apenas como antidemocráticos, não é entender a complexidade dos religiosos nas sociedades contemporâneas". Tradução livre da autora.
} 


\subsection{Uma questão de Gênero}

A trajetória dos estudos de gênero está pautada nos debates feministas, na reflexão sobre a hierarquia de gênero, relações de poder e da sujeição em que a mulher estaria subalterna e subordinada ao homem. Para Segato (1998), tal categoria é um dilema diante da perspectiva universal da hierarquia frente à possibilidade de existir, em algumas sociedades humanas, uma mera igualdade na diferença.

Verificam-se os avanços na problematização das diferenças e das relações entre homens e mulheres que, embora ainda insuficientes, inquietam o conhecimento ideológico de gênero. Mead (1988) afirma que não está interessada na existência ou inexistência de diferenças universais entre os sexos nem, tampouco, nas bases do feminino, mas, em comparar como três sociedades primitivas desenvolveram diferentes atitudes sociais com relação ao temperamento, baseando-se nas diferenças sexuais:

Estudei essa questão nos plácidos montanheses Arapesh, nos ferozes canibais Mundugumor e nos elegantes caçadores de cabeça de Tchambuli. Cada uma dessas tribos dispunha, como toda sociedade humana, do ponto de diferença de sexo para empregar como tema na trama da vida social, que cada um desses três povos desenvolveu de forma diferente. Comparando o modo como dramatizaram a diferença de sexo, é possível perceber melhor que elementos são construções sociais, originalmente irrelevantes aos fatos biológicos do gênero de sexo (Mead, 1988, 22).

Referindo-se às dificuldades de fazer uma antropologia feminista, Moore (1991) escreve que, o equacionamento do feminismo com o princípio antropológico de entender o outro a partir de seu próprio ponto de vista, torna-se difícil devido a que "pressupõe que há uma perspectiva ou ponto de vista de mulher que, sendo único, pode ser considerado como evidência de que existe uma inequívoca categoria sociológica de mulher". Observa-se que feminismo universaliza o conceito mulher e que a Antropologia particulariza tanto este como qualquer outro conceito.

Conforme Beauvoir (1967, 295): "homem acha-se ligado à coletividade, enquanto produtor e cidadão, por laços de uma solidariedade orgânica baseada na divisão do trabalho, a mulher é que é suscetível de encarná-lo com mais pureza: as relações profissionais do marido".

Aguiar (1997) também lembra que alguns autores como Morgan até Margareth Mead se aproximam da sexualidade masculina e feminina como elementos fundantes de uma organização social. Os antropólogos clássicos, como Morgan e Lévi-Strauss, descreveram 
o comportamento dos homens e das mulheres no ritual e na presença do imaginário mítico, denotando as interpretações que os etnólogos fizeram sobre as diferenças entre homens e mulheres e os papéis sociais definidos por eles (Aguiar, 1997).

Simone de Beauvoir (1967), em sua obra "O segundo sexo", escrita em 1949, esclareceu que "não se nasce mulher, torna-se mulher", expressando a definição do feminismo e desnaturalizando o ser mulher. Desta forma, a autora reformula a identidade de gênero inscrita na cultura.

Linda Nicholnson et al (2000), em sua obra "Interpretando Gênero", compara o corpo como um tipo de cabide em que vão se jogando diferentes artefatos culturais (que seriam os casacos), relativos à personalidade e ao comportamento. Tal modelo permitia teorizar sobre o relacionamento entre biologia e personalidade, aproveitando certas vantagens do determinismo biológico, ao mesmo tempo em que dispensava certas desvantagens.

Quando se pensa o corpo como um "cabide" em que são "jogados" certos aspectos de personalidade e comportamento, pode-se pensar no relacionamento entre os dados do "cabide" e aquilo que nele é jogado como algo não necessariamente determinista, mas também não acidental. No entanto, distinguir, através dos objetos, a personalidade, ainda não permite identificar de forma generalizada, podendo muitas vezes contribuir para percepções equivocadas. Pois, reconhece-se que existem diferenças entre mulheres. $\mathrm{O}$ contexto anterior é limitado e pode ser problemático.

O conhecimento sobre a mulher formula-se, então, a partir de uma relação de alteridade e não de identificação, como visto acima. Dessa forma, faz-se necessário o distanciamento para a contextualização do outro. Conforme Sarti $(2004,47)$ "contextualizar não significa situar o fenômeno estudado no âmbito mais geral da sociedade onde se insere, explicando o particular pelo geral, mas ao contrário, requer um passo cuidadoso e atento em outra direção". É um movimento que diz respeito à relação com o outro, requer escutar a explicação do outro sobre o mundo social do qual faz parte.

A noção de gênero revitaliza a tensão básica entre a relatividade e a universalidade das experiências humanas. Margaret Mead (1935) explica que a construção cultural do gênero tem seu ponto de partida na constatação inicial de que "mulher" e "homem" são entidades distintas, preenchidas com conteúdos variáveis, através das sociedades. Esse relativismo acaba por projetar o gênero como uma área de estudos transdisciplinar.

A partir dos anos 1970, a questão da universalidade da hierarquia de gênero, seguida por uma tendência de subordinação da mulher nas representações culturais disse respeito à estrutura que rege a "ideologia de gênero" nas mais diversas sociedades, que, embora 
apresentando diferenças, tendem a representar o lugar da mulher como um lugar subordinado.

O relativismo diz que a mulher e homem são categorias preenchidas com conteúdos diferentes em tradições diferentes e, até em épocas diferentes de uma mesma história. Apesar das diferenças culturais, existe uma forte tendência à universalidade da hierarquia de gênero, ou seja, da universalidade do gênero como uma estrutura de subordinação. Apesar das diferenças culturais, a mulher, tendenciosamente, vem ocupando um lugar de subordinação (Segato, 1988). Michelle Rosaldo (1974) explica que a hierarquia é oriunda de uma divisão de trabalho, entretanto, a desigualdade se torna acentuada porque, em sua grande maioria, o homem ocupa posição de prestígio.

A posição de Lévi-Strauss sobre a relação entre cultura e natureza, associa a mulher à natureza e homem à cultura. Tem-se, nessa perspectiva, uma pretenciosa desigualdade da mulher, que está associada à natureza/objeto e o homem como parte da cultura/ação transformadora, ou seja, um par de associações que configuraria uma hierarquia.

Dessa forma, os trabalhos etnográficos que tentaram contestar a tese da universalidade da hierarquia arruinaram com a premissa do determinismo natural e, com ela, do essencialismo biológico. Assim, assinalar para a relatividade e variabilidade os conteúdos associados com as categorias "mulher" e "homem" através dos tempos e das culturas, provou que elas são produtos histórico-culturais e não fatos da natureza.

Para Engels (1924), em sua obra sobre “As origens das famílias, a propriedade privada e o Estado", explica que a divisão do trabalho baseada no sexo implicou na desigualdade social, fazendo surgir as classes sociais baseadas na propriedade privada. Esse argumento ainda deixou uma brecha, pois a desigualdade social, em razão da propriedade privada, não era encontrada nos países socialistas e, no entanto, a hierarquia em relação ao gênero também se encontrava presente nessas nações.

Algumas causas da presente subordinação são marcadas na associação ao capitalismo, patriarcado, produção e reprodução de seres humanos. Para Firestone (1976), uma feminista radical concebe que a subordinação feminina está localizada no processo reprodutivo. Isso porque quando as mulheres estão com bebês recém-nascidos, necessitam estarem próximas à criança num período prolongado. Isto faz com que as mulheres também se tornem dependentes dos homens, pois precisa se dedicar totalmente ao filho, em razão da dependência física a ele. Diante deste contexto, o corpo aparece como o centro em que emana para onde convergem a opressão sexual e a desigualdade.

Com o lema "Direitos iguais à cidadania", a marcha feminista surgiu e se espalhou em toda a Europa e América do Norte, fazendo com que, nas décadas de 1920 e 1930, as mulheres 
conseguissem romper com a desigualdade em relação ao voto, à propriedade e à educação, que era somente direito e dever dos homens.

Adiante, com o movimento feminista na década de 1960, foi possível o surgimento de ideias centrais que marcaram a história, como a presença das mulheres em alguns espaços da política. O pensamento feminista questionava a subordinação por razões de natureza biológica ou natural, pois defendia que esta subordinação havia sido desenvolvida pelo homem em seu processo de construção social ou cultural, e, portanto, era possível a transformação deste cenário de desigualdade e subordinação. Nos Estados Unidos e na Inglaterra, no final da década de 1960, apresentava diferenças na percepção das origens e causas da opressão ${ }^{23}$.

Os questionamentos surgiam e a categoria mulher começou a ser desenvolvida pelas ideias feministas radicais que refletiam que as mulheres, para além de questões de classe e raça, são oprimidas pelo fato de serem mulheres. Era um reconhecimento político das mulheres como coletividade.

Vale ressaltar que, em termos gerais, as feministas radicais mantinham explicações conexas vivenciadas por várias mulheres, um discurso que atravessava o tempo e as culturas. Esse movimento de discurso feminista contestava concepções presentes no pensamento de esquerda que, numa concepção marxista, argumentava racionalmente a política para uma opressão e exploração objetiva das mulheres. Em razão disso, o movimento firmava a validade de uma teoria subjetiva de defesa das mulheres contra a objetiva de esquerda política.

Com essa política desproporcional e com um discurso desigual inclinaram-se as feministas a definir política como também qualquer relação de poder e de dominação masculina. Com a redefinição marxista de política nos cenários público e privado, poucas instituições conseguiram escapar do patriarcado, pois a dominação masculina esteve presente através do tempo e das culturas. Faz-se oportuno destacar que um dos interesses das feministas era ampliar o conhecimento científico sobre a situação da mulher, que visualizasse uma

\footnotetext{
${ }^{23}$ Para mais referências sobre a história do Feminismo, consultar também: Teles, M. A. de Almeida (1993). Breve historia do feminismo no Brasil. São Paulo: Brasiliense.

Toscano, Moema \& Goldenberg, Mirian (1992). A revolução das mulheres: um balanço do feminismo no Brasil. Rio de Janeiro: Revan.

Sojo, Ana (1985). Mujer e política: ensayo sobre el feminismo y el sujeto popular. San José: DEI. Grossi, Miriam Pillar \& Miguel, Sonia Malheiros (1991). Mapeamento dos grupos e organizações de mulheres, gênero, feministas dos anos 90 no Brasil. Florianópolis: Ed. da UFSC.

Gutierrez, Raquel (1985). O feminismo é um humanismo. São Paulo: Nobel. Lipovetsky, G. (2000). A terceira mulher. S. Paulo: Companhia das Letras.

Castelara, J. (1989). Feminismo: teoria e Prática. Rio de Janeiro: Núcleo de Estudos sobre a Mulher (NEM).
} 
perspectiva acadêmica, questionando a utilização do patriarcado como categoria de análise. De fato, a perspectiva tinha boa intenção e inicialmente teve impulso, porém não teve forças, pois os discursos, em âmbito universal, limitaram-se a enxergar o patriarcado apenas como uma espécie de dominação masculina.

Um importante marco das questões feministas foi desenvolver o conceito de gênero para superar algumas categorias centrais de estudos sobre mulheres. Rubin (1975) defendia que o sistema sexo/gênero era utilizado para transformar a sexualidade biológica produto de interesse da sociedade humana. Num intercâmbio levistraussiano, em que estuda a opressão das mulheres dentro dos sistemas sociais, defende que não existe uma definição de cultura para explicar a causa dessa dominação, o que existe é a subordinação das mulheres como produtos das relações sociais por meio dos quais sexo e gênero são organizados e produzidos.

Para Judith Shapiro (1981), os termos sexo e gênero são úteis para análise, pois explica o fato biológico e o cultural correspondentemente. Deixa claro que o gênero se refere às construções sociais, culturais, psicológicas que estão acima do determinismo biológico.

Diante do exposto, conclui-se que o conceito de gênero desenvolvido contra o patriarcado foi produto de análise no movimento feminista, que dentro de uma preocupação política, conseguiu chegar numa perspectiva feminista que trabalhasse o conceito de gênero como fruto de um interesse de defesa dos direitos das mulheres.

\subsection{Fundamentos dos Direitos Humanos}

Em linhas gerais, direitos humanos podem ser definidos como direitos universais concessíveis a qualquer indivíduo que esteja no gozo ou na habilidade de ser humano, naturalmente por existir ou viver em sociedade ou por estar em uma posição limiar de vida, devendo então ser assegurado ao mesmo indivíduo a manutenção de sua integridade, dignidade, vida e condições tangíveis de sobrevivência como alimentação, moradia, saúde e até educação, sendo esta, em termos de instrução, uma grandeza intangível (BARRETO, 2001).

No tocante aos direitos humanos, é possível ter uma visão jusnaturalista. O Jusnaturalismo se fundamenta em uma corrente, segundo a qual existe um conjunto de normas que são anteriores e superiores ao sistema, ou seja, as normas fixadas pelo Estado. Neste tocante, já na Antiguidade havia a visão jusnaturalista, simbolizada na peça de teatro Antígona de Sófocles, que é a personagem principal da obra, em que afirma que as leis dos homens não podem sobrepor às leis eternas dos deuses. (Herkenhoff, 1994). 
Apesar do reconhecimento do caráter histórico dos direitos humanos, o recurso à fundamentação jusnaturalista é perceptível até hoje. Ressalte-se que, em âmbito Internacional, a Declaração de Viena de 1993, emitida ao final da $2^{\text {a }}$ Conferência Mundial das Nações Unidas sobre Direitos Humanos, dispôs que os direitos humanos são direitos naturais de todos os seres humanos (Mendez, 1998).

$\mathrm{Na}$ consolidação do Estado Constitucional, fruto das revoluções liberais, foram-se inserindo os direitos humanos, tidos como naturais, no corpo das Constituições e das leis, sendo considerados então direitos positivados.

O risco aos direitos humanos, gerado pela adoção do positivismo, é visível, no caso de normas locais (inclusive as constitucionais) não protegerem ou reconhecerem determinado direito ou categoria de direitos humanos. Vale destacar que o exemplo nazista mostra a insuficiência de fundamentação positivista nacionalista dos direitos humanos.

A divergência entre as concepções jusnaturalistas e os positivistas reside que, na primeira, as normas não escritas podem ser superiores, proteger a todos os seres humanos, sendo, portanto, reveladoras da justiça, em face das normas postas incompatíveis. Já os positivistas nacionalistas, desprezam as normas reveladoras da justiça por não pertencerem ao ordenamento jurídico, inexistindo qualquer choque ou antagonismo com a norma posta. 


\section{A VISÃO DO PARLAMENTO RELIGIOSO BRASILEIRO SOBRE O DISCURSO DA ONU}

No Brasil, desde o período colonial, em 1500, a Igreja acompanha a história política do país, trazendo um modelo de religião Católica. Naquela época, a Igreja Católica já funcionava como instrumento de dominação social e política. Em 1840, nasce, no Brasil, um período conhecido como romanização do Catolicismo, em que a Igreja se vinculava às ordens do Papa e é, também, neste período em que nasce a disciplina "catolicismo romano", para a formação do Clero.

Em 1922, o Brasil vivencia uma atuação da Igreja na política, com a colaboração do Estado. Já a Constituição de 1934 demonstra com nitidez o elo do Estado e a Igreja, quando normatiza a instituição do ensino religioso nas escolas públicas e a presença de capelães nas Forças Armadas. Entre os anos de 1950 a 1960, a Igreja se afasta um pouco do regime do Estado Novo para atuar em defesa dos interesses da sociedade, como a questão do desenvolvimento, e em defesa dos direitos humanos e das liberdades democráticas.

Nos anos entre 1970 e 1978, a Igreja atua junto ao Estado nas áreas econômicas e políticas, colaborando, sobretudo no processo de transição para a democracia, ou seja, interagindo simultaneamente com a sociedade civil e com a sociedade política, no processo de negociação com a arena estatal para o restabelecimento da democracia no país (Stepan, 1987).

Com uma participação em defesa dos direitos humanos e da sociedade civil, é que a igreja, entre os anos de 1986 e 1988, começou a ocupar um lugar de destaque em favor das demandas populares, participando do processo constituinte para a criação da atual Carta Magna do país, mobilizando-se em favor de emendas populares à Constituição, como dando ênfase às políticas sociais e a formação de um Estado democrático de direito (Azevedo, 2004).

No Brasil, do Império até a República, a Igreja Católica cristã participou da construção dos direitos, onde se idealizava a subordinação da mulher em relação ao homem. Para a sociedade colonial, a única função da mulher, era propiciar herdeiros para a sociedade (Algranti, 1993)

\subsection{A mulher na construção dos direitos no Brasil}

Um fator de grande peso, em relação às qualidades indispensáveis da mulher nessa primeira fase de construção de direitos no Brasil, era a castidade. De influência católica, a 
mulher teria não só a obrigação, mas o dever de controlar seus impulsos sexuais e seus desejos enquanto estivesse solteira e, quando casada, deveria ser fiel ao marido, estando presa às normas sexuais impostas pelo matrimônio religioso (Algranti, 1993).

A condição de honra também era atribuída apenas às mulheres livres, portanto, as escravas, as índias e as negras eram consideradas mulheres sem honra e, por esse motivo, não tinham qualquer direito de recorrer à proteção das leis em caso de qualquer abuso sexual (Priore \& Bassapezi, 2004).

A religião impusera que a mulher que não se casava era uma mulher pecadora, considerada celibatária, cujo maior pecado era não ter filhos. O Estado, sob forte influência religiosa, impedia que elas expusessem seus pensamentos e, se as suas atitudes estivessem fora dos parâmetros considerados corretos pela Igreja, poderiam ser punidas, inclusive pelas duas Instituições: Igreja e Estado (Silva, 1983).

No século XIX, a virgindade feminina funcionava como um dispositivo para manter uma questão moral. Com o apoio das orientações dadas nas escolas, ademais da influência da religião, perdurou até tempos recentes, dentre outros aspectos culturais, a questão da virgindade como valor para o casamento (Monteiro, 2003).

Com relação ao direito de reprodução no Brasil, até 1930, vivenciou-se uma tendência prónatalista: segundo esta concepção as mulheres sendo vistas apenas como objeto para a reprodução da sociedade.

Já em 1970, diante do regime militar, o discurso era contra a natalidade. Foi nesse período que as pílulas anticoncepcionais foram comercializadas no Brasil. Como forma de ter o apoio da Igreja católica para que se articulassem em favor de seus demais direitos, as mulheres, por sua vez, comportaram-se de maneira condescendente, para não ir de encontro às ordens eclesiásticas, que eram contrárias aos métodos contraceptivos, (Stepan, 1987).

\subsection{O surgimento da bancada religiosa}

A década de 1980, com a redemocratização do país e a elaboração da nova Constituição Federal em 1988, marca um período no qual diversos grupos sociais buscam garantir seus direitos civis. A bancada parlamentar evangélica, eleita pela Assembleia Nacional Constituinte nas eleições de 1986, constituiu-se de 34 parlamentares evangélicos (Trevisan, 2013).

Contudo, a Frente Parlamentar Evangélica (FPE) só foi criada em 2003. A FPE é uma Associação civil de natureza não governamental, constituída no âmbito do congresso nacional, integrada por deputados federais e senadores da República. 
Pode ser considerada uma das mais expressivas dentro do Congresso Nacional e detentora de grande força política, a qual é liderada principalmente por religiosos e representantes da Assembleia de Deus.

Interessante ressaltar que não existem grupos políticos que se denominem bancada espírita, católica ou de outras religiões. Hoje, o grupo mais forte e que mais claramente defende seus interesses são os evangélicos e é por isso que se destacam no cenário ${ }^{24}$ político brasileiro.

Em um levantamento realizado pelo Instituto Brasileiro de Planejamento Tributário (IBPT), apontou-se que, apenas em 2013, cerca de 12 novas igrejas foram abertas por dia no Brasil. Já em uma estimativa do ministério evangélico servindo aos Pastores e Líderes (SEPAL), os evangélicos poderão ser mais da metade da população brasileira em 2020. Essas perspectivas são apoiadas em dados recentes levantados pela Receita Federal em 2014, apontando que, diariamente, as igrejas brasileiras arrecadam $\mathrm{R} \$ 60$ milhões, num total de $\mathrm{R} \$ 21,5$ bilhões por ano.

O cenário político abrange lideranças religiosas, principalmente na bancada parlamentar. Como demonstra Mariano (2011), os evangélicos (antes restritos ao campo religioso) migraram para a esfera midiática e política. Esses religiosos ampliaram o alcance de seus valores no que concerne à sociedade brasileira, levando ao Congresso justamente as ideias e valores daqueles que estavam limitados a seus templos.

A bancada evangélica é formada por bispos, pastores e parlamentares leigos alinhados a dogmas religiosos e demonstra força inédita na atual legislatura. Entre as prioridades do grupo estão: a limitação a reivindicações do movimento gay, o combate à flexibilização das leis sobre drogas, aborto, eutanásia, assim como também, do direito das mulheres. Esse grupo de parlamentares busca aprovar assuntos de seu interesse (Bancada evangélica ganha força inédita no Congresso, 2015, on-line).

Os evangélicos possuem participação significativa na política brasileira. Mesmo que os números não sejam tão expressivos, seus posicionamentos não passam despercebidos. Alguns evangélicos justificam sua atuação na política, com argumentos notoriamente religiosos, assim, são capazes de ferir o texto constitucional que admite a não confessionalidade, afirmando que as propostas de leis "ferem as escrituras sagradas" - por exemplo: a união estável entre pessoas do mesmo sexo - criando, a partir de então, na

\footnotetext{
${ }^{24}$ Para mais reflexão sobre a bancada evangélica, ver Prandi, R. \& Santos, R. W. dos (2017). Quem tem medo da bancada evangélica? Posições sobre moralidade e política no eleitorado brasileiro, no Congresso Nacional e na Frente Parlamentar Evangélica. Tempo soc. (29).
} 
classe evangélica, a moral e reafirmando a necessidade de ser ouvida e representada na política $^{25}$.

Marcos Pereira, presidente do Partido Republicano Brasileiro (PRB), legenda ligada à Igreja Universal, defende que os posicionamentos sobre questões do campo moral sejam claros entre os candidatos. Essa necessidade de levarem suas ideologias - e estarem sendo representantes dos direitos da sociedade - faz com que muitos projetos que versem sobre Direitos Humanos não se concretizem, ainda mais quando esse número de religiosos na frente parlamentar cresce a cada eleição.

A professora da Universidade Metodista, Magali Cunha, em uma entrevista (Lima, 2015, on-line) explica que a bancada evangélica, desde a sua formação, nunca teve uma pauta progressista. Não eram identificados até os anos 2010 como conservadores do ponto de vista sociopolítico e econômico, como o é a Maioria Moral nos Estados Unidos, exemplifica.

Os projetos da Bancada Evangélica interferiam apenas em assuntos de seu interesse, como a criação de feriados para concorrer com os católicos. Só que, recentemente, com o forte tradicionalismo moral que tem marcado a atuação da Frente Parlamentar Evangélica, trouxe para o discurso político temas como o da defesa da família e da moral cristã, contra a plataforma dos movimentos feministas e de homossexuais e dos grupos de direitos humanos, promovendo, portanto, um diálogo historicamente impensável no campo eclesiástico.

Isso torna evidente que seus interesses políticos se identificam com os temas de sua moralidade cristã, limitando a discussão sobre a aplicação dos direitos humanos. Lima (2015) explica que tais movimentos conservadores é que são causas reacionárias frente às conquistas sociais nas últimas décadas e conclui que o discurso político sobre direitos humanos pelos evangélicos limitou bastante outros movimentos sociais, por serem contrários às suas convicções, como os grupos LGBT.

Atualmente o Congresso vem promovendo discussões acaloradas sob o pretexto da ameaça à liberdade de expressão e religiosa que, uma vez sendo o projeto aprovado, traria aos grupos religiosos contrários à prática homossexual, o direito de se expressarem.

De acordo com Magali Cunha (Lima, 2015, on-line), “o movimento de protagonismo da bancada evangélica em direção ao conservadorismo é um capítulo recente da história do parlamento brasileiro". Os movimentos feministas, de homossexuais e dos Direitos

\footnotetext{
${ }^{25}$ Para melhor conhecer os meandros da política partidária no Brasil, conferir Schmitt, R. A. (2000). Partidos políticos no Brasil:(1945-2000). Zahar.
} 
Humanos vêm sofrendo esta resistência também por parlamentares católicos, formando uma espécie de aliança religiosa contra a aplicação dos Direitos Humanos.

Vale ressaltar que os grupos de evangélicos e católicos não possuem ideologias homogêneas em todas as questões, mas são sólidos no que se refere aos princípios defendidos pela doutrina cristã. Após ser criado o Comitê de Gênero, o Ministério da Educação cedeu às pressões dos parlamentares católicos e evangélicos e o alterou para o inespecífico Comitê de Combate à Discriminação. O Comitê só foi aprovado com a retirada da palavra "gênero" do documento. Após a alteração, porém, suas responsabilidades relacionadas à questão de gênero foram extintas e as normas passaram a ser relacionadas à "igualdade de todos perante a lei, sem distinção de qualquer natureza". Uma comitiva formada por quatro deputados da bancada católica se reuniu com o ministro Renato Janine Ribeiro para criticar a criação do Comitê de Gênero. Mais tarde, os fundamentalistas foram reclamar no palácio, quando, mais uma vez, o Governo ordenou recuar. O Ministério da Educação não conseguiu explicar o motivo da alteração. Foi neste contexto que se deu a criação de um Comitê de Combate à Discriminação, que centralizou todas as ações políticas nessa área (Castro, 2016).

\subsubsection{A bancada religiosa: da candidatura à eleição presidencial de 2018}

A bancada evangélica surgiu na eleição da Assembleia Constituinte, em 1986. É um grupo suprapartidário composto por parlamentares de diferentes igrejas pentecostais e neopentecostais. O nome oficial deste grupo é Frente Parlamentar Evangélica, mas passou a ser comumente chamada de Bancada Evangélica pela mídia, pelos seus próprios membros, pelos acadêmicos e pelo congresso. A principal motivação para sua existência é defender as premissas evangélicas contra a dominância política e social da Igreja Católica. As demandas de Movimentos Sociais - como o feminismo, o movimento LGBT e outros que desafiam tabus cristãos - avançaram ao longo dos anos, reforçando a atuação da bancada evangélica que combate as pautas progressistas. A redemocratização do país revelou os agentes políticos de orientação de esquerda, assim como evidenciou as características dos parlamentares, suas posições e suas orientações, trazendo à tona as dissidências e embates ideológicos que estavam encobertos pelo ambiente de censura. Nesse contexto, os evangélicos se colocam contra as pautas progressistas que defendem questões conflitantes com a moral cristã.

Os parlamentares percebem, aí, a necessidade de se unirem em torno de uma pauta comum da defesa da moralidade cristã. As eleições de candidatos do campo da esquerda passaram a ter como principais críticos os evangélicos em bloco. A partir de então, a bancada 
evangélica e os evangélicos passam a ser contrária a toda pauta da esquerda e aos partidos de esquerda, em 1990, 1994, 1998. Isso muda somente quando nas eleições de 2002 o candidato do Partido dos Trabalhadores, Luís Inácio Lula da Silva, desenvolve uma estratégia de aproximação às igrejas evangélicas, firmando acordos implícitos de não defender políticas polêmicas e incorporando agentes evangélicos, na construção de um mandato mais popular e democrático.

A partir de 2010, o tema dos direitos das mulheres e da população LGBT passa a se destacar nas campanhas eleitorais e nos projetos debatidos no Congresso Nacional, com reações negativas entre políticos evangélicos. Em 2013, a nomeação do deputado Marco Feliciano para a presidência da Comissão de Direitos Humanos e Minorias da Câmara culminou no revigoramento de campanhas por legislação pautada pela moralidade sexual religiosa, sob o rótulo "Defesa da Família Tradicional”, contra movimentos feministas e LGBT. Tais pautas encontram eco na população conservadora não religiosa e reforçam movimentos reacionários às conquistas de direitos, alcançadas nas últimas duas décadas.

A mídia auxilia a reforçar os embates entre os evangélicos e a esquerda brasileira, criando um cenário de guerra. Isso porque os movimentos sociais se desenvolvem consideravelmente nos últimos 20 anos, nos quais os grupos LGBT e feministas crescem visível e politicamente. Todo conflito que expõe posições bem marcadas e polêmicas geram o acirramento das posições, inclusive aumentando o radicalismo e angariando mais apoiadores para os dois lados. O conflito exposto midiaticamente influencia a opinião pública a escolher posicionamentos.

O candidato Jair Messias Bolsonaro foi o primeiro político a incorporar as pautas radicais evangélicas e todos os opositores da esquerda nacional. $\mathrm{O}$ discurso identificado como cristão e apoiado pelos líderes religiosos, passa a se moldar ao formato evangélico, orientado também pelos líderes das igrejas mais influentes que acreditaram que tomariam mais espaço dentro do governo. Esse contexto coloca os evangélicos e a bancada religiosa como agentes políticos essenciais nas estratégias político-partidárias.

No final do mês de novembro de 2018, após as eleições presidenciais, a bancada evangélica sofre um revés na relação com o presidente eleito, os parlamentares dessa bancada reivindicavam cadeiras no primeiro escalão do governo. $\mathrm{O}$ então presidente eleito pedira aos deputados três indicações para o Ministério da Cidadania, responsável por comandar os programas sociais do governo ao que foram indicados pelos deputados, os deputados paulistas dos partidos PSC, Podemos e PTB. No entanto, Bolsonaro escolheu um ex-ministro do governo anterior, o governo Temer. O pastor Silas Malafaia, líder do ministério Vitória em Cristo, ligado à Assembleia de Deus - homem com enorme poder 
em todo o país e dono de forte influência sobre a política e a mídia nacional - indicou também nomes para a composição do governo, porém, após a defesa do senador Magno Malta, os nomes foram recusados por Bolsonaro. Por fim, Damares Alves, pastora, ocupou a pasta do Ministério dos Direitos Humanos, sem passar pelo aval dos parlamentares evangélicos, causando uma estranheza desses com relação ao governo.

No fim de março de 2019, a Bancada Evangélica afirma sua autonomia e independência ao governo Bolsonaro.

\subsection{Laicidade do Estado e Direitos Humanos}

Nota-se que a laicidade presente nesta nação se mostra bastante comprometida diante da pressão dos congressistas evangélicos, bem como católicos, organizados sob o escudo da moral e da religião. Nesse quadro, o respeito aos Direitos Humanos passa bem distante, ainda que garantido constitucionalmente.

Importante é frisar que, por mais que o Brasil seja signatário de Convenções Internacionais de Direitos Humanos e que a constituição e leis nacionais expressamente normatizem a separação entre os campos político e religioso, a interação entre eles é extremamente presente.

Essa interação que existe entre religião e política, no Brasil, supera diferentes períodos e contextos, fazendo com que retarde ou dificulte as lutas sociais pelos direitos das minorias - ou fazendo com que tais direitos não sejam cumpridos, ou ainda que a interpretação ou criação de normas seja marcada com um tradicionalismo cristão que fere aos direitos humanos.

O Brasil ainda tem muito que amadurecer a respeito dos direitos humanos e da liberdade individual das pessoas. Ainda que a despeito de toda influência da igreja na sociedade e na política brasileiras, o princípio da Dignidade da Pessoa Humana se impõe de tal forma nesse Estado Democrático de Direito que sua efetivação exige ser absoluta.

Observou-se que as diferenças humanas não são vistas como algo natural pelos grupos religiosos. A FPE não vem demonstrando encará-las como direito fundamental do indivíduo para que efetivamente seja promovida a consolidação de uma sociedade mais solidária e igualitária.

O que se espera alcançar é que o legislativo brasileiro possa acompanhar o pensamento e o dinamismo da sociedade, posicionando-se acima das crenças da religião. Enseja-se também que os congressistas possam ceder espaço para a modernidade, permitindo que seja cumprida (ou ao menos se dialogue sobre) a Declaração Universal de Direitos Humanos, para que, no futuro, consiga-se humanizar ainda mais a sociedade e não aconteça o que 
ocorre agora: limitação da aplicação dos direitos humanos, desrespeito às diferenças humanas, naturais ou religiosas.

A proteção internacional dos direitos humanos das mulheres vem sendo introduzida na sociedade global desde 1919, com a participação das Organizações das Nações Unidas. Mediante várias conferências sobre direitos humanos, foram introduzindo defensivas através de seus discursos para proteger e até mesmo eliminar quaisquer formas de discriminação contra a mulher.

Cabe lembrar que, no Brasil, o discurso da ONU vem sofrendo limitações na sua aplicabilidade, em razão de posicionamentos contrários. São lideranças religiosas que, às vezes, por discriminação e preconceito, sequer sabem da existência dos tratados internacionais, que versam sobre os direitos e liberdades das mulheres.

Hodiernamente, a religião discute tais temas nas esferas de poder em que tem uma atuação participativa junto à sociedade e, muitas vezes, despreza os discursos da ONU. Sobretudo, quando atua no cenário político, defendendo que a 'vida é dada por Deus' e, por isso, é contra a descriminalização do aborto (Duarte et al, 2007). O que demonstra é que os argumentos religiosos e não políticos são utilizados para justificar a regulação da sexualidade e as decisões reprodutivas por meio de ações legislativas.

Por fim, vale ressaltar que a união homoafetiva, a adoção por casais homossexuais, descriminalização do aborto e a educação sobre "ideologia de gênero" e sexualidade dentro das escolas foram temas trazidos ao meio político. Estes traduziram como forma de ameaças aos parlamentares religiosos, que não só resistiram, mas que ainda tratam temas de direitos humanos e universais como crimes ou doenças, contrapondo-se a outros projetos de lei para inviabilizar a promoção dos direitos humanos.

Além dessa, outra proposta - que vítimas de estupro, fossem atendidas por psicólogos cristãos que as convencessem de manter a gravidez (Mattar, 2018) foram apresentadas, sem aprovação.

A bancada evangélica também vem violando os direitos humanos com ataques às propostas relacionadas aos direitos da comunidade LGBT. Um dos exemplos foi o kit Escola sem Homofobia, erroneamente chamado pelos evangélicos de 'Kit gay', cujo objetivo era promover a igualdade de gêneros no ambiente escolar e o respeito da diversidade sexual. Infelizmente a pressão da bancada fez a presidente Dilma, na época, suspender o kit.

O Projeto de Decreto Legislativo (PDC 521/2011), de autoria de Feliciano, tinha por objetivo questionar o reconhecimento legal da união homossexual como entidade familiar. Tal proposta tinha o intuito de eliminar tantas outras, dentre elas o projeto elaborado pelo deputado Jean Wyllys (PSOL-RJ), para permitir o casamento e adoção por homossexuais. 
Ainda, outra proposta legislativa realizada pelos evangélicos políticos foi que ficou conhecida de 'cura da homossexualidade', a qual viola o direito e liberdade sexual, proposta por eles para tentar trabalhar a mudança da orientação sexual ${ }^{26}$.

${ }^{26}$ Para entender a complexidade das disputas políticas no Brasil dentro do tema, ver:

Carneiro Campos, R. B., de Gusmão, E. H. A., \& de Barros Mauricio Junior, C. G. (2015). A DISPUTA PELA LAICIDADE: UMA ANÁLISE DAS INTERAÇÕES DISCURSIVAS ENTRE JEAN WYLLYS E SILAS MALAFAIA. Religião e Sociedade, 35(2).

da Silva, L. B., \& Paiva, C. C. (2016). Os embates discursivos entre os parlamentares Jean Wyllys e Bolsonaro durante a votação do impeachment. Temática, 12(8).

Alves, C. R. POLÍTICAS EDUCACIONAIS E FORMAÇÃO PARA A SEXUALIDADE NA ESCOLA: em foco o kit "escola sem homofobia". Gênero, Sexualidade e Corpo, 65. 


\section{A CONVENÇÃO SOBRE ELIMINAÇÃO DE TODAS AS FORMAS DE DISCRIMINAÇÃO CONTRA AS MULHERES (CEDAW) SOB A ÓTICA BRASILEIRA}

A violência contra a mulher não pode ser evidenciada como algo recente, nem pertencente apenas a um continente e muito menos atrelado a um único país. As histórias de agressão a seus direitos não podem sequer ser pontuadas ou datadas, pois, desde a antiguidade, existem as relações de poder que vislumbram cenários previamente conduzidos ou categorizados para se manter o domínio do sexo masculino sobre o feminino (Bourdieu, 1999).

A violação de direitos humanos das mulheres pode ser vista quando parte de uma sociedade age em desfavor de uma considerada 'categoria' por uma questão de gênero, seja em uma atuação discriminatória - que pode ser considerada como toda e qualquer conduta baseada no gênero - ou em uma atuação com base na violência, que cause ou passível de causar a morte, dano ou sofrimento físico ou psicológico à mulher (Saffiotti, 2004).

O Brasil não é o único em que as mulheres são vitimadas com o crime de homicídio pelo simples fato de serem do sexo feminino e daí a importância de se entender o significado de feminicídios (Brasil, 2015). O extremo da violência contra a mulher é o feminicídio, que é o assassinato das mulheres apenas pelo fato de serem mulheres e terem que aceitar a dominação masculina (Pasinato, 2011). As lutas dos grupos feministas no decorrer dos anos, desde meados séculos XIX e XX, não foram capazes de zerar os casos de maus tratos que ocorrem diariamente no mundo (Pinto, 2010).

\subsection{A Convenção sobre a Eliminação de todas as formas de Discriminação Contra a Mulher (CEDAW)}

Por este motivo, fez-se necessário trazer à sociedade contemporânea o debate e a discussão sobre ações concretas que promovessem a igualdade de direitos dos homens e mulheres. Desse modo, foi criada a Convenção sobre a Eliminação de todas as formas de Discriminação Contra a Mulher (CEDAW), um acordo mundial assinado por diversos países, inclusive o Brasil: "o primeiro tratado internacional que dispõe amplamente sobre os direitos humanos da mulher" (Pimentel, 2006, 14).

O Brasil, apesar de signatário dessa Convenção, traz dados comprovadamente alarmantes quanto à violência de gênero e ao feminicídio. Nos seis primeiros meses do ano de 2012 , 
foram feitos 47.555 registros de atendimento na Central de Atendimento à Mulher. E, em 2011, foram feitos 74.984 registros, bem inferior aos 108.491 de 2010 .

Registros de violência física contra a mulher vão desde lesão corporal leve, grave ou gravíssima, tentativa de homicídio e homicídio consumado. Foram registrados 2.318 casos de violência sexual como estupro, exploração sexual e assédio no trabalho em 2010 e 1.298, em 2011 (IBGE, 2017).

No Brasil, a instituição histórica do patriarcado existe desde a época de sua colonização. Até mesmo por influência da Igreja Católica, construiu-se um longo período de submissão das mulheres, sendo elas marginalizadas, até os dias atuais, por serem vistas ou percebidas como objeto sexual, ademais, aniquiladas, por se imporem à dominação masculina.

Devido à necessidade de lhes garantir os direitos (por elas precisarem de apoio social, econômico, civil, cultural e político), é que se debate uma conscientização em larga escala atualmente. Essa é a razão para se trabalhar a educação sobre questões de gênero. Através de políticas públicas, é imprescindível promover o diálogo sobre os direitos humanos, trazer à tona formas de compensação e proteção às mulheres, instrumentalizar, por meio do ensino, o que diz a Convenção sobre a Eliminação de todas as formas de Discriminação Contra a Mulher (CEDAW), na tentativa de diminuir os conflitos gerados pela violência de gênero e feminicídio no território nacional.

Em 13 de Setembro de 2002, foi publicado o decreto 4.377, que introduzia na República Federativa do Brasil a Convenção sobre a Eliminação de Todas as Formas de Discriminação contra a Mulher (Brasil, 2002).

$\mathrm{Na}$ presente convenção, os Estados Partes reafirmaram a fé nos direitos fundamentais, assim como também na dignidade do homem. E em razão do valor da pessoa humana, reafirmaram a intenção de igualar os direitos de homens e mulheres (Decreto $\mathrm{n}^{\mathrm{o}}$ 4.377/2002) 'CEDAW', que antes de normatizar seus trinta artigos, trazem suas intenções, considerações e preocupações, senão vejamos:

CONSIDERANDO que a Declaração Universal dos Direitos Humanos reafirma o princípio da não discriminação e proclama que todos os seres humanos nascem livres e iguais em dignidade e direitos e que toda pessoa pode invocar todos os direitos e liberdades proclamados nessa Declaração, sem distinção alguma, inclusive de sexo,

CONSIDERANDO que os Estados Parte nas Convenções Internacionais sobre Direitos Humanos tem a obrigação de garantir 
ao homem e à mulher a igualdade de gozo de todos os direitos econômicos, sociais, culturais, civis e políticos,

OBSERVANDO as convenções internacionais concluídas sob os auspícios das Nações Unidas e dos organismos especializados em favor da igualdade de direitos entre o homem e a mulher,

OBSERVANDO, ainda, as resoluções, declarações e recomendações aprovadas pelas Nações Unidas e pelas Agências Especializadas para favorecer a igualdade de direitos entre o homem e a mulher,

PREOCUPADOS, contudo, com o fato de que, apesar destes diversos instrumentos, a mulher continue sendo objeto de grandes discriminações,

RELEMBRANDO que a discriminação contra a mulher viola os princípios da igualdade de direitos e do respeito da dignidade humana, dificulta a participação da mulher, nas mesmas condições que o homem, na vida política, social, econômica e cultural de seu país, constitui um obstáculo ao aumento do bem-estar da sociedade e da família e dificulta o pleno desenvolvimento das potencialidades da mulher para prestar serviço a seu país e à humanidade,

PREOCUPADOS com o fato de que, em situações de pobreza, a mulher tem um acesso mínimo à alimentação, à saúde, à educação, à capacitação e às oportunidades de emprego, assim como à satisfação de outras necessidades,

CONVENCIDOS de que o estabelecimento da Nova Ordem Econômica Internacional baseada na equidade e na justiça contribuirá significativamente para a promoção da igualdade entre o homem e a mulher,

SALIENTANDO que a eliminação do apartheid, de todas as formas de racismo, discriminação racial, colonialismo, neocolonialismo, agressão, ocupação estrangeira e dominação e interferência nos assuntos internos dos Estados é essencial para o pleno exercício dos direitos do homem e da mulher,

AFIRMANDO que o fortalecimento da paz e da segurança internacionais, o alívio da tensão internacional, a cooperação mútua 
entre todos os Estados, independentemente de seus sistemas econômicos e sociais, o desarmamento geral e completo, e em particular o desarmamento nuclear sob um estrito e efetivo controle internacional, a afirmação dos princípios de justiça, igualdade e proveito mútuo nas relações entre países e a realização do direito dos povos submetidos à dominação colonial e estrangeira e a ocupação estrangeira, à autodeterminação e independência, bem como o respeito da soberania nacional e da integridade territorial, promoverão o progresso e o desenvolvimento sociais, e, em consequência, contribuirão para a realização da plena igualdade entre o homem e a mulher,

CONVENCIDOS de que a participação máxima da mulher, em igualdade de condições com o homem, em todos os campos, é indispensável para o desenvolvimento pleno e completo de um país, o bem-estar do mundo e a causa da paz,

TENDO presente a grande contribuição da mulher ao bem-estar da família e ao desenvolvimento da sociedade, até agora não plenamente reconhecida, a importância social da maternidade e a função dos pais na família e na educação dos filhos, e conscientes de que o papel da mulher na procriação não deve ser causa de discriminação, mas sim que a educação dos filhos exige a responsabilidade compartilhada entre homens e mulheres e a sociedade como um conjunto,

RECONHECENDO que para alcançar a plena igualdade entre o homem e a mulher é necessário modificar o papel tradicional tanto do homem como da mulher na sociedade e na família,

RESOLVIDOS a aplicar os princípios enunciados na Declaração sobre a Eliminação da Discriminação contra a Mulher e, para isto, a adotar as medidas necessárias a fim de suprimir essa discriminação em todas as suas formas e manifestações (Brasil, 2002).

A Convenção se tornou importante instrumento para se trabalhar conceitos, significado, expressões - como a expressão "discriminação contra a mulher" - condenando todo o tipo de discriminação que ferisse seus direitos políticos, civis, culturais e econômicos. 
Os países se comprometeram nos trinta artigos não só disciplinarem leis nacionais destinadas a assegurar a igualdade, mas institucionalizar ações concretas que dessem especial atenção à garantia dos direitos das mulheres (Brasil, 2002).

Com relação à necessidade de transformar os padrões socioculturais de conduta de homens e mulheres, o artigo $5^{\circ}$ da presente convenção deixou claro o compromisso que têm os estados membros signatários de interferir socialmente nessa mudança de comportamento e pensamento. O artigo vislumbra a necessidade de se garantir que a educação familiar inclua uma compreensão adequada da maternidade como função social" e "no que diz respeito à educação e ao desenvolvimento de seus filhos, essas medidas reconhecem notoriamente a intenção de incluir a educação não somente na esfera pública, mas privada, no seio de suas famílias, como base para se trabalhar questões igualitárias (Brasil, 2002). ” O artigo 10 enseja que os estados membros devem se articular através da educação, trabalhando as mesmas condições "de orientação em matéria de carreiras e capacitação profissional". Dando ênfase ao que diz o dispositivo, a "igualdade deve ser assegurada na educação pré-escolar, geral, técnica e profissional" e deve ocorrer o "estímulo à educação mista e a outros tipos de educação que contribuam para alcançar este objetivo". Para se alcançar esse objetivo o presente texto menciona a necessidade de outros métodos de ensino, que sirvam para eliminar conceitos estereotipados.

Foi possível concluir no que diz respeito à CEDAW que existem importantes princípios que são norteadores às condutas que devem ser adotas pelos países signatários o princípio da igualdade substantiva, "é aquela que assegura o tratamento uniforme de todos os homens, resultando em igualdade real e efetiva de todos, perante todos os bens da vida" (Silva, 2003, p. 36). Esta convenção é sem dúvida um acordo bastante representativo para uma formação educacional pública e privada que, através de ações concretas, pode diminuir a violência de gênero e feminicídio no Brasil.

\subsection{Violência de gênero e feminicídios}

O conceito 'violência de gênero' diz respeito a atos de violência praticados em decorrência da intolerância ao gênero a que pertencem as pessoas envolvidas. Apesar da expressão 'gênero' poder ser admitida tanto para mulheres quanto para homens, a expressão 'violência de gênero' se tornou um sinônimo de violência contra a mulher, pelo fato de as mulheres serem as maiores vítimas desse tipo de violência (Bandeira, 2014).

No Brasil, a Lei 11.340/06, a chamada Lei Maria da Penha, define violência doméstica ou familiar contra a mulher como sendo "qualquer ação ou omissão baseada no gênero que lhe cause morte, lesão, sofrimento físico, sexual ou psicológico e dano moral ou patrimonial", 
no âmbito da unidade doméstica, da família e em qualquer relação íntima de afeto, em que o agressor conviva ou tenha convivido com a agredida (Brasil, 2006).

Vale ressaltar que a Lei Maria da Penha foi resultado da Convenção sobre a Eliminação de Todas as Formas de Discriminação contra a Mulher (CEDAW). A partir do momento que o Brasil se comprometeu em tratar de forma especial os problemas de ordem igualitária com relação aos gêneros feminino e masculino - promoveu a aprovação do estatuto legal de proteção à mulher.

Os mecanismos de combate à violência de gênero não são novos. Desde meados dos anos 80, existe o empenho da polícia contra da violência doméstica. Antes disso, já havia algumas décadas que pesquisadoras de movimentos feministas começaram a estudar a possível contribuição do sistema jurídico para compelir as diversas violações dos direitos da mulher (Costa, 2005).

Em especial atenção ao papel do sistema judiciário na resolução dos conflitos de gênero, a esfera penal não depende somente dos dispositivos normativos para criminalizar tais condutas: utiliza-se também de elementos extralegais que se referem aos comportamentos sociais das vítimas e de seus agressores (Menezes \& Milani). Isso justifica também a implantação do tipo penal "feminicídio", que traduz como crime o comportamento do agressor de atentar contra a vida da mulher pelo fato de essa ser mulher.

Publicada em 09 de março de 2015, a Lei do Feminicídio veio assegurar, de forma específica, a punição mais severa aos homicídios que vitimam mulheres, quando eles estavam sob um contexto de violência de gênero. Nesse sentido, a lei trouxe o crime de feminicídio para o rol dos homicídios qualificados, e vinculou este crime ao rol dos crimes hediondos (Brasil, 2015).

A Lei do Feminicídio também se utilizou da expressão "violência doméstica e familiar" que foi tratada, definida e conceituada no art. $5^{\circ}$ da Lei Maria da Penha. Nesse sentido, cabe enfatizar que ambas as leis estão intimamente ligadas e que, além das hipóteses de violência doméstica e familiar descritas pela Lei Maria da Penha, havendo o homicídio de uma mulher por discriminação à sua condição de gênero, também estaremos diante de um feminicídio (Brasil, 2015).

Cabe ilustrar que o conceito de feminicídio difere de latrocínio, se uma mulher foi morta num contexto de violência doméstica praticada pelo seu companheiro, trata-se de feminicídio, justamente em razão do contexto está relacionado a uma questão de gênero, agora se uma mulher é morta em um roubo à mão armada, trata-se de latrocínio, onde a questão de gênero não teve qualquer relação, não há de se falar em feminicídio. Nesta 
hipótese como a lei não se insurge somente pelo fato de ser mulher, ausente o contexto de violência doméstica, o agente responderia pelo crime de latrocínio (Pasinato, 2011).

No Brasil, a cada uma hora e meia um homem assassina a uma mulher (IPEA, 2013). O país já ocupou o quinto lugar no triste ranking de países que mais matam mulheres no mundo (Waiselfisz, 2015). Ainda, 56\% dos homens admitiram que já praticaram alguma forma de agressão contra a mulher, como atos atentatórios à vida, a integridade física ou a liberdade sexual (Instituto Avon/Data Popular, 2013).

Diante do contexto apresentado, depreende-se que somente as leis com suas qualificadoras não são capazes de mudar a sociedade. Somente a educação (e nela inclui-se a conscientização em contextos públicos ou privados) - com sua característica basilar (por ser a base na família e na vida pública), é capaz de mudar a cultura e, somente através de uma transformação cultural, é que, paulatinamente, poderão ser revertidos esses dados de violência no Brasil.

\subsection{A importância do ensino a respeito da Convenção Sobre Eliminação de Todas as Formas de Discriminação Contra as Mulheres (CEDAW) para diminuir a violência de gênero e feminicídio no Brasil}

A realidade é que o próprio Poder Judiciário brasileiro não é pretencioso em reduzir a violência doméstica por meio de prisões, processos judiciais e até mesmo medidas protetivas. Nos últimos anos, após a Lei Maria da Penha, que foi resultado da CEDAW, o Judiciário vem adotando algumas estratégias com relação a alguns trabalhadores de áreas específicas, precisamente áreas onde haja grande concentração de funcionários do sexo masculino, para promover a reflexão e conscientização sobre violência de gênero (Correio Braziliense, 2019).

O próprio Conselho Nacional de Justiça (CNJ) tem defendido projetos pedagógicos de criação de programas de prevenção por meio da educação, através da portaria $n^{\circ}$ 15/2017, instituindo a Política Nacional de Enfrentamento à Violência contra as Mulheres no Poder Judiciário (Brasil, 2017).

Em alguns Estados, ações afirmativas de conscientização (através da educação) já se iniciaram - como é o caso do Maranhão, que, se utilizando da equipe multidisciplinar da Vara Especializada em Violência contra a Mulher de São Luís, verificou que o perfil dos homens que praticavam violência doméstica, em sua maioria, trabalhava na construção civil (10\%), no transporte urbano (6\%) e na vigilância (4\%), o que motivou, mais adiante, diversas orientações nesses locais de trabalho. Dessa forma, foi possível a implantação do projeto "Aprendendo com Maria da Penha no Cotidiano", permitindo que mais de três mil 
pessoas assistissem às palestras do projeto, cujo objetivo principal era desconstruir o machismo, que é o ponto central da prática de violência doméstica no Brasil (Correio Braziliense, 2019).

Outros debates nesse sentido foram promovidos pela visão diferenciada da promotora do Ministério Público de Goiás, Rúbian Corrêa Coutinho, que arquitetou o Projeto "Construindo Possibilidades". Conforme a servidora, "punições não são suficientes para estancar a violência doméstica" (Correio Braziliense, 2019). Ela produziu uma forma de palestra para ensinar como esses papéis foram assimilados, e os invertendo, com o intuito de desconstruir o machismo inserido na sociedade. As palestras estão sendo ministradas nos canteiros da construção civil e em outros setores, como de limpeza urbana e saneamento.

Outro exemplo são as ações de conscientização realizada pela $63^{\mathrm{a}}$ Promotoria de Justiça de Goiânia que, desde 2015, já reuniram aproximadamente três mil pessoas em oficinas de palestras e conscientização (Correio Braziliense, 2019).

Em 2016, o Tribunal de Justiça do Pará (TJPA) fez parceria com o Sindicato da Indústria da Construção do Estado do Pará (Sinduscon-PA) para dar instruções sobre a Lei Maria da Penha aos operários da construção civil. O TJPA também fez acordo com Associação Paraense dos Supermercados, promovendo o "projeto Mãos à obra: trabalhadores no combate à violência doméstica e familiar contra a mulher", que havia sido idealizado pela “Coordenadoria da Mulher em Situação de Violência Doméstica e Familiar do Tribunal" (Correio Braziliense, 2019).

Vale frisar que o poder judiciário não caminha inerte, pois vem traçando estratégias que poderão desconstruir a cultura do machismo no Brasil, a médio e longo prazo. O objetivo de reunir os homens no combate à violência contra a mulher, também é o foco da Coordenação das Delegacias Especializadas da Mulher, como acontece no estado Alagoas: articulada com o Conselho Regional de Engenharia e Agronomia (CREA-PB) e com o Sindicato da Intermunicipal das Indústrias da Construção Civil (Sintricom), promoveu uma orientação dirigida a mais de 600 trabalhadores (Correio Braziliense, 2019).

É notório que a iniciativa do Poder Judiciário de instruir a sociedade masculina é resultado do número de processos relativos à violência contra mulheres, que ao invés de diminuir desde a implantação da CEDAW e depois da Lei Maria da Penha, ainda continuam elevados. Com base nos dados do Judiciário brasileiro, tramitam no país mais de um milhão de processos relativos aos casos de violência doméstica contra a mulher (Brasil, 2017). 
Como poder representativo do Estado, o Poder Judiciário não deve ser o único a ter preocupação em desconstruir a cultura do machismo. Precisam atuar em dito propósito seus três poderes, pois têm a obrigação, em razão da Constituição Federal e da CEDAW, de garantir o direito igualitário entre homens e mulheres.

Os Poderes Legislativo e Executivo precisam se atentar à base do sistema educacional brasileiro para implantar as políticas públicas que ainda estão no papel ou promover a inclusão de dispositivos normativos educacionais que sequer foram discutidos (e, quando discutidos, houve uma distorção no que concerne a sua viabilização). É preciso salientar que as ações afirmativas de prevenção são medidas que visam reduzir e superar as gigantescas disparidades que foram acumuladas, historicamente, pelo fato de a sociedade brasileira ser bastante discriminatória e excludente (Louro, 1997).

O que minimamente se dialogou nessas esferas de poder foi o processo de implementação de uma política de cotas, as chamadas 'cotas de gênero' ou 'lei de cotas' que, recentemente, ainda estão sendo tratadas como tópico central das discussões no cenário político brasileiro (Grossi \& Aguinski, 2001).

A Lei de $n^{\circ}$ 9.100/95, que destina o mínimo de "trinta por cento e o máximo de setenta por cento para candidaturas de cada sexo", não viabilizou um aumento substancial de mulheres ativas na política (Grossi \& Aguinski, 2001). Isso deve ser compreendido fundamentalmente como uma medida repressiva, que não pode ser substancial para mudar drasticamente os espaços de poder.

Projetos implantados, dentro da escola, seria uma importante base de discussão para questões recorrentes relacionadas às diferenças sexistas. Louro (1997) afirma que a escola é um dos lugares onde se delimita símbolos de instrução, o que cada um pode fazer ou não fazer. Através de:

Seus quadros, crucifixos, santas ou esculturas, apontam aqueles (as) que deverão ser modelos e permite, também, que os sujeitos se reconheçam (ou não) em tais modelos. O prédio escolar informa a todos (as) a sua razão de existir. Suas marcas, seus símbolos e arranjos arquitetônicos "fazem sentido", instituem múltiplos sentidos, constituem distintos sujeitos (Louro, 1997, 58).

Contrariamente, o que se verifica é um retrocesso social no discurso político legislativo. Nem a CEDAW nem os direitos humanos (em geral) são de fato importantes aos partidários políticos que discutem ou já discutiram projetos no Congresso Nacional, cujo objetivo é, em suma ao contrário desta pretensão, que é interferir diretamente nos conteúdos abordados nas salas de aula, a fim de coibir o ensino sobre gênero e sexualidade. 
Criados sob a justificativa de proteger a família tradicional acabam por discriminar qualquer outro tipo de família - como se o padrão correto fosse o casal heterossexual afirmando que, falar-se em ideologia e sexualidade, seria motivar os jovens a serem homossexuais ou as meninas a engravidarem mais cedo. A própria CEDAW torna-se letra morta quando se há um discurso que limita o pluralismo ideológico e o Estado laico, normatizados na atual Constituição Federal.

Para finalizar, é notório que aqueles que são detentores de poder para tomada de decisões políticas - cujas ações deveriam ser pautadas numa justificativa legal e, sobretudo, centradas em garantir a nobreza dos pactos internacionais que versam sobre direitos humanos - parecem desconhecê-los e, se os conhecem, demonstram desprezá-los, completamente.

A violência e o feminicídio surgiram no ceio da família tradicional há tempos, mas seguem sendo uma problemática atual e mais do que presente nas famílias brasileiras. Os conceitos de dignidade da pessoa humana ou igualdade são desconhecidos, não dialogados e não ensinados - claramente visando perpetuar o machismo já cristalizado. Tal modalidade de preconceito vem sendo discursado sob (pretensos) argumentos religiosos ou morais, nos âmbitos privado e político, descaracterizando o conceito de estado laico e democrático de direito (previstos na Constituição Federal de 1988), o que pode ser constatado nos números alarmantes dos indicadores da prática do feminicídio e violência de gênero no Brasil. • 


\section{A EDUCAÇÃO DE GÊNERO E A IGREJA NO PLANO MUNICIPAL DE EDUCAÇÃO NA CIDADE DE FORTALEZA}

Com o avanço dos estudos sobre o comportamento humano e sobre o alcance da educação na vida dos indivíduos, notou-se que a educação de gênero é um componente fundamental na escolarização em todas as fases, pelo que se busca inclui-lo nos planos de educação. Mas no proceso de aprovação dos Plano Municipais de Eduação, em todo o território nacional, as câmaras legislativas e os conselhos de diversas cidades têm se transformado em um verdadeiro campo de batalha de ódio e de intolerância. Depois de longos processos de participação - que envolve professores, organizações da sociedade civil e gestores públicos na tarefa de delinear prioridades para a próxima década - os Planos começaram a ser recortados, no que concerne a questões de gênero e à sexualidade.

O tema se mostra cada vez mais necessário, pois a violência relacionada com a orientação sexual e o radicalismo são crescentes. A investigação da Universidade Federal de São Carlos apontou que os ambientes familiares e religiosos também são lugares predominantemente discriminatórios no que tange à orientação sexual. Com isso, os investigadores creem que a análise das questões familiares e religiosas como sendo causadoras da violência contra homossexuais deve estar na agenda de proposições e ações para a superação desses problemas no cotidiano escolar.

A mesma pesquisa da Universidade de São Carlos mostrou que 32\% dos homossexuais entrevistados afirmaram sofrer preconceito dentro das salas de aulas e que os educadores não sabiam reagir propriamente diante das agressões, de ordem física ou verbal, no ambiente escolar. Os dados, segundo os pesquisadores, convergem com aqueles apresentados no estudo do Ministério da Educação brasileiro, que ouviu 8.283 estudantes no grupo de idade entre 15 e 29 anos, no ano escolar de 2013 (em todo o país) e constatou que $20 \%$ dos alunos não querem ter em sala colegas de orientação homossexual ou transexual.

Nesse cenário, tem-se: de um lado, defensores dos direitos LGBT (lésbicas, gays, bissexuais, travestis, transexuais e transgêneros) e ativistas dos direitos das mulheres reivindicando que é papel da escola discutir gênero e sexualidade; e, do outro, fiéis portando bíblias, cruzes e rosários, expressando repúdio ao que foi qualificado como "ideologia de gênero". Disso decorre a distorção do tema e a incitação ao ódio toma o lugar da discussão profunda, cujo foco é a escola (GDE, 2009).

A educação é uma porta de entrada do indivíduo na sociedade, por isso deve avançar nas práticas educativas e sociais. Sabe-se que existe uma evolução da sociedade e que 
discussões que antes não existiam, como as divisões das tarefas domésticas, agora são posíveis. Discutir gênero é mostrar que pode existir igualdade e respeito na sociedade e na escola (Candau, 2008).

No contexto de intolerância em que o Brasil se insere, é relevante pensar na educação de gênero e no combate ao preconceito também contra homossexuais. Para ilustrar, pode-se mencionar como exemplo o caso de um menino de nome Alex, de 8 anos de idade, que foi morto pelo próprio pai por gostar de lavar louça e por bailar ao sabor da dança do ventre. Ele sofria castigos constantes impostos pelo pai que o mandava, reiteradas vezes, portar-se “como homem". Não se sabe se Alex já era homossexual em tão tenra idade, mas os relatos de diversos familiares e vizinhos asseguram que seu pai era extremamente homofóbico. O irmão mais velho do garoto já havia sido castigado por não ser "suficientemente mal". Depois de um dos "corretivos", o fígado de Alex se rompeu ocasionando a sua morte (Peixoto, 2018).

A violência desse caso é ainda mais trágica quando se podia ser evitada: Alex vivia com seu pai na cidade do Rio de Janeiro, porque sua mãe havia decidido não matricular seu filho em uma escola do município em que viviam (cidade de Mossoró, no estado do Rio Grande do Norte), por medo da reação adversa das outras crianças da escola em relação ao seu filho. Ao sair de sua terra natal para morar com o pai na cidade maravilhosa, a intolerância terminou por fazer de si outra vítima fatal (Peixoto, 2018). Episódios como esses são causados pelo preconceito e pelo ódio sistemático, que fomentam a ignorância, o obscurantismo e a violência. Portanto, há muitas razões para que a educação brasileira se preocupe com as questões de gênero e sexualidade, tratando-as como conteúdo escolar e de formação dos cidadãos ${ }^{27}$.

A discussão sobre gênero nas políticas educativas parte de uma falácia cruel: de que gênero, sexualidade e identidade (de gênero) são as invenções ideológicas. Hodiernamente, é muito comum se ver a desqualificação de determinadas visões do mundo como sendo "ideológicas" - um ideário sem fundamento na sociedade.

Em resposta a tal absurdo, a Associação Brasileira de Antropologia (ABA) publicou o "Manifesto pela igualdade de gênero na educação: por uma escola democrática, inclusiva e sem censura", firmado por 113 pesquisadores e grupos de estudos, que pretendem desmistificar certos argumentos. Alguns pontos do manifesto são apresentados a seguir.

\footnotetext{
${ }^{27}$ A dissertação de Peixoto (2018), defendida no Departamento de Sociologia da Universidade de Brasília, é repleta de casos que sensibilizam o leitor para o tema e merece recomendação aqui neste trabalho.
} 
Ao contrário de "ideologias" ou "doutrinas" sustentadas pela fundamentação de crenças ou fé, o conceito de gênero está baseado em parâmetros científicos de produção de saberes sobre o mundo. Gênero, enquanto um conceito, identifica processos históricos e culturais que classificam e posicionam as pessoas a partir de uma relação sobre o que é entendido como feminino e masculino. É um operador que cria sentido para as diferenças percebidas em nossos corpos e articula pessoas, emoções, práticas e coisas dentro de uma estrutura de poder. E é, nesse sentido, que o conceito de gênero tem sido historicamente útil para que muitas pesquisas consigam identificar mecanismos de reprodução de desigualdades no contexto escolar. (...) Quando se reivindica, então, a noção de "igualdade de gênero" na educação, a demanda é por um sistema escolar inclusivo, que crie ações específicas de combate às discriminações e que não contribua para a reprodução das desigualdades que persistem em nossa sociedade. Falar em uma educação que promova a igualdade de gênero, entretanto, não significa anular as diferenças percebidas entre as pessoas (o que tem sido amplamente distorcido no debate público), mas garantir um espaço democrático onde tais diferenças não se desdobrem em desigualdades. Exigimos que o direito à educação seja garantido a qualquer cidadã ou cidadão brasileira/o e, para isso, políticas de combate às desigualdades de gênero precisam ser implementadas. (ABANT, 2018 p.1)

No debate "Por que discutir gênero nas escolas?", realizado na Câmara de Vereadores da cidade de São Paulo, foram rebatidas as questões de que gênero seria uma ideologia e, assim, deve ser obrigatoriamente discutida pela sociedade porque é uma relação de poder que mata pessoas, que violenta e subjulga a milhões de indivíduos.

A violência contra a mulher está generalizada na sociedade, bem como na escola. Não faltam exemplos de casos ocorridos nas escolas, como é o caso de uma menina de 12 anos, que foi violentada dentro de uma escola de São Paulo, por um menino de 14 ano com ajuda de outros meninos. Nas periferias dessa mesma capital, vídeos do Youtube (sítio da internet) e "correntes" de mensagens, do Whatsapp (aplicativo de telefone celular), propagam as "top 10": um ranking no qual as meninas são listadas e insultadas como "vadias, piranhas" e dezenas de outros adjetivos perjorativos e perversos. As garotas 
afetadas por essa prática tentam o suicídio muitas vezes ou abandonam suas rotinas escolares. Um estudo recente da Agência É Nóis revelou que $77 \%$ das meninas acreditam que o machismo impacta no seu desenvolvimento escolar e social (Peixoto, 2018).

Já em se tratando de mulheres vítimas de agressão, segundo dados do PNAD / IBGE de 2009: 48\% das que sofrem violência são agredidas dentro de casa; 03 de cada 05 mulheres relatam ter sofrido violência dentro de relações; e 56\% dos homens reconhecem-se como agressores em algum momento de suas vidas. Em 2014, o Brasil recebeu 52.957 denúncias de violência contra a mulher. Na última década, 44.000 mulheres foram asassinadas no país (entre 2001 e 2011). No ano de 2003, os homicídios de mulheres aumentaram 17,2\%, ano em que 4,5 mi mulheres foram assassinadas no Brasil (Dantas \& Paulo, 2015).

A enumeração acima é pequena diante do tamanho da violência de gênero que afeta o país. A lista poderia crescer infinitamente. A escola, como espaço onde a sociabilidade se forma e pode ser transformada, deve se excluir do debate de gênero? Essa exclusão contribui para o crescimento da violência?

Ser homossexual ou transxessual no Brasil é um martírio. Desde cedo, qualquer comportamento que foge ao que se considera normal é tratado com desprezo, asco, violência física e psicológica, como no caso supracitado do menino Alex. Entretanto a violência vai mais além: em março de 2018, Peterson Ricardo de Oliveira, de 14 anos, morreu por ter sido golpeado numa escola pública da Região de São Paulo, porque seus pais eram gays. Fatos como esses se multiplicam em todo o território brasileiro.

O Grupo Gay da Bahía (ONG baiana voltada para a defesa dos homossexuais), informou que, no período de 2013 a 2014, um gay foi assassinado a cada 28 horas no país. Foram 312 assassinatos de pessoas sexualmente diversas em 2013. O informe demonstra dados mais chocantes: "o Brasil confirma sua posição de primeiro lugar no ranking mundial de assassinatos homofóbicos, concentrando $44 \%$ do total de execuções de todo o planeta". Os Estados Unidos, por sua vez, registraram 15 assassinatos de travestis em 2011, mesmo dispondo de 100 milhões de habitantes a mais, enquanto que, no Brasil, foram executados 128 transsexuais. Aponta ainda o informativo que a chance de um transsexual em solo brasileiro ser assassinado é de $1.280 \%$ vezes maior que em solo americano (Grupo Gay da Bahia, 2015, 38).

Outro aspecto que deve ser considerado é a violência de gênero em âmbito escolar que leva à evasão. Em virtude disso, faz-se necessário dispor de estratégias educacionais que minimizem a discriminação e a evasão escolar de LGBTI. Entre a população trans, as taxas de evasão escolar são ainda maiores, o que limita as opções profissionais e de vida desses indivíduos, separados dos estudos e do mercado de trabalho pelo preconceito. Muitas vezes 
os alunos e alunas que se reconhecem como trans são invisíveis nas escolas (não sendo chamados pelo nome social ) e se veem obrigados a abandonar a escola. Ainda assim, alguns educadores não se comovem, levando ao questionamento de por que as pessoas cisgêneros tem garantido o direito à vida e eles e elas não? Por que a diferença? Isso deve ser discutido para que possamos mudar a realidade educacional.

Além da necessidade no contexto brasileiro, a não discussão de gênero vai contra diversos tratados internacionais firmados pelo Brasil. São algumas dezenas de conferências internacionais, tratados, convenções e acordos que estariam sendo descuidados, porque os Planos Municipais de Educação excluem os termos ligados ao gênero.

Um PME que contemple as discussões de gênero diz muito mais respeito às mulheres, que são $50 \%$ da população. Discutir gênero nas escolas significa questionar a violência contra a mulher e desconstruir a mentalidade machista. Questionar em sala de aula a razão delas terem salários menores e espaço reduzido nos parlamentos. [Questionar isso] é, inclusive, ir na direção de documentos internacionais para a promoção de direitos das mulheres que vai desde a Carta das Nações Unidas a Declaração dos Direitos Humanos, passando pela Convenção Interamericana sobre a Concessão dos Direitos Civis às Mulheres que outorgou às mulheres os mesmos direitos civis que gozam os homens, [negar o gênero] é passar por cima da Convenção sobre os Direitos Políticos da Mulher, de 1953, a Convenção da Organização Internacional do Trabalho (OIT), de 1951, que dispõe sobre igualdade de remuneração entre gêneros, a Convenção da OIT de 1952 que versa sobre o amparo materno, a Convenção da OIT de 1958 que dispõe sobre a descriminação em matéria de emprego, a [resolução da] 156 da OIT de 1981, que estende aos homens a responsabilidade sobre a família, a Convenção Americana de Direitos Humanos de São José, a Convenção Mundial de Mulheres da Cidade do México, que reconheceu o direito da mulher à integridade física, inclusive, à autonomia de decisão sobre o seu corpo e o direito à maternidade opcional, a Convenção para Eliminar Todas as Formas de Discriminação sobre a Mulher, de 79, assim como as conferências mundiais sobre a mulher de Copenhague e Nairóbi, de 80 e 85, também a Convenção Interamericana para Prevenir, Punir e 
Erradicar a Violência Contra a Mulher, que aconteceu em Belém do Pará de 1994 e uma série de compromissos internacionais assumidos pelo Brasil em nome da igualdade de gênero. Ai você vê nessa Casa mulheres e meninas recrutadas em suas comunidades religiosas mostrando cartazes que dizem não ao gênero. (Grupo Gay da Bahia, 2015)

O machismo impacta a aprendizagem e a autopercepção de meninos e meninas. A forma como os alunos são avaliados e percebidos pelos adultos afeta fortemente a percepção que eles têm de si. Ainda que diversos papéis sejam repassados de geração em geração de maneira explícita, existem os preconceitos invisíveis - conteúdos ocultos na educação. Um deles fomenta a ideia de que os meninos são mais talentosos para Ciências Exatas e serão melhores cientistas, engenheiros e técnicos de informática que as meninas. No entanto, as pesquisas sobre o assunto desconstroem esse mito.

Pensando sobre a origem da ausência da presença feminina em posições profissionais da área de exatas, pesquisadores da Universidade de Telaviv fizeram um experimento com três grupos de alunos, da $6^{\mathrm{a}}$ série até o fim da idade escolar. Cada aluno teve provas idênticas sobre uma série de matérias e as provas foram corrigidas por dois grupos de professores: um que sabia os nomes dos alunos (e, portanto, era capaz de deduzir o sexo deles) e um que corrigiu provas anônimas (GDE, 2009).

Mesmo que as respostas dos alunos fossem idênticas, as correções foram desiguais. O grupo de professores que sabia os nomes deu notas maiores para as meninas. Esse feito, sem dúvidas, só ocorreu com as provas de Matemáticas e Ciências - as avaliações de inglês, por exemplo, tiveram correções parecidas. A conclusão dos investigadores foi que, em matemática e ciências, os professores subestimam as meninas e que isso produz um efeito duradouro. Quando os grupos de alunos observados estavam perto da graduação, poucas meninas mostraram interesse pelas áreas de Ciências Exatas.

A desigualdade de gênero também afeta aos meninos. Os estudos demonstram que o fracasso escolar e a evasão de jovens estão vinculados a referências de masculinidades difundidas socialmente. A identidade masculina é baseada na agressividade e na indisciplina. Segundo dados do IBGE de 2011, os meninos foram cada vez mais se afastando das salas de aula (37,9\% deles), haja vista que lhes foi negado seu direito à educação, reproduzindo uma cultura de violência (IBGE, 2018).

Com relação ao ambiente educacional brasileiro, os papeis seguem sendo reproduzidos, principalmente nos acontecimentos "lúdicos" que ocorrem na Instituição Escolar, tais como dança teatro, esportes e outras manifestações. As "territorialidades" são 
exemplificadas através de atividades para "meninos" e "meninas" como regras sociais, com códigos e significados que indicam "feminilidade" e "masculinidade" - no sentido estrito de "normalidade", de funções sociais previamente determinadas e, por isso, culturalmente impostas.

Se uma menina se inscreve em uma equipe de futebol ou um menino em um grupo de balé, a ideia de "normalidade" ("instintivamente" preconcebida) é quebrada e isso é visto de forma pejorativa, ferindo de maneira ampla a "feminilidade" e a "masculinidade" indicada como regra a partir desse e de outros juízos de valor, criando-se estigmas, cismas, rótulos, dúvidas, depreciações e juízos sem precedentes (Macedo, 2002),

A deturpação da sexualidade, estimulada culturalmente através de piadas, apelidos e comportamentos estilo "clube do bolinha", surge de maneira automatizada e, muitas vezes, estereotipada à luz do comportamento conservador que ainda está presente em diversos aparatos ideológicos do Estado e da sociedade (Althusser, 2007), tais como as escolas, as igrejas, famílias, etc. Sobre o preconceito, a segregação e o estigma é um feito que necessitamos "descongelar" as atitudes que causam violências e inferiorizações na sociedade e congelar, combater, impedir a intolerância de tal forma que podemos orientar a capacidade cognitiva e formativa do ser humano para que, finalmente, seja um indivíduo eminentemente humano. Reitera-se que o ser necessita "humanizar", conhecer direitos, desenvolver aspectos sociais da vida cidadã, manifestar suas inquietudes e conquistas referencias de respeito mútuo, entre as chamadas minorias sociais.

É inconcebível que no sistema de ensino não haja essa discussão. A própria escola (como instituição) necessita aperfeiçoar conhecimento e compreender que a sociedade é dinâmica, que caminha em constante transformação histórica e que os aclamados processos educativos, baseados na Teoria da Educação, necessitam de práxis social - sem pragmatismos forçados. É necessário que ações concretas e eficazes, e diálogos sejam realizados. Sobretudo, é preciso reconhecer que podemos e devemos transmutar o desnivelamento social, cultural e simbólico que ainda habita no ensino e na sociedade brasileira.

Outro aspecto a ser pensado é a relação entre preconceito e religião, pois discutir gênero é uma luta pela dignidade humana, portanto, pode ser entendida como uma luta cristã. Alguns líderes religiosos entendem que essa questão deve estar sobre qualquer doutrina para que se possa garantir uma educação laica. A suposta rixa entre religiosos e ativistas feministas e LGBTI levanta as recentes polêmicas que envolvem a educação, bem como as reflexões essenciais: somos capazes, na sociedade, de enfrentar nossos abismos? Somos capazes de acolher as pessoas que sofrem violências cotidianas? De criar um ambiente 
escolar capaz de focar nos desafios do nosso tempo e promover outra sociabilidade, pautada pela solidariedade e empatia?

\subsection{Discutir para construir}

Os documentos que devem ser construídos de maneira participativa e democrática - os Planos Municipais e Estaduais de Educação - devem ser elaborados contendo metas e estratégias para garantir o direito à educação para a população de uma determinada cidade ou estado no prazo de dez anos. Com tal propósito, parte da sociedade pede a inserção da educação de gênero.

A pastora luterana, Romi Márcia Bencke, que é secretaria do Conselho Nacional das Igrejas Cristãs do Brasil, expressa que é lamentável e, ao mesmo tempo, aterrorizante, que a violência contra a mulher não gere indignação. Diuturnamente, são casos e mais casos sem solução. A troca de cultura é gradual, por isso é necessário começar a falar abertamente sobre esses temas para que se substitua uma concepção de mundo patriarcal por uma visão de mundo diversificada, já que discutir problemas é fundamental em todos os espaços, especialmente nas escolas (CONIC, 2018).

Sobre a ação dos grupos que tem feito pressão sistemática para que a palavra "gênero" nem sequer estivesse mencionada nos Planos, Romi Márcia acredita que eles têm dificuldade em aceitar as transformações da sociedade. Para ela, há uma dificuldade em aceitar que, nos tempos de hoje, não cabe mais à religião normatizar a vida das pessoas. Lutar com as autonomias é difícil, mas as religiões precisam aceita-lo. A liberdade humana é um valor que também se relaciona com a fé, segundo a pastora (Salgado, 2015).

O enfoque das questões relacionadas com o gênero é essencial. É importante que os educadores sejam preparados para aborda-las de forma madura e inclusiva. O Brasil é um país em que a violência está inserida no cotidiano das pessoas e um número significativo de casos tem motivação sexista. A violência contra a mulher e contra a população LGBTI é resultado de um país em que prevalecem valores tradicionais, que tendem a reforçar relações de poder desiguais e opressivas. Problematizar tais valores é também uma tarefa da educação.

A partir do momento em que o tema da diversidade for efetivamente trabalhado nas escolas, a sociedade poderá dar passos concretos para a mudança de percepção do mundo. Para isso, há que se voltar para os valores presentes em décadas anteriores e compará-los com a atualidade, de maneira tal que as pessoas percebam como a história é dinâmica. Nos últimos anos, o Brasil tem dado passos importantes para a superação da desigualdade 
econômica e se faz necessário também andar em direção à superação de todas as formas de preconceito e discriminação (Salgado, 2015).

Uma das funções da religião é a preservação de tradições. Indubitavelmente, essa tarefa precisa ser feita em consonância com o contexto histórico e social no qual se vive. Os papéis de gênero mudaram de forma muito forte e rápida. Logo, também mudaram os papéis sociais dos homens e das mulheres.

Os modelos de família de hoje são bem diferentes dos modelos de família no começo do século XX, por exemplo. Não é possível para as igrejas dizer o que é um modelo de família aceitável ou não aceitável. Se em uma determinada família existe amor, respeito, carinho e diálogo, pode-se dizer que ali existe efetivamente uma família - independente se são dois homens, duas mulheres, ou uma mulher e um homem. Em um contexto de ausência de respeito, agressões e dominação, pode-se dizer que se trata de uma família com problemas, independentemente de quem a compõe. É o que a religião deveria avaliar e contribuir positivamente a transformar: as relações humanas, acorrendo, positivamente, para uma cultura de paz (Salgado, 2015).

De acordo com Romi Bencke (apud Salgado, 2015), nos grupos que atuam fortemente contra os temas de gênero, percebe-se uma resistência em aceitar as transformações que ocorreram na sociedade. As mudanças desestabilizam. Para reencontrar a segurança, para manter o mundo organizado, é necessário dar suporte às concepções que causam sensação de segurança. Outra compensação é a de que há a dificuldade em aceitar que nos tempos de hoje não cabe mais à religião normalizar a vida das pessoas.

A ideologia é um conjunto de crenças e ideias que constituem a visão de mundo de um determinado grupo ou classe social. As práticas e valores sociais podem corresponder a uma ideologia, mas eles mesmos não são uma ideologia. A ideologia é sempre uma representação social do mundo em um sentido mais amplo, assim, as relações de gênero e suas representações sociais podem expressar parte de uma determinada ideologia. O que existe, historicamente observado, é que os valores patriarcais têm fundamentado as relações de gênero. De tal maneira, tais valores pertencem a uma ideologia dominante.

Quando grupos propõem o debate sobre as relações de gênero e reclamam mudanças, estão problematizando uma ideologia que tem dominado e contribuído para as relações humanas pautadas na desigualdade entre os gêneros. A problematização das relações de poder é fundamental para que novas relações humanas e sociais sejam criadas. 


\section{2 (DES) construir: um retrocesso considerável}

A meta descrita no Plano Nacional de Educação- que trazia estratégias para os próximos 10 anos - como políticas curriculares para combater o preconceito e garantir o direito à diversidade de gênero. Entre outros itens, garantir o acesso dos transexuais e travestis às toaletes das instituições de ensino, de acordo com sua identidade de gênero; o direito ao uso de nomes sociais em lista de presença; e o combate ao preconceito e à discriminação de pessoas segundo sua orientação sexual (questão que não agrada, em nada, às igrejas cristãs).

Por medo da implantação destas políticas no campo da educação, algumas arquidioceses sugerem que, com o propósito de superar discriminações, sejam desconsideradas as diferenças. Nesse sentido, o texto diz que o respeito às minorias não pode impor a todo custo à destruição de valores consagrados no âmbito familiar e que a "ideologia de gênero" representa uma distorção completa ao conceito de homem e mulher. O posicionamento deixa claro na Carta Circular da Conferência Nacional dos Bispos do Brasil, da Regional Nordeste, no que se trata de falar de "ideologia de gênero" e orienta aos cristãos católicos a serem contrários à aprovação da temática (CNBB, 2015).

O texto emitido pela instituição fala que os padres devem se informar do que se trata a chamada "ideologia de gênero" e qual a posição da Igreja. Afirmam que a "ideologia de gênero" é uma tentativa de defender que não existe uma identidade biológica de sexualidade, mas uma construção definida socialmente. Os defensores dessa perspectiva buscam, segundo a CNBB, alcançar uma sociedade sem classificações de sexo e, para isso, deturpar as relações familiares, escolares, de reprodução e outros. Os bispos reafirmam que para eles a identidade é expressa biologicamente e se limita à dualidade homem e mulher (CNBB, 2015).

As igrejas Católica e Pentecostal estão conseguindo excluir qualquer referência a gênero no que concerne aos Planos Municipais e Estaduais de Educação, com o argumento de que estes estariam destruindo o papel da família de educar seus filhos.

No caso da capital cearense, Fortaleza, por exemplo, foram retirados do PME os seguintes pontos: denúncias de violências e discriminações de gênero e de identidade de gênero, raça e etnia, origem regional ou nacional, orientação sexual, deficiências e intolerâncias, assim como ações educativas relacionadas à Lei Maria da Penha. Também têm sido eliminadas as propostas pedagógicas que incorporem conteúdos sobre sexualidade, diversidade quanto à orientação sexual e identidade de gênero, bem como as propostas de ampliação da formação dos professores no que tange à superação da descriminação, do preconceito e da 
violência no ambiente escolar. A posição de tais entidades é surpreendente, uma vez que a cristandade pressupõe o compromisso contra a discriminação e a desigualdade.

São diversos os paradoxos criados por grupos ligados às igrejas cristãs: a CNBB declarou, por exemplo, que a introdução dessa "ideologia de gênero" na prática pedagógica das escolas trará consequências desastrosas para a vida das crianças e das famílias. Tais contradições entre o que prega Cristo ("Amarás ao teu próximo como a ti mesmo ${ }^{28}$ ), alicerce e razão do Cristianismo, e o que pregam aqueles que se dizem seus representantes na terra, também surpreendem especialistas. Jane Felipe, coordenadora da pesquisa intitulada "Gênero, Amor Romântico e Famílias: entre ideais e invisibilidade, os maustratos emocionais e a morte", do Programa de Pós-Graduação em Educação da Universidade do Rio Grande do Sul, afirmam que se trata de religiões que deveriam primar pelos direitos humanos, pela premissa de amor ao próximo, mas são justamente elas que pregam a violência a partir da ignorância e intolerância. Não sabem o que dizem quando falam de "ideologia de gênero" porque nunca estudaram a fundo (Felipe, 2009).

A pesquisadora lamenta que alguns parlamentares se mostrem insensíveis às questões de gênero, quando deveriam, por conta do cargo que ocupam, ter certa maleabilidade e recorda que as crianças possuem sexualidade e identidade e, justamente por esse motivo, é papel da escola também discutir questões de gênero em quaisquer disciplinas.

Membro do Laboratório de Psicologia Escolar e Educativa da Universidade Federal de Santa Catarina, Marivete Gesser explica que o gênero pode ser caracterizado como uma construção discursiva sobre nascer com um corpo com genitais masculinos ou femininos e, por meio de normas sobre masculinidade e feminilidade, vermo-nos construído como sujeitos generalizados. O preconceito de gênero está relacionado a esses discursos sociais que naturalizam lugares sociais para homens e mulheres, assim como patologizam aqueles que se colocam de modo diferente do esperado socialmente (GDE, 2009).

Segundo a mesma professora, o preconceito de gênero atravessa todas as instituições sociais - família, escola e Estado - justificando uma ampla discussão em políticas públicas de educação, saúde, justiça e assistência social. A escola tem sido um espaço privilegiado para discutir o tema e os professores têm sido atores importantes no combate às desigualdades. Por isso, vê-se como grande retrocesso a retirada das pautas relacionadas à igualdade de gênero em documentos como o PME e PEE. Quando se discute a questão de gênero por uma perspectiva que vá contra os padrões dominantes de masculinidade e feminilidade, contribui-se para a diminuição da homofobia, inclusive.

${ }^{28}$ Ver Marcos 12: 29-34. 
O estudo realizado entre o Ministério da Educação e o Instituto Nacional de Estudos e Pesquisa (INEP) mostra que de todos os alunos matriculados em diferentes níveis escolares da educação básica, metade é composta por meninos (25.150.851) e metade por meninas (24.620.520), em 2014. As diferenças entre heterossexuais, homossexuais e transgêneros podem ser barreiras enormes entre eles, causando rivalidades e divisões dentro da escola. É importante discutir gênero nas escolas não para negar ou promover outras possibilidades, mas para difundir o respeito à diversidade. Não se trata de ensinar ao menino a ser de determinada maneira, mas sim de respeitar quem é diferente e poder entender que existem outras opções (INEP, 2018).

A expressão que os conservadores têm usado, "ideologia de gênero", é uma falsa noção porque o conceito de gênero não tem um marco ideológico e, sim, sociológico. O gênero é uma palavra designada para lidar com as relações de poder e discriminação que sempre existiram em torno das identidades e papeis associados ao masculino e feminino, mais além do que o sexo biológico, para dizer que existe a discriminação contra o feminino. Essa foi uma construção conceitual de Direitos Humanos discutida em diversas conferencias da ONU e, nelas, o Brasil confirmou compromissos em relação referentes, no marco do PNE. Agora estados e municípios têm a oportunidade de reacender o debate (Rios, 2006).

Por fim, fica claro que o fato de o Brasil se tratar de um Estado laico, conforme previsto na Carta Magna de 1988, isso, por si só, não é impedimento para que as igrejas Cristãs sigam impondo seus pontos de vista sobre as legislações. Não debater é um argumento para se dar invisibilidade, é como um subterfúgio criado pelas pessoas que creem que ser gay é uma enfermidade. É preciso, justamente, visibilidade de todas as formas de discriminação. A escola, sendo um espaço de construção de identidade, deve assumir que a sociedade é racista, machista, homofóbica e criar regras para que seja um espaço social mais tolerante. Somente assim se podem formar pessoas melhores no futuro, no qual todos, sem exceção, possam ter seu lugar ao sol. Não obstante, em todas as idades se pode haver um tratamento respeitoso, no que concerne às referidas questões. 


\section{O ABORTO COMO DIREITO DAS MULHERES EM DEBATE}

O aborto é uma prática que ocorre em todas as sociedades do mundo, seja de maneira mais ou menos frequente. Assim, nos estudos antropológicos é sabido que este procedimento tem caráter universal.

O que parece universal não é tanto, aliás, a prática do aborto voluntário, atestada de modo muito desigual, ao que parece, conforme as sociedades e conforme as épocas (embora dados estatísticos sólidos não possam quase nunca ser estabelecidos), mas o reconhecimento da possibilidade dessa prática. Não há registro de exemplo de situações em que um informante (e, mais ainda, uma informante), interrogado sobre esse ponto, ignore do que se trata ou se espante, caso lhe seja explicado, que isso possa acontecer. A possibilidade de tirar os fetos do ventre antes de seu nascimento com a intenção de destruí-los parece, portanto, fazer parte dos quadros fundamentais da existência humana em sociedade (Boltansky, 2012, 208-209).

Há muitos tipos de abortos que são realizados ancestralmente entre os povos. Se considerado que a população brasileira tem em sua formação raízes indígenas, negras e europeias, é perceptível que está presente nela uma vasta gama de misturas culturais, o que influencia sobre as práticas abortivas. Os métodos mais utilizados são o uso de drogas abortivas, geralmente de origem vegetal com efeitos laxantes, purgativos, adstringentes, etc., sendo os meios naturais os mais conhecidos em praticamente todas as sociedades.

Existe também o uso de meios mecânicos ou internos (com a introdução de instrumentos na vagina da grávida), externos (pulos, golpes, cintos apertados na barriga, aplicação de materiais quentes como água, cinzas ou pedras sobre a parede abdominal) ou uma combinação destes diferentes métodos, como a introdução de drogas na vagina e a manipulação de órgãos sexuais.

Tais métodos, químicos ou mecânicos, têm correlação com cada uma das teorias locais referentes à reprodução e à gestação, sobre as quais repousa a confiança depositada em sua eficácia. São igualmente empregados meios mágicos (sentar-se sob determinada árvore, comer ou beber certo alimento, carregar um amuleto, etc.). Esses meios mágicos, nitidamente distinguidos dos meios mecânicos ou químicos em geral, repousam muitas vezes na 
realização de um ato transgressivo (o alimento ingerido é proibido etc.) (Boltanski, 2012, 209).

Atualmente no Brasil, o aborto está permitido em algumas situações específicas. Recentemente houve uma Arguição de Descumprimento de Preceito Fundamental (ADPF) 442, na pauta em discussão no Superior Tribunal Federal (STF) que pede a despenalização do aborte até a $12^{\mathrm{a}}$ semana de gestação. No debate, estatísticas sobre as ocorrências de aborto no Brasil e no mundo são usadas tanto por aqueles que defendem a legalização como por aqueles que são contrários, mas ainda falta muitas informações, gerado defasagens na discussão legal (Fernandes, 2017).

\subsection{Dados e discussão do aborto no Brasil}

Como a interrupção da gravidez é crime, é possível obter informações somente das ocorrências oficiais, os dados no Brasil são do Ministério da Saúde, calculados a partir de informações recolhidas no exercício do atendimento do Sistema Único de Saúde (SUS) e ajustadas a critérios estatísticos. Os dados, sem dúvida, só mostram os procedimentos legais, nos últimos anos, não há variação significativa nos registros. O aborto é legal em casos de estupro, risco à vida da mãe ou de feto anencefálico. De acordo com estes dados, em 2017, foram feitos 1.636 abortos legais.

Em uma audiência pública na Câmara dos Deputados, em dezembro de 2016, a Dra. Maria de Fátima Marinho, Diretora de Doenças Não Transmissíveis e Promoção da Saúde do Ministério da Saúde, apresentou algumas informações sobre o aborto no Brasil (Fernandes, 2017). De acordo com ela, entre 2011 e 2016, 4.262 adolescentes de 10 a 19 anos tiveram uma gestação resultante de estupro e o consequente nascimento do bebê. Quer dizer, um direito previsto em lei foi negado a mais de 700 jovens brasileiras por ano. Desta quantidade, 1,875 eram meninas de 10 a 14 anos, quase $73 \%$ do total. As outras 2.387 jovens tinham entre 15 e 19 anos, dentre esses casos 68,5\% das vezes o autor do estupro era um familiar.

Segundo o estudo "Estupro no Brasil: uma radiografia segundo os dados da Saúde", publicado pelo Instituto de Pesquisas Econômicas Aplicadas (IPEA), em 2014, em 7,1\% dos estupros resultaram em gravidez, segundo dados do SUS de 2011, entre as vítimas adultas que engravidaram em razão de estupro, 19,3\% realizaram aborto previsto em lei (Cerqueira \& Coelho, 2017). Essa proporção cai para 5\% entre adolescentes e 5,6\% em meninas. O procedimento para menores deve ser feito somente se a criança e o seu tutor estiverem de acordo. Tendo em conta a alta taxa de ocorrências de casos de estupros 
causados pelos próprios familiares (como autores do crime), é possível que a diferença na taxa de aborto entre menores de idade e adultos reflita esses casos (Fernandes, 2017).

Outro tipo de aborto legal é o caso dos fetos anencefálicos. Os abortos não se realizam sempre que possível. De acordo com dados apresentados pelo Ministério da Saúde, de 2006 a 2016, houve uma variação de 420 a 500 nascimentos de fetos anencefálicos. Isso significa que há mais de 400 mulheres que têm seus bebês anencefálicos ao ano, ainda que tenham direito ao aborto legalizado, cujo tipo de interrupção de gravidez é permitido desde 2012, por decisão do STF.

Além disso, há muitas dificuldades de acesso ao direito ao aborto, inclusive há as negativas dos profissionais de saúde. O questionário da International Women's Health Coalition (IWHC, 2016), que atua globalmente pelos direitos reprodutivos, mostra os impactos da chamada objeção de consciência. O termo se utiliza quando os profissionais alegam questões morais ou religiosas para não trabalhar em situações de aborto, ou em procedimentos que envolvem métodos contraceptivos.

Em ao menos 70 jurisdições, nacionais ou de outros países, existem previsões para o tipo de negativa, mas há falhas inclusive quando a lei prevê atenções de emergência. Muitas leis nacionais estabelecem que os profissionais devem realizar o aborto em caso de emergência. As evidências mostram claramente que as normas, inclusive quando estão em vigor, são extremamente difíceis de serem aplicadas, de acordo com a publicação Unconscionable (Schvey \& Kim, 2018), quando os provedores de cuidados negam a atenção à saúde.

O estudo relata o caso de uma mulher brasileira que, em 2015, com gravidez resultante de violência de estupro, foi a um centro especializado para vítimas de violência no hospital da Universidade Estadual de Pernambuco. Ali, o hospital forneceu a prescrição para um medicamento de indução de aborto, já que sua gravidez tinha menos de 10 semanas. Na ocasião, ela ouviu frases de críticas negativas à sua pessoa e de pré-julgamento, ressaltando uma possível falta de cuidado nas relações sexuais.

Foi perguntado, várias vezes à vítima se essa havia considerado bem sua decisão, no entanto, não houve uma preocupação em ouvi-la quanto às suas necessidades. A mulher só recebeu o tratamento inicial e, cinco dias depois, foi feita a aspiração manual do feto por uma médica, finalizando o tratamento. No Brasil, diretrizes do Ministério da Saúde estabelecem que os médicos têm o direito individual de recusar atendimento, a menos que não haja outro médico para atender à mulher, se houver risco de morte ou se a omissão de atendimento causar danos à paciente. 
O Governo Federal, assim como o sistema de saúde, não tem informação sobre o número de abortos ilegais praticados no país. Por se tratar de um delito (salvo as três situações supracitadas, permitidas por lei) não é possível se ter controle e, consequentemente, disporse de dados cofiáveis. Mas há dados que ajudam a medir essa clandestinidade: de acordo com o Datasus (2017) - departamento de informática do Sistema Único de Saúde do Brasil, responsável por coletar, processar e disseminar informações sobre saúde - foram registradas 177.464 curetagens pós-aborto, um tipo de raspagem da parte interna do útero. Em 2017, foram registrados 13.046 casos de realização de outro procedimento utilizado em casos de aborto, o esvaziamento do útero por aspiração manual intrauterina (AMIU). A prática dos dois procedimentos juntos somam 190.510 intervenções. Os números incluem tanto as atenções dos abortos clandestinos como alguns abortos espontâneos, mas a estimativa é que dois terços do total sejam ilegais (Lolatto \& Lisboa, 2013).

De acordo com o estudo, apesar de haver uma redução no total de curetagens nos últimos anos, a relação entre abortos e partos segue sendo a mesma. É preciso esclarecer ainda que existe uma diminuição da fecundidade no Brasil e que o número de partos, por tanto, também tem diminuído, o que significa dizer que a probabilidade de uma mulher brasileira engravidar também diminuiu. Em 2016, por exemplo, foram 11,7 abortos para cem partos. A média anual desde 2012 é similar, de 11,24. Outra evidencia de informação sobre procedimentos clandestinos é que os abortos ocorrem com frequência similar em países com leis mais restritas em comparação com aqueles com normas mais flexíveis, segundo um estudo do Instituto Guttmacher, organização de investigação sobre direitos reprodutivos (Fernandes, 2017).

Segundo a pesquisa, nos países onde a interrupção da gravidez não está permitida em nenhuma hipótese ou só em caso de risco de vida da mãe, são 37 abortos por cada mil mulheres. Nas nações com permissão sem restrição de motivo, a proporção é de 34 por mil mulheres. A estimativa é de 25 milhões de abortos inseguros no mundo por ano.

De acordo com o Datasus (Ministério da Saúde, 2017), a curetagem é um dos procedimentos mais comuns no SUS. Representa 3,9\% das 4.570 .216 cirurgias realizadas em 2017, cujo custo foi de $\mathrm{R} \$ 37,97$ milhões, valor similar a 2016 (R $\$ 37,2$ milhões) e a 2015 ( $\mathrm{R} \$ 38,8$ milhões de reais). A aspiração tem um custo de $\mathrm{R} \$ 120,00$, de modo que a estimativa é de $\mathrm{R} \$ 1,56$ milhão gastos no ano passado. Os dados revelam que o sistema público de saúde tem gastos significativos como consequência do aborto ilegal, a estimativa dos especialistas aponta a redução de custos se o procedimento for legalizado. 
A estimativa é que as intervenções pós-aborto, segundo o estudo publicado pelo Instituto Guttmacher $^{29}$, tenham custado mais de 232 milhões de dólares em países em desenvolvimento, em 2014. Se todas as mulheres tivessem o atendimento ao aborto legalizado respeitado, o gasto seria de vinte milhões de dólares, sendo que, no Brasil, os abortos nos casos permitidos pela lei custaram 360 mil reais por ano, de acordo com o ministério da Saúde (Fernandes, 2017), ou seja, o aborto legal custaria menos do que custam as intervenções pós-aborto.

\subsection{A questão legal do aborto no Brasil}

O direito das mulheres de realizar um aborto de forma legal até a $12^{\mathrm{a}}$ semana de gravidez é um dos temas que mais divide progressistas e conservadores no Brasil e no mundo. O STF tem se centrado no tema em audiências públicas com o objetivo de ouvir especialistas, instituições e organizações envolvidas. Os partidos de esquerda têm protocolado diversas ações em respeito às demandas da sociedade pela legalização do aborto, principalmente o Partido Socialismo e Liberdade (PSOL).

Dentro da área do Direito, os Direitos Humanos reconhecem internacionalmente a recomendação da legalização do aborto em todos os casos, em todos os países do mundo. Assim, a justificativa do direito brasileiro não é plausível quanto à condenação desse procedimento e deveria se incorporar às diretrizes do ordenamento jurídico internacional. As audiências feitas pelo STF na busca por informações sobre o tema valem para tentar formular o voto individual dos ministros, no sentido de determinar a posição brasileira sobre o aborto com a maior discussão possível (Betim, 2017).

Como já visto anteriormente, o aborto é possível em somente três casos: quando há a violência contra mulher, quando a gestação promove risco de vida da mãe e quando o feto é anencefálico. Mas a principal questão sobre o aborto é a classe social à qual a mulher pertence, visto que mulheres pobres, negras e com baixa escolaridade são as que realizam a maioria dos abortos ilegais, sendo também as que mais morrem em procedimentos inseguros.

As experiências com a legalização do aborto em outros países se deu através de plebiscitos e referendos, além de casos nos quais o próprio poder legislativo apoiou a mudança constitucional. No entanto, dentro desse conjunto de países, a lei ainda tem diferenças significativas, principalmente com relação ao tempo de gestação em que é permitido o

\footnotetext{
${ }^{29}$ Instituição de pesquisa que desde 1968 trabalha no estudo, educação e promoção da saúde e dos direitos sexuais e reprodutivos. (https://guttamacher.org)
} 
aborto. Porém, o principal objetivo já foi alcançado em todos eles: de acabar com as mortes de mulheres vítimas de abortos clandestinos.

As mulheres brasileiras estão submetidas a um congresso tipicamente masculino (a maioria é dos parlamentares é masculina), que conduz o debate sobre o aborto de forma conservadora, baseado numa opinião pública também conservadora que não permite ações progressistas, cujo intuito seja a proteção das mulheres. Por isso, é muito comum ver parlamentares ligados a igrejas evangélicas fazendo a condenação do aborto e das mulheres que o praticaram (Thomson, 2012).

O aborto é sempre visto como tabu, mesmo quando se tratam dos casos já mencionados, permitidos pela lei. Dessa maneira, os mais conservadores - sejam homens ou mulheres não o admitem na sociedade e muitas vezes não sabem lidar com esse direito alheio.

Tampouco se trata de uma atitude própria aos homens, pois as mulheres muitas vezes manifestam o mesmo "horror" à evocação desse ato, mesmo que nada impeça interpretar sua indignação como sinal de uma interiorização dos valores masculinos. O aborto é algo de que não se fala ou se fala com constrangimento, tendo o cuidado, na maioria das vezes, de mostrar claramente que, embora se saiba que "isso existe", tal prática não diz respeito nem aos próximos (os membros da parentela) nem mesmo ao coletivo a que se pertence (Boltanski, 2012, 210).

Os contrários à interrupção da gravidez se baseiam em questões morais e religiosas, argumentando que a vida começa na concepção e, por isso, deve ser protegida. Também dizem que a permissão poderia aumentar o número de abortos, ainda que os dados dos países que já o legalizaram mostrem justamente o oposto.

Entretanto o debate está crescendo no Brasil, sendo impulsionado por um movimento feminista (no país e no mundo) e por inúmeras manifestações nas ruas e nos espaços de discussão favoráveis à interrupção da gravidez. Argumentam que se trata de um tema de saúde pública e de direito da mulher de decidir sobre a sua vida e seu corpo, além da evidência científica de que a vida só começa depois da décima segunda semana de gravidez.

Para que a discussão avance, é importante entender que a legalização do aborto nas primeiras 12 semanas é uma questão de saúde pública e o setor médico, com argumentos científicos, deve ter voz (indo mais além do que a discussão sobre quando a vida começa) porque há muitas posições e nenhuma conclusão será alcançada. Em países como os Estados Unidos, segundo Galli, Sydow \& Adesse (2010), a Suprema Corte reconhece que 
o consenso não será alcançado justamente por causa das diferenças políticas sobre o direito à vida e quando ela começa. Nesse sentido, ela faz uma análise estritamente jurídica com base no direito à privacidade e cidadania, além de verificar se os direitos humanos das mulheres estão sendo violados ou não.

Em terras brasileiras, o Legislativo tampouco é o espaço mais apropriado para decidir sobre o assunto, portanto, cabe ao STF proteger os direitos das minorias. A separação de poderes permite que a Suprema Corte tenha poder judicial para rever a jurisprudência e determinar se é uma decisão política ou judicial. Quando se fala de uma decisão simplesmente política, não se pode dizer que tal decisão ocorra dentro um ambiente democrático, porque se as pessoas a favor do aborto são uma minoria, essa minoria nunca será ouvida no Legislativo. Então legalizar o aborto é uma questão de democracia que corresponde ao Supremo Tribunal, já que dito órgão tem o trabalho de representar os interesses das minorias, a partir de uma análise estritamente legal (Menezes \& Aquino, 2009).

O Supremo Tribunal Federal do Brasil tem sido progressista nas decisões nessa área, o que incentiva os defensores da legalização do aborto. Foi o tribunal que liberou a pesquisa com células-tronco embrionárias em 2008, permitiu união estável de homoafetivos em 2011 e legalizou o aborto de fetos anencefálicos em 2012. Por sua parte, o Conselho Nacional de Justiça adotou, em 2013, uma resolução que obriga os tribunais celebrarem o casamento entre pessoas do mesmo sexo com base na decisão do Supremo Tribunal de dois anos antes (Santos, 2012).

A jurisprudência do STF é progressiva e globalmente reconhecida, o que pode gerar uma corrente que pode atingir a outros países. Uma corrente que, aliás, já existe: a Câmara dos Deputados da Argentina aprovou recentemente a legalização do aborto até a $12^{\mathrm{a}}$ semana de gravidez, conferindo a decisão final ao Senado, enquanto o procedimento foi liberado na Irlanda em maio de 2018, via referendo. O Chile, historicamente restritivo, igualou sua legislação à brasileira no ano passado.

Enquanto o mundo discute a descriminalização do aborto, os critérios médicos e os períodos de gestação, o Brasil aponta para um debate que traz aspectos de extrema regressão: a discussão que tomou o cenário legislativo trata da criminalização do aborto defendida por alguns setores, mesmo no caso de estupro, hipótese legalmente prevista na legislação vigente como um caso de isenção de pena (Santos, 2012).

No entanto, que elementos podem justificar a proibição de que uma mulher vítima de um estupro tenha o direito de optar por ter ou não que gerar uma vida que lhe traga eternamente à memória uma violência que sofreu? Nenhum argumento minimamente 
lógico pode explicar essa proposição de mudança legislativa, além de invocações morais e religiosas.

Em um longo estudo feito sobre as relações entre religiões e gêneros, algumas conclusões vêm à luz sobre o que acontece nessa área que, em princípio, é privada, mas que se torna muito pública e até política:

Os estudos desenvolvidos nos últimos anos pelo grupo de pesquisa Gênero e Religião, na PUC de São Paulo, tornaram mais clara a consciência da necessidade de se interrogar o universo das religiões a partir de uma perspectiva feminista. Trabalhar a relação das mulheres com as religiões e destas com as mulheres é sempre estar sobre um campo minado. Dados estatísticos costumam confirmar a observação do senso comum de que as mulheres investem mais em religião do que os homens. Daí se conclui que elas seriam 'mais religiosas' do que eles. Tal visão esconde um enorme equívoco que as atuais formas fundamentalistas das religiões, no Ocidente como no Oriente, vêm desvendar. Na verdade, as religiões são um campo de investimento masculino por excelência. Historicamente, os homens dominam a produção do que é 'sagrado' nas diversas sociedades. Discursos e práticas religiosas têm a marca dessa dominação. Normas, regras, doutrinas são definidas por homens em praticamente todas as religiões conhecidas. As mulheres continuam ausentes dos espaços definidores das crenças e das políticas pastorais e organizacionais das instituições religiosas. O investimento da população feminina nas religiões dá-se no campo da prática religiosa, nos rituais, na transmissão, como guardiãs da memória do grupo religioso (Rosado-Nunes, 2005, 363).

A relação entre religião e direito, ao longo da história, trouxe muito mais problemas do que soluções justas e adequadas aos preceitos legais sedimentados na defesa da dignidade humana. Para o grupo denominado "Católicas pelo Direito de Decidir" (Almeida, 2012), se uma pessoa tem um nível de fé, acredita que mesmo sendo vítima de estupro a criança gerada desse ato de violência é uma bênção divina e deve ser concebida. Para o grupo é legítimo dar à luz e criar o rebento com todo o amor que qualquer criança merece, o que é digno de elevação espiritual. O problema é exigir que os demais mortais compartilhem da mesma opinião e tomem a mesma decisão. 
De acordo com o grupo, a visão da igreja sobre o aborto não se refere ao confronto criminal e legal dessa questão. O pecado não encontra punição em um sistema legal, isso é uma questão para a fé e a religião de cada um (Rosado-Nunes, 2005).

Discutir o direito ao aborto não é defender a obrigação de abortar, nem iniciar uma política de incentivo, mas apenas discutir o direito da mãe, vítima de estupro, de escolher entre ter ou não a criança, fruto de um ato de violência contra si. No Brasil, como em outros países, a lógica moralista e religiosa, impregnada de um forte componente sexista, dita o pseudoargumento da defesa da vida. É preciso se perceber que permanecendo em defesa da vida, o debate real se esconde: quando grupos conservadores se colocam em um lugar seguro, quem vai argumentar contra a vida? Assim, temos a velha prática de reduzir a complexidade em binômios convenientes nos quais o papel relevante do pai ausente ou o que torna a mulher responsável pelo planejamento familiar, sequer são considerados.

As religiões têm, explícita ou implicitamente, em seu bojo teológico, em sua prática institucional e histórica, uma específica visão antropológica que estabelece e delimita os papéis masculinos e femininos. $\mathrm{O}$ fundamento dessa visão encontra-se em uma ordem não humana, não histórica, e, portanto, imutável e indiscutível, por tomar a forma de dogmas. Expressões das sociedades nas quais nasceram, as religiões espelham sua ordem de valores, que reproduzem em seu discurso, sob o manto da revelação divina. O lugar das mulheres no discurso e na prática religiosa não foi, e frequentemente ainda não é, dos mais felizes (Rosado-Nunes, 2005, 363-364).

Assim, é responsabilidade das mulheres trazer vidas para o mundo, não para os homens. Esse pensamento faz com que as pessoas direcionem suas atenções e vigilância para a gestante e suas atitudes, seja uma gravidez por estupro ou não, deixando os homens fora de tudo.

Segundo Haidar (2012), a vida não é defendida, porque a vida é muito mais do que respirar e ter uma vida extrauterina. Que vida terá uma criança que tenha sido gerada por um crime de violação? Que vida terá um filho cuja mãe não demonstra afeto, porque isso sempre lembra a violência sofrida? São perguntas difíceis, difíceis, mas fundamentais quando se quer falar sobre a vida dessas pessoas. Por isso, é necessário que a hipocrisia do uso político do tema seja superada, levando-se em conta que essas mulheres continuarão a fazer abortos clandestinos e os problemas de saúde pública decorrentes continuarão a ocorrer.

\subsection{Moralismo cristão e aborto}


Menezes et al (2015) diz que ser contra o aborto e entender a vida como uma bênção, independentemente das condições em que foi concebida, não dá a ninguém o direito de impor seus achismos e crenças aos outros. Se uma pessoa é contra o aborto e se vê diante de uma situação de violência, talvez não aborte. No entanto, ela nunca poderá julgar a outrem que se encontre em tão dantesca situação ou lhe excluir a possibilidade de tomar a decisão que for mais acertada para si. Porque decidir ter ou não um filho em tais condições, é algo pertinente à mãe, vítima do crime e ninguém, muito menos o Estado, tem o direito de decidir por si.

Portanto, os preceitos morais e religiosos devem ser utilizados para orientar a vida de cada um, individualmente, mas nunca servir como parâmetros das políticas de Estado, especialmente na escolha de comportamentos que estão sendo penalizados.

A distinção, tematizada por numerosos antropólogos que estudaram as formas da dominação masculina, entre o mundo dos homens, como mundo oficial - do direito, escrito ou consuetudinário, da religião, da política e da praça pública, do exterior - e o mundo das mulheres, como mundo oculto, "privado", oficioso - o do interior, da casa, da magia, da bruxaria - tem sem dúvida um caráter bastante geral. Ela abrange, em primeiro lugar, tudo o que concerne à gestação e ao nascimento, domínio que se limita, na maioria das sociedades tradicionais, ao segredo propriamente feminino, aquele que tem por lugar a casa (o interior em oposição ao exterior, correspondendo à oposição entre o público e o privado) e, no interior da casa, o espaço reservado às mulheres. (Boltanski, 2012, 213).

Fica muito claro que há, efetivamente, uma separação dos mundos de homens e mulheres, que vai muito mais além de um machismo religioso e conservador, o que suscita a uma pertinente reflexão: se os homens ficassem grávidos, haveria discussões sobre o aborto? Por que as mesmas propostas punitivas não entram em pauta para pais que abandonam seus filhos? E quanto àqueles que apenas deram nome aos filhos, mas nunca participam de suas vidas, porque também não são criminalizados? Esse é o assunto a ser discutido que está por trás dos argumentos, revelando que o aborto também é uma questão relacionada à manutenção de poderes por parte da sociedade mais forte em detrimento de outra mais fraca.

A audiência pública no STF sobre o assunto teve como objetivo aumentar, de maneira dialógica e aberta, os atores externos da sociedade, o processo de coleta de informações 
técnicas e as diversas abordagens que o problema constitucional pode implicar; bem como a ampla capacitação do público e o contexto argumentativo do processo como método efetivo de discussão e construção da resposta jurisdicional, de acordo com o ministro que a convocou (Rosado-Nunes, 2005).

Os pedidos de exposição foram feitos no encontro, do qual foram selecionados: órgãos e organizações de saúde, tais como o Ministério da Saúde e a Federação Brasileira de Associações de Ginecologia e Obstetrícia; organizações religiosas, como a Conferência Nacional dos Bispos; de direitos humanos, Human Rights Watch; que ajuda as mulheres a interromper a gravidez, como Mulheres em ondas; bem como membros da Frente Parlamentar em Defesa da Vida (HRW, 2017).

Na ação debatida no STF, a Anis - Instituto de Bioética, Direitos Humanos e Gênero - é autora do PSOL. No processo, os advogados afirmam que a proibição é ineficaz e que o Estado brasileiro, em última análise, acaba sendo cúmplice de práticas semelhantes à tortura, às quais as mulheres se submetem para interromper a gestação (Fernandes, 2018). Em seu discurso, o bispo Dom Ricardo Hoepers (apud Bastos, 2018) criticou a falta de voz do feto no debate que, conforme ele, privilegia os direitos reprodutivos. Ainda segundo ele, o feto, a criança, nunca são mencionados porque todos os argumentos são direcionados à mulher. Segundo os religiosos, do ponto de vista da proporcionalidade, temos um grande problema, pois duas pessoas são tratadas de maneiras diferentes: uma tem todos os direitos e a outra não tem.

Essa falta de proporcionalidade decorre do fato de que não há uma definição no sistema legal brasileiro sobre quando a vida começa e, portanto, quando é possível falar sobre os direitos da pessoa. A bancada religiosa pressiona para que essa definição seja estabelecida desde a concepção. A mudança está contida na Proposta de Emenda Constitucional (PEC) 181/2015, cujo texto básico foi aprovado por uma comissão especial da Câmara em novembro de 2017. Se aprovado, poderá impedir o aborto em casos de estupro e risco de vida para as mulheres, previsto no Código Penal (Vicente, 2018).

O mesmo ponto de vista é proposto pelo Estatuto do Nascituro, em tramitação no Congresso $^{30}$. Os religiosos também destacaram a posição da CNBB em 2017 sobre a

\footnotetext{
30 “O presente projeto de lei, chamado "Estatuto do Nascituro", elenca todos os direitos a ele inerentes, na qualidade de criança por nascer. Na verdade, refere-se o projeto à expectativa de direitos, os quais, como se sabe, gozam de proteção jurídica, podendo ser assegurados por todos os meios moral e legalmente aceitos. Vários desses direitos, já previstos em leis esparsas, foram compilados no presente Estatuto. Por exemplo, o direito de o nascituro receber doação (art. 542. Código Civil), de receber um curador especial quando seus interesses colidirem com os de seus Pais (art. 1.692, Código Civil), de ser adotado (art. 1.621, Código Civil),
} 
descriminalização do aborto, para a qual o direito à vida é incondicional e começa a partir de quando o espermatozoide encontra o óvulo (CNBB, 2018).

Presidente da Frente Parlamentar em Defesa da Vida, deputado Diego Garcia defendeu a inclusão, na discussão, de instituições que trabalham no cuidado de mulheres para evitar abortos em políticas de saúde pública no Brasil, com o papel de auxiliar mulheres historicamente excluídas e também penalizadas pelo aborto porque, segundo o parlamentar, com o apoio não haveria necessidade de interromper a gravidez.

$\mathrm{Na}$ audiência, houve críticas de movimentos religiosos em favor da descriminalização, como o movimento "Católicas pelo Direito de Decidir", que luta há mais de 20 anos para que as mulheres brasileiras tenham o direito de escolha sobre o aborto. Alguns opositores lembraram que a Igreja Católica propõe a excomunhão para quem pratica o aborto, de modo que o exercício do catolicismo e da experiência católica com a defesa do aborto seria completamente incompatível.

O ônus financeiro que o Estado teria se a descriminalização fosse decidida pelo STF também foi criticado. No entanto, os países que legalizaram a interrupção da gravidez sustentam uma realidade diferente em relação aos gastos e riscos com esse tipo de procedimento.

O Uruguai, por exemplo, descriminalizou o aborto em 2012. Em 2014, de acordo com dados do Ministério da Saúde, houve 6.676 interrupções e um único óbito registrado como consequência do aborto clandestino. No Brasil, de acordo com a Pesquisa Nacional de Aborto (Observatório gênero y Equidad, 2016), 503.000 mulheres voluntariamente interromperam a gravidez no país em 2015. Quase metade dos procedimentos clandestinos termina em internações hospitalares. Pelo menos quatro mulheres morrem por dia de complicações decorrentes de interrupções da gravidez, de acordo com o Ministério da

de se adquirir herança (art. 1.798 e 1.799, 1 Código Civil), de nascer (Estatuto da Criança e do Adolescente, art. $7^{\circ}$ ), de receber do juiz uma sentença declaratória de seus direitos após comprovada a gravidez de sua mãe (arts. 877 e 878, Código de Processo Civil). O presente Estatuto pretende tornar integral a proteção ao nascituro, sobretudo no que se refere aos direitos de personalidade. Realça-se, assim, direito à vida, à saúde, à honra, à integridade física, à alimentação, à convivência familiar e proíbe-se qualquer forma de discriminação que venha a privá-lo de algum direito em razão do sexo, da idade, da etnia, da aparência, da origem, da deficiência física ou mental, da expectativa de sobrevida ou de delitos cometidos por seus genitores". Excerto da justificativa do projeto do Estatuto do Nascituro.

Projeto de Lei $N^{\circ}$ 478/2007. Dispõe sobre o Estatuto do Nascituro e dá outras providências. Recuperado de https://www.camara.gov.br/proposicoesWeb/fichadetramitacao?id

Proposicao=345103\#marcacao-conteudo-portal 
Saúde. Segundo a pesquisa, $67 \%$ dessas mulheres já têm filhos e $88 \%$ afirmam ter religião - 56\% são católicas, $25 \%$, evangélicas e $7 \%$ professam outras religiões.

Isso significa que 2,6 milhões de mulheres católicas praticaram o aborto ao longo de suas vidas no Brasil. Segundo a OMS - Organização Mundial da Saúde, a cada dois dias uma mulher morre vítima de morte resultante de aborto clandestino no Brasil. É a quarta causa de morte materna no país, tendo mais incidência na morte de mulheres pobres (Collucci \& Faria, 2018).

A ADPF (Arguição de Descumprimento de Preceito Fundamental) é vista pelo grupo religioso como uma afronta do Poder Judiciário ao Legislativo. O seminário faz parte da estratégia dos parlamentares católicos e evangélicos de dominar a discussão sobre o assunto. O evento foi organizado após a aprovação de requisitos na Comissão de Direitos Humanos e Legislação Participativa do Senado e nas comissões de Seguridade Social e Família e de Defesa dos Direitos das Pessoas com Deficiência da Câmara dos Deputados.

Outro dos convidados do grupo religioso, padre Rafael Solano, doutor em Teologia Moral da Pontifícia Universidade Gregoriana de Roma, criticou a distribuição dos métodos contraceptivos pelo Estado e defendeu a castidade. O religioso também afirmou que todos os tipos de planejamento familiar, especialmente regulados pelo Estado, destroem a consciência da liberdade do povo. Segundo ele, é impressionante perceber como em um país cheio de alegria e esperança como o Brasil, quando chega o carnaval, o que é oferecido para a população são preservativos e "pílulas do dia seguinte", para destruir a consciência de uma das maiores virtudes, que é a castidade (Fernandes, 2018).

Na avaliação do padre, não cabe à mulher decidir, pois toda criança que vem ao mundo é parte de uma história divina entre Deus e essa pessoa. Segundo suas palavras, o problema não é religioso, é humano. Você não tem direito sobre seu útero, sobre seu corpo, sobre si mesmo quando há outra pessoa em jogo, ele disse. Por outro lado, a organização não governamental “Católicas pelo Direito de Decidir”, existente desde 1993, lembra que é importante que a sociedade brasileira defenda o secularismo ${ }^{31}$ como um direito essencial,

\footnotetext{
${ }^{31}$ Secularismo é o princípio da separação entre instituições governamentais e instituições religiosas no qual o direito de ser livre do jugo do ensinamento religioso e o direito à liberdade da imposição governamental de uma religião sobre o povo dentro de um estado que é neutro em matéria de crença. (Ver: https://pt.wikipedia.org/wiki/Secularismo)
} 
entendendo que sua violação implica a violação de muitos outros direitos, principalmente, direitos sexuais e direitos reprodutivos ${ }^{32}$.

Em seu voto, o ministro Barroso argumentou que os artigos do Código Penal que criminalizam o aborto no primeiro trimestre da gravidez violam os direitos fundamentais das mulheres. As violações são, segundo o voto de Barroso, a autonomia das mulheres, a sua integridade física e mental, os seus direitos sexuais e reprodutivos e a igualdade de gênero. Na medida em que é a mulher que suporta a carga integral da gravidez, só haverá plena igualdade se lhe for concedido o direito de decidir sobre sua manutenção ou não, o ministro escreveu sobre o direito à igualdade de gênero (Fernandes, 2018).

No debate sobre o aborto, a maior dificuldade é dialogar com o setor religioso, isto é, com seus líderes e suas instituições. O discurso geralmente gira em torno da ideia de que aprovar o aborto é atacar a soberania de um povo de formação principalmente religiosa.

El hecho de que una creencia moral sea racional, es decir, fundamentada, defendida y justificada por un grupo de personas y válida para una determinada comunidad moral, no significa que sea razonable para la esfera pública en un Estado plural y laico. Por diversas razones, no toda creencia racional es considerada razonable para la razón pública y, en cuestión de aborto, gran parte de los valores que sostienen la inmoralidad del aborto no respetan el principio de la laicidad del Estado o del pluralismo moral razonable. El resultado de este acuerdo de argumentación moral es la seguridad política de que un juez, a pesar de participar de una determinada comunidad moral en su vida privada, cuando actúa como representante de la razón pública, no fundamenta sus juicios en sus creencias particulares ${ }^{33}$ (Diniz, 2005, 3).

\footnotetext{
${ }^{32}$ Ver também Petchesky, Rosalind Pollack. Direitos sexuais: um novo conceito na prática internacional. In: Barbosa, Regina Maria \& Parker, Richard. Sexualidades pelo avesso: direitos, identidades e poder. Rio de Janeiro: IMS/UERJ.
}

33 “O fato de uma crença moral ser racional, isto é, fundamentada, defendida e justificada por um grupo de pessoas e válida para uma determinada comunidade moral, não significa que seja razoável para a esfera pública em um estado plural e secular. Por várias razões, nem toda crença racional é considerada razoável por razões públicas e, em matéria de aborto, grande parte dos valores que sustentam a imoralidade do aborto não respeita o princípio da secularidade do Estado ou o pluralismo moral razoável. O resultado desse acordo de argumento moral é a segurança política de que um juiz, apesar de participar de certa comunidade moral em 
Mas esses líderes não representam exatamente seus seguidores, porque a maioria dos católicos no mundo não concorda com algumas das principais doutrinas da Igreja, como o aborto, o uso de anticoncepcionais e a proibição da comunhão para os divorciados; o mesmo acontece com outras religiões, o que torna necessário que a lei seja para todos e que a religião permaneça plural, moral e individual.

Quanto aos países com maioria católica, a França é o país com maior número de opiniões favoráveis - sempre e em alguns casos - ao aborto (93\%), seguido pela Espanha (88\%), Itália (83\%) e Polônia (82\%). Na América Latina, aqueles que mais aprovam essa forma de interrupção da gravidez - sempre e alguns casos - são brasileiros (81\%); seguidos pelos argentinos $(79 \%)$, mexicanos $(73 \%)$ e colombianos $(61 \%)$, segundo pesquisa publicada por Santos (2012).

O teólogo Wagner Francesco diz que o que a liderança da Igreja prega raramente é aceito pelo povo, porque não coincide com a realidade. A igreja, em geral, não legisla em favor da vida do povo, mas em favor do próprio interesse. Quando se diz que defender a proibição da prática do aborto é defender a vida, é importante dizer: a vida da instituição eclesiástica, seus dogmas e tradições são mais importantes que as pessoas (Santos 2012).

Segundo o teólogo, o argumento de apelar à religiosidade do povo não condiz com o que as pessoas realmente acreditam. A fé (que permanece fé) e a ciência (que permanece ciência) não se contradizem. Ele diz que é perceptível que nossa fé ou crença não impede que as pessoas pratiquem o aborto, usem drogas ou qualquer atitude que seja contrária aos seus dogmas. A verdade ou o discurso correto é inútil porque, como disse Schopenhauer, o conhecimento do bem e do mal não muda a vontade de ninguém.

Assim, é importante que questões de fé sejam resolvidas pela teologia e questões de saúde pública, pela política. É por isso que as áreas não devem ser misturadas, porque a cidade merece ser cuidadosa com as ferramentas certas. E o legislador deve sempre lembrar que a lei está viva, porque normatiza vidas e vidas estão mudando constantemente. O que foi valorizado e moralmente bom no passado (ontem), deixa de sê-lo no presente (hoje), como foi o caso da escravidão ocorrida há séculos e que hoje seria absolutamente intolerável.

O fato é que as mulheres abortam, sendo essa ação penalizada ou não. A criminalização viola, em primeiro lugar, a autonomia das mulheres, o que corresponde ao núcleo essencial

sua vida privada, quando age como representante da razão pública, não baseia seus julgamentos em suas crenças particulares". Livre tradução da autora. 
da liberdade individual, protegida pelo princípio da dignidade humana (Constituição Federal, 1988, artigo $1^{\circ}$, III).

A autonomia expressa a autodeterminação das pessoas, isto é, o direito de fazer suas escolhas básicas existenciais e tomar suas próprias decisões morais sobre a direção de suas vidas. Todo indivíduo - homem ou mulher - tem um espaço legítimo de privacidade dentro do qual ele / ela terá o direito de viver seus valores, interesses e desejos. Nesse espaço, o Estado e a sociedade não têm o direito de interferir. (Brasil, 2016).

\subsection{A posição da ONU}

A ONU, no Dia Internacional do Aborto Seguro, pediu aos países que não penalizem o término da gravidez, que revoguem suas leis e que libertem todas as mulheres que estão presas por terem decidido fazer um aborto, como a capacidade das mulheres de tomar decisões livres, para si e para suas próprias famílias. Eles não devem ser um privilégio reservado aos ricos, mas devem ser o direito de todas as mulheres e meninas em todo o

mundo. $\mathrm{O}$ mesmo se aplica ao direito à saúde e à liberdade de discriminação. É por isso que o grupo da ONU pede aos Estados para garantir que suas leis, políticas e práticas sejam baseadas nos Direitos Humanos e no reconhecimento da dignidade e autonomia das mulheres (ONU, 2016).

Os especialistas da ONU consideram que não é apenas a criminalização que é responsável pelo direito das mulheres ao aborto seguro a ser negado. Muitos fatores contribuem para que as mulheres não recebam serviços essenciais de saúde que lhes permitam interromper a gravidez e ter atenção pós-aborto, incluindo criminalização, redução da disponibilidade de serviços, estigmatização, dissuasão e atitudes depreciativas dos profissionais de saúde. Esses fatores levam milhões de mulheres a abortos inseguros e as deixam sem tratamento essencial para sua recuperação.

O grupo ressalta que negar às mulheres o aborto seguro é discriminação e violação dos direitos humanos, que afeta os mais pobres e os que estão em situação mais vulnerável. Portanto, muitas mulheres em todo o mundo continuam sofrendo leis discriminatórias que restringem seu acesso a cuidados de saúde adequados e limitam suas liberdades para fazer as melhores escolhas para si e suas famílias (ONU, 2016).

A Organização Mundial da Saúde reafirma que, quando mulheres e meninas não conseguem acesso a serviços eficientes de contracepção e abortamento seguro, há sérias consequências para sua saúde e de suas famílias e que, apesar dos recentes avanços tecnológicos, existem evidências de que muitos abortos inseguros permanecem ocorrendo e que muitas mulheres continuam sofrendo e morrendo. 
O novo estudo do IWCH (2016) fornece estimativas sobre abortos seguros e inseguros em todo o mundo. Pela primeira vez, inclui subclassificações na categoria de aborto inseguro. A distinção permite mais nuances para entender as diferentes circunstâncias do aborto entre mulheres que não têm acesso a abortos seguros e médicos treinados.

De acordo com o estudo, quando abortos são realizados de acordo com as diretrizes e padrões da OMS, o risco de complicações graves ou morte é insignificante. Aproximadamente $55 \%$ de todos os abortos de 2010 a 2014 foram realizados com segurança, o que significa que foram realizados por profissionais de saúde competentes, utilizando métodos recomendados pela OMS e de acordo com a duração da gravidez. No entanto, quase um terço (31\%) dos abortos foram classificados como menos seguros, o que significa que eles foram realizados por um profissional treinado, mas usando um método inseguro ou desatualizado, como curetagem aguda ou por uma pessoa não competente (IWHC, 2016).

Cerca de $14 \%$ foram considerados abortos inseguros, realizados por pessoas não competentes, utilizando métodos perigosos, como a introdução de objetos estranhos e o uso de chás. Altas taxas de mortalidade foram registradas em regiões onde os abortos ocorreram em circunstâncias inseguras. As complicações podem ser um aborto incompleto (incapacidade de remover do útero todo o tecido da gravidez), sangramento, lesões vaginais, cervicais e uterinas e infecções.

O estudo (IWHC, 2016) também analisou contextos que muitas vezes levam ao surgimento de práticas inseguras de aborto, incluindo leis e políticas de países sobre o procedimento, o custo financeiro para acessar serviços de aborto seguro, a disponibilidade desses serviços e profissionais, autoridades competentes e as atitudes da sociedade em relação ao aborto e à igualdade de gênero.

Em países onde o aborto é completamente proibido ou permitido apenas no caso de a vida ou a saúde física de uma mulher estar em risco, apenas um em cada quatro abortos é seguro. Nos países onde o aborto é legal, em termos mais amplos, aproximadamente nove entre dez abortos são realizados com segurança, confirmando que restringir o acesso ao procedimento não reduz o número de abortos realizados, de acordo com o estudo.

A maioria dos abortos realizados no oeste e no norte da Europa e na América do Norte é segura. Essas regiões também têm as menores taxas de aborto. A maioria dos países dessas regiões também tem leis de aborto relativamente permissivas; altos níveis de uso de contraceptivos, desenvolvimento econômico e igualdade de gênero; bem como serviços de saúde de alta qualidade - fatores que contribuem para o desempenho de abortos mais seguros (IWHC, 2016). 
Entre os países em desenvolvimento, a proporção de abortos seguros no leste da Ásia (incluindo a China) é semelhante às regiões desenvolvidas. No centro-sul da Ásia, entretanto, menos de um em dois abortos é seguro. Com exceção da África Austral, menos de um em cada quatro abortos no continente tem sido seguro.

$\mathrm{Na}$ América Latina, apenas um em cada quatro abortos é seguro, apesar do fato de que a maioria era categorizada como menos segura, já que é cada vez mais comum que as mulheres na região obtenham e auto administrem medicamentos. Isso significa que a região registrou menos mortes e menos complicações graves causadas por abortos inseguros. No entanto, esse tipo de uso informal de medicação abortiva não atende aos padrões da OMS (Diniz, Medeiros \& Madeiro, 2017).

O aborto inseguro ocorre quando a gravidez é interrompida por pessoas sem o treinamento e a informação necessários ou em um ambiente que não se encaixa nos padrões médicos mínimos necessários, ou em ambos os casos. Para evitar gravidezes indesejadas e abortos inseguros, os países precisam adotar políticas de apoio e compromissos financeiros para fornecer educação sexual abrangente, uma ampla gama de métodos contraceptivos, incluindo contracepção de emergência, aconselhamento adequado para planejamento familiar e acesso ao aborto legal e seguro.

A provisão de aborto legal e seguro é essencial para alcançar os Objetivos de Desenvolvimento Sustentável do acesso universal à saúde sexual e reprodutiva (meta 3.7). A OMS fornece diretrizes técnicas abrangentes e políticas para o uso de contraceptivos para prevenir gravidez indesejada, aborto seguro e o tratamento de complicações causadas por abortos inseguros (ONU, 2017).

Na tentativa de ajudar os países a atingir a meta, a OMS e a divisão populacional do Departamento de Assuntos Econômicos e Sociais das Nações Unidas lançaram um banco de dados aberto de leis, políticas e padrões de saúde sobre o aborto em países de todo o mundo. O banco de dados visa promover mais transparência para as leis e políticas de aborto, bem como para melhorar e ampliar a responsabilidade dos países pela proteção dos direitos humanos e da saúde de mulheres e meninas (ONU, 2017).

Em resumo, portanto, a segurança do aborto é um dos Direitos Humanos das mulheres e é necessário que os países garantam isso através de leis e práticas que priorizem a vida, e não das discussões religiosas que são, muitas vezes, carregados de preconceitos e disputas de poder sobre o corpo e decisões das mulheres.

Como todos os direitos que visam à igualdade entre as pessoas, o aborto deve ser respeitado e pensado como uma questão alheia à concepção religiosa de cada indivíduo. A religião é uma opção pessoal e o Estado não deve interferir. A concepção sobre os direitos 
do corpo também é uma posição individual. Portanto, o Estado deve garantir direitos, respeitando a vontade de cada cidadã / cidadão, independente da religião de cada uma/ um, pela laicidade que a ela ou ele lhe compete. 
PARTE 2 


\section{LÍDERES RELIGIOSOS}

Toda religião organizada no mundo tem indivíduos ou grupos que estão lá para guiar congregações de seguidores através das regras gerais de sua fé. Em geral, seus papéis principais são semelhantes: realizar os ritos e cerimônias exigidos por uma religião específica, como rituais de nascimento, rituais de maioridade, rituais de morte e qualquer outra coisa que a religião lançar. Eles também são os guardiões de tradição religiosa e muitas vezes assumem o papel de líder moral, bem como professor ou "guia".

Além de apenas guiar os seguidores de uma religião e realizar ritos e cerimônias, os sacerdotes receberam autoridade para realizar atos sagrados para a população, agindo como um elo entre as massas e sua divindade. Uma das funções mais importantes de um padre é realizar sacrifícios, humanos ou animais, a um deus ou deusa. O judeu-cristão, por exemplo, exigia sacrifícios rituais de animais, até que ele realizasse o "sacrifício supremo" e matasse seu filho.

Durante grande parte de sua história, a religião judaica foi administrada por padres, uma classe de cidadãos judeus que receberam poder social, econômico e político muito além daquele de realizar apenas os ritos sagrados do povo. Eles eram os segundos em poder apenas dos reis; quando os romanos assumiram, era a classe sacerdotal com a qual eles estavam mais preocupados. Abraão é considerado o primeiro sacerdote judeu, embora a linha tenha começado formalmente com seu bisneto, Levi. Evidentemente, nenhuma mulher podia ser sacerdote há 4.000 anos atrás.

Nos tempos modernos, os ritos judaicos são realizados pelo rabino, um estudioso e professor judeu. Um rabino não é especificamente um sacerdote, pois a classe sacerdotal (os Kohanim) ainda existe e, embora ainda devam respeitar certas restrições, os padres judeus modernos cumprem poucas funções especiais. Como no clero de outras religiões abraâmicas, os homens tradicionalmente assumiram o papel de rabino, e as mulheres ainda não podem ser rabinos no judaísmo ortodoxo, embora outras formas de judaísmo agora aceitem mulheres rabinos, a Rabino Julia Neuberger é uma exemplo notável.

Já nas Igrejas de tradições sacramentais (incluindo comunhão católica romana, ortodoxa, ortodoxa oriental e anglicana, algumas igrejas luteranas e várias comunidades menores) mantêm o sacerdócio. Geralmente compreende três "ordens sagradas" (bispo, sacerdote / presbítero e diácono) e está intimamente ligada ao conceito de "sucessão apostólica". Como norma, os padres lideram as congregações, enquanto os 
bispos administram grupos de paróquias (diocese/eparquia) e ordenam os padres e diáconos. Os padres recebem o poder de um bispo para realizar grandes sacramentos e também para realizar ritos adicionais, como a bênção da água benta. Os diáconos ajudam os bispos a administrar as tarefas da igreja. Os bispos de importantes dioceses (arquidioceses) são chamados "arcebispos" e geralmente têm funções de supervisão sobre os bispos dentro da arquidiocese. Dentro da Igreja Católica Romana, alguns (normalmente arcebispos) também são cardeais, cujos poderes incluem eleger um papa quando o velho morre ou renuncia.

De maneira um tanto controversa, os padres católicos fazem promessas de celibato. Por outro lado, as igrejas ortodoxas, episcopais e anglicanas podem ordenar homens casados como padres (embora um bispo ortodoxo deva ser celibatário). Os requisitos para se tornar sacerdote variam muito entre as comunidades, geralmente incluindo alguma forma de treinamento especializado. Para as principais denominações da América do Norte, o treinamento é oferecido em seminários e geralmente é oferecido como pós-graduação. Um candidato ao sacerdócio é ordenado pelo bispo por meio da cerimônia de imposição de mãos (na maioria dos casos, o candidato é ordenado como diácono primeiro, geralmente apenas alguns dias antes). Na teologia católica, isso deixa uma "marca indelével" em uma pessoa, fazendo dele um padre vitalício. A Igreja pode e pune os padres por atos disciplinares ou doutrinários, proibindo-os de agir na capacidade sacerdotal. Nas igrejas ortodoxas, uma pessoa pode ser "reprovada", removendo uma ordenação anterior.

Os padres católicos e ortodoxos devem ser do sexo masculino. As mulheres não podem ocupar posições de autoridade religiosa nessas seitas, exceto liderando uma comunidade de freiras como abadessa. Igrejas anglicanas e liberais luteranas ordenam sacerdotes mulheres e pelo menos alguns ramos têm bispos mulheres.

A Igreja de Jesus Cristo dos Últimos Dias tem um conceito elaborado de sacerdócio com vários graus, com base em sua própria ideia da sucessão apostólica com poderes de autoridade Joseph Smith, que foi supostamente ordenado por anjos. Em essência, todo adolescente do sexo masculino em boa posição na Igreja é ordenado na ordem do sacerdócio júnior.

Segundo Zepeda (2010), uma das principais mudanças provocadas pela Reforma Protestante foi a remoção de um grupo especializado de homens que eram as únicas pessoas capazes de interceder entre os fiéis e Deus, e a instituição da posição formal de que o relacionamento de cada pessoa com Deus era direto e pessoal. Isso está relacionado ao 
conceito de sacerdócio de todos os crentes. Mas ainda havia a necessidade de alguém realizar rituais e ensinar os fiéis sobre sua fé.

Não há uma distinção real entre os títulos ministro, reverendo, pregador, pastor etc., pois muitos termos diferentes descrevem efetivamente os mesmos papéis em suas igrejas individuais. Ao contrário dos católicos, eles têm permissão (ou, em alguns casos, até mesmo exigidos) de para ser ou foram casados, eles não têm a capacidade de realizar atos sobrenaturais e eles não (apesar do que os indivíduos possam alegar) mantêm autoridade suprema sobre qualquer pessoa, teologicamente. Eles são guias e, como os títulos sugerem, devem ser celebrados com grande honra, mas não são um conjunto ou seita especial de pessoas. Qualquer um pode se chamar ministro sem treinamento formal ou rito e legitimidade organizados. No entanto, as denominações maiores do cristianismo protestante requerem treinamento teológico avançado formal, geralmente em uma universidade. Além disso, como não existe uma "Igreja Protestante" formal, cada igreja ou denominação individual pode ou não ter legitimidade nos ministros de outras igrejas.

Um imã é um líder religioso muçulmano. Como pregadores e ministros, ele guia as pessoas em seu caminho religioso, ensina-as sobre o Alcorão e às vezes realiza rituais. Em teoria, os imãs sunitas detêm menos poder religioso do que os imãs xiitas, funcionando como líder em oração e como líder comunitário, e não como guia moral. ${ }^{[14]}$ Isso, no entanto, depende muito da comunidade local.

Qualquer um pode se tornar um imã. Não é preciso frequentar escolas especiais ou ser indicado pela comunidade religiosa em geral. No Islã sunita, os imãs são escolhidos por sua liderança e mérito, e por consenso da comunidade, enquanto acredita-se que os imãs xiitas sejam nomeados por Deus. Os imãs são quase universalmente masculinos. Apenas recentemente algumas mulheres entraram no papel, sempre nas chamadas mesquitas do estilo ocidental, e sempre levantando sérias controvérsias onde isso ocorre.

Monges e freiras são pessoas que escolhem ou são pressionadas a dedicar suas vidas ao culto religioso e se afastam (pelo menos por um determinado tempo) do resto da sociedade para essa prática solitária. Embora possam residir com outras pessoas, o princípio central de ser monge ou monja é esse foco pessoal e solitário na devoção.

No cristianismo, monges e monjas são indivíduos que desejam dedicar sua vida à adoração a Deus. Embora possam servir como professores, a menos que sejam ordenados, não são considerados como tendo nenhum dos poderes de intercessão dos padres. Sua atividade religiosa é pessoal e privada. 
Monges e monjas no budismo não apenas mantêm a devoção solitária dos monges em geral, mas agem (por um curto período ou por toda a vida) como uma conexão da comunidade com o divino, realizando vários rituais e celebrações pessoais por nascimentos, casamentos, funerais, e os doentes. No entanto, eles não lideram a comunidade nessas orações e rituais como um sacerdote ou ministro poderia fazer; eles os executam de forma solitária, como forma de homenagear a pessoa que está sendo celebrada. A família pode sentar-se ao redor do monge para compartilhar e assistir à experiência, mas geralmente não é uma atividade de grupo.

Como a maioria das principais religiões do mundo, e todas as religiões abraâmicas, provêm de uma tradição de patriarcado (e até misoginia na maioria dos casos), o papel das mulheres no clero é frequentemente controverso, como evidenciado por Mariano (2004). Há uma sugestão de que, na igreja primitiva antes de Constantino, as mulheres às vezes eram líderes e até sacerdotes. Apesar disso, para católicos romanos e evangélicos conservadores, é inaceitável que as mulheres tenham qualquer papel religioso oficial (padres ou ministros). As mulheres podem liderar orações, mas novamente não a partir de uma posição religiosa oficial, assim como uma oradora que presta testemunho. A sociedade em geral, fora dessas denominações e seitas fundamentalistas, está se tornando cada vez mais intolerante à discriminação de gênero; portanto, grupos evangélicos conservadores e dominados por homens provavelmente enfrentarão uma dificuldade crescente de recrutar novos membros quando estes sejam críticos, mas no Brasil ainda se nota expressiva expansão do número de fiéis.

Desde o final do século XX, todas as principais denominações protestantes permitiam que as mulheres fossem ministras. Existe uma tendência crescente de ver mulheres no ministério, oferecendo, supostamente, o que é frequentemente chamado de "toque introspectivo, pessoal e de cura" em comparação com um ministério mais antigo e patriarcal que estava centrado em "fazer o que eu digo", que era popular antes dos anos 1970, sugerindo que os ministros do sexo masculino foram fortemente afetados pelas mulheres, muito mais dispostos a abrir um lado emocional do ministério.

Há uma grande disputa em muitas denominações sobre as mulheres se tornarem bispos, o que as coloca em autoridade sobre o clero masculino de nível inferior.

No catolicismo há uma expectativa em muitas mulheres católicas de que o Papa Francisco promova um papel de liderança para as mulheres na igreja. Recentemente, um grupo de 
freiras americanas e católicas fez uma peregrinação a Roma para fazer ouvir seus pedidos. Elas visitaram locais antigos que evidenciam o importante papel de liderança que as mulheres tiveram nos primeiros séculos do cristianismo.

Os primeiros seguidores da seita de Jesus (ou culto, no sentido técnico do termo) focaram nele como professor, profeta e milagreiro; no começo, havia apenas uma sugestão de aspectos messiânicos em relação ao papel de Jesus. Modernos estudiosos e acadêmicos da Bíblia (historiadores do cristianismo, hebraístas, exegetas e teólogos), após séculos de pesquisa, análise, crítica textual e abordagem hermenêutica dos textos sagrados, juntamente com as descobertas da arqueologia bíblica, como os Manuscritos do Mar Morto, finalmente chegando ao ponto de entender quem era Jesus, o que ele disse e fez, o que era $o$ cristianismo enquanto ele ainda estava vivo e o que aconteceu depois de sua morte.

A Igreja Cristã o mundo inteiro a conhecem há 2000 anos, não existia durante e logo após a vida de Jesus: Jesus de Nazaré era judeu, e os primeiros seguidores do movimento de Jesus eram todos judeus. Ele cresceu na tradição judaica, praticando o judaísmo, seguindo a lei mosaica e adorando somente o Deus de Israel, e todos continuaram sendo judeus até morrerem; portanto, nenhum deles, partindo do próprio Jesus, compartilhou a crença de que Jesus era um ser divino, isto é, o Filho de Deus ou Deus encarnado.

Paulo de Tarso, um fariseu helenizado e zeloso que perseguiu os primeiros cristãos judeus por um tempo e se transformou em um convertido tardio ao movimento de Jesus depois de alguns anos, passou a ser aquele que erradicou completamente a fé cristã judaica de seu contexto e suas raízes judaicas, criando uma religião distinta e totalmente diferente, pregando o Evangelho aos gentios não judeus, ou seja, os gregos e os romanos, em todo o Império Romano, distorcendo-o com sua própria teologia e cristologia. As quais, juntas, são o núcleo do cristianismo paulino, até deturpando a mensagem para torná-la mais palatável aos prosélitos. .

Os judeus na comunidade cristã de Jerusalém, líder do centro do movimento de Jesus, se opuseram fortemente aos esforços de Paulo para converter os gentios, mas eles não foram capazes de detê-lo e desestabilizar as comunidades cristãs que ele fundou; sua missão se tornaria a Igreja dominante, e foi o que aconteceu após o assassinato de Tiago (62 d.C.) e o desastre trazido pela primeira guerra judaico-romana, que terminou com a destruição do Templo de Jerusalém (70 d.C.). 
O cristianismo apostólico original que veio antes de Paulo e se desenvolveu independentemente dele, por aqueles que conheceram e passaram um tempo com Jesus, estava em nítido contraste com a versão de Paulo da nova fé. Esse cristianismo perdido dominou durante a vida de Paulo, e somente com a morte de Tiago em 62 d.C., seguida pela destruição brutal de Jerusalém pelos romanos em 70 d.C., começou a perder sua influência como centro do movimento de Jesus. Ironicamente, foi a produção e edição final do próprio Novo Testamento, apoiando a versão de Paulo do cristianismo, que garantiu primeiro a marginalização e, posteriormente, a morte dessa forma original de cristianismo.

Não está claro qual Evangelho (canônico ou apócrifo) realmente apareceu primeiro, em que ordem os Evangelhos canônicos foram escritos. A única coisa que pode ser dita com certeza é que os primeiros evangelhos escritos provavelmente foram baseados na tradição oral, que poderia ter diferido muito dos eventos reais.

No período do Evangelho de Marcos (c. 70 a 100 d.C), há sugestões de que as igrejas primitivas eram tanto movimentos políticos quanto religiosos, desafiando ativamente a autoridade do Sacerdócio, e continham um forte senso do direito do indivíduo de acessar Deus sem intercessão sacerdotal.

Os dois outros relatos sinópticos do evangelho, Evangelho de Mateus (c. 80 a 100 d.C.) e Evangelho de Lucas (c. 90 a c. 130 d.C., baseado em parte em Marcos) e o Evangelho de João (c. 100 a c. 140 d.C.) começam a mostrar aspectos distintos de Jesus à medida que as Igrejas lutam pela mensagem e pelo significado de Jesus. Jesus era um amigo dos judeus e um inimigo dos romanos, ou o contrário? Jesus era principalmente humano, seus milagres poucos? Ou ele era piedoso, em grande parte um mágico, executando truques a cada passo?

Apesar dos esforços do Primeiro Concílio de Niceia, convocado por ordem do imperador romano Constantino I em 325 d.C, que tentou esmagar todas as filosofias, teologias e textos divergentes da existência e criar a primeira ortodoxia "oficial", o cristianismo continuou fragmentado. Na época de Marciano, o cristianismo do imperador (450 a 457 d.C.) estava se ramificando nas igrejas copta, etíope, eritreia, sica, apostólica armênia e malankara, bem como no cisma ortodoxo e católico romano oriental (grego) mais conhecido que sobreviveria até os dias atuais.

O cristianismo pegou várias ideias pagãs e as converteu para se encaixar em uma estrutura cristã. O conceito de numen ("divindade", "presença divina" ou "vontade divina" acabou se tornando regra pelo direito divino ou pela vontade de Deus. Assim, as divindades 
tutelares (um guardião, patrono ou protetor de um determinado lugar, característica geográfica, pessoa, linhagem, nação, cultura ou ocupação) foram divididas em santos (por exemplo, em vez de orar a Hermes / Mercúrio por uma viagem segura, orou - se a São Cristovão, bem como aos Anjos da Guarda que vem do conceito pagão de genius loci ("espírito de lugar") que também foi assimilado em santos. Tomado como um todo, o único requisito para ser cristão é a crença de que Jesus é o Messias, e que ele "morreu e ressuscitou por nossos pecados".

A Igreja Católica Romana e, por extensão, as Igrejas Protestantes, compartilham muitos pontos em comum que começam com o que foi escrito no Credo do Apóstolo, 390 d.C. que tenta assimilar os valores das várias correntes do cristianismo fundamental, mas ainda restaram questões teológicas sobre a natureza de Deus - Deus é um ou três? Deus é homem, ou também é mulher, ou tudo, ou nenhum? O Antigo e o Novo Testamento descrevem o mesmo Deus ou deuses diferentes?

- A natureza de Cristo - Jesus está amando? Ele é um Redentor vingativo?

- A natureza de Jesus - Jesus realmente existiu como um ser humano? A conexão de Jesus com Deus foi por nascimento ou por batismo?

- A natureza dos santos - Um santo é digno de veneração? Os santos podem conceder orações? Os santos existem?

- A natureza de Maria (a mãe de Jesus) - Ela pode curar pessoas? Ela deveria ser adorada? Ela era virgem a vida toda?

- A natureza do pecado - o pecado é uma representação de meras falhas humanas? O pecado é uma verdadeira raiz do mal em todos os seres humanos? O pecado pessoal (as coisas que cada um faz) é distinto do pecado original, que todo ser humano compartilha, independentemente de seus atos e ações?

- A natureza da vida após a morte - As almas dos crentes vão diretamente para o céu ou precisam fazer uma escala no Purgatório se suas vidas não foram completamente sem pecado? Ou eles estão "dormindo" até o retorno de Jesus?

- Intercessão - Alguém pode falar com Deus ou requer um intermediário ordenado pela Igreja?

- Sacramentos - O que são? Eles existem? Eles são necessários?

Da mesma forma sobrevivem fortes questões organizações do catolicismo que refletem questões sociais: 
- Padres - Qual é o papel deles ou deve haver padres?

- Papa - Existe um chefe da Igreja? Ele possui o poder da infalibilidade e como ele é selecionado?

- Idioma litúrgico - Quais idiomas podem ou devem ser usados?

- Qual é o papel das mulheres na Igreja? Na sociedade?

- E os gays, o aborto e outras questões "sociais"?

- Qual tradução da Bíblia devemos usar?

- A Bíblia deve ser entendida como verdade literal?

Toda vez que uma questão importante ou trivial não podia ser resolvida, a Igreja se fragmentava, levando à hoste de denominações e seitas que existem hoje. Em vários momentos, gnósticos,cátaros, protestantes, católicos,ortodoxosorientais, quakers, mórmon, universalistas e muitos outros grupos foram chamados de heréticos ou não cristãos por outros grupos cristãos. Historicamente, a heresia era, na maioria das igrejas, considerada um ato equivalente à traição e, nas situações em que a Igreja tinha poder temporal, as disputas sobre a doutrina levavam à perseguição maciça, tortura e assassinato como visto nas caças às bruxas da Inquisição.

Os teólogos há muito tempo se deparam com a questão sobre que realmente faz um cristão. Alguns grupos evangélicos usam as Quatro Leis Espirituais como uma definição básica de trabalho para fins de proselitização baseadas na salvação através de Jesus pelas obras e pela fé.

Provavelmente, o conceito mais fundamental do cristianismo é que a imperfeição inerente à humanidade (causada pelo pecado original de acordo com algumas tradições) requer salvação, dada pela graça de Deus, para que a humanidade resida na presença de Deus após a morte.

Antes da abordagem do cristianismo sobre a questão, a salvação era em parte realizada pelo sacrifício de animais para expiar os pecados de uma pessoa. De acordo com a doutrina cristã, Jesus foi o sacrifício final na cruz. Sua morte provocou o fim da necessidade de fazer sacrifícios contínuos e obedecer às milhares de leis que os judeus tinham.

Portanto, se a morte de Jesus sozinha não foi suficiente para livrar o mundo, ou mais importante, os indivíduos, do pecado, e permitir que alguém residisse com Deus, como exatamente alguém deveria obter a salvação? Como em qualquer outra doutrina teológica, existem várias escolas de pensamento, mas a maioria se resume a fé e ações, ou alguma combinação delas. Paulo sustentou que a salvação é alcançada principalmente pela fé, mas 
inclui a necessidade de levar uma vida livre de pecados graves, embora ele nunca tenha declarado que esses eram os únicos requisitos para a salvação e o autor da carta de Tiago sustentava que "a fé sem obras é morta" e o cristão também precisava mostrar sua fé realizando "boas obras". Originalmente, isso incluía a observação de rituais cerimoniais judaicos, como circuncisão e manutenção de kosher, no entanto, desde o incidente antioquino, os cristãos paulinos não eram obrigados a seguir nenhuma prescrição da lei mosaica.

As visões modernas sobre exatamente o que as pessoas precisam fazer para serem salvas incluem:

- Fé e obras: A primeira visão é que a salvação está na fé e nas obras. Isso significa que é preciso crer no sacrifício de Jesus $e$ realizar atos de penitência para ser absolvido dos pecados. Dar dinheiro à Igreja, atos de caridade para os necessitados e as chamadas "boas ações" também são - embora não sejam igualmente - importantes. Os católicos romanos e os ortodoxos orientais mantêm essa posição formalmente. Muitas igrejas protestantes seguem essa visão, embora geralmente não seja a doutrina oficial.

- Sola fide: A doutrina da sola fide ("somente pela fé") afirma que as boas obras não são estritamente necessárias para a salvação, mesmo sendo importantes para o crescimento pessoal e sendo um "bom cristão". No entanto, exceto por uma minoria marginal de "antinomianos“, os protestantes acreditam que não há obrigação de viver uma vida moral e de caridade e que não é necessário realizar obras para se absolver dos pecados. Anglicanos e luteranos sustentam que o batismo na Igreja é necessário para a salvação, enquanto outros adotam uma visão mais descentralizada e sustentam que a mera crença é suficiente.

- Eleição incondicional: a eleição incondicional é um princípio central do calvinismo. No calvinismo, as pessoas não têm livre arbítrio; Deus está no controle completo do universo e, portanto, Deus é quem decide se eles têm fé ou não. Consequentemente, Deus deve escolher quem é salvo e quem não é; aqueles que são salvos são conhecidos como "eleitos" e foram eleitos incondicionalmente, sem levar em consideração as crenças ou ações de cada indivíduo. Hoje, o hipercalvinismo, no qual se baseia o dominionismo, leva essa ideia ao extremo lógico.

- Universalismo: sustenta que o sacrifício de Jesus foi suficiente para todos os pecados da humanidade, independentemente da aceitação pessoal. 
A Bíblia é a base doutrinária do cristianismo. Todas as igrejas e denominações da religião cristã compartilham os 24 livros do "Antigo Testamento" os 27 livros do "Novo Testamento“. Uma única grande diferença entre as três principais escolas do cristianismo, "Ortodoxa Oriental", "Igreja Católica Romana" e as igrejas protestantes, são os outros livros que são considerados parte do cânon da Bíblia. Os católicos e os ortodoxos orientais incluem sete livros, os deuterocanônicos e as igrejas ortodoxas orientais reconhecem outros textos da Septuaginta grega.

Outra diferença crítica entre as denominações é a maneira como elas interpretam a Bíblia, quem eles acham que a escreveu e até mesmo o texto real da Bíblia. Em um extremo, a maioria dos fundamentalistas cristãos defende uma posição de inerrância bíblica, onde tudo o que é declarado na Bíblia deve ser tomado literalmente; em outro extremo, é a abordagem da "Bíblia folgada" de denominações liberais extremas, como os Universalistas Unitários, que permite ao adorador considerar qualquer coisa como escritura que ache inspiradora. O meio termo, adotado pelo protestantismo principal, bem como pelas igrejas católicas e ortodoxas, é $a$ infalibilidade bíblica: a crença de que a Bíblia foi escrita como um texto espiritual, não histórico ou científico, e, portanto, é inspirada no que diz respeito a seus ensinamentos morais e espirituais, mas não é necessariamente precisa em relação aos registros e pesquisas seculares. Os católicos e os ortodoxos têm mais margem de manobra para fazer isso, pois não dependem da doutrina protestante da sola scriptura (somente nas escrituras) e podem permitir um papel mais importante para a Igreja na interpretação da Bíblia.

O cristianismo fundamentalista é uma versão quase exclusivamente americana do cristianismo, embora tenham ficado felizes em compartilhá-lo com o resto do mundo, especialmente nos países da África, onde eles podem usar a pobreza para obter vantagens em proselitismo. De acordo com Smith (1991), o fundamentalismo cristão como seita é geralmente aceito como um fenômeno do início do século 20, mas não recebeu a atenção que merecia até os anos 1980 com a eleição de Ronald Reagan, que destacou suas visões religiosas em sua posição como funcionário eleito. Isso encorajou os fundamentalistas a sair da obscuridade, tentando aprovar leis para combater a aceitação humanista de coisas como direitos ao aborto e direitos homossexuais. No início da eleição presidencial dos EUA em 2012, praticamente todo candidato republicano à presidência era um fundamentalista cristão. 
Os cristãos fundamentalistas tendem a acreditar no seguinte:

- Uma Bíblia literal e infalível, mais adorada que o próprio Deus

- A partir disso, uma criação literal, um dilúvio literal e uma jovem Terra

- Busca desacreditar a biologia, a evolução, a geografia, a física, a paleoantropologia e outras ciências naturais que refutam irrefutavelmente uma Terra jovem

- A moralidade é muito é infalível, sem meios-termos

- O aborto é errado

- A homossexualidade é errada

- Os ateus são piores que os estupradores, assassinos, ditadores etc., que podem ser facilmente perdoados por seus pecados enquanto crerem na Bíblia

- Qualquer um que não acreditar de todo o coração em sua interpretação de Cristo será torturado para sempre no inferno .

Os cristãos fundamentalistas americanos distorcem a religião com outras questões políticas e "patrióticas", pressionando constantemente à assimilação dos seus valores religiosos na concepção e execução das leis. Com a expansão do fundamentalismo estadunidense países africanos e sul-americanos vêm cada vez mais assimilando estes valores, como o Brasil.

O cristianismo vê Deus como um Deus pessoal que interage com cada pessoa individualmente, de uma maneira muito reminiscente de ser outro humano. Enquanto os padres católicos assumem o manto de responsabilidade de Jesus e atuam essencialmente como figuras semelhantes a Jesus para a Igreja, outros membros da Igreja têm diferentes relações com Deus. As freiras literalmente se casam com Jesus, e alguns dos místicos mais extremos, em particular São João da Cruz e Santa Teresa de Ávila, escrevem sobre o relacionamento deles com Jesus como o de um amante de sua Noiva, incluindo momentos do que pode só se chama intimidade sexual.

A maioria dos protestantes tem uma visão menos sexual de Deus e fala de Deus ou Jesus como "um amigo", "um irmão" ou "um pai". Mas eles ainda veem o relacionamento como um relacionamento direto, onde Deus (ou Jesus) os ajuda pessoalmente. Os pedidos comuns incluem pedir a Jesus que faça coisas reais como ajudar a encontrar um objeto perdido ou ajudar determinado time de futebol a ganhar, mas problemas cruciais como curar a AIDS ou ajudar bebês que estão morrendo de doença e inanição às vezes são varridos para debaixo do tapete por pessoas mais superficiais. 
Pastores nas várias religiões protestantes tentam incentivar esse relacionamento individual e falam sobre esse relacionamento direto como a raiz ou o núcleo da fé cristã, muito mais do que o dogma que cerca a religião, que para eles é muito menos importante. De acordo com Oliveira (2011), vários pastores buscam fazer com que as pessoas se comprometam profundamente com seu "relacionamento" com Deus e ignorar as normas e até mesmo leis que as afastem do que foi indicado por Deus como correto.

O cristianismo ocupa um lugar especial no leste da Ásia, por causa de seu crescimento contínuo. Embora originalmente visto como hostil aos valores sociais e às crenças tradicionais, o cristianismo está gradualmente ganhando terreno no leste da Ásia, à medida que a conversão continua principalmente como um efeito posterior da globalização, a afirmação percebida dos valores ocidentais após a Guerra Fria e a insistência do cristianismo em proselitização por seus devotos. Enquanto isso as questões teológicas e organizacionais seguem irresolutas e a relação das igrejas com a política e as leis locais e as normas supranacionais ainda são tratadas por alguns líderes como facultativas, o que impacta a vida de um grande contingente populacional.

\subsection{Líderes Cristãos das Igrejas Católicas e Evangélicas em Fortaleza}

Nesta parte desta tese, serão tratados os temas de forma pragmática, de acordo com as pesquisas escolhidas para exemplificar a importância dos direitos das mulheres. A preocupação em apresentar a relação entre a discussão filosófica do direito e as implicações práticas do contexto social é reforçada, mostrando que o pensamento religioso reflete em ações.

Nessa seção, será dada atenção ao que os representantes, aqui chamados de líderes das igrejas evangélicas e católicas, pensam sobre questões de gênero entendendo que nos cultos e missas os discursos são assimilados pelos fiéis como verdades.

As instituições religiosas escolhidas em Fortaleza obedeceram pelo menos um dos três aspectos de importância, com o intuito de analisar a relevância do líder dentro da Instituição. Dentre tais aspectos, a busca pela importância se deu pela história da igreja ou por sua importância social e política, como também pelo número de fiéis.

Ressalte-se que a importância histórica se relaciona não só com o tempo em que o templo foi erguido, mas também a sua importância no desenvolvimento da região em seu entorno, pois muitas igrejas cumprem não só o papel de assistência espiritual, mas também social para a comunidade onde está localizada, proporcionando, mesmo que de forma tímida, um desenvolvimento da região na qual está inserida. 
Compreende-se que a importância política se relaciona também ao papel social da Igreja, principalmente quando essa procura satisfazer direitos em favor dos marginalizados pela sociedade, quando promove a realização das necessidades básicas das pessoas que não tem o alimento nem o que vestir, por exemplo. Assume um papel de suporte, quando o estado não cumpre suas responsabilidades legais para com o povo.

Foi possível entender que quanto maior for o número de fiéis de uma Instituição religiosa, mais apoio e público para propagar suas ideias ela terá, podendo inclusive ter influência política, quando esse quantitativo servir para candidatar representantes religiosos que pleiteiam cargos políticos.

É impressionante a quantidade de políticos religiosos que crescem nas esferas de poder no Brasil a cada ano eleitoral e que carregam consigo suas ideologias cristãs para serem aprovadas no parlamento brasileiro.

\subsection{Igreja Católica}

Fortaleza é uma cidade de cunho religioso católico muito forte, pois a igreja católica foi pioneira desde a fundação da cidade. Ainda hoje se mantém como ferramenta social de grande importância no desenvolvimento de trabalhos que visam uma melhoria de diversos aspectos sociais, tais como distribuição de alimentos, roupas e doações diversas aos menos favorecidos. Outros trabalhos de grande valia são desenvolvidos pela igreja católica, como por exemplo: a instrução dos conceitos cristãos, encontros de casais, acolhimento pastoral, suporte emocional a jovens e adultos, dentre outros, que proporcionam estabilidade emocional a sociedade (Pinto, 2018).

Para a escolha das igrejas que fariam parte da pesquisa de campo, foi necessário respeitar a hierarquia da igreja católica. Como por exemplo, a igreja do Rosário, considerada uma das mais antigas do estado (construída por escravos, daí a grande importância histórica), não pôde fazer parte da entrevista por ser hierarquicamente dirigida por outra igreja maior: a catedral de Fortaleza. Dessa forma, não foi permitido entrevistar o pároco responsável.

A título de informação, no início dos trabalhos da pesquisa de campo, quando se começou a busca por dez participantes religiosos católicos, recebeu-se três recusas, cujos motivos enumeram-se a seguir: medo de participação; desconforto com o tema e crença de que igrejas católicas não deveriam se envolver nesta tipologia de estudo.

$\mathrm{Na}$ tentativa da primeira entrevista, o religioso, mesmo depois de ter assinado o termo de concordância da pesquisa, ao inteirar-se da lista de perguntas, recusou-se a participar.

Devido à recusa supracitada, das dez igrejas católicas selecionadas para pesquisa, realizouse entrevista somente com os nove párocos das igrejas à continuidade: Santuário do 
Sagrado Coração de Jesus, Santuário de Nossa Senhora de Fátima, Nossa Senhora da Assunção (santa padroeira da cidade), Igreja do Carmo, Igreja de São Vicente de Paulo, Igreja da Paz, Igreja de Santa Luzia, São Francisco de Assis, São Benedito. Ao entrevistar os líderes religiosos dessas nove importantíssimas igrejas católicas da cidade de Fortaleza, foi possível perceber contradições, receios nas respostas e ausência de informações sobre alguns assuntos discutidos mundialmente.

A postura dos líderes católicos é elegante e rígida, já que existe uma tradição a ser seguida, além da hierarquia que obedecem. Há certa dificuldade em se contatar os padres. Primeiramente, é necessário dirigir-se à secretaria da igreja para marcar hora ou, através dela, obter-se o número de contato do padre. Em geral, o local da entrevista escolhido é o confessionário, no mesmo horário em que se atende às confissões dos fiéis. Dessa forma, muitas vezes foi necessário aguardar o atendimento confessional, para só então proceder à entrevista. O local de confissão é sempre muito aconchegante e discreto, de sigilo absoluto, pois as salas são totalmente fechadas, estando aí apenas o confessor e o padre.

Ao iniciar a entrevista com gravação de áudio, os padres demonstravam uma preocupação maior na escolha das palavras, na forma como se expressavam e havia uma necessidade em colocar sua opinião através de eufemismos, de modo a não contrariar nenhum grupo de pessoas ou afrontar opiniões já formadas como, por exemplo, o tema da "ideologia de gênero", sobre a qual diziam que, apesar do respeito que se deve ter sobre as escolhas de cada ser humano, tudo deve ser conversado e esclarecido, já que sua doutrina cristã reprova o homossexualismo veementemente.

Certas contradições ocorridas durante a entrevista também chamaram a atenção, como foi o caso do padre que quando questionado sobre violência de gênero respondeu:

Entrevistadora (E) - Você acha que é certo ou errado o termo violência de gênero?

Padre Entrevistado (PE) - Errado, erradíssimo.

E - Você acredita ou não que a violência baseada no gênero viola os direitos humanos ou é outra coisa?

PE - Viola. Só deixando claro assim que quando a gente fala de violência é diferente de um diálogo, um debate né? Que questionar a ideologia de gênero é uma coisa, é um debate, é um diálogo, é uma conversa de pessoas que estão pensando e estão fazendo interpretações e trazendo algo que vai responder mais às situações. Outra coisa é que agredir fisicamente e sucumbir à respeitabilidade ao outro, ao humano. 
É possível observar que para esse padre é confuso o conceito de "violência de gênero". Em um primeiro instante, diz ser errado o termo "violência de gênero" e, por fim, comenta que a "violência de gênero" viola os direitos humanos.

Reitera-se que em quase todas as entrevistas foi percebido um forte receio ao se tratar sobre "ideologia de gênero", como se essa ótica não pudesse atravessar as colunas do seu templo.

Ao traduzir a opinião do líder religioso, foi possível observar que suas respostas defendem os dogmas advindos do catolicismo. Mesmo desconhecendo conceitos técnicos de discussão sociológica ou jurídica, fica clara a defesa do patriarcado, pautado nas passagens bíblicas utilizadas por ele para ratificar suas afirmações. Em seu discurso, permaneceu omisso quanto aos direitos dos negros, mulheres, homossexuais e deficientes. Foi possível notar o embate ideológico com relação à igualdade de gênero. Pois além de desprezá-la, por não conhecer verdadeiramente os conceitos, admite a necessidade do patriarcado para se combater, conforme seus argumentos, a "ideologia de gênero".

Pode-se comprovar isso nas transcrições abaixo, nas quais deixou claro que a igreja católica vem desenvolvendo um trabalho de contenção da dissipação da "ideologia de gênero" em colégios e faculdades. Quando lhe foi questionado sobre direitos humanos e igualdade de gêneros, obteve-se essa resposta:

E - Trabalham-se de alguma forma os direitos humanos e direitos à igualdade de gênero na sua igreja? Como?

PE - Sim, inclusive estamos, desde o ano passado, desde 2017, com o arcebispo emérito de João Pessoa, Dom Aldo Pagotto, trabalhando com a pastoral familiar sobre essa questão do gênero, das ideologias de gênero, nas escolas, nas faculdades, é... Explicando o que está por trás da ideologia de gênero no campo religioso, não no campo civil. Nós sabemos que já está bastante avançado o discurso. Mas no campo religioso, volto a repetir que é uma "forçação" de barra, né, dizer que aquele que nasceu do gênero masculino, gênero feminino, muda-se de sexo como se muda de camisa e fica tudo muito tranquilo, muito normal, então a igreja principalmente por essa autoridade, o arcebispo, né, que emérito de João Pessoa, Dom Aldo, ele tem que trabalhar muito essa reflexão e não mudar sua cabeça, mas do discurso oficial do vaticano, do discurso oficial da CNBB - Conferência Nacional dos Bispos do Brasil e as orientações da igreja local. 
É evidente, a partir dessa fala, que existe uma movimentação da igreja católica contra a expansão da "ideologia de gênero" e união de pessoas do mesmo sexo. A não aceitação está sendo colocada de forma clara e objetiva e, além disso, existe um movimento de não emancipação da "ideologia de gênero", além de uma doutrinação com relação aos princípios católicos em ambientes educacionais. Foi possível perceber que existe um esforço de coibir os direitos humanos relacionados à livre orientação sexual e "ideologia de gênero": os padres estão trabalhando, percorrendo diversos estados do Brasil, adentrando em colégios e faculdades com palestras a respeito do conceito cristão e ao mesmo tempo demonstrando repulsa aos direitos acima mencionados.

Nas entrevistas realizadas, ficou bastante patente que, enquanto falavam, os religiosos se distanciavam do que havia sido indagado na pergunta e, ao invés de respondê-la, pareciam querer aproveitar a oportunidade para fazer uma pregação, sempre com explicações bíblicas, políticas, midiáticas e emoções intrínsecas, demonstrando desconsiderar a importância do que foi perguntado, sem sequer questionar a serventia da pesquisa.

\subsection{Igreja Evangélica}

A chegada dos primeiros protestantes à Fortaleza, no Estado Ceará, data de 1881, século XIX. Eles eram vinculados à igreja Presbiteriana. Em 1890, foi fundada a primeira igreja Presbiteriana da cidade, localizada à Rua Sena Madureira, esquina com Rua Pedro Borges, considerada a mais antiga e, por muitos anos, foi a única da cidade.

Atualmente, a religião evangélica organiza-se através de uma Ordem dos Ministros Evangélicos do Ceará - ORMECE, que foi fundada há cinquenta anos e que, por sua vez, elege de três em três anos uma nova diretoria com a finalidade de representar os ministros evangélicos junto à sociedade e aos órgãos governamentais do Estado ${ }^{34}$.

O principal critério para a escolha das entidades evangélicas foi a quantidade de fiéis. Os líderes evangélicos escolhidos foram ministros ou presidentes de ministérios da cidade de Fortaleza. Dentre essas igrejas, estão as Assembleias de Deus (AD), que tiveram dois de seus pastores escolhidos devido ao grande número de igrejas participantes da ordem ministerial (foram escolhidas as duas maiores $\mathrm{AD}$ existentes na cidade, a $\mathrm{AD}$ do bairro Montese, principal sede, e AD do bairro Cidade Oeste). Outros líderes escolhidos são das

\footnotetext{
${ }^{34}$ Os dados sobre a história das igrejas evangélicas e católica aqui relatados foram obtidos nas conversas e entrevistas com os religiosos durante a pesquisa.
} 
seguintes igrejas: Vale de Benção, Igreja de Deus no Brasil, Casa da Benção, Ministério Metodista, Igreja Evangélica Congregacional, Igreja Betesda e Missão Evangélica.

A coleta das assinaturas desses dez Pastores Evangélicos ocorreu de forma simples, pois nessa religião não existe nenhum tipo de hierarquia vertical a ser seguida e cada ministério tem o seu presidente fundador, que por sua vez tem o poder de decidir participar ou não, sem ter de consultar a superiores. Isso facilitou bastante, não só na locomoção, como no tempo de coleta das assinaturas do termo de comprometimento com a pesquisa, não havendo uma recusa sequer. Outro ponto positivo foi em relação ao acesso a esses Pastores. Por chamada telefônica foi possível agendar dia, local e hora da entrevista, facilitando muito a coleta de dados.

A comunicação com os pastores evangélicos se deu de maneira direta, pois eles seguem à risca os conceitos que entendem e acreditam ser bíblicos, sem deixar brechas para conceitos modernos de inserção. Dessa forma, os seus mecanismos de respostas se dão com mais clareza: que pode ser feito, o que é permitido, o que é aceitável é o que está escrito na bíblia; o que não está, não tem aprovação nenhuma. Assim fica claro compreender a restrição dos direitos humanos na visão evangélica, já que movimentos mundiais de difusão de conceitos sobre diversidade e "ideologia de gênero", por exemplo, não são entendidos ou bem recebidos por eles.

O preconceito é visível e notório em relação à "igualdade de gênero", "ideologia de gênero" e emancipação dos direitos humanos das mulheres, visto que, segundo eles, há passagens bíblicas que aprovam tal comportamento de não aceitação, conforme sua interpretação, reprovando tudo que não seja segundo a leitura deles do texto bíblico.

Os pastores evangélicos são mais diretos na hora de responder perguntas sobre assuntos desconhecidos. Simplesmente dizem não conhecer, não procuram justificar ou explicar o que desconhecem. Nas entrevistas, não existiu uma resposta positiva sequer quando foram questionados em relação à CEDAW (Convenção sobre eliminação de todas as formas de discriminação contra a mulher), em que o Brasil é signatário. Nenhum deles a conhecia ou já teria ouvido falar dela. Nenhum pastor conhecia o discurso da ONU sobre o direito a igualdade de gênero ou os direitos e liberdades sexuais reprodutivas. Ressalta-se que desconheciam, inclusive, o termo "violência de gênero".

\subsection{Igreja Católica e Evangélica}

Foi possível perceber uma grande diferença organizacional e comportamental entre católicos e evangélicos. Como primeiro aspecto, a hierarquia vertical seguida pela igreja 
católica que é inexistente para os evangélicos. Como segundo, as tradições católicas e representações históricas junto à sociedade e ao governo, devido ao tempo de existência. Como terceiro, a comunicação da igreja católica muito contida em comentar seus pontos de vista, sempre usando de muita cautela para não afrontar nenhum grupo, nem excluir nenhuma ideia ou posição de discursos atuais. O que diverge da evangélica, que demonstra indiferença ao discurso moderno ou aos novos costumes sociais. Demonstra, inclusive, considerar inaceitáveis os conceitos trazidos pela sociedade moderna.

Vale destacar que o tema "igualdade de gênero" trouxe uma grande angústia para as lideranças nas entrevistas. Descobrir uma nova maneira de conviver igualitariamente em todos os aspectos civis, morais, ideológicos, financeiros, profissionais, políticos, dentre muitos outros, parecia lhes causar um verdadeiro desconforto, quando questionados. Apesar de alguns quererem demonstrar que eram a favor da igualdade de gênero, argumentavam maneiras de se manter o homem no papel principal, de comando, de domínio, por exemplo.

Não conseguiam enxergar como anormalidade o domínio do homem no âmbito público ou privado, inclusive comandando mentes femininas. Consideram importante seu papel de trabalhar a mente dos fiéis com intuito de orienta-los (por meio de uma cultura ainda patriarcal e arcaica), sobre o que se pode ou não se pode fazer, conduzindo-os através da bíblia - coletânea de livros escritos há milhares de anos, por diversas pessoas diferentes (homens), de épocas históricas demasiado diferentes - para se que se perpetuem as ideias que traz, em sua totalidade.

Com base em um livro sagrado, justifica-se porque o homem se coloca como "coroa da criação divina" e, além de se intitular superior em tudo e a todos, existem papeis distintos e diferentes fundamentados nas leis de Deus. Como se as mulheres, lésbicas, gays, bissexuais, travestis, transexuais e pessoas intersexuais, por exemplo, tivessem que aceitar suas condições de "inferiores" ou se resignarem em não ter os mesmos direitos, em razão da bíblia.

\subsection{As entrevistas com os líderes religiosos}

A análise de dados ocorreu por meio de três categorias analíticas. São elas:

a) O papel político e social do líder;

b) O discurso do líder cristão sobre direitos humanos e gênero;

c) A percepção do líder, quanto ao discurso da ONU, sobre direitos humanos e gênero. 
As respostas foram dadas livremente de acordo com as perguntas, de forma aberta, assim a entrevistadora pôde coletar as opiniões de forma livre e integral. Foram respeitadas as identidades dos líderes, sendo identificados com um código, de acordo com a exigência do comitê de ética da pesquisa. O roteiro de perguntas e o parecer do comitê de ética estão nos anexos deste trabalho.

\subsection{Líderes cristãos das igrejas católicas e evangélicas em Fortaleza}

A entrevista foi dirigida a 20 líderes, tendo apenas uma recusa, por parte de um padre. Serão demonstradas a seguir as entrevistas com os religiosos que foram, efetivamente, realizadas e a discussão dos dados referentes às categorias de análises determinadas para a pesquisa. ${ }^{35}$

\section{A) Padre 1}

Entrevista com padre 1, administrador paroquial da Igreja São Benedito, quando questionado a respeito de uma definição rápida e concisa de direitos humanos, informou que: "Direitos humanos acredito que é toda ação que faça defender a vida, o ser humano na sua integridade de uma forma que ele se sinta respeitado, valorizado e próspero a continuar a crescer e se desenvolver nesse mundo".

De acordo com as palavras do entrevistado ele parece valorizar os direitos humanos e ter uma visão humanística, embora na sequência da entrevista ele demonstre certa resistência com relação ao assunto. Quando interrogado a respeito da importância dos direitos humanos para as pessoas e países, através da seguinte pergunta: "você acredita que os direitos humanos são muito, pouco ou alguma coisa de importante para as pessoas e países, ou seria melhor esquecê-los?", ao que ele respondeu:

"São importantes, muito importantes, porém precisariam ser mais bem exercidos. A grande questão que eu vejo, são intervenções e interpretações erradas dos direitos humanos, porque é pra defender grupo A, B, C, quando o seu interesse é importante e não no sentido do bem comum. Então hoje a gente escuta muita crítica; ai esse pessoal defende os direitos humanos, não sabe de nada ou querem uma sociedade desorganizada, não é isso. É porque quantas vezes há um interesse, uma ideologia particularizada e deturpa o que seria realmente o código de direitos humanos. " (Padre 1)

\footnotetext{
${ }^{35}$ Os nomes dos religiosos foram mantidos em sigilo, sendo representados por "padre" ou "pastor" seguido do número que representa a ordem das entrevistas.
} 
Aqui parece distinguir a defesa de interesses específicos, do bem comum, como se ambos fossem divergentes no tocante aos direitos humanos. Segundo ele, quem defende os direitos humanos não entende o que defende ou trabalha para que se tenha uma sociedade desorganizada, não trabalhando para o bem comum. De acordo com o seu raciocínio, existe um conluio - uma trama por parte de alguns, deturpando o real interesse do código que a ONU criou - o que caracteriza uma ideologia da "teoria da conspiração", na qual um líder sem fundamentação, baseado apenas no achismo próprio, levanta uma acusação infundada sobre os que defendem os direitos humanos. Ressalta-se, assim, um modo esquivo de responder, evitando ao máximo o posicionamento explícito sobre o tema.

Logo mais, o padre é questionado a respeito da família, concepção de família e papel que ela deve desempenhar em homens e mulheres: "Família é o espaço do desenvolvimento humano. A família ajuda o ser humano a se sentir melhor, mais respeitado enquanto sociedade, enquanto indivíduo e é na família que a gente aprende a amar, perdoar e recomeçar o caminho" (Padre 1).

Na citação acima o padre 1 entende que o seio da família é lugar onde seres humanos deveriam fazer parte de um ambiente no qual pudessem se "desenvolver", receber ajuda humanitária e se sentir melhor enquanto sociedade. Onde deveria receber amor, aprender a amar e recomeçar uma nova caminhada. No entanto, em seguida, fala sua opinião sobre gênero ao ser solicitado a tentar uma rápida definição de "gênero":

"O gênero, na verdade é homem, mulher, homem, mulher. Acredito que gênero em si hoje tá bem... "tá" (sic) tendo muita deturpação; gênero, sexo, sexualidade, desejo sexual, intenções e opções sexuais. Acredito que gênero mais do que nunca é homem, mulher, na sua natureza, na sua biologia. Ou existe homem ou existe mulher. Não existe meio termo" (Padre 1).

A pergunta formulada pela entrevistadora foi acerca de gênero, mas, em sua fala, fica evidente que o Padre 1 desconhece a "ideologia de gênero" e se opõe veementemente a qualquer outra definição de gênero que não seja o homem e a mulher, desde a época da criação. Logo, desaparece totalmente a ideia que permeia toda resposta acima, na qual, no seio da família, os seres humanos deveriam receber ajuda e se sentir melhor, além de ser um ambiente onde pudessem se "desenvolver" enquanto cidadãos, para seguir uma nova caminhada. Pelo que expressou o padre 1, não existe termo intermediário. Essa visão totalmente "engessada" define o gênero estritamente sob o ponto de vista biológico, 
desprezando a "questão de gênero" que define o ser humano na sua personalidade, identidade ou ideologia.

Quando o pároco foi questionado quanto ao seu conhecimento sobre o que diz a ONU sobre igualdade de gênero e, em conhecendo, qual sua opinião do discurso da ONU sobre o direito à igualdade de gênero; se já ouvira falar da convenção sobre a eliminação de todas as formas de discriminação contra as mulheres (CEDAW) e o que parece ser essa normativa internacional, pôs-se a negar, simplesmente, sem justificar suas respostas.

E quando indagado se existe alguma relação entre direitos, direitos humanos das mulheres e modalidades de relações de gênero, respondeu como se tivesse conhecimento sobre o assunto "Direitos e direitos humanos das mulheres nesse sentido eu vejo relação, agora de gênero já acho que é forçar um pouco a barra" (Padre 1).

A falta de informação do padre 1 é visível e notória sobre certos assuntos abordados nessa pesquisa como: direitos humanos das mulheres, igualdade de gênero, "ideologia de gênero", a convenção da mulher (CEDAW). Mais uma vez o entrevistado foi questionado sobre igualdade de gênero: "você acha que as pessoas devem ou não ser educadas para promover e respeitar a igualdade de gênero?"

"Sim, no sentido de não querer forçar organizações a aceitar aquilo que, por exemplo, aquilo que a ideologia de gênero hoje prega. Você pode nascer homem e se transformar numa mulher, no sentido em que a religião, a igreja, a organização institucional tem que ser forçada a aceitar como algo comum e não é comum, é algo extraordinário. A religião... ela encara, a instituição como algo extraordinário e não de forma natural. " (Padre 1)

Mais uma vez o líder veemente despreza o contexto que envolva o termo "gênero", mesmo aquele voltado às questões igualitárias, coloca como sendo algo que a religião condena e desaprova. Quando se questionou sobre a igualdade de gênero, ele considera extraordinário aceitar como comum esta igualdade.

Ao ser questionado a respeito do termo violência de gênero, se é certo ou errado o termo violência de gênero, responde com ênfase: "Errado, erradíssimo" (Padre 1).

O padre 1 parece não entender sobre o assunto violência de gênero. Além de não conhecer o que diz a ONU e a comissão interamericana de direitos humanos sobre assuntos tão relevantes, ainda se posiciona contrário a toda e qualquer proteção de direitos das pessoas que colocam seus sentimentos como diferentes do que ele e a igreja acreditam ser os “certos”. Em suas palavras há um desconforto enorme com a pergunta sobre esse tipo de violência. 
Quando questionado se as pessoas têm o direito de escolher de forma livre sua orientação sexual e suas relações sociais independentemente de seu sexo biológico, respondeu:

"Liberdade todos nós temos de fazer nossas opções, isso não significa que serão aceitas no sentido comum da sociedade, mas todos têm liberdade, acredito que há essa, essa liberdade pessoal, individual, é é".... essa pessoa vai ter que assumir as consequências também dessa opção. A sociedade em contrapartida vai se manifestar também em relação positiva ou negativa, mas o que está acima de toda essa relação, da escolha individual ou da sociedade que aceita ou não aceita, é o respeito pelo humano, esse respeito pelo humano está acima da questão do gênero, homem ou mulher (Padre 1).

Perguntado se deve, em sua opinião, ser facilitada ou proibida às uniões homossexuais, afirma que
"As uniões homossexuais elas têm que ser mais bem entendidas, em que sentido, sentido do civil. Quando vai para o campo do religioso, institucional é impossível ser debatido esse assunto porque as orientações bíblicas já se colocam como uma oposição à opção homossexual, né?! Se você pega, por exemplo, o alcorão dos muçulmanos, se você pega a torá judeus, se você pega a sagrada escritura bíblica para os católicos e para os evangélicos você vai encontrar textos bíblicos que proíbe a questão da homossexualidade né?! o pederasta... é.... então assim, para, para o discurso religioso é impraticável, é negado a questão do homossexualismo. No campo civil tudo é possível, inclusive como nós estamos agora no nosso país tendo a realidade do matrimônio civil, né, o contrato civil entre homens ou entre as mulheres." (Padre 1).

O pároco parece se contradizer, ao passo que sua opinião, na resposta supracitada, parece se esconder sob o manto da religião, sem emitir o que defende ou entende verdadeiramente. Quando questionado o que defende a ONU sobre o aborto e o que acha ele, como líder, respondeu:

Eu não conheço também o texto oficial, até porque, assim, tem países que o aborto já é oficializado e eu acredito que a ONU, ela fica no meio termo por causa justamente desta forma geral de ver o mundo, né?! Existem países que proíbem, como o Brasil, o aborto e 
tem países que já estão totalmente abertos. Então, eu não, eu não conheço o discurso oficial, mas creio que a ONU, ela fica em cima do muro, justamente porque ela não pode também ser causadora de conflito de interesse de nações (Padre 1).

Mais uma vez o padre não explicita sua opinião própria, e apenas responde o que acredita que defende a ONU, sem fundamentação teórica e verdadeira com relação ao aborto.

Perguntado a respeito dos trabalhos desenvolvidos pela instituição que administra, sobre assuntos tão latentes, questionou-se: "Trabalham-se, de alguma forma, os direitos humanos e direitos à igualdade de gênero na sua igreja"? Como? Ele respondeu:

"Sim, inclusive estamos, desde o ano passado, desde 2017 com o arcebispo emérito de João Pessoa dom Aldo Pagotto, trabalhando com a pastoral familiar sobre essa questão do gênero, das ideologias de gênero, nas escolas, nas faculdades, é.... explicando o que está por trás da ideologia de gênero no campo religioso, não no campo civil. Nós sabemos que já está bastante avançado o discurso. Mas no campo religioso, volto a repetir que é uma "forçação de barra", né, dizer que aquele que nasceu do gênero masculino, gênero feminino, muda-se de sexo como se muda de camisa e fica tudo muito tranquilo, muito normal. Então a igreja, principalmente por essa autoridade, o arcebispo, né, que emérito de João Pessoa, dom Aldo, ele tem que trabalhar muito essa reflexão e não mudar sua cabeça." (Padre 1).

Tem-se a expectativa que um líder de uma das maiores religiões do mundo, não tenha um posicionamento tão contraditório a respeito de assuntos tão sérios e debatidos hoje em dia - preso a um passado tão remoto - não deveria estar levantando uma bandeira opositora, sem antes se aprofundar no tema. Nota-se que há uma distorção sobre o assunto com força de reproduzir o mesmo pensamento para as mentes das massas, como os guias delas. Evidentemente as respostas sobre perguntas elaboradas para o esclarecimento da percepção pessoal do respondente leva a um possível desnudamento uma face ardilosa de não aceitação dos direitos humanos.

B) Padre 2

O padre entrevistado é responsável por uma das igrejas mais antigas dentro da capital do estado, administrador paroquial da Igreja do Carmo, situada em local privilegiado de Fortaleza, estando bem no centro da capital cearense. Atua com influência junto à 
comunidade em desenvolver um papel de orientador espiritual, confessor da comunidade ao entorno, orientador de casais e catequese local.

Quando questionado a respeito da importância da igreja a qual pertence, se acredita que sua religião em Fortaleza é muito ... alguma coisa ... sem importância? Ele responde:

É muita coisa, né?! A igreja, ela tem uma atuação muito forte e não é de hoje, né?! Já vem de muito tempo, aliás, desde o início, se for ver a história, acredito que você vai ver que a presença da igreja foi desde o início até mesmo da própria história do Ceará, né, e da própria história do Brasil, como tendo a primeira missa na Bahia, no Sul da Bahia, a primeira missa foi lá e tal. Acredito, né, como a pergunta que a igreja evidentemente aqui no Brasil não vem só daí, ela já vem desde o próprio Cristo e cremos e é assim que nós professamos. (Padre 2)

Observou-se que o padre 2 percebeu a grande importância que o grupo religioso ao qual pertence tem, porém, ainda assim, não procurou conhecer de forma aprofundada temas tão importantes para o desenvolvimento do seu trabalho junto à comunidade, uma vez que não soube informar o que diz a ONU e a Comissão Interamericana de Direitos Humanos como temas de direitos humanos e questões de gênero. Inclusive não soube responder perguntas sobre questões igualitárias e de gênero, deixando frases soltas sem terminar.

Quando questionado a respeito das contribuições da igreja para a promoção sociopolítica dos fortalezenses, responde: "Olhe, começa pelo... Tudo que implica no homem, a igreja está presente, né”?! (Padre 2)

No que concerne à resposta acima, a igreja deveria estar presente em tudo que implica no homem, porém os discursos internacionais de direitos Humanos como o que pronuncia a ONU, na concepção do respondente, parece não haver qualquer relação de interdependência.

Quando lhe foi perguntado a respeito de uma definição rápida e concisa de direitos humanos, ele informou: “o direito à vida”. Percebe-se a vacuidade de sua afirmação já que o ser humano pode estar altamente desnutrido e desnudo, sem qualquer condição digna social e ainda assim estar vivo. O conhecimento necessário para orientar a população que vive em de uma área central da capital deixa sérias lacunas entreabertas, com vagas percepções sobre temas tão debatidos em âmbito nacional e internacional.

No que diz respeito à família, então o padre se pronunciou da seguinte forma, quando questionado sobre sua concepção de família e papel que ela deve desempenhar em homens 
e mulheres: "Bem, a família, a concepção que se tem mesmo, que se deve ser preservada é como ela é né?!, pai, mãe e filho" (Padre 2).

Em sua resposta nota-se uma concepção restrita que preserva o conceito de família tradicional, diferente dos conceitos diversos da comunidade internacional, evidenciando uma forma engessada de pensar que, ainda que intente preservar um modelo de família, quando na realidade, está discriminando outras formas de família.

Quando interrogado se trabalha de alguma forma os direitos humanos e direitos à igualdade de gênero na sua igreja e de que forma, respondeu: "Não. Claro que trabalha é o respeito, trabalha para respeitar as pessoas e acolher, mas difundir ou... (risos) não" (Padre 2).

No comentário, é possível notar que o clérigo demonstra não ter o interesse em difundir assuntos sobre direitos humanos, inclusive não conhece e nem soube definir quando questionado temas sobre: definição de Gênero, Igualdade de Gênero, CEDAW Convenção da Mulher, Relações de Gênero, Liberdades Sexuais e Reprodutivas, Violência de Gênero, dentre outros.

Ao longo das entrevistas é perceptível a falta de esclarecimento e entendimento sobre Diretos Humanos, ao mesmo tempo que se desconhece ou se conhece um pouco e de forma incongruente frente às definições e relatórios da ONU, leis e convenções internacionais que discutem e definem tais temas para a comunidade internacional, a fim de viabilizar a promoção dos direitos humanos.

O que se percebeu é que existe um desinteresse, até negligenciando a importância de tais temas. Nas respostas do padre 2 revela-se que as falas são emitidas sem qualquer intuito nem mesmo aparente de se alinhar as pautas internacionais que tentam diminuir a violência, promover o bem-estar e a igualdade entre todos. Por outro lado, há notoriamente a intensão de conduzir povos com suas pregações e ideologias, já que os líderes religiosos se colocam no papel de orientadores.

C) Padre 3

Administrador Paroquial da Igreja da Paz, o padre é responsável por uma das igrejas mais antigas dentro da cidade localizada no lado Sul de Fortaleza trata-se de uma igreja antiga e muito tradicional. Tem como maior importância a catequese tradicional que é desenvolvida desde o seu nascimento.

As igrejas católicas antigas possuem uma arquitetura peculiar que remete ao passado, quando sua influência era ainda maior. Atualmente, o valor é mais histórico do que político e, em se tratando de movimentos sociais, esses são praticamente inexistentes. O padre 3 incorpora uma imagem bem resoluta e convicta das suas ideias e por isso não quis gravar o 
áudio da entrevista, sendo suas respostas colhidas por meio das anotações da pesquisadora. Dessa forma, suas respostas foram curtas, pois alegou estar com o tempo corrido e havia pessoas esperando para se confessar. Portanto, seguem as respostas aos questionamentos da entrevista.

Quanto à sua percepção com relação à contribuição sociopolítica mais importante de sua religião para os fortalezenses, respondeu: "Promoção humana" (Padre 3).

Mediante essa resposta, o pároco parecia se pautar pelas questões inerentes aos direitos humanos e igualdade de gênero. No entanto, devido às controvérsias trazidas pelas demais respostas, entende-se justamente o inverso dessa proposição ao responder negativamente às questões relativas aos temas. Vejamos:

E - Conhece o que diz a ONU sobre a igualdade de gênero? Se conhece, qual sua opinião do discurso da ONU sobre o direito à igualdade de gênero?

Padre 3 - "Não"

E - Você já ouviu falar da convenção sobre a eliminação de todas as formas de discriminação contra as mulheres (CEDAW)? Para você o que parece ser essa normativa internacional?

Padre 3 - "Não"

E - Você acha que existe alguma relação entre direitos, direitos humanos das mulheres e modalidades de relações de gênero?

Padre 3 - "Não".

E - Conhece o discurso da ONU sobre os direitos e liberdades sexuais e reprodutivas?

Padre 3 - "Não conheço".

Por outro lado, quando suas respostas não eram negativas, eram vagas, sem demonstrar apego às questões e atenção a esses assuntos:

E - Você acha que as pessoas devem ou não ser educadas para promover e respeitar a igualdade de gênero?

Padre 3 - "É um assunto a ser discutido".

E - Você acha que é certo ou errado o termo violência de gênero?

Padre 3 - "Violência é errado em todos os sentidos".

E - Sabe como se define esta violência pelos organismos internacionais?

Padre 3 - "Não". 
E - Trabalham-se de alguma forma os direitos humanos e direitos à igualdade de gênero na sua igreja? Como?

Padre 3 - "Não".

Compreendeu-se que o padre 3 separa o discurso religioso dos discursos de direitos humanos. Sem permitir essa relação de interdependência com o discurso internacional de direitos humanos, despreza o conhecimento sobre o assunto, e se entrega à própria sorte a orientar milhares de fiéis. Os direitos deveriam encontrar espaço em ambientes privados, porque notoriamente eles se propagam em ambientes públicos, estão intrínsecos à cultura secular e se perpetuam na contemporaneidade.

É consenso que promover uma visão mais humanística é o mesmo que se propagar os direitos humanos. Sendo assim, não há diferenciação quanto à promoção dos direitos por meios seculares ou religiosos, apenas deve haver uma vontade de fazê-lo. Apesar de mencionar que sua religião trabalha a promoção humana, resiste ao tema "direitos humanos e igualdade de gênero" no ambiente religioso.

D) Pastor 1

O entrevistado é administrador evangélico da Igreja Missão Evangélica Pentecostal do Brasil. O pastor entrevistado é responsável por uma igreja que chegou à cidade de Fortaleza no ano de 1939, e segue uma crença Protestante Pentecostal com muitas filiais espalhadas pela capital do Ceará. Essa igreja possui dois seminários e um orfanato, dessa forma se entende que é possuidora de força social e política.

Porém, quando se questiona a influência em termos de movimentos de reivindicação dos Direitos Humanos como passeatas e intervenções políticas, defende que apesar de não transparecer, há uma intenção de participar ou promover atividades em defesa das causas sociais e de outros entraves pelos quais, segundo ele, a igreja evangélica vem passando. Em sua resposta observamos claramente a sua vontade.

Participações em mobilizações sociais ou políticas destinadas a defender suas crenças e valores?

"Não. Não, eu não participo de nenhum movimento, embora já tenha pensado em algo nesse estilo por conta de algumas problemáticas que a igreja evangélica vem, vem passando né, acredito que nós devemos de uma forma ou de outra tentarmos mobilizarmos tanto pra, pra defender como também pra discutir e quebrar muitas, muitas questões, muito misticismo e muitas coisas que se inventa nos bastidores contra a própria religião cristã e principalmente nós evangélicos que tem... que acredito que 
algumas áreas desse evangelicalismo atual, contribui para essa difamação, entendeu? Mas de modo geral, acredito que a igreja evangélica poderia dialogar mais com o assunto com os setores das camadas sociais (Pastor 1)."

Nessa resposta, observa-se que o pastor 1 coloca uma ideia de que a própria religião evangélica moderna com a prática do "evangelicalismo atual”, assim citado por ele, contribui para a difamação da igreja evangélica. Provavelmente por não haver uma união mais concreta dos grupos e ministérios evangélicos a fim de alinhar os ideais num só movimento e concordância, a igreja passe por dificuldades quanto a ser mais assertiva na questão de orientação dos seus 'fiéis'.

Quando questionado a respeito da importância dos direitos humanos, respondeu que: "São muito importantes, embora ainda haja muita ruptura e preconceito né, com relação a determinadas camadas reprimidas, enfim homossexuais, pessoas de baixa renda, mas é importantíssimo né. É ruim com eles, pior sem eles" (Pastor 1).

Aqui, nessa declaração, o pastor 1 fala sobre o preconceito com relação a determinadas camadas reprimidas, ou seja, homossexuais e pessoas de baixa renda como sendo uma ruptura dos Direitos Humanos. Ou seja, o pastor diz que os Direitos Humanos são importantes justamente para defender essas minorias, ainda que com a ressalva de que são um problema, pois, em suas palavras: ruim com eles (os Direitos Humanos) pior sem eles. Logo, abaixo, numa outra resposta ele se contradiz, pois quando perguntado a respeito de sua opinião com relação a ser facilitada ou proibida às uniões homossexuais, ele responde que: "Não. Eu não posso defender isso como sacerdote cristão" (Pastor 1).

Há uma certa contradição com relação ao que foi dito antes, pois nessa resposta observa-se um preconceito por parte do pastor que não apenas discordou, mas também usou a palavra "isso" para se referir à homossexualidade. Em sua fala ele evidencia que não pode defender a união homossexual tendo em conta sua condição de sacerdote cristão, eximindo-se assim de uma resposta de cunho pessoal.

Quando lhe foi solicitada uma rápida e concisa definição de Direitos Humanos, ele responde que: "Garantir uma sociedade mais justa, mais igualitária né, respeitando os direitos e os deveres de cada um, se limita a viver a vida dentro desse amor fraternal, dentro dessa mutualidade" (Pastor 1).

A partir de seu discurso, pergunta-se: como pode ser construída uma sociedade mais justa e mais igualitária com base em preconceitos pessoais e religiosos, partindo, em princípio, da própria liderança religiosa que tem influência em ambientes públicos e em camadas populares, propagando ideias que levam a crer - de forma superficial - uma preocupação 
com os direitos humanos, mas ainda culturalmente cheia de preconceitos? Ao considerar apenas as duas falas, é possível entender que o pastor não comunga do pensamento igualitário que prega e ainda descrimina a prática de qualquer forma de construção amorosa que não seja a que ele aceita. Ajudando assim a difundir, não a igualdade e justiça que apregoa, mas o preconceito e a discriminação. Já o tão pregado e sonhado amor fraternal que ele semeou em suas palavras, dá lugar rapidamente à desigualdade e à falta de aceitação, quando não obedece aos seus critérios de mutualidade.

No mais, quando indagado acerca dos trabalhos realizados pela sua congregação para esclarecimento, para se trabalhar os direitos humanos e direitos à igualdade de gênero na sua igreja, ele responde negativamente, justificando que: “Até agora eu não vi nenhuma discussão, seja ela política ou religiosa, dentro da minha denominação sobre essa questão. Precisamos dialogar, conversar e até mesmo se preparar para receber essas pessoas na igreja" (Pastor 1). Nesse contexto, demonstra que a própria pergunta o pegou despreparado, pois parecia querer ter um argumento mais convincente de suas ideias cristãs.

O pastor 1 deixa claro que não é desenvolvido nenhum tipo de trabalho sobre Direitos Humanos e Igualdade de Gênero em sua congregação, ainda que demonstre a necessidade de discutir e haver alguma preparação para receber as pessoas na igreja. Assim como os outros líderes religiosos entrevistados, também não soube responder sobre o diploma internacional que fala sobre a eliminação de todas as formas de discriminação contra as mulheres (CEDAW), não conhece o que diz a ONU sobre a igualdade de gênero e, quanto à sua opinião sobre discurso da ONU no que concerne ao direito à igualdade de gênero, reconhece que "procura ter conhecimento desta área para poder dialogar com as pessoas" (Pastor 1).

Assim, apesar de reconhecer que procura ter conhecimento para dialogar com as pessoas, suas respostas abaixo não condizem com esse entendimento:

E - Qual sua opinião do discurso da ONU sobre direitos humanos? Sobre a organização social e familiar brasileira?

Pastor 1 - "É sobre isso que eu te falei né. Eu não tenho conhecimento de causa então não posso colocar aqui o meu ponto de vista não".

E - Conhece o discurso da ONU sobre os direitos e liberdades sexuais e reprodutivas?

Pastor 1 - "Não, não conheço nada sobre a ONU. Eu não sei”. 
Na sequência das perguntas, ao ser interrogado sobre sua opinião se as pessoas devem ou não ser educadas para promover e respeitar a igualdade de gênero, ele responde que: "Essa discussão está nas redes sociais né. A questão de gênero e tal, enfim, eu precisava conhecer mais do assunto para poder me posicionar, tanto é que eu não comento nada nas redes sociais". Ao se insistir na pergunta sobre o respeito às questões igualitárias, informou que:

É, seria interessante né? Eu acredito que... eu tenho muitos amigos e colegas homossexuais e respeito eles e a gente conversa numa boa. Mas a questão é a da influência... também é muito complexo esse assunto. A gente tenta se posicionar de uma forma assim, entendeu... a gente fica no meio termo ainda, esperando realmente que as coisas se encaixem (Pastor 1).

Com a resposta acima, verifica-se que a fala adquire um tom mais pessoal e revela atitudes de alguma forma inclusivas, já que o líder religioso diz ter boas relações com colegas e amigos homossexuais. A resistência a uma posição sacerdotal com relação à homossexualidade se justifica em não defender aquilo que não se conhece bem e ainda não tem um posicionamento das lideranças, e, em suas palavras "pode ser uma influência" para a sociedade. Ressalta-se que uma cultura secular e patriarcal rechaça a ideia desse diálogo. Mais adiante o pastor não soube informar se concorda com o termo violência de gênero. Ele não entende bem a pergunta então responde com outra pergunta; "Mas no sentido de quê de... de... de... violentar essas pessoas?" (Pastor 1).

Ao ser esclarecida positivamente sua dúvida, a fim de que pudesse ser observada sua opinião, ele respondeu: "Toda forma de violência né, o próprio nome já...deve ser descartada né, entendeu?! Eu acho que todo mundo tem o direito de viver, enfim, muitas vezes de optar né, entendeu?!" (Pastor 1).

O pastor não soube definir a violência conforme entendimento dos organismos internacionais, demonstrando não conhecer o assunto. $\mathrm{Na}$ sequência de respostas supracitadas, observa-se que ele além de não conhecer o discurso da ONU e da Comissão Interamericana de Direitos Humanos, no tange à Definição de Gênero, Igualdade de Gênero, CEDAW - Convenção da Mulher, Relações de Gênero, Liberdades Sexuais e Reprodutivas, Violência de Gênero e os demais temas abordados na entrevista, não realiza em sua congregação nenhuma forma de trabalho que vise propagar questões igualitárias de direitos humanos.

E) Pastor 2

O pastor 2 é administrador evangélico da Igreja Metodista do Brasil, igreja que chegou ao país em 2 de setembro de 1930, em São Paulo e hoje conta com uma membresia de 
400.000 (quatrocentos mil) fiéis. A crença Protestante Metodista conta com 9 filiais espalhadas pela capital do Ceará. A congregação possui força política por ser vinculada à ORMECE (Ordem dos Ministros Evangélicos do Ceará).

Quando questionado sobre sua influência em termos de movimentos de reivindicação dos Direitos Humanos desenvolvidos dentro da instituição religiosa, responde que: "Sim. Nós dialogamos sobre violência contra mulher, violência de gênero e masculinidades" (Pastor 2).

Contraditoriamente seu entendimento não compreende o que diz a ONU sobre a igualdade de gênero, desconhece a Convenção sobre a eliminação de todas as formas de discriminação contra as mulheres (CEDAW), dentre outras contradições:

E - Conhece o discurso da ONU sobre os direitos e liberdades sexuais e reprodutivas?

Pastor 2 - "Parcialmente".

E - Sabe a posição das Nações Unidas sobre o aborto? O que você acha?

Pastor 2 - "Não".

E - Você acha que é certo ou errado o termo violência de gênero?

Pastor 2 - "É correto. Está claro para nós que ferem negros e negras no Brasil e que as mulheres sofrem".

Apesar de ser de acordo com o termo violência de gênero e ter uma noção vaga do que seja, na resposta abaixo ele revela que de fato não conhece os discursos internacionais a respeito desse tipo de violência. Toda a orientação que ele repassa aos fiéis é meramente de caráter não oficial se comparado ao que diz o estado de Direito. Em outras palavras, se trata apenas de uma percepção própria e particular em relação ao tema, apesar de notável avanço ao reconhecer a violência de gênero e o sofrimento consequente, mesmo confundindo o termo com o racismo ao referir ao que sofrem negros e negras.

Dessa forma, fica claro que o pastor faz o seu trabalho cotidiano de "bom pastor" guiando suas "ovelhas" de maneira totalmente autônoma, pois não sabe e não segue as regras das normativas internacionais e sequer tem conhecimento em relação ao discurso da ONU e da Comissão Interamericana de Direitos Humanos, desconhece pautas levantadas nessa pesquisa como, por exemplo: Definição de Gênero, Igualdade de Gênero, CEDAW Convenção da Mulher, Relações de Gênero, Liberdades Sexuais e Reprodutivas, Violência de Gênero e o posicionamento sobre o Aborto dentre outros documentos relativos aos temas em questão. 
Concluiu-se que as definições do pastor 2 sobre questões igualitárias e de direitos humanos são vazias, pois não estão respaldadas em nenhum discurso Internacional de direitos humanos. Esse desconhecimento somado a uma autonomia de diálogo junto às comunidades pode ser preocupante quando se inicia um processo de resistência à evolução de costumes e identidades, mas quando chegam em suas congregações são contrariados por pensamentos desconectados da realidade mundial e podem ser confusos, levando, provavelmente, a um desconforto espiritual.

F) Pastor 3

O pastor 3 é administrador evangélico da Igreja Assembleia de Deus, vice-presidente e filho do pastor fundador e presidente da Assembleia de Deus, do Ministério do bairro Montese. A igreja Assembleia de Deus foi fundada no Brasil na data de 15 de novembro de 1927 em São Paulo-SP. A partir do ano de 1973, em uma proposta nova de trazer identidade da igreja com seu nascedouro, a Igreja Assembleia de Deus Independente, passou a ser chamada de Igreja Evangélica Assembleia de Deus Ministério Montese, ou como ficou conhecida, Igreja Montese. Em dezembro de 1984, o Pastor assumiu a presidência da Igreja, onde permanece até a presente data.

A Igreja Assembleia de Deus Ministério Montese, conta hoje com 112 congregações na Capital e Região Metropolitana distribuídas em 23 Setores e 126 Campos no Interior do Estado. A Igreja conta ainda com 187 Pastores, 377 presbíteros, 724 diáconos, 138 diaconisas e cerca de 18.000 membros.

Em 1993, a Igreja Evangélica Assembleia de Deus Ministério Montese, através do seu Presidente, Pastor 3, num ato de visão e ousadia fundou a Convenção Fraternal de Ministros das Assembleias de Deus de Montese - CONFRADEME, que posteriormente veio a se denominar Convenção Fraternal de Ministros das Assembleias de Deus do Estado do Ceará - CONFRADECE, devidamente registrada junto a Convenção Geral das Assembleias de Deus no Brasil (CGADB) sob o ${ }^{\circ}$. 051, contando com 51 Igrejas Filiadas e 383 Pastores.

A Igreja também tem investido na área social, tendo criado a Associação Cristã de Assistência Social e o Departamento Evangélico de Ação Social, que fundou a Escolinha Monte Sinai que hoje mantém cerca de 300 (trezentas) crianças carentes. Dessa forma entende-se que a igreja Assembleia de Deus, do bairro Montese não só tem importância histórica como também uma força política e social muito intensa no estado do Ceará.

Quando questionado em relação a participações em mobilizações sociais ou políticas destinadas a defender suas crenças e valores ele respondeu: "Sim temos. Constantemente defendemos aquilo que cremos aqui em nossa igreja" (Pastor 3 ). 
O pastor 3 iniciou o ministério que dirige junto com o pai, expandindo-o rapidamente. É dessa forma que eles defendem as suas crenças e ampliam com muito esforço o trabalho de ramificação do que acreditam. O que leva a crer que quanto maior o tamanho e a quantidade de instituições religiosas, maior é a influência sobre as massas. A população, principalmente carente, aproxima-se para congregar dessas ideias, e se torna um fiel.

Quando questionado sobre definição de gênero, respondeu que: "Para a bíblia sagrada, que é aquilo que eu creio, gênero é aquilo que o senhor Deus formou, homem e mulher" (Pastor 3).

Sobre concepção de família e papel que ela deve desempenhar em homens e mulheres, respondeu que: “A concepção que eu tenho de família é uma concepção bíblica. A bíblia sagrada fala de papeis bem definidos para o homem e para a mulher dentro do núcleo familiar" (Pastor 3).

O pastor 3 diz na resposta supracitada que homens e mulheres têm papeis bem definidos. Ora, então se infere que os papeis atuais são os mesmos descritos no texto sagrado e que, nesta concepção, deveria a mulher ficar em casa, enquanto o marido vai trabalhar, sendo ele o único mantenedor da casa. Tem-se assim o reforço de um discurso machista disfarçado pela convicção de fé na palavra divina. Escondido em palavras escritas numa era em que o regime patriarcalista definia como sendo família apenas uma conjuntura, o pastor 3 reafirma a submissão profissional e financeira da mulher, que, mesmo hoje, na sua visão, ainda deve ser defendido, mesmo diante de leis que normatizam a igualdade de direitos e deveres que ele mesmo, contraditoriamente, menciona a seguir.

Quando foi questionado se são trabalhados os direitos humanos e a igualdade de gênero em suas congregações, respondeu que: "Sim. Nós tratamos, à luz da bíblia sagrada, o respeito que nós devemos ter a todas as pessoas, mas aplicando aquilo que a palavra de Deus nos ensina de que o senhor Deus nos fez homens e mulheres" (Pastor 3).

Quando questionado se as pessoas devem ou não ser educadas para promover e respeitar a igualdade de gênero, respondeu que: "Sim" (Pastor 3).

Contraditoriamente, apesar de excluir da identidade de gênero os diferentes papéis dialogados pela comunidade internacional de direitos humanos, responde que deve haver respeito e promoção a esses direitos. Observa-se que na percepção do pastor, os papeis definidos na bíblia há centenas de anos são os mesmos que devem ser pregados hoje. Isso quer dizer que a sociedade não deve mudar. Não deve pensar diferente, desrespeitando o direito de pensar e entender livremente, pois, para este líder, as normas de conduta da sociedade devem ser aquelas que estão definidas na bíblia. 
Quando questionado se é certo ou errado o termo violência de gênero, responde: "não conheço bem o termo violência de gênero" (Pastor 3). Quando inquirido se ele sabe como se define essa violência pelos organismos internacionais, responde que não (Pastor 3). Inquerido se acredita ou não que a violência baseada no gênero viola os direitos humanos ou é outra coisa responde: "Se a violência contra gênero for contra homem e mulher, sim" (Pastor 3).

O pastor 3 deixa claro nessa última resposta que a limitação do que seja gênero na sua opinião, ou seja, o homem e a mulher, exclusivamente. Apesar de já ter dito concordar com a promoção e o respeito à igualdade de gênero, porém, divergentemente, fez questão de mencionar que só representa violência se for contra homens e mulheres, deixando de fora a comunidade LGBT, reforçando que a identidade de gênero é uma realidade não compreendida pelo entrevistado. Portanto, não deveriam estar sendo ignorados os direitos de igualdades de gênero, à diversidade e direitos humanos.

Faz-se necessário pensar uma tendência de diálogo no âmbito religioso, já que esse líder não deixa de ter uma atuação social e política na vida das pessoas. Assim, ignorando conceitos e documentos dos quais o Brasil é signatário, vem agindo junto aos fiéis, através de um debate de enfrentamento aos discursos internacionais, sem se alinhar a tais discursos, levando suas massas a também desprezar o que diz a ONU sobre questões igualitárias, de forma crítica e até mesmo discriminatória, restringindo suas liberdades de formar, inclusive, suas próprias convicções. E isso não pode ser ignorado, pois é uma espécie de violência simbólica muito presente nas práticas doutrinárias religiosas.

G) Padre 4

O padre 4 é administrador paroquial da igreja católica Nossa Senhora da Assunção, padroeira da capital do estado do Ceará. Trata-se de uma igreja com forte referência religiosa no estado e grande importância histórica, uma vez que existe um feriado municipal exclusivo para essa Santa, 15 de agosto, quando se comemora a Festa da padroeira da capital.

Para celebrar a data, a arquidiocese de Fortaleza realiza uma caminhada com Maria, a Santa que leva o nome da igreja e reúne milhares de pessoas. É um evento que começa às duas horas da tarde na ponte do rio Ceará e termina com a chegada da procissão à Catedral de Fortaleza.

Sua influência em termos de movimentos de reivindicação dos Direitos Humanos, como passeatas e animações externas ao setor paroquial acontece sempre que necessário. O padre 4 diz participar de vários eventos. Informou como sendo sua contribuição maior para a 
sociedade a grande missão de administrar a paróquia que atende um grande número de fiéis.

Quando questionado sobre colaborações com a vida eclesiástica, respondeu que: "Bem, colaboro na administração da paróquia como pároco, ou seja, é uma grande missão que Jesus tem nos oferecido e confiado e também colaboro na questão da evangelização" (Padre 4).

O padre 4 diz que administrar uma paróquia desse porte, com uma atividade intensa, é de grande responsabilidade, além de colaborar na evangelização dos fiéis. Quando questionado a respeito da força do seu grupo religioso e a importância dele para os fortalezenses, ele respondeu: “A nossa religião, a Católica, ela é predominante aqui em Fortaleza, então ela tem uma revê... Tem uma importância muito grande" (Padre 4).

Diante dessa resposta, questionou-se sobre as contribuições da igreja a que pertence para as questões sociopolíticas, então, informou: “A partir da fé, na fé que possa levar as pessoas a pensar toda forma de convivência. Que a fé envolve o econômico, envolve o social e evolve claro o político. Então a fé, uma fé comprometida com os aspectos sociais" (Padre 4).

Ele parece dialogar que a fé tem um papel importante nas questões sociais. O que permite uma ideia de interdependência entre o religioso e o político, e entre o religioso com as questões sociais.

Logo adiante, quando questionado a respeito da sua definição sobre os Direitos Humanos, responde que:

Tudo aquilo que está ligado ao ser humano, a sua dignidade, a sua totalidade, envolve a vida do ser humano, né?! Os direitos, então, está ligado ao princípio cristão, o principio religioso, o princípio da fé, né?! Então, os direitos humanos está aí, realmente para que possa ter uma vida digna, justa e fraterna para todos (Padre 4).

O padre 4 fala claramente na resposta supracitada que a fé e o religioso estão diretamente ligados aos Direitos Humanos. Logo abaixo ele diz que o discurso da ONU é de fato muito importante para os seres humanos, quando responde que: "Como um órgão regulador, como um órgão fiscalizador que se preocupa com os direitos humanos, ele tem uma função importantíssima" (Padre 4).

Apesar de demonstrar um apoio a ONU e a Comissão Interamericana de Direitos Humanos, parece não entender o discurso internacional. Essa contradição se observa a seguir, quando questionado sobre o que dizem e articulam os discursos internacionais 
acerca de Direitos Humanos. Pode-se notar perfeitamente na quantidade de perguntas com respostas negativas:

E - Conhece o que diz a ONU sobre a igualdade de gênero? Se conhece, qual sua opinião do discurso da ONU sobre o direito à igualdade de gênero?

Padre 4 - "Não".

E - Você já ouviu falar da convenção sobre a eliminação de todas as formas de discriminação contra as mulheres (CEDAW)? Para você o que parece ser essa normativa internacional?

Padre 4 - "Não".

E - Você acha que existe alguma relação entre direitos, direitos humanos das mulheres e modalidades de relações de gênero?

Padre 4 - "Não".

E - Conhece o discurso da ONU sobre os direitos e liberdades sexuais e reprodutivas?

Padre 4 - "Não".

E - Você acha que é certo ou errado o termo violência de gênero?

Padre 4 - "Eu acho errado".

E - Sabe como se define essa violência pelos organismos internacionais?

Padre 4 - "Não. Não sei".

Observa-se que existe uma contradição, pois o entrevistado se coloca a favor daquilo que posteriormente assume ser desconhecido para ele. Ao passo que as perguntas adiante vão revelar seu desprezo por aquilo que informa desconhecer, contudo, suas respostas vão deixar nítido que sabe e conhece o tema, apenas não aceita, e rechaça por meio do que acredita ser correto, através de sua moral religiosa, no tocante aos direitos humanos.

Quando questionado se a violência baseada no gênero viola os direitos humanos ou é outra coisa, respondeu com certo desdém, levando em consideração suas crenças religiosas. Senão, vejamos:

Que a violência baseada no gênero... olha, hoje muito se fala na questão da questão do gênero, né e dá uma ênfase muito grande, né. É como se tivesse violando essa questão da escolha tal, tal, tal. Creio eu que, direitos humanos são direitos para ser homem e ser mulher, está muito claro. Então tem que respeitar essa identidade 
do ser humano. Se vier a infringir alguma coisa nesse sentido, então viola (Padre 4).

Quando questionado se acredita que as pessoas têm o direito de manifestar de forma livre sua orientação sexual e suas relações sociais independentemente de seu sexo biológico, respondeu: "Creio que não, eu não acredito nisso" (Padre 4).

O Padre 4, inicialmente, demonstrou na entrevista ser um defensor dos direitos humanos. Portanto suas palavras soam de forma a violar tais direitos, uma vez que ele deixa claro que direitos humanos é só para homens e mulheres, já a sociedade LGBT, por exemplo, estaria fora dessa proteção.

Quando foi questionado sobre as cotas das mulheres, para eliminar a discriminação e promover a igualdade de oportunidades, como forma de correção histórica e de transformação de suas vidas de maneira mais igualitária (que a dos homens), sua resposta foi contrária às cotas. Aliás, não só se opôs, mas também disse acreditar que isso causaria às mulheres um efeito contrário, gerando ainda mais discriminação e desigualdade.

Um momento de crescimento e expansão de uma nova consciência que prioriza o direito das classes que não são e nunca foram minorias quantitativas, mas sociais (mulheres e LGBT), é, pelo padre, intrinsecamente, desprezada. Uma cultura secular tão presente nos discursos junto ao seio social, cuja visão humanística que se diz ter é ainda utilizada para se manter privilégios, escravizar sentimentos, restringindo, portanto, o direito à liberdade e à igualdade. Então, questiona-se até que ponto uma moral religiosa pode ter a força de sobrepor a um estado de direito.

H) Padre 5

Administrador Paroquial da igreja São Vicente de Paulo, o padre entrevistado é responsável por uma igreja antiga, fundada e erigida em 27 de março de 1971. É pastoral de referência no bairro Dionísio Torres, Fortaleza - CE. Segue uma agenda bem movimentada com inúmeros compromissos paroquiais como: retiro paroquial, a pastoral da família, pastoral do acolhimento das crianças, pastoral do idoso carente, pastoral do batismo, pastoral bíblica, pastoral do canto, pastoral da juventude, pastoral da liturgia.

Quanto aos movimentos, existem o apostolado mãe rainha, apostolado da oração, legião de Maria, terço dos homens, dia de pentecostes, via sacra, na quarta-feira de cinzas (início da quaresma), a coroação da imagem de nossa senhora que começa com uma missa, às cinco horas da tarde, e o curso bíblico inicial.

Diante de uma agenda tão extensa é possível visualizar a proporção de sua influência popular, tanto no que diz respeito à questão espiritual como social. Uma demonstração de 
movimentação de força religiosa e espiritual muito intensa, bem como de uma participação social bastante relevante na comunidade local.

Quando questionado a respeito da sua percepção de força do grupo religioso a que pertence, respondeu que: "Eu acho que é muito forte" (Padre 5). E quando interpelado sobre a contribuição sociopolítica mais importante de sua religião para os fortalezenses, respondeu: "Eu acredito na questão das pastorais sociais" (Padre 5).

O padre 5 acredita que sua religião é muito importante para os fortalezenses e que também tem muita força para contribuir numa construção sociopolítica na cidade de Fortaleza, como foi visto nas respostas supracitadas. No entanto, mesmo com tanta influência, o padre não demonstrou entendimento acerca do discurso internacional sobre direitos humanos:

E - Qual sua opinião do discurso da ONU sobre direitos humanos? Sobre a organização social e familiar brasileira?

Padre 5 - "Não tenho opinião, não tenho conhecimento viu".

E - Conhece o que diz a ONU sobre a igualdade de gênero? Se conhece, qual sua opinião sobre discurso da ONU no que diz respeito ao direito à igualdade de gênero?

Padre 5 - "Não".

E - Você já ouviu falar da convenção sobre a eliminação de todas as formas de discriminação contra as mulheres (CEDAW)? Para você o que parece ser essa normativa internacional?

Padre 5 - "Não, não tenho conhecimento".

E - Você acha que existe alguma relação entre direitos, direitos humanos das mulheres e modalidades de relações de gênero?

Padre 5 - "Não tenho conhecimento".

E - Conhece o discurso da ONU sobre os direitos e liberdades sexuais e reprodutivas?

Padre 5 - "Não tenho conhecimento".

E - Você acha que as pessoas devem ou não ser educadas para promover e respeitar a igualdade de gênero?

Padre 5 - "Não, não, não".

E - Sabe como se define a violência de gênero pelos organismos internacionais?

Padre 5 - "Não tenho conhecimento". 
E - Você acredita ou não que a violência baseada no gênero viola os direitos humanos ou é outra coisa?

Padre 5 - "Eu acho que é outra coisa".

E - O que opina sobre majorar os tipos penais hoje existentes para combater a violência exercida pelos homens contra as mulheres e o feminicídio?

Padre 5 - "Eu passo essa daí".

E - Acredita que as pessoas têm o direito de escolher em de forma livre sua opção sexual e suas relações sociais independentemente de seu sexo biológico?

Padre 5 - "Não eu não concordo".

E - Sabe a posição das nações unidas sobre o aborto? O que você acha?

Padre 5 - "Não tenho conhecimento".

E - Trabalha-se de alguma forma os direitos humanos e direitos à igualdade de gênero na sua igreja? Como?

Padre 5 - "Não, Não, Não".

As perguntas parecem ter causado um certo desconforto ao clérigo, assim como suas respostas negativas também foram desconcertantes. O padre demonstrou não conhecer absolutamente nada sobre Direitos Humanos e tampouco sobre os discursos da ONU e da Comissão Interamericana de Direitos Humanos. Questiona-se até que ponto é permitido pela lei brasileira ser atentatório aos direitos em geral, ao que está previsto em lei, sob a alegação de desconhecimento da normativa. Pelo contrário, no Direito, ninguém é isento de penalidades alegando que não a conhece, ainda que a maioria da população, assim como o entrevistado, não tenha conhecimento completo nem mesmo de leis locais. Aqui fica evidente a necessidade de maiores esforços no sentido de efetivamente divulgar e esclarecer as pessoas, especialmente aquelas capazes de influenciar massas, sobre as normas referentes aos direitos humanos.

Quando se questionou sobre a livre escolha sexual das pessoas e suas relações sociais independentemente de seu sexo biológico, diz não concordar. No entanto, é importante que seja claro que a liberdade de expressão não deve ser utilizada de forma a violar outros direitos. A preocupação aqui não é o que se diz numa entrevista, é como essa ideia que fere a normativa de direitos humanos se propaga nas instituições e, principalmente, fora delas.

Ademais, em sua entrevista, discorda que as escolas deveriam trabalhar a conscientização das pessoas sobre a igualdade de gênero, bem como propagar a ideia de que a violência de 
gênero transgredi os direitos humanos. Sua influência, conforme supracitado, nas diversas pastorais (da família, do acolhimento das crianças, do idoso carente, do batismo, bíblica, do canto, da juventude e da liturgia), trabalha com base no diálogo humano. Questões igualitárias, presumivelmente, não são tradadas nos diálogos sociais dentro das pastorais, como se o Estado de direito fosse confessional e não laico, fazendo crer que deve ser obedecido ao que diz a fé cristã, inclusive no âmbito escolar.

Conclui-se, portanto, que há desinteresse, por parte do religioso, não só com o estado de direito (laico) e as leis nacionais e internacionais que versam sobre direitos humanos, mas sua oposição às questões de gênero para o trabalho das questões igualitárias. O que se promove é a não transformação secular cultural do patriarcalismo dentro das instituições religiosas, com forte influência social.

I) Padre 6

Administrador paroquial da igreja São Francisco de Assis, o padre entrevistado é responsável por uma paróquia com mais de cinquenta anos de existência. Foi fundada por padres holandeses que erigiram a primeira nave expandindo posteriormente por todo o bairro do Antônio Bezerra, em Fortaleza-CE. Conta-se com aproximadamente cinquenta mil pessoas frequentadoras da igreja, de acordo com a comunidade do entorno.

Sua influência em termos de movimentos sociais acontece por intermédio de grupos sociais de apoio à comunidade como o acompanhamento do idoso e distribuição de cestas básicas para famílias cadastradas. Existe também um convênio com o posto de saúde e na escola do bairro, nas proximidades da igreja, com palestras e atendimento pastoral. Dessa forma se caracteriza uma enorme importância dessa instituição religiosa para a comunidade, que oferece diversos projetos de melhorias sociais e até mesmo de defesa dos direitos humanos. Quando questionado a respeito do que seriam Direitos Humanos, através de uma rápida definição, o pároco respondeu que seria liberdade. E, ao ser questionado se acredita ou não que homens e mulheres devem ter direitos iguais no local de trabalho, respondeu que: “perante a constituição, sim” (Padre 6).

O padre 6 ao responder a primeira pergunta demonstra entender que Direitos Humanos seria o mesmo que ter liberdade, ao passo que na segunda pergunta desassocia o questionamento sobre sua opinião, omitindo-a, e mostrando conhecer a lei geral do país ao dizer que perante a Constituição Federal Brasileira as mulheres devem ter direitos iguais aos homens. Ora veja, a pergunta está bem colocada, questiona se ele concorda que a mulher tem direitos iguais no local de trabalho, mas ele diz que os direitos da mulher são atribuídos pela lei e deixa de fora a sua própria opinião. 
Acredita-se que o padre 6, apesar de dizer que tem diversos projetos de melhorias sociais e até mesmo oferecer projetos em defesa dos direitos humanos, parece não entender o que são os direitos humanos efetivamente. Parece não compreender bem o discurso da ONU sobre Direitos Humanos. Relata desconhecer definição de Gênero, Igualdade de Gênero, CEDAW - Convenção da Mulher, Relações de Gênero, Liberdades Sexuais e Reprodutivas, Violência de Gênero, dentre outros questionamentos na entrevista.

Conclui-se que os diálogos, assim como os outros vão se repetindo. Suas orientações são apegadas ao manto religioso, mesmo esse que se diz defensor de direitos humanos, parece se esquivar, seja pelo medo em dispor em contrário ao que a religião permite, seja pelo desconhecimento do que diz as normativas.

J) Padre 7

Administrador Paroquial da igreja Santa Luzia. O padre entrevistado é responsável por uma igreja que foi erigida sob a fundamentação de um milagre ocorrido em benefício de uma família tradicional à época, quando uma criança foi curada de um problema nos olhos. Desde então, a família da criança e o povo da comunidade local ergueram o prédio, que ainda hoje sedia a paróquia. A santa é conhecida como a Padroeira dos olhos.

A força sociopolítica dessa instituição decorre do tempo de existência e da historicidade que a instituição religiosa tem junto a seus adeptos, atendendo à comunidade do bairro Meireles, cuja dimensão geográfica é bastante considerável.

Quando questionado quanto à importância da sua igreja para Fortaleza, o pároco afirmou ser muito importante, e, no que concerne à contribuição sociopolítica mais importante de sua religião para os fortalezenses, respondeu: "A contribuição essencial está no discernimento e também na liberdade de dar a cada um a decisão que deve ser tomada. Não necessariamente engaiolar ou encaixar as pessoas, mas dar a elas o poder de reflexão, de serem protagonistas de suas próprias decisões" (Padre 7).

Observa-se que o padre 7 inicia sua entrevista falando que uma das contribuições sociopolíticas de sua religião é contribuir para a tomada de decisões dos seus fiéis, dando a eles o poder de reflexão. Resta de fato demonstrar que a sua igreja não interfere no agir, contribui de forma a fazer com que seus fiéis possam agir ou mesmo pensar de acordo com suas próprias decisões.

Quando se questiona sobre uma definição rápida e concisa de direitos humanos, responde:

"Direitos humanos se inicia dentro de um processo de cultura e é resgatar o direito de ser. Àquilo que o Papa Francisco tanto deseja que as pessoas estejam para o outro, estar para o outro, não simplesmente ter o outro como objeto, como coisificação das 
relações, mas uma relação de interação. Por isso direitos humanos é fundamental que coexista para que de fato seja visto que aqueles e aquelas que muitas vezes são colocados à margem, mas que possam também ter seus direitos guardados." (Padre 7).

Ele ao responder enfatiza que os direitos humanos são fundamentais para que os marginalizados pela sociedade tenham seus direitos resguardados. Porém no decorrer da pesquisa o padre se contradiz ao esquivar-se de aprofundar uma definição sobre gênero. Senão vejamos o que respondeu, quando foi questionado sobre uma rápida definição de gênero:

“É um perigo até esse termo do gênero porque entra aquela ideologia do gênero e gênero de fato é o homem e mulher, essas outras questões é aderida de outra realidade, então a gente tem de deixar distinta também a pergunta que ela pode ter duas facetas ao mesmo tempo. Então a gente tem que ter cuidado. A própria campanha da fraternidade deste ano, quando fala da temática da violência tem uma das orações que chama atenção com relação à questão do gênero e é claro que esse tema ele pode ser mal conduzido. Para nós, enquanto igreja, enquanto realidade católica e cristã, aliás, essencialmente como cristãos; gênero significa masculino e feminino. As demais outras realidades que hoje está se aplicando aí, é uma questão ideológica e aí tem que ter cuidado com isso." (Padre 7).

$\mathrm{Na}$ resposta supracitada, o padre demonstra se preocupar em tornar distinta "ideologia de gênero" e gênero de fato, o que tenta explicar que o gênero de fato é homem e mulher, e é o que deve ser respeitado. Enfatiza, inclusive, ser "muito perigoso" o termo "gênero" e a "ideologia de gênero", mesmo tendo explicado na outra questão a importância de se resgatar o direito humano de "ser". Deixa bem definido que seu entendimento por gênero é "feminino" ou "masculino" e que, para se falar de violência de gênero tem que se tomar todo um cuidado para não ser malconduzido, o que se infere que o líder religioso não quer ser mal interpretado em seus posicionamentos sobre a temática de gêneros.

Abaixo é possível ver outra profunda contradição do padre sobre o mesmo tema, quando lhe foi perguntado se conhece o que diz a ONU acerca da igualdade de gênero. E, em conhecendo, qual a opinião dele sobre o discurso da ONU no tocante à igualdade de gênero: 
"Tem uma, uma questão que está sendo colocada, foi por isso que eu te falei lá no começo. Essa questão de gênero ela pode ser mal interpretada. Uma coisa é uma questão de gênero, homem e mulher, outra coisa é ideologia de gênero, então eu acho que a pergunta pode se tornar um pouco capciosa e aí é preciso de fato ser distinta do que se quer de fato. Porque senão o próprio direitos humanos acabam estar produzindo um texto que favorece uma realidade que não tem nada a ver. Uma coisa é você favorecer, outra coisa é você respeitar certas tendências, são duas questões bem distintas. Uma coisa é você fazer um marketing em torno, uma propaganda em torno de uma possibilidade sem ver o todo da pessoa." (Padre 7).

Em primeiro lugar, o líder religioso tenta separar igualdade de gênero da "ideologia de gênero", defendendo o determinismo biológico, que consiste na ideia de que há apenas os gêneros binários, o que gera desigualdades e opressões ao excluir as possibilidades que fujam ao masculino e feminino determinados ao nascimento. E é nesse momento que faz uma crítica à construção da igualdade de gênero, haja vista que existem diferenças entre as mulheres (diferenças entre si) e entre os homens (entre si), uma vez que existem diferentes masculinidades e feminilidades. Consequentemente, também existem diferentes formas de expressar a afetividade e a sexualidade. Quando define as características de gênero somente no conceito "homem e mulher"”, suscita o desrespeito à diversidade, o que é exatamente o oposto do que tenta demonstrar.

Não é possível falar em igualdade de gênero quando se tenta fazer uma definição. A discussão de gênero é justamente contra uma ideologia baseada na natureza e na biologia. No seguimento da entrevista, o religioso corrobora sua oposição à diversidade, aliás, ao que parece para ele a diversidade inexiste, e, talvez por isso mesmo, sequer deva ser proferida:

"Eu prefiro ficar... novamente a pergunta novamente coloca aquela palavrinha que assim. Se você disse assim: violência do homem contra a mulher, da mulher contra o homem tal, tal, tal, tal, tal... lei da penha e etc. deixa as coisas mais claras... se coloca gênero, gênero, gênero, está focado mais é a ideologia do gênero que está por trás da palavra. São uma manobra de pergunta colocada pra isso. Porque do que propriamente dita poderia trazer uma reflexão mais séria pra análise das questões essenciais, novamente puxa pra 
uma tendência que não é por aí, o essencial do nosso dia se... o diálogo que deveria haver na realidade sócio brasileira, entendeu? As pessoas estão mais aprisionadas a certas coisinhas do que aquilo que é essencial." (Padre 7).

O padre 7 rechaça a palavra "gênero" de seu discurso como sendo algo inaceitável. Faz uma analogia à violência do homem contra a mulher e da mulher contra o homem, associando-a à existência da Lei Maria da Penha, como se a violência ligada ao conceito de gênero não tivesse um equivalente jurídico. Em suas palavras, mais uma vez o determinismo biológico prevalece sobre a diversidade. Dessa forma, parece querer abstrair totalmente o conceito de gênero, igualdade de gênero, fazendo crer que pode ser confundida com o conceito de "ideologia de gênero", o que leva a crer que, só em pronunciar tais palavras talvez consideradas por ele como profanas, torne-se tendencioso àquilo.

Quando foi indagado se já tinha ouvido falar ou se conhecia o discurso sobre os temas internacionais de proteção aos direitos humanos:

E - Já ouviu falar da convenção sobre a eliminação de todas as formas de discriminação contra as mulheres (CEDAW)? Para você o que parece ser essa normativa internacional?

Padre 7 - Não.

E - Conhece o discurso da ONU sobre os direitos e liberdades sexuais e reprodutivas?

Padre 7 - Não.

E - Sabe como se define esta violência pelos organismos internacionais?

Padre 7 - Não.

Conclui-se que o padre 7 não compreende os conceitos internacionais que envolvem temas sobre direitos humanos, suas palavras soam preconceituosas em relação às questões de gênero. Contradizem-se com o início da entrevista, em que afirma que os direitos humanos se iniciam dentro de um processo de cultura e é importante para se resgatar o direito de "ser". O que prega não é o que de fato defende, pelo contrário, nota-se em suas evasivas um viés que pode ser discriminatório e ofensivo, pautando-se naquilo que acredita ser o correto dentro da cultura religiosa à qual se vincula.

L) Padre 8

Administrador paroquial do Santuário de Nossa Senhora de Fátima, o padre entrevistado é responsável pelo Santuário mais visitado de Fortaleza-CE. Para que se entenda o porquê da 
existência da Igreja de Fátima, é preciso retroceder no tempo, aos idos de 1952, antes até, ano de 1946, mês de abril, quando o Conselho Internacional da Juventude Católica Feminina de Portugal aventou a hipótese de uma imagem peregrina de Nossa Senhora de Fátima.

Dá-se início à peregrinação e, após percorrer vários países da Europa e alguns estados do Brasil, a imagem peregrina chega a Fortaleza no dia 09 de outubro de 1952. E, naquele dia, comungaram mais de duas mil pessoas. Do princípio do mês até aquela data, quase dez mil pessoas, em preparação da vinda de Nossa Senhora. Dessa forma, se configura desde sua fundação até os dias atuais como a igreja que, segundo a própria arquidiocese, é a instituição religiosa católica que mais atende pessoas em todo o estado do Ceará.

Pela fundação, historicidade e quantidade de fiéis o santuário se torna gigantesco, tendo, portanto, uma força política e social. Não apenas por ser visitada todos os dias e em todas as horas de seu funcionamento, assim como também, pelo trabalho desenvolvido pelo padre 8, que desenvolve diversos trabalhos não apenas com a comunidade do entorno, mas também na rádio Dom Bosco e na internet. É tamanha a contribuição que são diárias suas atividades de coordenação da igreja de Fátima, cujas salas de confessionários estão abarrotadas de pessoas advindas de diversos bairros da cidade.

Quando o padre foi questionado sobre cargos e movimentos orquestrados pelo por ele, respondeu:

$$
\begin{aligned}
& \text { "Sou assessor da pastoral da arquidiocese de Fortaleza, sou também } \\
& \text { do conselho presbiteral, sou também do colégio dos consultores da } \\
& \text { arquidiocese, sou coordenador regional, quer dizer; de todo o } \\
& \text { Ceará, da liturgia e sou também orientador... é... na parte de leitura } \\
& \text { orante na rádio Dom Bosco. Só trabalho viu? isso tudo é só } \\
& \text { trabalho, viu?!" (Padre 8). }
\end{aligned}
$$

Quando se perguntou a respeito de tarefas de difusão ou de ensino (catequese), respondeu que:

"Sim, temos na rádio dom Bosco é... é todos os domingos, às seis horas da manhã nossa leitura orante, mas temos também o vídeo que a gente faz através de WhatsApp e Facebook, mensagem do evangelho. Então toda semana a gente faz um videozinho, um minuto e meio. São, é uma luta para se fazer." (Padre 8).

Quando indagado sobre participações em mobilizações sociais ou políticas destinadas a defender suas crenças e valores, respondeu que: "se são no sentido de..., dos movimentos 
em defesa da vida, então a gente vai também. É da defesa da moradia, a gente também vai. São em defesa dos direitos humanos, também nós participamos" (Padre 8).

Quando interpelado sobre outras colaborações com a vida eclesiástica, respondeu que:

"São palestras e conferências da área de saúde (e meu mestrado é de saúde), então eu contribuo nessa área, sobretudo é, ligando saúde e salvação. Então saúde e salvação andam muito juntos, então eu contribuo muito nessa área na parte de orientação e também de receber as pessoas aqui para que elas sejam orientadas. " (Padre 8).

O líder religioso do Santuário da igreja Nossa Senhora de Fátima tem uma agenda de compromissos bastante extensa. São muitas as atividades do padre no sentido de propagação da fé cristã. Nota-se que o padre é um líder que arrasta multidões e as orienta.

Quando, na entrevista, pediu-se que desse uma definição rápida e concisa de direitos humanos, mencionou: "Respeito à liberdade humana". E, tratando-se de uma rápida definição de gênero, respondeu: "Identificação".

O padre 8 disse na resposta supracitada que gênero é uma identificação pessoal e a ideologia defende essa mesma tese. Que o ser humano tem uma identidade espiritual de se sentir identificado de alguma forma. Porém no decorrer das perguntas dessa pesquisa, pôde-se observar também certas contradições nas respostas e que o pároco desconhecia os discursos e tratados internacionais de direitos humanos, como, por exemplo, a convenção sobre a eliminação de todas as formas de discriminação contra as mulheres (CEDAW), além de demonstrar não concordar com a igualdade de gênero.

Ressalta-se que, quando questionado se as pessoas deveriam ou não ser educadas para promover e respeitar a igualdade de gênero, respondeu: "Não. No sentido de quê?... que desde que eu nasci, eu me entendo como homem, né?! Eu posso até ter outras opções ou meios de fazer, mas então nesse sentido por quê, por que as pesquisas científicas todas negaram essa igualdade de gênero?".

Ademais, pode-se observar algumas contradições ou negativas em suas respostas:

E - Você acha que é certo ou errado o termo violência de gênero?

Padre 8 - “Acho errado. Porque não está defendendo ninguém”.

E - Sabe como se define esta violência pelos organismos internacionais?

Padre 8 - "Não."

E - Você acredita ou não que a violência baseada no gênero viola os direitos humanos ou é outra coisa? 
Padre 8 - "É outra coisa. É outra coisa".

E - Trabalham-se de alguma forma os direitos humanos e direitos à igualdade de gênero na sua igreja? Como?

Padre 8 - "Não. A gente trabalha os direitos, mas sem focar as igualdades de gênero porque para nós é uma farsa".

Observa-se que o padre, no começo da entrevista, quando lhe foi indagado sobre o que é gênero, respondeu que é "[...] Identificação" (Padre 8). E na pergunta supramencionada diz que acha errado o termo violência de gênero ao passo que responde que não sabe sua definição. Mais adiante acredita se tratar de uma "outra coisa" e, por último, afirma que a igualdade de gênero é uma farsa. Por mais que aparente desconhecer o termo "violência de gênero", revela-se que é, ao mesmo tempo, ignorado e desprezado.

A justificativa de desconhecer as normativas sobre direitos humanos no âmbito da CEDAW e dos discursos da ONU não exclui os líderes religiosos de responsabilizações no tocante à orientação que dá aos fiéis, pois ninguém pode invocar a religião para descumprir uma obrigação legal a todos imposta. E são objetivos de a República Federativa do Brasil promover o bem de todos, sem preconceitos de origem, raça, sexo, cor, idade e quaisquer outras formas de discriminação. Ainda nossa Constituição no seu art. $4^{\circ}$ (Brasil, 1988), no tocante às suas relações internacionais, tem como princípio a prevalência dos direitos humanos. O que cabe à sociedade é promover a igualdade e a prevalência dos direitos humanos, não o contrário, desprezando-os como se não fossem normativas a serem obrigatoriamente observadas.

M) Pastor 4

Administrador evangélico da Igreja Casa da Benção. A igreja Casa da Benção nasceu em junho de 1964 num dos momentos de maior conturbação no Brasil, quando o comunismo ameaçava desintegrar a liberdade do povo brasileiro, nascia na cidade de Belo Horizonte a igreja Tabernáculo Evangélico de Jesus, precisamente no dia 9 de junho de 1964. A primeira igreja era fundada na antiga Praça Vaz de Melo, onde hoje é a Rodoviária de Belo Horizonte. Uma igreja eminentemente brasileira, sem nenhum vínculo com as tradicionais igrejas evangélicas internacionais.

Nasceu num reduto da tradicional família mineira e, em 1980, a grande catedral que seria a sede nacional da Casa da Bênção já se espalhava por todos os recantos do Brasil. Em 1985 foi inaugurada a Catedral da Bênção, a maior igreja do Distrito Federal, com capacidade para cinco mil pessoas sentadas.

Hoje, aos 45 anos de existência, mede-se a grandiosidade da igreja Casa da Bênção pelo crescimento da obra em todo o Brasil e também no exterior. São mais de 2000 igrejas 
espalhadas pelo Brasil e outros países, como: Estados Unidos, Argentina, Chile, Ghana, Costa do Marfim, Japão, Inglaterra, Suíça e inúmeros outros.

Com essa proporção, fica configurada sua grandeza e importância na história brasileira, e, consequentemente, no cenário sociopolítico do país, inclusive, na cidade de Fortaleza, Ceará.

Quando o líder religioso, pastor 4, foi questionado a respeito de uma definição rápida de direitos humanos, ele afirmou "igualdade". E quanto à sua concepção de família, respondeu que: "gênero masculino e feminino na sociedade" (Pastor 4).

O pastor informa na resposta supracitada que família se caracteriza por ser formada por homens e mulheres. Dessa forma, é possível inferir que segundo sua concepção é possível imaginar que se uma avó criar seu neto, ou o sobrinho for criado pela tia, não se caracteriza família. Ou, se por ventura, a criança for criada por dois homens ou duas mulheres que possuem uma união estável perante a lei, ainda assim, não configura família. Como dito, até o momento, em suas falas, definiu os direitos humanos num conceito de igualdade e, em seguida, ao definir família como a união do "gênero masculino e feminino na sociedade" há exclusão da igualdade entre as pessoas na denominação de família.

Quando questionado sobre uma rápida definição de "gênero", prontamente disse: "sexo masculino e sexo feminino", revelando uma confusão entre os conceitos de gênero e sexo, a qual é recorrente em toda a sociedade brasileira.

Nas respostas a seguir, adota um discurso desigual, de forma a legitimar e naturalizar a violação dos direitos humanos:

E - Você acha que o homem é por natureza superior ou igual em valor e capacidade em relação às mulheres?

Pastor 4 - "De forma histórica o homem exerce o papel de liderança e não de superioridade, de forma psicológica, emocional, os dois têm sua igualdade".

E - Quem deve mandar em casa e sobre os filhos?
a) homens
b) mulheres
c) os dois
Pastor 4 - O homem, o homem.

Fica clara sua forma machista de pensar, pois se observa uma bipartição do julgamento de superioridade quando ele diz que não acha o homem superior a mulher de forma psicológica e social, porém diz que ao homem é atribuído o papel de liderança, de forma histórica, e quem deve mandar em casa sobre os filhos é o homem. 
Então demonstrou ser a favor da diminuição da mulher, atribuindo o papel de comando sobre os filhos somente ao homem, posicionamento que contradiz a legislação em vigor, a qual atribui a guarda e orientação dos filhos à família e não apenas ao homem. A visão patriarcal evidenciada pelo líder deflagra a desigualdade entre os papéis de pai e mãe, de forma a desprestigiar os direitos das mulheres. É, sem dúvidas, surpreendente que um orientador espiritual de uma grande congregação possa desferir palavras preconceituosas às questões igualitárias. É lamentável que os entrevistados, em sua grande maioria, veem o homem e a mulher, mas não enxergam os seres humanos, que estão dentro de cada um.

Sobre sua opinião com relação à importância que deve ter a ONU ou a comissão interamericana de direitos humanos para o funcionamento social e político do Brasil, respondeu: "exatamente frisar de forma pragmática o julgamento e a implantação de normas para todos na sociedade de forma igual" (Pastor 4).

$\mathrm{Na}$ resposta supracitada fornecida pelo pastor 4, ele mais uma vez fala de implantação da igualdade para o funcionamento social e político do Brasil. Um discurso igualitário que parece não corresponder a outras questões suscitadas na entrevista. Vejamos as contradições:

$\mathrm{E}$ - Conhece o que diz a ONU sobre a igualdade de gênero?

Pastor 4 - Atualmente é é é... sim e deixam muito a desejar, esquecendo a tradição, a cultura e a história da humanidade.

E - Se conhece, qual sua opinião do discurso da ONU sobre o direito à igualdade de gênero?

Pastor 4 - É esse exatamente o problema. Querer igualar certas práticas a uma tradição e isso é totalmente inconcebível.

E - Deve em sua opinião serem facilitada ou proibida às uniões homossexuais?

Pastor 4 - É.... proibida.

Diante de tais respostas, o que se verifica é a tentativa de justificar a desigualdade com base numa tradição e cultura que não pode ser rompida. Para o entrevistado é inconcebível igualar certas práticas, tais como as uniões homossexuais. Em suas respostas nota-se a busca pela manutenção de um sistema, não apenas religioso, que reproduz paradigmas e dogmas que foca no argumento histórico conservador e não se atém às diversas realidades humanas presentes em nossa sociedade. Abaixo restará demonstrado que desconhece as normativas internacionais sobre as questões igualitárias e de gênero: 
E - Você já ouviu falar da convenção sobre a eliminação de todas as formas de discriminação contra as mulheres (CEDAW)? Para você o que parece ser essa normativa internacional?

Pastor 4 - Não.

E - Você acha que existe alguma relação entre direitos, direitos humanos das mulheres e modalidades de relações de gênero?

Pastor 4 - Não.

E - Conhece o discurso da ONU sobre os direitos e liberdades sexuais e reprodutivas?

Pastor 4 - Não.

E - Sabe a posição das nações unidas sobre o aborto? O que você acha? Pastor 4 - Não sei.

E - Trabalham-se de alguma forma os direitos humanos e direitos à igualdade de gênero na sua igreja? Como?

Pastor 4 - Sim, de forma resgatando a tradição e a história e ao mesmo tempo também respeitando as diferenças.

Por mais que não se entenda das normativas internacionais, o pastor explica que trabalha os direitos humanos e a igualdade de gênero na sua igreja, de forma a resgatar a tradição e a história e, ao mesmo tempo, respeitando as diferenças. Provavelmente, tais diferenças não estariam relacionadas a igualar certas práticas nem aceitar as uniões homossexuais, por exemplo.

N) Pastor 5

O pastor 5 é administrador evangélico da igreja de Deus no Brasil. A igreja iniciou como instituição religiosa em 19 de agosto de 1886 na cidade de Monroe Tennessee, na Carolina do Norte. Um homem chamado Richard Green Spurling, ex-batista e pregador, juntou-se a outras nove pessoas e formaram uma união cristã com a finalidade de seguir o "Novo Testamento" como uma regra de fé e prática. Vinte e um anos depois o nome Igreja de Deus se tornou oficial.

Hoje a Igreja de Deus tem mais de 7 milhões de membros em 178 países e territórios, com cerca de 36 mil congregações ao redor do mundo. A igreja de Deus no Brasil se ramificou por todo o país e também em Fortaleza.

Quando questionado sobre o papel da família na vida dos seres humanos o pastor respondeu que:

"Eu tenho uma concepção de família que é aquela família tradicional, né? Pai, mãe, esposa e os filhos e a exceção é quando, 
quando, aquela família onde filhos são criados por um tio, por uma avó, quando se perde o pai ou a mãe então a minha concepção é a concepção tradicional de família né?! Cada um tem uma... para formação do caráter da criança a importância do pai e da mãe, da mulher e do homem, né?!" (Pastor 5).

Quando questionado sobre uma definição rápida de "gênero": "é a própria diferenciação que existe no mundo, né? Entre masculino, feminino essa a diferença que existe na própria..., no mundo em que nós vivemos de masculino e feminino" (Pastor 5).

Dessa forma fica caracterizado um conceito padrão de família, sob uma visão tradicional, necessitando obrigatoriamente da figura do pai e mãe, precisamente do homem e da mulher. Fora deste contexto, não seria a família tradicional. Para ele, o conceito de gênero é o que resulta do determinismo biológico, só podendo ser diferenciado entre masculino e feminino.

Ademais, quando questionado sobre as normativas internacionais, informa desconhecê-las:

E - Qual a sua opinião do discurso da ONU sobre direitos humanos?

Pastor 5 - Desconheço, né?!. Não conheço.

E - Qual sua opinião do discurso da ONU sobre direitos humanos?

Sobre a organização social e familiar brasileira?

Pastor 5 - É aí eu não conheço. Aí eu teria que ler para opinar.

E - Conhece o que diz a ONU sobre a igualdade de gênero? Se conhece, qual sua opinião do discurso da ONU sobre o direito à igualdade de gênero?

Pastor 5 - Não.

E - Você já ouviu falar da convenção sobre a eliminação de todas as formas de discriminação contra as mulheres (CEDAW)? Para você o que parece ser essa normativa internacional?

Pastor 5 - É, também não conheço.

E - Você acha que existe alguma relação entre direitos, direitos humanos das mulheres e modalidades de relações de gênero?

Pastor 5 - Também não sei.

E - Conhece o discurso da ONU sobre os direitos e liberdades sexuais e reprodutivas?

Pastor 5 - Não. 
Quando questionado sobre achar certo ou errado o termo violência de gênero, respondeu que:

\begin{abstract}
"Então, mais uma vez se a violência é cometida é contra o homem ou a mulher eu acredito que isso a pergunta, não sei, o que é certo ou errado em violência de gênero. E por que não violência à mulher. É... O homem nasce... é é a pessoa nasce ou homem ou mulher, ela não nasce gênero. Ela nasce ou homem ou uma mulher se a violência é contra o homem ou contra a mulher." (Pastor 5).
\end{abstract}

Quando questionado se era a favor de ações positivas em benefício das mulheres, tais como: cotas para formar listas eleitorais para compor governos ou tribunais, respondeu "Não, não. Discordo". Informou que deveria haver esse acesso da mulher aos governos e tribunais em virtude da meritocracia, confirmando um senso comum na sociedade brasileira de que as cotas, sejam quais forem, não são "merecidas" ou necessárias.

$\mathrm{Na}$ entrevista, observou-se que o pastor ainda discorda das cotas na política em favor das mulheres, deixando que elas se emancipem por conta própria. Acaba, assim, explicitando um machismo intrínseco ao demonstrar não se preocupar com o cenário político atual, no qual os espaços públicos são ocupados em sua maioria por homens.

O pastor parece naturalizar este cenário desigual, e quando questionado sobre sua opinião sobre serem facilitadas ou proibidas as uniões homossexuais, respondeu que:

"Eu acredito que não deveria ser....ser facilitado, né?! Mas proibido, eu acho que é uma, uma utopia, né?! Proibir já que a natureza do homem ela, ela, ela própria já ... no mundo em que nós vivemos, ela discorda das leis de Deus, da exigência moral de Deus na sua palavra. Então, proibir não dá! Mas serem facilitados não, porque não é um, uma prática que, que se construa uma sociedade melhor, uma prática, é...” (Pastor 5).

O pastor 5 diz nas respostas supracitadas que não comunga da igualdade de gênero e nem apoia as práticas homossexuais. E, quando inquirido sobre os trabalhos voltados aos direitos humanos, realizados na sua congregação religiosa, informou que sim. Trabalha-se da seguinte forma:

"Sobre quando nós falamos sobre a criação do homem ou da mulher sendo da mesma essência, não tendo diferenças constitucionais. Assim como o homem e a mulher é natureza humana completa, sem faltar nada, então cada, cada sociedade define o papel de cada, de cada gênero, o homem e a mulher na 
sociedade, né?! Então nós ensinamos na, na, na igreja a importância do homem e da mulher na constituição de uma família, de uma família saudável, de uma família feliz, do, do...da importância do papel deles na sociedade, então a gente procura a partir daquilo que a bíblia ensina, das nossas crenças, das nossas convicções ensinar a igreja.” (Pastor 5)

De que forma o senhor trabalha na sua igreja os direitos humanos e o direito de igualdade de gênero? (Pergunta novamente elaborada)

“É através do ensino, através da pregação, através da orientação. São conquistas através do ensino da história, a conquista da liberdade à conquista de direitos básicos, então a gente ensina para que a pessoa saiba dos seus direitos como homem e saiba dos direitos de cada um". (Pastor 5).

A preocupação aqui não corresponde à crença do religioso, mas à sua pregação e orientação, por serem discordantes e difusoras de valores que violam os direitos inerentes à pessoa humana, previstos na Constituição e em tratados internacionais. Quando tais direitos não são desconhecidos, são ignorados. Pior ainda: as ideias contrárias aos direitos humanos são propagadas a uma coletividade como verdade absoluta a partir do texto bíblico e não das leis e da sociedade em constante mudança, e repassadas de geração a geração através da cultura patriarcal enraizada na fé cristã. Então, aquilo que não é defendido, nem considerado aceitável passa a ser discriminado, rebaixado. Dessa forma, naturalizam-se a violência e o preconceito para com todos os valores que vão de encontro aos ensinamentos religiosos.

O) Pastor 6

Administrador evangélico da Igreja Congregacional Pentecostal do Brasil que é uma ramificação do movimento Holiness, que se originou nos EUA entre 1840 e 1850, como forma de propagar os ensinamentos de John Wesley sobre santificação e reavivamento da igreja. O pastor entrevistado é responsável por uma igreja que chegou ao Brasil em 1914 e se ramificou em várias localidades no Brasil. Em Fortaleza, propagou-se de tal forma que já existem cinco congregações e mais de quatorze mil fiéis.

Devido a sua considerável quantidade de membros, e devido ao tempo de atuação na evangelização do entrevistado, é possível considerar que seu discurso é um propagador de massas e gerações.

Quando questionado a respeito da contribuição sociopolítica de sua religião para a sociedade fortalezense, o pastor 6 respondeu: "Normas e valores". E, ao lhe ser perguntado 
se acreditava sobre a compatibilidade entre os direitos humanos e as crenças religiosas, respondeu que: "eu creio que estão incompatíveis no momento". Ademais, informou na entrevista que seria melhor se o estado fosse confessional.

Deixou transparecer que defende somente a crença cristã, que as normas e valores devem ser baseadas nessa crença, inclusive o estado deveria ser confessional no seu entendimento. Para o pastor 6, o que importa é a opinião dele de acordo com sua religião e sua crença. Ainda sugere ajustes para os discursos mundiais de direitos humanos, pois o que mundialmente está sendo propagado está errado, no seu ponto de vista. Seguem suas respostas às indagações realizadas:

E - Você acredita que os direitos humanos são muito ... pouco ... Alguma coisa... de importante para as pessoas e países ou seria melhor esquecê-las?

Pastor 6 - Os direitos humanos são importantes, porém, da maneira como está sendo tratados, eu acho que precisam de certos consertos".

E - Tente por favor, uma definição rápida e concisa de direitos humanos.

Pastor 6 - Eu não tenho como explicitar agora o que seriam esses direitos humanos.

E - Tente por favor, uma rápida definição de "gênero".

Pastor 6 - Essa daqui eu não vou explicitar.

E - Quem deve mandar em casa e sobre os filhos?
a) Homens
b) Mulheres
c) os dois

Pastor 6 - Mandar em casa, os homens.

O pastor 6 além de não conseguir definir as normativas internacionais de defesa dos direitos humanos, disse que precisariam ser "consertadas". Sobretudo, afirmou ainda que em casa o homem é quem deve mandar e também sobre os filhos. Isso significa que o homem tem o papel inclusive de mandar na esposa, ao se tomar uma leitura extensa da afirmativa.

Quando questionado a respeito da concepção de família e papel que ela deve desempenhar em homens e mulheres, respondeu que: "família ela tem um papel ímpar com relação a homens e mulheres e os direitos humanos eles têm sim que manter e preservar essa concepção da família, principalmente a família no original" (Pastor 6). 
Na resposta supracitada com relação à concepção de família, mais uma vez um líder religioso entrevistado defende o conceito de família tradicional, sem justificar a necessidade de se abster de outras formas de famílias existentes. A afirmativa é feita sem dialogar porque tais normativas não deveriam abordar os demais arranjos familiares, como se o original, que se baseia no Antigo Testamento, (homem, mulher e filhos) fosse superior a outras formas de convivência e que os defensores de direitos humanos deveriam preservar a concepção de família original - o que é totalmente contraditório para um estado de direito que é não confessional. A desobediência à lei é propagada, inclusive, como se as normas morais e religiosas fossem superiores ao estado de direito constituído.

Quando questionado se as pessoas têm o direito de escolher de forma livre sua orientação sexual e suas relações sociais independentemente de seu sexo biológico, respondeu: Não, não. Eu não acredito que as pessoas tenham esse direito não, porque Deus já as formou daquele jeito, então biblicamente falando, é totalmente ao contrário do que está nas escrituras.

Quando questionado, em sua opinião, se um marido em casa maltrata sua esposa, acredita que ela deve:
a) denunciar e separar do abusador;
b) resignadamente pensar na unidade familiar;
c) reconciliar-se com o agressor;
d) outros.

Pastor 6 - Ela deve reconciliar-se com o agressor.

Na opinião do Pastor entrevistado, de forma objetiva e direta, defende-se que quando uma mulher é agredida pelo companheiro, não deve denunciar, mas se reconciliar com o agressor. Ainda que a igreja fosse absolutamente separada do ambiente público, e se dela não houvesse qualquer interveniência no campo político, sua visão nunca seria individual, mas popularizada, uma vez que atende a uma massa de fiéis. É plenamente possível que lideranças religiosas, tais como esta, possam vir aconselhando mulheres de sua congregação a aceitarem qualquer tipo de violência, com a justificativa de manter a integridade familiar e isso, definitivamente, não pode, nem deve ser desprezado. É inconcebível naturalizar e versar como admissíveis atos atentatórios aos direitos humanos, sob a justificativa do que diria a bíblia ou os costumes tradicionais.

Essa resposta emitida evidenciou possíveis omissões, cuja negligencia do líder, enquanto mentor espiritual, parece autorizar e legitimar - sob o véu da cultura, tradição e religião - a violência contra a mulher. $O$ pastor se comporta como se dispusesse de direitos de 
interferência sobre a ação de seus fiéis, direitos esses logicamente indisponíveis, já que se trata de personalidade humana.

Apesar da Constituição Federal de 1988 prever a proteção aos locais de culto e suas liturgias, isso não significa que os líderes das instituições mantenedoras de ditos locais poderão tomar decisões que sejam atentatórias e violadoras de direitos.

Quando questionado sobre as normativas internacionais, o pastor 6 afirmou desconhecêlas. Porém, apesar de desconhecer, na sua entrevista, conforme já mencionado, afirma que tais propósitos das normativas de direitos humanos precisam ser retificados. Ressalta-se que popularizar discursos sem a devida fundamentação é o mesmo que intentar contra o estado de direito. Sob argumentos morais e religiosos, o líder se mostra, bem como seus fiéis, preconceituosos quanto às uniões homoafetivas, bem como discriminatórios no que concerne à mulher.

P) Pastor 7

Administrador evangélico da Igreja Missão Evangélica Pentecostal do Brasil, o pastor entrevistado é responsável por uma igreja que é filial de um grande ministério evangélico e, por esse motivo, foram entrevistados dois pastores do mesmo ministério. A igreja possui dois seminários e um orfanato, além de nove congregações pela cidade de Fortaleza e é ramificada em todos os estados brasileiros.

Essa igreja possui força política por ser vinculada a ORMECE (Ordem dos Ministros Evangélicos do Ceará). Assim, fica caracterizada a importância histórica e sociopolítica do ministério para os fortalezenses e para o país como um todo. Sua influência em termos de desenvolvimentos sociais é grande e o conceito de evangelização pentecostal é um dos maiores do país.

Quando indagado sobre as questões familiares, o pastor 7 informou que a família é peça fundamental de uma sociedade, principalmente para a construção de uma sociedade igualitária.

É de bom alvitre ressaltar que o pastor mencionou "a construção de uma sociedade igualitária”, porque se pressupõe no início da entrevista que suas manifestações e seus discursos estão em consonância ao que entende que sejam os direitos humanos, porém, contraditoriamente, demonstrou ser contra as cotas de mulheres no âmbito político e jurídico sob o pretenso argumento de que a implantação de cotas não seria prestigiar a igualdade.

Vejamos: 
$\mathrm{E}$ - O que você acha de ações positivas em favor das mulheres, tais como cotas para formar listas eleitorais para compor governos ou tribunais?

Pastor 7 - Eu não acredito em cotas porque não é princípio de igualdade.

As cotas foram justamente criadas como forma de compensação legal histórica para possibilitar a aceleração da igualdade entre homens e mulheres, então, o estado de direito entende que as mulheres historicamente foram prejudicadas em diversas áreas sociais (tais como a área jurídica, política, profissional, dentre inúmeras outras) e ainda hoje sofrem esse tipo de injustiça social por conta do regime patriarcalista do passado.

Ademais, quando questionado sobre as normativas internacionais, respondeu que:

E - Qual sua opinião do discurso da ONU sobre direitos humanos? Sobre a organização social e familiar brasileira?

Pastor 7 - Não estou inteirado sobre o discurso da ONU a esse respeito.

E - Conhece o que diz a ONU sobre a igualdade de gênero? Se conhece, qual sua opinião do discurso da ONU sobre o direito à igualdade de gênero?

Pastor 7 - Não.

E - Você já ouviu falar da convenção sobre a eliminação de todas as formas de discriminação contra as mulheres (CEDAW)? Para você o que parece ser essa normativa internacional?

Pastor 7 - Não, não ouvi falar.

E - Sabe como se define essa violência pelos organismos internacionais?

Pastor 7 - Essa pergunta tem relação com a anterior, portanto eu também não vou... vou ficar sem responder.

E - Você acredita ou não que a violência baseada no gênero viola os direitos humanos ou é outra coisa?

Pastor 7 - A mesma coisa da anterior.

Quando questionado sobre sua opinião se devem ser facilitadas ou proibidas às uniões homossexuais, respondeu "eu penso que cada indivíduo tem o direito de fazer suas escolhas, mas isso não deve ser uma política de estado" (Pastor 7).

Ao ser questionado se trabalham de alguma forma os direitos humanos e direitos à igualdade de gênero na sua igreja: 
"Sim. Pregando o evangelho. Eu penso que o evangelho ele explicita nos seus princípios relações familiares sadias. O que acontece quando a violência no seio familiar se usando a desculpa religiosa, na verdade é uma hermenêutica equivocada da própria bíblia sagrada" (Pastor 7).

Trabalhar os direitos humanos e a igualdade de gênero é o mesmo que trabalhar as relações familiares, segundo o pastor 7, essa seria a interpretação do evangelho. Entretanto, a ótica religiosa não se fundamenta em estado de direito. O pastor 7 , apesar de concordar que o indivíduo possa fazer suas escolhas, o estado não deveria trabalhar essa política, ou seja, uma política de igualdade, pois ela seria contra a família considerada sadia, de acordo com o entendimento da igreja.

Importante destacar que o próprio pastor entende que a violência no seio familiar não pode ser desculpa religiosa, e que seria uma hermenêutica equivocada com relação à bíblia sagrada. E isto é preocupante, pois a hermenêutica equivocada influencia a cultura, por isso não é razoável um diálogo de obediência somente ao que prega o evangelho. Portanto, é uma imprudência promover que o teor do discurso religioso seja imperativo à lei, pois arrasta massas, vigorando entendimentos coletivos contrários aos direitos humanos.

\section{Q) Pastor 8}

Administrador evangélico da igreja Assembleia de Deus, localizada no bairro Montese. Trata-se de uma igreja muito antiga que segue as mesmas vertentes religiosas da Assembleia de Deus - Ministério Montese. Ou seja, existe o ministério Montese, mas também existem as igrejas Assembleia de Deus. O pastor entrevistado anteriormente é administrador do Ministério, já o pastor dessa pesquisa é responsável por administrar a igreja e os cultos ministrados na Assembleia de Deus.

O Pastor entrevistado demonstrou desconhecer as normativas internacionais e também não quis emitir sua opinião, o que impossibilitou nossa percepção sobre seu discurso:

E - Sua opinião sobre discurso da ONU sobre direitos humanos? E sobre a organização social e familiar brasileira?

Pastor 8 - Como eu falei, eu não conheço bem o discurso da ONU sobre esse assunto, por isso eu não queria entrar em detalhes. Se eu tivesse aqui uma cópia em mãos, eu poderia bem, dar o meu ponto de vista. 
E - Conhece o que diz a ONU sobre a igualdade de gênero? Se conhece, qual sua opinião acerca do discurso da ONU sobre o direito à igualdade de gênero?

Pastor 8 - Ouvi falar, é o que eu tô falando. Ouvi falar, por isso eu não tenho uma cópia do material, eu não quero dar aqui a minha opinião e me expor a uma... a algo que possa ser incorreto. Já, já respondi, né?!

E - Você já ouviu falar da convenção sobre a eliminação de todas as formas de discriminação contra as mulheres (CEDAW)? Para você o que parece ser essa normativa internacional?

Pastor 8 - Ouvi falar, mas como já disse, não cheguei a estudar sobre esse assunto.

E - Você acha que existe alguma relação entre direitos, direitos humanos das mulheres e modalidades de relações de gênero?

Pastor 8 - Se existe alguma...

E - Relação? (Insistência no foco da pergunta).

Pastor 8 - É... Eu vou optar não por responder aqui, porque vejo que é muito detalhado. Eu não estou aqui... vou optar por não responder essa...

E - Conhece o discurso da ONU sobre os direitos e liberdades sexuais e reprodutivas?

Pastor 8 - Não, não conheço.

E - Sabe como se define essa violência pelos organismos internacionais?

Pastor 8 - Eu não sei os detalhes é por isso que eu estou falando. Não conheço.

E - Sabe a posição das nações unidas sobre o aborto? O que você acha?

Pastor 8 - Eu não conheço os detalhes da posição das nações unidas, mas eu já ouvi falar algo e de qualquer forma, vejo que também lá há um embate muito grande sobre essa questão, a um embate por que há também pessoas a favor e contra.

A entrevista com esse líder não obteve sucesso, porque não cabe adivinhar o que se passa na mente do religioso, mas interpretar. No entanto, seu discurso foi vazio de opiniões e 
conhecimentos sobre as normativas internacionais, o que impediu de utilizar a entrevista como contribuição para análise de sua percepção na pesquisa.

R) Padre 9

Administrador paroquial do Santuário Coração de Jesus, o padre entrevistado é responsável por uma das igrejas mais antigas dentro da capital do estado. E por isso mesmo, pesa a seu favor a importância histórica em um lugar privilegiado bem no centro de Fortaleza. Desde 1901, os Frades Capuchinhos estabeleceram-se na capital cearense. Tratava-se dos Frades da Missão da Província da Lombardia (Itália), tendo o Maranhão como sede e centro de irradiação do trabalho missionário desde o norte do Brasil.

No Ceará, encontraram um campo religioso favorável, chegando a Canindé no final do Século XIX e fixando-se em Fortaleza em 1901, no bairro de Messejana, onde se construiria um profícuo Seminário Seráfico, anos depois. Assumiram então a Igreja do Coração de Jesus. Uma residência para os frades foi providenciada em Fortaleza, assim como também os Capuchinhos foram marcando seu trabalho missionário no campo da educação, especialmente cristã, fundando o colégio Pio X.

Junto a isso surge também o trabalho social da Liga do Pão de Santo Antônio, trabalho esse de auxílio espiritual e material aos mais carentes. A igreja e Santuário Sagrado Coração de Jesus foi sempre marcada pela presença forte de grandes missionários, desde italianos até os nativos que se formavam nas mesmas fileiras seráficas. Sua influência na vida sociopolítica da cidade de Fortaleza é enorme como também o é a quantidade de fiéis, fazendo pesar sobre os ombros desse antigo santuário uma importância política e social.

Quando questionado a respeito de uma definição rápida de Direitos Humanos, respondeu:

“Direitos Humanos seria o respeito à pessoa humana, né?! E do ponto de vista cristão, essa pessoa é criada a imagem e semelhança de Deus e quando Jesus Cristo assume o nosso corpo, né? Ele passa a ser para nós um modelo acabado de ser humano, né? Então o ser humano tem uma grande divindade". (Padre 9).

Do ponto de vista do padre 9, os direitos humanos estariam baseados no respeito à pessoa humana e que o homem é imagem e semelhança de Deus. Ou seja, o ser humano é parte de Deus e tem em si uma divindade espiritual que garante a ele o direito ao respeito.

Quando questionado a respeito de uma rápida definição de gênero, o padre responde que: "gênero masculino e feminino". E quando lhe é perguntado se os homens devem ou não compartilhar do trabalho doméstico em casa com as mulheres, respondeu: "sim, eu acho que não há nada que proíbe, né? Se bem que o preconceito é o que prevalece, mas do ponto 
de vista, assim, da fé não tem nada que proíba, não tem nada que imponha a mulher, por exemplo, a ser escrava do homem, né?" (Padre 9).

$\mathrm{Na}$ resposta supracitada é possível identificar que até mesmo o padre 9 percebe que na sociedade contemporânea ainda existe o preconceito contra as mulheres imposto pelos homens, que em sua grande maioria se casam ainda pensando em ser servidos de todas as formas pelas mulheres, que no fim acabam por se tornarem verdadeiras escravas dos parceiros.

Quando questionado de acordo com sua opinião sobre a importância que deve ter a ONU ou a comissão interamericana de direitos humanos para o funcionamento social e político do Brasil, respondeu:

"Eu acho que a observância das normas que vem dessas instituições coloca o Brasil em sintonia com o resto do mundo. Assim querer fazer um caminho paralelo, houve o momento já na história que a interferência externa fez ou muito no abrandamento de situações de opressão que a gente tinha aqui, né? "(Padre 9).

Quando questionado sobre sua opinião com relação ao discurso da ONU sobre direitos humanos, respondeu que:

"Eu não diria que eu sou totalmente inteirado sobre o discurso, né, de modo que não poderia opinar sobre detalhes, mas de uma maneira geral, naquilo que é compatível com respeito à pessoa, por exemplo, o direito à vida a preservação da vida em relação do homem com o meio ambiente, nós cristãos católicos concordamos. É tanto que há uma comissão da Santa Sé que faz parte também da ONU, né?" (Padre 9).

Apesar de não se achar muito inteirado sobre o discurso da ONU e da comissão Interamericana de Direitos Humanos, ainda assim, pelo pouco que conhece o padre 9, é possível ver uma percepção razoavelmente alinhada com a realidade dos discursos internacionais.

Quando indagado acerca de sua opinião com relação ao discurso da ONU sobre direitos humanos e sobre a organização social e familiar brasileira, respondeu: "Eu diria que nesse ponto também eu careceria de mais informações também para opinar com segurança" (Padre 9). Quando questionado se conhece o que diz a ONU sobre a igualdade de gênero e, em conhecendo, qual sua opinião do discurso da ONU sobre o direito à igualdade de gênero, afirmou: "Em profundidade, não" (Padre 9). 
Dessa forma fica caracterizado que o padre 9 não pode colaborar também com a pesquisa em virtude do desconhecimento sobre as normativas internacionais, porém, de forma tímida, demonstrou-se alinhado aos preceitos defendidos pelos Direitos humanos no início da sua conversa. Seriam necessárias mais informações sobre sua opinião com relação à igualdade de gênero, por exemplo, e de que forma pudesse trabalhar isso na sua igreja, portanto sendo parcialmente aproveitada sua percepção para a pesquisa.

\section{S) Pastor 9}

O pastor 9 é supervisor estadual da Igreja Batista Vale de Benção. A igreja foi fundada no dia 25 de setembro de 1982. A primeira sede foi estabelecida no bairro Parquelândia, em Fortaleza - CE, numa modesta casa. Desde então, observa-se um constante processo de expansão da obra que atualmente atinge as 5 regiões geográficas do Brasil, com Igrejas no Distrito Federal e nos Estados do Ceará, Tocantins, Amazonas, Paraná, Rio de Janeiro. Também dispõe de sede nos Estados Unidos da América.

O Ministério Batista Vale de Bênção além de anunciar o evangelho, volta-se para a beneficência em geral, através da Associação Beneficente Vale de Bênção e para a educação cristã, por meio de escolas bíblicas. Dessa forma configura-se a importância sociopolítica da congregação e a força de movimento espiritual sobre as massas sociais, principalmente a juvenil, visto que contam com grupos de jovens coordenados pela geração da benção, secretaria vinculada à igreja, que elabora festas e acampamentos anuais em Fortaleza.

Quando lhe foi indagado sobre o envolvimento social em passeatas ou qualquer outro tipo de movimentos externos à congregação e qual a média de pessoas participam desses movimentos, respondeu que: "Não. Só na igreja mesmo e são baseados na família, nos valores da família, nós fazemos atividades e temos anualmente a 'Marcha da Família Cristã' que nós realizamos. Nós temos uma participação média em torno de mil pessoas” (Pastor 9).

Quando questionado sobre outras contribuições eclesiásticas: "Bom, no meu caso, eu era professor também de teologia, então eu ministro aulas de teologia em alguns seminários aqui na cidade de Fortaleza e no estado do Ceará" (Pastor 9).

Quando perguntado sobre sua percepção de contribuição sociopolítica mais importante de sua religião para os fortalezenses, respondeu que:

"De forma muito prática, as ações sociais que nós realizamos com certa regularidade, fazemos várias ações sociais ao longo de um 
ano e isso traz muitos (deu ênfase) benefícios para as comunidades onde nós estamos inseridos. Então de forma objetiva, nossa grande contribuição é através da ação social. De forma mais indireta, através da vida dos indivíduos, que uma vez que esse indivíduo tem contato com Deus, entende à sua condição, procura viver uma vida melhor, mais digna, isso claro também repercute para uma melhora na sociedade" (Pastor 9).

Interpelado sobre os discursos internacionais sobre direitos humanos, se acredita que são muito... pouco... Alguma coisa... de importante para as pessoas e países ou seria melhor esquecê-las, respondeu:

"Eu não tenho tanta propriedade, de forma específica, quando se fala de direitos humanos. Mas eu presumo, apesar da minha pouca informação de que os direitos humanos eles são muito importantes pra que nós possamos ter uma sociedade democrática, de respeito e que possa, que possamos viver com os diferentes, respeitando os diferentes" (Pastor 9).

Quando questionado sobre uma definição rápida e concisa de direitos humanos, afirmou:

"Para mim, direitos humanos seriam uma manutenção, uma organização, um estabelecimento da dignidade humana. Qualquer coisa que venha a ferir isso que nós chamamos de dignidade humana, na bíblia, nós chamamos de vida e vida com abundancia, uma vida onde esse direito humano é digno e que a pessoa possa viver de forma razoável, nós entendemos como direitos humanos" (Pastor 9).

Quando questionado sobre uma rápida definição de gênero, respondeu que:

“É.... pra mim, gênero é uma condição do ser humano já que o ser humano é do gênero humano e que nessa condição de gênero humano ele pode se expressar nas duas sexualidades masculina ou feminina" (Pastor 9).

O pastor coloca na resposta supracitada que percebe gênero numa linguagem onde apenas existe uma dicotomia a respeito das questões de gênero com relação à sexualidade biológica dos seres humanos, que são apenas dois: masculino e feminino.

Quando questionado se o homem é por natureza superior ou igual em valor e capacidade em relação às mulheres, disse: 
"O homem no sentido do macho, no gênero masculino né? Igual, igual em dignidade, capacidade, valor, dignidade, direito são iguais, podem ter funções diferentes, é.... distinções de finalidades, porque, por exemplo, até onde eu sei o homem não pode procriar, a mulher é a única que detém organicamente as condições para carregar um filho. Por exemplo, quando você ver as leis do trabalho, as leis trabalhistas elas beneficiam a mulher, porque essa mulher quando ela vai ter o seu filho, ela vai passar por um processo de resguardo, a mesma lei não dá para o homem, porque entende que o homem não passa pelo mesmo processo orgânico. Então em valor, em dignidade, em inteligência e em integridade eles são iguais, mas eles acabam tendo funções diferentes por questões biológicas, por questões orgânicas” (Pastor 9).

Quando questionado se os homens devem ou não compartilhar do trabalho doméstico em casa com as mulheres, respondeu que:

"Sim. Aí eu vou dizer por mim, eu compartilho com minha esposa das atividades domésticas, fiz isso porquê sempre vi meu pai fazer, meu pai sempre ajudou em casa. Nunca deixou de ser homem ou se transformou em menos homem por isso, como eu também entendo que eu não deixo ou me torno menos homem por ajudar a minha esposa, pelo contrário, eu acho que isso até enobrece a minha relação com ela, porque eu sei as demandas que ela tem." (Pastor 9).

Quando questionado se acredita que os homens e as mulheres devem ter direitos iguais no espaço privado e familiar, respondeu que:

“Acredito que sim. Apesar que existe separações, distinções como eu lhe disse pela própria limitação orgânica, né, biológica, por exemplo eu acho que a mulher ela deve se aposentar mais cedo do que o homem, porque? Porque toda mulher que trabalha fora quando ela chega em casa ela tem um terceiro turno, ela tem um terceiro expediente, ela vai cuidar de casa, por mais que o marido ajude e acaba que as tarefas de casa elas são maiores para as mulheres então eu entendo que por causa dessas questões que são sociais, a mulher deve ter o direito de se aposentar antes do homem. Então os direitos são iguais. São os direitos são iguais para 
se aposentar, mas tem determinadas situações que eu acho que a mulher deve ser mais beneficiada do que o homem, por exemplo, uma dessa. " (Pastor 9)".

O Pastor diante dessa resposta parece entender que, por questões sociais, a mulher teria um terceiro turno (um terceiro expediente). Mesmo que o homem a ajude, ela ficaria com a parte maior, que seria a realização das tarefas do lar. Justifica que ela deve ter a proteção garantida de poder se aposentar mais cedo, devido a essa questão social que repercute no aspecto trabalhista. Sua resposta evidencia que socialmente há uma situação desigual da mulher dentro do próprio lar. Ele enxerga a necessidade de dignificar a mulher, ajudando-a nas tarefas domésticas e defende regras especiais de aposentadoria, que é o mesmo de obedecer ao princípio da isonomia: "devemos tratar igualmente os iguais e desigualmente os desiguais, na medida das suas desigualdades.

Anteriormente havia mencionado que costuma ajudar sua esposa porque entende as demandas que ela tem. Tal resposta soa muito bem para verificar que ela tem mais atividades que ele. E isso, por mais que seja socialmente e culturalmente aceito, é uma forma de discriminação, ou seja, é a permanência de uma cultura desigual que atribui à mulher as tarefas domésticas e coloca a participação do homem como ajuda e não como um dever, como o é para a mulher.

Conclui-se que, em razão do conhecimento do pastor, através do acúmulo de conhecimentos adquiridos no decorrer de dois cursos de graduação (em Sociologia e Teologia), professor universitário e de seminário evangélico, seu o discurso parece dialogar com a necessidade de se dignificar a mulher, ao passo que também leva a crer que já naturalizou esta diferença de direitos como sendo algo normal, e o homem teria um papel paliativo nesta ajuda de luta pela igualdade.

T) Pastor 10

Administrador evangélico da Igreja Betesda. O pastor entrevistado é responsável pela instituição religiosa, que em 2008 se desvinculou da Assembleia de Deus e tornou-se uma comunidade cristã independente. A partir de 2012 passou a ministrar o tema Espiritualidade Viva. Segue uma linha de evangelismo da Teologia Relacional. É uma instituição religiosa com voz e força social considerável, pois participa de movimentos sociais de evangelismo.

Quando questionado sobre outras colaborações com a vida eclesiástica, respondeu: "sim, participo de outras colaborações, sim, com a vida eclesiástica no âmbito social principalmente" (Pastor 10). 
Quando questionado sobre sua percepção de força do grupo religioso que pertence. Se acredita que sua religião em Fortaleza é muito ... alguma coisa ... sem importância, afirmou: "ela é extremamente importante. $\mathrm{O}$ ato de fé e o processo religioso é importante para qualquer sociedade, e na nossa, no caso de Fortaleza" (Pastor 10).

Quando questionado sobre sua percepção com relação à contribuição sociopolítica mais importante de sua religião para os fortalezenses, informou que:

“A nossa contribuição sociopolítica, além da questão da votação, hoje nós temos vários homens e mulheres que estão tanto no âmbito do executivo, do legislativo também participando, quanto hoje a igreja está muito aberta para as questões sociais. Em especial a minha igreja faz isso" (Pastor 10).

Ressalta-se que a força política perpetuada em sua igreja se origina da votação, e logo informa que tem vários homens e mulheres da congregação no âmbito dos poderes executivo e legislativo. Tal resposta evidencia que o papel da igreja não consiste apenas num discurso restrito a seus templos, mas fomenta os fiéis a ocuparem cargos políticos de poder e a apoiá-la em questões sociais.

As instituições religiosas e suas liturgias não manifestam somente religiosidade ou crença. Seu poder inicia com o trabalho social, e, em seguida, dada a magnitude da força da "fé", estende seus "tentáculos" e alcança o Congresso Nacional. Com o apoio dos membros (fiéis, seguidores), que legitimam os discursos de seus líderes, na hora de legislar, emergem-se todos os temas, (pré) conceitos e crenças que se delibera ou já foram deliberados dentro das paredes do templo, propagando a clara relação entre religião e estado, ainda que este seja laico.

Inquirido se acredita que os direitos humanos são muito... pouco... alguma coisa... de importante para as pessoas e países ou seria melhor esquecê-las, respondeu: "Pelo amor de Deus. Assim como estado laico, os direitos humanos são direitos que representam o poder e o dever de vivermos em sociedade, então os direitos humanos ele é fundamental" (Pastor $10)$.

Porém, apesar de afirmar que os direitos humanos são fundamentais, o líder desconhece as normativas internacionais de direitos humanos:

E - Qual sua opinião do discurso da ONU sobre direitos humanos?

Sobre a organização social e familiar brasileira?

Pastor 10 - Eu não conheço o discurso da ONU sobre a questão familiar brasileira, em especial. 
E - Conhece o que diz a ONU sobre a igualdade de gênero? Se conhece, qual sua opinião sobre discurso da ONU acerca do direito à igualdade de gênero?

Pastor 10 - Também não, não conheço.

E - Você já ouviu falar da convenção sobre a eliminação de todas as formas de discriminação contra as mulheres (CEDAW)? Para você o que parece ser essa normativa internacional?

Pastor 10 - Não, nunca ouvi falar não.

E - Você acha que as pessoas devem ou não ser educadas para promover e respeitar a igualdade de gênero?

Pastor 10 - Sim. Devem ser educadas para respeitar.

Quando questionado se acha certo ou errado o termo violência de gênero, respondeu: "É.... eu realmente não sei o que o termo está querendo dizer de forma mais abrangente". E, ao lhe ser perguntado se sabia como se define essa violência pelos organismos internacionais, afirmou: "por não saber o termo, o que significa em abrangência, não posso responder" (Pastor 10).

Apesar de informar que os direitos humanos são fundamentais, devido ao fato de o estado ser laico, parece não entender os termos que embasam uma conversa relacionada ao tema. Exatamente por o estado ser laico é que o direito deveria ser compreendido e visto. É o que diz o art. $3^{\circ}$ da lei de introdução às normas do direito brasileiro, que nos garante a eficácia de nosso ordenamento jurídico ao estipular a presunção de conhecimento da lei, que prevê que ninguém pode descumpri-la, alegando que a desconhece. O que leva a crer que não existe a intenção de promover esse discurso sobre as normativas de direitos humanos, no âmbito religioso.

A linguagem religiosa reforça ou exprime demandas por direitos humanos ou por identidade nacional em contextos nos quais a linguagem da política ou da cultura secular é ainda muito frágil ou se tornou suspeita de autoritarismo e indiferença à sorte de milhares de pessoas. Em tudo isso, o que é público ou privado, propriamente político ou propriamente religioso, já não pode ser definido de forma categórica e estável (Burity, 2005).

A falta de delimitação do que é público e do que é privado, e do que é político ou do que é religioso, faz com que discursos como os desses líderes sejam lançados à própria sorte, no que concerne à orientação de milhares de fiéis. Essas pessoas (fiéis), muitas vezes, carecem de pensamento crítico e conhecimento prévio acerca dos temas tratados, o que as torna 
presas fáceis de qualquer doutrinação. Dessa forma, o que é originalmente religioso se torna também político, e (em muitos casos, inclusive) legislado.

Percebe-se que o movimento quanto à busca de humanidade e liberdade depende da comunicação de um discurso igualitário. Os líderes católicos e evangélicos são políticos de multidões e promovem com seus discursos o enfraquecimento das ideologias libertárias e de igualdade. Segundo Habermas, apenas a "assunção de uma razão humana comum constitui a base epistêmica para a justificação de um poder do Estado secular que independe de legitimações religiosas" (Habermas, 2007 p.135).

O Brasil caminha num sentido inverso: as religiões são instituições legitimadas a deliberar politicamente e o Estado parece promover ainda mais esse discurso, quando, paulatinamente, adota as ideias religiosas. Ressalta-se que, com a promulgação da Constituição de 1891, o Brasil foi elevado ao status de Estado "aconfessional". Desde esta Constituição até a atual Carta Magna de 1988, apesar de retrocessos trazidos pela Constituição de 1934, todas as constituições dispuseram sobre a separação da Igreja e do Estado. Não houve alterações significativas nos diferentes textos constitucionais (Brasil, 1988).

A Constituição Federal de 1988 incorporou dispositivos que demonstram, na verdade, não ter diminuído o espaço conferido à atuação religiosa no terreno público, pelo contrário, ampliou-o: inicia fazendo, no seu preâmbulo, a invocação ao nome de Deus; previu a educação religiosa nas escolas públicas e a prestação de assistência religiosa nas instituições de internação coletiva; prevê a imunidade tributária e alianças entre o Estado e Igreja para fins de interesse coletivo.

Dessa forma, o tratamento dado à temática das relações Igreja e o Estado não é problematizado por constitucionalistas brasileiros. E um dos efeitos disso é a violência, seja ela física, institucional ou simbólica. Por outro lado, os conceitos bíblicos de amor e paz são validados, mas precisam urgentemente abranger outra conotação, mais igualitária e menos preconceituosa ou discriminatória.

As reflexões de Vaggione (2005) parecem úteis para analisar as relações religiosas e políticas na sociedade brasileira, pois no Brasil as religiões sempre estiveram presentes no espaço público e, na contemporaneidade, continuam a ter nele uma presença significativa, sobretudo na arena política, com grande legitimidade e, portanto, sendo um importante ator político no cenário democrático.

Verifica-se que o discurso religioso com os temas como família, moral, educação, reprodução e planejamento familiar pouco foi alterado ao longo da trajetória brasileira nas relações entre religião e política. Assim, também suas práticas foram sendo justificadas nos 
mandamentos morais e religiosos, inclusive no tocante à formulação de leis. E, com esta participação atuante junto à coletividade, conseguiu aproximação com as camadas sociais mais carentes de proteção estatal, levando até si e as orientando com seus dogmas.

\section{RESISTÊNCIA X CONSERVADORISMO SOBRE EDUCAÇÃO DE GÊNERO NO CONTEXTO POLÍTICO LOCAL}

A situação política que envolve a inclusão de questões de gênero nas escolas está intimamente ligada à defesa das mulheres e da população LGBT. Isso porque os mesmos parlamentares que são contrários às ações que protegem esses grupos contra a violência são, também, contrários à discussão de gênero nas escolas. Os parlamentares que defendem os conteúdos de gênero nas escolas são os mesmos que defendem as minorias contra qualquer tipo de violência.

Nesta seção serão expostas as ações de duas parlamentares, uma vereadora ativista dos Direitos Humanos, Larissa Gaspar, fortemente atuante na Câmara de Vereadores da cidade de Fortaleza, e a deputada conhecida como Dra ${ }^{a}$ Silvana, pastora evangélica que aparece várias vezes na coleta de dados por falas contrárias à qualquer ação em defesa das mulheres e LGBT.

\subsection{Veradora Larissa Gaspar, Fortaleza, Ceará}

Formada em direito, Larissa começou sua carreira política ainda durante a sua graduação, na Universidade de Fortaleza - UNIFOR. A vereadora se engaja em questões humanitárias e ligadas aos direitos humanos. Seu trabalho é voltado para a defesa dos direitos da mulheres e minorias. Militante feminista, presidente da Comissão de Direitos Humanos, ela é defensora da igualdade de gênero e dos direitos dos animais. "Larissa se engajou na defesa do parto normal e humanizado, da amamentação em livre demanda. Além disso, luta pelo fim da violência contra a mulher, pela desconstrução da cultura machista e pelo incentivo à participação política das mulheres”, diz a página do mandato na internet (Anuário do Ceará, 2019, on-line).

O seu mandato produz materiais contra a violência de gênero, pelas mulheres e pelo público LGBT - lésbicas, gays, bissexuais, travestis, transexuais e transgêneros. Neles, há a busca de esclarecer os direitos, os termos usados pelos grupos feministas e LGBT, explicações de como obter ajuda diante da violência de gênero, entre outros. Em um dos textos, há o seguinte trecho: 
O Brasil é o país do mundo onde mais se matam pessoas lésbicas, gays, bissexuais, travestis, mulheres transexuais, homens trans e intersex (LGBTI). (...) De acordo com dados do Centro de Referência LGBTI Janaina Dutra, da prefeitura de Fortaleza, foram 30 assassinatos no Ceará em 2017, sendo desses, oito na região metropolitana, 12 em outras cidades do interior e 10 em Fortaleza. (Larissa Gaspar, 2018, on-line).

O texto inclui as seguintes ações no sentido de proteção aos direitos das minorias sociais:

- Projeto de lei 85/2017 cria o Dia Municipal do Enfrentamento à Transfobia, a ser celebrado no dia 15 de fevereiro, data em que a travesti Dandara dos Santos foi brutalmente assassinada em Fortaleza.

- $\quad$ Projeto de lei 476/2017 proíbe discriminação e violência em razão de gênero no ambiente escolar

- Indicação 333/2017 cria o Fundo Municipal em Defesa da População LGBT que possibilita arrecadar recursos para ações de promoção à defesa dos direitos dessa população

- $\quad$ Projeto de lei 86/2017 inclui no Plano de Educação a discussão sobre racismo, lgbtfobia, preconceito religioso e outros tipos de preconceitos e discriminação dentro das escolas.

- Indicação 129/2018 cria o Monumento Municipal de Tolerância e Respeito à população LGBT

- Indicação 671/2017 dispõe sobre convênio entre Abrigo Thadeu Nascimento e Prefeitura Municipal de Fortaleza (Material produzido pelo mandato da Vereadora Larissa Gaspar, 2018).

Em outro material, intitulado "Fortaleza das Mulheres", do tipo panfleto, distribuído ao público feminino, há a preocupação em se observar o recorte racial da população feminina. O texto sugere que as mulheres busquem apoio policial e jurídico em caso de violência doméstica ou não:

Dos dois milhões e 700 mil habitantes de Fortaleza, cerca de 53\% são mulheres. E pelo Censo do IBGE de 2010, a maior parte delas se declara negra ou parda. Muitas são chefes de família, responsáveis diretamente por seus lares. E elas enfrentam uma dura realidade: Fortaleza é a quarta capital do país em homicídios de 
mulheres, de acordo com o Mapa da Violência 2015. (Larissa Gaspar, 2018, on-line).

O texto segue com indicações de números de telefones e endereços úteis, como dos Centros de Referência Municipais de atenção aos públicos, LGBT, população de rua e mulheres, do centro jurídico gratuito da Universidade de Fortaleza, da Delegacia da Mulher e da Coordenadoria da Diversidade Sexual da Prefeitura de Fortaleza.

O mandato produziu também uma cartilha de orientação a jornalistas e pessoal da imprensa sobre como lidar com a divulgação de casos ligados à área de Direitos Humanos, o "Manual Por Uma Comunicação Pelos Direitos Humanos": ...É uma publicação do mandato da Vereadora Larissa Gaspar (PPL), de Fortaleza, e tem como objetivo servir de objeto de consulta para estudantes e profissionais de comunicação social. (...) Do código de ética dos jornalistas, (...) selecionamos os capítulos que tratam da violência sexual contra crianças e adolescente, violência contra a mulher e suicídio. Esses assuntos são recorrentes na cobertura jornalística e costumam gerar dúvidas sobre temas e abordagens. (Larissa Gaspar, 2018, on-line).

O mandato da vereadora Larissa Gaspar também se preocupa em emitir informativos das ações da parlamentar. 


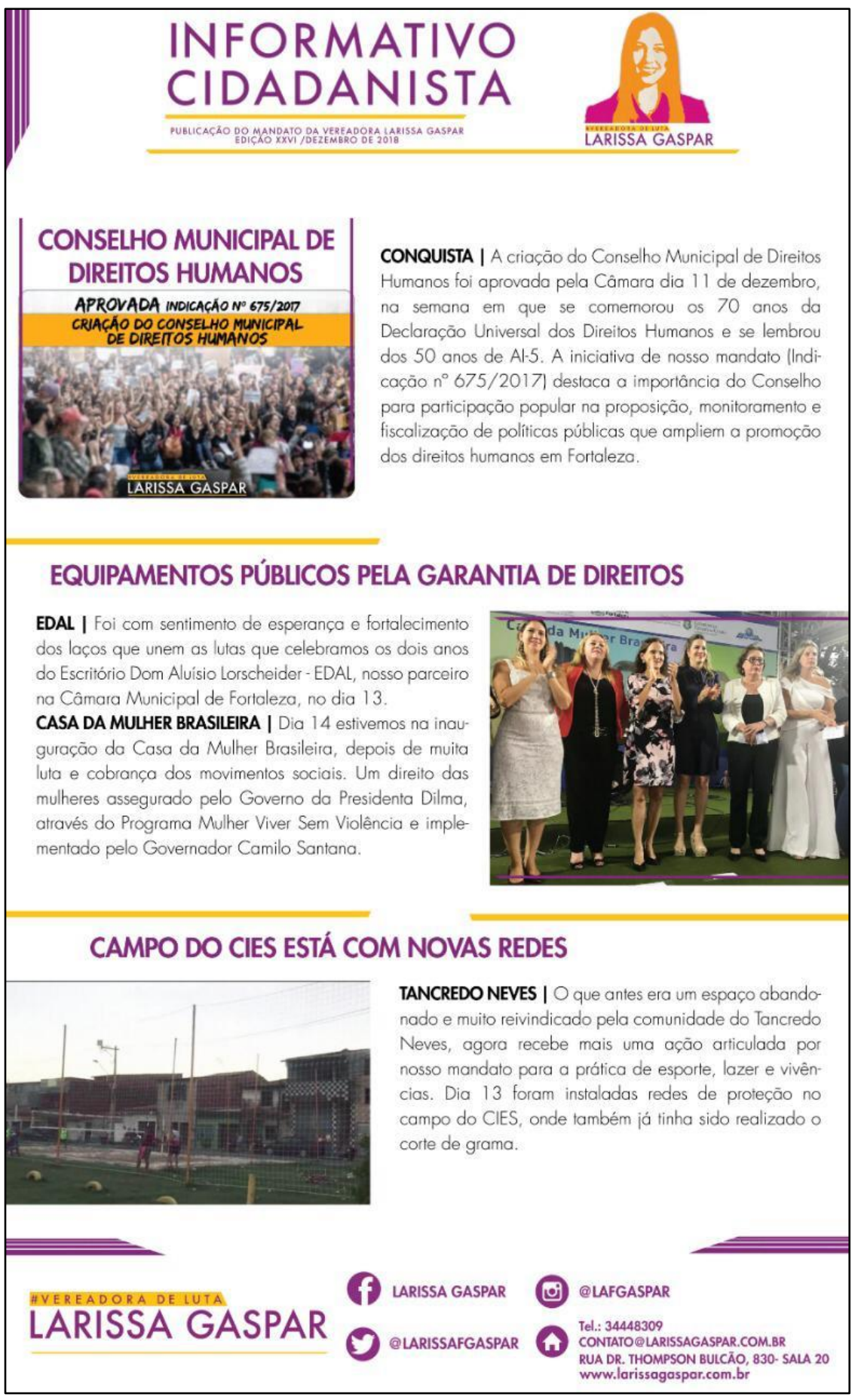

Figura 2 - Informativo do Mandato da Vereadora Larissa Gaspar.

Fonte: Larissa Gaspar, 2018, on-line.

O texto continua com temas sobre a violência e exploração de crianças e sobre o estupro, termos a serem usados e termos que são colocados equivocadamente pela mídia no tratamento de assuntos delicados como esses. Além das orientações, a cartilha traz a discussão sobre eles, no intuito de respeitar o profissional do jornalismo.

Os materiais aqui relatados ilustram o engajamento da vereadora e seu mandato na defesa dos direitos humanos, em particular nas questões que envolvem gênero. 
Larissa Gaspar se preocupa em participar do cotidiano da Câmara de Vereadores e se pronunciar, marcando oposição às falas e ações conservadoras de outros parlamentares e da prefeitura municipal. Na matéria "Câmara rejeita incluir debate sobre sexismo nas escolas”, do Jornal O Povo, a vereadora aparece em relato sobre o exercício parlamentar:

A Câmara Municipal de Fortaleza rejeitou ontem recurso da vereadora Larissa Gaspar (PPL) contra parecer negativo da Comissão de Constituição, Justiça e Legislação (CCJ) ao Projeto de Lei n ${ }^{\text {o }}$ 86/2017, de sua autoria, que incluía no Plano Municipal de Educação (PME) artigo contra "violências sexistas, raciais, religiosas e LGBTfóbicas”. Cerca de 30 manifestantes contra e favoráveis ao Projeto de Lei (PL) estiveram presentes à sessão. Discussão que deveria ser sobre legalidade da matéria, que tramita na CCJ, tornou-se debate sobre "ideologia de gênero". Por 23 votos a sete, os vereadores contrários à proposta afirmaram que o Projeto é inconstitucional, visto que o PME “deve ser preservado, mantendo sua originalidade" pelo período de vigência, de dez anos da elaboração. Apoiadores da proposta, porém, alegam que o relator da CCJ, Jorge Pinheiro (PSDC), se utilizou de argumentos “contra 'ideologia de gênero"” para barrar a matéria, já que o termo surge no parecer do parlamentar. Em defesa do recurso que apresentou, Larissa Gaspar disse que o conteúdo do projeto define que a escola traga "conteúdo para a pacificação de diálogos, cultura de paz contra violências sexistas, raciais, LGBTfóbicas e respeito à identidade de gênero". (...) Em sua tese, a vereadora cita “decisão do Supremo Tribunal Federal (STF)", do ministro Luís Roberto Barroso, em Arguição de Descumprimento de Preceito Fundamental (ADPF), que declarou inconstitucionalidade de lei que "vista impedimento" de "adoção de políticas de ensino que tratem de gênero, de orientação sexual"36. (O POVO, 21/09/2017, on-line)

As deliberações sobre o Plano Municipal de Educação de Fortaleza tiveram a presença constante da vereadora. Preocupada com a segurança de minorias que podem sofrer violências no ambiente escolar, ela tenta incluir artigo que assegura a discussão de

${ }^{36}$ Ver a matéria completa no apêndice dos dados da pesquisa documental. 
conteúdos de gênero dentro do Plano: "XII - formação em conteúdos que contribuam para a pacificação de diálogos. A superação de preconceitos, discriminações, violências sexistas, raciais, religiosas e LGBTfóbicas dentro e fora do ambiente escolar e orientação para o ensino público e privado no reconhecimento positivo no respeito à identidade de género", de acordo com suas atividades:

Tabela 1

\section{Projetos propostos pela vereadora Larissa Gaspar.}

\begin{tabular}{|c|c|c|}
\hline $\begin{array}{c}\text { Número } \\
\text { do projeto }\end{array}$ & Titulo do Projeto & Data \\
\hline $3 / 2017$ & $\begin{array}{c}\text { Ementa: cria o bloco carnavalesco Adeus Amélia e inclui } \\
\text { no calendário oficial de eventos do município de } \\
\text { Fortaleza. }\end{array}$ & 04-01-17 \\
\hline $4 / 2017$ & $\begin{array}{l}\text { Ementa: dispõe sobre a obrigatoriedade das maternidades } \\
\text { de parto e estabelecimentos hospitalares congêneres, da } \\
\text { rede pública privada do município de Fortaleza em } \\
\text { permitir a presença de doulas durante o período de } \\
\text { trabalho de parto, parto e pós-parto imediato, sempre que } \\
\text { solicitadas pela parturiente. }\end{array}$ & 04-01-17 \\
\hline $5 / 2017$ & $\begin{array}{l}\text { Ementa: dispõe sobre a obrigatoriedade de inclusão de } \\
\text { alimentos orgânicos ou de base agroecológica na } \\
\text { alimentação escolar no âmbito do sistema municipal de } \\
\text { ensino de Fortaleza e dá outras providências. }\end{array}$ & 04-01-17 \\
\hline $6 / 2017$ & $\begin{array}{l}\text { Ementa: dispõe sobre o atendimento obrigatório e } \\
\text { integral de pessoas em situação de violência sexual em } \\
\text { unidades de saúde do município de Fortaleza. }\end{array}$ & $04-01-17$ \\
\hline $16 / 2017$ & $\begin{array}{l}\text { Ementa: determina a realização de audiência pública } \\
\text { como procedimento prévio à revisão tarifária dos serviços } \\
\text { públicos municipais concedidos ou permitidos no } \\
\text { município de Fortaleza e dá outras providências. }\end{array}$ & $17-01-17$ \\
\hline $17 / 2017$ & $\begin{array}{l}\text { Ementa: combate o desperdício de alimentos no } \\
\text { município de Fortaleza e dá outras providências. }\end{array}$ & $17-01-17$ \\
\hline
\end{tabular}




\begin{tabular}{|c|c|c|}
\hline $23 / 2017$ & $\begin{array}{l}\text { Ementa: reconhece o grafite como manifestação artística, } \\
\text { estabelece a semana e o dia municipal do grafite e dá } \\
\text { outras providências. (com } 01 \text { emenda) }\end{array}$ & $24-01-17$ \\
\hline $41 / 2017$ & $\begin{array}{l}\text { Ementa: institui o programa de conservação, uso racional } \\
\text { e reaproveitamento das águas no município de Fortaleza. }\end{array}$ & $07-02-17$ \\
\hline $42 / 2017$ & $\begin{array}{c}\text { Ementa: institui a Semana Municipal de Apoio e } \\
\text { Conscientização sobre o Parto Humanizado e dá outras } \\
\text { providências }\end{array}$ & $07-02-17$ \\
\hline $85 / 2017$ & $\begin{array}{c}\text { Ementa: estabelece o dia } 15 \text { de fevereiro como o dia } \\
\text { municipal de enfrentamento a transfobia. }\end{array}$ & 06-03-17 \\
\hline $86 / 2017$ & $\begin{array}{l}\text { Ementa: acrescenta inciso ao art. } 4^{0} \text { da lei no 10.371, } \\
\text { de } 24 \text { de julho de } 2015 \text { - plano municipal de educação. } \\
\text { Acrescenta inciso ao Art. } 45 \text { da Lei } 10.371 \text { de } 24 \text { de julho } \\
\text { de } 2015 \text {, com a redação a seguir: } \\
\text { "XII - formação em conteúdos que contribuam para a } \\
\text { pacificação de diálogos. A superação } \\
\text { De preconceitos, discriminações violências sexistas, } \\
\text { raciais, religiosas e LGBTfóbicas dentro e fora do } \\
\text { ambiente escolar e orientação para o ensino público e } \\
\text { privado no reconhecimento positivo no respeito à } \\
\text { identidade de género." }\end{array}$ & 06-03-17 \\
\hline $91 / 2017$ & $\begin{array}{l}\text { Ementa: dispõe sobre o gerenciamento de pessoas não } \\
\text { identificadas civilmente nas unidades de saúde } \\
\text { participantes, conveniadas e não conveniadas, do SUS. }\end{array}$ & 09-03-17 \\
\hline $109 / 2017$ & $\begin{array}{l}\text { Ementa: institui o programa lei Maria da Penha nas } \\
\text { escolas municipais de Fortaleza. }\end{array}$ & $21-03-17$ \\
\hline $129 / 2017$ & $\begin{array}{l}\text { Ementa: veda a contratação de empresas de trabalho } \\
\text { temporário ou empresas prestadoras de serviços a } \\
\text { terceiros que tenham como objeto o desenvolvimento de } \\
\text { atividades-afins exercidas no âmbito da administração } \\
\text { direta ou indireta do município de Fortaleza. }\end{array}$ & $31-03-17$ \\
\hline
\end{tabular}




\begin{tabular}{|c|c|c|}
\hline $160 / 2017$ & $\begin{array}{l}\text { Ementa: institui, no âmbito municipal de Fortaleza o Dia } \\
\text { Municipal do Rock e dá outras providências. }\end{array}$ & 26-04-17 \\
\hline $161 / 2017$ & $\begin{array}{l}\text { Ementa: acrescenta ao artigo } 7^{\circ} \text { da lei } \mathrm{n}^{\circ} 8.004 / 97 \text {, que } \\
\text { regulariza o sistema de moto táxi no município de } \\
\text { fortaleza, na forma que indica. }\end{array}$ & $26-04-17$ \\
\hline $162 / 2017$ & $\begin{array}{c}\text { Ementa: dispõe sobre o uso obrigatório de motocímetro } \\
\text { para os moto taxistas no âmbito do município de } \\
\text { Fortaleza e dá outras providências. }\end{array}$ & 26-04-17 \\
\hline $203 / 2017$ & $\begin{array}{c}\text { Ementa: dispõe sobre a criação, composição, competência } \\
\text { e funcionamento do conselho municipal de esporte e } \\
\text { lazer. }\end{array}$ & $22-05-17$ \\
\hline $314 / 2017$ & $\begin{array}{l}\text { Ementa: institui o programa "Escola sem Censura" } \\
\text { no município de Fortaleza na forma que indica. }\end{array}$ & $17-08-17$ \\
\hline $331 / 2017$ & $\begin{array}{l}\text { Ementa: altera o artigo } 1^{\circ} \text { da lei no } 10.540 \text {, de nove de } \\
\text { setembro de } 2016 \text {, que dispõe sobre a proibição de } \\
\text { utilização de veículos de tração animal em } \\
\text { estabelecimentos de comercialização de material de } \\
\text { construção e/ou similares. }\end{array}$ & $23-08-17$ \\
\hline $332 / 2017$ & $\begin{array}{c}\text { Ementa: inclui a Mostra de Música Petrúcio Maia no } \\
\text { calendário oficial do município de Fortaleza e dá outras } \\
\text { providências. }\end{array}$ & $24-08-17$ \\
\hline $333 / 2017$ & $\begin{array}{c}\text { Ementa: inclui o Festival "Forcaos" no calendário oficial } \\
\text { de eventos do município de Fortaleza e dá outras } \\
\text { providências. }\end{array}$ & $25-08-17$ \\
\hline $383 / 2017$ & $\begin{array}{c}\text { Ementa: estabelece percentual mínimo dos recursos } \\
\text { aplicados anualmente em publicidade e propaganda para a } \\
\text { promoção de campanhas educativas afirmativas dos } \\
\text { direitos humanos. }\end{array}$ & $18-09-17$ \\
\hline
\end{tabular}




\begin{tabular}{|c|c|c|}
\hline $423 / 2017$ & $\begin{array}{l}\text { Ementa: dispõe sobre a vedação de atribuir nomes de } \\
\text { violadores de direitos humanos a órgão, prédios, vias, } \\
\text { honrarias e bens de qualquer natureza pertencentes à } \\
\text { administração pública direta e indireta no âmbito do } \\
\text { município de Fortaleza e dá outras providências. }\end{array}$ & $19-10-17$ \\
\hline $435 / 2017$ & $\begin{array}{l}\text { Ementa: dispõe sobre a proibição do comércio de veneno } \\
\text { denominado "organofosforado carbamato", conhecido por } \\
\text { chumbinho, em estabelecimentos comerciais de Fortaleza, } \\
\text { e dá outras providências. }\end{array}$ & $31-10-17$ \\
\hline $443 / 2017$ & $\begin{array}{l}\text { Ementa: dispõe sobre o direito à gratuidade para pessoas } \\
\text { com HIV-aids, no pagamento de tarifas do sistema de } \\
\text { transporte público de Fortaleza, e dá outras providências. }\end{array}$ & $06-11-17$ \\
\hline $457 / 2017$ & $\begin{array}{l}\text { Ementa: altera a lei n. } 10.328 \text {, de } 12 \text { de março de } 2015 \text {, } \\
\text { que redefine o programa locação social no âmbito do } \\
\text { município de Fortaleza, e dá outras providências. }\end{array}$ & $09-11-17$ \\
\hline $458 / 2017$ & $\begin{array}{l}\text { Ementa: determina a inclusão, nos sites da prefeitura } \\
\text { e da câmara municipal de Fortaleza, de relação de } \\
\text { serviços que compõem a rede de enfrentamento à } \\
\text { violência contra as mulheres, e dá outras providências. }\end{array}$ & $10-11-17$ \\
\hline $476 / 2017$ & $\begin{array}{l}\text { Ementa: proíbe a prática de atos de discriminação ou } \\
\text { violência em razão de gênero, cor, idade, orientação } \\
\text { sexual, deficiência, opção religiosa, origem ou cultura, } \\
\text { em estabelecimentos de ensino públicos ou privados, } \\
\text { estabelece sanções e dá outras providências. }\end{array}$ & $23-11-17$ \\
\hline $490 / 2017$ & $\begin{array}{l}\text { Ementa: institui a gratuidade temporária no sistema } \\
\text { de transporte público coletivo do município de } \\
\text { Fortaleza para mulheres em situação de violência e dá } \\
\text { outras providências. }\end{array}$ & $30-11-17$ \\
\hline $500 / 2017$ & $\begin{array}{l}\text { Ementa: dispõe sobre o uso de fogos de artifício } \\
\text { silenciosos em eventos públicos e particulares no } \\
\text { município de Fortaleza e dá outras providências. }\end{array}$ & $05-12-17$ \\
\hline
\end{tabular}




\begin{tabular}{|c|c|c|}
\hline $501 / 2017$ & $\begin{array}{l}\text { Ementa: institui a semana municipal de prevenção e } \\
\text { enfrentamento ao HPV (papiloma vírus humano) e dá } \\
\text { outras providências. }\end{array}$ & $05-12-17$ \\
\hline $502 / 2017$ & $\begin{array}{l}\text { Ementa: dispõe sobre a implantação de medidas de } \\
\text { informação à gestante e á parturiente sobre a política } \\
\text { nacional de atenção obstétrica e neonatal, visando à } \\
\text { proteção delas contra a violência obstétrica no âmbito do } \\
\text { município de Fortaleza, e dá outras providências. }\end{array}$ & $05-12-17$ \\
\hline $503 / 2017$ & $\begin{array}{l}\text { Ementa: dispõe sobre a obrigatoriedade das unidades } \\
\text { básicas de saúde, unidades de pronto atendimento, } \\
\text { prontos-socorros, ambulatórios e demais estabelecimentos } \\
\text { hospitalares a fixarem placas informando a escala de } \\
\text { médicos e suas respectivas especialidades, e dá outras } \\
\text { providências. }\end{array}$ & $06-12-17$ \\
\hline $504 / 2017$ & $\begin{array}{c}\text { Ementa: dispõe sobre o afastamento remunerado de } \\
\text { servidoras municipais vítimas de violência sexual ou } \\
\text { em situação de violência doméstica e familiar, no } \\
\text { âmbito do município de Fortaleza, e dá outras } \\
\text { providências. }\end{array}$ & $06-12-17$ \\
\hline $516 / 2017$ & $\begin{array}{l}\text { Ementa: declara patrimônio cultural de Fortaleza o evento } \\
\text { parada pela diversidade do Ceará e o inclui no calendário } \\
\text { oficial de eventos do município. }\end{array}$ & $11-12-17$ \\
\hline
\end{tabular}

Fonte: Câmara de Vereadores de Fortaleza, 2018, on-line.

\subsection{Deputada Estadual Dra. Silvana, Ceará}

Silvana Oliveira de Sousa (Dra. Silvana) é natural de Fortaleza. É casada com um parlamentar e pastor e é mãe de dois filhos. Formada em Medicina pela Universidade Federal do Ceará (UFC), com especialização em Clínica Médica e Dermatologia pela mesma instituição. Em 2010, assumiu como deputada estadual suplente pelo PMDB. Em 2014, foi eleita com 41.449 votos.

É uma das principais defensoras do projeto "Escola sem Partido", de sua autoria no Ceará. O objetivo do projeto é proibir em sala de aula "a prática de doutrinação política e ideológica bem como a veiculação de conteúdos ou a realização de atividades de cunho 
religioso ou moral que possam estar em conflito com as convicções dos pais ou responsáveis pelos estudantes". Condena veementemente a "ideologia de gênero".

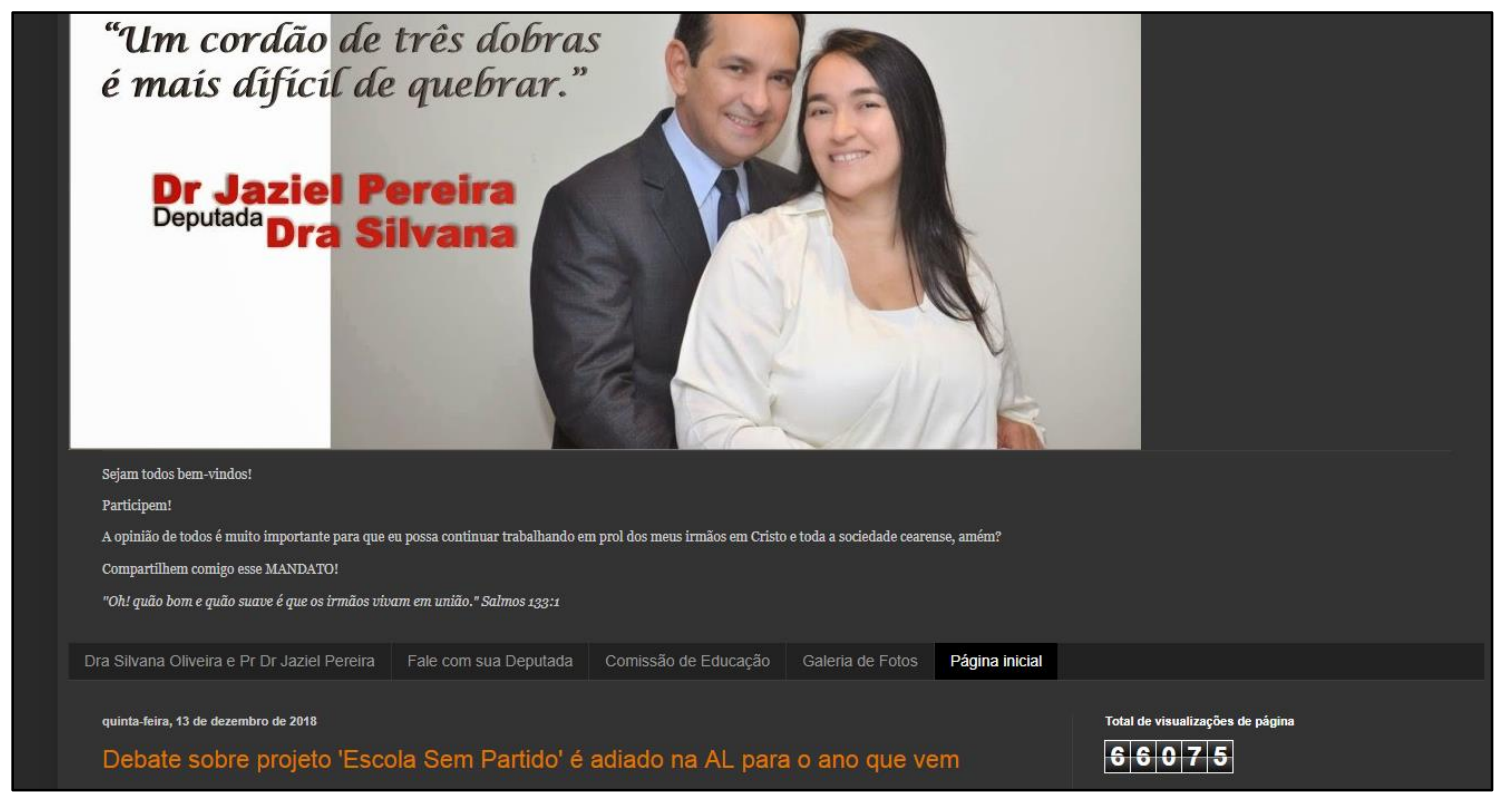

Figura 3 - Ilustração da página da internet da Deputada Dra. Silvana.

Fonte: Blog da Dra. Silvana, 2018, on-line.

A deputada é reconhecida por suas posições religiosas e embates exaltados na Assembleia Legislativa. Na rede mundial de computadores é fácil encontrar muitas matérias em que ela coloca sua opinião pessoal, sempre pautada na religião. $\mathrm{O}$ discurso cristão é reforçado nas falas dos deputados da bancada evangélica constantemente, como no trecho da matéria “"Somos sociedade cristã', diz deputada por alteração no Plano de Educação”, de três de maio de 2016, como registrado em na notícia:

Segundo deputada, estimular o combate contra o preconceito é "doutrinação" de gênero. A deputada Dra. Silvana (PMDB) voltou a defender nesta terça-feira, três, a remoção dos termos "LGBT", "gênero" e "diversidade" do Plano Estadual de Educação do Ceará. $\mathrm{O}$ projeto, que inclui entre seus pontos o combate à discriminação em escolas, deve ser votado ainda nesta semana pela Assembleia Legislativa. "Somos uma sociedade cristã por maioria e estamos em um estado laico. Logo, não podemos doutrinar as nossas crianças na sala de aula", diz Silvana, pastora evangélica. Ela apresentou diversas emendas retirando os termos da proposta. Carlos Matos (PSDB) já afirmou que trechos buscam implantar ideologia do "marxismo" no Brasil. Ely Aguiar (PSDC) destacou que fez emenda solicitando que a "ideologia de gênero" não seja 
abordada para alunos menores de 12 anos. "Esse PT é um partido das trevas, querendo levar para as crianças ideias anormais. O líder do Governo na Casa deve liberar a bancada", assinalou o deputado, apresentador de programas policiais (O Povo, 03/05/2016, on-line).

A predominância do tema "gênero" sobre outras matérias, muitas vezes mais importantes, foi denunciada pelo jornal O Povo em 2017 (O POVO, "O Ceará que a Assembleia discute. Discursos sobre gênero ultrapassam seca em debates na Assembleia”, 03/12/2017). Esse fato demonstra a gravidade do fenômeno da apropriação da discussão educacional pela política e religião.

Entre parlamentares mais ligados a este tipo de defesa, se destacou neste ano Dra. Silvana (PMDB). Pastora evangélica, a peemedebista é responsável por quase a metade dos discursos sobre gênero na Casa, e convocou audiência para debater o movimento Escola Sem Partido. Entre outros temas, Silvana defende que instalação de comissão para "físcalizar" ensino de gênero e chegou até a elogiar a Escola Educar SESC, de Fortaleza, após ela orientar uma adolescente transexual de 13 anos a deixar a escola. "A diretora se posicionou de maneira valente e serena", disse em sessão do Legislativo. A escola voltou atrás da decisão. "Não há perseguição à preferência sexual de ninguém, mas se todas as pessoas quiserem mudar seus nomes vai haver uma insegurança jurídica e fragilizar as nossas legislações", justifica Silvana. Questionada sobre o tema, a deputada nega qualquer tipo de discriminação e diz que a "ideologia de gênero" busca "desafiar valores" do cristianismo. "Acredito na união da sociedade cristã contra essa imposição. O tempo inteiro a Rede Globo está tentando impor isso como algo normal”. (O POVO, 03/12/2017, on-line).

Essa atitude dos parlamentares, de usarem a religião como plataforma política, pode ser estratégia para angariar votos. Assim, as pautas conservadoras são usadas não só como propostas, mas como meio de se destacar para conquistar eleitores. Os políticos usam temas polêmicos para impulsionar seus discursos nos períodos eleitorais e ganharem visibilidade. Segundo matéria do Diário do Nordeste, alguns pesquisadores afirmam que discurso é demagógico e pouco propositivo, outros defendem ser reflexo do atual cenário. Neste ano, a deputada Silvana Oliveira propôs a criação de uma frente parlamentar contra a “ideologia de gênero" no Ceará. A Assembleia Legislativa do Estado aprovou, em outubro, 
lei que impõe restrições a exposições em espaços públicos em nome "das famílias". (DIÁRIO DO NORDESTE, "Pautas conservadoras viram aposta eleitoral”, 26/12/2017)

Em outra matéria, de 15 de março de 2018, a parlamentar é citada:

A deputada Silvana Oliveira (PMDB) levou ontem à tribuna mais uma denúncia do que chamou de ideologia de gênero em escolas públicas do estado. Ela mostrou um livro didático que está sendo confeccionado para ser utilizado no município de Umirim abordando questões relacionadas à sexualidade. A parlamentar, que preside a comissão de Educação na Câmara de deputados, disse que vai acionar o MP e voltou a defender a instalação de uma frente parlamentar de fiscalização da ideologia de gênero no Ceará. No ano passado, a deputada havia relatado casos semelhantes nos municípios de Cedro e Quesébio. "Professor, cumpra o seu papel, não fique calado, denuncie. Que vou lá, exponho o prefeito, a prefeita, quem quer que seja o secretário de educação. Quem quiser enfrentar essa deputada, o voto da população na eleição. Ideologia de gênero nas escolas nós não aceitamos, nós somos a maioria" (Diário do Nordeste, 15/03/2018, on-line).

Assim, ela se coloca como uma das principais opositoras às pautas progressistas, sejam feministas ou não. No quadro abaixo estão as propostas da deputada nos anos de 2016 e 2017 para comparação sobre os tipos de propostas que são de sua autoria durante o exercício do mandato.

Tabela 2

Projetos propostos pela deputada Dra. Silvana.

\begin{tabular}{|c|c|c|}
\hline $\begin{array}{c}\text { Número } \\
\text { do } \\
\text { projeto }\end{array}$ & Título do Projeto & Data \\
\hline $8 / 16$ & $\begin{array}{c}\text { Ementa: Institui o dia estadual de mobilização contra a } \\
\text { dengue, a chikungunya e a zika. }\end{array}$ & $10-02-16$ \\
\hline $195 / 16$ & $\begin{array}{c}\text { Ementa: Institui a semana estadual do livro e de } \\
\text { incentivo à leitura, a escrita e dá outras providências. }\end{array}$ & $04-10-16$ \\
\hline
\end{tabular}




\begin{tabular}{|c|c|c|}
\hline $74 / 18$ & $\begin{array}{l}\text { Ementa: Considera de utilidade pública a organização } \\
\text { não governamental happy day Lavras com sede no } \\
\text { município de Lavras da Mangabeira, estado do Ceará. }\end{array}$ & 02-04-18 \\
\hline $207 / 15$ & $\begin{array}{l}\text { Ementa: Concede o título de cidadão cearense ao Sr. } \\
\text { Robson Lemos Rodovalho e dá outras providências. }\end{array}$ & 09-09-15 \\
\hline $26 / 16$ & $\begin{array}{l}\text { Ementa: Institui o dia do pastor evangélico no estado } \\
\text { do Ceará. }\end{array}$ & $22-02-16$ \\
\hline $245 / 15$ & $\begin{array}{c}\text { Ementa: Considera de utilidade pública a associação } \\
\text { Amigos de Jesus, com sede na cidade de Morada } \\
\text { Nova, estado do Ceará. }\end{array}$ & $22-10-15$ \\
\hline $99 / 15$ & $\begin{array}{l}\text { Ementa: Dispõe sobre a utilização solar em prédios e } \\
\text { obras públicas executadas com recursos do estado. }\end{array}$ & $14-05-15$ \\
\hline $190 / 15$ & $\begin{array}{l}\text { Ementa: Considera de utilidade pública o instituto } \\
\text { restaurar de desenvolvimento social, com sede no } \\
\text { município de Fortaleza, estado do Ceará. }\end{array}$ & $19-08-15$ \\
\hline $273 / 15$ & $\begin{array}{l}\text { Ementa: Institui, no âmbito do sistema estadual de } \\
\text { ensino do Ceará, o programa escola sem partido. }\end{array}$ & $09-12-15$ \\
\hline $100 / 15$ & $\begin{array}{l}\text { Ementa: Institui e inicial no calendário oficial de } \\
\text { eventos do estado do Ceará, o dia de valorização do } \\
\text { cartão de vacinação. }\end{array}$ & $14-05-15$ \\
\hline $147 / 16$ & $\begin{array}{l}\text { Ementa: Disciplina, no âmbito do estado do Ceará, } \\
\text { manifestações sociais, culturais e/ou de gênero e dá } \\
\text { outras providências. “art. 1. Fica proibido em todo } \\
\text { território do estado do Ceará, durante manifestações } \\
\text { públicas, sociais, culturais e/ou de gênero, a } \\
\text { satirizarão, ridicularização e /ou toda e qualquer } \\
\text { outra forma de menosprezar ou vilipendiar dogmas e } \\
\text { crenças de toda e qualquer religião." }\end{array}$ & 23-06-16 \\
\hline
\end{tabular}




\begin{tabular}{|c|c|c|}
\hline $54 / 18$ & $\begin{array}{c}\text { Ementa: Estabelece restrições ao trânsito e à } \\
\text { permanência de menores de } 18 \text { anos nas ruas em horário } \\
\text { estipulado. }\end{array}$ & 07-02-18 \\
\hline $165 / 16$ & $\begin{array}{l}\text { Ementa: Concede o título de cidadão cearense, ao Sr. } \\
\text { Bispo doutor Manoel Ferreira e dá outras providências. }\end{array}$ & 18-07-16 \\
\hline $255 / 17$ & $\begin{array}{l}\text { Ementa: Concede o título de cidadão cearense ao Sr. } \\
\text { Pastor Silas Malafaia e dá outras providências. }\end{array}$ & 21-09-17 \\
\hline $96 / 18$ & $\begin{array}{c}\text { Ementa: Dispõe sobre a construção de anexo para } \\
\text { acolher os pacientes que permanecem no corredor do } \\
\text { Hospital Geral de Fortaleza - HGF. }\end{array}$ & 31-10-18 \\
\hline $145 / 17$ & $\begin{array}{l}\text { Ementa: Institui a campanha de divulgação sobre o uso } \\
\text { correto da cadeirinha de segurança no transporte de } \\
\text { crianças no âmbito do estado do Ceará. }\end{array}$ & 04-12-17 \\
\hline $31 / 17$ & $\begin{array}{l}\text { Ementa: Institui a obrigatoriedade de tradutor e } \\
\text { intérprete da língua brasileira de sinais (libras) nas } \\
\text { unidades de saúde do estado do Ceará. }\end{array}$ & $30-03-17$ \\
\hline $32 / 17$ & $\begin{array}{c}\text { Ementa: Dispõe sobre a inclusão de atividades } \\
\text { esportivas e culturais para famílias nas escolas no estado } \\
\text { do Ceará. }\end{array}$ & $30-03-17$ \\
\hline $85 / 17$ & $\begin{array}{l}\text { Ementa: Institui o programa estadual de cuidados } \\
\text { paliativos no âmbito da saúde pública. }\end{array}$ & 08-08-17 \\
\hline $180 / 15$ & $\begin{array}{c}\text { Ementa: Institui residência médica em cirurgia bariátrica } \\
\text { no hospital geral Dr. César Cals }\end{array}$ & $22-09-15$ \\
\hline $65 / 15$ & $\begin{array}{l}\text { Ementa: Dispõe sobre a utilização da energia solar nas } \\
\text { escolas da rede pública estadual. }\end{array}$ & 22-04-15 \\
\hline $16 / 15$ & $\begin{array}{c}\text { Ementa: Dispõe sobre a criação da Feira Anual do Meio } \\
\text { Ambiente nas escolas da rede pública estadual de } \\
\text { ensino. }\end{array}$ & $19-02-15$ \\
\hline $202 / 15$ & $\begin{array}{l}\text { Ementa: Institui, no âmbito do sistema estadual de } \\
\text { ensino do Ceará, o programa escola sem partido. }\end{array}$ & 16-11-15 \\
\hline
\end{tabular}


Fonte: Assembleia Legislativa do Ceará, 2018, on-line.

Dentro desse contexto, é importante lembrar também que as parlamentares escolhidas neste estudo são também mulheres. Essa característica levanta a reflexão de que elas fazem parte da parcela da população que seria beneficiada com as ações de prevenção da violência de gênero. O que fica claro na análise das ações das parlamentares, juntamente com os dados coletados, é a característica contundente que as difere drasticamente: a deputada Dra. Silvana é pastora evangélica e a vereadora Larissa Gaspar é advogada e não usa argumentos religiosos nos seus discursos.

As duas, por serem mulheres, provavelmente conhecem histórias de violência contra outras mulheres e isso deveria sensibiliza-las positivamente no sentido de defenderem o fomento às discussões de gênero para a conscientização contra o machismo. Diante do contexto brasileiro atual, onde muito se discute as dificuldades de enfrentamento contra a violência doméstica e sexual, é inegável que as duas parlamentares reconheçam a problemática e se informem, pela mídia ou por casos reais de relatos que se espalham. Assim, é latente o questionamento: porque há mulheres que são contra as ações que visam à proteção das mulheres, mesmo que através da educação?

A única resposta possível é que a religião conduz o pensamento daqueles que se opõem às discussões de gênero. Escondidos atrás da máscara do conservadorismo, os argumentos que suportam o status quo machista se desenvolvem pautados na religião cristã.

\section{VIOLAÇÃO DOS DIREITOS DA MULHER: CASO MARIELLE NA IMPRENSA}

Segundo Bourdieu (2001), a violência simbólica na vida cotidiana das mulheres geralmente se compõe pelo falso reconhecimento da própria violência da sociedade, ainda que exista uma certa condolência, consentimento e cumplicidade.

É importante entender que os discursos da imprensa se fundem nas relações cotidianas, práticas sociais, processos e disposições institucionais, além de revelar as posições desse grupo editorial e confirmar, em geral, o que a população de prestígio de determinada sociedade considera como valores positivos ou negativos. 
Violência simbólica se representa na imprensa pela construção de discursos que, em geral, limitam a liberdade de expressão da vítima ou alteram suas linhas de determinado segmento contendo outras conotações. De fato, atualmente se analisa que a violência simbólica é permeável, insidiosa e invisível, mas também legitima e sustém outras formas de violência.

Os discursos tradicionais que se aplicam a uma certa sociedade são reverberados em ambientes domésticos e meios de comunicação, que conduzem a um sentido que proporciona tradição, isto é, o que se repete geralmente é tomado como o correto e aplicado a toda a sociedade.

É importante destacar que a compreensão sobre a ação da violência simbólica é uma valiosa ferramenta para gerar polêmicos debates sobre a difusão da violência. Tal feito vai demonstrar que não se trata somente de violência contra a mulher, mas da violência de gênero e seus reflexos que produzem sistemas de vulnerabilidades com ideias sobre raça ou etnia, como acontece com a educação, as condições sociais e a orientação sexual.

A tradição que se mantem em certos veículos de informação vai na contramão das políticas de promoção da igualdade de gênero, determinadas pelas legislações nacionais e acordos internacionais, dirigidos à igualdade de gênero e à promoção da mulher, tal como se determina a Declaração Universal dos Direitos Humanos.

A dinâmica social das práticas cotidianas é a medida usada muitas vezes, de diversas maneiras, pela desigualdade de gênero e micro contexto de poder. Tal feito possibilita diferentes formas de violência para seguir com a violência sistemática dos direitos de determinados grupos sociais. Os processos de violência simbólica são causados por procedimentos institucionais e discursos que permitem que várias formas de violência exercida contra as mulheres sejam aceitas, normalizadas e reproduzidas com impunidade.

Do mesmo modo, Philippe Bourgois (2004) examina como as categorias de violência estrutural, simbólica, cotidiana e íntima - se propõem; tal investigação proporciona uma visão mais clara para as causas subjacentes e tipos de violência que existem nas nossas vidas cotidianas.

O conceito de violência simbólica é útil e ponte teórico para entender a imersão da subordinação, dominação e exploração que muitas mulheres experimentam nas suas vidas cotidianas. A violência simbólica é produzida, reproduzida e considerada legítima através de "esquemas" que são "imanentes ao habitus de todos" (Bourdieu, 2001).

$\mathrm{Na}$ realidade, os esquemas que são "moldados por condições similares e, portanto, objetivamente harmonizados, funcionam como matrizes das percepções, pensamentos e ações de todos os membros da sociedade", estão inscritos nos corpos em forma de 
“disposições", e eles podem, finalmente, sobreviver muito tempo depois do desaparecimento das condições sociais de produção (Bourdieu, 1999).

Portanto, dispositivos - habitus - são inseparáveis das relações e estruturas de poder que as produzem. Os dominados decodificam as relações de dominação a partir da perspectiva dominante - e parecem, pois, "naturais" (Bourdieu, 1999).

Ainda que tenham existido avanços legais e legislativos desde a década de 1990, tais avanços, em alguns casos, não só debilitaram a especificidade e particularidade das experiências das mulheres, como também induzem a um enfoque mais imediato da violência. Dessa maneira, ignoram a complexidade do funcionamento cotidiano da violência contra as mulheres e a necessidade de revisar os valores da igualdade de gênero na prática.

Nesse sentido se sente, todavia, o suporte invisível do poder e controle masculino em espaços públicos e privados e também a natureza endêmica e rotineira dessa violência (Stanko, 2006). Logo, não é necessariamente o ato tangível de violência que impõe uma forma de controle sobre as mulheres, senão a "internacionalização através da socialização contínua" da possibilidade da violência.

Os estudos exploram as opressões intersectarias de raça, classe e gênero para chamar a atenção sobre as formas em que a especialidade do negro, das minorias e das experiências de mulheres étnicas foram mal representadas, descuidadas ou silenciadas (Gill, 2004). Os relatos questionam as identidades de vítima/sobrevivente em narrativas da violência cotidiana, categorizando-as ou discriminando-as pelo ocorrido em suas vidas.

Logo, quando se discute sobre os direitos humanos e especificamente os direitos atribuídos às mulheres, trata-se de uma combinação de conscientização, programas de intervenção e ativismo (Williamson \& Abrahams, 2014).

\subsection{A mulher}

Filha de Marinete e Antônio Francisco da Silva Neto, Marielle Franco nasceu em 1980, no Complexo da Maré, conjunto de favelas situadas na Zona Norte da cidade do Rio de Janeiro.

Em 1998, uma tragédia pessoal marcou a vida de Marielle: uma de suas melhores amigas morre por causa de uma bala perdida em um enfrentamento entre policiais e traficantes da Maré. Esse foi o motivo que a impulsionou a entrar na luta pelos direitos humanos.

Em 2002, a vereadora ingressou na Pontifícia Universidade Católica do Rio de Janeiro, a PUC-RJ, para o curso de Ciências Sociais. Bolsista do PROUNI, o Programa Universidade para Todos, graduou-se e iniciou sua carreira acadêmica no mestrado da Universidade Federal Fluminense, a UFF, onde obteve esse título. Em 2006, começou a atuar na política 
com seu amigo Marcelo Freixo, deputado eleito pelo estado do Rio de Janeiro. Dessa amizade surge uma associação entre eles de dez anos e culminou na eleição de Marielle para a Câmara de Vereadores.

Como parlamentar, Marielle presidiu a comissão de Defesa da Mulher e, quando foi executada, integrava uma comissão para monitorar a intervenção federal na segurança na cidade do Rio de Janeiro. Essa mulher, vereadora de uma das maiores cidades do Brasil, além das suas lutas particulares desde a adolescência, presidia a Comissão dos Direitos das Mulheres da cidade, por ela representava ainda mais as mulheres, incluindo as que foram excluídas pela sociedade.

No dia 14 de março de 2018, foi assassinada em um atentado, em um carro onde estava, com 13 tiros matando também o motorista do veículo Anderson Pedro Gomes. ${ }^{37}$

\subsection{As mulheres}

Ainda nos nossos dias, as mulheres se dão conta pela maior parte da sociedade brasileira como cidadãos de segunda classe. Por isso as lutas pelos seus direitos são ainda necessárias.

Existe um verdadeiro esforço em muitas organizações para que as leis sejam aprovadas e colocadas em prática, como a ONU - Organização das Nações Unidas - especialmente em sua divisão ONU Mulheres que se baseia em vários acordos internacionais que regem o trabalho da ONU Mulheres, entre eles:

- Convenção sobre a eliminação de todas as formas de discriminação com a mulher (CEDAW). A lei de direitos das mulheres é fundamental para todos os programas das Nações Unidas. Mais de 185 países são signatários da Convenção.

- A Declaração e a Plataforma de Ação de Pequim, adotada pelos governos, revisada no Mundial sobre a Mulher, de 1995. Os Estados membros reafirmaram e redesenharam em 2000, durante a revisão global de cinco anos, e se comprometeram a acelerar a revisão e 10 anos, em 2005, e em 2015, na revisão de 20 anos.

\footnotetext{
${ }^{37}$ Os dados da vida e trajetória de Marielle Franco foram complementados com informações da internet, de reportagens aleatórias sobre a vereadora e de outras fontes, principalmente o blog da vereadora: Blog Marielle Franco. https://www.mariellefranco.com.br/quem-e-marielle-franco-vereadora.
} 
- A Resolução 1325 do Conselho de Segurança da ONU sobre as mulheres, a paz e a segurança (2000), voltada às mulheres em risco de violência entre as mulheres e as mulheres na tomada de decisões com relação à prevenção e resolução de conflitos. Posteriormente, nas resoluções de número 1820 (2008), 1888 (2009), 2889 (2009) e 1960 (2010).

- A Declaração do Milênio e os Objetivos do Milênio foram abordados por todos os membros da ONU e definiu um conjunto de metas para promover a igualdade de gênero e combater a pobreza, a fome, questões de saúde, o analfabetismo e a degradação ambiental entre 2000 e $2015^{38}$.

Os acordos mencionados estão em sintonia com os direitos das mulheres, com sua defesa e tomada de poder na sociedade, mas as ações contrárias seguem presentes, mesmo nos países signatários como o Brasil.

\subsection{0 discurso}

Todos os dias milhares de brasileiros perdem a vida em conflitos sociais e civis nas grandes cidades. Os noticiários não bastam para tanto sangue de tanta gente negra, pobre e periférica que muitas vezes não está inserida na criminalidade, mas perde sua vida nos embates por causa do tráfico de drogas.

Para alguns periódicos, essa multidão se coloca nas mesmas condições, e as notícias expressam suas ideias a respeito das vítimas e os autores da violência que não são exatamente a verdade.

No caso das notícias sobre a morte de Marielle, existe algo, além disso. O que se passou foi uma desqualificação da sua pessoa, das mulheres, das negras, das lésbicas, das pobres e das ativistas. Vejamos como uma revista de grande circulação e poder no país dedicou suas páginas ao assassinato da vereadora e construiu sua imagem a partir do evento de sua morte.

\footnotetext{
${ }^{38}$ Material fornecido pela equipe do mandato da Vereadora Marielle Franco em 2018, em contato pessoal direto.
} 


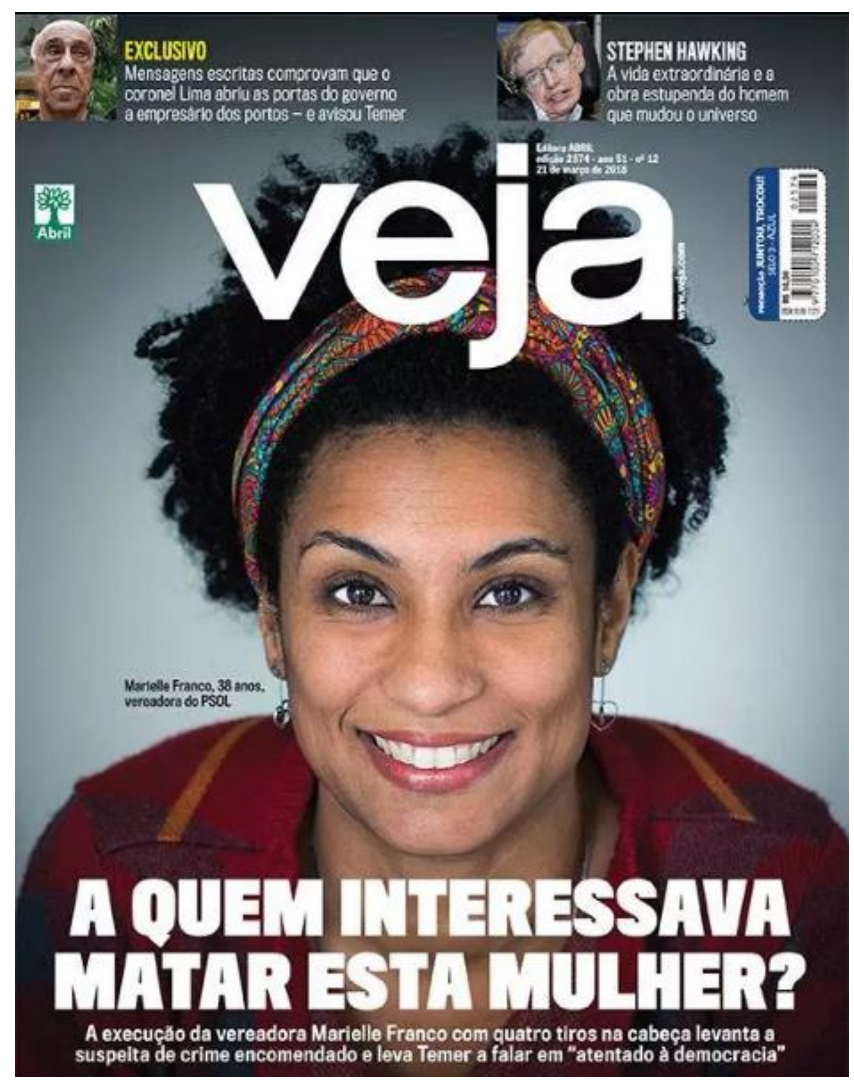

Figura 4 - Capa da Revista Veja sobre o assassinato de Marielle Franco.

Fonte: Revista Veja, edição 2574 de 21/06/2016.

O veículo de comunicação em questão é a Revista Veja (2016), do grupo Editora Abril, é uma revista de distribuição semanal brasileira. Criada em 1968, pelos jornalistas Roberto Civita e Mino Carta, a revista trata de temas variados de alcance nacional e global. Entre os temas tratados com frequência estão questões políticas, econômicas e culturais. Com uma tiragem superior a um milhão de cópias, sendo a maioria de assinaturas, a Revista Veja é o periódico de maior circulação no Brasil.

O enunciado da matéria da revista traz a grande dúvida que até o momento não foi esclarecida pelas autoridades policiais, que, ainda, buscam os assassinos da vereadora e seu motorista. O feito foi rapidamente questionado nas mais distintas publicações, nas quais os periodistas expõem suas opiniões e suposições sobre o porquê e o quê aconteceu. Dentre elas, surgiram muitas questões sobre o que poderia ser a causa central do assassinato e quem foi Marielle.

Na mesma revista da ilustração acima, há a matéria em que uma desembargadora do Estado do Rio de Janeiro fala sobre a vereadora, a partir do que tinha lido nas redes sociais:

\section{DESEMBARGADORA DIZ QUE MARIELLE 'ESTAVA ENGAJADA COM BANDIDOS'}


Com base em fake news, Marília Castro Neves, do TJ-RJ, afirmou em comentário que vereadora morta 'foi eleita pelo Comando Vermelho'

Por Da redação Publicado em 16 mar 2018, 22 h46.

A desembargadora Marília Castro Neves, do Tribunal de Justiça do Rio de Janeiro (TJ-RJ), afirmou no Facebook que a vereadora Marielle Franco (PSOL), assassinada na quarta-feira, estava "engajada com bandidos". O comentário foi feito como resposta a uma postagem do advogado Paulo Nader, que chamou a parlamentar de "lutadora dos direitos humanos".

Ao fazer o post, a desembargadora se baseou inadvertidamente em fake news (notícias falsas) que correm pela web. À coluna da jornalista Mônica Bergamo, na Folha de S. Paulo, que revelou o comentário, Marília afirmou que não conhecia Marielle até saber de sua morte e que postou informações "que leu no texto de uma amiga". Ela criticou o que chamou de "politização" do assassinato. "Outro dia uma médica morreu na Linha Amarela e não houve essa comoção. E ela também lutava, trabalhava, salvava vidas".

Ela escreveu em seu comentário:

“A questão é que a tal Marielle não era apenas uma 'lutadora'; ela estava engajada com bandidos! Foi eleita pelo Comando Vermelho e descumpriu 'compromissos' assumidos com seus apoiadores”, escreveu a magistrada, que insinuou que a morte da vereadora foi consequência de cobrança de "dívidas". "Qualquer outra coisa diversa é mimimi da esquerda tentando agregar valor a um cadáver tão comum quanto qualquer outro", finalizou (Revista Veja, 2018).

À luz da Análise de Discurso, é possível entender que o texto revela mais as posições das mulheres na sociedade, além de evidenciar que a principal diretriz da CEDAW não é colocada em prática no Brasil e que, o que está definido como discriminação contra as mulheres, segue sendo a realidade mais comum:

Toda distinção, exclusão ou restrição baseada no sexo e que tenha por objetivo ou resultado prejudicar ou anular o reconhecimento, acontecimento ou exercício pela mulher, independente do seu estado civil, com base na igualdade do homem ou da mulher, dos 
direitos humanos e liberdades fundamentais nos campos político, econômico, social, cultural e civil ou em qualquer outro campo (ONU, 1979).

Pela análise da notícia, tomando em conta a sua construção: é uma notícia publicada na seção Brasil da revista Veja, no dia 16 de março de 2018. Disso se tira que a revista foi lançada três dias depois do assassinato. Ainda mais: o texto principal foi tomado de uma publicação da rede social Facebook. Paulo Nader escreveu, na sua página, sua opinião sobre a comoção com respeito ao assassinato, depois Marília Castro Neves também o fez.

De acordo com o texto, a vereadora Marielle Franco foi a quinta vereadora com mais votos na sua cidade, há anos era ativista da causa dos direitos humanos e das mulheres na sua comunidade. Mas estava no segundo ano do exercício do mandato, em um partido criado em 2004, ou seja, era pouco conhecida no cenário político fora da sua cidade. Além disso, sabe-se que no Brasil a corrupção e a associação ao crime são comuns, incluindo a associação a criminosos narcotraficantes para eleger políticos que os represente e garantam seus interesses.

No Brasil se vive um momento de muita incerteza política e de polarização entre a esquerda e a direita, surgida por um impeachment presidencial visto como golpe por metade da população. Somado a isto, o assassinato se deu de forma misteriosa e com poucos indícios da autoria, por isso surgiram muitas duvidas sobre a vereadora e as possíveis causas da sua morte e de seu motorista.

As mulheres, então, seguem fora da igualdade em todos os campos. São a maioria nas universidades, mas seus salários são menores, ainda que existam leis laborais que o proíbam (artigo 461 da Consolidação das Leis do Trabalho), são minoria na representação política, mesmo com a Lei de Cotas de 2009.

No lugar de fala que é colocado na matéria (Veja, 2018), a desembargadora Marília de Castro Neves é uma advogada que ocupa cargo de desembargadora. É uma mulher branca, aristocrática, filha de militares. Tem 61 anos e é conhecida no seu ambiente de trabalho por não controlar as palavras.

Ao final, na matéria a fala da desembargadora diz mais que somente sua opinião ou ponto de vista. Fazer julgamento sobre uma pessoa que não se conhece, por meio de dúvidas implantadas, é uma característica da aristocracia que sempre esteve no poder e que não pode lidar com certos fatos. Um desses é o fato de que as pessoas criam a "politização" do assassinato e busquem pelos culpados, não só busquem como cobrem às autoridades que suas ações obscuras venham à luz e que os crimes contra as pessoas pobres, negras e periféricas não sejam um cadáver a mais (Veja, 2018). 
O texto publicado pela desembargadora, baseado em notícias supostamente falsas, estampava em suas entrelinhas um preconceito comum à aristocracia, quando se refere a pessoas que pertencem à parcela excluída da sociedade: segundo ela, a vereadora estaria engajada com bandidos, teria sido eleita a mando de uma facção criminosa e que o seu assassinato resultaria de ajuste de contas por não cumprir supostos compromissos. Como se fosse impossível que uma pessoa, cujas raízes eram simplórias, não pudesse ter boa índole e ter vencido por méritos próprios, tais como estudo, determinação e trabalho.

Ao final, a desembargadora compara Marielle a uma médica. Medicina é uma carreira muito valorizada no Brasil, país que lida com uma grave desigualdade econômica, e, mesmo que tenha avançado no acesso à educação, ainda dispõe de um imenso abismo de desigualdade financeira no que concerne à remuneração paga às profissões (uma médica ganha muito mais que uma socióloga).

A fala que contém todos os preconceitos é de uma mulher com amplo conhecimento sobre leis - já que se trata de uma desembargadora - e sobre os crimes que comete quando os expõe publicamente. É uma mulher que não representa as outras mulheres, senão o poder, ao posicionar-se do mesmo lado daqueles que julgam a dor dos outros como "vitimismo da esquerda tentando agregar valor a um cadáver tão comum como qualquer outro" (apud Veja, 2018).

Fica evidente que há cotidianamente violações aos direitos das mulheres e os violadores estão fortemente empoderados e estabelecidos nos espaços de poder. Assim, as políticas de igualdade necessitam ser intensificadas. A ONU tem feito declarações contrárias à impunidade no Brasil e em favor do esclarecimento do assassinato da vereadora.

Representantes de direitos humanos da ONU apontaram, em comunicado oficial, que o assassinato de Marielle é alarmante, já que tem o objetivo de intimidar a todos aqueles que lutam pelos direitos humanos e pelo Estado de Direito no Brasil.

Os especialistas da ONU pedem investigação rápida e imparcial dos assassinatos, alertando que a execução de Marielle é um sintoma assustador dos atuais níveis de violência no país. "Marielle foi uma extraordinária defensora de direitos humanos. Ela defendeu os direitos dos negros, das populações LGBTI, das mulheres e dos jovens das favelas mais pobres do Rio. Marielle será lembrada como um símbolo de resistência para comunidades marginalizadas historicamente no Brasil”, diz o comunicado. (ONU Mujeres, 2018).

No mesmo comunicado eles lembram que Marielle criticou o uso da força militar no Rio de Janeiro e a intervenção federal na segurança pública do estado. Pedem ainda às autoridades brasileiras mais proteção de defensores de direitos humanos do país. "Pedimos às autoridades brasileiras que usem este momento trágico para revisar suas escolhas em 
promoção de segurança pública e, em particular, para intensificar substancialmente a proteção de defensores de direitos humanos no país".

Os especialistas da ONU recordam que como vereadora, Marielle era membro da comissão que acompanha a intervenção no Rio de Janeiro e dias antes de sua morte denunciou o uso da força pela Polícia Militar na Favela de Acari, na zona norte da cidade.

Os representantes da ONU ressaltaram ainda que, em um final de semana, durante uma operação policial na Rocinha, na zona sul do Rio, oito pessoas morreram e que a segurança pública não deve ser praticada nunca em detrimento dos direitos humanos. "Respostas repressivas que miram e marginalizam pessoas pobres e negras são inaceitáveis e contraprodutivas", enfatizaram.

Concluindo, a mulher brasileira alcançou, em um século, níveis de poder e participação na sociedade, antes inimagináveis. Muitas conquistas foram obtidas pelas brasileiras, principalmente a partir da Constituição de 1988 (Brasil, 1988), quando feministas e mulheres de várias organizações se reuniram para entregar aos constituintes a Carta das Mulheres Brasileiras, que resultou na conclusão de muitas reivindicações. Destaca-se o artigo 5, que trata da igualdade de direitos entre mulheres e homens.

No mundo do trabalho, as mulheres estão mais qualificadas e leis como a de número 110/2011 foi promulgada em 2012, com punições a empresas que diferenciarem salários entre homens e mulheres para as mesmas funções, têm feito justiça a essa presença de forma paritária. As discussões sobre a licença maternidade, a aposentadoria, o aborto, e a saúde da mulher, entre outros temas, passam a formar parte da agenda política. Quanto à escolaridade, as pesquisas apontam que as mulheres têm mais anos de estudos que os homens, o que possibilita o crédito das melhores vagas no mercado de trabalho.

Com respeito às políticas sociais, a mulher de comprovada vulnerabilidade tem obtido autonomia financeira graças a programas do governo com o Bolsa Família cujo número de beneficiadas chega a $70 \%$ do total. Também é necessário lembrar as políticas de gênero implantadas pela Secretaria Nacional de Políticas para as Mulheres, criada em 2003 e que se responsabiliza pelas políticas públicas para mulheres em uma visão de integração em rede, com as áreas de saúde, educação e transporte. Os programas como o pacto pela não violência, políticas para Igualdade de Gênero e Brasil Carinhoso, entre outros, formam parte da proposta de inclusão social e tem, nas mulheres, seu público alvo.

A luta pelo fim da violência contra a mulher, cenário das lutas das mulheres desde os anos de 1960, encontrou esperança na promulgação da Lei Maria da Penha, em 2006. Sem dúvida, a efetiva aplicação com rigor de lei não se tem realizado, haja visto o alto número de feminicídios no país. Todavia, há muito que fazer para colocar fim na violência contra a 
mulher, mas o grande salto da Lei Maria da Penha ${ }^{39}$ é a troca de enfoque, no que se tem por violência no âmbito privado e se trata como responsabilidade do poder público e de toda a sociedade. Já não se aceitam as justificativas como "matou por amor", "matou por honra" ou "em briga de marido e mulher ninguém mete a colher".

Ainda que exista uma rede de enfrentamento à violência contra a mulher, há muitas cidades que, todavia, não se tem beneficiado com a sua presença. Quando existe, carece de pessoas especializadas e infraestrutura para atender às mulheres. Nos institutos médicos legais a situação se torna ainda mais embaraçosa, já que a mulher, que tem suficiente vergonha por ter sofrido violência, se vê exposta a um tratamento desumano.

Por fim e a cabo, se percebe que existe uma clara contradição no país: ao mesmo tempo em que as mulheres estão mais qualificadas e há leis que finalmente as favorecem, existe um machismo cultural e ideológico que coloca a mulher de forma inferior, desqualificando-a quando atua na política, exigindo mais dela no mundo do trabalho e assassinando-a por se sentir dono de seu corpo e de sua alma, além de tratá-la em seus atos e discursos com vários tipos de violências, incluindo a simbólica. Esse tipo de situação é muito danosa, mas, na maioria das situações é difícil de comprovar, e por isso causa mais estrago, em muitos casos, levando anos para recuperar as vítimas.

É possível concluir que nos discursos cotidianos a imagem da mulher segue sendo moldada para servir certos grupos sociais nos quais predomina o ponto de vista machista e conservador. Inclusive nos discursos de outras mulheres e nos meios de comunicação aparentemente neutros. Assim, vivemos sob a ideologia de que a mulher, sobretudo a negra, a pobre, a periférica, é um objeto a mais da representação imaginária que interpela os sujeitos a tomar posição em determinados lugares na sociedade, mas cria a ilusão de liberdade do sujeito ainda que este lugar já esteja determinado.

${ }^{39}$ LEI 11.340/2006. Texto Integral. Disponível em: http://www.observe.ufba.br/lei_integra. 


\section{MOVIMENTOS PELA EDUCAÇÃO E CONSTRUÇÃO LEGAL DO TEMA NO BRASIL}

A educação no Brasil sofre ataques desde a redemocratização política em 1985. Disputas pela hegemonia ideológica dos conteúdos ofertados em sala de aula ocorrem com o objetivo de realizar a manutenção do sistema vigente, o status quo, o poder da elite e a contenção de possíveis rupturas políticas.

Nos últimos anos, esse cenário é visto com especial atenção, pois a relação entre escola e democracia está ameaçada. A emenda constitucional apelidada de "Emenda do Fim do Mundo”, aprovada no Governo Michel Temer em 2015, congela os gastos públicos com saúde e educação por 20 anos. Essa medida impede que seja respeitado o Plano Nacional de Educação aprovado em 2014 no Congresso Nacional (Brasil, 2014), que estabelece, dentre outras providências, o aumento gradativo de investimentos de recursos na educação pública.

A Confederação Nacional da Educação - CONAE - também foi modificada e passou a receber a intervenção do Ministério da Educação, a partir de 2015, modificando a composição do órgão sem debate prévio. No mesmo período, surge o "Escola sem Partido", um movimento da sociedade civil que visa a aprovação da regulação dos conteúdos didáticos das escolas, limitando o livre exercício docente (Saviani, 2016).

Ocorre que a educação nacional passa por mudanças e disputas importantes. As proposições de normas legislativas para o controle do ensino estão em debate e movimentos democráticos se opõem à onda autoritária surgida em 2015. Nessa seção será tratado esse tema e expostas as principais correntes que discutem a educação no país, começando pela explicação da legislação e em seguida os movimentos em torno da questão.

\subsection{Perspectivas legais para a educação nacional no Brasil: PNE e BNCC}

Desde a Constituição de 1988, o país tem a obrigação de planejar plurianualmente o ensino como meio de garantir o futuro de crianças, jovens e adultos. Assim, os municípios, estados e Distrito Federal devem seguir, em seus planejamentos, as diretrizes e metas do BNCC e do PNE (Brasil, 2014).

Segundo Valente e Romano (2002), os textos propostos durante a década de 1990 para propor diretrizes da educação brasileira pecaram em não conseguir estipular estratégias de ação para tornar possíveis objetivos simples de avanço dos índices de ensino nacionais. $\mathrm{O}$ Fundo Monetário Internacional - FMI - exigiu que o governo alcançasse objetivos de 
educação, forçando a criação de uma política nacional que se adequasse aos anseios internacionais.

Surge então, durante o Governo Fernando Henrique Cardoso, uma disputa entre forças, um lado defende a elaboração de políticas universalistas, de investimentos e de desenvolvimento, enquanto que de outro lado havia a defesa de aprovação de um documento mais genérico e inexpressivo, que daria liberdade ao setor privado de ensino. $\mathrm{O}$ presidente aprova, então, um texto simples, sem a proposição de estratégias, chamado por Valente e Romano de "carta de intenções" por seu caráter vago (Valente \& Romano, 2002).

A pressão social, os profissionais de ensino e forças políticas interessadas no desenvolvimento da educação forçaram a elaboração de um documento com conteúdo mais sólido e ações efetivas para o avanço do ensino para o decênio seguinte. O Plano tardou a ser concluído, ficando as metas definidas para o período correspondido entre 2014 e 2024. A execução das leis será de responsabilidade do Ministério de Educação, com avaliação e monitoramento da Comissão de Educação, Cultura e Esporte do Senado Federal, do Conselho Nacional de Educação e do Fórum Nacional de Educação (Observatório do PNE, 2018).

Na CARTA CAPITAL, sob o título de "Gênero e ensino religioso juntos na base curricular", discute-se sobre a BNCC.

A projeção de um Plano para planejar avanços no ensino no país é um avanço, no sentido de que estabelece metas e propõe a reflexão sobre os rumos que o Brasil pretende tomar. Junto com a reflexão, é natural que surjam as contradições e debates.

\subsubsection{O Plano Nacional de Educação}

O atual texto aprovado levou quatro anos para sua finalização, após discussões e disputas no congresso nacional brasileiro. O PNE anterior findou sua vigência em 2010, o que significa que o atual Plano deveria ter sido iniciado em 2011.

Em 2010, o projeto de lei n. 8.053 tramitou no Congresso, obtendo cerca de 3 mil propostas de emendas (Aquino, 2015). Os maiores entraves do texto foram sobre o financiamento da educação.

Aprovado pela lei 13.005, de 25 de junho de 2014 (Brasil, 2014), tem vigência de 10 anos a contar da data de publicação da lei e visa cumprir metas e estratégias para a educação nacional pública e privada. Dividido em diretrizes e metas, o texto tem por objetivo fazer respeitar a Constituição Federal. 
Seu artigo primeiro cita o artigo 214 da Constituição de 1988, segundo a qual estabelece que deverá ser elaborado um plano plurianual para articulação do sistema de educação nacional, com metas, estratégias e objetivos para assegurar a manutenção e desenvolvimento do ensino no país para erradicação do analfabetismo, universalização do atendimento escolar, melhoria da qualidade, formação para o trabalho, formação científica, humana e tecnológica (Brasil, 1988).

De acordo com o Plano, são suas diretrizes:

I - erradicação do analfabetismo;

II - universalização do atendimento escolar;

III - superação das desigualdades educacionais, com ênfase na promoção da cidadania e na erradicação de todas as formas de discriminação;

IV - melhoria da qualidade da educação;

$\mathrm{V}$ - formação para o trabalho e para a cidadania, com ênfase nos valores morais e éticos em que se fundamenta a sociedade;

VI - promoção do princípio da gestão democrática da educação pública;

VII - promoção humanística, científica, cultural e tecnológica do País;

VIII - estabelecimento de meta de aplicação de recursos públicos em educação como proporção do Produto Interno Bruto - PIB, que assegure atendimento às necessidades de expansão, com padrão de qualidade e equidade;

IX - valorização dos(as) profissionais da educação;

$\mathrm{X}$ - promoção dos princípios do respeito aos direitos humanos, à diversidade $\mathrm{e}$ à sustentabilidade socioambiental.

As metas do Plano correspondem a um conjunto de 20 pontos, com proposições de estratégias de como alcançar esses objetivos. As metas, de forma resumida, são:

Tabela 3

\section{Metas do Plano Nacional de Educação.}

Meta 1 - Universalização do ensino na pré-escola e ampliação da oferta em creches.

Meta 2 - Universalização do ensino fundamental de nove anos e garantir que os alunos concluam na idade recomendada.

Meta 3 - Universalizar o ensino médio e garantir a taxa de $85 \%$ a taxa líquida de matrículas.

Meta 4 - Universalizar o ensino para a população, de 4 a 17 anos, com deficiência, superdotação e transtornos de desenvolvimento, com estruturas para atender suas 
necessidades.

Meta 5 - Alfabetizar todas as crianças até o terceiro ano do ensino fundamental.

Meta 6 - Atender em tempo integral em escola pública 50\% dos matriculados no ensino básico.

Meta 7 - Fomentar a melhora do ensino em todas as etapas, tendo como referência a avaliação do Índice de Desenvolvimento da Educação Básica - IDEB.

Meta 8 - Elevar a média de escolaridade da população de 18 a 29 anos.

Meta 9 - Elevar a taxa de alfabetização da população com 15 anos ou mais para $93,5 \%$ até 2015.

Meta 10 - Oferecer educação de jovens e adultos integrada à formação profissional.

Meta 11 - Triplicar as matrículas da educação profissional e técnica, sendo $50 \%$ da expansão no ensino público.

Meta 12 - Elevar a taxa básica de educação superior para 50\%.

Meta 13 - Ampliar a proporção de mestres e doutores do corpo docente de ensino superior para $75 \%$, sendo $35 \%$ para doutores.

Meta 14 - Elevar o número de matrículas em cursos de pós-graduação stricto sensu.

Meta 15 - Realizar juntamente com os estados e municípios a política de formação dos profissionais de educação, garantindo cursos de licenciatura e formação específica.

Meta 16 - Formar 50\% dos professores da educação básica em nível de pósgraduação.

Meta 17 - valorizar os professores da rede pública e equiparar os salários aos rendimentos médios de profissionais com o mesmo nível de escolaridade

Meta 18 - elaborar planos de carreira para os profissionais da educação básica e superior da rede pública.

Meta 19 - assegurar a gestão democrática associada à consulta à comunidade escolar.

Meta 20 - Ampliar o investimento público em educação pública em todos os níveis

Fonte: elaboração própria com dados do Plano Nacional de Educação, 2014. 
A cada dois anos, durante a vigência deste Plano, deverão ser realizados estudos de monitoramento e avaliação pelo Instituto Nacional de Estudos e Pesquisas Educacionais Anísio Teixeira - INEP (Brasil, 2014).

\subsubsection{BNCC}

A Constituição de 1988 (Brasil, 1988) prevê a existência de um a base nacional para a Educação Infantil e Ensino Fundamental para se adequar a níveis mais bem qualificados em competição com o cenário internacional.

A Base Nacional Comum Curricular (BNCC) é uma norma elaborada pelo Ministério da Educação do Brasil e pelo Conselho Nacional de Educação que define o conjunto de matérias a serem desenvolvidas na Educação Básica, de forma que todos os alunos devam desenvolver as mesmas habilidades ao longo das etapas escolares (BRASIL, 2017). O intuito é proporcionar o alinhamento das escolas com relação ao conteúdo das disciplinas ensinadas, para superar as fragmentações educacionais.

O texto da BNCC propõe o desenvolvimento de dez competências gerais, onde se entende competência como "a mobilização de conhecimentos (conceitos e procedimentos), habilidades (práticas, cognitivas e sócio emocionais), atitudes e valores para resolver demandas complexas da vida cotidiana, do pleno exercício da cidadania e do mundo do trabalho" (BRASIL 2017).

São as seguintes competências a serem estimuladas na Educação Básica, que compreende Educação Infantil, Ensino Fundamental e Ensino Médio:

Tabela 4

\section{Competências da BNCC.}

\section{COMPETÊNCIAS GERAIS DA BASE NACIONAL COMUM CURRICULAR}

1. Valorizar e utilizar os conhecimentos historicamente construídos sobre o mundo físico, social, cultural e digital para entender e explicar a realidade, continuar aprendendo e colaborar para a construção de uma sociedade justa, democrática e inclusiva.

2. Exercitar a curiosidade intelectual e recorrer à abordagem própria das ciências, incluindo a investigação, a reflexão, a análise crítica, a imaginação e a criatividade, para investigar causas, elaborar e testar hipóteses, formular e resolver problemas e criar soluções (inclusive tecnológicas) com base nos conhecimentos das diferentes áreas. 
3. Valorizar e fruir as diversas manifestações artísticas e culturais, das locais às mundiais, e também participar de práticas diversificadas da produção artístico-cultural.

4. Utilizar diferentes linguagens - verbal (oral ou visual-motora, como Libras, e escrita), corporal, visual, sonora e digital -, bem como conhecimentos das linguagens artística, matemática e científica, para se expressar e partilhar informações, experiências, ideias e sentimentos em diferentes contextos e produzir sentidos que levem ao entendimento mútuo.

5. Compreender, utilizar e criar tecnologias digitais de informação e comunicação de forma crítica, significativa, reflexiva e ética nas diversas práticas sociais (incluindo as escolares) para se comunicar, acessar e disseminar informações, produzir conhecimentos, resolver problemas e exercer protagonismo e autoria na vida pessoal e coletiva.

6. Valorizar a diversidade de saberes e vivências culturais e apropriar-se de conhecimentos e experiências que lhe possibilitem entender as relações próprias do mundo do trabalho e fazer escolhas alinhadas ao exercício da cidadania e ao seu projeto de vida, com liberdade, autonomia, consciência crítica e responsabilidade.

7. Argumentar com base em fatos, dados e informações confiáveis, para formular, negociar e defender ideias, pontos de vista e decisões comuns que respeitem e promovam os direitos humanos, a consciência socioambiental e o consumo responsável em âmbito local, regional e global, com posicionamento ético em relação ao cuidado de si mesmo, dos outros e do planeta.

8. Conhecer-se, apreciar-se e cuidar de sua saúde física e emocional, compreendendo-se na diversidade humana e reconhecendo suas emoções e as dos outros, com autocrítica e capacidade para lidar com elas.

9. Exercitar a empatia, o diálogo, a resolução de conflitos e a cooperação, fazendo-se respeitar e promovendo o respeito ao outro e aos direitos humanos, com acolhimento e valorização da diversidade de indivíduos e de grupos sociais, seus saberes, identidades, culturas e potencialidades, sem preconceitos de qualquer natureza.

10. Agir pessoal e coletivamente com autonomia, responsabilidade, flexibilidade, resiliência e determinação, tomando decisões com base em princípios éticos, democráticos, inclusivos, sustentáveis e solidários. 
As leis que definem os conteúdos de ensino são uma preocupação para os docentes nacionais e para os interessados na condução do conhecimento. Isso porque a determinação dos currículos pode gerar a ideia de limitação da ação educativa nas escolas. Questões sobre quem decide o que ensinar e como ensinar por grupos específicos direciona o conhecimento por vieses não generalistas.

\subsection{Movimentos pela Educação}

Tanto a proposição de normas quanto os movimentos que acompanham o tema estão inseridos na concepção democrática de Estado. Não haveria a possibilidade de existência da reflexão se o autoritarismo político a proibisse. Assim, pode-se pensar que a ação política nos dois sentidos - pelas mudanças legais ou pela ação direta social - estão relacionados a ideia de cidadania. Exercer a ação política como participação é exercer a cidadania e compreender que cada pessoa pertence ao sistema social. Não há democracia sem cidadania.

No contexto brasileiro, as lutas pela educação participam da ideia do exercício da cidadania, uma vez que buscam mudanças a partir da intervenção social direta. O PNE e o BNCC tiveram a intensa participação da opinião pública nas modificações dos textos até o texto final, como se vê no trabalho desta tese.

Na década de 1980, surge a ideia da "educação pela e para a cidadania". Segundo o autor Paulo Freire (apud Gadotti, 2000):

Escola cidadã é aquela que se assume como um centro de direitos e de deveres. O que caracteriza é a formação para a cidadania. A Escola Cidadã, então, é a escola que viabiliza a cidadania de quem está nela e de quem vem a ela. Ela não pode ser uma escola cidadã em si e para si. Ela é cidadã na medida mesma em que se exercita na construção da cidadania de quem usa o seu espaço. A Escola Cidadã é uma escola coerente com a liberdade. É coerente com o seu discurso formador, libertador. É toda escola que, brigando para ser ela mesma, luta para que os educandos e educadores também sejam eles mesmos. E como ninguém pode ser só, a Escola Cidadã é uma escola de produção comum do saber e da liberdade. É uma escola que vive a experiência tensa da democracia (Paulo Freire apud Gadotti, 2000). 
O autor propõe, no livro Pedagogia da Autonomia (Freire, 1997), que o indivíduo deve ter respeitados a sua autonomia e dignidade como imperativos éticos obrigatórios, não uma questão opcional que se pode dar ou não aos outros.

A Escola Cidadã nasceu no final da década de 1980, quando a educação pública popular passou a ser pensada como elemento importante no desenvolvimento nacional. Com o intuito da sua implementação em âmbito municipal, o movimento teve sua experiência principal na gestão da Prefeita Luiza Erundina, na cidade de São Paulo, por Paulo Freire. A prática descende das experiências ocorridas nas escolas dos Estados Unidos, que levavam a ideia de apropriação da cidadania política aos negros, na disseminação da importância do voto entre os jovens, na década de 1930. Buscava-se instrumentalizar a ação política, portanto (Gadotti, 2000).

No início da década de 1980, o Brasil experimentava uma efervescência dos movimentos sociais que lutavam pelos seus direitos, principalmente a população de menor poder aquisitivo que demandavam ações do Estado para minimizar as desigualdades sociais como os movimentos pela terra, movimentos sindicais e trabalhistas. Nesse contexto, onde havia grande engajamento social por demandas populares, causado pelo desgaste advindo da ditadura militar (1964-1985), os debates políticos pela democracia se fortaleciam. A militância pela educação popular aparece como alternativa para a construção da consciência política e cidadã da população.

A Escola Cidadã contribuía para a criação da "Nova Cidadania", para fomentar a organização social para a defesa de sua autonomia e direitos. Assim, propõe inclusive que os diretores das escolas sejam escolhidos por meio de eleição entre a comunidade, professores, alunos e funcionários da unidade escolar (Gadotti, 2000). As experiências se espalharam pelo país e fomentaram outras ideias relacionadas à ação política e social, pela valorização da educação e da cidadania.

A pesquisa de Peroni e Caetano (2016) constata que representantes do ensino privado têm sido protagonistas nas decisões da BNCC. Como exemplo, tem-se o movimento 'Todos pela Educação', onde os empresários influenciam o governo federal na agenda educacional e também vende produtos ligados à área. Por esse e outros movimentos caminham em direção um possível rumo à privatização do ensino brasileiro.

A constituição de um ensino que não respeite as particularidades regionais, aplicado a todo território sem dar conta das graves diferenças culturais, fere a formação dos alunos. Os professores também precisam ter respeitadas as suas vozes e garantida a sua autonomia de ensino em sala. 
Em contrapartida, em 2013, surge o Movimento pela Base Nacional Comum. Formado por profissionais que atuam na área de educação e interessados na mesma, contam com a participação de membros ligados à iniciativa pública e privada, como "Fundação Lemann, principal apoiadora e articuladora da reforma curricular, Cenpec, Instituto Natura, Instituto Ayrton Senna, Instituto Unibanco, Fundação SM, Insper e Instituto Fernando Henrique Cardoso" (Peroni \& Caetano, 2015).

\subsubsection{O movimento Escola sem Partido}

Idealizado no ano de 2004, pelo advogado Miguel Nagib ${ }^{40}$, o movimento Escola sem Partido ganha proporção nacional e visibilidade na mídia em 2014. Os efeitos dos protestos de 2013 no Brasil, que levaram milhares de pessoas às ruas por diversas demandas difusas e que culminaram nos protestos que contribuíram para o impeachment da Presidenta Dilma Roussef, criaram no país um ambiente de polaridade política. A mídia televisiva e escrita balizaram os debates acerca dos rumos políticos do país, causando um sentimento de medo e reforçando o conflito entre pessoas de posições diferentes. As pessoas foram expostas a um debate hostil, onde o debate político foi trocado pela intolerância política ${ }^{41}$. Conforme noticiado

O programa tramita em projetos de lei no Senado e na Câmara. Em pelo menos dez estados, incluindo o Ceará, há propostas do mesmo teor nas assembleias legislativas. Os textos traçam deveres dos professores na educação básica da rede pública. Entre eles, não promover em sala de aula os próprios interesses e concepções ideológicas, religiosas, morais, políticas e partidárias. $\mathrm{O}$ movimento quer que sejam cumpridos pelos docentes deveres que já existem, segundo o advogado Miguel Nagib, coordenador da iniciativa nascida em 2004. Naquele ano, houve experiência que ele considerou negativa na escola da filha: um professor de história falou de Che Guevara e São Francisco de Assis como duas pessoas que abriram mão de tudo pela ideologia. Desde então, Nagib coleta depoimentos de alunos, pais e professores, argumentando que a doutrinação ideológica existe e é ilegal. Para Nagib, há um

\footnotetext{
${ }^{40}$ As propostas e justificativas para o projeto Escola sem Partido, propostas por Nagib, estão nos anexos da tese e foram retiradas da internet.

${ }^{41}$ A problemática do contexto social que levou o Brasil à polaridade política está na introdução da tese e é discutida brevemente.
} 
desequilíbrio quando o professor se aproveita da posição de autoridade e da audiência cativa dos alunos (O Povo, "Projetos de lei. Educação sem ideologia?", 31/07/2016).

O idealista do projeto afirma que existem muitas evidencias de práticas abusivas da função docente, de "doutrinação" e "propaganda comunista", partidária e ideológica ${ }^{42}$. O site da internet do movimento e a página da rede social Facebook explicam os termos do projeto e suas justificativas. Segundo ele, a autoridade dos pais é usurpada quando o ambiente escolar apresenta conteúdos diferentes ou contrários aos conceitos compartilhados em $\operatorname{casa}^{43}$.

Em 2014, o deputado Flávio Bolsonaro (PSL) ${ }^{44}$ levou a proposta de lei para a Assembleia Legislativa do Rio de Janeiro. Na mesma época, outros projetos se espalhavam pelo Brasil com o mesmo conteúdo.

Com o processo de impeachment da ex-presidente Dilma Rousseff e um país dividido politicamente - como ficou claro nas urnas em 2014 - o movimento Escola sem Partido ganha força no país, sob o discurso de que professores não podem transmitir aos estudantes nenhum tipo de posicionamento, seja político, ideológico ou religioso. As ideias do movimento transformaram-se em projetos de lei em tramitação no Congresso Nacional, estados e municípios. (...) O movimento Escola sem Partido foi fundado em 2004 pelo procurador de Justiça de São Paulo, Miguel Nagib. Em 2014, ganhou força quando se transformou no Projeto de Lei 2974/2014, apresentado na Assembleia Legislativa Estadual do Rio de Janeiro (Alerj). O movimento disponibilizou, então, dois modelos de projetos de lei, estadual e municipal. Em âmbito nacional, projetos semelhantes tramitam tanto na Câmara dos Deputados - Projeto de Lei (PL) 867/2015, de autoria do deputado Izalci Lucas (PSDBDF) - quanto no Senado Federal - Projeto de Lei do Senado (PLS)

\footnotetext{
${ }^{42}$ Ver também EL PAÍS. (2016, 25 junho). "O professor da minha filha comparou Che Guevara a São Francisco de Assis" - Movimento Escola Sem Partido foi criado a partir da indignação de um pai com um professor. Disponível em: <http://brasil.elpais.com/brasil/2016/06/23/politica/1466654550_367696.html> Acesso em 25 jul. 2017.

${ }^{43}$ Essas ideias e justificativas estão nas páginas da internet e da rede social: $\underline{\text { www.escolasempartido.org e no }}$ Facebook pelo @escolasempartidooficial.

${ }^{44}$ Flávio Bolsonaro é filho do Presidente eleito em 2018, Jair Bolsonaro.
} 
193/2016, de autoria do senador Magno Malta (PR-ES). Em consulta pública aberta no site do Senado Federal, uma maioria manifesta-se contra o projeto de lei, por uma pequena diferença. Ao todo, até sexta-feira (14), $183.604(48,1 \%)$ eram favoráveis, enquanto 197.765 (51,9\%) eram contrários (O Povo, "Movimento Escola sem Partido ganha força no país, mas divide professores", 31/03/2016).

A argumentação de seus apoiadores é de que a escola pública tem sido alvo de uma doutrinação comunista exercida, principalmente, pelos professores de matérias da área de ciências humanas. Os docentes seriam responsáveis por disseminar a ideologia comunista aos jovens de todas as faixas etárias contra a moral e os bons costumes ${ }^{45}$.

Carregado de valores morais cristãos, o discurso em defesa do Escola sem Partido afirma que as escolas devem se preocupar com a formação moral dos alunos, direcionando o que deve ser ensinado de acordo com determinadas visões de mundo. A influência das religiões cristãs é o ponto principal do texto, onde, por exemplo, recomenda-se o ensino religioso e a teoria do criacionismo - baseada na bíblia que diz que Deus teria criado o homem do barro - em detrimento da Teoria da Evolução das Espécies - a única cientificamente comprovada. Outro tema forçadamente carregado de moralidade pelos membros deste movimento é a educação sexual nas escolas (Nicolazzi, 2016).

As propostas de leis para os âmbitos federal, estadual e municipal, assim como modelos de decretos, estão disponíveis em um site na internet, para download sem a necessidade de elaboração do parlamentar proponente. Não são expostas muitas informações na página, há um texto de justificativas, uma área de perguntas e respostas e uma outra área com propostas de perguntas a serem feitas para jornalistas e questionadores do projeto com as respostas prontas.

As ideias principais estão dispostas no site do movimento e são as seguintes:

\footnotetext{
${ }^{45}$ As notícias dos jornais estão nos apêndices desta tese.
} 


\section{Deveres do professor}

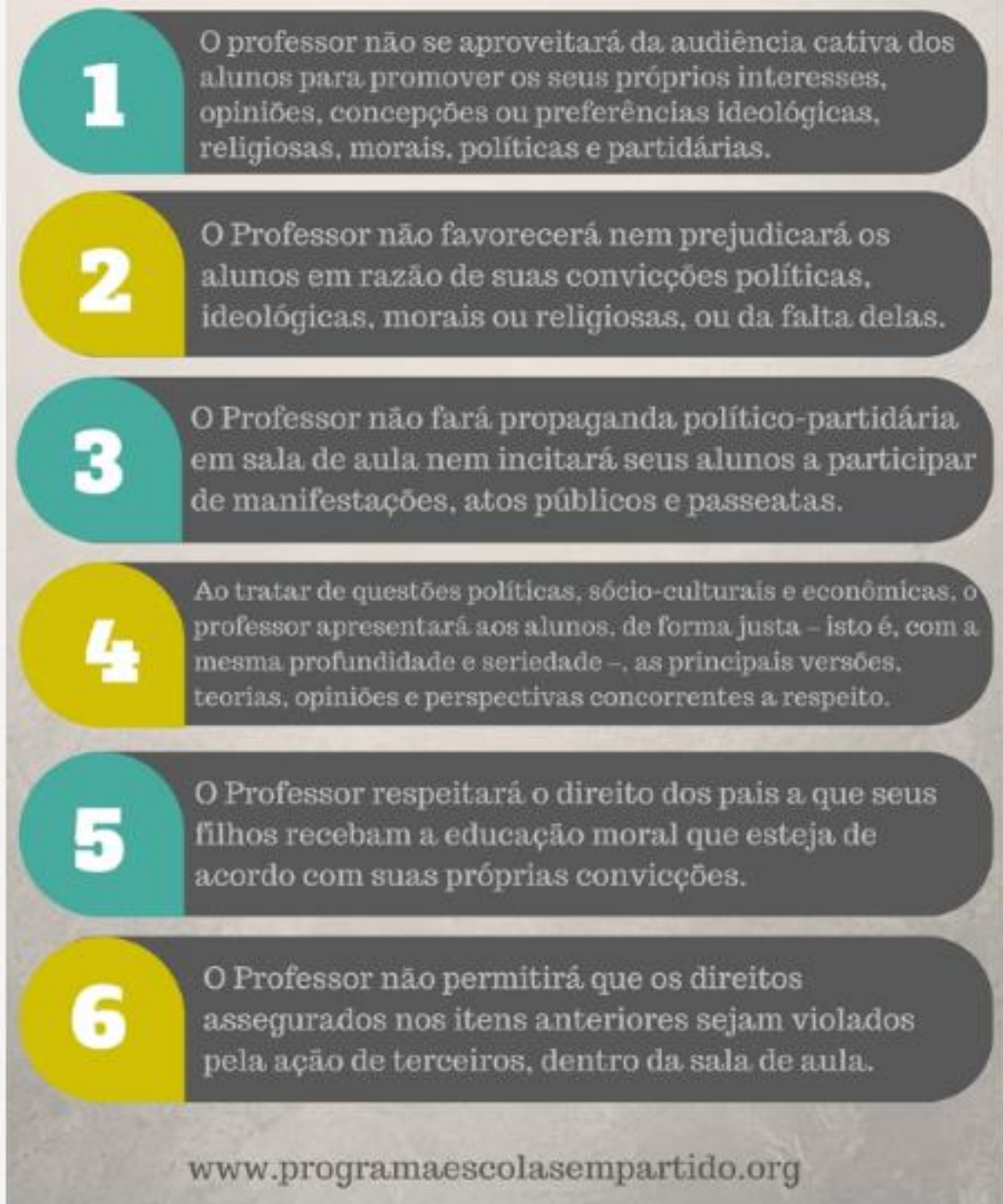

Figura 5 - Deveres do professor segundo o movimento Escola sem Partido.

Fonte: Escola sem Partido (2018).

Portanto, os defensores do Escola sem Partido não precisam refletir sobre o assunto em caso de entrevistas para a mídia, as respostas estão prontas - para o caso de o defensor ser entrevistado - e as perguntas também - no caso do defensor ser o entrevistador. Os modelos prontos das leis estão nos anexos desta tese para consulta.

As ideias em torno do projeto Escola sem Partido surgem de partido de direita do país, em destaque o Partido Social Cristão (PSC), o Partido da Social Democracia Brasileira (PSDB), Democratas (DEM), Partido Progressista (PP), Partido da República (PR), Partido Republicano Brasileiro (PRB) e parte do Partido do Movimento Democrático Brasileiro 
(PMBD), agora MDB. Observando a fonte e os principais apoiadores do movimento percebe-se que ele na verdade não é "sem partido".

Abaixo, a reprodução da matéria publicada na Revista Carta Capital sobre o projeto no Congresso Nacional:

Na terça-feira 8, o deputado Flavinho (PSC) apresentou o projeto da Escola Sem Partido (PL 7180/14) prevendo que cada sala de aula tenha um cartaz com seis deveres dos professores, entre os quais o primeiro é a proibição de que os docentes "cooptem" os estudantes para correntes políticas, ideológicas ou partidárias. $\mathrm{O}$ projeto propõe, na verdade, a escola de partido único, porque proíbe o debate e a livre circulação de ideias nas salas de aula. Para muitos, trata-se de uma verdadeira "Lei da Mordaça". O programa obriga os professores a manter a suposta neutralidade em sala de aula ao lecionar várias disciplinas como, por exemplo, história e geografia. Claro que não se pode ser favorável a nenhuma espécie de doutrinação no ambiente escolar, mas os defensores do Escola sem Partido, como destacou a Confederação Nacional dos Trabalhadores em Estabelecimentos de Ensino (Contee) ao dizerem que "desconhecem solenemente o processo pedagógico, uma vez que educação pressupõe, em seu sentido pleno, o incentivo à capacidade reflexiva, ao diálogo, à construção da cidadania, sendo, portanto, uma atividade política por excelência, no aspecto etimológico da palavra”. Qualquer proposta fora disso é defender uma escola acéfala, que formaria estudantes completamente alienados. Desnecessário dizer que esse é o mundo ideal para os maus políticos. Como falar do Golpe Militar de 1964 sem lembrar as perseguições, prisões e assassinatos de civis promovidos pelo Estado brasileiro durante a Ditadura Militar? Como explicar o fim da União Soviética sem uma contextualização política e econômica? Os apoiadores mais afoitos (e conservadores) dessa proposta já defendem até exclusão de disciplinas como Filosofia e Sociologia da grade curricular das escolas. Um absurdo total; ou seja, seria cômico se não fosse trágico, uma vez que, em caso de descumprimento dessas propostas de lei, professores estariam sujeitos a várias punições, que vão desde uma suspensão, demissão 
e até, acredite, prisão. Apesar de não ter qualquer sustentação pedagógica e jurídica, as propostas do tal Escola sem Partido já tramitam em vários Estados brasileiros. Em 2017, o Partido Progressista, o Partido Social Cristão, Partido da Social Democracia Brasileira e MDB (Movimento Democrático do Brasil, ex-PMDB) foram os partidos que mais apresentaram PLs do 'Escola sem Partido' e contra 'ideologia de gênero' pelo país. Desde 2014, quando foi apresentado o primeiro projeto de lei, de autoria de Flávio Bolsonaro, na Assembleia Legislativa do Rio de Janeiro, a média por ano de projetos idênticos ficava em torno de 20. Em 2017, chegou a 91, de acordo como estudo do grupo Professores Contra o Escola Sem Partido. Melhor seria se esses políticos substituíssem os professores por robôs que poderiam, assim, transmitir o conteúdo para os alunos ou talvez simplificar tudo com uma simples consulta na internet. É bom lembrar que o referido programa ainda contraria a Constituição Federal, que prevê a liberdade de aprender, ensinar, pesquisar e divulgar o pensamento, a arte e o saber. A Contee tem reiteradamente apontado - incluindo na campanha nacional contra a Lei da Mordaça e na vitoriosa Ação Direta de Inconstitucionalidade (ADI) impetrada no Supremo Tribunal Federal - que a censura, a perseguição e a criminalização dos professores representam uma afronta à Constituição, à liberdade de aprender e ensinar e à concepção de uma educação crítica, democrática e cidadã. No ano passado, a educação brasileira foi criticada pela Organização das Nações Unidas (ONU) precisamente pela retirada dos termos "gênero" e "orientação sexual" do texto da Base Nacional Comum Curricular (BNCC). A Lei da Mordaça afronta os principais tratados internacionais dos quais o Brasil é signatário, entre eles a Declaração Universal dos Direitos Humanos que, no seu artigo 18, destaca: "Toda pessoa tem direito à liberdade de pensamento, de consciência e de religião; este direito implica a liberdade de mudar de religião ou de convicção, assim como a liberdade de manifestar a religião ou convicção, sozinho ou em comum, tanto em público como em privado, pelo ensino, pela prática, pelo culto e pelos 
ritos". E no artigo 19: "Todo o indivíduo tem direito à liberdade de opinião e de expressão, o que implica o direito de não ser inquietado pelas suas opiniões e o de procurar, receber e difundir, sem consideração de fronteiras, informações e ideias por qualquer meio de expressão..." (CARTA CAPITAL, "Falso discurso da Escola Sem Partido avança no Congresso", 14/05/2018).

No mês de julho de 2016, na idade de Curitiba no estado do Paraná, uma professora de sociologia foi afastada do Colégio Estadual Professora Maria Gai Grandel. A professora abordou as ideias de Karl Marx, filósofo alemão que escreveu, entre outros livros, O Capital e O Manifesto do Partido Comunista. Seus alunos teriam feito um trabalho de escola sobre o filósofo e, por esse motivo, a docente foi acusada de doutrinação comunista. Os alunos realizaram manifestações em defesa da professora (Ramos \& Stampa, 2016). Notícias como essa não foram exceções.

O artigo de Ramos e Stampa (2016) relaciona o projeto Escola Sem Partido que tramitou no Congresso Nacional com documentos elaborados durante a ditadura no Brasil que provam a perseguição do regime contra professores pelo Sistema Nacional de Inteligência SNI. São apresentadas cópias de arquivos confidenciais de denúncias contra professores que seriam contra o regime ditatorial. A “caça aos subversivos" teria causado diversas prisões e mortes de docentes e funcionários de escolas e universidades com inclinações ou militância de esquerda.

No dia 24 de maio, a Câmara Municipal de Porto Alegre deu abertura ao processo referente ao PL 124/2016, de autoria do vereador Valter Nagelstein. Segundo nos é informado no site da Câmara, tal projeto tem por objetivo instituir, "no âmbito da educação municipal, as diretrizes orientadoras ao comportamento aos estabelecimentos de ensino, funcionários, responsáveis e corpo docente, no ministério que envolve o ensino de questões sóciopolíticas, preconizando a abstenção da emissão de opiniões de cunho pessoal que possam induzir ou angariar simpatia a determinada corrente político-partidária-ideológica, desviando-se da neutralidade e do equilíbrio necessários à condução do aprendizado do corpo discente". (...). De modo geral, os textos destes projetos e suas respectivas justificativas invocam a neutralidade do Estado contra o que é definido como doutrinação ideológica, política e partidária, sem que uma definição mínima do 
que vem a ser tal doutrinação seja oferecida e justapondo de forma pouco precisa conceitos como ideologia política e ideologia partidária. Um dos pontos mais controversos destes projetos reside na ideia de que os educadores e educadoras não devem discutir, nos espaços escolares, temas e conteúdos que possam contradizer as convicções morais dos pais e mães dos estudantes. Dependendo da turma, um professor estaria em uma situação de impasse ao tratar das origens da humanidade, pois não poderia discutir o evolucionismo diante de um aluno cuja crença familiar preconizasse o criacionismo. Da mesma forma, um adepto do liberalismo poderia ter sua moral familiar questionada em uma aula de história que discutisse as relações entre classes sociais e industrialização no século XIX, ou uma família socialista poderia acusar o professor do seu filho de ferir seus valores morais em uma aula sobre a ideologia liberal e a crença no livre mercado. E estes exemplos nem tocam ainda em outras questões tão ou mais sensíveis, como a educação sexual e o tema das relações de gênero (FÓRUM, “Qual o partido da escola sem partido?”, 02/06/2016).

No dia 11 de dezembro de 2018, após 12 sessões infrutíferas, o PL 7180 foi arquivado na Comissão Especial de Educação da Câmara dos Deputados, o que foi considerado uma vitória por parlamentares da oposição, educadores e estudantes. Segundo as normas da casa, as comissões temáticas são desfeitas ao fim da legislatura - entretanto, o tópico deve retornar à pauta em 2019. O teor do projeto também deve ser julgado no STF (Supremo Tribunal Federal).

\subsubsection{Escola sem partido e gênero}

Em decorrência da tentativa de regulação dos conteúdos curriculares, os apoiadores do Escola sem Partido aproveitaram o debate para sugerir a supressão de conteúdos relacionados à educação de gênero nas escolas. Os debates que discutiram o tema no cenário político se armaram de argumentos morais para defender que as crianças podem ser influenciadas pelas aulas e tender para uma sexualidade homossexual ou perverter as lições morais apreendidas dentro de casa com a família.

Em resumo, o movimento Escola sem Partido que tinha como objetivo, em teoria, reprimir orientações políticas - chamadas de doutrinação pelos conservadores -, acabou ganhando outras bandeiras, incluindo no projeto inicial ideias mais abrangentes em defesa, segundo 
eles, da família e dos bons costumes. A educação sexual, por exemplo, seria um incentivo para a iniciação sexual precoce, ou o ensino de conteúdos pela igualdade de gênero geraria uma massa de crianças homossexuais porque descobririam que somos todos iguais e todas as formas de manifestação da sexualidade deve ser respeitada.

Não foi possível determinar na pesquisa, pela coleta de dados na mídia impressa, o exato momento em que se fundiram as duas temáticas, mas é possível compreender que o Movimento Escola sem Partido abriu espaço para o debate sobre os conteúdos de gênero. O que se vê é que após 2014, quando o projeto toma maior visibilidade nacional, ele é atrelado a questões mais conservadoras e as bandeiras conservadoras se integram ao embate político ideológico, como noticiado sob o título "Projetos de lei. Educação sem ideologia?"

Uma palavra está no centro da discussão sobre a educação brasileira: doutrinação — o ato de ensinar os princípios de uma crença, sistema ou ciência. Há 12 anos, a defesa do programa Escola Sem Partido é evitar que ela aconteça e impeça a pluralidade de ideias. O movimento ganha corpo em projetos de lei no Brasil. E o conceito e as implicações da proposta são questionados e suscitam uma diversidade de opiniões conflitantes (...) Entre eles, não promover em sala de aula os próprios interesses e concepções ideológicas, religiosas, morais, políticas e partidárias. (...) Os projetos de lei da Escola Sem Partido trazem também a vedação da "aplicação dos postulados da teoria ou ideologia de gênero". No Senado, a proposta é incluir o programa na Lei de Diretrizes e Bases da Educação, com exceção para escolas particulares e confessionais (orientadas por grupos religiosos). Nesses casos, pais e responsáveis assinariam autorização concordando com os conteúdos e valores transmitidos (O Povo, 31/07/2016).

Portanto, as demandas sobre a educação brasileira, alvo de disputas ideológicas, tem duas frentes principais que se opõem nos debates sobre o PNE e o BNCC, aqueles que defendem a liberdade de pensamento e aqueles que defendem o conservadorismo pautados na moralidade cristã. Nesse contexto, surgem os movimentos que apoiam os grupos envolvidos na disputa, dando maior visibilidade aos discursos e angariando adeptos.

A mesma moralidade que busca impedir o livre pensamento político se fortaleceu com os discursos cristãos que se aproximaram da ideia inicial. Em consequência, o ensino 
religioso e a eliminação de conteúdos de gênero do currículo escolar se tornaram também uma preocupação. 


\section{A “IDEOLOGIA DE GÊNERO" NA MÍDIA: USOS POLÍTICOS E MANIPULAÇÃO DA MÍDIA.}

Nesta seção, será examinada a abordagem da mídia sobre as políticas de gênero. Dessa forma, foi feita a análise de conteúdo de veículos de comunicação impressa, buscando o termo "ideologia de gênero" e interpretando a aparição das notícias de forma cronológica por periódico, somando quatro periódicos considerados de grande circulação no estado do Ceará, sendo dois mais conservadores (Diário do Nordeste e O Povo) e dois mais progressistas (Carta Capital e Revista Fórum), os dois últimos de circulação nacional porque não há mídia de esquerda no estado.

Assim, foi feita uma pesquisa especial para esta seção, com amostragem disponível nos apêndices deste trabalho, que mostrou como pode ser manipulado politicamente o tema. $\mathrm{O}$ resultado é que as opiniões podem ter repercussões práticas na sociedade, fazendo com que a população tenha a tenência de interpretar fatos de acordo com as abordagens da mídia.

\subsection{A metodologia de análise de conteúdo}

A análise de conteúdo é a metodologia usada para decodificar, descrever, e interpretar o conteúdo de inúmeros tipos de documentos, auxiliando na sistematização dos dados e compreensão dos resultados além da leitura comum (Moraes, 1999). O importante a ser ressaltado é que o pesquisador esteja ciente dos objetivos envolvidos no desenvolvimento do trabalho e observar: 1) Quem fala, 2) Para dizer o que, 3) A quem, 4) De que modo, 5) Com que finalidade e 6) Com que resultados.

Dentro das diversas correntes que propõem contribuir para o aprimoramento da técnica, os pontos principais para a utilização do método são as seguintes etapas, de acordo com Moraes (1999):

1 - Preparação das informações;

2 - Unitarização ou transformação do conteúdo em unidades;

3 - Categorização ou classificação das unidades em categorias;

4 - Descrição;

5 - Interpretação

Esse trabalho fez a escolha pela análise de conteúdo porque esta ferramenta metodológica possibilita compreender os discursos escondidos na publicação dos eventos. Como se pretende estudar as ideias e tendências por trás do debate sobre o ensino de conteúdos ligados à sexualidade, observar como as notícias são carregadas de manipulação, de acordo 
com a linha editorial de cada periódico, corrompendo a capacidade individual de cada leitor de formular suas próprias conclusões sobre cada assunto.

A sociedade recebe a informação conforme ela lhe é passada. Este é o ponto sobre o qual se apoia esta etapa da tese, mostrar como a mídia apresenta o tema.

\subsubsection{A análise proposta por Laurence Bardin}

A Análise de Conteúdo proposta por Laurence Bardin (1977), professora de psicologia na Université Paris V, auxilia a compreensão das disputas ideológicas produzidas pelas mídias, como no caso desta pesquisa de tese. O material utilizado aqui é essencialmente jornalístico e por isso a escolha deste tipo de análise.

A autora escreve de maneira resumida sobre o trabalho do pesquisador:

$\mathrm{O}$ analista é como um arqueólogo. Trabalha com vestígios: os "documentos" que pode descobrir ou suscitar. Mas os vestígios são a manifestação de estados, de dados e de fenómenos. Há qualquer coisa para descobrir por e graças a eles. Tal como a etnografia necessita da etnologia, para interpretar as suas descrições minuciosas, o analista tira partido do tratamento das mensagens que manipula, para inferir (deduzir de maneira lógica) conhecimentos sobre o emissor da mensagem ou sobre o seu meio, por exemplo. Tal como um detective, o analista trabalha com índices cuidadosamente postos em evidência por procedimentos mais ou menos complexos. Se a descrição (a enumeração das características do texto, resumida após tratamento) é a primeira etapa necessária e se a interpretação (a significação concedida a estas características) é a última fase, a inferência é $o$ procedimento intermediário, que vem permitir a passagem, explícita e controlada, de uma à outra (Bardin, 1977, 39).

Bardin coloca que a análise de conteúdo é existente desde os primórdios da imprensa. As pesquisas que utilizam este método se tornaram mais frequentes quando a imprensa toma mais espaço na divulgação de informações e opiniões, tanto que no período da Guerra Fria os pesquisadores o usaram para detectar correntes de pensamento prós e contrárias à União Soviética, podendo, dessa forma, validar a força e capacidade de alcance de determinados pensamentos assim como detectar mídias alternativas oposicionistas ao mainstream capitalista (Bardin, 1977). 
Tanto as análises de conteúdo mais próximas de vertentes da linguística quanto as alinhadas à psicologia, jornalismo ou direito, a preocupação é de examinar a interpretação de discursos. Uma vez que a comunicação é a transmissão das ideias e conhecimentos, o uso da mesma pode ser manipulado ou direcionado, instigando os pesquisadores das diversas áreas a adaptar a técnica aos objetivos de cada trabalho, seja para obter a comprovação de uma tese já estabelecida, ou seja, para explorar uma questão e desenvolver uma pesquisa exploratória.

Pelo seu uso para pesquisas qualitativas ou quantitativas, a análise de conteúdo se desenvolve largamente após a década de 1950. Quantitativa quando o pesquisador busca elencar em números a quantidade de repetição de um termo ou ideia, usando estatísticas e análises numéricas como acessório de análise; qualitativa quando o observador interpreta os sentidos usados para determinado termo ou ideia, distinguindo sentidos e entendendo como se desenvolvem na linguagem escrita e na publicização de conteúdos escritos (Bardin, 1977).

Assim, o método tem larga utilização, podendo ser adaptável às pesquisas e ser usado em diversos objetos. Bardin (1977) estabelece no seu livro como utilizar a análise de conteúdo e indica exemplos de sua aplicação, inclusive. O primeiro passo é a coleta de dados, sendo necessário identificar a fonte dos dados e qual será a amostragem.

Após a coleta e definição da pesquisa é necessária a codificação dos dados. Essa codificação representa a transformação dos dados dos textos em uma representação sistemática que possibilita ao leitor compreender os resultados da análise.

Para isso, segundo Bardin (1977) define-se a 1) unidade de registro onde se pode escolher entre uma palavra ou um tema. Quando se escolhe o uso de uma palavra específica a pesquisa tende a ser relacional com as outras palavras que surgem junto a ela, adjetivos, advérbios, substantivos. Já com o tema, busca-se uma unidade de significação mais complexa, onde é necessário definir um "núcleo de sentido" dado à comunicação. Um personagem, um objeto ou um acontecimento são também entendidos como temas.

A 2) unidade de contexto, que é a compreensão de como a unidade de registro é situada dentro da comunicação, seja em um parágrafo ou frase. A extensão dessa unidade pode variar dependendo da necessidade da análise, aprofundando-se mais no texto do qual faz parte ou recortando-se somente a frase onde se encaixa.

A autora deixa claro que há uma distinção entre a unidade de registro e a 3) regra de contagem. As aparições do termo pesquisado são contabilizadas, fazendo com que certas comunicações sejam mais relevantes para a pesquisa do que outras. De outra forma, o 
termo pode aparecer com mais intensidade dependendo da forma como é utilizado no contexto ou pelo número de aparições por trecho.

Há também o aspecto da direção que se coloca, sendo positiva ou negativa, sendo perceptível no conjunto do texto. Caso haja mais de uma unidade de registro, a ordem em que aparecem também deve ser considerada para dar prioridades aos casos, assim como a posição do termo no texto - se colocado no título ele tem um peso, no subtítulo, outro e assim por diante (Bardin, 1977).

Após esta primeira etapa e coleta, o passo seguinte do método proposto por Bardin é a fase de categorização dos dados. Os textos ou trechos devem ser classificados e agrupados pela forma como aparecem - intensidade, frequência, contexto... - de forma a organizar a pesquisa adequadamente e, para isso, são dadas algumas orientações. Ela afirma que os dados devem ser encarados como objetos que devem ser guardados dentro de gavetas, cada um tem seu lugar, para que na análise não sejam cometidos enganos de interpretação. Assim, no agrupamento dos dados, cada unidade não deve ser colocada em mais de um conjunto, em cada categoria é imprescindível à homogeneidade entre os dados, segundo a obrigatoriedade da pertinência e objetividade.

É a partir deste ponto que é possível estabelecer o tipo de análise de conteúdo que se pretende usar, sendo as seguintes: análise categorial, de avaliação, de enunciação, proposicional do discurso, de expressão e das relações (Bardin, 1977).

A partir do entendimento sobre o método, desenvolvido anteriormente por autores estabelecidos internacionalmente, é possível realizar a descrição de como esta pesquisa foi realizada. A seguir, será relatado como foi feita a coleta de dados e o método usado, de fato.

\subsubsection{Método de coleta de dados}

Dentro do escopo de pesquisa já discutido na parte teórica desta tese, observou-se a validade de coletar dados nos meios de imprensa conhecidos da Região Nordeste do Brasil. Como não foi possível acolher dados de mídias de mesmo alcance, com mesma abordagem, foram escolhidos quatro periódicos, dois com posicionamento mais progressista e dois conservadores.

Como não há jornais impressos reconhecidamente progressistas na Região Nordeste, foram selecionadas duas revistas de alcance nacional e dois jornais locais nordestinos. As revistas são identificadas como progressistas e os Jornais como conservadores.

A diferença de apresentação dos periódicos - serem revistas e jornais - não modifica a análise para esta pesquisa, visto que os conteúdos debatidos pelos veículos são 
essencialmente os mesmos: notícias relacionadas à política local e nacional e questões sociais, entre outros assuntos.

Ao encarar essa dificuldade da escolha das mídias, pensou-se em trabalhar as páginas da internet - a blogosfera - que tratassem de assuntos que se encaixam dentro da categoria feminista, na região do nordeste brasileiro, para compreendem como as ativistas desse movimento social de posicionaram na discussão.

Até o momento, considerou-se inadequada essa análise porque se distancia dos outros dados coletados por se tratar de um tipo de mídia absolutamente distinta. O que difere a blogosfera da mídia impressa são os seguintes pontos elencados nesse tópico:

- Os blogs têm alcance diferente das publicações impressas, atingindo um público distante entre os meios de comunicação.

- Entende-se que as comunicações feitas pela internet têm um público mais específico, visto que cada leitor procura páginas direcionadas a temas mais específicos do que os jornais, que tratam de temas gerais. Por isso, os jornais impressos atendem um público que busca leitores interessados em notícias gerais e conteúdos diversos.

- A construção dos textos nesses dois tipos de mídia é elaborada de maneira distinta, pelas razões citadas acima. A abordagem do conteúdo feita para cada público-alvo é um fator que distingue os dados oriundos da internet dos dados da mídia tradicional que é vendida em bancas de jornal.

Decidiu-se, portanto, utilizar os dados disponíveis para a população do nordeste brasileiro disponível para aquisição na forma física, por entender que os seus leitores estão interessados em temas diversos e assimilam as informações passadas pelo periódico de forma mais pulverizada com outros assuntos.

Assim, foram escolhidas as revistas de distribuição nacional que publicam conteúdos considerados de posicionamento político de esquerda. São elas:

A) JORNAL DIÁRIO DO NORDESTE

185 ocorrências do termo "Ideologia de Gênero".

B) JORNAL O POVO

44 ocorrências do termo "Ideologia de Gênero".

C) REVISTA CARTA CAPITAL

160 ocorrências do termo "Ideologia de Gênero".

D) REVISTA FÓRUM

211 ocorrências para o termo "Ideologia de Gênero". 
$\mathrm{Na}$ pesquisa documental realizada, portanto, foram coletadas matérias jornalísticas que contém o termo "Ideologia de Gênero" ou o tema estritamente relacionado ao termo, configurando assim a unidade de registro da análise, cuja sistematização dos artigos utilizados neste trabalho está nos apêndices, no final do texto.

Em linguagem estatística - embora não tenha sido usada análise quantitativa na pesquisa, porém, da mesma forma, buscando exemplificar mais especificamente o método de pesquisa pragmática - a amostra é composta pelas matérias que trazem "gênero" no corpo do texto das publicações do jornal, observando como variável dependente o tema educação ou o tema política. O universo dos dados são as publicações feitas entre 2016 e 2018 pelos periódicos: O Povo, Diário do Nordeste, Revista Fórum e Revista Carta Capital.

É importante salientar os usos da palavra "gênero" encontrados durante a pesquisa. Segundo o dicionário Houaiss:

Gê.ne.ro 1 conjunto de espécies com a mesmo ORIGEM ou as mesmas particularidades 2 p.ext. tipo, classe; estilo < gosta desse g. de roupas $>3$ classe de estilo, técnica ou natureza artística ou literária $\langle g$. épico $>4 \mathrm{em}$ gramática, categoria que classifica as palavras em masculino, feminino e neutro 5 BIO na classificação dos seres vivos, subdivisão da família, categoria que agrupa espécies relacionadas segundo a história da evolução e distinguíveis das outras por diferenças marcantes $\Delta$ gêneros s.m.pl. 6 mercadorias, esp. Agrícolas e comestíveis; víveres (Houaiss, Villar \& Franco, 2001, 368).

As definições descritas acima pertencem a uma série de usos que esta palavra pode ter dentro de um conteúdo. Essa gama de possiblidades forneceu desafios à coleta, pois trouxe ao universo amostral um conjunto de textos que não fazem parte do tema específico que se deseja aqui.

Percebe-se, portanto que, para a questão que se faz objeto deste trabalho, o uso é dado em sentido sociológico dentro de um discurso (Johnson, 1997). Assim como a sociologia se apropriou da disciplina biologia a palavra "raça" para designar as diferenças étnicas e sociais entre grupos de seres humanos, "gênero" também toma uma ressignificação própria para entender as diferenças sociais entre homens, mulheres, homossexuais, bissexuais e transgêneros. 
Gênero: A palavra "gênero" está em vias de entrar no vocabulário da sociologia francófona - gender já está em uso desde há mais de dez anos na sociologia anglo-saxónica - para designar o que tem a ver com a diferenciação social entre os dois sexos. Tem a vantagem, sobre a palavra "sexo", de sublinhar a necessidade de separar as diferenças sociais das diferenças biológicas. Os papéis sexuais eram tradicionalmente concebidos como o resultado de uma divisão natural do trabalho que atribuía às mulheres as responsabilidades domésticas e a educação dos filhos. Para os sociólogos de orientação feminista, a divisão sexual das tarefas, longe de ser a consequência natural de diferenças biológicas, foi construída e mantida pela sociedade. A teoria feminista põe no centro das suas preocupações a distribuição do poder e dos recursos entre homens e mulheres e as imagens e símbolos associados aos dois sexos e às suas relações. Põe em questão a separação entre família e trabalho ou entre domínio privado e domínio público que fundamentou a abordagem funcionalista estrutural dos papéis sexuais. Considera o género como uma dimensão fundamental de toda a organização social, ao mesmo título que a classe, e como uma categoria construída socialmente tanto no lugar de trabalho, na família, na escola como nas esferas económica, política e cultural (Johnson, 1997, 113).

Vê-se na atualidade das discussões de movimentos sociais, novos ou já estabelecidos, a necessidade de criar novas denominações a elementos geradores de conflito, para descrever, elucidar e evidenciar fenômenos produtos da dinâmica social. Quando, contudo, se busca a palavra-chave livremente nos periódicos selecionados, o resultado é uma variedade de conteúdos que misturam os usos do termo e mesclam temas, objetivos, assuntos.

Por isso é necessário se atentar à variável dependente na análise de conteúdo que neste caso é o tema "educação", que dá à comunicação o núcleo de sentido onde se insere a unidade de registro (Bardin, 2009). Os outros termos que surgem, como variáveis independentes, são: "violência", "política", "cultura" e "economia".

A coleta de artigos da imprensa foi realizada respeitando a noção sociológica de gênero, ou seja, a ideia de feminino e masculino ligada à sexualidade do indivíduo, por escolha ou aceitação biológica. 
O método de coleta prático foi acessar as plataformas digitais as mídias escolhidas - com login não restritos ou restritos, com acesso possível por meio de pagamento - para coleta das amostragens de artigos. Assim, em cada plataforma buscou-se pelo termo "ideologia de gênero" na barra de pesquisas indicada.

Por processo automático do sistema, os sites apresentam os resultados, cada um de sua maneira, com sua interface específica. Os resultados são fornecidos de formas diferentes, com identificação na página do número do exemplar completo, ou somente o artigo em especial, ou com resposta a termos que englobam "ideologia" e "gênero". De acordo com a metodologia de Bardin, fez-se especial recorte na amostragem utilizando o termo e o seu conceito, visando artigos que se encaixam no tema "Educação" e "Política".

Após, a seleção dos dados, foi feita a leitura atenta dos textos e sistematizados de acordo com o apêndice deste trabalho que contém os dados. Munida dos dados, a pesquisa pôde ser descrita.

Escolheu-se realizar a leitura como uma narrativa, como a história contada pelos periódicos dos acontecimentos, de forma isolada e particularizada. Espera-se que o leitor desta tese tenha a mesma percepção do leitor do periódico acerca das notícias e dos acontecimentos ligados ao tema da tese.

Em seguida, a comparação e a análise dos periódicos relacionalmente é feita para se ter a real noção das tendências editoriais das mídias.

\subsection{A "IDEOLOGIA DE GÊNERO"}

As disputas político-ideológicas surgidas após os debates sobre o Plano Nacional de Educação - PNE, no final de 2015, foram fortemente amparadas e impulsionadas pela forma como foram publicizados os conteúdos relacionados à educação no Brasil. Nos conflitos gerados encontram-se dois polos de interesse: de um lado, políticos e intelectuais identificados como de posicionamento político mais à esquerda e, do outro lado, políticos e intelectuais de direita.

Os primeiros, mais progressistas, desejam que o PNE incorpore a obrigatoriedade do ensino da educação sexual no conteúdo das escolas. Já o outro polo é contrário a esta ideia, afirmando que este tipo de matéria perverte a mente das crianças e as incentiva a iniciar suas vidas sexuais mais cedo. O ambiente dessas discussões extrapola o espaço político partidário, no congresso ou nos governos, e alcança a opinião pública.

As mídias passam a ser as porta-vozes dos discursos de agentes prós e contras a inclusão do tema no PNE. As matérias que tratam do assunto retratam essas posições, ficando a cargo da linha editorial ser imparcial em cada jornal ou revista. 
Da mesma forma acontece com a aprovação da Base Nacional Comum Curricular - BNCC -, disputado entre conservadores e progressistas, que define os conteúdos a serem incluídos na educação brasileira, no intuito de uniformizar as matérias discutidas em salas de aulas, públicas e privadas, do país.

Independente da argumentação política, um fato se tornou importante para medir os reflexos dos embates ideológicos. A parcela daqueles que são contrários à inclusão de educação sexual nas escolas criaram um termo específico, que acabou sendo o símbolo e a palavra-chave para compreender a lógica deste fenômeno, o termo cunhado é a "ideologia de gênero".

Esse nome se deve a ideia de que os conservadores consideram que a esquerda exerce uma propaganda ideológica contra as crianças, formulando uma "ideologia esquerdista" que apoia projetos que são contrários aos bons preceitos da família cristã tradicional. Por isso a invenção do uso da palavra ideologia carrega esse peso de proporcionar uma ilusão, induzindo os estudantes ao erro moral.

A palavra que segue é "gênero". O conceito sociológico tem tido sua utilização mais frequente nos últimos anos por causa da força que movimentos sociais ligados ao feminismo e ao público LGBT tem tomado na política nacional, em busca de direitos de igualdade entre indivíduos de qualquer orientação, identificação ou posição sexual, primordialmente contra qualquer tipo de discriminação ligada à sexualidade. Mais à frente, serão contrapostas as teses de cada polo desse embate.

Se faz importante, assim, compreender a lógica da dinâmica das posições políticas pela produção de conteúdo das mídias. Se as empresas de comunicação são parciais ou não, se mostram as notícias e as noções de forma consistente e fiel aos acontecimentos.

\subsubsection{Leitura dos dados}

Os dados são expostos a seguir de forma descritiva conforme a ordem cronológica. Por se tratar de textos fornecidos por revistas e jornais de assuntos variados, com o objetivo de noticiar acontecimentos nacionais ou regionais, considerou-se mais interessante para a proposta de pesquisa a descrição dos textos da forma e na ordem como aparecem nos resultados da busca, ou seja, cronológica.

A descrição que se segue reflete, portanto, a linha editorial das mídias e o fluxo dos acontecimentos conforme relatados dentro da linha editorial de cada meio de comunicação impressa usado como fonte de dados.

a) DIÁRIO DO NORDESTE 
Os dados coletados sobre o tema da pesquisa no periódico Diário do Nordeste são, na maioria, notas e comentário de opiniões. Observa-se assim a distância dada nas matérias relevantes com o assunto das discussões de gênero nas escolas.

Essa postura está de acordo com a história do jornal, que tem se mostrado mais conservadora e tende a não publicar pautas progressistas ligadas à política nacional. Diferentemente, porém, quando a essas pautas se relacionam à cultura e entretenimento, onde os temas sobre homossexualidade, gênero e feminismo aparecem para tratar de conteúdos descontraídos, em falas que remetem à força da mulher, às novas expressões artísticas, às obras de literatura, cinema, teatro e televisão.

Esse lugar dado às questões de gênero, por vezes de marginalidade, sendo excluídas das primeiras páginas e das páginas de política, expõe a discriminação do jornal. Em meio a tempos turbulentos de feminicídios e homofobias, em que preconceitos de gênero tem ocupado as páginas policiais e essas questões têm sido discutidas na política nacional, a exemplo do PNE, a omissão do periódico em relatar a problemática transparece o conservadorismo. É como se ignorar os fatos fizesse o problema desaparecer.

Em outros pontos, o termo "gênero" é encontrado nas páginas de economia para tratar de desigualdade no mercado de trabalho ou sobre a propaganda e publicidade voltada para o público feminino, abordagens que não auxiliam para a mudança social.

A primeira aparição do termo Gênero, dentro do tema buscado, no Diário do Nordeste, no período delimitado, data de 31 de fevereiro de 2016. Em uma nota pequena sobre violência contra a mulher, a autora coloca sua opinião de que os jovens devem discutir gênero nas escolas para evitar atitudes violentas contra as mulheres ${ }^{46}$. $\mathrm{O}$ artigo fala que se os casos de violência contra as mulheres são tão frequentes, os alunos deveriam saber dissertar sobre, assim como a exemplo da redação do ENEM - Exame Nacional do Ensino Médio - do ano anterior.

Outras matérias são de cunho informativo sobre as pautas da assembleia legislativa, sem que se dê muito enfoque ao debate de gênero na escola, como o trecho da matéria intitulada "Debate Perdido no Tempo", a seguir:

O foco inicialmente visível é o Plano Estadual de Educação, conjunto de medidas baseadas no Plano Nacional de Educação que norteia políticas públicas vitais para a sociedade - dando conta inclusive de confrontar preconceitos sexuais e de gênero. Outro, um tanto escamoteado, é uma queda de braço político-religiosa que

${ }^{46}$ Os dados estão sistematizados nos apêndices deste trabalho. 
há anos impõe questionamento a qualquer iniciativa que soe minimamente progressista. Algo que espanta pelo caráter ultrapassado de algumas ideias (Diário do Nordeste, 31/02/2016).

Nesse excerto é possível perceber que as tensões na câmara acontecem pelas questões político religiosas, causando paralisia nas discussões de projetos importantes para o estado como aqueles voltados para a educação. Nos meses seguintes, há pequenas notas nas edições sobre as mesmas disputas entre os deputados envolvendo o tema, sempre citando os embates político religiosos.

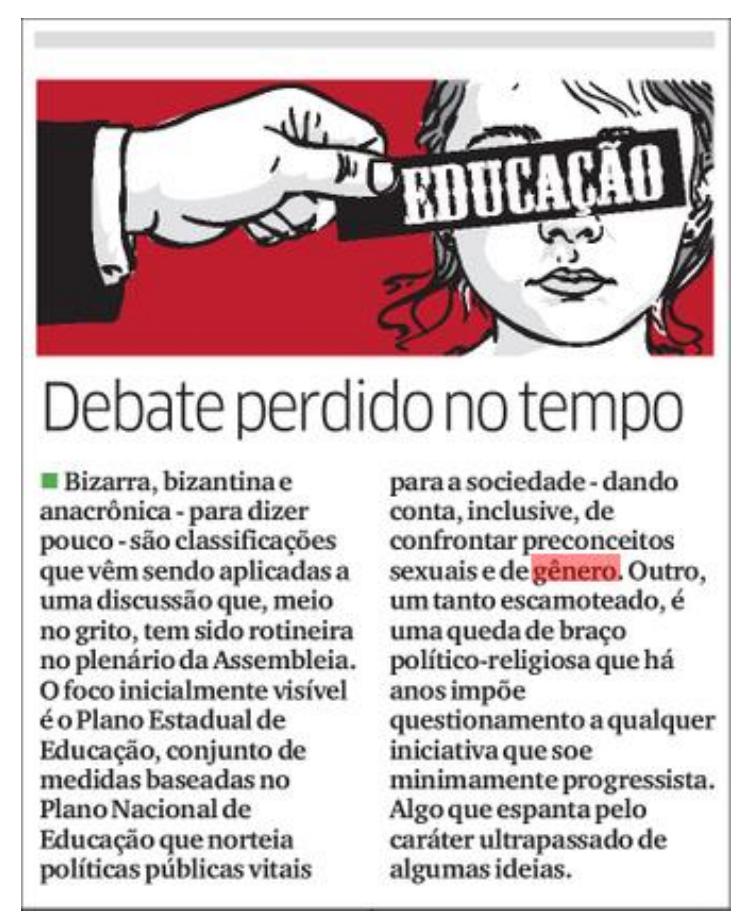

Figura 6 - Debate perdido no tempo, Diário do Nordeste.

Fonte: Diário do Nordeste, "Debate perdido no tempo, 31/03/2016.

Na matéria de 07 de maio do mesmo ano, o artigo de título "Bancada religiosa comemora Plano", se referindo ao Plano Estadual de Educação - PEE. Diz a Deputada Silvana Oliveira do PMDB, identificada como cristã evangélica:

Foi uma vitória do povo cristão e prova que, mesmo com vitória apertada em determinado momento, com a diferença de apenas um voto, temos a consciência tranquila de que $80 \%$ da população se sente contemplada com o que conseguimos, um plano neutro (Diário do Nordeste, 07/05/2016).

O periódico publica, em 16 de maio, que um deputado pede a fiscalização das escolas estaduais para que se cumpra o Plano, notadamente no que se refere ao impedimento da “utilização de ‘ideologia de gênero’ na educação estadual” (Diário do Nordeste, Execução 
precisa de fiscalização, 16/05/2016). Essa afirmação do deputado mostra claramente a intenção de regular os conteúdos aplicados em sala de aula pelos professores, e a ênfase dada pelo jornal a esse tipo de opinião, sem estabelecer crítica, denota também o endosso do Diário do Nordeste à fala do político.

No dia 10 de outubro de 2017, no artigo "Deputado critica ideologia de Gênero" é relatado que o Deputado Ely Aguiar, do PSDC, fez um pronunciamento onde em que reforçou os pontos pelos quais pediu o veto ao Plano Estadual de Educação no ano anterior, os quais tratavam sobre sexualidade e gênero. Ali, o deputado afirma que a "ideologia é uma fonte de destruição da família e de implantação do regime comunista" (Diário do Nordeste, Deputado critica "ideologia de gênero", 26/10/2017). A matéria ainda diz que foi feito um requerimento para a instauração de uma Frente Parlamentar para a Fiscalização da "ideologia de gênero".

No final daquele ano, em 26 de dezembro de 2017, o texto "Pautas conservadoras viram aposta eleitoral" expõe a estratégias dos deputados de usarem o conservadorismo do eleitorado para fazer manipulação dos projetos. Os políticos usam temas polêmicos para impulsionar seus discursos nos períodos eleitorais e ganharem visibilidade.

Para pesquisadores, discurso é demagógico e pouco propositivo. Outros defendem ser reflexo do atual cenário. Neste ano, a deputada Silvana Oliveira propôs a criação de uma frente parlamentar contra a ideologia de gênero no Ceará. A Assembleia Legislativa do Estado aprovou, em outubro, lei que impõe restrições a exposições em espaços públicos em nome 'das famílias' (Diário do Nordeste, 26/12/2017).

O ministério Público Federal é citado como agente capaz de intervir com ações para defender a isonomia das escolas e a liberdade dos professores somente em 2018. Na nota "Escola sem partido - MPF pede que STF barre projetos", o argumento é de que a escola não pode sofrer violações. Afirma que o MPF pediu que o STF julgue a inconstitucionalidade das leis que impedem conteúdos programáticos em escolas.

Por último, a matéria de 15 de março de 2018, intitulada "Deputada reclama de livro didático", diz:

A deputada Silvana Oliveira (PMDB) levou ontem à tribuna mais uma denúncia do que chamou de ideologia de gênero em escolas públicas do estado. Ela mostrou um livro didático que está sendo confeccionado para ser utilizado no município de Umirim abordando questões relacionadas à sexualidade. A parlamentar, que 
preside a comissão de Educação na Câmara de deputados, disse que vai acionar o MP e voltou a defender a instalação de uma frente parlamentar de fiscalização da ideologia de gênero no Ceará. No ano passado, a deputada havia relatado casos semelhantes nos municípios de Cedro e Quesébio. "Professor, cumpra o seu papel, não fique calado, denuncie. Que vou lá, exponho o prefeito, a prefeita, quem quer que seja o secretário de educação. Quem quiser enfrentar essa deputada, o voto da população na eleição. Ideologia de gênero nas escolas nós não aceitamos, nós somos a maioria" (Diário do Nordeste, 15/03/2018).

A quantidade se textos publicados com o tema da pesquisa é ínfima em comparação com o tamanho do debate suscitado nacionalmente. Embora alguns pesquisadores possam entender esse fato como prejudicial à pesquisa, deve-se entender que a escassez de dados é também um indicador. No caso da coleta de conteúdos na mídia impressa, subentende-se, de certa forma, a omissão da redação do periódico em relação ao tema.

b) O POVO

O periódico O Povo apresenta uma amostragem bem mais extensa de dados. As matérias são mais robustas, as descrições mais interessantes e os textos melhor elaborados.

No dia 24 de março de 2016, o artigo "Marxismo" e "censura LGBT": deputados saem contra Plano de Educação", publicado na página de Política apresenta a questão pela primeira vez no ano. A descrição de falas e posicionamentos de atores importantes nesse processo corroboram a preocupação do jornal em esclarecer os fatos:

Para Carlos Matos (PSDB), ação tem por trás "projeto de poder" da esquerda pela implantação do marxismo. "Há um grande problema no plano, no ponto onde trata da questão de gêneros. Ali está sendo implantada uma ideologia", diz Matos, ligado ao grupo católico Shalom. Ely Aguiar (PSDC) também contesta: “Orientação sexual de uma criança começa em casa, pela família, e não na escola”. Já Dra. Silvana (PMDB), pastora evangélica, tem questionado audiências da comissão que debate o PEE na Casa. Segundo ela, encontros têm sido "direcionados ao público LGBT" (Lésbicas, Gays, Bissexuais, Travestis e Transexuais), com audiências voltadas para "outros públicos" sendo censuradas. "Precisamos de uma audiência que contemple todos os segmentos da sociedade e não que apenas um tenha o direito de se manifestar", diz. Com mais 
de 20 metas para melhorar índices da educação no Ceará, o Plano Estadual de Educação não traz, em nenhum ponto, qualquer espécie de discussão sobre orientação sexual com crianças. Em sua meta mais polêmica, a de número 8 , o plano trata da elevação da escolaridade média de alunos, destacando ações para setores marginalizados ou vítimas de preconceito. Entre eles, estão o de alunos LGBT. Sobre este ponto, são previstas "criação de políticas específicas para elevação da escolaridade" de LGBTs e a formação de professores e gestores capazes de lidar com temas de diversidade sexual, bem como questões "ambientais, étnico-raciais, de inclusão, musicais, de gênero e de educação sexual". O PEE, no entanto, trata mais de questões específicas, como instituição de cursos preparatórios para o ENEM, erradicação do analfabetismo e melhora do desempenho em diversas disciplinas, como matemática. Ao contrário do que pregam boatos, não há "kit gay" ou qualquer distribuição de material sobre educação sexual para crianças $(O$ Povo, 24/03/2016).

Essa matéria é um exemplo da forma como o conteúdo é apresentado ao leitor, com os nomes dos envolvidos e as falas. A preocupação se estende para as consequências do problema, como no artigo de 27 de março de 2016, "Polêmica sobre questões de gênero pode deixar alunos de Recife sem livros", onde relata que vereadores da bancada evangélica da cidade de Recife se manifestam contra os livros didáticos adotados pelas escolas da cidade sugeridos pelo Ministério da Educação por causa de conteúdos que desses livros. A matéria cita um trecho onde é citada a existência de famílias com pais de mesmo sexo, em outro ponto há uma ilustração de uma família com pais e uma menina branca e um menino negro, sugerindo uma família com adoção. Diretora e professoras foram consultadas e disseram que avaliaram o material didático, considerando os mesmos os melhores ${ }^{47}$.

\footnotetext{
${ }^{47}$ Para melhor entendimento da matéria, ver a coletânea dos dados do jornal O Povo, que traz textos na íntegra e resumos explicativos.
} 


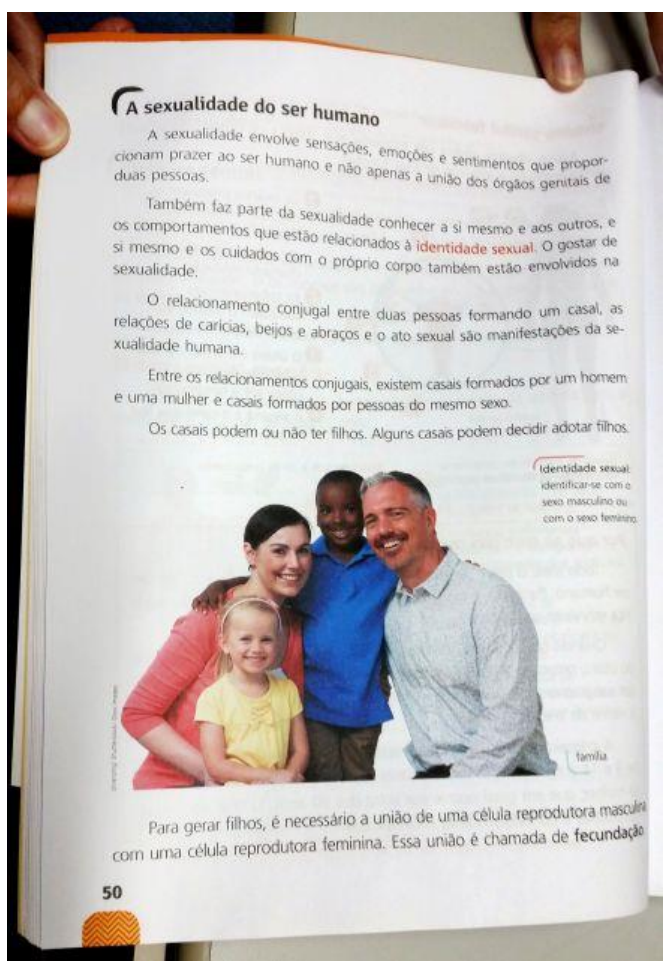

Figura 7 - Ilustração do livro didático que gerou conflito na Assembleia Legislativa. Fonte: O Povo, Questões de gênero podem deixar alunos sem livros, 28/03/2016.

Somente esse ponto sobre os livros é explorado em quatro artigos diferentes. Também é destacada a preocupação sobre a dita "ideologia de gênero" no âmbito nacional. No dia 28 de abril de 2016, a matéria "Silas Malafaia ${ }^{48}$ pede a [Michel] Temer 'cuidado' na escolha do ministro da educação".

Segundo um deputado federal ligado a Malafaia, o líder da Assembleia de Deus disse a Temer que se preocupa com a questão da chamada "ideologia de gênero" aplicada à Educação, defendida por políticos progressistas de esquerda. A bancada evangélica na Câmara dos Deputados é contra a indicação do senador José Serra (SP) para a pasta. "Serra é a esquerda do PSDB junto com o expresidente Fernando Henrique Cardoso", justificou um parlamentar da bancada. O tucano era um dos nomes cotados para o ministério, mas nesta quinta surgiu como possível titular do Itamaraty $(\mathrm{O}$ Povo, 28/04/2016).

\footnotetext{
${ }^{48}$ Líder religioso de grande influência nacional e apresentador de programa de televisão voltado para público evangélico.
} 
O discurso cristão é reforçado nas falas dos deputados constantemente, como no trecho da matéria “"Somos sociedade cristã', diz deputada por alteração no Plano de Educação", de 3 de maio de 2016:

Segundo deputada, estimular o combate contra o preconceito é "doutrinação" de gênero. A deputada Dra. Silvana (PMDB) voltou a defender nesta terça-feira, 3, a remoção dos termos "LGBT", "gênero" e "diversidade" do Plano Estadual de Educação do Ceará. O projeto, que inclui entre seus pontos o combate à discriminação em escolas, deve ser votado ainda nesta semana pela Assembleia Legislativa. "Somos uma sociedade cristã por maioria e estamos em um estado laico. Logo, não podemos doutrinar as nossas crianças na sala de aula", diz Silvana, pastora evangélica. Ela apresentou diversas emendas retirando os termos da proposta. Carlos Matos (PSDB) já afirmou que trechos buscam implantar ideologia do "marxismo" no Brasil. Ely Aguiar (PSDC) destacou que fez emenda solicitando que a "ideologia de gênero" não seja abordada para alunos menores de 12 anos. "Esse PT é um partido das trevas, querendo levar para as crianças ideias anormais. O líder do Governo na Casa deve liberar a bancada", assinalou o deputado, apresentador de programas policiais (O Povo, 03/05/2016).

Em contraposição às falas dos deputados, o periódico publica artigos com opiniões contrárias à censura nas escolas (O Povo, "Escola livre é escola sem mordaça", 03/05/2016; "Projetos de lei. Educação sem ideologia?", 31/07/2016). No dia 13 de maio do mesmo ano, há a publicação de uma compilação de duas opiniões, uma contrária e outra a favor do Plano Estadual de Educação de Alagoas (O Povo, "Confronto de ideias", 13/05/2016). No texto "Movimento Escola sem Partido ganha força no país, mas divide professores", (O Povo, 15/10/2016), também expõe a opinião dos dois lados do debate, o contrário e o favorável,

Os contrários dizem que objetivo do projeto é evitar direcionamento ideológico (O Povo, "Debate. A escola e o equilíbrio entre visões divergentes", 31/07/2016). A seguir, um excerto de artigo "Escola Livre ou Terceira Margem", que visa proporcionar a reflexão sobre a questão:

Quem quiser estudar uma árvore específica, faz-se necessário estudá-la em seu habitat, a floresta. Para compreender o funcionamento de algum órgão humano, é fundamental entendê-lo 
integrado ao sistema do corpo (...) tudo se conecta. A concepção do conhecimento enquanto ilha há muito perdeu sentido. Pensemos num arquipélago. O conceito de "Escola Sem Partido" pretende fazer do ensino uma ilha, como se o conhecimento técnico fosse a supremacia a ser alcançada pelos jovens alunos (...) Por trás dessa cortina de fumaça, querem tirar dos jovens o direito de questionar, de duvidar e, principalmente, de criticar. A quem interessa tal retrocesso no ensino do País? Existe uma pressão conservadora organizada que visa acabar com os investimentos nas pesquisas científicas das universidades públicas (...) O encontro com o outro, com o diferente, com o desconhecido, é a célula que move o conhecimento e, por conseguinte, a democracia. Alargar essa questão é viver a pulsão da pluralidade social ( $O$ Povo, 05/09/2016).

O periódico passa a expor, portanto, expõe as posições favoráveis e as contrárias ao ensino de conteúdos que envolvem gênero nas escolas. Afirma, inclusive, que a divisão do país se dá também por causa do impeachment da presidente Dilma Roussef, que separou o pensamento político na sociedade brasileira, entre os cidadãos, em direita e esquerda $(O$ POVO, "Movimento Escola sem Partido ganha força no país, mas divide professores", 15/10/2016). Essa divisão teria separado a sociedade brasileira entre favoráveis à expresidenta e os contrários a ela teria sido transposta ao debate sobre o ensino no país assim como aconteceu com outras pautas.

As forças políticas do país percebem esse cisma e se organizam em torno dele, direcionando seus discursos no sentido de aumentar sua base eleitoral, apoio ou para terem visibilidade: "Crivella tem contra-atacado acusando o adversário de querer implantar nas escolas a chamada 'ideologia de gênero"” (O POVO, "Candidato do PRB mantém vantagem no Rio", 28/10/2016). Assim também têm ocorrido movimentos para defender um conjunto de ideias, de forma nebulosa de posicionamentos políticos sempre orientados pela direita ou esquerda. A exemplo da notícia "Grupo faz ato em Fortaleza em apoio à Lava Jato", sobre um protesto que pediu revogação do estatuto do desarmamento e o fim do foro privilegiado em Fortaleza:

Outras questões também foram debatidas na manifestação, que contou com trio elétrico, como ideologia de gênero, "escola sem partido", aborto e reforma da Previdência. Profissionais de diversas áreas, que apoiam o movimento, discursaram para os 
manifestantes. Pautas como ideologia de gênero e a escola sem partido vão ser abordadas hoje. No caso do psiquiatra Cláudio Costa, ele vem abordando um pouco sobre ideologia de gênero. Deixem nossas crianças em paz (O POVO, 26/03/2017).

A bancada evangélica se posiciona diretamente contra o ensino de gênero, da mesma forma como age diante proposições progressistas, como sobre a união homoafetiva, legalização das drogas e do aborto. Os parlamentares usam a religião para manipular a opinião pública e se sobressaírem em situações polêmicas (O POVO, "SP: Malafaia diz a tucanos que evangélicos não negociarão 'ideologia de gênero'", 17/08/2017).

Em dezembro de 2017, o jornal divulga que as discussões sobre gênero são tão recorrentes e supervalorizadas que ultrapassam a discussão do maior problema do estado do Ceará: a seca (O POVO, "O Ceará que a Assembleia discute. Discursos sobre gênero ultrapassam seca em debates na Assembleia", 03/12/2017). De acordo com a reportagem, mesmo com os níveis mais baixos dos reservatórios da região, os deputados preferem discutir a “doutrinação socialista" e a "ideologia de gênero" em escolas.

Este jornal, O Povo, realizou um levantamento dos assuntos mais comentados na Assembleia Legislativa e constatou que "discussões sobre o debate de gênero para crianças - classificada como 'ideologia de gênero' por grupos críticos - mobilizou pelo menos 48 pronunciamentos na Casa. O número supera discursos sobre a seca, 46, e até problemas mais estruturais da educação, 33" (O POVO, "O Ceará que a Assembleia discute. Discursos sobre gênero ultrapassam seca em debates na Assembleia”, 03/12/2017).

c) CARTA CAPITAL

A revista Carta Capital tem circulação nacional e é vendida em bancas de jornal. Tem tendência reconhecidamente de posição política mais à esquerda e seu conteúdo trata de cultura, educação, sociedade e política.

O primeiro artigo da amostragem traz uma notícia do Estado de Pernambuco, "No Recife, diversidade sexual pode deixar alunos sem livros" (CARTA CAPITAL, 29/03/2016). A reportagem diz que a bancada religiosa municipal quer banir livros que falam sobre questões de gênero e homossexualidade de qualquer conteúdo debatido nas escolas. A diretora de uma das escolas municipais conta que ficou sabendo da proibição somente no dia da distribuição do material, o que, segundo ela, foi um grave desrespeito por parte dos vereadores e que os livros não possuem o conteúdo que eles dizem possuir.

A revista publica logo no dia 8 de abril, 10 dias após a publicação sobre a proibição dos livros didáticos em Recife, um artigo de opinião com especialistas na área da educação sobre a neutralidade política dentro da escola. A neutralidade seria um desafio, mas é 
incentivada pelos especialistas, "o desafio colocado aos educadores é trabalhar em uma perspectiva de educação de direitos humanos, pautada pela igualdade, sem distinção de gênero, etnia, orientação sexual e, principalmente, política" (CARTA CAPITAL, "Como lidar com a polarização política dentro da escola? ”, 29/03/2016).

No dia 01 de junho, novamente, a revista publica uma reflexão sobre a questão política na educação (CARTA CAPITAL, “A falácia da Escola Sem Partido - ou do pensamento único”, 01/06/2016), onde o autor relaciona a violência contra a mulher no Brasil à falta de debate sobre a questão na sociedade. Diz que educar é um ato político por si e que o projeto Escola sem Partido estaria tentaria silenciar o pensamento crítico, exaltando o poder da reflexão social. Logo após, dias depois, outro texto (CARTA CAPITAL, "A escola tem um papel fundamental para romper com a cultura de estupro", 07/06/2016), trata da relação entre violência contra a mulher e a falta de educação para a igualdade no ensino público.

Outros textos também são publicados nesse sentido (CARTA CAPITAL, "Discutir gênero não tem nada a ver com 'apologia gayzista", 19/07/2016; "Escola Sem Partido: estratégia golpista para calar a educação", 08/08/2016; "Vamos falar sobre gênero?”, 26/10/2016; "Como trabalhar a igualdade de gênero na escola", 08/03/2017). Outros textos trazem a notícia amparada pela reflexão do tema, como quando um vereador de São Paulo tentou impedir a ocorrência de uma "Semana de Gênero" em uma escola da unidade (CARTA CAPITAL, "Por que é tão difícil falar de gênero na escola?", 04/11/2016).

A Carta Capital faz a análise do texto da última versão da Base Curricular para Ensino Infantil e Fundamental, sob o título "Conheça a última versão da Base Curricular para Ensino Infantil e Fundamental". O documento prescreve os objetivos de aprendizagem que deverão nortear os currículos de todas as escolas do País.

O texto é concluído com atraso - estava previsto para junho de 2016 - e ainda precisa ser aprovado pelo Conselho Nacional de Educação (CNE) e, posteriormente, homologado pelo ministro da Educação, Mendonça Filho. Entre os pontos mais polêmicos, estão a supressão do conceito de gênero do conteúdo e a determinação do inglês como idioma estrangeiro obrigatório a ser ensinado. Para a especialista, no entanto, o grande desafio começa com a homologação da BNCC. "Uma coisa é o documento, outra é o currículo. Isto é, a adaptação da prática pedagógica que isso demandará das escolas, sem falar de uma revisão na formação inicial e continuada dos professores e dos materiais didáticos". Outro ponto que precisará ser reformulado são as matrizes que 
edificam as avaliações externas do País. "Geralmente, vemos o ensino sendo pautado pelas avaliações e, agora, essa lógica precisará se inverter", aponta Patrícia (CARTA CAPITAL, 06/04/2017).

A preocupação do periódico em esclarecer aos seus leitores o conteúdo do texto da Base Nacional Comum Curricular é mais importante, no sentido de informar a população, do que contar os meandros dos bastidores dos conflitos políticos em torno da sua aprovação ou não. No dia 13 do mesmo mês, a revista continua a discutir o conteúdo da BNCC criticando a retirada dos conteúdos ligados à discussão de gênero no ensino (CARTA CAPITAL, "A sociedade perde ao não discutir gênero na escola", 13/04/2017). Depois, em 6 de julho, outro artigo fala sobre dúvidas relacionadas ao texto, aonde o BNCC chega à sua terceira versão e recebe fortes críticas (CARTA CAPITAL, "Base Nacional Comum Curricular: muitas perguntas, poucas respostas", 06/07/2017).

A Carta Capital acusa o Estado Brasileiro de omissão com relação aos crimes de homofobia no país quando se exime da discussão de gênero nas escolas, afirmando que os prejuízos com o silenciamento sobre as temáticas de gênero e sexualidade em sala de aula não são apenas da população LGBT, mas de toda a sociedade (CARTA CAPITAL, “Quando a tática do Estado para lidar com a homofobia é a omissão”, 16/05/2017).

Para defender a sua posição, a revista usa também de uma pesquisa para legitimar que o Estado brasileiro deve incluir pautas sobre igualdade nos planos de educação nacional (CARTA CAPITAL, "84\% dos brasileiros apoiam a discussão de gênero nas escolas", 26/06/2017). Essa pesquisa foi contratada pelo movimento Católicas pelo Direito de Decidir ao IBOPE Inteligência com 2 mil entrevistados.

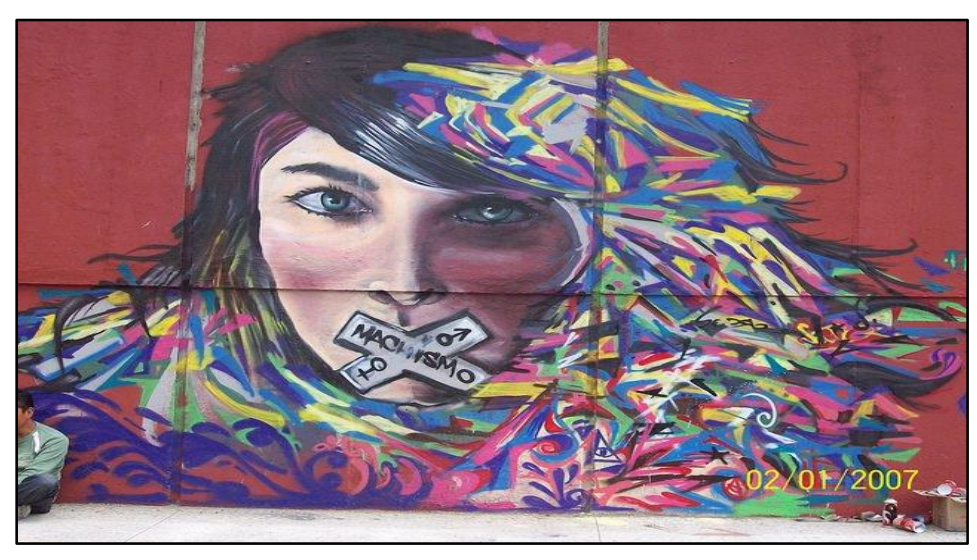

Figura 8 - A sociedade perde ao não discutir gênero na escola.

Fonte: Imagem relacionada ao artigo "A sociedade perde ao não discutir gênero na escola“ de 13 de abril de 2017, em versão somente digital no site da Carta Capital. Disponível em www.cartaeducacao.com.br. 
As disputas tornam-se mais fortes entre os defensores e os críticos de uma política educacional mais inclusiva. Nos meses que se seguem, no final de 2017 , fica claro que as disputas extrapolam os limites da arena política do congresso e das câmaras legislativas e alcançam a sociedade civil, provocando conflitos entre grupos sociais ${ }^{49}$. Em agosto, a revista Carta Capital publica um texto em que expõe que professores têm sido vítimas de perseguições, em artigo intitulado "Escola sem partido intimida e persegue professores" (CARTA CAPITAL, 02/08/2017).

A bancada religiosa passa a requisitar a inserção de ensino religiosa nas escolas após o nono ano do ensino fundamental na Base Nacional Comum Curricular, de acordo com o artigo "Gênero e ensino religioso juntos na base curricular" (CARTA CAPITAL, 06/12/2017). O texto conta que "a Base indica que os adolescentes a partir do $9^{\circ}$ ano (15 anos) deverão discutir o tema segundo 'diferentes tradições religiosas e filosofias de vida". O artigo ainda diz que "Um dos aspectos da proposta da BNCC é a presença de propostas que contemplam os interesses dos empresários da educação, como produtores de softwares e materiais educativos" (CARTA CAPITAL, "Escola sem partido intimida e persegue professores", 02/08/2017).

A Carta Capital publica a notícia mais preocupante em seguida. Segundo a revista, o jornal Gazeta do Povo criou uma plataforma para denúncias de estudantes que acreditam sofrer “doutrinação" em sala de aula, afirmando que esse tipo de ação pode gerar perseguições a professores: "Segundo informações da reportagem veiculada pelo jornal, são crescentes os casos de condutas inapropriadas de professores em sala de aula, a chamada doutrinação, 'quando um professor usa seu tempo em sala de aula para extrapolar os conteúdos prédefinidos com claro posicionamento ideológico"” (CARTA CAPITAL, "Jornal Gazeta do Povo cria "Monitor da Doutrinação" para as escolas", 08/12/2017). O artigo continua com a opinião de um especialista:

"A confiança dentro das salas de aula deve ser mantida e reforçada." Para o doutor em Direito do Estado e professor Adjunto do Bacharelado em Políticas Públicas da Universidade Federal do ABC (UFABC), Salomão Ximenes, além de inconstitucional, a iniciativa pode ser configurada como um conjunto de crimes previstos no Código Penal, como ameaça, constrangimento ilegal e

\footnotetext{
${ }^{49}$ Sobre este ponto será discutido ainda nessa seção, na subseção "Consequências sociais".
} 
associação criminosa. A iniciativa também é vista com preocupação pelo "É muito grave um órgão da imprensa acuar servidores no exercício da profissão. Isso não é controle social, apenas uma estratégia para acuar os professores”, critica. A ideia da plataforma seria reunir essas denúncias e promover averiguação dos casos. A primeira reportagem sobre o assunto afirmava que, uma vez recebidas as denúncias e checadas as informações, "a equipe da Gazeta entra em contato com a escola e, quando necessário, a Secretaria de Educação do estado ou do município para ouvir a resposta de quem de direito. Para ele, o veículo cria um "tribunal pedagógico" para fazer pressão sobre as comunidades escolares e as escolas, alinhada à agenda do Escola sem Partido. "Isso vai fazer com que os professores tenham medo de abordar em suas aulas temas ligados à conquista dos direitos sociais, sexualidade e teoria da evolução, por exemplo", avalia. $\mathrm{Na}$ plataforma é possível buscar o registro das denúncias por modalidade de ensino - Fundamental, Médio e Superior - e também por estado. O que apresenta maior número de registros é o Rio Grande do Sul, com quatro denúncias (CARTA CAPITAL, 08/12/2017).

Três dias depois o Jornal Gazeta retira do ar o "Monitor da Doutrinação" após críticas de professores, empresários e sindicatos (CARTA CAPITAL, “Após pressão, jornal Gazeta do Povo tira do ar Monitor da Doutrinação”, 11/12/2017).

No dia 15 daquele mesmo mês, é publicada a aprovação da BNCC (CARTA CAPITAL, “Conselho aprova Base Nacional Comum Curricular", 15/12/2017), em meio a polêmicas sobre ensino religioso e esvaziamento do debate sobre gênero, Conselho Nacional de Educação aprova as diretrizes, com ensino religioso e sem conteúdos de educação de gênero.

A revista passa a publicar textos sobre o Escola sem partido e as influências da bancada evangélica na educação, sempre com o posicionamento de que a escola deve ser livre e que o ensino de conteúdos ligados à promoção da igualdade de gênero deve ser também, em igual medida, preservado.

O último texto da amostragem traz a reflexão sobre o projeto Escola Sem Partido. O excerto a seguir, contido em "Falso discurso da Escola Sem Partido avança no Congresso", traz a leitura que o periódico faz do processo de tentativa de implementação do projeto: 
Na terça-feira 8, o deputado Flavinho (PSC) apresentou o projeto da Escola Sem Partido (PL 7180/14) prevendo que cada sala de aula tenha um cartaz com seis deveres dos professores, entre os quais o primeiro é a proibição de que os docentes "cooptem" os estudantes para correntes políticas, ideológicas ou partidárias. $\mathrm{O}$ projeto propõe, na verdade, a escola de partido único, porque proíbe o debate e a livre circulação de ideias nas salas de aula. Para muitos, trata-se de uma verdadeira "Lei da Mordaça". O programa obriga os professores a manter a suposta neutralidade em sala de aula ao lecionar várias disciplinas como, por exemplo, história e geografia. Claro que não se pode ser favorável a nenhuma espécie de doutrinação no ambiente escolar, mas os defensores do Escola sem Partido, como destacou a Confederação Nacional dos Trabalhadores em Estabelecimentos de Ensino (Contee) ao dizerem que "desconhecem solenemente o processo pedagógico, uma vez que educação pressupõe, em seu sentido pleno, o incentivo à capacidade reflexiva, ao diálogo, à construção da cidadania, sendo, portanto, uma atividade política por excelência, no aspecto etimológico da palavra”. Qualquer proposta fora disso é defender uma escola acéfala, que formaria estudantes completamente alienados. Desnecessário dizer que esse é o mundo ideal para os maus políticos. Como falar do Golpe Militar de 1964 sem lembrar as perseguições, prisões e assassinatos de civis promovidos pelo Estado brasileiro durante a Ditadura Militar? Como explicar o fim da União Soviética sem uma contextualização política e econômica? Os apoiadores mais afoitos (e conservadores) dessa proposta já defendem até exclusão de disciplinas como Filosofia e Sociologia da grade curricular das escolas. Um absurdo total; ou seja, seria cômico se não fosse trágico, uma vez que, em caso de descumprimento dessas propostas de lei, professores estariam sujeitos a várias punições, que vão desde uma suspensão, demissão e até, acredite, prisão. Apesar de não ter qualquer sustentação pedagógica e jurídica, as propostas do tal Escola sem Partido já tramitam em vários Estados brasileiros. Em 2017, o Partido 
Progressista, o Partido Social Cristão, Partido da Social Democracia Brasileira e MDB (Movimento Democrático do Brasil, ex-PMDB) foram os partidos que mais apresentaram PLs do 'Escola sem Partido' e contra 'ideologia de gênero' pelo país. Desde 2014, quando foi apresentado o primeiro projeto de lei, de autoria de Flávio Bolsonaro, na Assembleia Legislativa do Rio de Janeiro, a média por ano de projetos idênticos ficava em torno de 20. Em 2017, chegou a 91, de acordo como estudo do grupo Professores Contra o Escola Sem Partido. Melhor seria se esses políticos substituíssem os professores por robôs que poderiam, assim, transmitir o conteúdo para os alunos ou talvez simplificar tudo com uma simples consulta na internet. É bom lembrar que o referido programa ainda contraria a Constituição Federal, que prevê a liberdade de aprender, ensinar, pesquisar e divulgar o pensamento, a arte e o saber. A Contee tem reiteradamente apontado - incluindo na campanha nacional contra a Lei da Mordaça e na vitoriosa Ação Direta de Inconstitucionalidade (ADI) impetrada no Supremo Tribunal Federal - que a censura, a perseguição e a criminalização dos professores representam uma afronta à Constituição, à liberdade de aprender e ensinar e à concepção de uma educação crítica, democrática e cidadã. No ano passado, a educação brasileira foi criticada pela Organização das Nações Unidas (ONU) precisamente pela retirada dos termos "gênero" e "orientação sexual" do texto da Base Nacional Comum Curricular (BNCC). A Lei da Mordaça afronta os principais tratados internacionais dos quais o Brasil é signatário, entre eles a Declaração Universal dos Direitos Humanos que, no seu artigo 18, destaca: "Toda pessoa tem direito à liberdade de pensamento, de consciência e de religião; este direito implica a liberdade de mudar de religião ou de convicção, assim como a liberdade de manifestar a religião ou convicção, sozinho ou em comum, tanto em público como em privado, pelo ensino, pela prática, pelo culto e pelos ritos". E no artigo 19: “Todo o indivíduo tem direito à liberdade de opinião e de expressão, o que implica o direito de não ser inquietado pelas suas opiniões e o de procurar, receber e difundir, 
sem consideração de fronteiras, informações e ideias por qualquer meio de expressão..." (CARTA CAPITAL, 14/05/2018).

A Carta Capital possui um editorial que se coloca à esquerda nas discussões e na leitura dos eventos nacionais relacionados à educação de gênero. No conjunto de artigos que compõem a amostra percebe-se que a revista é tendenciosa na defesa da liberdade do ensino e da livre exposição de ideias.

\section{d) REVISTA FÓRUM}

A Revista Fórum traz um posicionamento mais à esquerda no debate colocado sobre o ensino de gênero nas escolas. O conteúdo é voltado mais para a análise dos acontecimentos e exposição de opiniões, deixando faltar na função informativa dos eventos. Assim, a leitura dos dados mostra uma revista que se preocupa em dar as explicações sem detalhar os fatos.

O primeiro artigo analisa a fala do então deputado Jair Bolsonaro - eleito presidente do Brasil em 2018 - onde denuncia a existência de um "kit gay" no ensino público do país (FÓRUM, "Bolsonaro grava vídeo sobe educação e revista especializada desmente frase por frase", 17/01/2016). O material exibido em um vídeo na internet, onde o deputado diz ser de apologia à homossexualidade, seria parte do material "Escola sem Homofobia" que visa discutir igualdade com alunos.

Bolsonaro, entre outras inverdades que diz ao longo de todo o vídeo, mostra livros que sequer são distribuídos nas escolas e ainda confunde a revista 'Nova Escola' também com um livro, afirmando que ela é distribuída para crianças em escolas públicas. A publicação, então - que é especializada em educação -, resolveu produzir um outro vídeo em que desmente cada informação improcedente dita por Bolsonaro. "Quando o assunto é educação, pergunte a quem conhece", escreveu a revista no final do vídeo que batizou de "Checagem de informações" (FÓRUM, 17/01/2016).

O segundo artigo da amostra exemplifica essa característica de publicar opiniões. O prefeito de São Bernardo do Campo (SP), Luiz Marinho, que é ex-ministro do Governo Lula e figura forte do Partido dos Trabalhadores (PT), fez declarações sobre a inclusão de conteúdos de gênero na educação que desagradaram setores da sociedade e do partido ao qual ele pertence. A Fórum publica, então, o posicionamento do setorial LGBT e de Mulheres do PT nacional, que repudia as afirmações machistas (FÓRUM, "Mulheres e LGBTs do PT repudiam declarações de ex-ministro Luiz Marinho”, 27/01/2016). 
Em junho a Câmara de Vereadores de Porto Alegre abre processo para instituir "diretrizes orientadoras ao comportamento aos estabelecimentos de ensino, funcionários, responsáveis e corpo docente, no ministério que envolve o ensino de questões sócio-políticas, preconizando a abstenção da emissão de opiniões de cunho pessoal que possam induzir ou angariar simpatia à determinada corrente político-partidário-ideológica” (FÓRUM, “Qual o partido da escola sem partido?”, 02/06/2016). A revista publica um texto que critica essa posição dos vereadores, afirmando que o ensino de outros conteúdos estaria em risco pelo controle ideológico do projeto.

A revista mantém o caráter de denúncia contra ações relacionadas à ideia do "Escola sem Partido". A presidenta do Sindicato dos Professores do Ensino Oficial do Estado de São Paulo, Maria Izabel Azevedo Noronha, escreve um artigo para a revista reclama da ação de uma corrente da Igreja Católica dentro de uma escola do Estado de São Paulo, dizendo que haveria ali uma doutrinação religiosa. Argumenta que, enquanto se discute a proibição de determinados conteúdos ditos "doutrinadores, outros são permitidos, principalmente os religiosos e conservadores (FÓRUM, "O que fazia uma seita religiosa em uma escola estadual paulista?", 04/06/2016)".

Ainda em junho, a Fórum apresenta mais um texto, chamada "Clóvis Gruner: O excepcional normal", em que relaciona a falta de discussão sobre questões de gênero com a violência urbana gerada pelo preconceito:

Aqui nossa esfera pública é atravessada pela vontade religiosa e privada: nas escolas, estamos proibidos de discutir gênero; psicologias cristãs defendem a "cura gay"; e o Estado ameaça com um Estatuto que não reconhece como família outra que não a formada pela união entre um homem e uma mulher (FÓRUM, 16/06/2016).

A perseguição de políticos ligados às igrejas cristãs aumenta. No dia 8 de julho, uma deputada evangélica foi informada sobre um trabalho escolar passado por um professor, na cidade de Brasília, e decidiu interferir: "depois de ter recebido reclamações sobre esse debate em seu gabinete, Sandra Faraj decidiu encaminhar um ofício ao colégio cobrando “esclarecimentos' e 'providências legais cabíveis"” (FÓRUM, "Deputada evangélica pede "providências legais" contra professor que debateu homofobia em sala de aula", 08/07/2016).

O trabalho pedido pela escola envolvia temas como transexualidade e homofobia, o que é permitido pelo PNE porque envolve cidadania e direitos humanos. A deputada federal do PT, Erika Kokay, representou contra a dep. Sandra Faraj em conformidade com o 
Conselho Regional de Psicologia, o Conselho de Direitos Humanos e o Sindicato dos Professores do Distrito Federal. Em resposta, Sandra se disse vítima de uma perseguição e que as escolas só devem ensinar matérias como Matemática, Língua Portuguesa, Ciências, Física e Química (FÓRUM, “Deputada evangélica pede “providências legais” contra professor que debateu homofobia em sala de aula", 08/07/2016).

A revista defende o argumento de que há perseguição aos professores, tanto que quando noticiou a nomeação e desoneração do ministro da educação Adolfo Sachida, que aconteceram no mesmo dia por causa de seu polêmico apoio ao Escola sem Partido, ressalta que uma professora foi suspensa de uma escola depois que seus alunos fizeram uma paródia do funk "baile de favela" que abordava Karl Marx ${ }^{50}$ (FÓRUM, "Em algumas horas, MEC nomeia e exonera economista ligado ao "Escola Sem Partido"”, 12/07/2016). No dia 14 de julho, o historiador e professor da Universidade Federal do Paraná, Clóvis Gruner, explica no artigo "Uma farsa chamada "Escola sem Partido":

“A Escola sem Partido teme uma sociedade mais plural e sensível às diferenças e a diversidade, sejam elas étnicas, religiosas, de classe ou gênero, e sabe que uma escola e uma educação de qualidade são condições imprescindíveis para a construirmos". Hoje, projetos de lei que visam banir do ensino a "doutrinação ideológica" e instituir uma "escola sem partido" seguem em andamento em sete estados (RJ, GO, SP, ES, CE, RS, PA) e no DF. Em um, Alagoas, ele já foi aprovado pela Assembleia Legislativa. A inconsistência do projeto aparece já na argumentação que o justifica: o objetivo é "garantir a neutralidade política, religiosa e ideológica" e, ao mesmo tempo, "a pluralidade de ideias". Bom, ou bem se é neutro, ou bem se é plural: ser ao mesmo tempo duas coisas antagônicas e excludentes é bastante difícil. Mas a contradição não é o único nem o maior problema do projeto e da escola que ele pretende parir (FÓRUM,14/07/2016).

Da mesma forma, mais de um ano depois, uma aluna é suspensa de sua escola depois de criticar censura. Jovem de 17 anos resolveu rebater panfleto lançado pela escola Univest de Lages, em Santa Catarina, e recebeu punições; mãe estuda acionar a Justiça (FÓRUM, "Aluna é suspensa depois de criticar escola que proibiu discutir sexo, gênero e religião", 20/10/2017).

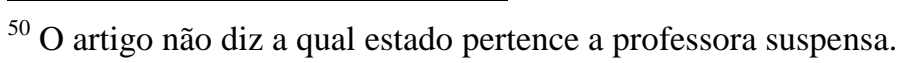


Um movimento contra o Escola sem Partido se organizam após consequências do projeto, no Rio de Janeiro. Nomeado como Frente Escola sem Mordaça, foi lançado em comemoração ao Dia dos Professores, por sindicalistas, docentes, estudantes, ativistas, mães, pais e responsáveis. Embora não tenha tido grande repercussão, o protesto apresenta a contraposição ao conservadorismo e às perseguições (FÓRUM, "Sindicalistas, estudantes e pais lançam ‘Frente Escola sem Mordaça' no Rio de Janeiro”, 16/10/2016).

O alcance das discussões à rua acontece dos dois lados da questão. Em 29 de outubro de 2017, é noticiada uma confusão entre grupos em um debate sobre gênero, na cidade do Guarujá (FÓRUM, “Grupo fascista cria tumulto em debate sobre "ideologia de gênero" em Guarujá", 29/10/2017). Durante uma discussão sobre gênero, um grupo de fanáticos neopentecostais invadiu a atividade e passou a ofender e ameaçar as pessoas presentes, além de tentar impedir o andamento da atividade:

Um show de intolerância, fascismo, falta de respeito e educação foi visto no evento Desafios de uma educação libertadora, que debateu questões relacionadas à ideologia de gênero e ao universo LGBT, realizado neste sábado (28), na Câmara Municipal de Guarujá, litoral de São Paulo. Durante os debates, um grupo de fanáticos neopentecostais invadiu a atividade, provocando tumulto, ofendendo e ameaçando as pessoas presentes, além de tentar impedir o andamento da atividade. A organização do encontro, democraticamente, concedeu o direito à fala aos fascistas, que se utilizaram do microfone para destilar o ódio peculiar, mas, em contrapartida, queriam impedir de se pronunciar quem tivesse ideias diferentes (FÓRUM, 29/10/2017).

O presidente em exercício, Michel Temer, aprova a versão da BNCC em dezembro de 2017. Excluindo o combate à descriminação de gênero e incluindo o ensino religioso, a nova base curricular nacional do Ministério da Educação atende às demandas da bancada evangélica e retira menções de gênero na educação. Segundo ela, partir de 2018, "as escolas devem discutir discriminação de gênero e sexualidade apenas dentro do âmbito do Ensino Religioso" (FÓRUM, "Temer exclui combate à discriminação de gênero na base curricular e inclui tema na área de Ensino Religioso", 06/12/2017).

\subsection{Uso político e religioso do conflito}

Movimentos ligados à educação nacional têm demandado políticas orientadoras da educação desde a redemocratização do país - após o fim da ditadura militar que perdurou 
de 1964 a 1985. Porém, com o acirramento da polarização política do país após 2013, as disputas ideológicas entre a parcela conservadora (de direita) e os progressistas (de esquerda) avança sobre a educação nacional, atuando de forma decisiva nas proposições acerca do ensino básico no Brasil.

O texto a seguir publicado em "SP: Malafaia diz a tucanos que evangélicos não negociarão 'ideologia de gênero'" descreve esta disputa, onde os políticos de origem religiosa, comumente os pastores e bispos de igrejas protestantes evangélicas, utilizam das discussões da educação para defender posições não políticas.

Em discurso ao lado do governador de São Paulo, Geraldo Alckmin, e do prefeito João Doria [do estado de São Paulo]- ambos cotados para disputar a Presidência da República em 2018 pelo PSDB -, o pastor Silas Malafaia adiantou que a comunidade evangélica não vai negociar princípios e apoiar políticos que defenderem bandeiras como aborto, casamento gay, legalização das drogas e "ideologia de gênero".

"Quem quiser fazer graça na eleição para o politicamente correto, para a ideologia de gênero, casamento gay, legalização das drogas e aborto, vai embora, segue seu caminho", afirmou Malafaia em evento na zona norte da capital paulista que reuniu lideres evangélicos. "Não vamos negociar nossos valores. Não vamos negociar em nenhuma eleição", acrescentou o pastor, que classificou a ideologia de gênero como uma "engenharia do diabo feita para destruir famílias".

Ele foi bastante aplaudido pelos presentes nos momentos em que defende os "valores da família".

Alckmin e Doria participaram na manhã desta quinta-feira, 17, de um café da manhã com líderes evangélicos e, na sequência, abriram uma feira de produtos gospel que acontece até sábado na Expo Center Norte, centro de convenções na zona norte da capital paulista. Ambos também acompanharam um culto, onde oraram com as mãos erguidas, tendo a bandeira do Brasil como pano de fundo.

Os tucanos, porém, evitaram se posicionar em relação às bandeiras defendidas pelos evangélicos e citadas por Malafaia. Foi a primeira vez em que o governador e o prefeito dividiram o mesmo palanque desde que Doria intensificou sua agenda de viagens pelo Brasil - o 
que foi visto por aliados de Alckmin como uma campanha antecipada pelo Palácio do Planalto.

O presidente Michel Temer também era aguardado no evento, mas acabou cancelando sua participação.

Em discurso antagônico ao de Doria, que prega o antipetismo, Alckmin defendeu a "conciliação". "Nós precisamos nos inspirar na igreja. Nos momentos conturbados, a igreja é nosso porto seguro. Precisamos deixar essa divisão de nós contra eles para nos unir em torno de valores. Uma casa dividida não caminha", afirmou o governador, que também destacou a importância da indústria gospel na geração de empregos e o papel social das igrejas evangélicas.

Doria, por sua vez, fez um discurso mais protocolar, no qual exaltou a igreja, disse que o "bem sempre vai prevalecer sobre o mal" e defendeu a religião como saída ao vício das drogas. Concluiu sua fala dizendo que "feliz é a nação que tem Deus no coração". Tanto Doria quanto Alckmin deixaram o local sem falar com a imprensa (O POVO, 17/08/2017).

No texto fica claro o uso do tema para polemizar a questão e angariar votos dos evangélicos para determinados políticos ligados às igrejas cristãs. Mesmo os políticos paulistas que já anteveem as eleições de 2018 aproveitam do evento religioso para endossar o discurso conservador do pastor, Silas Malafaia. Silas é líder do ministério Vitória em Cristo, corrente da igreja pentecostal Assembleia de Deus. Ele é também apresentador de um programa evangélico, que possui programação diária de evangelização na televisão aberta, em horário nobre, de alcance nacional. Os políticos paulistas citados, Dória e Alckmin são católicos.

No Rio de Janeiro acontece um movimento parecido, mas neste estado a relação dos políticos locais com a igreja é mais próxima. Marcelo Crivella, político do Partido Republicano Brasileiro - PRB - no estado, é bispo e cantor gospel da Igreja Universal do Reino de Deus. Usa o termo "ideologia de gênero" para atacar a esquerda. Na eleição de 2017 para a prefeitura da cidade do Rio, em oposição à Marcelo Freixo, do partido de esquerda Socialismo e Liberdade - PSOL - que defende temas ligados aos Direitos Humanos. 
O candidato do $\mathrm{PRB}$ à prefeitura do Rio, Marcelo Crivella, mantém-se em primeiro lugar nas intenções de voto na disputa do próximo domingo, segundo nova pesquisa divulgada ontem pelo Ibope. Crivella tem 46\%, contra 29\% de Marcelo Freixo (PSOL), mesmos índices do levantamento realizado na semana passada. Crivella tem contra-atacado acusando o adversário de querer implantar nas escolas a chamada ideologia de gênero. Também tem acusado a revista Veja e os veículos de comunicação das Organizações Globo de tentarem interferir na disputa eleitoral com mentiras que o prejudicam (O Povo, 28/10/2016).

A disputa teve como vencedor Marcelo Crivella, afirmando a força do uso político da religião, entre outros motivos que fizeram dele prefeito da cidade.

A combinação de política com religião também está presente em Tianguá, no estado do Ceará, a 329 quilômetros de Fortaleza. Na discussão sobre o Plano Municipal de Educação, o tema "respeito à diversidade" criou tumulto em sessão da câmara entre conservadores e $\operatorname{progressistas}^{51}$, noticiado em "Votação de Plano Municipal de Cultura gera polêmica e ataques homofóbicos":

Após ser alterada, a meta 16 do plano fala apenas em "apoiar a realização de atividades culturais e instituições de cultura e educação como forma de promover o debate sobre o respeito à diversidade". Natal afirma que, para seguir a votação, precisou ser retirado texto qualquer menção à sigla LGBT ou às religiões de matriz africanas. $\mathrm{O}$ suplente de vereador passou a receber áudios que considera violentos. O POVO Online teve acesso às gravações. Em uma delas, uma mulher - que se identifica como uma moradora do município - diz que Natal está criando uma "sujeira" na cidade. "Os evangélicos estão contra. Vai ser um problema pra próxima política. Olha que evangélico é coisa séria", diz. "Sou uma pessoa que faço parte do movimento público e muita gente me conhece. Já fui muito influente na política. Não vamos aceitar isso", continua. Em outro áudio direcionado ao suplente, um homem anônimo classifica o projeto como "atordoado" e diz que ele "não pode colocar o nome das pessoas de bem" no plano. "Não tenho nada

${ }^{51} \mathrm{O}$ artigo completo encontra-se nos apêndices deste trabalho. 
contra os 'viados'. Quem quer dar o ** que dê. Se a opção dele é ser *******, é problema dele", diz o homem. "Ele pegar a ********** dele e jogar dentro de Tianguá para a Prefeitura ser responsável, não tem nada a ver". Uma terceira pessoa, que se identifica como vereador Mariano Diniz, diz também em áudio que a Secretaria da Cultura tenta "empurrar goela abaixo" o projeto. "Sempre me posicionei contra essa meta porque eles não adequaram meu pedido de comemorar o dia da bíblia. Não respeitaram também", dispara. "Me procuraram para conversar na Câmara Municipal. Que fechei a porta pra eles. Não aceito mais diálogo". A discussão continuou no Facebook. Em uma das postagens sobre o assunto, um homem afirma que é preciso unir forças e "exigir que veados e sapatão sejam apedrejados em praça pública" (O Povo, 20/11/2017).

Após a polêmica, a Secretaria de Cultura do Estado do Ceará comunicou que possui uma equipe especializada na produção de políticas de cultura, responsável pelas elaborações e planejamentos, que entende a cultura como formadora do processo civilizatório e que mantém diálogo com prefeitos e dirigentes locais. "O Ceará tem uma diversidade cultural muito grande. É necessário defendermos o enfrentamento dos gargalos do setor para afirmação plena dos direitos culturais e para pensar a cultura como o modelo de desenvolvimento que queremos para o País", disse o secretário de cultura à época (O Povo, "Votação de Plano Municipal de Cultura gera polêmica e ataques homofóbicos", 20/11/2017).

Percebe-se, também, que há uma falta de conhecimento por parte da população e que os políticos interessados em usar do tema para angariar votos pervertendo os seus sentidos, notadamente no uso do termo “ideologia de gênero". A população, os eleitores, desenvolvem lógicas errôneas para o debate educacional no Brasil, por consequência perde-se tempo com teorias falsas.

Ao invés dos políticos refletirem as vontades do povo, acontece o contrário, os políticos influenciam o pensamento de seus eleitores e se conseguem mais poder.

$\mathrm{O}$ artigo “Opinião: igrejas neopentecostais ameaçam democracia na América Latina” do O Povo discute essa ideia de que se perde muito tempo com ideias religiosas dentro da política e se deixa de pensar em assuntos mais importantes para a população, reflexo do aumento do radicalismo religioso em toda a América Latina: 
O poder crescente de seitas evangélicas e partidos políticos "moralizadores" estão colocando as democracias da região à prova. Um país onde se fundam mais facções religiosas que escolas, como a Colômbia, pode avançar? A luta das igrejas neopentecostais na América Latina é uma luta pelos pobres: por sua consciência, por suas carteiras e por seus votos. Seu êxito se deve também ao fracasso da Igreja católica em atender às necessidades de milhões que buscam apoio num mundo cada vez mais frustrante e sem aparente futuro. E a história de abusos sexuais do dogma católico deixou, além disso, um rastro de repúdio em vários países e contribuiu para a erosão de um poder passado. (...) É assustador é que muitos desses pastores tenham tanto êxito com ideias excludentes e um discurso de ódio. Em suas pregações, Piraquive descarta que pessoas com deficiência física possam assumir a veiculação da "palavra de Deus". Uma postura discriminatória em todos os países latinoamericanos, que, pelas suas Constituições, se definem como pluralistas e laicos, fundados sobre o respeito e a dignidade humana, e garantidores da liberdade de expressão e de culto. Paradoxalmente, apesar de essas sociedades terem avançado cultural e economicamente, também graças ao princípio liberal e protestante de que "os pensamentos são livres", o movimento neopentecostal ataca o Estado de opinião. O radicalismo de suas ideias contra as conquistas dessas sociedades abertas, como a abolição da pena de morte, a autodeterminação da mulher e o respeito aos direitos das minorias é difamado como uma suposta "ideologia de gênero" que pretende destruir a família e a moral. (O POVO, 10/02/2018).

A constatação de que se discute mais gênero do que a seca foi feita pelo jornal sobre todos os discursos proferidos na casa legislativa estadual no ano de 2017, superando também outros assuntos da educação (O POVO, "O Ceará que a Assembleia discute. Discursos sobre gênero ultrapassam seca em debates na Assembleia", 03/12/2017). Esse fato demonstra a gravidade do fenômeno da apropriação da discussão educacional pela política e religião.

“Isso é extremamente natural e democrático. O Brasil é um país de maioria conservadora, as famílias são baseadas nos valores cristãos. 
Então o parlamento acaba sendo uma caixa de ressonância do que o povo sente, do que ele quer ver os deputados defendendo", diz Ely Aguiar (PSDC). "O próprio eleitor pressiona, a gente sente essa pauta", corrobora Mário Hélio (PDT). Fernando Hugo (PP) destaca ainda que o debate entre os temas se acirrou por conta de uma reação da população à "imposição" de posturas não conservadoras que teria ocorrido durante governos do PT. "O Brasil vinha de um processo intenso de esquerdização", diz. Entre parlamentares mais ligados a este tipo de defesa, se destacou neste ano Dra. Silvana (PMDB). Pastora evangélica, a peemedebista é responsável por quase a metade dos discursos sobre gênero na Casa, e convocou audiência para debater o movimento Escola Sem Partido. Entre outros temas, Silvana defende que instalação de comissão para "fiscalizar" ensino de gênero e chegou até a elogiar a Escola Educar SESC, de Fortaleza, após ela orientar uma adolescente transexual de 13 anos a deixar a escola. "A diretora se posicionou de maneira valente e serena", disse em sessão do Legislativo. A escola voltou atrás da decisão. "Não há perseguição à preferência sexual de ninguém, mas se todas as pessoas quiserem mudar seus nomes vai haver uma insegurança jurídica e fragilizar as nossas legislações", justifica Silvana. Questionada sobre o tema, a deputada nega qualquer tipo de discriminação e diz que a "ideologia de gênero" busca "desafiar valores" do cristianismo. “Acredito na união da sociedade cristã contra essa imposição. $\mathrm{O}$ tempo inteiro a Rede Globo está tentando impor isso como algo normal”. (O POVO, 03/12/2017).

Quando a política é entendida pela população como um espaço representativo da sociedade, onde conversam os "líderes" da sociedade, uma correlação de legitimidade é estabelecida. De forma abstrata, o que o governo e as câmaras legislativas discursam é absorvido na teia social como falas autorizadas.

A população vê seus preconceitos autorizados quando, no ambiente político, os preconceitos são legitimados. Acontece, por consequência a naturalização de ideias, o que antes era antidemocrático passa a ser, como nas falas contra o movimento LGBT ou contra o movimento feminista. 
A noção de Direitos Humanos, de acordo com a professora Martínez Quintero (2016) é distorcida, estabelecem-se novas noções do que é direito e do que é o Direito Humano. É estipulado a quem devemos respeitar como o "homem de bem", particularmente o homem, branco, cis, hétero, de classe média ou média alta. Os outros indivíduos devem segui-lo ou são oposição ao Brasil. Ainda, na opinião da professora, existe uma confusão entre a violência de gênero e a violência doméstica, o que enfraquece a eficácia e a aplicação das normas destinadas a combater a violência de gênero e as violações de direitos humanos (STF, 2015).

A violência contra gays, transexuais e mulheres é naturalizada, como se vê em "A verdadeira "ideologia de gênero",

O brutal espancamento, seguido de morte, de Dandara, bem como a violência desferida contra Herica, semanas depois, na avenida José Bastos (ambas pessoas trans) são fatos mais do que oportunos para nos fazerem recuar um pouco no tempo e pensar melhor sobre o porquê da violência contra pessoas trans ainda ser tão legitimada ou, ao menos, pouco "choradas". No ano de 2015, assistimos a uma verdadeira "cruzada nacional" em todos os espaços do Poder Legislativo por parte de parlamentares ligados às diversas instituições religiosas, para retirarem dos Planos Estaduais e Municipais de Educação qualquer referência às questões de gênero. Seus discursos, de Norte a Sul do País, diziam o mesmo: queriam transformar as escolas em espaços de "destruição da família", a ensinar "as crianças a serem gays" e coisas do tipo. Discurso ralo, mas que impôs dura derrota aos movimentos LGBT e, em especial, às pessoas que sofrem, diuturnamente, discriminações por conta de sua identidade de gênero (que pode assumir as feições de um assassinato, como vemos sempre). O que chamavam de "ideologia de gênero" é, na verdade, um conjunto de estudos que, desde os anos 1970, passaram a questionar a ideologia dominante em seus diversos aspectos: no que tange a uma suposta inferiorização da mulher e seu papel "essencial" de condutora do lar, o que sustenta o machismo e as diversas faces da misoginia; a denúncia de uma suposta anormalidade daqueles que não se orientavam sexualmente para o sexo oposto, os homossexuais, por tanto tempo tidos como "doentes"; a despatologização das identidades trans, daqueles e 
daquelas que não se identificavam com seu corpo biológico, mas, sim, com o outro gênero etc. É isso que os estudos de gênero desconstroem, na possibilidade de construção de um espaço social plural. Mas, nossa escola, e a sociedade, viu-se "livre" dessas problemáticas, fazendo com que menos espaço exista para pessoas diferentes, continuando a relegar-se, a pessoas como Dandara e Herica, o espaço da violenta exclusão (O POVO,21/03/2017).

Em 03 de janeiro de 2019, lei número 13.796, o presidente eleito, alinhado às forças conservadoras cristãs e crítico da liberdade de expressão na escola, promulga a lei que determina a opção do aluno se ausentar das aulas onde o tema não esteja de acordo com a sua religião:

\section{O PRESIDENTE DA REPÚBLICA}

Faço saber que o Congresso Nacional decreta e eu sanciono a seguinte Lei:

Art. $1^{\circ}$ A Lei $n^{\circ}$ 9.394, de 20 de dezembro de 1996 (Lei de Diretrizes e Bases da Educação Nacional), passa a vigorar acrescida do seguinte art. $7^{\circ}-\mathrm{A}$ :

“Art. $7^{\circ}$-A Ao aluno regularmente matriculado em instituição de ensino pública ou privada, de qualquer nível, é assegurado, no exercício da liberdade de consciência e de crença, o direito de, mediante prévio e motivado requerimento, ausentar-se de prova ou de aula marcada para dia em que, segundo os preceitos de sua religião, seja vedado o exercício de tais atividades, devendo-se-lhe atribuir, a critério da instituição e sem custos para o aluno, uma das seguintes prestações alternativas, nos termos do inciso VIII do caput do art. $5^{\circ}$ da Constituição Federal:

I - prova ou aula de reposição, conforme o caso, a ser realizada em data alternativa, no turno de estudo do aluno ou em outro horário agendado com sua anuência expressa;

II - trabalho escrito ou outra modalidade de atividade de pesquisa, com tema, objetivo e data de entrega definidos pela instituição de ensino.

$\S 1^{\circ}$ A prestação alternativa deverá observar os parâmetros curriculares e o plano de aula do dia da ausência do aluno. 
$\S 2^{\circ} \mathrm{O}$ cumprimento das formas de prestação alternativa de que trata este artigo substituirá a obrigação original para todos os efeitos, inclusive regularização do registro de frequência.

$\S 3^{\circ}$ As instituições de ensino implementarão progressivamente, no prazo de 2 (dois) anos, as providências e adaptações necessárias à adequação de seu funcionamento às medidas previstas neste artigo. (Vide Lei $\mathrm{n}^{\circ}$ 13.796, de 2019)

$\S 4^{\circ} \mathrm{O}$ disposto neste artigo não se aplica ao ensino militar a que se refere o art. 83 desta Lei."

Art. $2^{\circ}$ Esta Lei entra em vigor após decorridos 60 (sessenta) dias de sua publicação oficial (Brasil, 2019).

O texto é assinado pelo presidente Jair Messias Bolsonaro e pelo então ministro da justiça Sergio Moro. A medida parece tentar apaziguar os dois lados da questão, mas mantém o caráter discriminatório do conteúdo disciplinar das escolas, pois permite que a religião se imponha sobre a liberdade e a autonomia da autoridade do professor.

O governo estabelece uma relação de subordinação da escola às religiões ao pressupor que alguns alunos se ausentarão das atividades propostas pelo professor, obedecendo o mando de líderes religiosos sem justificativa plausível que não o preconceito. Deve ser lembrado, porém, que as religiões de raízes africanas sempre foram excluídas quando se trata de ensino religioso em instituições públicas e privadas, sendo atribuídos os ideais cristãos na totalidade dos conteúdos da disciplina.

Ou seja, a leitura da lei leva a concluir que ou o aluno cristão assiste as aulas que falam de sua própria religião ou ele se ausenta. Os alunos que possuem outra orientação religiosa nunca tiveram essa opção. A doutrinação religiosa sempre foi a cristã, diferente daquilo que os cristãos tanto argumentam.

Portanto, como foi visto, as abordagens sobre os acontecimentos acerca das políticas de gênero têm apresentações diferentes, de acordo com a política editorial de cada periódico. Os periódicos que se posicionam de forma mais progressista descrevem as ações como positivas e necessárias para as mulheres e a população LGBT, os periódicos conservadores as colocam como ameaças ao status quo.

A problemática é que os leitores dos diferentes veículos de comunicação passam a entender os acontecimentos como positivos ou negativos, dependendo da abordagem feita. Não são apresentados dados abrangentes e imparciais, fornecendo uma opinião, mesmo que indireta, propondo de antemão as considerações que devem ser tomadas. 
As ideias do que seria verdadeiro ou falso, válido ou ameaça, positivo ou negativo, são colocadas nas matérias, direcionando o pensamento do leitor no conjunto de informações apresentadas. Assim, as conclusões dos interlocutores dos jornais e revistas tendem a ser niveladas pelas políticas editoriais dos mesmos.

Num momento em que a sociedade brasileira se depara com crimes movidos pelo ódio de gênero, é necessário que o poder público tome atitudes para preservar a integridade das populações que sofrem discriminação. $O$ apoio da opinião pública é mais do que necessário, fazendo com que as abordagens, que porventura são também discriminatórias, prestem um desserviço à população em geral e às políticas afirmativas de grupos minoritários.

\subsubsection{Discursos do atual cenário político}

Os discursos proferidos em campanha pelo atual presidente foram elaborados estrategicamente para angariar evangélicos e conservadores, chegando ao ponto do radicalismo contra a esquerda, sem discutir pautas de forma técnica. Isso porque a preocupação em aumentar a base de apoio era superior à importância da qualidade do debate, em um momento político onde as forças se radicalizaram e criaram um ambiente de guerra. A polarização política colocava em oposição duas forças: a esquerda e a direita, na disputa por votos em um ambiente conturbado por acusações de corrupção de vários agentes políticos.

Para ganhar o apoio de eleitores evangélicos e conservadores, Bolsonaro radicaliza seus discursos de campanha, trazendo para o cotidiano político brasileiro preconceitos até então velados. As críticas do candidato à movimentos sociais, carregadas de ódio, se tornaram mais expressivas e importantes na disputa eleitoral para ele do que a busca por alianças, diálogos com os diversos grupos e partidos, ou a elaboração técnicas de propostas que convençam as mais variadas posições. O Brasil é um país de presidencialismo de coalisão e como tal é imprescindível estabelecer alianças e contatos para obter apoio no Congresso Nacional. Esse apoio é utilizado para a aprovação das medidas políticas do poder executivo e sem ele não há governabilidade.

Para obter a base necessária, a principal promessa para os partidos políticos e a elite econômica nacional é a reforma da previdência. Envolta de uma série de contradições e achismos, a reforma tem sido um atrativo para a elite desde o impeachment da expresidente Dilma e a posse de Temer. Bolsonaro se aproveitou do interesse dos empresários pela reforma da previdência e, aliada às pautas conservadoras, conquistou o apoio econômico e popular suficiente. 
Daí tem-se a problemática pós-campanha: os discursos do atual presidente não se sustentam para costurar acordos no congresso. Mesmo a pauta da previdência passa por alterações e recebe duras críticas porque o presidente não discute o texto com políticos. As posições rígidas deixam claro que Bolsonaro não espera ter que debater suas políticas com o congresso, usando como moeda de troca somente as verbas a serem liberadas e os cargos no governo. Essa posição inflexível dificulta o diálogo entre os Poderes Legislativo e Executivo, de forma que não há desenvolvimento de políticas públicas.

Assim também ocorre com os discursos sobre as questões sociais, como os temas relacionados à gênero. A composição do governo Bolsonaro não contemplou o prometido pelo presidente em campanha, os cargos não foram rifados para a base evangélica e muito menos divididos entre técnicos. A ministra Damares Alves, do recém-criado Ministério da Mulher, da Família e dos Direitos Humanos, representa essa problemática. Seu cargo estava cotado para uma indicação das igrejas evangélicas, mas foi ocupado por alguém que não tem expressão política, técnica ou social. Porém, com o discurso cristão, carregado de preconceito e moralismo, demonstra em seus pronunciamentos, em função da direção do ministério, ideias fracas politicamente e que não se sustentam nem com os conservadores, nem com os interessados no bom andamento da política da pasta. A ministra é pastora evangélica e já disse que "o Estado é laico, mas a ministra é terrivelmente cristã" (G1, 'Estado é laico, mas esta ministra é terrivelmente cristã', diz Damares ao assumir Direitos Humanos, 02-01-19).

No artigo publicado pela plataforma G1 "Estado é laico, mas esta ministra é terrivelmente cristã', diz Damares ao assumir Direitos Humanos", sobre o discurso de posse da ministra, o texto diz:

Outros temas abordados pela ministra:

Vida desde a concepção: Damares afirmou que gostaria que o ministério se chamasse "Ministério da Vida e da Alegria". "E por falar em vida, eu falo vida desde a concepção", destacou.

Violência contra a mulher: Damares Alves citou denúncias de violência contra a mulher e afirmou que, no governo de Jair Bolsonaro, nenhuma será ignorada.

'Doutrinação ideológica': A nova ministra também ressaltou que um dos desafios do governo será acabar com o "abuso da doutrinação ideológica". "Acabou a doutrinação ideológica de crianças e adolescentes no Brasil", disse. "Neste governo, menina será princesa e menino será príncipe. Está dado o recado. Ninguém 
vai nos impedir de chamar nossas meninas de princesas e nossos meninos de príncipes", acrescentou.

'Riscos' à família

Em uma palestra de 2014, cujo tema era "Riscos que corre a família brasileira", Damares Alves disse que, à época, estava preocupada com um decreto editado em 2009 pelo governo Luiz Inácio Lula da Silva. Segundo ela, o texto declarava "que a família brasileira tem que ser destruída".

O decreto mencionado na palestra pela ministra trata do Programa Nacional de Direitos Humanos e estabelece a "desconstrução da heteronormatividade" sob o argumento de que é preciso "incluir nos sistemas de informação do serviço público todas as configurações familiares constituídas por lésbicas, gays, bissexuais, travestis e transexuais".

"Eles querem muito mais que construir no Brasil a homonormatividade. Eles querem, pior, destruir a heteronormatividade. Isso me preocupa muito, mas eu gostaria que esta nação tivesse outro decreto. Sou cristã, pastora e a minha regra de fé é a Bíblia", disse Damares na ocasião (G1, 02-01-19).

O texto deixa clara a posição conservadora e moralista da ministra frente aos temas da sua pasta, com declarações que evidenciam a falta de capacidade técnica e a defesa do moralismo cristão em detrimento da laicidade do Estado e dos direitos humanos universais. Desde então a ministra tem sido criticada em várias falas, inclusive quando disse que no governo Bolsonaro "as meninas vestem rosa e os meninos vestem azul”.

Outra característica bizarra deste governo é a presença da opinião do presidente na rede social Twitter, onde afirma a todo momento seus posicionamentos preconceituosos. Os filhos do presidente também são bastante presentes, emitindo falas, às vezes desmentidas posteriormente pelo governo, como porta-vozes do pai presidente. Essa característica informal de Bolsonaro e se governo evidencia o seu despreparo como político do Poder Executivo.

Portanto, o despreparo do Governo no trato com o social demonstra que a sociedade brasileira ainda terá muitos desafios a superar para encontrar a igualdade de direitos, seja de gêneros ou outros tipos de direitos negados à população, principalmente às minorias. 


\section{CONCLUSÃO}

A tese chega ao seu objetivo, portanto, em apresentar a relação entre o discurso religioso cristão e político sob a tutela do conservadorismo da imprensa na cidade de Fortaleza-CE, o que é notícia, sempre foi a preocupação da mídia, seja esta impressa ou não. E nos períodos de 2016 ao ano de 2018, tornou-se notícia embates ideológicos sobre questões de gênero. Principalmente porque havia uma tentativa de legitimar opiniões políticas de bases religiosas cristãs para se tomar o poder político daqueles que já estavam há muito no poder, como no caso do partido político dos trabalhadores.

A mídia impressa, de forma geral, se omitiu em oferecer argumentos qualificados em defesa dos direitos humanos, o que pareceu mais estimular com ênfase os embates ideológicos e contraposições sobre o tema, repetindo, portanto, a divisão de valores, como quisesse apenas agradar ao leitor daquilo que ele deseja ouvir, que em sua maioria são religiosos cristãos, utilizando-se do discurso: direita/esquerda, conservadores/progressistas, dentre outros que fez e ainda faz dividir opiniões sobre tal temática.

Para dar início ao tratamento dos dados da imprensa local ou regional, escolheu-se relatar o caso específico do assassinato da vereadora Marielle Franco, como a mídia publicou o acontecimento e as matérias carregadas de opiniões sobre a mulher Marielle. Ressalta-se nessa seção o machismo enraizado no país, até mesmo na fala de mulheres sobre mulheres. É importante observar que a imagem da mulher é acompanhada de muito preconceito, até onde deveria haver neutralidade.

A tese analisa a relação entre a religião e políticas para mulheres e, para isso, escolheu-se abordar como os periódicos tratam essa relação a partir das publicações sobre os Planos de Educação, alvos de intensos conflitos. Isso se complica quando os legisladores interferem em programas que têm alcance profundo na sociedade brasileira, os parlamentares, seguindo as orientações das igrejas às quais pertencem, visam moldar os conteúdos a serem ensinados em sala de aula. A educação torna-se, assim, um espaço de disputas ideológicas. A real importância do Estado de Direito não é defendida pela mídia impressa dos quatro periódicos estudados, a violência de gênero de forma imperceptível chega, em alguns periódicos, ser conexa com a ausência de discussão sobre igualdade de gênero nas escolas. A superficialidade com a temática, priorizando "o que é notícia" dado os discursos dos religiosos que queriam se autopromover e se eleger no ano eleitoral de 2018, e, portanto, convocando a mídia para seus discursos e sendo atrativos com seus fiéis cristãos, os valores morais religiosos parecem adoçar a vida dos eleitores e dos leitores, e a imprensa precisa ser a favor desta 'notícia' para não desagradar seu público. 
O Estado é laico e é democrático de direito, conforme Constituição vigente, e a mídia detém um papel de preservar estes valores sociais, e não legitimar a disjunção deles, como se fosse uma questão de escolha de qual time se quer pertencer. A mídia cearense e nacional deixou claro que não existe este pertencimento com relação aos direitos humanos, por mais que a mídia nacional fosse mais progressista com defesas ao discurso de igualdade de gênero nas escolas, não elencou de forma elucidativa os tratados e Convenções Internacionais de que o Brasil é signatário, e por isso tem compromissos de erradicar com a desigualdade de gênero, com a violência e discriminação contra a mulher. As revistas nacionais defenderam, mas não elucidaram de forma fundamentada no 'direito', utilizando-se apenas da dialética dos questionamentos suas defesas.

A implementação do plano nacional de educação para se discutir gênero nas escolas foi um tema utilizado pelas lideranças religiosas com intuito de se autopromover como político através de discursos de bases religiosas cristãs na mídia contra o tal implementação, ou seja, um projeto formidável de romper a sociedade, que não se trata somente de um projeto religioso cristão, além disso de um projeto político de retirada do poder, pois quando fragmentados as opiniões dos eleitores se torna menos forte o poder do povo, que o exerce através da democracia, a moral passa sobrepor ao direito, e as bases fortes se flexibilizam de forma subliminar, por isso faz-se necessário que a imprensa tenha sua ótica voltada a defesa dos direitos humanos e do Estado Democrático de Direito, seja de forma proposital ou tendenciosa, é através da imprensa que os direitos humanos se comunica com a sociedade.

Quando o tema da notícia da matéria publicada se aproxima de alguma forma dos tabus religiosos, o termo que mais se utiliza de forma perceptível para se explicar o contexto pesquisado é "contra a ideologia de gênero", e quando esta imprensa falha nesta discussão, ao invés de trazer ganhos à sociedade, demonstrou-se diante das ideologias suscitadas pela religião cristã em posse do poder político, perseguição e fiscalização ao que o professor diz em sala de aula, e como efeito disso a persecução a favor do machismo e patriarcalismo. O que faz pensar inclusive o aumento nos números de violência doméstica e familiar contra a mulher no Estado do Ceará.

Mesmo o jornal O Povo que tratou mais do assunto do que o Diário do Nordeste, a igualdade de gênero é que deveria ter sido o diálogo suscitado pela mídia denunciando como os políticos tentam embutir na sociedade suas ideologias sobre infundados argumentos de agirem contra "a ideologia de gênero". Era uma forma da imprensa agir se preocupando como as pessoas estão percebendo isso. O que não fez na maioria de seus 
periódicos, apenas fez uma narrativa descritiva sobre a opinião do político cristão, e de forma bastante isolada, algumas reflexões se contrapondo.

Ressalte-se que se não é explicado ao receptor da informação o que existe é uma falsa noção no termo ideologia de gênero, o mesmo que se diz cristão irá glorificar tais iniciativas pelos que lutam contra "ideologia de gênero", que são os mesmos que defendem a escola sem partido, que são os mesmos que perseguem e fiscalizam o que os professores dizem em sala de aula, sob a infundada argumentação que estes pretendem doutrinar seus alunos. Questiona-se, portanto, até que ponto esta imprensa de fato tem liberdade? Porquê suas fontes de pesquisa foram quase que unanimemente na seção de política, descrevendo a narrativa de políticos religiosos, mas do que na seção de educação? Por que as temáticas de seus artigos em destaque 'o religioso' estava no início do assunto? Será que a 'notícia' é mais importante que a fonte fidedigna? As fontes dos questionamentos poderiam ser por exemplo o que diz a CEDAW, o que entende a ONU sobre tais pautas. A sociedade, através da comunicação do discurso na imprensa, permanece inerte ou defensiva dos seus principais valores, os cristãos, ou seja, a sociedade perde em detrimento da liberdade de imprensa e democracia não "andarem juntas".

Portanto, foi possível observar que o discurso da principal imprensa escrita de Fortaleza, nos anos de 2016 até 2018, após a aprovação e publicação do Plano Nacional de Educação (2014), não conseguiu superar às desigualdades, visto que muitos municípios de diferentes estados do Ceará ganharam força com este debate ideológico em desfavor, inclusive implementando normas de penalização aos professores que assim discutissem sobre gênero com seus alunos ou, como consequência, na cidade de Fortaleza, não conseguiu que fosse implementado a discussão sobre igualdade de gênero no plano municipal de educação. A imprensa escrita não traduziu o quê disciplina as diretrizes do Plano Nacional de Educação na promoção dos direitos humanos e à diversidade, ou seja, foi constatado que os discursos da mídia local de Fortaleza mantêm os tabus e desigualdades na abordagem de temas ligados ao gênero.

Fica evidente que o conservadorismo criado nas igrejas tem reflexo na opinião pública e nos discursos da mídia. A imprensa escrita de maior circulação em Fortaleza reforça o moralismo religioso, em contraposição com as revistas de alcance nacional escolhidas para expor o outro lado da notícia. As opiniões conservadoras dos leitores são legitimadas e reforçadas pela abordagem dada pelos jornais locais. O pensamento do leitor é direcionado pela linha editorial do veículo de comunicação que lê e os jornais são conduzidos pelo conservadorismo cristão. 
No caso do tema da "igualdade de gênero", os periódicos locais ou demonstram serem contra as ações que visam esse objetivo ou se abstém de expor muitas informações, mesmo sendo de edição diária. Ou seja, ou se posiciona contra a igualdade de gênero de forma velada, defendendo o conservadorismo, ou simplesmente não comentam os eventos relacionados. Diferentemente das revistas que se posicionam com orientação política de esquerda, que discutem e expõem as informações mais completas. Esses últimos periódicos não são locais, são nacionais e semanais, entrando na pesquisa como marcador de posição progressista.

Dessa forma, conclui-se que a mídia é fortemente influenciada pela religião, fortalecendo os argumentos moralistas e conservadores desenvolvidos pelos líderes cristãos. Essa problemática serve como um entrave no avanço dos direitos humanos no Brasil, causando a demora na tomada de decisões que favoreçam políticas de defesa das mulheres, contra a violência de gênero.

A luta pelos direitos humanos deve significar um esforço da humanidade pelo progresso da sociedade. Tendo surgido o pensamento sobre a igualdade e o bem comum conjuntamente ao surgimento da filosofia clássica, na Grécia antiga, sabe-se que os primeiros filósofos já debatiam o sentido da justiça. Assim, os direitos humanos foram discutidos durante toda a história da humanidade, baseada na crença da justiça entre os homens. Porém, no decorrer da história, entraves ao progresso da justiça entre os homens aparecem ligados à religião, notadamente à religião cristã.

As religiões tendem a estabelecer diferenças entre os seres humanos com base em crenças; diferenças que acabam levando à desigualdade e geram processos de discriminação e exclusão que distingue entre crentes da própria religião e crentes das outras religiões. Os primeiros são considerados eleitos por Deus e gozam de todos os privilégios que a divindade tem reservados para seus fiéis, tanto nesta vida como na última. Os membros de outras religiões são considerados inferiores e estão sujeitas a punição nesta vida e no futuro, bem como aqueles que não cabem nos modos de vida determinados. E que se destina a justificar em uma revelação divina dirigida a um povo, uma comunidade, um grupo humano. No final, o fundamento é baseado em um ato arbitrário do Deus em quem se acredita.

A religião católica, detendo grande poder político e como a principal religião no mundo ocidental, teve forte influência sobre as formulações das constituições de diversos países, como visto na segunda seção desta tese. Ainda que a filosofia e o direito tenham evoluído, a separação entre o Estado e a religião não é totalmente respeitada: a laicidade pregada sob 
a argumentação da racionalidade é desrespeitada frequentemente. A tradição religiosa está nas entrelinhas das constituições e do direito.

No Brasil, destacando-se a religião cristã, os direitos da mulher são, dessa forma, negados em função do conservadorismo religioso. Argumentos pautados sobre a "honra" e a moralidade imponham uma série de restrições à liberdade feminina, impedindo o exercício de direitos civis e políticos, como a problemática dos direitos reprodutivos e o impedimento do voto até 1932. A formação da bancada evangélica após a Constituição de 1988 significa a força retrógrada dos direitos sociais no Brasil. Enquanto movimentos sociais, militantes dos direitos humanos, acadêmicos e interessados na igualdade de gêneros no país se esforçam para alcançar a equidade entre homens e mulheres, políticos populistas usam a religião e discursos baseados no evangelho da bíblia para se elegerem, propondo pautas moralistas e atrapalhando o progresso dos direitos humanos. O que faz acreditar que o aumento da violência doméstica, do machismo e do patriarcalismo no Brasil advém destas influências. No contexto internacional, a luta pela igualdade de gênero avança apesar da influência da religião nos países.

O aborto, por exemplo, é tratado na tese como um direito da mulher ligado aos direitos humanos, por ser um exemplo de direito reprodutivo. Como esse direito está ligado ao tema da vida, os religiosos no Brasil se opõem a ele totalmente, julgando a ação como “assassinato". O tabu em torno da questão também se deve ao fato da dificuldade de se determinar o momento do início da vida.

Enfim, a contribuição da discussão sobre o aborto para este trabalho reside no fato de suscitar muitas questões sobre o conceito de vida, tema quase exclusivo da religião. $\mathrm{O}$ conflito entre a soberania da mulher sobre o próprio corpo e o domínio da religião sobre qualquer debate relacionado à vida ilustra claramente como o moralismo cristão se coloca contrário aos direitos da mulher. O direito, locus da discussão, é influenciado pelo ideário religioso coletivo instalado no Brasil.

Para, contudo, apresentar o que é o discurso religioso e sua oposição à igualdade de gênero, entrevistas foram feitas com pastores e padres da cidade de Fortaleza. Nas conversas, expostas na seção sete, vê-se que todos os líderes religiosos têm posicionamentos contrários ao que se entende como equidade de gênero.

Essas respostas não são conclusões individuais, são baseadas na tradição dos preceitos cristãos que, por causa do conteúdo da bíblia, acreditam em um modelo de mundo retrógrado, criado pelos textos dos evangelhos que descrevem a sociedade de dois mil anos atrás. 
Esses discursos, as leituras de mundo feitas pelos religiosos com base no livro da bíblia e seus mitos, são ensinados durante as homilias (nas missas), sermões e cultos. Os fiéis assimilam os modelos como corretos e utilizam esse discurso para julgar e condenar as pessoas que têm concepções diferentes. Isso resulta nos conflitos políticos sobre o conceito de família, de soberania da mulher sobre seu corpo, sobre educação sexual e outros temas tidos como tabus. Entende-se que as entrevistas realizadas foram suficientes para compreender o pensamento cristão da cidade e sua relação com os temas que envolvem os direitos humanos e das mulheres.

No contraponto, são apresentadas parlamentares locais da cidade de Fortaleza, suas ações e características. Aí fica claro que, mesmo as duas parlamentares apresentadas serem mulheres, quando a discussão política ocorre sobre direitos relacionados à mulher, a religião é preponderante na decisão e opinião da deputada evangélica. A vereadora defensora dos direitos da mulher, por sua vez, não tem relação com nenhuma religião relatada de forma pública. Ali é concluído que a religião conduz o pensamento daqueles que a seguem.

Por fim, foi possível entender que as lideranças cristãs extremistas se articulam para propagar e defender seus interesses morais em termos de manipulação e legitimação para o exercício do poder político, pois fica claro que a igreja mobiliza os seus fiéis para atuarem politicamente, como agentes políticos e depois como eleitores. Assim porque os políticos usam do discurso cristão para se colocarem como porta-vozes de determinados posicionamentos, principalmente aqueles posicionamentos diretamente defendidos nas igrejas e que angariam base eleitoral. Os fiéis seguem os políticos que defendem os mesmos pensamentos e filosofias dos líderes religiosos.

A mídia conservadora impressa endossa o posicionamento emitindo um discurso alheio à igualdade de gênero, principalmente se utilizando da expressão contra "ideologia de gênero" promovido por religiosos extremistas na política, que executam um debate contra a promoção destes direitos humanos no exercício parlamentar. Assim, a violência contra a mulher ocorre livremente embora haja ações para proibição; conclui-se que de fato a expressão "ideologia de gênero" é explorada para emitir falas contrárias ao avanço dos direitos humanos buscando a igualdade de gênero contra a violência.

Portanto, a tese traz a contribuição da reflexão sobre as políticas públicas para as mulheres no Brasil. Muito além da apresentação das leis e políticas existentes, ou das ações do Estado nesse sentido, este trabalho convida a pensar sobre as origens dos conflitos morais em torno dos obstáculos da promoção da igualdade de gênero. 
O debate aberto sobre as questões de gênero, suscitado pelos movimentos feministas, trouxe consigo as falas antagonistas a esses grupos. Organizações, líderes, pessoas públicas e políticos brasileiros se manifestaram contrários às posições que buscam alcançar maior respeito aos direitos das mulheres e aos direitos humanos. As razões pelas quais há aqueles que impedem o avanço das ações pelos direitos humanos são várias, mas a tese apresentada discute parte dessas razões: o conservadorismo religioso cristão.

As religiões de base cristã são a maioria no Brasil. Oriundas do catolicismo, existem as religiões protestantes e pentecostais que se baseiam fortemente nos ensinamentos bíblicos. Quando os políticos falam em nome da Bíblia, recusam terminantemente as políticas públicas voltadas para a igualdade de gênero porque pressupõem conceitos sobre a família e o papel da mulher que são anacrônicas, como foi visto na seção onde as falas dos líderes religiosos são analisadas. Como a Bíblia é baseada em um contexto social que retrata o mundo de dois mil anos atrás, e antes disso, não é possível fazer as mesmas correlações com o momento atual, visto que o mundo mudou tanto quanto as relações sociais mudaram completamente.

Ressalte que a violência inicia a partir do momento em que se restringe a forma de pensar ou de se expressar, quando se impõe limitações nas decisões e escolhas das pessoas, utilizando-se inclusive da mídia, seja esta impressa, seja os canais de televisão aberta para expandir ainda mais seus discursos. Haja vista que o discurso de líderes religiosos em canais de televisão aberta, por várias vezes remonta a utilizar elementos diretos de violência simbólica, daí a importância e a necessidade de, em uma sociedade plural, levantar tais questões.

Na medida em que, a igreja, pelo discurso oficial do líder, discrimina ou inferioriza identidades humanas com suas diversidades e personalidades ou outras entidades religiosas, torna-se preocupante, pois tende a legitimar e uniformizar todo o contexto social religioso em detrimento a outros grupos que também tem presença na sociedade multicultural brasileira.

No plano normativo, talvez se possa afirmar que o Estado brasileiro ainda é laico, sem interferências das Igrejas no poder público e na política. Contudo, se verifica uma atuação social e política, seja nas disputas cotidianas das relações sociais de poder, em que o religioso ainda se faz presente com grande expressão nas camadas sociais, sob a justificativa de acolher os desamparados, e não raramente, na arena pública, fazendo leis ou administrando políticas públicas, restando, portanto, impregnadas de valores religiosos. Tal fato tem implicações negativas graves no que diz respeito à garantia da cidadania e dos direitos fundamentais em favor de todos os cidadãos, sem qualquer distinção. 
Ressalte que nas entrevistas realizadas, as respostas eram contraditórias, ou estrategicamente se travestiam em discursos fundados nos princípios dos direitos humanos, mas com fundamentos morais e religiosos, o que desprestigiava um tratamento igualitário e universal.

Assim, remeter a atuação do religioso somente ao problema do fundamentalismo ou da superação da separação Igreja e o Estado pode não ser a melhor forma de lutar por uma sociedade mais diversa, multicultural e democrática, bem como garantir os direitos de igualdade e de liberdade a todos os cidadãos.

Torna-se necessário aos líderes a relativizar os seus postulados teóricos clássicos e, consequentemente, os seus pontos de partida para pensarem as religiões como importantes atores políticos do jogo democrático. Somente assim, torna-se possível avançar no processo de consolidação da democracia e na garantia dos direitos humanos e fundamentais.

A percepção da imprensa ou de um líder com relação ao discurso da ONU sobre direitos humanos e gênero se estrutura a partir de elementos próprios que se autorregulam. Ao passo que se dialoga com a importância deste discurso para a promoção dos direitos humanos, se legitima as "dominações" e até mesmo ideologias advindas de um sistema cultural e patriarcal. Da propagação do discurso seja através da imprensa ou das respostas dos líderes religiosos, claramente se percebia o ato de "PREGAR", ou seja, de querer embutir suas ideias.

Ressalte que, em um Estado de direito onde todos têm assegurados pela lei seu espaço, não há mais lugar para legitimações ou privilégios de determinados seguimentos. É preciso um Estado laico e com práticas laicas com comunicação direta com a sociedade, conscientizando-as.

Finalmente, fazendo as interações entre os discursos locais e nacionais foi possível se determinar o comportamento de uma determinada cultura, que por dependências às tradições existentes trazem um impacto social e político, principalmente em detrimento de 'situações de oportunidade política' e 'oportunidades discursivas' condicionam um comportamento e um agir social. E este agir ao invés de promover igualdade, obedecendo o que diz a Convenção sobre eliminação de todas as formas de discriminação contra a mulher, promove a discriminação e o preconceito, por consequência, gera a violência, atentando contra os direitos humanos.

A violência e o desrespeito aos direitos humanos surgem dessa incompreensão. Falta pensar o social e renovar o pensamento dos indivíduos para racionalizar as relações humanas no intuito de eliminar as mazelas sociais. 
Os discursos proferidos iludem e moldam o pensamento dos fiéis. A miopia causada pela fé nas falas dos líderes cristãos impede que a sociedade enxergue o mundo como ele é, colocando-os em uma situação de ignorância dos problemas que o machismo causa diariamente.

A educação de gênero é um componente fundamental na escolarização em todas as fases, de modo que se procura incluí-la nos planos de educação. Mas, depois de um processo eleitoral muito disputado pelo governo federal, o representante do conservadorismo no Brasil venceu.

O mesmo acontece com as orientações sexuais; a questão é cada vez mais necessária, pois a violência relacionada à orientação sexual e ao radicalismo está aumentando nos ambientes familiar e religioso, locais que também são locais predominantes de discriminação por orientação sexual.

Com isso, pesquisadores, segundo Felipe (2016), acreditam que a análise de questões familiares e religiosas como causas de violência contra homossexuais deve estar na pauta de propostas e ações para superar esses problemas no cotidiano escolar. A pesquisa mostrou que $32 \%$ dos homossexuais entrevistados afirmaram sofrer preconceitos dentro das salas de aula e também que os educadores ainda não sabem como reagir adequadamente às agressões, que podem ser físicas ou verbais, no ambiente escolar.

Esta posição de alguns membros do governo que ocupam lugares de grande importância, como a Ministra da Mulher, Família e Direitos Humanos, Damares Alves, que afirma que uma "nova era" no país, está agora aberta, na qual "menino veste azul e menina usa rosa". O discurso foi dito após a cerimônia de transferência em que Damares assumiu o portfólio. No discurso de posse, a ministra já havia afirmado que "menina será princesa e menino será príncipe".

Ao contrário das "ideologias" ou "doutrinas" sustentadas pela fundação de crenças ou fé, o conceito de gênero é baseado em parâmetros científicos de produção de conhecimento sobre o mundo. O gênero, como conceito, identifica processos históricos e culturais que classificam e posicionam as pessoas a partir de um relacionamento sobre o que é entendido como feminino e masculino. E é neste sentido que o conceito de gênero tem sido historicamente útil para muitas investigações

Quando foi pauta pela Base Nacional Comum Curricular a noção de "igualdade de gênero" na educação, a demanda é por um sistema escolar inclusivo, que crie ações específicas para combater a discriminação e que não contribua para a reprodução das desigualdades que persistem em nossa sociedade. 
Falar de uma educação que promova a igualdade de gênero, no entanto, não significa anular as diferenças percebidas entre as pessoas (que têm sido amplamente distorcidas no debate público), mas garantir um espaço democrático onde tais diferenças não se desdobram nas desigualdades.

A violência contra as mulheres é generalizada na sociedade e também nos ambientes escolares. A escola, como espaço onde essa sociabilidade é formada e pode ser transformada, não deve ser afastada do debate de gênero e de como sua construção cultural contribui para o crescimento dessa violência.

Ser gay ou transexual no Brasil é um martírio. Desde cedo, qualquer comportamento que fuja do que é considerado "normal" é tratado com desprezo, aversão, violência física e psicológica. Mas a violência vai além: em 2018, Peterson Ricardo de Oliveira, de 14 anos, morreu após ser espancado em uma escola pública da Grande São Paulo devido ao fato de seus pais serem gays. Eventos como estes se multiplicam em todos os estados brasileiros.

O Brasil confirma sua posição de primeiro lugar no ranking mundial de assassinatos homofóbicos, concentrando $44 \%$ do total de execuções de todo o planeta. Nos Estados Unidos, com 100 milhões de habitantes a mais do que nosso país, houve 15 assassinatos de travestis em 2011, enquanto no Brasil, 128 "trans" foram executados. O risco, portanto, de uma transexual ser assassinada no Brasil é $1.280 \%$ maior do que nos Estados Unidos (GGB, 2015 p.38).

A abordagem das questões de gênero é essencial. É importante que os educadores estejam preparados para abordar essas questões de maneira madura e inclusiva. O Brasil é um país onde a violência faz parte do cotidiano e um número significativo de casos é sexista.

Da mesma forma, é fundamental que os temas da sexualidade e da orientação sexual façam parte do currículo escolar e das discussões na sociedade, de modo que deixa de ser um tabu assassino de vidas que não se encaixam nas premissas dos fanáticos para as ordens intactas e das cores definidas. 


\section{REFERÊNCIAS}

A Bíblia Sagrada: Antigo e Novo Testamento (1969). Sociedade Bíblia do Brasil.

A, C. de J. M. \& FONSECA, Rosa, M. G. S. (2008). Considerações sobre violência doméstica, gênero e o trabalho das equipes de saúde da família. Rev. Esc. Enfermagem USP, 42 (3): 591-5.

ABANT. (2015) Manifesto pela Igualdade de Gênero na Educação. Disponible en www.portal.abant.org.br/images/Noticias/. Acceso: 27 set 2018.

Agência Senado (2017, 26 julho). Projetos. Mais de 350 mil internautas já opinaram sobre o programa Escola Sem Partido. Senado (versão digital). Disponível em: https://www12.senado.leg.br/noticias/materias/2016/07/26/mais-de-350-mil-internautas-jaopinaram-sobre-o-programa-escola-sem-partido/tablet

Aguiar, N. (1997). Gênero e Ciências Humanas: desafio às ciências desde a perspectiva das mulheres. Rio de Janeiro: Rosa dos Tempos.

Algranti, L. M. (1993) Honradas e devotas: mulheres da colônia. Condição feminina nos conventos e recolhimentos do sudeste do Brasil, 1750-1822. Rio de Janeiro: José Olympio.

Almeida, H. B. (2012). Aborto: o grande tabu no Brasil. Católicas pelo Direito de Decidir. Disponível em: http://www.catolicas.org.br/noticias/conteudo.asp? cod=340 Consultado:28/03/2018.

Althusser L. (2007). Aparelhos Ideológicos de Estado. São Paulo: Editora Graal (10).

Alves, B.M. (1980). Ideologia \& feminismo. A luta da mulher pelo voto no Brasil. Petrópolis: Vozes.

Alves, J.A.L (2005). Os direitos humanos na Pós-Modernidade. São Paulo: Perspectiva.

Alves, M. M. (1979). A Igreja e a política no Brasil. São Paulo: Editora Brasiliense.

Aquino, L. M. S. (2015). Formulação do Plano Nacional de Educação 2014-2024: a gestão democrática da escola na política pública. Doutorado em Educação. Porto Alegre, RS: Universidade Federal do Rio Grande do Sul.

Arendt, H. (1963). On revolution. New York : The Viking Press.

Arendt, H. (1990). Entre o passado e o futuro. São Paulo: Perspectiva.

Arendt, H. (1993). A dignidade da política: ensaios e conferências. Rio de Janeiro: Relume-Dumará.

Athayde, T. D. (1931). Debates pedagógicos. Rio de Janeiro: Schmidt Editor, 67-106.

Azevedo, D. (2004). A Igreja Católica e seu papel político no Brasil. Estudos avançados, 18(52), 109-120. Disponível em: <http://dx.doi.org/10.1590/S010340142004000300009>. 
Balmes, J.(1988). A Igreja Católica em face da escravidão. São Paulo: Centro Brasileiro de Fomento Cultural.

Bandeira, L. M. (2014) Violência de gênero: a construção de um campo teórico e de investigação. Soc. estado (29) 2: 449-469. Disponível em <http://dx.doi.org/10.1590/S0102-69922014000200008>.

Barbalho, J. (1924). Constituição Federal brasileira comentada. Rio de Janeiro.

Bardin, L. (1997). Análise de Conteúdo. Lisboa: Edições 70.

Barretto, V. P. (2001). Da Interpretação à Hermenêutica Constitucional. Direito e Justiça (Faculdade de Direito da PUC/RS). Porto Alegre (23).

Bastos, M. (2018). Mulheres cristãs baseiam em sua fé defesa dos direitos reprodutivos e do aborto legal. Gênero e Número. Página da Internet. Disponível em: http://www.generonumero.media/mulheres-cristas-baseiam-em-sua-fe-defesa-dos-direitosreprodutivos-e-do-aborto-legal/

Batista, V. (2017) Justiça usa educação para reduzir machismo e violência doméstica. Correio Braziliense - blog do servidor. 26 de abril de 2017. Disponível em: < $\mathrm{http} / / /$ blogs.correiobraziliense.com.br/servidor/justica-usa-educacao-para-reduzirmachismo-e-violencia-domestica/>.

Beauvoir, S. D. (1967). O segundo sexo: a experiência vivida. Tradução de Sérgio Milliet, 2.

Berguer, P. (1985). O dossel sagrado: elementos para uma teoria sociológica da religião. 3a ed. São Paulo: Paulus, (3).

Betim, F. (2017). “Cura gay': o que de fato disse o juiz que causou uma onda de indignação”. El país Brasil. Recuperado de https://brasil.elpais.com/brasil/2017/09/19/politica/1505853454_712122.amp.html

Blog da Dra. Silvana. Disponível em http://deputadasilvana.blogspot.com.

Blog Marielle Franco. https://www.mariellefranco.com.br/quem-e-marielle-francovereadora.

Bobbio, N. (1998). Verbete “Ideologia”. In Bobbio, N.; Matteucci, N. \& Pasquino, G. Dicionário de Política. Rio de Janeiro: Nova Fronteira, (1).

Bobbio, N. (1909). A era dos direitos. Tradução Carlos Nelson Coutinho. Apresentação de Celso Lafer. Rio de Janeiro: Elsevier.

Bobbio, N. (1987). O Estado, formas de estado, formas de governo. Brasília: Instituto Tancredo Neves.

Boltanski, L. (2012). As dimensões antropológicas do aborto. Revista Brasileira de Ciência Política, (7), 205-245. https://dx.doi.org/10.1590/S0103-33522012000100010

Borges, J.P(2013). Padre Cícero, entre a política e a religião. Revista Fórum (online), (6721) 9, jan.2013. Disponível em: < http://www.revistaforum.com.br/2013/01/09/padrecicero-entre-a-politica-e-a-religiao/> . 
Bourdieu, P.(1999). A dominação masculina. Rio de Janeiro: Bertrand Brasil.

Bourdieu, P. (1999). A Economia das Trocas Simbólicas. Trad. Sergio Miceli \& outras/os. São Paulo: Editora Perspectiva 5.

Bourdieu, P. (2004). O poder simbólico. Rio de Janeiro: Bertrand Brasil (7).

Bourdieu, P. (2001) Masculine Domination Cambridge: Polity Press.

Bourgois, P. (2004) 'The Everyday Violence of Gang Rape'. In Scheper-Hughes, N. \& Bourgois, P. Violence in War and Peace: An Anthology, Malden, MA, Blackwell, 343348.

Brasil (1824). Constituição Política do Império do Brasil. Disponível em < http://www.planalto.gov.br/ccivil_03/constituicao/constituicao24.htm>. Acesso em 25 de fev. 2018.

Brasil (1891). Constituição Federal de 1891. Disponível em < http://www.planalto.gov.br/ccivil_03/constituicao/constituicao91.htm>. Acesso em 25 de fev. 2018

Brasil (1988). Constituição da Republica Federativa do Brasil. Senado Federal.

Brasil (2002). Decreto $n^{\circ} 4.377$, de 13 de setembro de 2002. Promulga a Convenção sobre a Eliminação de Todas as Formas de Discriminação contra a Mulher, de 1979, e revoga o Decreto no 89.460, de 20 de março de 1984. Disponível em: <http:// http://www.planalto.gov.br/ccivil_03/decreto/2002/D4377.htm>.

Brasil (2006). Lei Maria da Penha. Lei N. ${ }^{\circ} 11.340$, de 7 de agosto.

Brasil (2014). Lei $n^{o}$ 13.005, de 25 de junho de 2014. Aprova o Plano Nacional de Educação- PNE e dá outras providências. Disponível em: <http://www.planalto.gov.br/ccivil_03/_ato2011-2014/2014/lei/113005.htm> Acesso em 25.jul.2017.

Brasil (2015). Lei do Feminicído. LEI No 13.104, de 9 de março de 2015.

Brasil (2016). Supremo Tribunal Federal. Habeas Corpus 124.306. Rio de Janeiro. Voto Vista - Ministro Luís Roberto Barroso. 29 de novembro.

Brasil (2017). BNCC. Base Nacional Comum Curricular. Disponível em: http://basenacionalcomum.mec.gov.br/wp-content/uploads/2018/02/bncc-20dez-site.pdf.

Brasil (2017). PORTARIA N.15, DE 8 DE MARÇO DE 2017. Institui a Política Judiciária Nacional de enfrentamento à violência contra as Mulheres no Poder Judiciário e dá outras providências. Disponível em: http://www.cnj.jus.br/files/conteudo/arquivo/2017/03/48676a321d03656e5e3a4f0aa3519e6 2.pdf $>$.

Brasil (2019). Lei 13.796, 03 de janeiro de 2019. Altera a Lei ${ }^{\circ}$ 9.394, de 20 de dezembro de 1996 (Lei de Diretrizes e Bases da Educação Nacional), para fixar, em virtude de escusa de consciência, prestações alternativas à aplicação de provas e à frequência a aulas realizadas em dia de guarda religiosa. Disponível em: http://www.planalto.gov.br/CCIVIL_03/_Ato2019-2022/2019/Lei/L13796.html 
Bruneau, T. (1974). O catolicismo brasileiro em época de transição. São Paulo: Loyola.

Burity, J. A. (2005) Religião e política na Fronteira: desinstitucionalização e deslocamento numa relação historicamente polêmica. Revista de Estudos da Religião REVER, (4): 27-45.

Calado, M. A. G. (2010). A laicidade estatal face à presença de símbolos religiosos em órgãos públicos. Jus Navigandi, Teresina, (15) 2565, 10 jul. Disponível em: <http://jus.com.br/artigos/16962>. Acesso em: 01/05/2017.

Campos, R. B. C., \& Gusmão, E. H. (2010). Religião em movimento: relações entre religião e modernidade. Campos-Revista de Antropologia, 11(1).

Candau, V. L. (2008). Direitos humanos, educação e interculturalidade: as tensões entre igualdade e diferença. PUC. Rev. Bras.Educação (Rio de Janeiro), 3(37).

Casanova, J. (1999). Religiones públicas e privadas. In: J. Auyero. Cája de herramientas. Buenos Aires.

Castro, G. (2015). Ministério da Educação cede à pressão de religiosos e destitui o Comitê de Gênero. Brasilpost (versão digital), 23 de setembro. Disponível em: <http://www.brasilpost.com.br/2015/09/23/mec-comite-genero_n_8184294.html>.

Cerqueira, D., \& Coelho, D. D. S. C. (2017). Estupro no Brasil: uma radiografia segundo os dados da Saúde. Brasília: IPEA (11).

Cifuentes, R. L. (1989). Relações entre a Igreja e o Estado: a Igreja e o Estado à luz do Vaticano II, do Código de Direito Canônico de 1983 e da Constituição Brasileira de 1988. Rio de Janeiro: José Olympio (2).

CNBB (2015). Confederação Nacional dos Bispos do Brasil. Diretrizes Gerais da Ação Evangelizadora da Igreja no Brasil 2015-2019 (Documentos da CNBB, 102). São Paulo: Paulinas (1)

CNBB (2018). Confederação Nacional dos Bispos do Brasil. Aborto: leia as íntegras dos discursos da CNBB no STF. Pagina de internet. CNBB. 06 agosto. Disponível em: http://www.cnbb.org.br/aborto-leia-as-integras-dos-discursos-da-cnbb-no-stf/

Comparato, F. K. (2006). Ética: direito, moral e religião no mundo moderno. São Paulo: Companhia das Letras.

Comparato, F. K. (2017). A Afirmação Histórica dos Direitos Humanos. Editora Saraiva (11).

CONIC (2018). Conselho Nacional das Igrejas Cristãs do Brasil. Site da internet. Disponível em https://www.conic.org.br/

Correio Braziliense (2019). Feminicídios e tentativas de assassinato disparam no Brasil em 2018. Versão digital. Disponível em: https://www.correio braziliense.com.br/app/noticia/brasil/2019/01/08/interna-brasil,729519/ feminicídios-etentativas-de-assassinato-disparam-no-brasil-em-2018. 
Cretella Junior, J. (1967). Curso de filosofia do direito. São Paulo: José Bushatsky.

Cristaldo, H. (2015). Queixas de violência doméstica pelo 180 aumentam 133\% este ano em relação a 2015. Revista Agência Brasil. Disponível em http://agenciabrasil.ebc.com.br/geral/noticia/2016-08/queixas-de-violencia-domesticapelo180-aumentam-133-este-ano-em-relacao-2015. (2).

Dallari, D. de A. (2010). Direitos humanos e cidadania. São Paulo: Editora Moderna

Dantas, C. \& Paulo, P.P.(2015). Uma em cada 5 mulheres já foi vítima de violência; saiba como denunciar. G1 São Paulo (versão digital). 7 de novembro. Disponível em: http://g1.globo.com/sao-paulo/noticia/2015/11/uma-em-cada-5-mulheres-ja-foi-vitima-deviolencia-saiba-como-denunciar.html

De Oliveira, A. C. G., \& de Oliveira, R. P. (1977). O Cristianismo e a Escravatura no Império Romano. Humanitas Coïmbra, 29, 145-203. Disponível em <https://www.uc.pt/fluc/eclassicos/publicacoes/ficheiros/humanitas29/30/07_Oliveiras.pdf $>$ Acesso em 20.02.2016.

De Souza, A. R. (2012). O pluralismo cristão brasileiro. Revista Caminhos-Revista de Ciências da Religião, 10(1), 129-141.

De Souza, S. D. (2004). Revista Mandrágora: gênero e religião nos Estudos Feministas. Revista Estudos Feministas, 122. Disponível em: <http://dx.doi.org/10.1590/S0104-026X2004000300014>. Acesso em 16 de janeiro de 2016.

Diniz, D; Medeiros, M. \& Madeiro, A. (2017). Pesquisa Nacional de Aborto 2016. Ciência e Saúde coletiva (22) 2: 653-660. Disponível em: http://dx.doi.org/10.1590/141381232017222.23812016 .

Dreher, M. N. (1994) A Igreja no Mundo Medieval. São Leopoldo: Sinodal, (6) 2.

Duarte, L. F. et al (2007). Entre o público e o privado. A influência dos valores religiosos na tramitação de Projetos de Lei no Brasil. Relatório de Pesquisa. São Paulo: PROSARE/CCR/MacArthur, mimeo.

Emmerick, R. (2010). As relações Igreja/Estado no Direito Constitucional Brasileiro. Um esboço para pensar o lugar das religiões no espaço público na contemporaneidade. Sexualidad, Salud y Sociedad-Revista Latinoamericana, (5). Disponível em: http://www.epublicacoes.uerj.br/index.php/SexualidadSaludySociedad/article/view/383/822

Engels, F. (1924). El origen de la familia, de la propiedad privada y del Estado. Ediciones Akal.

Escola sem Partido (2018). Site da internet. Disponível em: http://www.escolasempartido.org.

Esquivel, J. C. (2008). Laicidades relativas: avatares de la relación Estado-iglesia en Brasil. Los retos de laicidad y la secularización en el mundo contemporáneo. $1^{\mathrm{a}}$ ed. México, DF: El Colegio de México, Centro de Estudios Sociológicos.

Falcon, F.J.C (1994). Iluminismo. São Paulo: Editora Ática. 
Fausto, B. (1996). História do Brasil. São Paulo: Editora da Universidade de São Paulo -Edusp.

Favretto, A. (2017). Evangélicos e católicos se unem e criam ação contra a ideologia de gênero. Sempre Família (página de internet). Disponível em: https://www.semprefamilia.com.br/evangelicos-e-catolicos-se-unem-e-criam-acao-contraa-ideologia-de-genero/

Felipe, J. (2009). Gênero, sexualidade e formação docente: uma proposta em discussão. In Xavier Filha, Constantina. Educação para a sexualidade, para a equidade de gênero e para a diversidade sexual. Campo Grande/MS: Editora da UFMS. (1) 1: 45-55.

Felipe, J. (2016).Maus-tratos emocionais e formação docente. Entrelaçando gênero e diversidade: violências em debate. / Nanci Stancki da Luz, Lindamir Salete Casagrande (org.). - Curitiba: Ed. UTFPR.

Fernandes, C. (2017). Família patriarcal no Brasil. Revista Brasil Escola (versão digital). Disponível em <http://brasilescola.uol.com.br/historiab/familia-patriarcal-nobrasil.htm>.

Fernandes, M. (2018). STF inicia debate sobre descriminalização do aborto até $12^{a}$ semana de gravidez. Agência Huffpost. Página da internet. 3 agosto. Disponível em: https://www.huffpostbrasil.com/2018/08/03/stf-inicia-debate-sobre-descriminalizacao-doaborto-ate-12a-semana-de-gravidez_a_23493221/?utm_hp_ref=br-homepage

Filgueiras, F. (2009). A tolerância à corrupção no Brasil: uma antinomia entre normas morais e prática social. Opinião Pública, 15(2), 386-421. Disponível em: < http://dx.doi.org/10.1590/S0104-62762009000200005>.

Fiorin, J. L. (1990). Tendências da análise do discurso. Estudos Linguísticos (19): 173-9.

Firestone, S. (1976). La dialéctica del sexo. Editorial Kairós.

Foucault, M. (1986). Arqueologia do saber. Rio de Janeiro: Forense Universitária, 2.

Foucault, M. (1996) Ordem do Discurso. São Paulo: Loyola.

Fragoso, H. (1992). A Igreja na formação do Estado liberal. História da Igreja no Brasil. Petrópolis: Vozes (2) 141 - 253.

Freire, P. (1997). Pedagogia da Autonomia. São Paulo: Cortez.

Freston, P. (1994). Evangélicos na política do Brasil: História ambígua e desafio ético. Curitiba: Encontrão.

Frezzatti J., Wilson A.(2011). A construção da oposição entre Lamarck e Darwin e a vinculação de Nietzsche ao eugenismo. Sci. stud. Net. (9) 4, pp.791-820. <http://dx.doi.org/10.1590/S1678-31662011000400004>.

Funari, P.P. (2012). As religiões que o mundo esqueceu: como egípcios, gregos, celtas, astecas e outros povos cultuavam seus deuses. São Paulo: Contexto (1). 
Gadotti, M. (2000). Escola cidadã educação pela cidadania. Disponível em acervo.paulofreire.org. Acessado em dezembro de 2018.

Galli, B; Sydow, E. \& Adesse, L. (2010) Autonomia reprodutiva em questão: relatos de mulheres sobre aborto e estigma em Mato Grosso do Sul. Rio de Janeiro: Ipas Brasil. Disponible: http://www.aads.org.br/wp/wpcontent/uploads/2011/06/MS_Casos2010.pdf 17.

GDE: Gênero e Diversidade na Escola. (2009). Módulo 3, Sexualidade e orientação sexual, Unidade 1, Texto 1: Homem ou mulher, que pergunta é essa? Ministério da Educação, UFPA.

Geertz, C. (1989). A interpretação das culturas. Rio de Janeiro: LCT.

Gil, A.C. (2010). Como elaborar projetos de pesquisa. São Paulo: Atlas, 5.

Gill, A.C. (2004) 'Voicing the Silent Fear: South Asian Women's Experiences of Domestic Violence'. The Howard Journal of Criminal Justice. (43) 5 465-483.

Gomes, F.(1995). Histórias de Quilombolas: mocambos e comunidades de senzalas no Rio de Janeiro - século XIX. Rio de Janeiro: Arquivo Nacional.

Grossi, P., \& Aguinski, B. (2001). Por uma nova ótica e uma nova ética na abordagem da violência contra mulheres nas relações conjugais. Violências e gênero: Coisas que a gente não gostaria de saber, 19-45.

GRUPO GAY DA BAHIA (2015). Relatório 2013- 2014. Disponível em https://homofobiamata. files.wordpress.com/2015/01/relatc3b3rio- 2014s.pdf.

Habermas, J. (2007) Entre Naturalismo e Religião: estudos filosóficos. Rio de Janeiro: Tempo Brasileiro.

Haidar, F. H; Oliveira, U. F. \& Nascimento, L. F. (2001). Escolaridade materna: correlação com os indicadores obstétricos. Cadernos de Saúde Pública 17: 1025-1029.

Haidar, R. (2012) O direito de não ser um útero à disposição da sociedade: aborto legal pela vida das mulheres. Disponível em: http://www.conjur.com.br/2012- abr17/direito-mulher-nao-utero-disposicao-sociedade

Hannah A.(2012). Ideias que chocaram o mundo. Direção de Margarethe von Trotta. Alemanha, Luxemburgo, França, Israel. (113 min.). Título original: Hannah Arendt.

Herkenhoff, J.B. (1994). Curso de Direitos Humanos - Volume I (Gênese dos Direitos Humanos). São Paulo: Editora Acadêmica.

Hervieu-Léger, D. (2008). O peregrino e o convertido: a religião em movimento. Petrópolis: Vozes.

Hirata, H. (2010). Mundialização, divisão sexual do trabalho e movimentos feministas transnacionais. Revista Feminista, Recife (2).

Hooks, B. (1997). 'Violence in intimate relationships: A feminist perspective' in O’Toole, L. and Schiffman, J. R. (1997) Gender violence: Interdisciplinary perspectives. New York: New York University Press. 
Houaiss, A., Villar, M., \& Franco, F. M. (2001). Dicionário Houaiss da língua portuguesa. Editora Objetiva. Rio de Janeiro.

HRW (2017). Humans Rights Watch. Relatório Brasil 2017. Página da Internet. Disponível em: https://www.hrw.org/pt/world-report/2018/country-chapters/313303.

Hunt, L. (2009). A invenção dos direitos humanos uma história. Tradução Rosaura Eichenberg. São Paulo: Companhia das Letras.

IBGE (2012). Violência contra a mulher. Novembro. Disponível em: <http://teen.ibge.gov.br/noticias-teen/2822-violencia-contra-mulher>.

IBGE (2018). Estatísticas de Gênero: indicadores sociais das mulheres no Brasil. Estudos e Pesquisas- Informações demográficas e socioeconômicas (38). Disponível em https://biblioteca.ibge.gov.br/visualizacao/livros/liv101551_informativo.pdf

INEP (2018). Instituto Nacional de Estudos e Pesquisas Educacionais. Sinopse de estatísticas da Educação Básica. Disponível em: http://inep.gov.br/sinopses-estatisticasda-educacao-basica

Instituto Avon/Data Popular (2013).Percepções dos homens sobre a violência doméstica contra a mulher. Disponível em:〈http://centralmulheres.com.br/data/avon/Pesquisa-Avon-Datapopular-2013.pdf > Acesso em: 20 jul. 2017.

IPEA (2013). Instituto de Pesquisa Econômico Aplicada. Diversas pesquisas. Brasília. Disponível em: <http://www.ipea.gov.br/agencia/images/stories/PDFs/dides/140506_relatoriodeatividadesi pea2013.pdf $>$.

IWHC (2016). International Women's Health Coalition. Annual Report 2016. Disponível em <https://iwhc.org/wpcontent/uploads/2017/05/IWHC-2016AnnualReport.pdf>.

Johnson, A. G. (1997). Dicionário de sociologia. Zahar. Rio de Janeiro.

Knippel, E.L. \& Nogueira, M.C.A.(2010). Violência doméstica - A Lei Maria da Penha e as normas de direitos humanos no plano internacional. Porto Alegre: Sergio Antonio Fabris.

Lafer, C. (1995). A ONU e os direitos humanos. Estudos avançados, 9(25), 169-185. Disponível em: < http://dx.doi.org/10.1590/S0103-40141995000300014>. Acesso em 10 de maio de 2017.

Lauretis, T. (1987). A tecnologia do gênero. Technologies of gender, Indiana University Press, 1-30. Disponível em: < http://www.scribd.com/doc/81873993/ATecnologia-do-GeneroTeresa-de-Lauretis>.

Lima, H. (2015). Evangélicos representam tradicionalismo moral contra lutas de excluídos. Rede Brasil Atual (versão digital), 25 abril. Disponível em: $<$ http://www.redebrasilatual.com.br/politica/2015/04/bancada-evangelica-influenciaatedeputados-catolicos-1215.html> 
Lima, O. (1956). O Império brasileiro, p. 162, cit. por Cruz Costa, J. Contribuição à história das ideias no Brasil. Rio de Janeiro.

Lolatto, S. \& Lisboa, T,K. (2013) Profissionais de Serviço Social frente à questão do aborto - a ética em debate. In Revista Bagoas 09: 65-85. Disponível em: https://periodicos.ufrn.br/bagoas/article/view/4656

Lopes, R. (2008). Ceticismo e Vida contemplativa em Nietzsche. Belo Horizonte: UFMG.

Louis, M. V. (2006). Diga-me: o que significa gênero? Sociedade e Estado, 21 (3), 711-724. Disponível em: <http://dx.doi.org/10.1590/S0102-69922006000300008>.

Louro, G. L. (1997). Gênero, sexualidade e educação. Uma perspectiva pósestruturalista. Petrópolis, RJ: Vozes.

Macedo, M. (2002) Relações de gênero no contexto urbano: um olhar sobre as mulheres. In Perspectivas de Gênero: Debates e questões para as ONGs.

Machado, C.(2013), "É muita mistura: projetos religiosos, políticos, sociais, midiáticos, de saúde e segurança pública nas periferias do Rio de Janeiro". Religião e Sociedade (33) 2 13-36.

Mariano, R. (2011). Laicidade à brasileira. Católicos, pentecostais e laicos em disputa na esfera pública. Civitas-Revista de Ciências Sociais, 11(2).

Mariconda, P. R. (1997). A questão da autonomia da ciência em Galileu. Conferência proferida no II Encontro de Estudos Filosóficos do Século XVII. São Paulo, 26 de maio.

Martinez, S.D.T (2008). Violência Institucional: Violação dos Direitos Humanos da Mulher. Palestra. II Fórum de Violência contra a mulher. Presidente Prudente 21/11/2008. Disponível em: http://www. recriaprudente. org. br/site/abre_artigo. asp.

Gaspar. L. (2018). Nosso Mandato. Disponível em https://larissagaspar.com.br/nosso$\underline{\text { mandato .Acesso em } 12 \text { nov.2018 }}$

Mariano, R. (2003)“Efeitos da Secularização do Estado, do pluralismo e do mercado religiosos sobre as igrejas pentecostais”. Civitas, Porto Alegre, 3(1), 111-125.

Martínez Quintero, M.E.(2016). “El discurso de los derechos humanos en perspectiva histórica. El síndrome de la Torre de Babel", en Pando Ballesteros, Paz; Muñoz Ramírez, Alicia y Garrido Rodríguez Pedro: Pasado y presente de los Derechos Humanos, mirando al futuro, Madrid, La Catarata.

Mattar, L. D. (2008). Reconhecimento jurídico dos direitos sexuais: uma análise comparativa com os direitos reprodutivos. Sur, Revista Internacional de Direitos Humanos, (5) 8: 60-83. Disponível em: http://dx.doi.org/10.1590/S180664452008000100004. Acesso em 20 set. 2017.

Mead, M. (1935). Sex and temperament in three primitive societies. New York: William Morrow. 
Melo, S.L. (2010). A religiosidade no Brasil colonial: o caso da Bahia (séculos XVI$X V I I)$. Dissertação (Mestrado em Ciência das Religiões) - Universidade Federal da Paraí-ba, João Pessoa.

Mendez, J.E. (1998). Proteção Internacional dos Direitos Humanos. IN: Direitos Humanos no Século XXI, Seminário Direitos Humanos no Século XXI, 10 e 11 de setembro de 1998, Rio de Janeiro.

Menezes C., T., Gonçalves Nitschke, R., Mendonça Lopes, R. L., Pereira Gomes, N., \& Freire Diniz, N. M. (2015). Cotidiano de mulheres com história de violência domestica e aborto provocado. Texto \& Contexto Enfermagem, 24(1).

Menezes, A. R. S., \& Milani, G. D. Direitos Humanos em tempos de barbárie. Revista Publicum, 3(1), 134-156.

Menezes, G. \& Aquino, E. M. L. (2009) Pesquisa sobre o aborto no Brasil: avanços e desafios para o campo da saúde coletiva. Caderno de Saúde Pública. Disponible: http://www.scielo.br/pdf/csp/v25s2/02.pdf . Consultado 18/08/2018

Ministério da Saúde (2017). DATASUS. Informações de Saúde. PNS - Pesquisa Nacional de Saúde - 2017: módulo de cobertura de mamografia entre mulheres de 50 anos ou mais. Brasília (DF). Disponível em: http:// tabnet.datasus.gov.br/cgi/ deftohtm.exe?pns/pnskb.def

Monteiro, P. (2003). Max Weber e os dilemas da secularização: o lugar da religião no mundo contemporâneo. Novos Estudos Cebrap, (65): 34-44.

Moore, H. L. (1991). Antropología y feminismo (Vol. 3). Universitat de València.

Moraes, R. (1999). Análise de conteúdo. Revista Educação, Porto Alegre (22) 37: 732.

Mouffe, C.Religião, democracia liberal e cidadania. In Os Votos de Deus. Evangélicos, política e eleições. Burity, Joanildo A. \& Machado, Maria Das Dores C. (2006). Recife: Fundação Joaquim Nabuco.

Nascimento Filho, A. J.(2005). Bartolomeu de Las Casas, um cidadão universal: uma questão de alteridade com os povos do Novo Mundo. São Paulo: Loyola,

Natividade, M. (2006). Homossexualidade, gênero e cura em perspectivas pastorais evangélicas. Revista Brasileira de Ciências Sociais, 21(61), 115-132. Disponível em: <http://dx.doi.org/10.1590/S0102-69092006000200006>.

Natividade, M. (2016). Uma homossexualidade santificada? Etnografia de uma comunidade inclusiva pentecostal. Relig. soc. (30) 2: 90-121. Disponível em: <http://dx.doi.org/10.1590/S0100-85872010000200006>. Acesso em: 12 de fevereiro de 2016.

Nicholson, L.; Soares, L. F. G. \& de Lima Costa, C. (2000). Interpretando o gênero. Estudos feministas, 9-41.

Nicolazzi, F.F. (2016). Qual o partido da escola sem partido? Revista do LHISTE. Porto Alegre, RS (3) 5: 82-85. 
OBSERVATORIO GÉNERO Y EQUIDAD.(2016) Uruguay: no registra muertes por aborto desde que es legal. Disponible: http://www.observatoriogeneroyequidad. cl/index.php/bloc-mainmenu-9/26-novedades/7164- uruguay-no-registra-muertes-porabortodesde-que-es-legal. Consultado 15/08/2018 Forense.

Oliveira Filho, J. (1968). Origem cristã dos direitos fundamentais do homem. Ed

Oliveira, F.R.C.(2011) Religião e participação política: considerações sobre um pequeno município brasileiro , e-cadernos CES [Online], 13 |2011. Acesso 10 nov. 2019. Disponível em http://journals.openedition.org/eces/568

ONU (1979). Organização das Nações Unidas. Convenção sobre a eliminação de todas as formas de discriminação contra as mulheres - CEDAW. Disponível em: http://www.onumulheres.org.br/wp-content/uploads/2013/03/convencao_cedaw1.pdf.

ONU (2016). Organização das Nações Unidas. Saúde sexual e reprodutiva é inseparável dos outros direitos humanos, destacam especialistas da ONU. 11 março. Disponível em: <https://nacoesunidas.org/saude-sexual-e-reprodutiva-einseparavel- dosoutros-direitos-humanos-destacam-especialistas-da-onu/> Acesso em: 26 set. 2017.

ONU (2017). Organização das Nações Unidas. OMS: proibição não reduz número de abortos e aumenta procedimentos inseguros. Página da internet. 28 de setembro. Disponível em: https://nacoesunidas.org/oms-proibicao-nao-reduz-numero-de-abortos-eaumenta-procedimentos-inseguros/

ONU MUJERES (2018). http://lac.unwomen.org/es . Acesso em 29 de agosto de 2018.

Pasinato, W. (2011). "Femicídios" e as mortes de mulheres no Brasil. Cad. Pagu (37): 219-246. Disponível em: < http://dx.doi.org/10.1590/S0104-83332011000200008>.

Pêcheux, M. (1990) Apresentação da AAD. In: GADET, F., HAK, H. Por uma análise automática do discurso. Campinas: Pontes.

Peixoto, V. B. (2018). Violência contra LGBTs no Brasil: a construção sóciohistórica do corpo abjeto com base em quatro homicídios. Dissertação. Brasília: Universidade Federal de Brasília.

Pereira, C.M.S. (2004). Instituições de direito civil. Rio de Janeiro: Forense (20).

Peroni, V.M.V \& Caetano, M.R. (2016). O público e o privado na educação-Projetos em disputa?Retratos da Escola (9) 17: 2016.

Pimentel, S. (2006) Convenção sobre a Eliminação de Todas as Formas de Discriminação contra a Mulher (apresentação). In Instrumentos Internacionais de Direitos das Mulheres. Brasília: Secretaria Especial de Políticas para as Mulheres.

Pinski, C.B. \& Pedro, J.M. (2010). Igualdade e Especificidade. In: Pinsky, Jaime \& Pinsky, Carla Bassanezi. História da Cidadania. São Paulo: Contexto, 264-309.

Pinto, C.R.J (2003). Uma história do feminismo no Brasil. Editora Fundação Perseu Abramo, São Paulo. 
Pinto, C.R.J (2010). Feminismo, história e poder. Revista de Sociologia Politica (18) 36: 15-23. Disponível em: 〈http://dx.doi.org/10.1590/S0104-44782010000200003〉.

Pinto, T.S. (2018). A Igreja Católica no Brasil. Brasil Escola. Disponível em <http://brasilescola.uol.com.br/historiab/igreja-catolica-no-brasil.htm>.

Piovesan, F. (1997). Direitos humanos e o direito constitucional internacional. São Paulo: M. Limonad (2).

Priore, M.D \& Bassanezi, C. (2004). História das mulheres no Brasil. São Paulo: Contexto (7).

Ramos, A.C. (2017). Curso de direitos humanos. São Paulo: Saraiva (4).

Ramos, M.S \& Stampa, I. (2016). SUBVERSÃO E RESISTÊNCIA DOCENTE: Notas sobre a ditadura militar e o movimento Escola sem Partido. Revista Espaço do Currículo. (9) 2.

Reale, M. (1996). Paradigmas da cultura contemporânea. São Paulo: Editora Saraiva.

Revista Veja (2016). A quem interessava matar esta mulher? Editora Abril, (2574) 21 de março. Disponível em: https://veja.abril.com.br/edicoes-veja/2574. Acesso em 31 de agosto de 2018.

Revista Veja (2018). Desembargadora diz que Marielle 'estava engajada com bandidos'? Editora Abril, Versão digital. 9 de abril. Disponível em: https://veja.abril.com.br/brasil/desembargadora-diz-que-marielle-estava-engajada-combandidos/. Acesso em 31 de agosto de 2018.

Rios, R. R. (2006). Para um direito democrático da sexualidade. Horizontes Antropológicos. Porto Alegre. 12 (26) 71-100.

Rosado, M. J. (2001). O impacto do feminismo sobre o estudo das religiões. cadernos pagu, (16), 79-96. Disponível em: <http://dx.doi.org/10.1590/S010483332001000100005>.

Rosado-Nunes, M. J. (2005). Gênero e religião. Revista Estudos Feministas, 13(2), 363-365. São Paulo.

Rosaldo, M. (1974). Women, Culture, and Society: A Theoretical Overview. In Rosaldo, Michelle Z. \& Louise Lamphere (1974) Women, Culture and Society. Stanford: Stanford University Press.

Rubin, G. (1975). The traffic in women: notes on the political economy of sex. In Reter, Rayna. Toward an anthropology of women. New York: Monthly Review.

Saccomani. (1998). Verbete “Fascismo”. In Bobbio, N.; Matteucci, N. \& Pasquino, G. Dicionário de Política. Rio de Janeiro: Nova Fronteira, (1).

Saffioti, H.I.B. (2004). Gênero e patriarcado: violência contra mulheres. In: Venturi, Gustavo et al. A mulher brasileira nos espaços público e privado. São Paulo: Fundação Perseu Abramo. 79-80. 
Salgado, G.M. (2015, 11 junho). Pastora defende a abordagem de questões de gênero na educação. Brasil de Fato (versão digital). Disponível em: https://www.brasildefato.com.br/node/32246/.

Santos, B. C. (2012). Aborto, direitos reprodutivos e feminismo na França de Nicolas Sarkozy. [Internet]. Rev. bras. ciênc. Politica. Disponivel: http://seer.bce.unb.br/index.php/ rbcp/article/view/6613.

Santos, D. (2012) Supremo decide por 8 a 2 que aborto de feto sem cérebro não é crime. G1. Disponilble: g1.globo.com/brasil/noticia/2012/04/supremo-decide-por-8-2-queaborto -de- feto-sem-cerebro-nao-e-crime.html.

Sarlet, I.W. (2009). A eficácia dos Direitos Fundamentais: uma teoria geral dos Direitos Fundamentais na perspectiva constitucional. Porto Alegre: Livraria do Advogado, 10.

Sarti, C. A. (2004). A família como ordem simbólica. Psicologia usp, 15(3), 11-28.

Sarti, C. (1988). Feminismo no Brasil: uma trajetória particular. Cadernos de Pesquisa (64) 38-47.

Saviani, D. (2016). Educação escolar, currículo e sociedade: o problema da base nacional comum curricular. Movimento-Revista de Educação, (4). 8.

Scavone, L. (2008). Religiões, gênero e feminismo. Rev Estudos da Religião, 2(4), 1-

Scherer-Warren, I. (2014). Manifestações de rua no Brasil 2013: encontros e desencontros na política. Caderno CRH, 27(71).

Schmitt-Pantel, P. (2003). A criação da mulher: um ardil para a história das mulheres. O corpo feminino em debate. São Paulo: Ed. Unesp, 129-156.

Segato, R.L. (1988). Os percursos do gênero na antropologia e para além dela. Brasília: Departamento de Antropologia.

Shapiro, J. (1981). Anthropology and the study of gender. Soundings, 446-465.

Silva, F.D.L.L.(2001). Princípio constitucional da igualdade. Rio de Janeiro: Editora Lumen Júris: 36.

Silva, M. B.N.(1983). Sistema de casamento no Brasil colonial. Rio de Janeiro.

Silva, M.D. (2014). Do Gênesis à gênese da hermenêutica filosófica: a interpretação como locus da criação da realidade na decisão judicial. Tese. Programa de Pós-Graduação em Direito, Centro de Ciências Júridicas / FDR, Universidade Federal de Pernambuco, Recife.

Simões, S.D. (1985). Deus, pátria e família. As mulheres no Golpe de 1964. Petrópolis: Vozes.

Smith, C. (1991), The emergence of Liberation Theology: Radical Religion and Social Movement Theory. Chicago: University of Chicago Press. 
Soares, B. (2006). A Violência Doméstica e as Pesquisas de Vitimização. Documento apresentado no II Encontro Nacional de Produtores e Usuários de Informações Sociais, Econômicas e Territoriais - CONFEST. IBGE, Rio de Janeiro. Disponível em http://www.ibge.gov.br/confest_e_confege/pesquisa_trabalhos/arquivosPDF/M705_01.pdf $>$.

Sodré, N.W. (1999). História da imprensa no Brasil. Rio de Janeiro: Mauad.

Souza, L.M. (2009). O diabo e a Terra de Santa Cruz: feitiçaria e religiosidade popular no Brasil Colonial. São Paulo: Companhia das Letras.

Spector, N. (2001) Manual para redação de teses, projetos de pesquisa e artigos científicos. Rio de Janeiro: Guanabara Koogan (2).

Stanko, E. A. (2006). 'Theorizing About Violence: Observations from the Economic and Social Research Council's .Violence Research programme' Violence Against Women (12) 6: 543-555. Terra.

Stepan, A. (1987). Os militares: da abertura à Nova República. Rio de Janeiro: Paz e

Tabak, F. (2002). O laboratório de Pandora: estudos sobre a ciência no feminino. Rio de Janeiro.

Tatagiba, L. (2018). Entre as ruas e as instituições: os protestos e o impeachment de Dilma Rousseff. Lusotopie, 17(1), 112-135.

Tavares, A. R. (2016). O direito fundamental ao discurso religioso: divulgação da fé, proselitismo e evangelização. Revista Brasileira de Estudos Constitucionais-RBEC, Belo Horizonte, ano, 3, 17-47.

Teixeira, F. (2011). Sociologia da Religião: enfoques teóricos. 4 ed. - Petrópolis, RJ: Vozes (4).

Telles Junior, G. (1986). A Constituição, a Assembleia Constituinte e o Congresso Nacional. São Paulo: Saraiva.

Thomas, G. (1982). Política indigenista dos portugueses no Brasil. 1500-1640. São Paulo: edições Loyola.

Thomson, J. J. (2012) Uma defesa do aborto. [Internet]. Revista Brasileira de Ciência Política. Disponível em: http://seer.bce.unb.br/index.php/rbcp/article/view/6614/5338. Consultado 12/08/2018.

Tomazela, J.M. (2018, 01 novembro). Escola Sem Partido completa 1 ano em cidade do interior paulista e não tem efeito prático. Educação. O Estado de São Paulo (versão digital). Disponível em: https://educacao.estadao.com.br/noticias/geral,escola-sem-partidocompleta-1-ano-em-cidade-do-interior-paulista-e-nao-tem-efeito-pratico,70002578008

Trevisan, J. B. (2013). Evangélicos pentecostais na política partidária brasileira: de 1989 a 2010. Revista Brasileira de História das Religiões, 15. Disponível em: <http://www.dhi.uem.br/gtreligiao/pub.html>. 
Trindade, A. A. C. (1997). Dilemas e desafios da Proteção Internacional dos Direitos Humanos no limiar do século XXI. Revista Brasileira de Política Internacional, 40(1), 167-177. Disponível em: 〈http://dx.doi.org/10.1590/S0034-73291997000100007〉.

Vaggione, J.M. (2005). Los roles políticos de la religión. Gênero y sexualidad más allá del secularismo. In: Vassallo, M. En nombre de La vida. Córdoba/Argentina: Católicas por el Derecho a Decidir.

Vainer, B. Z. (2010). Breve histórico acerca das constituições do Brasil e do controle de constitucionalidade brasileiro. Revista Brasileira de Direito Constitucional, 16(1), 161191.

Valente, I. \& Romano, R. (2002). PNE: Plano Nacional de Educação ou carta de intenção. Educação \& Sociedade, 23 (80): 96-107.

Vicente, L.M.D. (2018). Judicialização e sujeição social: uma análise dos direitos das mulheres no marco constitucional de 1988 e seus retrocessos. Arquivos Brasileiros de Psicologia, 70(spe), 176-189. Recuperado de http://pepsic.bvsalud.org/scielo.php?script=sci_arttext\&pid=S1809$52672018000400015 \& \operatorname{lng}=$ pt\&tlng=pt.

Waiselfisz, J.J. (2015). Mapa da Violência 2015: Homicídio de Mulheres no Brasil. São Paulo: Instituto Sangari.

Williamson, E. \& Abrahams, H. A. (2014). 'A review of the provision of intervention programmes for female victims and survivors of domestic abuse in the UK'. Journal of Women and Social Work (29) 178-191.

Zepeda, J.J.L.(2010), "Secularização ou ressacralição? O debate sociológico contemporâneo sobre a teoria da secularição". Revista Brasileira de Ciências Sociais, 25(73), 129-141.

Referências das notícias citadas no corpo do texto da tese, na ordem em que aparecem.

CARTA CAPITAL, "Gênero e ensino religioso juntos na base curricular", 06-122017.

O Povo, “Projetos de lei. Educação sem ideologia?”, 31/07/2016.

O Povo, "Movimento Escola sem Partido ganha força no país, mas divide professores”, 31/03/2016.

CARTA CAPITAL, "Falso discurso da Escola Sem Partido avança no Congresso", $14 / 05 / 2018$

FÓRUM, “Qual o partido da escola sem partido?”, 02/06/2016.

O Povo, “Projetos de lei. Educação sem ideologia?”, 31/07/2016.

Diário do Nordeste, “Debate perdido no tempo”, 31/02/2016

Diário do Nordeste, “Bancada religiosa comemora Plano”, 07/05/2016

Diário do Nordeste, “Execução precisa de fiscalização”, 16/05/2016 
Diário do Nordeste, “Deputado critica “ideologia de gênero,” 26/10/2017

Diário do Nordeste, "Pautas conservadoras viram aposta eleitoral”, 26/12/2017

Diário do Nordeste, “Deputada reclama de livro didático”, 15/03/2018

O Povo, "Marxismo" e "censura LGBT": deputados saem contra Plano de Educação, $24 / 03 / 2016$

O Povo, “Questões de gênero podem deixar alunos sem livros”, 28/03/2016.

O Povo, "Silas Malafaia pede a Temer 'cuidado' na escolha do ministro da Educação’'28/04/2016

O POVO, "SP: Malafaia diz a tucanos que evangélicos não negociarão 'ideologia de gênero'”, 17/08/2017

O Povo, “Candidato do PRB mantém vantagem no Rio”, 28/10/2016

O POVO, "Votação de Plano Municipal de Cultura gera polêmica e ataques homofóbicos", 20/11/2017

O POVO, "Opinião: igrejas neopentecostais ameaçam democracia na América Latina”, 10/02/2018

O POVO, "O Ceará que a Assembleia discute. Discursos sobre gênero ultrapassam seca em debates na Assembleia”, 03/12/2017

O POVO, "O Ceará que a Assembleia discute. Discursos sobre gênero ultrapassam seca em debates na Assembleia”, 03/12/2017

O POVO, “A verdadeira 'ideologia de gênero”, 21/03/2017

O Povo, "Somos sociedade cristã", diz deputada por alteração no Plano de Educação," 03/05/2016

O Povo, "Escola livre é escola sem mordaça", 03/05/2016; "Projetos de lei. Educação sem ideologia?", 31/07/2016

O Povo, "Confronto de ideias", 13/05/2016

O Povo, "Debate. A escola e o equilíbrio entre visões divergentes", 31/07/2016

O Povo, "Escola Livre ou Terceira Margem", 05/09/2016

O POVO, "Movimento Escola sem Partido ganha força no país, mas divide professores”, 15/10/2016

O POVO, “Candidato do PRB mantém vantagem no Rio”, 28/10/2016

O POVO, “Grupo faz ato em Fortaleza em apoio à Lava Jato”, 26/03/2017

O POVO, "SP: Malafaia diz a tucanos que evangélicos não negociarão 'ideologia de gênero'”, 17/08/2017 
O POVO, "O Ceará que a Assembleia discute. Discursos sobre gênero ultrapassam seca em debates na Assembleia”, 03/12/2017

CARTA CAPITAL, "No Recife, diversidade sexual pode deixar alunos sem livros", 29/03/2016

CARTA CAPITAL, "Como lidar com a polarização política dentro da escola?", 29/03/2016

CARTA CAPITAL, "A falácia da Escola Sem Partido - ou do pensamento único”, $01 / 06 / 2016$

CARTA CAPITAL, "A escola tem um papel fundamental para romper com a cultura de estupro”, 07/06/2016

CARTA CAPITAL, "Discutir gênero não tem nada a ver com 'apologia gayzista", 19/07/2016

CARTA CAPITAL, "Escola Sem Partido: estratégia golpista para calar a educação", 08/08/2016

CARTA CAPITAL, “Vamos falar sobre gênero?”, 26/10/2016

CARTA CAPITAL, "Como trabalhar a igualdade de gênero na escola”, 08/03/2017

CARTA CAPITAL, "Por que é tão difícil falar de gênero na escola?”, 04/11/2016

CARTA CAPITAL, "Conheça a última versão da Base Curricular para Ensino Infantil e Fundamental”, 06/04/2017

CARTA CAPITAL, "A sociedade perde ao não discutir gênero na escola", $13 / 04 / 2017$

CARTA CAPITAL, "Base Nacional Comum Curricular: muitas perguntas, poucas respostas", 06/07/2017

CARTA CAPITAL, "Quando a tática do Estado para lidar com a homofobia é a omissão”, 16/05/2017

CARTA CAPITAL, "84\% dos brasileiros apoiam a discussão de gênero nas escolas", 26/06/2017

CARTA CAPITAL, "Escola sem partido intimida e persegue professores", 02/08/2017

CARTA CAPITAL, "Jornal Gazeta do Povo cria "Monitor da Doutrinação" para as escolas", 08/12/2017

CARTA CAPITAL, "Após pressão, jornal Gazeta do Povo tira do ar Monitor da Doutrinação", 11/12/2017

CARTA CAPITAL, "Conselho aprova Base Nacional Comum Curricular", $15 / 12 / 2017$ 
CARTA CAPITAL, "Falso discurso da Escola Sem Partido avança no Congresso", $14 / 05 / 2018$

FÓRUM, "Bolsonaro grava vídeo sobe educação e revista especializada desmente frase por frase”, 17/01/2016

FÓRUM, "Mulheres e LGBTs do PT repudiam declarações de ex-ministro Luiz Marinho”, 27/01/2016

FÓRUM, “Qual o partido da escola sem partido?”, 02/06/2016

FÓRUM, "O que fazia uma seita religiosa em uma escola estadual paulista?", $04 / 06 / 2016$

FÓRUM, “Clóvis Gruner: O excepcional normal”, 16/06/2016

FÓRUM, "Deputada evangélica pede "providências legais" contra professor que debateu homofobia em sala de aula", 08/07/2016

FÓRUM, "Em algumas horas, MEC nomeia e exonera economista ligado ao 'Escola Sem Partido"”, 12/07/2016

FÓRUM, 'Uma farsa chamada "Escola sem Partido",', 14/07/2016

FÓRUM, "Aluna é suspensa depois de criticar escola que proibiu discutir sexo, gênero e religião”, 20/10/2017

FÓRUM, "Sindicalistas, estudantes e pais lançam 'Frente Escola sem Mordaça' no Rio de Janeiro”, 16/10/2016

FÓRUM, “Grupo fascista cria tumulto em debate sobre "ideologia de gênero" em Guarujá”, 29/10/2017

FÓRUM, "Temer exclui combate à discriminação de gênero na base curricular $e$ inclui tema na área de Ensino Religioso”, 06/12/2017 


\section{APÊNDICE 1 - DADOS DIÁRIO DO NORDESTE}

1.

\begin{tabular}{|l|l|}
\hline DATA 31-02-2016 & Nota \\
\hline TÍTULO DO ARTIGO: Violência contra a mulher \\
\hline Autor: Nilze Costa e Silva \\
\hline Tema: Violência contra a Mulher \\
\hline ARGUMENTO CENTRAL: Os jovens precisam discutir gênero nas escolas \\
\hline Nomes dos atores citados: \\
\hline Outras Informações importantes: \\
\hline $\begin{array}{l}\text { Resumo: Texto sobre o tema da redação do ENEM que tratou da Violência Contra a } \\
\text { Mulher: “O que se comentou nas redes sociais é que o tema da redação teria sido difícil. } \\
\text { Como difícil se as notícias de agressão a mulheres são tão constantes?" }\end{array}$ \\
\hline
\end{tabular}

2.

\begin{tabular}{|c|c|}
\hline DATA 31-02-2016 & Nota \\
\hline \multicolumn{2}{|c|}{ TÍTULO DO ARTIGO: Debate perdido no tempo } \\
\hline \multicolumn{2}{|c|}{ Autor: Não especificado. } \\
\hline \multicolumn{2}{|l|}{ Tema: Educação } \\
\hline \multicolumn{2}{|c|}{$\begin{array}{l}\text { ARGUMENTO CENTRAL: como está o debate político na assembleia do Estado do } \\
\text { Ceará. }\end{array}$} \\
\hline \multicolumn{2}{|c|}{ Nomes dos atores citados: } \\
\hline \multicolumn{2}{|c|}{ Outras Informações importantes } \\
\hline $\begin{array}{l}\text { Resumo: "O foco } \mathrm{i} \\
\text { medidas baseadas } \mathrm{n} \\
\text { para a sociedade - } \mathrm{d}\end{array}$ & $\begin{array}{l}\text { cialmente visível é o Plano Estadual de Educação, conjunto de } \\
\text { Plano Nacional de Educação que norteia políticas públicas vitais } \\
\text { do conta inclusive de confrontar preconceitos sexuais e de gênero. }\end{array}$ \\
\hline
\end{tabular}


Outro, um tanto escamoteado, é uma queda de braço político-religiosa que há anos impõe questionamento a qualquer iniciativa que soe minimamente progressista. Algo que espanta pelo caráter ultrapassado de algumas ideias".

3.

\begin{tabular}{|l|l|}
\hline DATA 11-03-2016 & Nota \\
\hline
\end{tabular}

TÍTULO DO ARTIGO: Plano de Educação

Autor: Não especificado.

Tema: PNE

ARGUMENTO CENTRAL: Informativo

Nomes dos atores citados:

Outras Informações importantes:

Resumo: Nota pequena sobre a avaliação do PNE pelo Estado do PE. Diz que há pressa na aprovação e que há pontos polêmicos a serem discutidos como a questão de gênero.

4.

\begin{tabular}{|l|l|}
\hline DATA 30-04-2016 & Política \\
\hline
\end{tabular}

TÍTULO DO ARTIGO: Bancada religiosa critica 'urgência' para votação

Autor: Não especificado.

Tema:

ARGUMENTO CENTRAL: Alguns deputados estaduais continuam querendo retirar do Plano termos como 'LGBT' e 'gênero'.

Nomes dos atores citados:

Outras Informações importantes:

Resumo: O texto expõe as disputas na câmara com relação ao teor do projeto e a inclusão 
de questões de gênero.

5.

DATA 07-05-2016

TÍTULO DO ARTIGO: Bancada religiosa comemora Plano

Autor: Não especificado.

Tema: Plano Estadual de Educação

ARGUMENTO CENTRAL:

Nomes dos atores citados: Silvana Oliveira (PMDB)

Outras Informações importantes:

Resumo: Fala da deputada "Foi uma vitória do povo cristão e prova que, mesmo com vitória apertada em determinado momento, com a diferença de apenas um voto, temos a consciência tranquila de que $80 \%$ da população se sente contemplada com o que conseguimos, um plano neutro."

6.

\begin{tabular}{|l|l|}
\hline DATA 11-05-2016 & Política \\
\hline \multicolumn{1}{|c|}{ TÍTULO DO ARTIGO: Deputados ressaltam a importância da matéria }
\end{tabular}

Autor: Não especificado.

Tema:

ARGUMENTO CENTRAL:

Nomes dos atores citados:

Outras Informações importantes:

Resumo: O texto descreve as opiniões de alguns parlamentares eu celebram o diálogo na Câmara, a divergência de opiniões e o resultado do projeto enviado para o secretário de 
educação do Estado.

7.

DATA 16-05-2016

TÍTULO DO ARTIGO: Execução precisa de fiscalização

Autor: Não especificado.

Tema: PEE

ARGUMENTO CENTRAL: O estado precisa fiscalizar a aplicação do plano.

Nomes dos atores citados: Dep. Elmano de Freitas

Outras Informações importantes:

Resumo: Na casa legislativa, o caráter de urgência solicitado para a matéria terminou sem ser efetivado por conta do debate em relação à possibilidade do uso do nome social nas escolas. O impasse acabou incluindo como diretriz do PEE o impedimento da "utilização de ideologia de gênero na educação estadual".

8.

\begin{tabular}{|l|l|}
\hline DATA10-10-2017 & Política \\
\hline TÍTULO DO ARTIGO: Aumenta o número de propostas de cunho religioso \\
\hline Autor: Não especificado. \\
\hline Tema: Religião e política \\
\hline ARGUMENTO CENTRAL: Além de defenderem uso da Bíblia em escolas e faculdades, \\
deputados querem proibir manifestações artísticas \\
\hline Nomes dos atores citados: vários parlamentares \\
\hline Outras Informações importantes: \\
\hline Resumo: Desde o início da atual Legislatura, com deputados eleitos ligados a movimentos \\
\hline
\end{tabular}


religiosos, a Assembleia Legislativa passou a contar com pautas mais conservadoras, não somente nos discursos no Plenário 13 de Maio, mas também nas propostas apresentadas. Nos últimos meses, aumentou o número de matérias com conteúdo ligado a entidades religiosas na Casa. Presidente da Comissão de Educação, a deputada Silvana Oliveira (PMDB) é uma espécie de representante da bancada religiosa ao lado de David Durand (PR), Walter Cavalcante (PMDB) e Carlos Matos (PSDB), sendo que os dois primeiros representam movimentos Evangélicos e os outros dois católicos. Além deles, outros parlamentares apresentaram nos últimos meses propostas de interesse de classes religiosas, como foi o caso de Bruno Pedrosa, do Partido Progressista (PP), que na semana passada colocou para tramitar projeto tornando disponível nas bibliotecas das escolas e universidades públicas, no mínimo, sete exemplares da Bíblia Sagrada nos seus acervos. "Disponibilizar a Bíblia nas bibliotecas públicas é uma medida relevante para todos os estudantes", justificou. Ferreira Aragão (PDT) é outro que tem apresenta do pautas conservadoras, algumas beirando à censura prévia, como outros parlamentares relataram na tribuna da Casa. É dele projeto que determina a proibição de manifestações artística em teatros, museus, cinemas e em prédios públicos e particulares "visem incentivar a práticas criminosas. Dentre as proibições estariam temas como "pedofilia; atos de terrorismo; que atentem contra a fé e religião; que atentem contra a ordem e a paz". Após participar de audiência em favor da chamada "Escola sem Partido", que contou com a presença do deputado federal Eduardo Bolsonaro (PSC-RJ), a deputada Silvana subiu à tribuna, na semana passada, para criticar ações de professores que estariam aportando conteúdos do que ela chama de "ideologia de gênero "em sala de aula. Diante disso, a parlamentar propôs a criação de uma Frente Parlamentar para fiscalizar as escolas e evitar o que ela chama de "doutrinação política e ideológica".

9.

\begin{tabular}{|l|l|}
\hline DATA 25-10-2017 & Política \\
\hline TÍTULO DO ARTIGO: Deputado lamenta foco dado ao PNE
\end{tabular}

Autor: Não especificado.

Tema: PNE

ARGUMENTO CENTRAL: 
Nomes dos atores citados: Dep.Fernando Hugo (PP)

Outras Informações importantes:

Resumo: O parlamentar acredita que se perdeu tempo demais discutindo assuntos do Plano Nacional e Estadual de Educação que precarizaram o debate curricular, como questões ligadas à sexualidade dos alunos. $\mathrm{O}$ deputado criticou o ensino de ideologias nas escolas.

10.

\begin{tabular}{|l|l|}
\hline DATA 26-10-2017 & Política \\
\hline
\end{tabular}

TÍTULO DO ARTIGO: Deputado critica "ideologia de gênero"

Autor: Não especificado.

Tema: Política

ARGUMENTO CENTRAL:

Nomes dos atores citados: Ely Aguiar (PSDC)

Outras Informações importantes:

Resumo: Desde que vieram à tona relatos envolvendo a disseminação de 'ideologia de gênero' em escolas públicas do interior do estado, o assunto tem sido frequentemente debatido no Plenário da Assembleia Legislativa por parlamentares. Em pronunciamento ontem, o deputado Ely Aguiar (PSDC), autor da emenda que vetou do Plano Estadual de Educação, no ano passado, pontos eu tratavam da sexualidade e gênero, afirmou que a ideologia é uma fonte de destruição da família e de implantação do regime comunista. Um requerimento para a instalação de uma Frente Parlamentar para a Fiscalização da Ideologia de Gênero aguarda votação na casa.

11.

\begin{tabular}{|l|l|}
\hline DATA 21-12-2017 & Nacional \\
\hline
\end{tabular}

TÍTULO DO ARTIGO: BNCC tem até 2020 para implantação 
Autor: Não especificado.

Tema: Educação

ARGUMENTO CENTRAL:

Nomes dos atores citados:

Outras Informações importantes:

Resumo: A base, documento de mais de 450 páginas, é dividida em cinco áreas de conhecimento: linguagens, matemática, ciências da natureza, ciências humanas e ensino religioso. Menção às expressões de identidade de gênero e orientação sexual foram alvo de polêmica, dividiram educadores e grupos religiosos e acabaram retiradas do texto. Durante evento de homologação, o ministro anunciou que o governo vai liberar R 100 milhões em 2018 para apoiar a implantação da Base. Também presente, o presidente Michel Temer disse que a base curricular era esperada há 20 anos e criticou os seus antecessores por não terem levado o tema adiante.

12.

\begin{tabular}{|l|l|}
\hline DATA 26-12-2017 & Política \\
\hline
\end{tabular}

\section{TÍTULO DO ARTIGO: Pautas conservadoras viram aposta eleitoral}

Autor: William Santos

Tema: Política eleitoral

ARGUMENTO CENTRAL: Os políticos usam temas polêmicos para impulsionar seus discursos nos períodos eleitorais e ganharem visibilidade.

Nomes dos atores citados:

Outras Informações importantes:

Resumo: Para pesquisadores, discurso é demagógico e pouco propositivo. Outros defendem ser reflexo do atual cenário. Neste ano, a deputada Silvana Oliveira propôs a criação de uma frente parlamentar contra a ideologia de gênero no Ceará. A Assembleia Legislativa do Estado aprovou, em outubro, lei que impõe restrições a exposições em 
espaços públicos em nome 'das famílias'.

13.

\begin{tabular}{|l|l|}
\hline DATA 20-01-2018 & Cidade \\
\hline
\end{tabular}

TÍTULO DO ARTIGO: Volta às aulas de Lara deixa a escola com cor de diversidade

Autor: Cadu Freitas

Tema: Educação e gênero

ARGUMENTO CENTRAL: história da menina transexual, Lara, na escola

Nomes dos atores citados: SESC (escola), Defensoria Pública do Estado do Ceará

Outras Informações importantes:

Resumo: Após polêmica de trasnfobia, garota conta como foi a primeira semana de aula no oitavo ano do colégio. "A decisão pela promoção de ações relativas à questão foi garantida no acordo firmado entre a instituição de ensino e a família na Defensoria Pública do Estado do Ceará 'a gente entendia que o ocorrid0o não era apenas um dano individual, mas coletivo. Solicitamos essas campanhas como forma de retratação, incluindo questões de identidade de gênero e orientação sexual a serem abordadas na escola"”.

14.

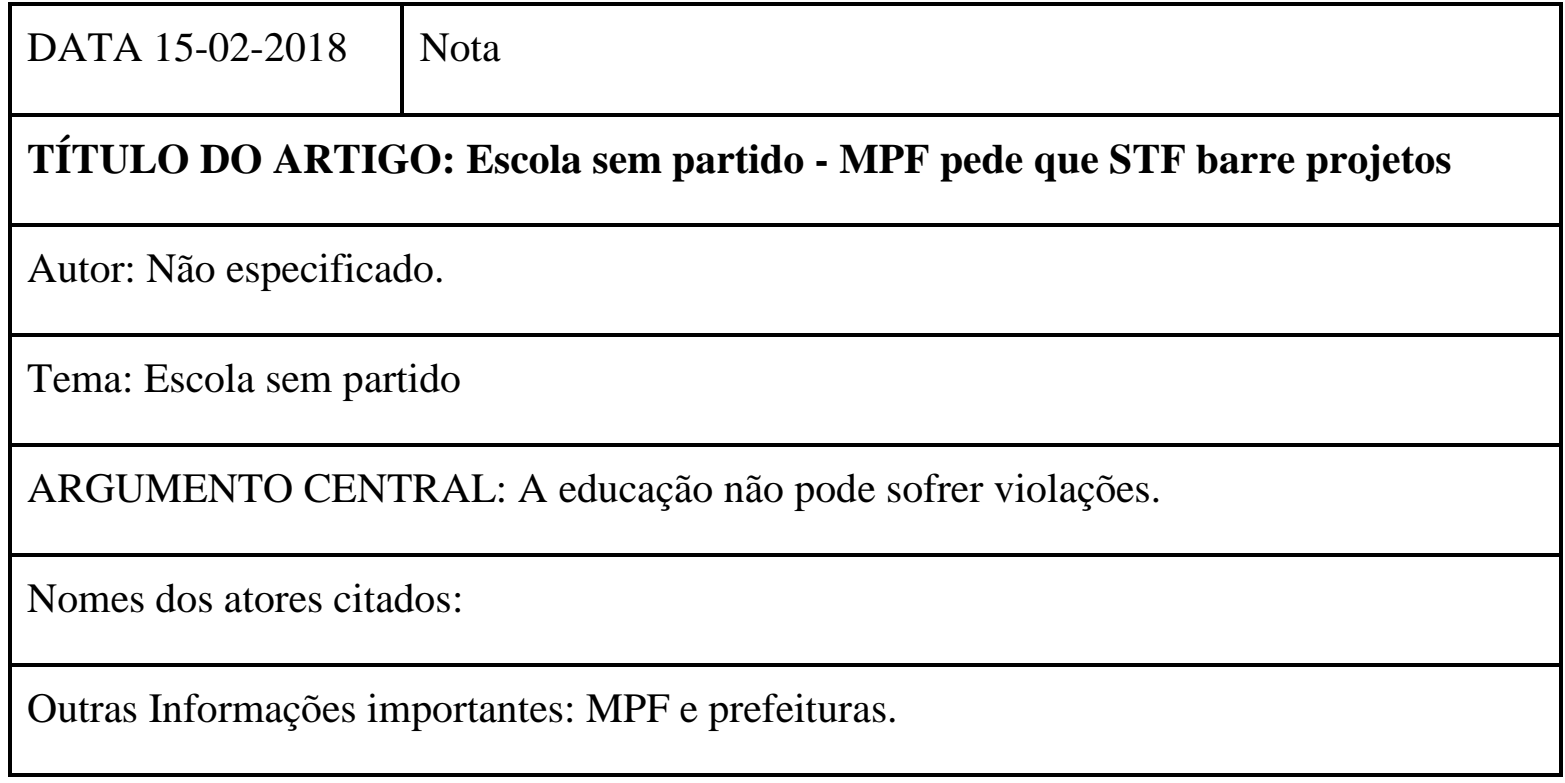


Resumo: O ministério Público Federal quer que o STF julgue a inconstitucionalidade de duas leis municipais - Criciúma (SC) e Ocauçu (SP) - sobre ensino de questões de gênero e da escola sem partido violar direito à educação.

15.

\begin{tabular}{|l|l|}
\hline DATA 22-02-2018 & Regional \\
\hline
\end{tabular}

\section{TÍTULO DO ARTIGO: Ideologia de gênero gera polêmica em Sobral}

Autor: Marcelino Júnior

Tema: Ideologia de gênero

ARGUMENTO CENTRAL: relato sobre votação acirrada na cidade sobre projeto de vereador que proíbe qualquer assunto relacionado à discussões de gênero nas escolas públicas e particulares do município

Nomes dos atores citados:

Outras Informações importantes:

Resumo: O assunto colocou, de um lado, católicos e evangélicos, do outro, ativistas do movimento LGBT e outras lideranças.

16.

DATA15-03-2018

TÍTULO DO ARTIGO: Deputada reclama de livro didático

Autor: Não especificado.

Tema: Ideologia de Gênero

ARGUMENTO CENTRAL:

Nomes dos atores citados: Dep. Silvana Oliveira (PMDB)

Outras Informações importantes: 
Resumo: A deputada Silvana Oliveira (PMDB) levou ontem à tribuna mais uma denúncia do que chamou de ideologia de gênero em escolas públicas do estado. Ela mostrou um livro didático que está sendo confeccionado para ser utilizado no município de Umirim abordando questões relacionadas à sexualidade. A parlamentar, que preside a comissão de Educação na Câmara de deputados, disse que vai acionar o MP e voltou a defender a instalação de uma frente parlamentar de fiscalização da ideologia de gênero no Ceará.

No ano passado, a deputada havia relatado casos semelhantes nos municípios de Cedro e Eusébio. "Professor, cumpra o seu papel, não fique calado, denuncie. Eu vou lá, exponho o prefeito, a prefeita, quem quer que seja o secretário de educação. Quem quiser enfrentar essa deputada, o voto da população na eleição. Ideologia de gênero nas escolas nós não aceitamos, nós somos a maioria". 


\section{APÊNDICE 2 - DADOS DO JORNAL O POVO}

1

\begin{tabular}{|c|c|}
\hline DATA 24/03/2016 & Politica \\
\hline \multicolumn{2}{|c|}{$\begin{array}{l}\text { TÍTULO DO ARTIGO: "Marxismo" e "censura LGBT": deputados saem contra } \\
\text { Plano de Educação }\end{array}$} \\
\hline \multicolumn{2}{|c|}{ Autor: CARLOS MAZZA } \\
\hline \multicolumn{2}{|c|}{$\begin{array}{l}\text { Tema: Políticos criticam o Plano Estadual de Educação, principalmente as questões de } \\
\text { gênero na educação. }\end{array}$} \\
\hline \multicolumn{2}{|c|}{ ARGUMENTO CENTRAL: } \\
\hline \multicolumn{2}{|c|}{$\begin{array}{l}\text { Nomes dos atores citados: Carlos Matos (PSDB), Ely Aguiar (PSDC), Dra Silvana } \\
\text { (PMDB), }\end{array}$} \\
\hline \multicolumn{2}{|c|}{ Outras Informações importantes: } \\
\hline $\begin{array}{l}\text { Resumo: } \\
\text { Formado principal } \\
\text { sobretudo trechos } \\
\text { sexual. Para Carlos } \\
\text { implantação do ma } \\
\text { questão de gêneros } \\
\text { católico Shalom. El } \\
\text { começa em casa, pe } \\
\text { tem questionado au } \\
\text { têm sido "direcior } \\
\text { Transexuais), com } \\
\text { "Precisamos de um } \\
\text { apenas um tenha o } \\
\text { índices da educação } \\
\text { qualquer espécie d } \\
\text { polêmica, a de nú } \\
\text { destacando ações pa }\end{array}$ & $\begin{array}{l}\text { nte por parlamentares da bancada evangélica, o grupo criticou } \\
\text { documento que preveem combate à discriminação por orientação } \\
\text { Iatos (PSDB), ação tem por trás "projeto de poder" da esquerda pela } \\
\text { smo. "Há um grande problema no plano, no ponto onde trata da } \\
\text { li está sendo implantada uma ideologia", diz Matos, ligado ao grupo } \\
\text { Aguiar (PSDC) também contesta: "Orientação sexual de uma criança } \\
\text { família, e não na escola".Já Dra Silvana (PMDB), pastora evangélica, } \\
\text { ncias da comissão que debate o PEE na Casa. Segundo ela, encontros } \\
\text { los ao público LGBT" (Lésbicas, Gays, Bissexuais, Travestis e } \\
\text { audiências voltadas para "outros públicos" sendo censuradas. } \\
\text { audiência que contemple todos os segmentos da sociedade e não que } \\
\text { ireito de se manifestar", diz. Com mais de } 20 \text { metas para melhorar } \\
\text { lo Ceará, o Plano Estadual de Educação não traz, em nenhum ponto, } \\
\text { liscussão sobre orientação sexual com crianças. Em sua meta mais } \\
\text { ro } 8 \text {, o plano trata da elevação da escolaridade média de alunos, } \\
\text { setores marginalizados ou vítimas de preconceito. Entre eles, estão o }\end{array}$ \\
\hline
\end{tabular}


de alunos LGBT. Sobre este ponto, são previstas "criação de políticas específicas para elevação da escolaridade" de LGBTs e a formação de professores e gestores capazes de lidar com temas de diversidade sexual, bem como questões "ambientais, étnico-raciais, de inclusão, musicais, de gênero e de educação sexual”. O PEE, no entanto, trata mais de questões específicas, como instituição de cursos preparatórios para o ENEM, erradicação do analfabetismo e melhora do desempenho em diversas disciplinas, como matemática. Ao contrário do que pregam boatos, não há "kit gay" ou qualquer distribuição de material sobre educação sexual para crianças.

3

\begin{tabular}{|l|l|}
\hline DATA 25/03/2016 & EDUCAÇÃO \\
\hline TÍTULO DO ARTIGO: Deputados saem contra Plano Estadual de Educação
\end{tabular}

Autor: Carlos Mazza

Tema: Plano Estadual de Educação

ARGUMENTO CENTRAL: Deputados contra a discussão de gênero no Plano Estadual de Educação

Nomes dos atores citados: Carlos Matos (PSDB), Ely Aguiar (PSDC), Dra Silvana (PMDB),

Resumo: [Deputados estaduais saíram nesta semana em críticas ao novo Plano Estadual de Educação (PEE), em discussão na Assembleia Legislativa. Formado principalmente por parlamentares da bancada evangélica, o grupo criticou sobretudo trechos do documento que preveem combate à discriminação por orientação sexual.

Para Carlos Matos (PSDB), ação tem por trás "projeto de poder" da esquerda pela implantação do marxismo. "Há um grande problema no plano, no ponto onde trata da questão de gêneros. Ali está sendo implantada uma ideologia”, diz Matos, ligado ao grupo católico Shalom. Ely Aguiar (PSDC) também contesta: “Orientação sexual de uma criança começa em casa, pela família”.

Dra Silvana (PMDB), pastora evangélica, tem questionado audiências da comissão que debate o PEE. Segundo ela, encontros têm sido "direcionados ao público LGBT" (Lésbicas, Gays, Bissexuais, Travestis e Transexuais), com censura a audiências voltadas para "outros 
públicos”.

O plano

Com mais de 20 metas para melhorar índices da educação no Ceará, o Plano Estadual de Educação não traz, em nenhum ponto, qualquer espécie de discussão sobre orientação sexual com crianças. Em sua meta mais polêmica, a de número 8, o plano trata da elevação da escolaridade média de alunos, destacando ações para setores marginalizados ou vítimas de preconceito.

Entre eles, estão o de alunos LGBT. Sobre este ponto, são previstas "criação de políticas específicas para elevação da escolaridade" de LGBTs e a formação de professores e gestores capazes de lidar com temas de diversidade sexual, bem como questões “ambientais, étnico-raciais, de inclusão, musicais, de gênero e de educação sexual”.

O PEE, no entanto, trata mais de questões específicas, como instituição de cursos preparatórios para o Enem, erradicação do analfabetismo e melhora do desempenho em diversas disciplinas.

4

\begin{tabular}{|l|l|}
\hline DATA 27/03/2016 & Brasil Educação \\
\hline
\end{tabular}

TÍTULO DO ARTIGO: Polêmica sobre questões de gênero pode deixar alunos do Recife sem livros

Autor: Agência Brasil

Tema: Conteúdos sobre a questão de gênero nos materiais didáticos

ARGUMENTO CENTRAL: Bancada cristã da Câmara de Vereadores de Recife tenta proibir uso de obras que citam questões de gênero e homossexualidade

Nomes dos atores citados: MEC, bancada cristã, Luiz Eustáquio (Rede) e Carlos Gueiros (PSB), deputado Joel da Harpa (PROS), Marta Beatriz (diretora de escola), professora Luci França,

Outras Informações importantes:

Resumo: Vereadores da bancada evangélica da cidade de Recife se manifestam contra os livros didáticos adotados pelas escolas da cidade sugeridos pelo Ministério da Educação por 
causa de conteúdos que desses livros. A matéria cita um trecho onde é citada a existência de famílias com pais de mesmo sexo, em outro ponto há uma ilustração de uma família com pais e uma menina branca e um menino negro, sugerindo uma família com adoção. Diretora e professoras foram consultadas e disseram que avaliaram o material didático, considerando os mesmos os melhores.

\begin{tabular}{|l|l}
\hline DATA 27/03/2016 & Educação
\end{tabular}

TÍTULO DO ARTIGO: Polêmica sobre questões de gênero pode deixar alunos do Recife sem livros

Autor: AGÊNCIA BRASIL

Tema: Bancada cristã da Câmara de Vereadores tenta proibir uso de obras que citam questões de gênero e homossexualidade.

ARGUMENTO CENTRAL:

Nomes dos atores citados:

Outras Informações importantes: Mesmo conteúdo do artigo anterior.

Resumo: Alunos da rede municipal do Recife podem ficar sem livros didáticos de várias disciplinas por três anos caso a bancada cristã da Câmara de Vereadores consiga proibir o uso de obras que citam questões de gênero e homossexualidade. Os parlamentares pediram à prefeitura a retirada dos livros distribuídos pelo Ministério da Educação (MEC) que tratam de diversidade sexual. O Executivo local defende o uso dos títulos e avisa que não arcará com a reposição caso as obras sejam realmente proibidas. Em nota, o MEC afirma que não há possibilidade de substituição dos exemplares. No centro do problema está um livro de ciências para alunos do $5^{\circ}$ ano do ensino fundamental, cuja idade regular é 10 anos. No capítulo sobre sexualidade do ser humano, o livro Juntos Nessa 5, da editora Leya, traz dois parágrafos contestados pelos vereadores. O livro destaca que "faz parte da sexualidade conhecer a si mesmo e aos outros, e os comportamentos que estão relacionados à identidade sexual”. A explicação vem em outra parte da mesma página - identidade sexual quer dizer "identificar-se com o sexo masculino 
ou com o sexo feminino".

Há ainda outro trecho que fala da união homoafetiva. "Entre os relacionamentos conjugais, existem casais formados por um homem e uma mulher e casais formados por pessoas do mesmo sexo". Ao lado da explicação, uma foto de família formada por mãe, pai, uma menina e um garotinho, o único negro do grupo. Os principais agentes da cruzada contra os livros didáticos são os vereadores Luiz Eustáquio (Rede) e Carlos Gueiros (PSB). Eustáquio chegou a levar um exemplar do Juntos Nessa 5 ao plenário da Câmara dos Vereadores para "mostrar o conteúdo ensinado em sala de aula".

“A questão de homofobia, essa questão de as pessoas terem de ser respeitadas como elas são, eu ensino isso aos meus filhos. É diferente da questão que está sendo ensinada no livro. Ela induz que você vai escolher se é masculino ou feminino, e é sobre isso que tenho plena discordância. E principalmente você ensinar questões de sexualidade para crianças a partir dos 6 anos aos 10 anos de idade. Eu acho que esse é um papel dos pais", afirma. Evangélico da Assembleia de Deus, o vereador é autor de dois requerimentos endereçados ao prefeito do Recife, Geraldo Júlio (PSB), sobre o tema. Um deles pede informações sobre todos os livros entregues às escolas municipais, incluindo quantidade e obras. A intenção, segundo ele, é criar uma frente parlamentar para analisar todas as obras e indicar quais podem ser usadas pela prefeitura. O segundo requerimento solicita a retirada de todo o material didático que contenha qualquer menção a gênero da rede de ensino. De acordo com o Ministério da Educação (MEC), foram distribuídos 623 livros do aluno e 23 manuais do professor do livro de ciências Juntos Nessa ( $5^{\circ}$ ano) para dez escolas da rede municipal do

Recife.

O vereador Carlos Gueiros também entrou na briga para proibir o uso do livro nas escolas. Autor do Projeto de Lei de n⿳ 26/2016, ele quer não só proibir o título como “outros meios definidos que versem sobre a ideologia de gênero e diversidade sexual". Iniciada na Câmara de Vereadores, a polêmica já tomou proporções estaduais. $\mathrm{Na}$ Assembleia Legislativa de Pernambuco (Alepe), o deputado Joel da Harpa (PROS), diácono da Igreja Batista, também apresentou projeto de lei pedindo a proibição dos livros. O PL 709/2016, publicado no Diário Oficial do estado no dia 8 de março, impede não só o uso do material didático como o ensino de qualquer tema semelhante. "Nós entendemos que o povo brasileiro, a grande maioria, não aceita a orientação da ideologia de gênero sobretudo nas escolas e principalmente no ensino fundamental. Vendo 
essa grande proporção de pernambucanos que não aceita a entrada da ideologia de gênero nos planos estaduais de educação, até porque o próprio plano na questão de gênero foi rejeita na Assembleia, então apresentamos essa proposta para que a ideologia fique de fora de uma vez por todas nas escolas", justifica. Joel da Harpa nega que seja homofóbico. "Não vejo dessa forma até porque eu acho que qualquer tipo de preconceito deva ser combatido. Seja relativo a cor, seja homossexual, qualquer tipo de preconceito", disse. "Se o cidadão resolveu ser homossexual é um direito que assiste a ele e nós devemos respeitar e abraçar e amar essas pessoas. $\mathrm{O}$ que a gente combate é a ideologia de gênero para as crianças nas escolas. O que eu acredito é que a ideologia de gênero é um incentivo à homossexualidade."

Diretora defende a escolha do livro Na rede de ensino do Recife, a Escola Municipal Abílio Gomes foi uma das que escolheu o Juntos Nessa 5 para as turmas de 50 ano do ensino fundamental. A instituição, que na avaliação do Índice de Desenvolvimento da Educação Básica (Ideb) de 2013 teve a nota mais alta entre as unidades municipais do Recife, fica na comunidade Entra Apulso, uma região pobre do bairro de Boa Viagem, zona sul da capital pernambucana. Com um exemplar nas mãos, a diretora Marta Beatriz de Araújo critica a versão dos parlamentares sobre conteúdo lo do livro. “O livro não estimula, não incita, simplesmente cita que existem casais formados por pessoas do mesmo sexo. Que se identificam com pessoas do mesmo sexo. Isso não é um estímulo à escolha, é a constatação de um fato que tem na sociedade. Nós, enquanto educadores, não podemos nos furtar do dever de ter na sala um espaço de discussão, e não estímulo. O aluno tem direito a ter esse espaço de discussão", defende Marta Beatriz, explicando que trata a questão pelo viés do combate ao preconceito e à homofobia. A gestora não é a única a discordar da intenção dos vereadores. Em uma das salas do $5^{\circ}$ ano, a professora Luci França pede licença à turma para receber a diretora. Enquanto as crianças fazem um exercício de um dos livros fornecidos pelo Ministério da Educação, Luci é rápida em dar a sua opinião ao saber da reportagem. “Hoje a preocupação maior em termo de educação seria justamente com essa geração de crianças com microcefalia. Fazer um projeto para preparar educadores para daqui a cinco anos receber essas crianças, e não se preocupar com questão de gênero. Porque aqui na escola o trabalho que a gente faz é de respeito às diferenças. Um papel de cidadania, e não de interferir na opção sexual, porque esse tipo de orientação cabe à família. A escola orienta 


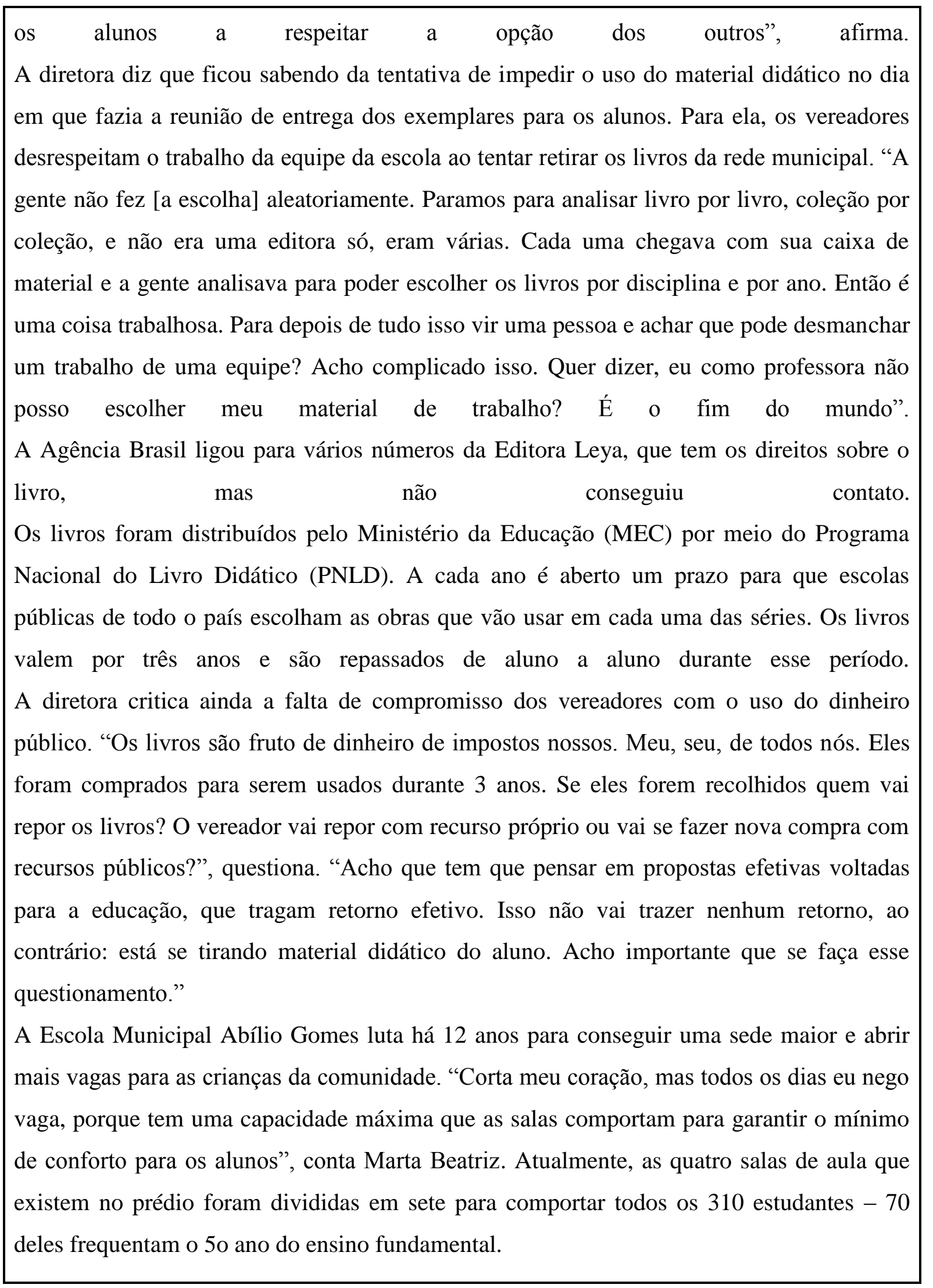

\begin{tabular}{|l|l|}
\hline DATA 28/03/2016 & Recife \\
\hline
\end{tabular}




\section{TÍTULO DO ARTIGO: Questões de gênero podem deixar alunos sem livros}

Autor: SUMAIA VILELA / AGÊNCIA BRASIL

Tema: Conflito dos vereadores envolvendo os livros didáticos.

ARGUMENTO CENTRAL: Vereadores da bancada cristã criticam trechos de livro didático que falam sobre união homoafetiva e identidade sexual

Nomes dos atores citados:

Outras Informações importantes: Mesmo conteúdo do artigo anterior

Resumo: Um dos pontos da polêmica é o trecho que cita que existem "casais formados por pessoas do mesmo sexo"

Alunos da rede municipal do Recife podem ficar sem livros didáticos de várias disciplinas por três anos caso a bancada cristã da Câmara de Vereadores consiga proibir o uso de obras que citam questões de gênero e homossexualidade. Os parlamentares pediram à prefeitura a retirada dos livros distribuídos pelo Ministério da Educação (MEC) que tratam de diversidade sexual. O Executivo local defende o uso dos títulos e avisa que não arcará com a reposição caso as obras sejam realmente proibidas. Em nota, o MEC afirma que não há possibilidade de substituição dos exemplares.

No centro do problema está um livro de ciências para alunos do $5^{\circ}$ ano do ensino fundamental, cuja idade regular é 10 anos. No capítulo sobre sexualidade do ser humano, o livro Juntos Nessa 5 (Ed. Leya) destaca que "faz parte da sexualidade conhecer a si mesmo e aos outros, e os comportamentos que estão relacionados à identidade sexual".

Há ainda outro trecho que fala da união homoafetiva. "Entre os relacionamentos conjugais, existem casais formados por um homem e uma mulher e casais formados por pessoas do mesmo sexo".

Os principais agentes da cruzada contra os livros didáticos são os vereadores Luiz Eustáquio (Rede) e Carlos Gueiros (PSB). Eustáquio chegou a levar um exemplar do Juntos Nessa 5 ao plenário da Câmara dos Vereadores para "mostrar o conteúdo ensinado em sala de aula".

“A questão de homofobia, essa questão de as pessoas terem de ser respeitadas como elas são, eu ensino isso aos meus filhos. É diferente da questão que está sendo ensinada no livro. Ela induz que você vai escolher se é masculino ou feminino, e é sobre isso que tenho plena discordância”, afirma. 
Evangélico da Assembleia de Deus, o vereador é autor de dois requerimentos endereçados ao prefeito do Recife, Geraldo Júlio (PSB), sobre o tema. Um deles pede informações sobre todos os livros entregues às escolas municipais, incluindo quantidade e obras. A intenção, segundo ele, é criar uma frente parlamentar para analisar todas as obras e indicar quais podem ser usadas pela prefeitura. O segundo requerimento solicita a retirada de todo o material didático que contenha qualquer menção a gênero da rede de ensino.

O vereador Carlos Gueiros também entrou na briga para proibir o uso do livro nas escolas. Autor do Projeto de Lei de $n^{\circ}$ 26/2016, ele quer não só proibir o título como “outros meios definidos que versem sobre a ideologia de gênero e diversidade sexual".

Iniciada na Câmara de Vereadores, a polêmica já tomou proporções estaduais. $\mathrm{Na}$ Assembleia Legislativa de Pernambuco (Alepe), o deputado Joel da Harpa (PROS), diácono da Igreja Batista, também apresentou projeto de lei pedindo a proibição dos livros. O PL 709/2016, publicado no Diário Oficial do estado no dia 8 de março, impede não só o uso do material didático como o ensino de qualquer tema semelhante.

7

\begin{tabular}{|c|c|}
\hline DATA 28/04/2016 & Política \\
\hline \multicolumn{2}{|c|}{$\begin{array}{l}\text { TÍTULO DO ARTIGO: Plano de Educação tem urgência aprovada e será votado em } \\
\text { até uma semana }\end{array}$} \\
\hline \multicolumn{2}{|c|}{ Autor: Redação O POVO Online } \\
\hline \multicolumn{2}{|c|}{$\begin{array}{l}\text { Tema: Deputados da bancada evangélica, como Dra. Silvana (PMDB), têm questionado o } \\
\text { projeto do governo }\end{array}$} \\
\hline \multicolumn{2}{|c|}{ ARGUMENTO CENTRAL: } \\
\hline \multicolumn{2}{|c|}{ Nomes dos atores citados: } \\
\hline \multicolumn{2}{|c|}{ Outras Informações importantes: Ainda o mesmo conteúdo. } \\
\hline $\begin{array}{l}\text { Resumo: Projeto po } \\
\text { urgência aprovado } 1 \\
\text { proposta terá de ser } \\
\text { do governo, Evandr }\end{array}$ & $\begin{array}{l}\text { nico, o novo Plano Estadual de Educação do Ceará teve regime de } \\
\text { ta quinta-feira, 28, pela Assembleia Legislativa. Com a medida, a } \\
\text { tada pela Casa até a próxima semana. A urgência, pedida pelo líder } \\
\text { eitão (PDT), provocou embates na sessão desta quinta no }\end{array}$ \\
\hline
\end{tabular}


Legislativo.

Segundo deputados da oposição, a medida inclui pontos que ainda precisam de mais debate no parlamento. Já o governo argumenta que, caso o projeto não seja votado nos próximos dias, o governo pode perder convênios e recursos federais.

O documento é criticado sobretudo por membros da bancada evangélica, que contestam trechos que preveem o combate à discriminação por orientação sexual. A oposição apresentou diversos requerimentos removendo qualquer menção a termos do tipo. Para Carlos Matos (PSDB), ação tem por trás “projeto de poder" da esquerda pela implantação do marxismo.

“Ali está sendo implantada uma ideologia”, diz o deputado. Dra Silvana (PMDB), pastora evangélica, tem questionado audiências da comissão que debate o PEE. Segundo ela, encontros têm sido "direcionados ao público LGBT" (Lésbicas, Gays, Bissexuais, Travestis e Transexuais), com censura a audiências voltadas para "outros públicos".

O plano

Com mais de 20 metas para melhorar índices da educação no Ceará, o Plano Estadual de Educação não traz, em nenhum ponto, qualquer espécie de discussão sobre orientação sexual com crianças. Em sua meta mais polêmica, a de número 8, o plano trata da elevação da escolaridade média de alunos, destacando ações para setores marginalizados ou vítimas de preconceito.

Entre eles, estão o de alunos LGBT. Sobre este ponto, são previstas “criação de políticas específicas para elevação da escolaridade" de LGBTs e a formação de professores e gestores capazes de lidar com temas de diversidade sexual, bem como questões "ambientais, étnico-raciais, de inclusão, musicais, de gênero e de educação sexual". O Plano, no entanto, trata mais de questões específicas, como instituição de cursos preparatórios para o Enem, erradicação do analfabetismo e melhora do desempenho em diversas disciplinas.

\begin{tabular}{|l|l|}
\hline DATA 28/04/2016 & Política \\
\hline
\end{tabular}

TÍTULO DO ARTIGO: Plano de Educação tem urgência aprovada e será votado em até uma semana

Autor: Redação O POVO Online 
Tema: O documento é criticado sobretudo por membros da bancada evangélica, que contestam trechos que preveem o combate à discriminação por orientação sexual

ARGUMENTO CENTRAL:

Nomes dos atores citados:

Outras Informações importantes:

Resumo: Projeto polêmico, o novo Plano Estadual de Educação do Ceará teve regime de urgência aprovado nesta quinta-feira, 28, pela Assembleia Legislativa. Com a medida, a proposta terá de ser votada pela Casa até a próxima semana. A urgência, pedida pelo líder do governo, Evandro Leitão (PDT), provocou embates na sessão desta quinta no Legislativo. Segundo deputados da oposição, a medida inclui pontos que ainda precisam de mais debate no parlamento. Já o governo argumenta que, caso o projeto não seja votado nos próximos dias, o governo pode perder convênios e recursos federais.O documento é criticado sobretudo por membros da bancada evangélica, que contestam trechos que preveem o combate à discriminação por orientação sexual. A oposição apresentou diversos requerimentos removendo qualquer menção a termos do tipo. Para Carlos Matos (PSDB), ação tem por trás "projeto de poder" da esquerda pela implantação do marxismo.

[SAIBAMAIS 3]“Ali está sendo implantada uma ideologia”, diz o deputado. Dra Silvana (PMDB), pastora evangélica, tem questionado audiências da comissão que debate o PEE. Segundo ela, encontros têm sido "direcionados ao público LGBT" (Lésbicas, Gays, Bissexuais, Travestis e Transexuais), com censura a audiências voltadas para "outros públicos".

O plano

Com mais de 20 metas para melhorar índices da educação no Ceará, o Plano Estadual de Educação não traz, em nenhum ponto, qualquer espécie de discussão sobre orientação sexual com crianças. Em sua meta mais polêmica, a de número 8, o plano trata da elevação da escolaridade média de alunos, destacando ações para setores marginalizados ou vítimas de preconceito.Entre eles, estão o de alunos LGBT. Sobre este ponto, são previstas "criação de políticas específicas para elevação da escolaridade" de LGBTs e a formação de professores e gestores capazes de lidar com temas de diversidade sexual, bem como questões "ambientais, étnico-raciais, de inclusão, musicais, de gênero e de educação sexual".O Plano, no entanto, trata mais de questões específicas, como instituição de cursos preparatórios para o Enem, erradicação do analfabetismo e melhora do desempenho em 
diversas disciplinas.

9

\begin{tabular}{|l|l|}
\hline DATA 28/04/2016 & Política \\
\hline TÍTULO DO ARTIGO: Silas Malafaia pede a Temer 'cuidado' na escolha do ministro \\
da Educação
\end{tabular}

10

\begin{tabular}{|l|l|}
\hline DATA 30/04/2016 & ARTIGO \\
\hline TÍTULO DO ARTIGO: Escola livre é escola sem mordaça \\
\hline Autor: Carlos Mazza \\
\hline Tema: Opinião sobre os debates de gênero na escola. \\
\hline ARGUMENTO CENTRAL: \\
\hline
\end{tabular}


Nomes dos atores citados: Renan Filho, Ricardo Nezinho (PMDB), Jair Bolsonaro, Dra Silvana,

Outras Informações importantes:

Resumo: Em março de 1925, o pacato Tennessee, sudeste dos EUA, passou a polêmica "lei Butler", que proibia o ensino da teoria da evolução nas escolas do Estado. Para os deputados, qualquer interpretação da origem da vida estranha aos escritos bíblicos não era ciência, mas “opinião". Pego cometendo o crime de repassar ensinamentos de Charles Darwin para crianças, o professor substituto John Scopes foi preso e submetido à Justiça,em embaraçoso episódio que ficou conhecido como o "julgamento do macaco de Scopes". Em abril de 2016, o Brasil reeditou sua própria versão da Lei Butler, no não tão pacato Alagoas - hoje o Estado com as maiores taxas de homicídios do País. Na última terça-feira, a Assembleia alagoana derrubou veto do governador Renan Filho ao projeto "Escola Livre". Prevaleceu texto do deputado Ricardo Nezinho (PMDB), que proíbe professores de dar opinião em sala de aula e exige "neutralidade".

No Ceará, a "Lei Nezinho" também tem sua versão por meio do projeto "Escola sem Partido", da deputada Dra. Silvana (PMDB), ainda em tramitação. Segundo ela, "é notório" que professores têm utilizado do ambiente escolar para doutrinar jovens. Ela destaca especialmente a "ideologia de gênero" - termo usado para classificar tese que defende a educação inclusiva de jovens LGBTs. Outros apoiadores de leis do tipo se arvoram na denúncia de doutrinação "marxista" e de "esquerda" nas escolas.

Teorias da conspiração de lado, uma coisa é certa: se existe doutrinação marxista nas escolas, ou ela tem organizadores extremamente incompetentes ou tem falhado miseravelmente. De 50 anos para cá, a “opinião geral” brasileira permanece um dos aspectos mais estáveis e permanentes de nossa sociedade.

Não é surpresa, portanto, que um dos políticos mais conservadores do País, Jair Bolsonaro(PSC-RJ), tenha virado febre entre mais jovens, com montagens cômicas do "Bolsomito" aparecendo aos montes. Assim, sob o pretexto de garantir a liberdade, se institui uma mordaça que impede o debate e cria uma norma jurídica insustentável. A julgar pela tese de alguns parlamentares, veremos preso um professor que defender em classe que um homossexual é um ser humano que não merece ser discriminado? No fim das contas, é a história que separará, mais uma vez, quem é Scopes e quem é Butler.

11. 


\begin{tabular}{|c|c|}
\hline DATA 03/05/2016 & ANTI-DISCRIMINAÇÃO \\
\hline \multicolumn{2}{|c|}{$\begin{array}{l}\text { TÍTULO DO ARTIGO: "Somos sociedade cristã", diz deputada por alteração no } \\
\text { Plano de Educação }\end{array}$} \\
\hline \multicolumn{2}{|l|}{ Autor: Carlos Maza } \\
\hline \multicolumn{2}{|c|}{$\begin{array}{l}\text { Tema: Dra Silvana quer remover termos "LGBT", "gênero" e "diversidade" do Plano de } \\
\text { Educação, em votação na Assembleia. Pontos visam combater o preconceito }\end{array}$} \\
\hline \multicolumn{2}{|c|}{$\begin{array}{l}\text { Nomes dos atores citados: Dra. Silvana (PMDB), Carlos Matos (PSDB), Ely Aguiar } \\
\text { (PSDC) }\end{array}$} \\
\hline \multicolumn{2}{|c|}{$\begin{array}{l}\text { Outras Informações importantes: Matéria publicada na versão online e impressa. Aparece } \\
\text { duas vezes na pesquisa. }\end{array}$} \\
\hline \multirow{3}{*}{\multicolumn{2}{|c|}{$\begin{array}{l}\text { Resumo: Segundo deputada, estimular o combate contra o preconceito é "doutrinação" de } \\
\text { gênero } \\
\text { A deputada Dra. Silvana (PMDB) voltou a defender nesta terça-feira, 3, a remoção dos } \\
\text { termos "LGBT”, "gênero" e“diversidade" do Plano Estadual de Educação do Ceará. O } \\
\text { projeto, que inclui entre seus pontos o combate à discriminação em escolas, deve ser votado } \\
\text { ainda nesta semana pela Assembleia Legislativa. "Somos uma sociedade cristã por maioria } \\
\text { e estamos em um estado laico. Logo, não podemos doutrinar as nossas crianças na sala de } \\
\text { aula", diz Silvana, pastora evangélica. Ela apresentou diversas emendas retirando os termos } \\
\text { da proposta. Carlos Matos (PSDB) já afirmou que trechos buscam implantar ideologia do } \\
\text { "marxismo" no Brasil. }\end{array}$}} \\
\hline & \\
\hline & \\
\hline \multicolumn{2}{|c|}{$\begin{array}{l}\text { Ely Aguiar (PSDC) destacou que fez emenda solicitando que a "ideologia de gênero" não } \\
\text { seja abordada para alunos menores de } 12 \text { anos. "Esse PT é um partido das trevas, querendo } \\
\text { levar para as crianças ideias anormais. O líder do Governo na Casa deve liberar a bancada", } \\
\text { assinalou o deputado, apresentador de programas policiais. }\end{array}$} \\
\hline
\end{tabular}

12

\begin{tabular}{|l|l|}
\hline DATA 05/05/2016 & Política \\
\hline
\end{tabular}

TÍTULO DO ARTIGO: Deputados votam hoje Plano de Educação e incentivos

Autor: 
Tema: O texto do Plano Estadual de Educação que vai a debate não contém trechos sobre orientação sexual que causaram polêmica entre deputados. Assembleia também vota incentivos fiscais para instalação de termelétricas

\section{ARGUMENTO CENTRAL:}

Nomes dos atores citados:

Outras Informações importantes:

Resumo: Elmano de Freitas é relator do projeto do Plano Estadual de Educação. Segundo ele, plano será aprovado com tranquilidade. Deputados votam hoje na Assembleia Legislativa do Ceará dois projetos polêmicos: o Plano Estadual de Educação (PEE) e o de incentivo fiscal à instalação de usinas termelétricas de gás natural no Ceará. Envolto em controvérsias desde o início de sua tramitação na Casa, ainda no ano passado, o PEE obteve consenso e deve ser aprovado com tranquilidade, segundo Elmano de Freitas (PT), relator do projeto. De acordo com o petista, o documento aprovado pela comissão é "resultado da média da casa". "Não é unanimidade, mas é um pouco da posição de cada um dos parlamentares. Nenhuma emenda ficou prejudicada", disse.

Com 188 emendas, a negociação feita entre 15 deputados suprimiu "qualquer menção com base na denominada "ideologia do gênero"”, afirmou Elmano, referindo-se ao trecho que havia causado discussão entre parlamentares cearenses. $\mathrm{O}$ deputado estadual Carlos Matos (PSDB), um dos principais críticos da inclusão de orientações de gênero nas escolas do Estado, também avalia o resultado com satisfação. Ele acredita que o projeto será aprovado. (...) "Foram 188 emendas -132 dessas, adaptadas; 18 pareceres contrários. Negociamos a retirada de 37 emendas. Restam para o Plenário três emendas, no máximo”, diz Elmano de Freitas, relator do Plano Estadual de Educação.

13

\begin{tabular}{|l|l|}
\hline DATA $13 / 05 / 2016$ & Online
\end{tabular}

TÍTULO DO ARTIGO: CONFRONTO DAS IDEIAS

Autor:

Tema: De acordo com o projeto de lei Escola Livre, do deputado Ricardo Nezinho (PMDB- 
AL), os professores não podem induzir os alunos em assuntos políticos, religiosos e ideológicos em sala de aula. A iniciativa ajudará a atingir a neutralidade do professor na escola?

Nomes dos atores citados: Airton de Almeida Oliveira, Presidente do Sindicato dos Estabelecimentos de Ensino da Educação da Livre Iniciativa do Estado do Ceará (SinepeCE); Julianne Melo, Assessora jurídica do Centro de Defesa da Criança e do Adolescente (Cedeca) Ceará.

Outras Informações importantes:

Resumo: O texto é a compilação de duas opiniões, uma contrária e outra a favor do Plano Estadual de Educação de Alagoas.

14

\begin{tabular}{|c|c|}
\hline DATA 18/05/2016 & Online política \\
\hline \multicolumn{2}{|c|}{$\begin{array}{l}\text { TÍTULO DO ARTIGO: Feliciano grava vídeo provocando artistas que criticam o fim } \\
\text { do MinC }\end{array}$} \\
\hline \multicolumn{2}{|c|}{$\begin{array}{l}\text { Tema: "Vocês estão tristes com o fim do ministério da Cultura? Procurem o ministério do } \\
\text { Trabalho", afirma o parlamentar }\end{array}$} \\
\hline \multicolumn{2}{|c|}{ Nomes dos atores citados: Marcos Feliciano (PSC/SP) } \\
\hline $\begin{array}{l}\text { Resumo: O deputad } \\
\text { publicado no Youtu } \\
\text { Ministério da Cultur } \\
\text { Temer (PMDB), ao } \\
\text { da Cultura? Procure } \\
\text { Feliciano que acreso } \\
\text { ali há décadas como } \\
\text { sobre a possibilidad } \\
\text { parlamentar fala tam }\end{array}$ & $\begin{array}{l}\text { Marcos Feliciano (PSC/SP) mandou um recado, em um vídeo } \\
\text { aos artistas que estão se mobilizando e criticando o fim do } \\
\text { (MinC), que foi integrado pelo presidente em exercício, Michel } \\
\text { inistério da Educação. "Vocês estão tristes com o fim do Ministério } \\
\text { o Ministério do Trabalho. Vão arrumar o que fazer", ressalta } \\
\text { ta: "Os ministros devem ter força para encarar funcionários que estão } \\
\text { ivistas pagos", afirma. Na gravação, Feliciano faz algumas alertas } \\
\text { o governo de se tornar "refém de "grupos criados pelo PT". O } \\
\text { Em sobre perigos da "Ideologia de gênero pregada pelo PT". }\end{array}$ \\
\hline
\end{tabular}

15. 
DATA 29/05/2016

TÍTULO DO ARTIGO: CONFRONTO DE IDEIAS

Autor:

Tema:

ARGUMENTO CENTRAL:

Nomes dos atores citados: David Durand, Deputado estadual (PRB);

Outras Informações importantes:

Resumo: No Plano Estadual de Educação, foi recusada a educação sexual nas escolas.

Promover a discussão de gênero é uma obrigação que cabe só às famílias?

David Durandm Deputado estadual (PRB)

Sim

Inicialmente é importante esclarecer que não existiu discussão sobre educação sexual nas escolas.

Com relação à polêmica ocorrida no plenário, na data de votação, esclareço que girou em torno da permissão ou não de "nome social" nos registros e documentos escolares.

Diante dessas considerações, aproveito para esclarecer nosso posicionamento sobre a abordagem da "ideologia de gênero" no ambiente escolar e o papel da família no processo educacional.

A família possui importante papel constitucional e a ela são atribuídos direitos e deveres acerca da educação de seus filhos. Diante dessa "regra", é necessário respeitar os valores familiares, de uma forma geral, pois estes são diversos nas famílias brasileiras.

Entendemos, também, que a educação vai além do ensino escolar, ou seja, o conhecimento do ponto de vista técnico. Dessa forma, as escolas ao desempenharem sua missão não podem exercer ações que afrontem a educação familiar de seus alunos. A escola cabe garantir que os seus alunos recebam formação curricular determinada pelo Ministério da Educação, e garantir um ambiente cívico e respeitoso com todos.

A tratativa ou ensino acerca do tema "ideologia de gênero" não cabe à escola, pois, dentre outros motivos, não contempla para fins de ensinamento ou discussão, em ambiente escolar, a educação de forma pacificada, na sociedade atual.

Vale destacar que o Plano Nacional de Educação não autoriza nos próximos 10 anos a 
discussão nas escolas de questões relacionadas à "ideologia de gênero".

Em suma, a família é a única instituição responsável e competente para tratar de assuntos que estejam sob a óptica moral, que é diversificada. Portanto, "gênero" é assunto de trato exclusivamente familiar, respeitada obviamente as diversas concepções.

Augusta Brito Deputada estadual (PCdoB)

Não

Entendo que as famílias são essenciais na educação sexual dos jovens e contemplar a discussão de gênero e educação sexual nas escolas não tira a responsabilidade das famílias. Pelo contrário, reforça. A escola tem que ser o espaço de aprendizagem que os jovens vão trazer os ensinamentos das suas famílias e vão ampliar.Por isso, a escola tem que estar cada vez mais preparada para acolher e trabalhar com as diferenças.

Eu sou enfermeira e, como profissional, é importante salientar que as doenças sexualmente transmissíveis estão atingindo cada vez mais cedo a juventude e isso ocorre porque não está havendo esse debate nem nas famílias nem na escola. Agora, o Plano Estadual rejeitou a educação sexual nas escolas sem elaborar uma construção de como os temas seriam abordados para contemplar a sociedade cearense.

As escolas já abordam reprodução humana e métodos contraceptivos, mas poderiam aprofundar esses e outros assuntos a partir da realidade dos nossos jovens. É necessário falar sobre a vida sexual que se inicia cada vez mais cedo, sobre planejamento familiar, trazer dados sobre DST para informar a juventude que, sem prevenção, pode contrair doenças sérias, não só pra eles mas para seus futuros filhos. A educação sexual não é nem pode ser tratada como um tabu. Ela tem que ser compreendida como uma política conjunta de educação e de saúde pública para a juventude.

É preciso formarmos jovens conscientes com o presente e o futuro, capazes de, por meio da informação que receberam na escola, erradicar as DSTs e deixá-las no passado.

O Estado brasileiro tem que priorizar esses debates para que a população das próximas décadas agradeça pelas vidas mais saudáveis dos adultos e das novas gerações.

DATA 31/07/2016

TíTULO DO ARTIGO: Projetos de lei. Educação sem ideologia?

Autor: 
Tema: Nascido em 2004, o movimento Escola Sem Partido ganhou força nos últimos dois anos. Com projetos de lei espalhados no Brasil, o papel da educação entra no embate de um País ideologicamente polarizado

\section{ARGUMENTO CENTRAL:}

Nomes dos atores citados:

Outras Informações importantes:

Resumo: Uma palavra está no centro da discussão sobre a educação brasileira: doutrinação — o ato de ensinar os princípios de uma crença, sistema ou ciência. Há 12 anos, a defesa do programa Escola Sem Partido é evitar que ela aconteça e impeça a pluralidade de ideias. O movimento ganha corpo em projetos de lei no Brasil. E o conceito e as implicações da proposta são questionados e suscitam uma diversidade de opiniões conflitantes.

O programa tramita em projetos de lei no Senado e na Câmara. Em pelo menos dez estados, incluindo o Ceará, há propostas do mesmo teor nas assembleias legislativas. Os textos traçam deveres dos professores na educação básica da rede pública. Entre eles, não promover em sala de aula os próprios interesses e concepções ideológicas, religiosas, morais, políticas e partidárias.

O movimento quer que sejam cumpridos pelos docentes deveres que já existem, segundo o advogado Miguel Nagib, coordenador da iniciativa nascida em 2004. Naquele ano, houve experiência que ele considerou negativa na escola da filha: um professor de história falou de Che Guevara e São Francisco de Assis como duas pessoas que abriram mão de tudo pela ideologia. Desde então, Nagib coleta depoimentos de alunos, pais e professores, argumentando que a doutrinação ideológica existe e é ilegal. Para Nagib, há um desequilíbrio quando o professor se aproveita da posição de autoridade e da audiência cativa dos alunos.

É como se o professor tivesse absoluta capacidade de sedução e convencimento, ironiza o educador Idevaldo Bodião, aposentado pela Universidade Federal do Ceará (UFC). Para ele, seria necessário um esforço de orquestração para transmitir os mesmos valores.

Conforme Bodião, é importante observar o contexto em que o projeto ganhou força. $\mathrm{O}$ professor aponta um retrocesso rápido e violento no Brasil desde 2014, com o avanço de pautas conservadoras. Um dos exemplos é a retirada do termo "gênero" do Plano Nacional de Educação, no Congresso, em 2015. Ainda segundo o professor, esta trincheira já surgiu nacionalmente articulada, com o mesmo resultado nos planos estaduais e municipais. Os 
versões, teorias, opiniões e perspectivas concorrentes a respeito da matéria.

5. O professor respeitará o direito dos pais a que seus filhos recebam a educação religiosa e moral que esteja de acordo com suas próprias convicções.

6. O professor não permitirá que os direitos assegurados nos itens anteriores sejam violados pela ação de estudantes ou terceiros dentro da sala de aula."

21

\begin{tabular}{|l|l|}
\hline DATA 05/09/2016 & Opinião \\
\hline
\end{tabular}

TÍTULO DO ARTIGO: Escola Livre ou Terceira Margem

Autor: Saraiva Júnior, Auditor fiscal do Trabalho

Tema: Escola sem Partido

ARGUMENTO CENTRAL:

Nomes dos atores citados:

Outras Informações importantes:

Resumo: EDUCAÇÃO

Quem quiser estudar uma árvore específica, faz-se necessário estudá-la em seu habitat, a

floresta. Para compreender o funcionamento de algum órgão humano, é fundamental entendê-lo integrado ao sistema do corpo. As mudanças climáticas no planeta estão relacionadas a vários acontecimentos, como o repentino aquecimento de uma corrente marítima no oceano Pacífico e as queimadas da vegetação do semiárido no Nordeste brasileiro. Tudo se conecta. A concepção do conhecimento enquanto ilha há muito perdeu sentido. Pensemos num arquipélago.

O conceito de "Escola Sem Partido" pretende fazer do ensino uma ilha, como se o conhecimento técnico fosse a supremacia a ser alcançada pelos jovens alunos.

Ou seja, o estudante precisa saber matemática e não deve se interessar em relacionar essa matéria a questões de cunho antropológico ou mesmo artístico.

Por trás dessa cortina de fumaça, querem tirar dos jovens o direito de questionar, de duvidar e, principalmente, de criticar. A quem interessa tal retrocesso no ensino do País?

Existe uma pressão conservadora organizada que visa acabar com os investimentos nas 
pesquisas científicas das universidades públicas. A verdadeira intenção é enfraquecê-la para, em seguida, privatizá-la. Depreende-se que cursos como Letras, História, Ciências Sociais, Artes e Filosofia, dentre outros, que fazem os estudantes pensarem criticamente a realidade tenderão a ser extintos do ensino público.

O encontro com o outro, com o diferente, com o desconhecido, é a célula que move o conhecimento e, por conseguinte, a democracia. Alargar essa questão é viver a pulsão da pluralidade social. Daí porque é impossível apagar a dialética do sistema cognitivo da história do gênero humano. É intrínseco que o outro traz em sua bagagem crenças, ideologias, valores e práticas que enriquecem nossos saberes e nossas experiências. O importante é estar aberto e livre para o debate de ideias. A juventude, no ardor do conhecimento, necessita do conhecimento dos opostos para avançar com inteligência os caminhos. Nesse caso, todos precisam conhecer Karl Marx e Adam Smith, Agostinho de Hipona e Martinho Lutero, Lênin e Hitler, Leonardo Boff e Plínio Salgado, Eduardo Suplicy e Eduardo Cunha. É imperativo conhecer os vários ângulos de uma paisagem em que estamos inseridos, bem como a terceira margem do rio.

25

\begin{tabular}{|c|c|}
\hline DATA $15 / 10 / 2016$ & Educação \\
\hline \multicolumn{2}{|c|}{$\begin{array}{l}\text { TÍTULO DO ARTIGO: Movimento Escola sem Partido ganha força no país, mas } \\
\text { divide professores }\end{array}$} \\
\hline \multicolumn{2}{|c|}{ Autor: Elza Fiuza/Agência Brasil } \\
\hline \multicolumn{2}{|c|}{$\begin{array}{l}\text { Tema: Para alguns professores, Escola sem Partido aumenta insegurança sobre como } \\
\text { trabalhar em sala de aula. Para outros, as escolas não devem funcionar como centro de } \\
\text { doutrinação }\end{array}$} \\
\hline \multicolumn{2}{|c|}{ ARGUMENTO CENTRAL: } \\
\hline \multicolumn{2}{|c|}{ Nomes dos atores citados: } \\
\hline \multicolumn{2}{|c|}{ Outras Informações importantes: } \\
\hline \multicolumn{2}{|l|}{ Resumo: } \\
\hline Com o processo de & peachment da ex-presidente Dilma Rousseff e um país dividido \\
\hline
\end{tabular}


politicamente - como ficou claro nas urnas em 2014 - o movimento Escola sem Partido ganha força no país, sob o discurso de que professores não podem transmitir aos estudantes nenhum tipo de posicionamento, seja político, ideológico ou religioso. As ideias do movimento transformaram-se em projetos de lei em tramitação no Congresso Nacional, estados e municípios.(...) O movimento Escola sem Partido foi fundado em 2004 pelo procurador de Justiça de São Paulo, Miguel Nagib. Em 2014, ganhou força quando transformou-se no Projeto de Lei 2974/2014, apresentado na Assembleia Legislativa Estadual do Rio de Janeiro (Alerj). O movimento disponibilizou, então, dois modelos de projetos de lei, estadual e municipal. Em âmbito nacional, projetos semelhantes tramitam tanto na Câmara dos Deputados - Projeto de Lei (PL) 867/2015, de autoria do deputado Izalci Lucas (PSDB-DF) - quanto no Senado Federal - Projeto de Lei do Senado (PLS) 193/2016, de autoria do senador Magno Malta (PR-ES). Em consulta pública aberta no site do Senado Federal, uma maioria manifesta-se contra o projeto de lei, por uma pequena diferença. Ao todo, até sexta-feira (14), 183.604 (48,1\%) eram favoráveis, enquanto $197.765(51,9 \%)$ eram contrários.

26

DATA $28 / 10 / 2016$

TÍTULO DO ARTIGO: Candidato do PRB mantém vantagem no Rio

Autor: O Estado de S. Paulo.

Tema: Campanha eleitoral para prefeitura da cidade do Rio de Janeiro

ARGUMENTO CENTRAL:

Nomes dos atores citados:

Outras Informações importantes:

Resumo: O candidato do PRB à prefeitura do Rio, Marcelo Crivella, mantém-se em primeiro lugar nas intenções de voto na disputa do próximo domingo, segundo nova pesquisa divulgada ontem pelo Ibope. Crivella tem 46\%, contra 29\% de Marcelo Freixo (PSOL), mesmos índices do levantamento realizado na semana passada.

Crivella tem contra-atacado acusando o adversário de querer implantar nas escolas a 
chamada ideologia de gênero. Também tem acusado a revista Veja e os veículos de comunicação das Organizações Globo de tentarem interferir na disputa eleitoral com mentiras que o prejudicam.

28

\begin{tabular}{|c|c|}
\hline DATA 21/03/2017 & Jornal impresso \\
\hline \multicolumn{2}{|c|}{ TÍTULO DO ARTIGO: Emanuel Freitas: A verdadeira "ideologia de gênero" } \\
\hline \multicolumn{2}{|c|}{$\begin{array}{l}\text { Autor: Emanuel Freitas, Professor de Teoria Política da Universidade Estadual do Ceará } \\
\text { (Uece) }\end{array}$} \\
\hline \multicolumn{2}{|l|}{ Tema: } \\
\hline \multicolumn{2}{|c|}{ ARGUMENTO CENTRAL: } \\
\hline \multicolumn{2}{|c|}{ Nomes dos atores citados: } \\
\hline \multicolumn{2}{|c|}{ Outras Informações importantes: } \\
\hline \multicolumn{2}{|c|}{$\begin{array}{l}\text { Resumo: O brutal espancamento, seguido de morte, de Dandara, bem como a violência } \\
\text { desferida contra Herica, semanas depois, na avenida José Bastos (ambas pessoas trans) são } \\
\text { fatos mais do que oportunos para nos fazerem recuar um pouco no tempo e pensar melhor } \\
\text { sobre o porquê da violência contra pessoas trans ainda ser tão legitimada ou, ao menos, } \\
\text { pouco "choradas". }\end{array}$} \\
\hline \multicolumn{2}{|c|}{ No ano de 2015, assistimos a uma verdadeira "cruzada nacional" em todos os espaços do } \\
\hline \multirow{2}{*}{\multicolumn{2}{|c|}{$\begin{array}{l}\text { Poder Legislativo por parte de parlamentares ligados às diversas instituições religiosas, para } \\
\text { retirarem dos Planos Estaduais e Municipais de Educação qualquer referência às questões } \\
\text { de gênero. Seus discursos, de Norte a Sul do País, diziam o mesmo: queriam transformar as } \\
\text { escolas em espaços de "destruição da família", a ensinar "as crianças a serem gays" e coisas } \\
\text { do tipo. Discurso ralo, mas que impôs dura derrota aos movimentos LGBT e, em especial, } \\
\text { às pessoas que sofrem, diuturnamente, discriminações por conta de sua identidade de } \\
\text { gênero (que pode assumir as feições de um assassinato, como vemos sempre). }\end{array}$}} \\
\hline & \\
\hline \multicolumn{2}{|c|}{$\begin{array}{l}\text { O que chamavam de "ideologia de gênero" é, na verdade, um conjunto de estudos que, } \\
\text { desde os anos 1970, passaram a questionar a ideologia dominante em seus diversos } \\
\text { aspectos: no que tange a uma suposta inferiorização da mulher e seu papel "essencial" de }\end{array}$} \\
\hline
\end{tabular}


condutora do lar, o que sustenta o machismo e as diversas faces da misoginia; a denúncia de uma suposta anormalidade daqueles que não se orientavam sexualmente para o sexo oposto, os homossexuais, por tanto tempo tidos como "doentes"; a despatologização das identidades trans, daqueles e daquelas que não se identificavam com seu corpo biológico, mas, sim, com o outro gênero etc. É isso que os estudos de gênero desconstroem, na possibilidade de construção de um espaço social plural.

Mas, nossa escola, e a sociedade, viu-se "livre" dessas problemáticas, fazendo com que menos espaço exista para pessoas diferentes, continuando a relegar-se, a pessoas como Dandara e Herica, o espaço da violenta exclusão.

\begin{tabular}{|l|l}
\hline DATA 26/03/2017 & MANIFESTAÇÃO \\
\hline
\end{tabular}

TÍTULO DO ARTIGO: Grupo faz ato em Fortaleza em apoio à Lava Jato

Autor:

Tema: Protesto pediu revogação do estatuto do desarmamento e o fim do foro privilegiado ARGUMENTO CENTRAL:

Nomes dos atores citados:

Outras Informações importantes:

Resumo: (...)Outras questões também foram debatidas na manifestação, que contou com trio elétrico, como ideologia de gênero, "escola sem partido", aborto e reforma da Previdência. Profissionais de diversas áreas, que apoiam o movimento, discursaram para os manifestantes. "São pautas que vão ser abordadas hoje

"Pautas como ideologia de gênero e a escola sem partido vão ser abordadas hoje. No caso do psiquiatra Cláudio Costa, ele vem abordando um pouco sobre ideologia de gênero.

Deixem nossas crianças em paz. São temas para, talvez, adultos em universidades, mas não para crianças. Elas estão sendo atacadas. Não queremos nenhuma ideologia, seja heterossexual ou homossexual. Respeitem as nossas crianças. Não queremos que essa pauta seja inclusa nas escolas. 


\begin{tabular}{|c|c|}
\hline DATA 17/08/2017 & Política \\
\hline \multicolumn{2}{|c|}{$\begin{array}{l}\text { TÍTULO DO ARTIGO: SP: Malafaia diz a tucanos que evangélicos não negociarão } \\
\text { 'ideologia de gênero' }\end{array}$} \\
\hline \multicolumn{2}{|l|}{ Autor: } \\
\hline \multicolumn{2}{|l|}{ Tema: } \\
\hline \multicolumn{2}{|c|}{ ARGUMENTO CENTRAL: } \\
\hline \multicolumn{2}{|c|}{$\begin{array}{l}\text { Nomes dos atores citados: Geraldo Alckmin, e do prefeito João Doria, pastor Silas } \\
\text { Malafaia, Michel Temer. }\end{array}$} \\
\hline \multicolumn{2}{|c|}{ Outras Informações importantes: } \\
\hline \multicolumn{2}{|c|}{$\begin{array}{l}\text { Em discurso ao lado do governador de São Paulo, Geraldo Alckmin, e do prefeito João } \\
\text { Doria - ambos cotados para disputar a Presidência da República em } 2018 \text { pelo PSDB -, o } \\
\text { pastor Silas Malafaia adiantou que a comunidade evangélica não vai negociar princípios e } \\
\text { apoiar políticos que defenderem bandeiras como aborto, casamento gay, legalização das } \\
\text { drogas e "ideologia de gênero". }\end{array}$} \\
\hline \multicolumn{2}{|c|}{$\begin{array}{l}\text { "Quem quiser fazer graça na eleição para o politicamente correto, para a ideologia de } \\
\text { gênero, casamento gay, legalização das drogas e aborto, vai embora, segue seu caminho", } \\
\text { afirmou Malafaia em evento na zona norte da capital paulista que reuniu lideres } \\
\text { evangélicos. "Não vamos negociar nossos valores. Não vamos negociar em nenhuma } \\
\text { eleição", acrescentou o pastor, que classificou a ideologia de gênero como uma "engenharia } \\
\text { do diabo feita para destruir famílias". }\end{array}$} \\
\hline \multicolumn{2}{|c|}{$\begin{array}{l}\text { Ele foi bastante aplaudido pelos presentes nos momentos em que defendeu os "valores da } \\
\text { família". }\end{array}$} \\
\hline \multicolumn{2}{|c|}{ Alckmin e Doria participaram na manhã desta quinta-feira, 17, de um café da manhã com } \\
\hline \multicolumn{2}{|c|}{$\begin{array}{l}\text { líderes evangélicos e, na sequência, abriram uma feira de produtos gospel que acontece até } \\
\text { sábado no Expo Center Norte, centro de convenções na zona norte da capital paulista. }\end{array}$} \\
\hline \multicolumn{2}{|c|}{$\begin{array}{l}\text { Ambos também acompanharam um culto, onde oraram com as mãos erguidas, tendo a } \\
\text { bandeira do Brasil como pano de fundo. }\end{array}$} \\
\hline $\begin{array}{l}\text { Os tucanos, porém, } \\
\text { evangélicos e citads }\end{array}$ & $\begin{array}{l}\text { itaram se posicionar em relação às bandeiras defendidas pelos } \\
\text { or Malafaia. Foi a primeira vez em que o governador e o prefeito }\end{array}$ \\
\hline
\end{tabular}


dividiram o mesmo palanque desde que Doria intensificou sua agenda de viagens pelo Brasil - o que foi visto por aliados de Alckmin como uma campanha antecipada pelo Palácio do Planalto.

O presidente Michel Temer também era aguardado no evento, mas acabou cancelando sua participação.

Em discurso antagônico ao de Doria, que prega o antipetismo, Alckmin defendeu a "conciliação". "Nós precisamos nos inspirar na igreja. Nos momentos conturbados, a igreja é nosso porto seguro. Precisamos deixar essa divisão de nós contra eles para nos unir em torno de valores. Uma casa dividida não caminha", afirmou o governador, que também destacou a importância da indústria gospel na geração de empregos e o papel social das igrejas evangélicas.

Doria, por sua vez, fez um discurso mais protocolar, no qual exaltou a igreja, disse que o "bem sempre vai prevalecer sobre o mal" e defendeu a religião como saída ao vício das drogas. Concluiu sua fala dizendo que "feliz é a nação que tem Deus no coração". Tanto Doria quanto Alckmin deixaram o local sem falar com a imprensa

31

DATA 21/09/2017

TÍTULO DO ARTIGO: Câmara rejeita incluir debate sobre sexismo nas escolas

Autor: DANIEL DUARTE

Tema: Recurso da vereadora Larissa Gaspar (PPL) queria incluir no Plano de Educação debate sobre violências

ARGUMENTO CENTRAL:

Nomes dos atores citados: Larissa Gaspar (PPL), Jorge Pinheiro (PSDC), Gardel Rolim (PPL)

Outras Informações importantes:

Resumo: A Câmara Municipal de Fortaleza rejeitou ontem recurso da vereadora Larissa Gaspar (PPL) contra parecer negativo da Comissão de Constituição, Justiça e Legislação ao Projeto de Lei n ${ }^{\circ} 86 / 2017$, de sua autoria, que incluía no Plano Municipal de Educação 
(PME) artigo contra "violências sexistas, raciais, religiosas e LGBTfóbicas".

Cerca de 30 manifestantes contra e favoráveis ao PL estiveram presentes à sessão.

Discussão que deveria ser sobre legalidade da matéria, que tramita na CCJ, tornou-se debate sobre "ideologia de gênero".

Por 23 votos a sete, os vereadores contrários à proposta afirmaram que o PL é inconstitucional, visto que o PME “deve ser preservado, mantendo sua originalidade” pelo período de vigência, de dez anos da elaboração. Apoiadores da proposta, porém, alegam que o relator da CCJ, Jorge Pinheiro (PSDC), se utilizou de argumentos "contra 'ideologia de gênero" para barrar a matéria, já que o termo surge no parecer do parlamentar.

Em defesa do recurso que apresentou, Larissa Gaspar disse que o conteúdo do projeto define que a escola traga "conteúdo para a pacificação de diálogos, cultura de paz contra violências sexistas, raciais, LGBTfóbicas e respeito à identidade de gênero".

No entanto, para o presidente da CCJ, Gardel Rolim (PPL), o projeto "altera o PME", que “delineia a atuação escolar do município, construído por muitas mãos” e que não pode ser alterado no Legislativo.

"É feito todo um debate com instituições que tratam da educação em Fortaleza. Se cada vereador quiser alterar o PME a cada mês, como será o plano no nono ano? Como a educação pode ser planejada?”, questionou Gardel. Ele ainda disse se basear no artigo 272 da Lei Orgânica do Município, que decreta que "compete exclusivamente ao Sistema Municipal de Educação (SME) estabelecer a organização curricular" e "definição dos conteúdos curriculares".

Autora do projeto, Larissa replicou que "não existe nenhum vício de ilegalidade ou inconstitucionalidade" no projeto. "Isso não trata de grade curricular. Diretriz é diferente. O que proponho é diretriz ao PME. Nenhum vereador citou a constituição”, disse.

Em sua tese, a vereadora cita “decisão do Supremo Tribunal Federal (STF)", do ministro Luís Roberto Barroso, em Arguição de Descumprimento de Preceito Fundamental (ADPF), que declarou inconstitucionalidade de lei que "vista impedimento" de "adoção de políticas de ensino que tratem de gênero, de orientação sexual”.

DATA 18/10/2017

TÍTULO DO ARTIGO: Internautas confundem referência a Pink Floyd com arco-íris LGBT e atacam post do Polenguinho 
Autor: Redação O POVO Online

Tema:

ARGUMENTO CENTRAL: Apesar das críticas, a maioria dos comentários elogiou a ação e a referência roqueira

Nomes dos atores citados:

Outras Informações importantes:

Resumo: Homenagem do Polenguinho a Pink Floyd. (Foto: Reprodução)

Um post da marca Polenguinho gerou polêmica entre alguns internautas nas redes sociais após uma homenagem ao disco "The Dark Side of the Moon", do Pink Floyd, ser confundida com um arco-íris, símbolo da causa LGBT.

A montagem foi publicada na última segunda-feira, 16, na página oficial do Facebook do Polenguinho, e várias pessoas atacaram a marca afirmando que eles estavam fazendo uma "apologia à ideologia de gênero".

"Até o polenguinho fazendo ideologias de gênero? Na boa, empresa põe arco-íris, já está incitando o fato. Menos um produto em meu lar e dos meus familiares", afirma um dos comentários.

Após a polêmica, a marca resolveu se posicionar e explicar a referência usada no post:

"Nossa equipe criativa teve como inspiração a capa do álbum The Dark Side of The Moon, da banda Pink Floyd, para "brincar" com o conceito de fominha, tão utilizado quando o assunto é Polenguinho. Prezamos pela paz, pelo respeito e pela igualdade em nossa comunidade aqui. Embora não tenhamos feito alusão ao movimento LGBT+, temos máximo respeito pela causa. Contamos com todos que adoram o queijinho mais querido do Brasil desde mil novecentos e bolinha para fomentar uma comunicação afetuosa e fluida por aqui! Obrigado.", escreveu a assessoria de comunicação da empresa.

Apesar das críticas, a maioria dos comentários de internautas elogiou a ação e exaltou a escolha da referência roqueira: "Bela sacada com a capa do Pink Floyd, saquei de cara a referência !! Um dos melhores álbuns do Floyd diga-se de passagem", exaltou um internauta. 
DATA $12 / 11 / 2017$

TÍTULO DO ARTIGO: A semana. Torquemadas contra o século XXI

Autor: Émerson Maranhão, Editor de Conteúdo do Núcleo de Audiovisual

Tema: Arte e Teoria Queer

ARGUMENTO CENTRAL:

Nomes dos atores citados:

Outras Informações importantes:

Resumo: Fosse me dado o poder de desver, minhas retinas fatigadas não registrariam uma nesga sequer de duas cenas dantescas que atravessaram a semana. Na primeira, manifestantes se reuniram no portão do Sesc Pompeia, em São Paulo, para protestar contra a participação da filósofa e escritora norte-americana Judith Butler em um colóquio acadêmico. Como se a intolerância ao livre pensar e a opressão aos que a ele estimulam não fossem por si só indício do espírito inquisitorial que serve de leitmotiv a tal grupo, os manifestantes explicitaram suas intenções torquemadescas. Atearam fogo a uma boneca em tamanho natural com o rosto da escritora, enquanto gritavam: “Queimem a bruxa!". Três dias depois, Judith e sua esposa, a professora Wendy Brown, foram perseguidas e agredidas verbalmente por duas mulheres e um homem, em um aeroporto. Intelectual respeitada internacionalmente e uma das principais pesquisadoras do feminismo e da Teoria Queer, Judith foi agredida no Brasil por supostamente ser a "mãe da Ideologia de Gênero", a que seus detratores responsabilizam pelo "fìm da infância". Com estes atos de violência contra a escritora, assistimos ao estabelecimento de uma anacrônica Idade das Trevas em nosso País. E o pior, desconfio que seja apenas o começo. A Caixa de Pandora foi aberta, não duvidem. Aguentemos as consequências.

34

\begin{tabular}{|l|l|}
\hline DATA 15/11/2017 & Versão impressa \\
\hline
\end{tabular}

TÍTULO DO ARTIGO: "Butler e a cultura autoritária no Brasil"

Autor: Ana Rita Fonteles Duarte, Historiadora; professora da Universidade Federal do 
Ceará (UFC); Elias Ferreira Veras, Historiador; professor da Universidade Estadual do Ceará (Uece-Fafidam)

Tema:

ARGUMENTO CENTRAL:

Nomes dos atores citados: Judith Butler

Outras Informações importantes:

Resumo: Judith Butler é uma filósofa norte-americana que tem dedicado suas reflexões às questões de gênero, poder e ética. Obras de sua autoria, como "Problemas de gênero" e "Quadros de Guerra", traduzidas em diversos países, são algumas das contribuições dessa intelectual que nos ajudam a pensar os desafios da democracia contemporânea. Quais corpos importam? Quais vidas são choradas? Quais espaços de liberdade são possíveis?

Sua recente vinda ao Brasil, para uma palestra em São Paulo, provocou discursos de ódio de grupos ultraconservadores, que acusaram Butler de "disseminar" a "ideologia de gênero". Em seu retorno, foi agredida por senhoras, no aeroporto, que a chamaram de "pedófila", demonstrando franca ignorância sobre suas ideias.

Os discursos contra Butler revelam o medo das discussões observado antes na proibição do "kit-gay", na eliminação da palavra gênero dos planos de educação, no recrutamento de professores "cristãos" para avaliação de livros do MEC e nos ataques às exposições artísticas queer.

Essas censuras revelam uma cultura autoritária brasileira, herança da ditadura civil-militar, mas anterior a ela. Durante a ditadura, o debate sobre a censura considerava que os brasileiros não estariam preparados para determinados conteúdos. No centro desse debate, a busca por defender um ideal de família mítico formado por pai, mãe e filhos. Uma matéria recente publicada na revista Piauí revela que o departamento responsável pela censura, na ditadura, ordenou a queima de milhares de filmes, discos, livros considerados impróprios em fornos de aeroportos e indústrias como a Votorantim e, em Fortaleza, na extinta Brasil Oiticica. Nem Lucíola, de José de Alencar, escapou.

Se, naquele período, o termo ideologia foi ligado ao comunismo, agora ele é associado aos estudos de gênero e aos grupos LGBTS e feministas. Desse modo, as discussões, tão fundamentais para a compreensão e a transformação das relações sociais desiguais marcadas por gênero, raça e classe são transformadas em "ideologias" que ameaçam à 
família.

O pensamento autoritário brasileiro pretende identificar as discussões de gênero e a luta pelos direitos humanos como coisas de "degenerados" e "bandidos". Por sua vez, as manifestações de apoio à Butler, assim como nossa luta cotidiana por uma sociedade na qual as pessoas possam viver suas diferenças com liberdade, mostram que continuaremos resistindo.

35

DATA 20/11/2017

TÍTULO DO ARTIGO: Votação de Plano Municipal de Cultura gera polêmica e ataques homofóbicos

Autor: RUBENS RODRIGUES

Tema: Plano Municipal de Cultura de Tianguá-CE

ARGUMENTO CENTRAL:

Nomes dos atores citados:

Outras Informações importantes:

Resumo:

A elaboração do Plano Municipal de Cultura (PMC) de Tianguá, cidade localizada a 329,1 km de Fortaleza, tem gerado caloroso debate no município desde sua primeira votação, em junho deste ano. Uma das pessoas a frente da elaboração e implementação do plano, o artista, produtor cultural e presidente do Conselho de Política Municipal de Cultura, Natal Portela, afirma que a oposição ao projeto tem desencadeado ameaças e violações aos direitos da comunidade LGBT tianguaense.

Em maio deste ano, o plano foi lido em sua primeira versão e votado em audiência pública com a presença do secretário da Cultura do Estado, Fabiano Piúba dos Santos. O documento, que tinha uma meta de cultura LGBT e uma ação para as expressões religiosas de matriz africana, conseguiu nove votos a favor, até que o décimo vereador a votar, Mariano Diniz, pediu vista do projeto, ainda conforme Portela. O procedimento suspende a votação para que o documento seja analisado antes de voltar ao plenário da casa legislativa. 
Foi quando surgiram os primeiros boatos a respeito do Plano. "Uma pessoa que não consegui identificar espalhou um boato no Facebook de que eu estava querendo implementar uma cartilha de ideologia de gênero para ensinar as crianças a serem homossexuais", conta Portela, que no ano passado foi eleito primeiro suplente de vereador do município.

Após ser alterada, a meta 16 do plano fala apenas em "apoiar a realização de atividades culturais e instituições de cultura e educação como forma de promover o debate sobre o respeito à diversidade". Natal afirma que, para seguir a votação, precisou ser retirado texto qualquer menção à sigla LGBT ou às religiões de matriz africanas.

O suplente de vereador passou a receber áudios que considera violentos. O POVO

Online teve acesso às gravações. Em uma delas, uma mulher - que se identifica como uma moradora do município - diz que Natal está criando uma "sujeira" na cidade. "Os evangélicos estão contra. Vai ser um problema pra próxima política. Olha que evangélico é coisa séria", diz. "Sou uma pessoa que faço parte do movimento público e muita gente me conhece. Já fui muito influente na política. Não vamos aceitar isso", continua.

Em outro áudio direcionado ao suplente, um homem anônimo classifica o projeto como "atordoado" e diz que ele "não pode colocar o nome das pessoas de bem" no plano. "Não tenho nada contra os 'viados'. Quem quer dar o ** que dê. Se a opção dele é ser *******, é problema dele", diz o homem. "Ele pegar a ********** dele e jogar dentro de Tianguá para a Prefeitura ser responsável, não tem nada a ver".

Uma terceira pessoa, que se identifica como vereador Mariano Diniz, diz também em áudio que a Secretaria da Cultura tenta "empurrar goela abaixo" o projeto. "Sempre me posicionei contra essa meta porque eles não adequaram meu pedido de comemorar o dia da bíblia. Não respeitaram também", dispara. "Me procuraram para conversar na Câmara Municipal. Eu fechei a porta pra eles. Não aceito mais diálogo".

A discussão continuou no Facebook. Em uma das postagens sobre o assunto, um homem afirma que é preciso unir forças e "exigir que veados e sapatão sejam apedrejados em praça pública" (sic). Outra pessoa classifica que o projeto é uma tentativa de "acabar com a família, o modelo de Deus".

\section{Comprando a briga}

Procurado pelo O POVO Online, o vereador Mariano Diniz confirma a veracidade do áudio, e afirma que a audiência realizada em maio deste ano foi realizada atendendo a um pedido dele. De acordo com Diniz, no próximo dia 29 uma nova audiência deve ocorrer na Câmara Municipal para debater novamente o projeto. Ele diz que havia no plano o objetivo de 
"adotar nas escolas municipais" uma cartilha sobre homossexualidade, além do Município arcar com a realização da parada da diversidade local.

"Que façam isso, mas sem o dinheiro público. Não que eu seja discriminador. Tenho eleitor gay, parente gay. Sou contra fazer disso uma obrigatoriedade, de fazer com que as crianças sejam gays. O direito de educar os filhos é dos pais, não dos colégios", diz. "Fui o único vereador contra. Os outros ficaram com medo. Eles falavam que era melhor não brigar com os 'viados'. Você me desculpe o termo. É uma decisão minha. Estou comprando a briga mesmo".

\section{"Ascensão de forças conservadoras"}

A Secretaria da Cultura do Estado do Ceará (Secult) informou, por meio de nota, que possui uma coordenação responsável pelo acompanhamento da elaboração dos planos. A pasta tem feito encontros com os gestores e dirigentes municipais e atualmente faz a revisão da lei do Sistema Estadual de Cultura, para reforçar o conceito de cultura como processo civilizatório, "ainda mais importante no atual momento, de tentativa de ascensão de forças conservadoras".

Em nota, a pasta confirma que o secretário Fabiano Piúba esteve na audiência pública de Tiaguá para orientar os gestores municipais para a importância da implantação dos Sistemas Municipais de Cultura e da Elaboração dos Planos Municipais de Cultura, além de apresentar detalhes da política cultural do Estado.

"O Ceará tem uma diversidade cultural muito grande. É necessário defendermos o enfrentamento dos gargalos do setor para afirmação plena dos direitos culturais e para pensar a cultura como o modelo de desenvolvimento que queremos para o País", diz o texto.

\begin{tabular}{|l|l|}
\hline DATA & Versão impressa \\
\hline TíTULO DO ARTIGO: O Ceará que a Assembleia discute. Discursos sobre gênero \\
ultrapassam seca em debates na Assembleia \\
\hline Autor: CARLOS MAZZA \\
\hline $\begin{array}{l}\text { Tema: Raramente lembrado até o anos passado, o debate sobre gênero em escolas } \\
\text { despontou ao lado de assuntos como violência e saúde entre os mais comentados por } \\
\text { parlamentares }\end{array}$ \\
\hline
\end{tabular}


ARGUMENTO CENTRAL:

Nomes dos atores citados:

Outras Informações importantes:

Resumo: Amargando seis anos seguidos de seca, o açude Castanhão registrava em 2 de outubro volume próximo de 3,3\% da capacidade total: um dos mais baixos níveis desde a criação do reservatório, em 2002. No mesmo dia, deputados estaduais do Ceará debatiam de forma acalorada problemas até pouco tempo atrás desconhecidos no Estado: “doutrinação socialista" e a "ideologia de gênero" em escolas.

"Isso é mais importante que qualquer matéria", disse o deputado federal Eduardo Bolsonaro (PSC-SP), convidado do evento. O destaque a temas morais não foi exclusivo daquela data: Em 2017, temas de gênero e o "Escola Sem Partido" figuraram ao lado de assuntos como violência e saúde entre os mais comentados na Assembleia.

A informação tem base em levantamento do O POVO em registros da Casa sobre discursos de deputados em 2017. Ao todo, discussões sobre o debate de gênero para crianças classificada como "ideologia de gênero" por grupos críticos - mobilizou pelo menos 48 pronunciamentos na Casa. O número supera discursos sobre a seca, 46, e até problemas mais estruturais da educação, 33 .

Em sua grande maioria, discursos sobre o tema - até ano passado raramente citado na Casa - partiram do lado contrário ao ensino. Outros temas mais próximos de setores conservadores, como a defesa do armamento de civis, a proibição do aborto inclusive em casos de estupro e até restrições para imigrantes também cresceram, registrando quase 60 menções.

“Isso é extremamente natural e democrático. O Brasil é um país de maioria conservadora, as famílias são baseadas nos valores cristãos. Então o parlamento acaba sendo uma caixa de ressonância do que o povo sente, do que ele quer ver os deputados defendendo", diz Ely Aguiar (PSDC). “O próprio eleitor pressiona, a gente sente essa pauta”, corrobora Mário Hélio (PDT).

Fernando Hugo (PP) destaca ainda que o debate entre os temas se acirrou por conta de uma reação da população à "imposição" de posturas não conservadoras que teria ocorrido durante governos do PT. "O Brasil vinha de um processo intenso de esquerdização”, diz.

\section{Debate acirrado}

Entre parlamentares mais ligados a este tipo de defesa, se destacou neste ano Dra. Silvana 
(PMDB). Pastora evangélica, a peemedebista é responsável por quase a metade dos discursos sobre gênero na Casa, 19, e convocou audiência para debater o movimento Escola Sem Partido.

Entre outros temas, Silvana defendeu instalação de comissão para "fiscalizar" ensino de gênero e chegou até a elogiar a Escola Educar Sesc, de Fortaleza, após ela orientar uma adolescente transexual de 13 anos a deixar a escola. "A diretora se posicionou de maneira valente e serena", disse em sessão do Legislativo. A escola voltou atrás da decisão.

"Não há perseguição à preferência sexual de ninguém, mas se todas as pessoas quiserem mudar seus nomes vai haver uma insegurança jurídica e fragilizar as nossas legislações”, justifica Silvana.

Questionada sobre o tema, a deputada nega qualquer tipo de discriminação e diz que a "ideologia de gênero" busca "desafiar valores" do cristianismo. "Acredito na união da sociedade cristã contra essa imposição. O tempo inteiro a Rede Globo está tentando impor isso como algo normal".

\section{SAIBA MAIS}

1 Apesar do surgimentos de novos temas na Assembleia, violência e saúde continuam sendo, de longe, os assuntos comentados no Legislativo.

2 Para deputados, inclusive da base aliada, a razão é "óbvia". "O Estado deve fechar o ano na Casa dos cinco mil homicídios. Vivemos uma epidemia", diz Fernando Hugo. Ele afirma, no entanto, que problema é "nacional", não se restringindo ao Ceará.

3 Entre os demais postos, figuram diversos assuntos ligados à política "em si", principalmente aqueles em que parlamentares discutem sobre ou pedem auxílio para problemas de suas bases eleitorais no interior do Estado.

4 Entre os temas mais comuns neste sentido, estão também denúncias envolvendo o avanço da Operação Lava Jato, votação de denúncias contra o presidente Michel Temer no Congresso Nacional e as novidades nos processos na Justiça Federal contra o ex-presidente Lula.

DATA 20/12/2017

TÍTULO DO ARTIGO: Mendonça Filho: não há dissidência significativa no DEM à reforma 
Autor: Agência Estado

Tema: Orientação política do MEC

ARGUMENTO CENTRAL:

Nomes dos atores citados: ministro da Educação, Mendonça Filho (DEM), Michel Temer,

Outras Informações importantes:

Resumo: O ministro da Educação, Mendonça Filho (DEM), disse nesta quarta-feira, 20, que seu partido, o DEM, apoiará majoritariamente a reforma da Previdência. Segundo o ministro, "não há dissidência significativa" no DEM em oposição à reforma das regras de aposentadoria.

Mendonça Filho negou que o presidente da República, Michel Temer, tenha feito um apelo para que ele pressione e tente convencer deputados a votarem favoravelmente à reforma no retorno do recesso legislativo, em fevereiro.

"Com relação ao Democratas, a reforma da Previdência está bem assimilada e temos maioria ampla favorável. Não há nenhuma missão dada a mim pelo presidente com relação à reforma da Previdência, estou focado na Educação", afirmou a jornalistas, depois da cerimônia de homologação da nova Base Nacional Comum Curricular (BNCC) para o ensino infantil e fundamental, no Palácio do Planalto, em Brasília.

O ministro afirmou que a BNCC do Ensino Médio será encaminhada para análise do Conselho Nacional de Educação no primeiro trimestre de 2018.

Ele disse que, ao citar em seu discurso que o texto não se aprisionou à "ideologia de gênero", "expressou claramente a pluralidade e o respeito às diferenças": "Isso é o que importa".

DATA 09/02/2018

TÍTULO DO ARTIGO: Jornalista acusa dono da Riachuelo de ser contra movimento LGBT e prega boicote à loja

Autor: Redação O POVO Online

Tema: Conflito de consumidor com loja envolvendo o tema 
ARGUMENTO CENTRAL:

Nomes dos atores citados:

Outras Informações importantes: As reações na economia como a citada na matéria podem ser reflexos das discussões iniciadas pela inserção da questão de gênero no PNE.

Resumo:

Em seu perfil do Facebook, Alexandre Putti postou uma foto do cartão da loja Riachuelo quebrado. No texto que acompanha a imagem, o jornalista de São Paulo relata que resolveu não comprar mais roupas da marca depois que descobriu que o dono da empresa, Flávio Rocha, é apoiador de costumes conservadores que são contrários às pautas LGBTs. O empresário palestrou recentemente em São Paulo apoiando o manifesto "Brasil 200", que defende pautas como a escola sem partido, economia liberal e o combate à chamada "ideologia de gênero".

Alexandre afirma que os posicionamentos de Flávio vão lhe custar clientes. "Ele só esqueceu de um detalhe: muitos dos seus clientes são essas pessoas que ele quer combater. Pois bem, agora ele não ganha mais nenhum centavo do meu dinheiro. Dinheiro LGBT. Pink money”, diz. Pink Money, ou Dinheiro Rosa, é um nome dado ao poder de compra da população de gays, lésbicas, bissexuais e transgêneros.

O jornalista termina seu post chamando as pessoas para se juntarem à causa e não comprar mais na Riachuelo. "Por uma questão de sobrevivência das manas que morrem todos os dias no nosso país vítimas do preconceito e da opressão de pessoas como Flávio”.

O post do jornalista coleciona 35 mil reações e mais de 11.500 compartilhamentos. Nos comentários do texto, comentários mostram ideias divergentes. "Quem anda ao do lado do MBL merece meu mais absoluto desprezo", comentou um usuário que utilizou a hashtag Boicote à Riachuelo. Outros afirmam que, após saber do posicionamento político do empresário, vão virar clientes da loja.

\section{Outro lado}

Em nota, a Riachuelo informou que seu presidente, Flávio Rocha, apóia a família independente do modelo de constituição e da orientação sexual de seus membros. Sobre declarações referentes ao movimento Brasil 200, a marca reafirma que não há a pretensão de eleger parlamentares para o Congresso.

Sobre a própria marca, a nota diz que a Riachuelo é uma empresa plural, democrática e que apóia a diversidade em todas as suas faces, sem nenhuma forma de preconceito. A loja se 
coloca como a maior empregadora de transexuais do Brasil.

39

\begin{tabular}{|c|c|}
\hline DATA 10/02/2018 & Mundo \\
\hline \multicolumn{2}{|c|}{$\begin{array}{l}\text { TÍTULO DO ARTIGO: Opinião: igrejas neopentecostais ameaçam democracia na } \\
\text { América Latina }\end{array}$} \\
\hline \multicolumn{2}{|c|}{ Autor: José Ospina-Valencia é jornalista da redação da DW em espanhol } \\
\hline \multicolumn{2}{|l|}{ Tema: } \\
\hline \multicolumn{2}{|c|}{ ARGUMENTO CENTRAL: } \\
\hline \multicolumn{2}{|c|}{ Nomes dos atores citados: } \\
\hline \multicolumn{2}{|c|}{ Outras Informações importantes: } \\
\hline \multicolumn{2}{|c|}{$\begin{array}{l}\text { Resumo: O poder crescente de seitas evangélicas e partidos políticos "moralizadores" estão } \\
\text { colocando as democracias da região à prova. Um país onde se fundam mais facções } \\
\text { religiosas que escolas, como a Colômbia, pode avançar?A luta das igrejas neopentecostais } \\
\text { na América Latina é uma luta pelos pobres: por sua consciência, por suas carteiras e por } \\
\text { seus votos. Seu êxito se deve também ao fracasso da Igreja católica em atender às } \\
\text { necessidades de milhões que buscam apoio num mundo cada vez mais fustrante e sem } \\
\text { aparente futuro. E a história de abusos sexuais do dogma católico deixou, além disso, um } \\
\text { rastro de repúdio em vários países e contribuiu para a erosão de um poder passado. } \\
\text { (...) }\end{array}$} \\
\hline \multicolumn{2}{|c|}{$\begin{array}{l}\text { É assustador é que muitos desses pastores tenham tanto êxito com ideias excludentes e um } \\
\text { discurso de ódio. Em suas pregações, Piraquive descarta que pessoas com deficiência física } \\
\text { possam assumir a veiculação da "palavra de Deus". Uma postura discriminatória em todos }\end{array}$} \\
\hline \multicolumn{2}{|c|}{ os países latinoamericanos, que, pelas suas Constituições, se definem como pluralistas e } \\
\hline \multicolumn{2}{|c|}{$\begin{array}{l}\text { laicos, fundados sobre o respeito e a dignidade humana, e garantidores da liberdade de } \\
\text { expressão e de culto. }\end{array}$} \\
\hline $\begin{array}{l}\text { Paradoxalmente, ap } \\
\text { também graças ao } \mathrm{p} \\
\text { movimento neopent }\end{array}$ & $\begin{array}{l}\text { ar de essas sociedades terem avançado cultural e economicamente, } \\
\text { cípio liberal e protestante de que "os pensamentos são livres", o } \\
\text { ostal ataca o Estado de opinião. O radicalismo de suas ideias contra as }\end{array}$ \\
\hline
\end{tabular}


conquistas dessas sociedades abertas, como a abolição da pena de morte, a autodeterminação da mulher e o respeito aos direitos das minorias é difamado como uma suposta "ideologia de gênero" que pretende destruir a família e a moral.

40

\begin{tabular}{|c|c|}
\hline DATA 22/02/2018 & Política \\
\hline \multicolumn{2}{|c|}{ TÍTULO DO ARTIGO: 10 VOTOS A 9} \\
\hline \multicolumn{2}{|c|}{ Autor: Redação O POVO Online } \\
\hline \multicolumn{2}{|c|}{$\begin{array}{l}\text { Tema: Vereadores de Sobral mantêm veto de Ivo à lei que proíbe "ideologia de gênero" nas } \\
\text { escolas O veto do prefeito Ivo Gomes (PDT) foi acatado por } 10 \text { vereadores contra nove que } \\
\text { defendiam a polêmica lei }\end{array}$} \\
\hline \multicolumn{2}{|c|}{ ARGUMENTO CENTRAL: } \\
\hline \multicolumn{2}{|c|}{ Nomes dos atores citados: Adauto Izidoro Arruda, do PMDB, Ivo Ferreira Gomes (PDT) } \\
\hline \multicolumn{2}{|c|}{ Outras Informações importantes: } \\
\hline \multicolumn{2}{|c|}{$\begin{array}{l}\text { Resumo: A sessão da Câmara de Vereadores de Sobral, nessa terça-feira, 20, decidiu pela } \\
\text { manutenção do veto do prefeito Ivo Ferreira Gomes (PDT) a um projeto de lei que proibia o } \\
\text { ensino da "ideologia de gênero" nas escolas públicas e municipais. O PL é assinado pelo } \\
\text { vereador Adauto Izidoro Arruda, do PMDB. Em votação secreta, o veto foi mantido por } 10 \\
\text { votos contra nove. O momento foi presenciado por diversos ativistas a favor do veto e por } \\
\text { manifestantes a favor do projeto de lei. O Projeto de Lei de número } 2154 \text { foi apresentado } \\
\text { em novembro de } 2017 \text {. No texto, o vereador afirma que uma disciplina que "tente orientar a } \\
\text { sexualidade dos alunos ou que tente extinguir o gênero masculino e ou feminino como } \\
\text { gênero humano" não deveria ser ensinada nas escolas. Adauto escreve que isso iria contra o } \\
\text { respeito aos "laços familiares e ensinamentos religiosos tradicionais". Já o prefeito Ivo }\end{array}$} \\
\hline \multicolumn{2}{|c|}{$\begin{array}{l}\text { Gomes anunciou o veto em } 9 \text { de janeiro afirmando no documento que a lei seria } \\
\text { inconstitucional, pois é a União que tem poder de decidir as diretrizes e bases da educação } \\
\text { no País. Além disso, ele reiterou que a Base Nacional Comum Curricular (BNCC) aprovada } \\
\text { em } 2017 \text { não apresentava nenhuma disciplina com as características que o projeto de lei } \\
\text { pretendia barrar. O texto do veto fala ainda que tratar as questões de gênero que existem na }\end{array}$} \\
\hline
\end{tabular}


sociedade, bem como de sexualidade, não serve para influenciar alunos ou praticar doutrinação. "Ajudar a entender a sexualidade dos alunos e protegê-los contra a violência e discriminação" seria, segundo o documento, o objetivo principal dessa discussão ser levada às escolas. Ivo Gomes entende que, proibindo o debate, a escola não iria auxiliar na superação da exclusão social.

41

\begin{tabular}{|c|c|}
\hline DATA 18/03/2018 & Versão impressa - Entrevista \\
\hline \multicolumn{2}{|c|}{ TÍTULO DO ARTIGO: Martír Silva. Execução de Marielle fortalece a luta } \\
\hline \multicolumn{2}{|c|}{ Autor: JULIO CAESAR } \\
\hline \multicolumn{2}{|c|}{$\begin{array}{l}\text { Tema: Martír Silva é mulher, negra e defensora do feminismo e dos direitos humanos. } \\
\text { Sentiu a morte de Marielle, mas a referencia presente, assim como as lutas que trava }\end{array}$} \\
\hline \multicolumn{2}{|c|}{ ARGUMENTO CENTRAL: } \\
\hline \multicolumn{2}{|c|}{ Nomes dos atores citados: } \\
\hline \multicolumn{2}{|c|}{ Outras Informações importantes: } \\
\hline \multicolumn{2}{|l|}{ Resumo: } \\
\hline \multicolumn{2}{|c|}{ Mulher, negra, intelectual, líder. Características que, pasmem, podem ser afrontosas. } \\
\hline \multirow{2}{*}{\multicolumn{2}{|c|}{$\begin{array}{l}\text { Ameaçam, ao mesmo passo que fortalecem a busca por igualdade. Francisca Martír da Silva } \\
\text { tem todas elas. Advogada, professora universitária, mestre em Políticas Públicas e assessora } \\
\text { jurídica do Conselho Regional de Serviço Social e do deputado Guilherme Sampaio (PT). A } \\
\text { mulher que se descobriu feminista antes mesmo de entender o recorte da própria negritude }\end{array}$}} \\
\hline & \\
\hline \multicolumn{2}{|c|}{ — e de tudo que isso significava — afirma que a democracia é o caminho para qualquer } \\
\hline \multirow{6}{*}{\multicolumn{2}{|c|}{$\begin{array}{l}\text { conquista. Mas que a garantia estatal de direitos não garante eficácia e, principalmente, não } \\
\text { contempla o comportamento. A cultura sobre ser mulher precisa mudar. Para Martír, a } \\
\text { morte da vereadora Marielle Franco (Psol), com quatro tiros, não deverá calar as vozes que } \\
\text { contrapõem o que já está posto. Na verdade, aqueles que defendem os direitos humanos já } \\
\text { são mesmo alvo desde sempre. Martír se referiu durante toda a entrevista como se Marielle } \\
\text { ainda estivesse viva. Porque, suponho, seja assim que se sinta. (Sara Oliveira) }\end{array}$}} \\
\hline & \\
\hline & \\
\hline & \\
\hline & \\
\hline & \\
\hline \multicolumn{2}{|c|}{ O POVO - O movimento feminista no Brasil realmente avançou? } \\
\hline
\end{tabular}


Martír Silva: Avançou na condição de se tornar um sujeito político, nas reivindicações, na defesa dos direitos. E um outro elemento de avanço é a visibilidade que se dá hoje ao recorte de raça para as mulheres. Durante muito tempo, o feminismo foi um movimento político de defesa, mas viam as mulheres como um monólito, como um bloco uniforme. É preciso distinguir as mulheres a partir da raça, da região onde moram, da geração, da orientação sexual. Esses recortes aprofundam sobre a vida as mulheres e suas lutas específicas.

OP - O que é preciso para que esse feminismo mais distinto também avance?

Martír Silva: Políticas públicas, precisamos de ação governamental dentro de um estado democrático. E precisamos também promover revoluções cotidianas nos comportamentos e na cultura, da forma de resistência das pessoas e da sociedade. A medida que se proíbe a discussão de gênero, a verificação dessas diferenças, a proposição de medidas que eliminem essas diferenças, acaba-se impedindo o avanço. A ideia de que a ideologia de gênero é nociva para a sociedade, disseminada pelos conservadores, é muito ruim para a perspectiva do movimento feminista.

OP - Machismo e racismo estão sempre juntos?

Martír Silva: Estão imbricados, são codependentes. E são necessários para sustentar um certo padrão de sociedade que nós temos. Patriarcado e racismo são as duas principais pilastras da sociedade clássica e capitalista. Então, eles caminham juntos, se reforçam. OP - Vivemos uma tendência de embranquecimento, de a mulher negra não se reconhecer negra de verdade?

Martír Silva: Existem as denominações parda, morena, moreninha, mulata. Elas escamoteiam a condição racial mesmo. Mas, nos últimos tempos, em especial as meninas negras têm se empoderado nesse autorreconhecimento. Na escolha do cabelo cacheado, nas roupas mais identificadas com a raça negra, temos a marcha das mulheres negras... Movimento racial Quando começou, na década de 1980, a se assumir negra, Martír ouviu de um amigo que a autorrefe-rência era para ganhar eleições do Centro Acadêmico OP - Como foi esse autorreconhecimento para você ?

Martír Silva: Me tornei mulher antes de me tornar negra. A pauta feminina chegou mais cedo para mim, a militância começou aos 20 anos com o envolvimento em grupos feministas. O recorte da negritude veio ao longo do tempo, com a aproximação de questionamentos e da politização dessa pauta. Claro que eu sabia que a minha pele era escura, mas se tinha uma ideia de que toda família tinha uma pessoa com a pele escura. Meu pai tem a pele escura, minha mãe, pele clara. Tenho irmãos de todas as cores. E como isso 
era uma questão que escamoteava socialmente, a percepção dos preconceitos e da discriminação também não era forte como hoje. Eu referencio nas minhas companheiras negras que há uma certa exaltação nessa autoidentificação. Quando você se descobre alguma coisa é como se tivesse descoberto uma coisa fundamental sua que é muito positiva. Uma coisa muito bem resolvida.

OP - O que significou lutar pelo feminismo quando você tinha 19 anos e hoje? Quais as diferenças?

Martír Silva: Nos anos 1980, eu tive a oportunidade de participar de debates para construção da própria Constituição. As lutas feministas ganhavam espaço político, a luta contra a violência, a criação de equipamentos públicos e de instrumentos de participação. Estávamos partindo do nada, quando a mulher começava a surgir como sujeito político, quando houve a mudança do poder parental. Mas não avançamos na cultura de relações de gênero, que são seculares e vêm sendo questionadas o tempo todo. Uma diferença que eu encaro como negativa nos tempos atuais é o florescimento de posicionamentos machistas descarados, que nos chamam de feminazi, que tratam de forma abjeta qualquer referência às mulheres, sobretudo as feministas. A uma profusão de letras de músicas... A história tem essa dinâmica. Nós temos escolas de princesa em pleno século XXI.

Feminismo "Avançamos muito, mas não do ponto de vista das relações de gênero, que vêm sendo questionadas ao longo do tempo (...) Temos escola de princesa em pleno séc XXI" OP - Você afirma que é preciso democracia para que o feminismo consiga avançar. Como a morte da Marielle ameaça essa democracia?

Martír Silva: A morte dela foi uma representação real, porque a vida dela foi eliminada, e simbólica, do enfrentamento de forças que querem interromper a democracia no Brasil. Foi um recado de que a eliminação de pessoas defensoras dos direitos humanos é possível. Foi um recado de muita coragem de quem o fez. Porque está assumindo riscos, primeiro o da opinião pública, porque houve uma mobilização muito forte Brasil afora. O que demonstra uma força de resistência das pessoas, da sociedade. E de reconhecimento pela condição de mulher, de negra, de defensora dos direitos humanos, moradora da favela, que Marielle encarna. Será que se ela fosse homem, branco, de classe média, moradora da zona sul, defendendo as mesmas posições, seria morta? É uma pergunta que não quer calar. $\mathrm{O}$ ambiente antidemocrático é favorável à força, à opressão, às condutas ilegais. $\mathrm{O}$ assassinato da Marielle só pode ter acontecido num momento de fragilidade da democracia. Ela conseguiu estudar, se tornou intelectual, galgou liderança na sua comunidade, foi eleita. Conseguiu referenciar um pensamento político que contraria todos os papeis que são dados 
para a juventude da periferia.

OP - Conseguir conquistar tudo isso afrontou a quem?

Martír Silva: Os conservadores, os neonazistas, os neofascistas. Porque não podemos negar que hoje no Brasil existem braços politicamente organizados desses segmentos. Não é à toa que a morte dela foi comemorada nas redes sociais. Repito que a democracia fragilizada permite isso, que espaços públicos de pensamento sejam ocupados por pensamentos ultraconservadores.

OP - O que aconteceu à ela amedronta os ativistas por direitos humanos?

Martír Silva: Os defensores de direitos humanos já sentem a fragilidade da segurança há muito tempo. O que diferencia a morte da Marielle é que, além de ativista, era ela uma parlamentar. A gravidade é o recado que se passa: não temos limites sobre quem vamos exterminar. Por outro lado, as grandes mobilizações no Brasil inteiro representam que há uma determinação de que há resistência. Até porque é necessário. Sem essa defesa, como vai ficar a população da periferia? A mercê do absurdo de autoridades e da inacessibilidade de políticas públicas e direitos sociais. Houve uma catarse, mas não para o medo, para o recuo. Ela cria indignação e isso faz acumular força.

42

\begin{tabular}{|l|l|}
\hline DATA 10/05/2018 & Versão impressa \\
\hline TÍTULO DO ARTIGO: Projeto Escola Sem Partido avança e reacende polêmica na \\
educação
\end{tabular}


Partido, na terça-feira, 8 , as articulações para dar seguimento à votação ou barrar a matéria se intensificaram. Cada bloco tem suas estratégias e, no meio da discussão, está a possível modificação da Lei de Diretrizes e Bases da Educação (LDB) e do livre posicionamento de professores em sala de aula.

A proposta destaca que há uma "doutrinação" política e sexual feita por docentes. De acordo com o relator da matéria, deputado Flavinho (PSC-SP), o que ficou constatado é que alunos que não compactuam com ideologias de esquerda, de movimentos LGBT e feministas, são perseguidos. "Quando falo de doutrinação sexual, falo dessa agenda de militantes que querem a todo custo implementar a ideologia de gênero", diz.

O texto apresentado proíbe o professor de mostrar pensamentos políticos, ideológicos ou partidários e ressalta que a educação sexual deve ficar apenas a cargo da família. Flavinho desconsiderou que o ensino do que chama de "ideologia de gênero" seja uma forma de combate ao preconceito e fortaleceu que o ensino religioso pode, sim, estar presente nas escolas. "A escola tem de oferecer e o aluno pode ou não participar”, afirma.

O objetivo do relator do texto é que a votação ocorra ainda neste mês, sem ir a Plenário. Porém, Gláuber Braga (Psol-RJ), uma das vozes mais atuantes contra a proposta, membro da comissão de 35 deputados que a julga, afirmou que não será fácil. "Vamos trabalhar para que a matéria demore a ser votada, vamos fazer um pedido de vistas e depois ainda tem a discussão", detalha. A estratégia contará ainda com recursos como o de obstrução, quando parlamentares liderados se retiram e não deixam a votação acontecer.

“Outro recurso é exigir que a matéria não fique só na comissão, mas que vá para Plenário. Na Casa, o partido nem sempre acompanha a posição do parlamentar fundamentalista", avalia Gláuber. Ele considera a seriedade de colocar os professores na posição de ilegalidade. "O professor que fizer uma análise crítica sobre a educação pública poderá estar cometendo uma ilegalidade", diz.

Para o professor de história da Universidade Federal do Paraná (UFPR), Clóvis Gruner, se aprovado, o projeto pode retirar o aprendizado histórico das escolas. "Se um professor de história estiver ensinando sobre cultura africana e um aluno, de uma família religiosa, se recusar a aprender... Isso põe em risco o aprendizado formal”, analisa. Clóvis destaca que um parecer de 2016, da Procuradoria Geral da União, já julgava o projeto e surgiu ainda em 2004, inconstitucional. "Esse movimento, hoje, já atua perseguindo. Uma lei como essa, mesmo que não aprovada, fortalece essa postura", frisa. 
O Movimento LGBT em Fortaleza é forte, entre lobos e dementadores, e resiste o arco-íris.

44

\begin{tabular}{|l|l|}
\hline DATA 26/06/2018 & Política \\
\hline TÍTULO DO ARTIGO: Nova política \\
\hline Autor: Carlos Matos, Deputado estadual (PSDB) \\
\hline Tema: Marketing político de Carlos Matos \\
\hline ARGUMENTO CENTRAL: \\
\hline Nomes dos atores citados: \\
\hline $\begin{array}{l}\text { Outras Informações importantes: } \\
\text { Resumo: } \\
\text { “A essência é o servir. Lutar pelo bem comum. Ao longo do mandato travei lutas pelo } \\
\text { futuro do nosso Estado alcançando a vitória contra a máquina governista que, sem maiores } \\
\text { reflexões, segue a vontade dos governantes, como no caso da ideologia de gênero, em que o } \\
\text { governo pretendia adotá-la na educação. Tivemos uma votação apertada de } 10 \text { x 9, } \\
\text { impedindo a adoção de uma ideologia que destrói a família pelos próximos dez anos.” }\end{array}$ \\
\hline
\end{tabular}

\section{APÊNDICE 3 - DADOS DA CARTA CAPITAL}

1.

\begin{tabular}{|c|c|}
\hline DATA 25-02-2016 & Feminismo \\
\hline \multicolumn{2}{|c|}{ TÍTULO DO ARTIGO: Querem assassinar o gênero } \\
\hline \multicolumn{2}{|c|}{ Autor: por Maíra Kubík Mano } \\
\hline \multicolumn{2}{|l|}{ Tema: Feminismo } \\
\hline $\begin{array}{l}\text { ARGUMENTO CE } \\
\text { para derrubar o mov }\end{array}$ & $\begin{array}{l}\text { RAL: A discussão da palavra gênero na câmara não será suficiente } \\
\text { ento feminista. }\end{array}$ \\
\hline
\end{tabular}


Nomes dos atores citados: Partido Republicano Brasileiro

Outras Informações importantes: Medida Provisória 696/15, Erica Kokay (PT-DF)

Resumo: Bom, ao dizermos que há uma relação de gênero, percebemos, com certa facilidade, que existe um posicionamento privilegiado nessa relação, o do homem, branco, heterossexual, cisgênero, que é o sujeito hegemônico em nossa sociedade. Isso mexe com nossa objetividade e nossas subjetividades, contribuindo para desnaturalizar as opressões. E os "de cima", como diria Florestan Fernandes, obviamente não querem mudar sua confortável posição. Pensam então ser preciso impedir o "gênero" de existir. Querem assassiná-lo e toda a pluralidade que vem com a possibilidade de refexão.

Mas isso, nobres congressistas, é apenas tapar o sol com peneira. $\mathrm{O}$ ato violento de exclusão da palavra "gênero" do vocabulário legislativo, perpetrado consecutivamente nos últimos anos, não será suficiente para impedir novas existências, problematizações, rompimentos e enfrentamentos às opressões. As possibilidades se espalham mais rápido que do que vocês conseguem reagir. Assim nos mostraram os feminismos no ano passado, que das ocupações das escolas paulistas às ruas das grandes cidades com o Fora Cunha e contra o PL 5069, dominaram o debate público.

2.

\begin{tabular}{|l|l|}
\hline DATA 29-03-2016 & Pernambuco \\
\hline TÍTULO DO ARTIGO: No recife, diversidade sexual pode deixar alunos sem livros
\end{tabular}

Autor: Agência Brasil

Tema: Diversidade sexual na escola

ARGUMENTO CENTRAL: Bancada religiosa municipal quer banir livros que falam sobre questões de gênero e homossexualidade

Nomes dos atores citados: MEC, Os principais agentes da cruzada contra os livros didáticos são os vereadores Luiz Eustáquio (Rede) e Carlos Gueiros (PSB)

Outras Informações importantes: Fala do Programa Nacional do Livro Didático

Resumo: Os vereadores uerem barrar o uso de um determinado livro já escolhido por 
escolas de Recife. "Nós entendemos que o povo brasileiro, a grande maioria, não aceita a orientação da ideologia de gênero sobretudo nas escolas e principalmente no ensino fundamental. Vendo essa grande proporção de pernambucanos que não aceita a entrada da ideologia de gênero nos planos estaduais de educação, até porque o próprio plano na questão de gênero foi rejeita na Assembleia, então apresentamos essa proposta para que a ideologia fique de fora de uma vez por todas nas escolas", justifica.

A diretora diz que ficou sabendo da tentativa de impedir o uso do material didático no dia em que fazia a reunião de entrega dos exemplares para os alunos. Para ela, os vereadores desrespeitam o trabalho da equipe da escola ao tentar retirar os livros da rede municipal. “O livro não estimula, não incita, simplesmente cita que existem casais formados por pessoas do mesmo sexo. Que se identificam com pessoas do mesmo sexo. Isso não é um estímulo à escolha, é a constatação de um fato que tem na sociedade. Nós, enquanto educadores, não podemos nos furtar do dever de ter na sala um espaço de discussão, e não estímulo. O aluno tem direito a ter esse espaço de discussão", defende Marta Beatriz, explicando que trata a questão pelo viés do combate ao preconceito e à homofobia"

3.

DATA 8-4-2016

TíTULO DO ARTIGO: Como lidar com a polarização política dentro da escola?

Autor:

Tema: MARSÍLEA GOMBATA

ARGUMENTO CENTRAL: Educadores passam por desafios para manter a neutralidade política entre os alunos na escola

Nomes dos atores citados: professor da Faculdade de Educação da USP, José Sérgio Carvalho, Doutora em políticas sociais pela PUC-SP e educadora popular do Instituto Paulo Freire, Francisca Pini, Ana Cláudia Crivellaro, orientadora educacional do Ensino Fundamental do Colégio Rio Branco, Denise Jardim, coordenadora pedagógica do Ensino Fundamental II da Stance Dual School,

Outras Informações importantes: Fala de gênero relacionado ao impeachment e de polarização política nacional. 
Resumo: Enquanto Denise aponta o uso da linguagem descritiva como uma ferramenta interessante para o professor que terá de trabalhar de forma objetiva para desassociar, por exemplo, cores de partidos políticos, Ana lembra que o educador sempre deve buscar ser um mediador ao mostrar que ambos os lados de um conflito têm uma opinião a ser respeitada. Uma vez que os insultos ou agressões persistam, os pais devem ser chamados para uma conversa com a equipe pedagógica da instituição de ensino."No momento no qual a sociedade se defronta com uma odiosidade que beira o reacionarismo, o desafio colocado aos educadores é trabalhar em uma perspectiva de educação de direitos humanos, pautada pela igualdade, sem distinção de gênero, etnia, orientação sexual e, principalmente, política", conclui Francisca.

4.

\begin{tabular}{|c|c|}
\hline DATA 1-6-2016 & A \\
\hline \multicolumn{2}{|c|}{$\begin{array}{l}\text { TíTULO DO ARTIGO: A falácia da Escola Sem Partido (ou do pensamento } \\
\text { único) }\end{array}$} \\
\hline \multicolumn{2}{|c|}{ Autor: PEDRO HENRIQUE OLIVEIRA GOMES } \\
\hline \multicolumn{2}{|l|}{ Tema: Educação } \\
\hline \multicolumn{2}{|c|}{$\begin{array}{l}\text { ARGUMENTO CENTRAL: A doutrinação ideológica está presente nas escolas desde } \\
\text { sempre com seus conteúdos, suas relações }\end{array}$} \\
\hline \multicolumn{2}{|c|}{ Nomes dos atores citados: } \\
\hline \multicolumn{2}{|c|}{$\begin{array}{l}\text { Outras Informações importantes: Usa dados do mapa da violência para falar de violência } \\
\text { contra a mulher. }\end{array}$} \\
\hline \multicolumn{2}{|c|}{$\begin{array}{l}\text { Resumo: Para o projeto Escola Sem Partido, discutir feminismo e homofobia é é } \\
\text { doutrinação ideológica e imposição da } \underline{\text { ideologia de gênero nas escolas. Como reflexo da }} \\
\text { sociedade, as escolas são espaços marcados pela opressão às mulheres e a discriminação } \\
\text { sexual. Na maioria dos casos, as ações e as reações são silenciadas e banalizadas. Será que } \\
\text { é necessário ter a discussão nas escolas? Creio que os dados e as informações a seguir nos }\end{array}$} \\
\hline
\end{tabular}


mostrarão a urgência da discussão na sociedade. Neste contexto, Escola Sem Partido (ou Escola de Pensamento Único) é um projeto para silenciar vozes, buscar estabilidades e criar novos espaços de conforto e conformismo social, cultural e intelectual. A instabilidade, o diferente, a emergência, a diversidade incomodam. Discutir as desigualdades sociais, o feminismo, a discriminação sexual, entre outros assuntos, é provocar instabilidades nesse sistema de histórias e pensamentos únicos. Doutrinação ideológica está presente nas escolas desde sempre com seus conteúdos, com seus discursos, com suas relações. Educar é um ato político em si.

O pensar crítico é outro papo. A atitude socialmente crítica é emancipação. Ela combate e rompe com o desenvolver enciclopédico e elitizante das escolas tradicionais. Educar é analisar as realidades e a nossa sociedade, selecionando aquilo que é urgente para ser conhecido, discutido, problematizado. Se analisar criticamente as realidades é um problema, que possamos subverter a lógica do pensamento único. É preciso continuar nessa luta para garantir uma educação para a liberdade e para a autonomia.

Por uma educação que reconheça nossos povos tradicionais e seus saberes, garanta o bem estar das pessoas, valorize o fazer coletivo, pratique a democracia nas suas relações, entre outras medidas que integram a agenda da educação em direitos humanos, especialmente por um mundo socialmente justo e ambientalmente responsável.

5.

\begin{tabular}{|l|}
\hline DATA 7-6-2016 \\
\hline $\begin{array}{l}\text { TíTULO DO ARTIGO: A escola tem um papel fundamental para romper com a } \\
\text { cultura de estupro }\end{array}$ \\
\hline Autor: MARSÍLEA GOMBATA \\
\hline $\begin{array}{l}\text { Tema: } \\
\text { na escola' defendem que escola inclua questões de gênero em seus planos pedagógicos }\end{array}$ \\
\hline $\begin{array}{l}\text { Nomes dos atores citados: Michele Escoura, Beatriz Accioly Lins e Bernardo Fonseca } \\
\text { Machado, que acabam de lançar o livro Diferentes, não desiguais - A questão de gênero } \\
\text { na escola(Reviravolta/ Cia. das Letras). }\end{array}$ \\
\hline
\end{tabular}


Outras Informações importantes:

Resumo: É contra essas heranças, concluem os autores, que a escola deve ser encarada com um papel social de formar cidadãs e cidadãos reflexivos, críticos e aptos a construírem uma sociedade mais justa e aberta a novas estratégias possíveis. "A primeira ação de grande importância é a inclusão de temas como gênero e diversidade no Projeto Político Pedagógico da escola, que tem autonomia para construir seus princípios e desenhar seus planos de ação", observa Beatriz, ao ressaltar a importância da família nessa construção.

6.

DATA 9-6-2016

TÍTULO DO ARTIGO: Escola Sem Partido preocupa por questionar a transmissão dos saberes, afirma Janine

Autor: THAIS PAIVA

Tema: Ex-ministro da Educação, Renato Janine Ribeiro defende a escola como um espaço para o confronto de conhecimentos, não de crenças

ARGUMENTO CENTRAL: Entrevista com ministro.

Nomes dos atores citados: Ministro da Educação entre abril e outubro de 2015, o professor titular de Ética e Filosofia Política na USP, Renato Janine Ribeiro.

Outras Informações importantes:

Resumo: Hoje, é quase certo que o PNE não será atendido até 2024. Primeiro, porque nós perdemos dois anos de crise econômica durante o segundo governo Dilma, e até nos recompormos levará um certo tempo. E, segundo, porque nós temos hoje um governo que tem uma outra visão dessas questões e que também não sabemos se conseguirá recompor a economia. Então o PNE está correndo sérios riscos. Agora, a essa altura a melhor coisa 
que se tem a fazer é focar nas metas que dizem respeito a creche, pré-escola e Ensino Fundamental. Focar nos primeiros anos de vida do aluno. Não podemos mais ficar adiando a questão da Educação Básica.

7.

\begin{tabular}{|l|l|}
\hline DATA 19-07-2016 & Educação \\
\hline TÍTULO DO ARTIGO: Discutir gênero não tem nada a ver com “apologia gayzista”
\end{tabular}

Autor: Raisa Pina

Tema:

ARGUMENTO CENTRAL: O que mais choca nos comentários de uma parcela considerável da população é a confusão sobre o que significa, realmente, discutir gênero nas escolas

Nomes dos atores citados: *Raisa Pina é jornalista e pesquisadora da Instituto de Bioética, Direitos Humanos e Gênero (Anis)

Outras Informações importantes: Artigo de opinião

Resumo: Sem discussão sobre gênero, mulheres são estrangeiras no mundo, têm a voz diminuída, têm o comportamento silenciado e domesticado - mulher precisa fechar as pernas, falar baixo, concordar.

Mas eu entendo essas pessoas tão cheias de ódio no coração quando nos propomos a questionar esse regime de poder. Dever ser muito triste nascer homem pensando que a mulher está aí para apenas dizer sim, e, de repente, chega uma mulher toda empoderada, falando para ele lavar as próprias louças.

8.

\begin{tabular}{|l|l|}
\hline DATA 08-08-2016 & Opinião
\end{tabular} 


\section{TíTULO DO ARTIGO: Escola Sem Partido: estratégia golpista para calar a educação}

Autor: Claudia Dutra e Camila Moreno

Tema: Escola sem partido

ARGUMENTO CENTRAL: O projeto da direita para a educação dissemina concepções e práticas preconceituosas, discriminatórias e excludentes

Nomes dos atores citados: deputado Izalci (PSDB-DF) e do senador Magno Malta (PRES)

Outras Informações importantes: Projeto Escola Sem Partido(PLS 193/2016, PL 1411/2015 e PL 867/2015) Rogério Marinho (PSDB-RN)

Resumo: Trata-se de uma elaboração que contraria o princípio constitucional do pluralismo de ideias e de concepções pedagógicas, assim como o da liberdade de aprender, ensinar, pesquisar e divulgar o pensamento, a arte e o saber, considerando como válidos determinados conteúdos que servem à manutenção do status quo e como doutrinários aqueles que representam uma visão crítica.

Em recente Nota Técnica, o Ministério Público considera que o PL Escola sem Partido é inconstitucional porque "está na contramão dos objetivos fundamentais da República Federativa do Brasil, especialmente os de 'construir uma sociedade livre, justa e solidária' e de 'promover o bem de todos, sem preconceitos de origem, raça, sexo, cor, idade e quaisquer outras formas de discriminação". A estratégia do movimento chamado "Escola Sem partido" é enfrentar o projeto político educacional de transformação que exigiu rupturas com a concepção de educação fundamentada na visão elitista, conservadora, meritocrática, mercadológica e patriarcal que se revelava discriminatória, segregadora e excludente. Além do confronto legislativo, tais setores passaram a interferir na condução das políticas em curso, como o cancelamento do Comitê de Gênero no âmbito do MEC. Entre outras ações nesta linha, estão ataques a iniciativas que afirmam a educação para a igualdade de gênero, o respeito e a valorização das diferenças, compreendendo a importância da abordagem contextualizada da educação em direitos humanos, da ética e da cidadania. Considera-se que o PL "Escola Sem Partido" impõe uma condição de tutela 
aos estudantes, descritos como seres "vulneráveis" no processo educacional, e que elimina a liberdade de ensino e aprendizagem, privando os estudantes da construção de consciência crítica, como se fossem incapazes de construir suas próprias sínteses, reflexões, posições e precisassem estar sob tutela de "leis de mordaça". Também, esse projeto transforma o ato educativo em uma mera reprodução e expressão do poder vigente, rotulando toda abordagem crítica como subversiva à ordem social e aos padrões morais da família e os educadores como doutrinadores, sobre os quais deve recair a condição de obediência à ideologia do golpe. O PL veda ainda, em sala de aula, "a prática de doutrinação política e ideológica bem como a veiculação de conteúdos ou a realização de atividades que possam estar em conflito com as convicções religiosas ou morais dos pais ou responsáveis pelos estudantes". Convicções morais que sejam preconceituosas, homofóbicas e racistas não devem justamente ser desconstruídas?

9.

DATA 26-10-2016

TÍTULO DO ARTIGO: Vamos falar sobre gênero?

Autor: Joanna Burigo

Tema: Gênero

ARGUMENTO CENTRAL: Gênero, PT e comunismo não são a mesma coisa.

Nomes dos atores citados:

Outras Informações importantes: Texto de opinião

Resumo: Para muita gente gênero, esquerda, PT e comunismo são tudo a mesma coisa. É evidente que não são, tanto que chega a parecer redundante listar as diferenças. Mas sem fazer isso, como sequer começar a dialogar com quem não está disposto a assimilar que "querer ideologia de gênero na escola" é uma frase inteiramente falaciosa? O propósito de discutir gênero nas escolas é justamente para que não haja imposição ideológica, na escola, acerca de gênero. Discutir gênero na escola, bem como no trabalho, em Hollywood, na família, no mundo dos negócios, na História, enfim, em geral, é discutir as 
formas com que gênero pauta nossas vidas sociais.

10.

DATA 4-11-2016

TíTULO DO ARTIGO: Por que é tão difícil falar de gênero na escola?

Autor: THAIS PAIVA

Tema:

ARGUMENTO CENTRAL: Tentativa de vereador de barrar "Semana de Gênero" em escola de São Paulo mostra como o tema carece de debate e está fundamentado em preconceitos

Nomes dos atores citados: vereador Ricardo Nunes (PMDB)

Outras Informações importantes:

Resumo: A diretora mandou derrubar os alambrados que cerceavam a circulação dos alunos e decretou que a escola passaria a ficar aberta também nos fins de semana. Em outras palavras, a partir daquele momento, o investimento seria feito no sentido de dar mais autonomia aos alunos e fomentar o diálogo com pais e comunidade.

Desde então, a escola tornou-se referência em educação pública pelo seu caráter inclusivo e democrático. Exemplo disso era a Semana do Gênero, uma série de atividades e rodas de conversa que se estenderia do dia 25 a 27 de outubro abordando assuntos como violência contra as mulheres, desigualdade de gênero e machismo.

No dia 25 de outubro, porém, em meio aos preparativos, um ofício emitido pelo chegou à escola exigindo a suspensão do evento. Segundo o documento, a escola se apoiava falsamente nos parâmetros curriculares nacionais elaborados pelo MEC ao incluir o tema 
de orientação sexual no ensino fundamental. O vereador ainda exigia o nome dos envolvidos na atividade para que houvesse a "responsabilização daqueles diretamente envolvidos". Em resposta à notificação, a Amorim Lima, por meio da Secretaria Municipal de Educação, enviou um ofício à Câmara dos Vereadores no qual, entre outros pontos, esclareceu que a Semana encontrava-se respaldada na política municipal de educação e na legislação vigente e que tal base legal assegurava a autonomia da escola para gestão do projeto político-pedagógico e o desenvolvimento de suas ações.

11.

DATA 08-03-2017

TíTULO DO ARTIGO: Como trabalhar a igualdade de gênero na escola

Autor: THAIS PAIVA

Tema: Gênero

ARGUMENTO CENTRAL: Especialista elenca atitudes que escolas e professores podem adotar para combater o machismo

Nomes dos atores citados: Cláudia Fusco, gerente de conteúdo do OLGA, projeto feminista criado em abril de 2013

Outras Informações importantes:

Resumo: Da divisão das atividades esportivas à distinta expectativa de aprendizagem em determinadas disciplinas como Matemática. Apesar dos avanços conquistados pela luta feminista, $\underline{\text { o machismo }}$ ainda está muito presente no espaço escolar. Dados como estes mostram como professores e gestores precisam ser orientados a não reproduzir estereótipos e preconceitos dentro da escola. "Dentro de salas, quadras e laboratórios, não pode haver coisas de menino ou de menina. E, quando surgirem conflitos relacionados a gênero, o assunto deve ser abordado de forma clara, para que sejam convertidos em aprendizado", conclui o estudo. 
12.

DATA 6-4-2017

TíTULO DO ARTIGO: Conheça a última versão da Base Curricular para Ensino Infantil e Fundamental

Autor: THAIS PAIVA

Tema:

ARGUMENTO CENTRAL: O documento prescreve os objetivos de aprendizagem que deverão nortear os currículos de todas as escolas do País

Nomes dos atores citados:

Outras Informações importantes:

Resumo: O texto é concluído com atraso - estava previsto para junho de 2016 - e ainda precisa ser aprovado pelo Conselho Nacional de Educação (CNE) e, posteriormente, homologado pelo ministro da Educação, Mendonça Filho. Entre os pontos mais polêmicos, estão a supressão do conceito de gênero do conteúdo e a determinação do inglês como idioma estrangeiro obrigatório a ser ensinado. Para a especialista, no entanto, o grande desafio começa com a homologação da BNCC. "Uma coisa é o documento, outra é o currículo. Isto é, a adaptação da prática pedagógica que isso demandará das escolas, sem falar de uma revisão na formação inicial e continuada dos professores e dos materiais didáticos”. Outro ponto que precisará ser reformulado são as matrizes que edificam as avaliações externas do País. "Geralmente, vemos o ensino sendo pautado pelas avaliações e, agora, essa lógica precisará se inverter”, aponta Patrícia.

13.

DATA $13-4-2017$

TíTULO DO ARTIGO: A sociedade perde ao não discutir gênero na escola

Autor: $\underline{\text { ANA LUIZA BASILIO }}$ 
Tema:

ARGUMENTO CENTRAL:

Nomes dos atores citados: Movimento Brasil Livre (MBL)

Outras Informações importantes:

Resumo: O expoente mais recente dessa lógica se apresentou no último dia 6 de abril, data em que o Ministério da Educação (MEC) entregou a terceira e última versão da Base Nacional Comum Curricular (BNCC) ao Conselho Nacional de Educação (CNE) para ser votada.O documento chegou aos conselheiros com uma diferença da versão que foi entregue previamente a jornalistas sob embargo. No texto, foram suprimidos os termos "gênero" e "orientação sexual" de artigos que tratam das competências e habilidades requeridas dos estudantes. A referência à igualdade de gênero também foi retirada de algumas políticas educacionais estaduais e municipais. Estados como Acre, Bahia, Ceará, Espírito Santo, Goiás, Pernambuco, Piauí, Paraná, Santa Catarina, São Paulo, Sergipe, Tocantins sancionaram seu planos sem a menção, segundo levantamento da iniciativa De Olho nos Planos. O Plano Municipal de São Paulo também foi aprovado sem a palavra gênero após pressão de grupos religiosos. As especialistas concordam que a decisão do MEC de recuar diante à pauta de gênero e ceder a pressões de grupos contrários pode "fragilizar" as escolas, mas reforçam a necessidade das unidades se apoiarem nos marcos legais que garantem a promoção de uma educação comprometida com a igualdade de gênero, raça e sexualidade, como a Constituição Federal, a Lei de Diretrizes e Bases (LDB), o Plano Nacional de Educação (PNE), a própria Lei Maria da Penha e outros dispositivos legais e acordos dos quais o Brasil é signatário.

14.

DATA 16-5-2017

TÍTULO DO ARTIGO: Quando a tática do Estado para lidar com a homofobia é a omissão

Autor: Anna Helena Altenfelder é presidente do Conselho de Administração do Centro de Estudos e Pesquisas em Educação, Cultura e Ação Comunitária-Cenpec. 
Tema:

ARGUMENTO CENTRAL: Os prejuízos com o silenciamento sobre as temáticas de gênero e sexualidade em sala de aula não são apenas da população LGBT, mas de toda a sociedade

Nomes dos atores citados:

Outras Informações importantes:

Resumo: Conforme aponta outra pesquisa, realizada por Miriam Abramovay, as violências cotidianas no ambiente de aprendizado "podem ter como consequência, ainda, constantes trocas de estudantes de sala, mudanças de escola, abandono e reprovações, com impacto direto no fracasso escolar". Ou seja, resultam na sonegação do direito humano à Educação a uma parcela da população brasileira para a qual o Estado tem se mostrado omisso ao não implementar políticas de combate à homo/lesbo/bi/transfobia. Exemplos dessa omissão estão em todas as esferas e em governos de diferentes matizes políticos. É ao que assistimos quando o MEC retira a diversidade sexual e de gênero da Base Nacional Comum Curricular; quando estados e municípios se negam a incluir políticas de combate à homo/lesbo/bi/transfobia em seus planos decenais de Educação; quando o governo federal veta a distribuição do kit anti-homofobia nas escolas; quando vereadores e deputados aprovam projetos de lei inconstitucionais que visam impedir educadores de discutirem essas temáticas; quando professores, gestores e funcionários praticam ou se calam diante da violência. Todas essas atitudes, é importante que se diga, contrariam a Constituição Brasileira, a Lei de Diretrizes e Bases da Educação Nacional (LDB), o Plano Nacional de Educação (PNE), as Diretrizes Nacionais de Educação e Diversidade, além de tratados internacionais de que o Brasil é signatário. Não à toa, o Estado brasileiro já foi questionado sobre esse tema pelo Comitê dos Direitos da Criança da ONU, pelas relatorias especiais do Alto Comissariado de Direitos Humanos e por outros Estados-membros da organização.

15.

DATA 23-6-2017 


\section{TíTULO DO ARTIGO: Governo atua na contramão do PNE}

Autor: Cara, 39, cientista político, coordenador geral da Campanha Nacional pelo Direito à Educação e doutorando em educação (USP).Andressa Pellanda, 26, cientista política e assessora da Campanha Nacional pelo Direito à Educação.

Tema: PNE

ARGUMENTO CENTRAL: O Plano Nacional de Educação 2014-2024 completa seu terceiro ano de vigência e de descumprimento

Nomes dos atores citados:

Outras Informações importantes:

Resumo: É o caso do desmonte do programa Brasil Alfabetizado, da revogação da Portaria do Sistema Nacional de Avaliação da Educação Básica (Sinaeb), da aprovação da Reforma do Ensino Médio; da criação do programa Criança Feliz, das idas e vindas de versões da Base Nacional Comum Curricular (BNCC) - com a retirada dos termos “identidade de gênero" e "orientação sexual” de sua última versão - e da publicação da minuta do novo Programa Nacional do Livro Didático (PNLD), desconsiderando que a BNCC ainda não tem versão final, a ser aprovada pelo Conselho Nacional de Educação (CNE). Está aí a comprovação da falta de prioridade que é dada ao Plano Nacional de Educação pelo governo de Michel Temer.

16.

DATA 26-06-2017

TÍTULO DO ARTIGO: $84 \%$ dos brasileiros apoiam a discussão de gênero nas escolas

Autor: ANA LUIZA BASILIO

Tema: 
ARGUMENTO CENTRAL: Pesquisa ouviu mais de 2 mil entrevistados com 16 anos ou mais em 143 municípios do país

Nomes dos atores citados: Católicas pelo direito de decidir

Outras Informações importantes:

Resumo: Os movimentos contrários à discussão de gênero nas escolas não expressam a opinião da maior parte da sociedade. É o que demonstra uma pesquisa encomendada ao IBOPE Inteligência pela Católicas pelo Direito a Decidir, divulgada na segunda 26. Dados do estudo, realizado em fevereiro deste ano com entrevistados de 143 municípios, revelam que $84 \%$ são favoráveis a discussão sobre igualdade entre homens e mulheres nas escolas; uma parcela de $72 \%$ também apoia a ideia de professores discutirem o direito das pessoas viverem livremente sua sexualidade, sejam elas heterossexuais ou homossexuais.

17.

DATA 6-7-2017

TíTULO DO ARTIGO: Base Nacional Comum Curricular: muitas perguntas, poucas respostas

Autor: ANA LUIZA BASILIO

Tema:

ARGUMENTO CENTRAL: Documento começa a ser discutido na sexta 7 em audiências públicas pelo país; especialistas ainda falam em assegurar pautas importantes

Nomes dos atores citados:

Outras Informações importantes:

Resumo: A BNCC chega à sua terceira e última versão envolta em críticas, em grande parte motivadas pela instabilidade política que atravessa o país. Desde a entrega de sua 
primeira versão, em setembro de 2015, o país já conheceu três ministros da educação e dois presidentes. A expectativa é que a sociedade possa discutir o documento e fazer contribuições antes que o CNE produza um projeto de resolução que deve ser homologado pelo Ministério da Educação (MEC) e então virar norma nacional. O coordenador executivo adjunto da Ação Educativa, Roberto Catelli, tem uma visão um pouco mais otimista com a agenda das audiências, por entender ser uma possibilidade de restabelecer o diálogo com as diferentes representações da sociedade civil. No entanto, entende ser fundamental que se volte no tema da diversidade nas escolas. Nesta última versão, o MEC suprimiu os termos orientação sexual e gênero, cedendo a pressões de representantes das frentes parlamentares evangélica. "Precisamos nos sentir representados", atesta.

20.

DATA 2-8-2017

TÍTULO DO ARTIGO: Escola sem Partido intimida e persegue professores

Autor: ANA LUIZA BASILIO

Tema: Escola sem Partido

ARGUMENTO CENTRAL: Docentes relatam casos de perseguição em sala de aula, sob acusação de doutrinarem seus estudantes

Nomes dos atores citados:

Outras Informações importantes:

Resumo: O especialista relembra o episódio do veto ao material educativo produzido pelo Ministério da Educação 'Escola sem Homofobia', em 2011, que acabou sendo chamado por setores conservadores da sociedade e do Congresso Nacional de 'kit gay'. "A ideologia de gênero é utilizada para causar esse pânico moral”.

Em sua análise, soma-se a isso a agenda do Escola sem Partido, programa criado em 2004 
pelo procurador de Justiça de São Paulo, Miguel Nagib, que defende a ideia de uma "educação neutra" a partir da justificativa de que as escolas seriam locais de doutrinação, em parte praticada pelos professores que se aproveitam da audiência cativa de seus estudantes para impor suas ideias.

21.

DATA 10-10-2017

TíTULO DO ARTIGO: Base Nacional Comum Curricular é alvo de grupos religiosos

Autor: ANA LUIZA BASILIO

Tema:

ARGUMENTO CENTRAL: A Frente Parlamentar Evangélica elaborou um ofício pedindo a retirada dos termos gênero, identidade de gênero e orientação sexual da BNCC

Nomes dos atores citados: deputados federais Takayama (PSC-PR), presidente da Frente Parlamentar Evangélica, Givaldo Carimbão (PHS-AL), presidente da Frente Parlamentar mista Católica Apostólica Romana, Allan Rick (DEM - AC), presidente da Frente Parlamentar em Defesa da Vida e da Família e o senador Magno Malta (PR-ES), presidente da Frente Parlamentar Mista da Família e Apoio à Vida

Outras Informações importantes:

Resumo: Sob a justificativa de alinhamento aos interesses das famílias brasileiras, os proponentes pedem a intervenção do governo para "livrar as crianças de serem submetidas a uma ideologia destinada a desconstruir suas identidades". Segundo os parlamentares, o termo gênero, ao desconsiderar as evidências científicas, e portanto a identidade de gênero e a orientação sexual de cada um, daria espaço para construções sociais impostas sobre os indivíduos.

22. 
DATA 6-12-2017

TÍTULO DO ARTIGO: Gênero e ensino religioso juntos na base curricular

Autor: Carol Scorce

Tema:

ARGUMENTO CENTRAL: CNE delibera versão da BNCC eu orienta o ensino básico no país.

Nomes dos atores citados:

Outras Informações importantes:

Resumo: O mais polêmico ponto é a discussão de gênero e sexualidade, que migrou para uma recém-criada de ensino religioso. A área não existia na versão anterior do documento, apresentado pelo MEC em abril deste ano. Agora, a Base indica que os adolescentes a partir do $9^{\circ}$ ano (15 anos) deverão discutir o tema segundo "diferentes tradições religiosas e filosofias de vida". Na versão da Base elaborada sob a gestão do ministro Mendonça Filho (DEM), trechos que indicavam as discussões de gênero já haviam sido suprimidos. Agora a questão migra para a área do ensino religioso. $\mathrm{O}$ ensino religioso opcional também está previsto no documento. É a Lei de Diretrizes e Bases da Educação (LDB) que prevê o caráter facultativo da matéria, e, por isso, segundo críticos, não deveria estar prevista na Base, cujo objetivo é estabelecer indicadores mínimos de aprendizagem. Um dos aspectos da proposta da BNCC é a presença de propostas que contemplam os interesses dos empresários da educação, como produtores de softwares e materiais educativos, alvo das principais críticas de educadores e pesquisadores que defendem um plano mais inclusivo, priorizando o ensino de caráter público. A ideia de a educação ter um documento nacional que oriente as políticas pedagógicas é uma demanda antiga de educadores, pesquisadores e comunidade escolar de modo geral. Até então as unidades de ensino orientavam suas abordagens de maneira genérica, com prerrogativas distintas definidas por cidades e estados, e por materiais didáticos escolhidos pelo governo federal. A BNCC está prevista na Lei de Diretrizes e Bases da Educação (LDB), promulgada em 1996. Quando o documento ganhar força de lei - ou seja, após a aprovação do Conselho 
Nacional de Educação - ao menos $60 \%$ da pedagogia nas escolas deverão seguir a orientação nacional. Aproximadamente 50 milhões de estudantes serão afetados.

23.

DATA 6-12-2017

TÍTULO DO ARTIGO: MEC rebaixa Conselho Nacional de Educação a cartório

Autor: Fernando Cássio

Tema: Conselho Nacional de Educação

ARGUMENTO CENTRAL: Ao que tudo indica, parecer "técnico" do Conselho Nacional de Educação deve finalizar as discussões sobre a Base Nacional Comum Curricular nos próximos dias

Nomes dos atores citados: Mendonça Filho (ministro da Educação) e Maria Helena Guimarães de Castro (secretária executiva do MEC), Presidente Michel Temer

Outras Informações importantes:

Resumo: Dentre as pequenas questões, o debate especializado sobre os componentes curriculares já se considera superado no adiantado da hora, bem como a retirada das menções a gênero na última versão. Nesse particular, a diretriz do MEC tem sido a de evitar conflitos entre grupos cujos interesses não coincidam com os do próprio Ministério. Retirar para não polemizar. É bem provável que o CNE também não se anime com esse debate.

24.

\begin{tabular}{|l|l}
\hline DATA 8-12-2017 & Educação
\end{tabular}

TÍTULO DO ARTIGO: Jornal Gazeta do Povo cria "Monitor da Doutrinação" para as escolas 


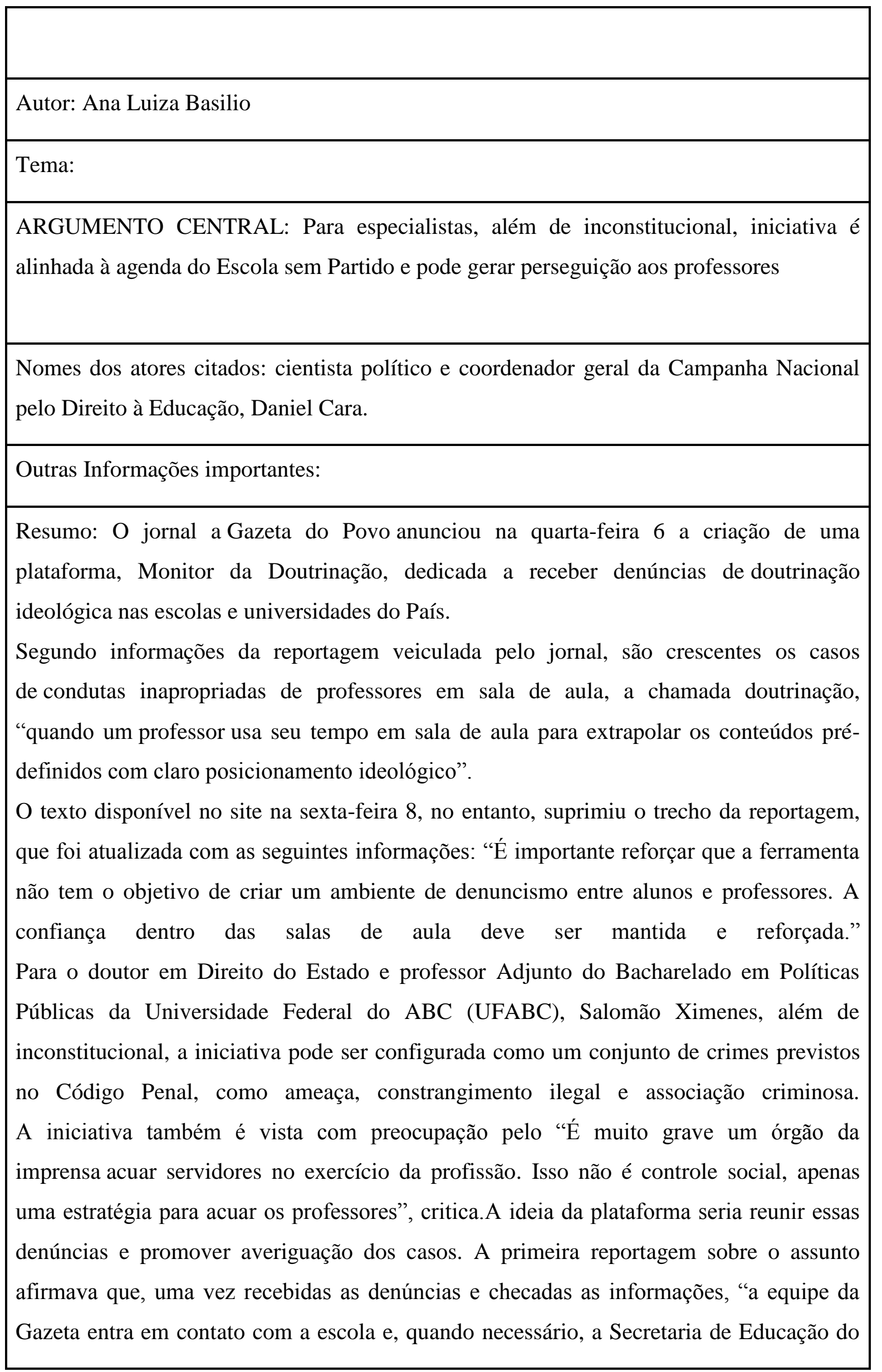


estado ou do município para ouvir a resposta de quem de direito. Para ele, o veículo cria um "tribunal pedagógico" para fazer pressão sobre as comunidades escolares e as escolas, alinhada à agenda do Escola sem Partido. "Isso vai fazer com que os professores tenham medo de abordar em suas aulas temas ligados à conquista dos direitos sociais, sexualidade e teoria da evolução, por exemplo", avalia. Na plataforma é possível buscar o registro das denúncias por modalidade de ensino - Fundamental, Médio e Superior - e também por estado. O que apresenta maior número de registros é o Rio Grande do Sul, com quatro denúncias.

A mais recente diz respeito ao Colégio Municipal Pelotense, em Pelotas (RS), acusado de se aproveitar da Semana da Diversidade para promover a ideologia de gênero. Entre outras críticas, o texto ataca uma palestra dada na escola sobre a experiência de um homem trans. "As informações apresentadas não tinham base científica alguma, eram só teses. O objetivo era doutrinar na questão de gênero", aponta o relato. Em São Paulo, a denúncia é contra a roda de debate Criança Viada Travesti na Escola realizada pela Faculdade de Educação da USP em outubro. No texto publicado no Monitor da Doutrinação há uma crítica ao fato do evento discutir possibilidades de crianças $\begin{array}{llll}\text { viverem fora da } & \text { cis-heteronorma. }\end{array}$ A agenda do evento, na época de sua divulgação, girava em torno da discussão sobre orientação sexual e identidade de gênero na infância e adolescência em espaços educativos. No post do Facebook de divulgação do evento, constam questionamentos tais como: "Como estudantes, profissionais de educação, pesquisadoras e ativistas vem lutando pra transformar a escola em um espaço de proteção, conhecimento e liberdade?" A perseguição às atividades que pautam a diversidade e orientação sexual acontece devido à ideia da ideologia de gênero, "um discurso falacioso e criado para gerar pânico moral", na opinião de Joanna Burigo, mestre em Gênero, Mídia e Cultura e colunista de CartaCapital. A especialista afirma que a agenda é construída dentro de alas bastante conservadoras, ligadas às religiões cristãs, e encontra interlocutores em organizações menores.

Joanna explica que os pressupostos dos estudos de gênero são totalmente contrários à chamada ideologia. "Diferentemente dos que nos chamam de ideólogos de gênero, não trabalhamos para que as crianças sejam o que elas ainda não sabem que são, mas pelo desenvolvimento de políticas públicas capazes de promover uma vida digna às pessoas que já não cumprem certas regras de gênero", explica.

Em seu entendimento isso passa pelo debate da diversidade, da sexualidade e da 
despreparo pedagógico e humano, ao incitar, na escola, o clima de denuncismo e perseguição." Após a repercussão negativa, no domingo 11 o jornal Gazeta do Povo publicou um posicionamento explicando os motivos para a exclusão da ferramenta. No texto, coloca que a repercussão levou a equipe a refletir "se a ferramenta era condizente com o papel da comunicação, a finalidade editorial e a personalidade da Gazeta do Povo." O jornal afirma também ter se questionado se a ferramenta contribuía efetivamente para a construção de um ambiente permanente de debate cordial e construtivo. "Se nos colocávamos de forma amiga, respeitosa e inspiradora para fortalecer a educação brasileira. Se estávamos, de fato, cumprindo o propósito de dar poder às pessoas para compreender e transformar para melhor o seu ambiente. Se colocávamos, nesta ferramenta, a comunicação a serviço do desenvolvimento de nossa terra e nossa gente, como é missão deste veículo." Em outra passagem do posicionamento, o jornal admite concordar com parte substancial da nota de repúdio assinada pelo Sindicato e que, embora não fosse a intenção, a ferramenta acabava por incitar na escola o clima de denuncismo e perseguição. $\mathrm{O}$ veículo, no entanto, alega não concordar com situações de abuso. "Elas existem e têm se tornado muito frequentes, tanto com a manifestação recorrente de opiniões de caráter partidário quanto com a exposição de temas moralmente inadequados", afirma em trecho da reportagem. A Gazeta do Povo afirma que responderá a esses casos com publicações, após rigorosa apuração jornalística. "Não mais com o uso do Monitor da Doutrinação, tirado do ar a partir do momento da publicação deste texto". A nota de repúdio do Sindicato afirmava, ainda, que o jornal estimulava que pais, mães, estudantes e comunidade denunciassem o que, individualmente, considerassem fora dos seus valores familiares, religiosos, políticos e sociais. $\mathrm{O}$ fato de deixar as denúncias públicas na plataforma também foi criticado pela instituição, que pontuou: "assim, a Gazeta faz da sala de aula, palco de repressão moral". A nota ainda afirmava que a ferramenta parecia ter mais uma preocupação política do que realmente educacional. "Ao incitar postagens de denúncias sobre as supostas "doutrinação política" e "ideologia de gênero" - termo já erroneamente carregado de valores moralistas e excludentes - o jornal quer colocar a sociedade em uma disputa maniqueísta. É uma caça ao comunismo, como vista em períodos sombrios da história mundial." Outro trecho do texto questionava a editoria de educação do veículo: "Se o jornal Gazeta do Povo está realmente tão preocupado com o conteúdo pedagógico repassado em sala de aula, por que não há nenhuma matéria ou divulgação da Conferência Nacional Popular de Educação (Conape)? As etapas municipais acontecem neste mês. Esse é o espaço 
organizativo e democrático aberto a todo e qualquer cidadão que queria propor, sugerir, debater sobre tudo que se passa nas escolas (conteúdo, formas de administração, como tratar das questões de igualdade, etc). Especialistas ouvidos por CartaCapital também questionaram a medida. O doutor em Direito do Estado e professor adjunto do Bacharelado em Políticas Públicas da Universidade Federal do ABC (UFABC), Salomão Ximenes, afirmou que a iniciativa não encontrava amparo legal. "Além de inconstitucional, pode ser configurada como um conjunto de crimes previstos no Código Penal, como ameaça, constrangimento ilegal e associação criminosa", disse à reportagem. O cientista político e coordenador geral da Campanha Nacional pelo Direito à Educação, Daniel Cara, também criticou a ação, chamando-a de "tribunal pedagógico" e considerou grave atuação de um veículo de imprensa para acuar servidores públicos em exercício. Para ele, a ferramenta era alinhada à agenda do Escola sem Partido.

26.

DATA 15-12-17

TÍTULO DO ARTIGO: Conselho aprova Base Nacional Comum Curricular

Autor:

Tema:

ARGUMENTO CENTRAL: Em meio a polêmicas sobre ensino religioso e esvaziamento do debate sobre gênero, Conselho Nacional de Educação aprova as diretrizes

Nomes dos atores citados:

Outras Informações importantes:

Resumo: A Base como está é muito criticada por entidades educacionais, especialmente por ter esvaziado questões ligadas à educação de gênero, e que poderiam prever ações de tolerância e respeito nas escolas. A última versão alocou precariamente as questões de gênero dentro de uma área dedicada ao ensino religiosa, igualmente alvo de críticas. O documento Indica que os adolescentes a partir do $9^{\circ}$ ano (15 anos) deverão discutir o tema segundo "diferentes tradições religiosas e filosofias de vida".

O que é 
A ideia de a educação ter um documento nacional que oriente as políticas pedagógicas é uma demanda antiga de educadores, pesquisadores e comunidade escolar de modo geral. Até então as unidades de ensino orientavam suas abordagens de maneira genérica, com prerrogativas distintas definidas por cidades e estados, e por materiais didáticos escolhidos pelo governo federal.

A BNCC está prevista na Lei de Diretrizes e Bases da Educação (LDB), promulgada em 1996. Quando o documento ganhar força de lei - ou seja, após a aprovação do Conselho Nacional de Educação - ao menos $60 \%$ da pedagogia nas escolas deverão seguir a orientação nacional. Aproximadamente 50 milhões de estudantes serão afetados.

27.

DATA $14-02-2018$

TÍTULO DO ARTIGO: MPF pede suspensão de leis que formalizam Escola Sem Partido

Autor:

Tema:

ARGUMENTO CENTRAL: As leis alvos das ações são de Criciúma, em Santa Catarina, e Ocauçu, no interior de São Paulo

Nomes dos atores citados:

Outras Informações importantes:

Resumo: A Procuradoria Federal dos Direitos do Cidadão (PFDC), do Ministério Público Federal (MPF), quer que o Supremo Tribunal Federal (STF) suspenda e julgue a inconstitucionalidade de duas leis municipais que tratam do ensino de questões de gênero e da Escola Sem Partido. Para a procuradoria, as regras violam garantias fundamentais do direito à educação. Uma das leis foi aprovada pelo município de Criciúma, em Santa Catarina, e cria o chamado Programa Escola Sem Partido. A norma ${ }^{\circ}$ 7.159/2018 diz que “o poder público não se imiscuirá no processo de amadurecimento sexual dos alunos nem permitirá qualquer forma de dogmatismo ou proselitismo na abordagem de gênero". Também estabelece que o $\mathrm{s}$ professores não podem manifestar opinião política ou estimular a participação dos estudantes em protestos, entre outras regras. A outra norma 
que o órgão do MPF pede que seja sustada é a do município de Ocauçu, em São Paulo. Nesta cidade, a Lei 1.725/2017 proibiu a distribuição, apresentação ou indicação de qualquer material, como livros e filmes, "contendo manifestação subliminar da igualdade (ideologia) de gênero nos locais Públicos, Privados de Acesso ao Público e Entidades de Ensino". Entre os temas vetados, a norma cita explicitamente "igualdade ou desigualdade de gênero".

Direito à educação

A Procuradoria afirma que as leis violam o direito à educação, a liberdade de ensino e o direito da criança, do adolescente e do jovem a ser colocado a salvo de toda forma de discriminação e violência. Afirma também que as normas ferem o direito de o estudante receber uma educação que o prepare para o exercício da cidadania, o respeito à diversidade e para o convívio em uma sociedade plural - princípios tratados como básicos pela Constituição Federal Brasileira. Além disso, aponta que elas violam o pacto federativo por incidirem em uma área, a fixação de diretrizes e bases da educação, que é de competência federal. Por outro lado, pondera que o Brasil é signatário de pactos que tratam da questão de gênero, como a Convenção Interamericana para Prevenir, Punir e Erradicar a Violência contra Mulher, de 1994, que prevê a educação como instrumento imprescindível para o combate à violência contra a mulher. Após exposição sobre os conceitos e a doutrina jurídica, a procuradoria conclui que "o propósito da lei impugnada de cercear a discussão, no ambiente escolar, de certos assuntos, contraria os princípios conformadores da educação brasileira, dentre os quais, as liberdades constitucionais de aprender, ensinar, pesquisar e divulgar a cultura, o pensamento, a arte e o saber; o pluralismo de ideias e de concepções religiosas e de concepções pedagógicas; e a gestão democrática do ensino público". As representações sobre as duas leis municipais foram entregues à procuradora-geral da República, Raquel Dodge, a quem cabe ingressar com ações perante o Supremo Tribunal Federal (STF). Não há data fixada para que Dodge manifeste-se sobre o pedido.

28.

DATA 23-02-2017

TÍTULO DO ARTIGO: Entidades elaboram manual contra a censura nas escolas

Autor: 
Tema:

ARGUMENTO CENTRAL: Projeto será produzido a partir de financiamento coletivo; ideia é respaldar professores contra grupos conservadores

Nomes dos atores citados: Ação Educativa, QuatroV, Rede Escola Pública e Universidade e Agência Pressenza

Outras Informações importantes:

Resumo: A ideia é produzir um documentário sobre o assunto, além de um e-book e um site, onde os professores poderão encontrar informações como: o que fazer se a sua sala de aula for invadida, como proceder se publicarem um vídeo te difamando, principais tipos de defesa jurídica e administrativa, como denunciar as tentativas de censura na imprensa, como retirar conteúdo difamatório da internet e um guia de bolso com telefones e informações úteis.

29.

\begin{tabular}{|l|l|}
\hline DATA 08-0302018 & Sociedade \\
\hline TÍTULO DO ARTIGO: As evangélicas e a justiça de gênero
\end{tabular}

Autor: Magali do Nascimento Cunha

Tema:

ARGUMENTO CENTRAL: As injustiças contra as quais as mulheres lidam atualmente são derivadas da ideologia de gênero patriarcal.

Nomes dos atores citados:

Outras Informações importantes: Texto muito bom para entender religião cristã e gênero.

Resumo: Esta ideologia de gênero continua sendo difundida pela educação formal, pelo conjunto de leis, pelos meios de comunicação, pelas religiões. Como o poder de uma ideologia é tornar as coisas naturais, homens e mulheres a reproduzem como algo "normal" e certo. E dela vêm o silenciamento, a conformação e também a violência nas 
constituíram como dominantes. Em nosso caso, as diferentes vertentes do cristianismo. Este imaginário, que protege algumas vertentes religiosas, permite que atrocidades sejam cometidas em nome da fé e de uma pretensa moral. Ainda, a utilidade do manto místico dos saqueadores inspira formas modernas de dissimular a destruição. Como nos slogans: Deus é bom e agro é pop.

Assim, muitos líderes religiosos que sofrem acusações e processos por crimes como pedofilia, corrupção, violência sexual, apologia ao estupro, dentre outros, são muitas vezes protegidos por suas próprias comunidades de fé, no lugar de ser no mínimo repreendidos por elas.

Armados deste poder religioso, os cavaleiros do apocalipse tomaram de assalto as instâncias políticas, fornecendo a "Bíblia" como mais uma arma aos interesses compartilhados com a Bancada do "Boi" e a da "Bala" na manutenção de seus privilégios. Os sinais deste verdadeiro apocalipse, patrocinado por um falso moralismo religioso, são abundantes. $\mathrm{O}$ avanço recente do projeto Escola Sem Partido é um deles. O projeto que tem como propulsora a bancada religiosa, segunda maior do Congresso, objetiva proibir a utilização do conceito de gênero e expressões como identidade de gênero em sala de aula. No último 8 de maio, a comissão especial incumbida de analisar o projeto, também composta por integrantes da bancada religiosa, apresentou relatório favorável à proposta. Ao criticar o que define como "ideologia de gênero", o relator, o deputado Flavinho do PSC, não dissimula seu partidarismo, e aponta sem nenhum constrangimento a pluralidade e diversidade sexual como males a serem combatidos para o bem da continuidade da espécie e da manutenção da sociedade ocidental.

A falsa neutralidade exigida de quem está à frente da tarefa educativa é na verdade a obrigação de que se assuma a posição política excludente e opressora do projeto, que se constitui destarte como uma violação ao Estado laico e uma infinidade de direitos. Laicidade que é uma condição fundamental para uma democracia efetiva. Para além dos canais de comunicação (tevê, rádio, jornal) de que são proprietários ou aliados, da utilização das novas mídias sociais digitais e dos seus tradicionais púlpitos como instrumentos de propagação ideológica, buscam agora o reconhecimento institucional para atuar com o mesmo fim no currículo e dinâmica escolares. Uma interferência política grave no presente da educação, como também no futuro social, atuando deliberadamente para que as injustiças, as desigualdades e as violências não sejam enfrentadas e, portanto, sigam vigorando.

Inútil seria tentar argumentar com estes cavaleiros que o reconhecimento da existência de 
diferentes configurações familiares, da diversidade no campo da orientação e identidade sexual, não altera em nada os direitos daqueles que vivem situações reconhecidas dentro do padrão normativo atualmente. Mas sim a ampliação desses conceitos a fim de eliminar a zona de vulnerabilidade e desproteção de quem não é reconhecido pela norma.

Inútil ainda seria apresentar os dados históricos que comprovam que a civilização ocidental, forjada sob a égide religiosa com a força bélica e o esteio do ouro, verte sangue e suor da exploração e dor da maioria em prol do regozijo de uma ínfima minoria.

Inútil seria, pois é propriamente esta sociedade que pretendem manter. Seus alvos não são aleatórios, são desveladamente selecionados para abrir caminho ao projeto de dominação. Seguem eles, os cavaleiros do apocalipse, cavalgando leviandade e aniquilando qualquer manifestação de vida que se levante em meio a sua devastação.

Eles estão por toda a parte, utilizando Bíblias como armas antidireitos e vestindo Cristo como escudo. Mas não poderiam estar mais distantes "Dele”. Basta olhar com mais cuidado para ver que estão desnudos.

31.

DATA 14-05-2018

TÍTULO DO ARTIGO: Falso discurso da Escola Sem Partido avança no Congresso

Autor: João Batista da Silveira

Tema:

ARGUMENTO CENTRAL: Para coordenador da Contee, projetos da Escola Sem Partido representam a nova Lei da Mordaça

Nomes dos atores citados: Ler o texto.

Outras Informações importantes: O texto explica todo o processo de instituição do projeto "Escola sem Partido"

Resumo: Na terça-feira 8, o deputado Flavinho (PSC) apresentou o projeto da Escola Sem Partido (PL 7180/14) prevendo que cada sala de aula tenha um cartaz com seis deveres dos professores, entre os quais o primeiro é a proibição de que os docentes "cooptem" os estudantes para correntes políticas, ideológicas ou partidárias. 
O projeto propõe, na verdade, a escola de partido único, porque pró́be o debate e a livre circulação de idéias nas salas de aula. Para muitos, trata-se de uma verdadeira "Lei da Mordaça".

O programa obriga os professores a manter a suposta neutralidade em sala de aula ao lecionar várias disciplinas como, por exemplo,história e geografia. Claro que não se pode ser favorável a nenhuma espécie de doutrinação no ambiente escolar, mas os defensores do Escola sem Partido, como destacou a Confederação Nacional dos Trabalhadores em Estabelecimentos de Ensino (Contee) ao dizerem que "desconhecem solenemente o processo pedagógico, uma vez que educação pressupõe, em seu sentido pleno, o incentivo à capacidade reflexiva, ao diálogo, à construção da cidadania, sendo, portanto, uma atividade política por excelência, no aspecto etimológico da palavra".

Qualquer proposta fora disso é defender uma escola acéfala, que formaria estudantes completamente alienados. Desnecessário dizer que esse é o mundo ideal para os maus políticos.

Como falar do Golpe Militar de 1964 sem lembrar as perseguições, prisões e assassinatos de civis promovidos pelo Estado brasileiro durante a Ditadura Militar? Como explicar o fim da União Soviética sem uma contextualização política e econômica?

Os apoiadores mais afoitos (e conservadores) dessa proposta já defendem até exclusão de disciplinas como Filosofia e Sociologia da grade curricular das escolas. Um absurdo total; ou seja, seria cômico se não fosse trágico, uma vez que, em caso de descumprimento dessas propostas de lei, professores estariam sujeitos a várias punições, que vão desde uma suspensão, demissão e até, acredite, prisão.

Apesar de não ter qualquer sustentação pedagógica e jurídica, as propostas do tal Escola sem Partido já tramitam em vários Estados brasileiros. Em 2017, o Partido Progressista, o Partido Social Cristão, Partido da Social Democracia Brasileira e MDB (Movimento Democrático do Brasil, ex-PMDB) foram os partidos que mais apresentaram PLs do 'Escola sem Partido' e contra 'ideologia de gênero' pelo país.

Desde 2014, quando foi apresentado o primeiro projeto de lei, de autoria de Flávio Bolsonaro, na Assembleia Legislativa do Rio de Janeiro, a média por ano de projetos idênticos ficava em torno de 20. Em 2017, chegou a 91, de acordo como estudo do grupo Professores Contra o Escola Sem Partido.

Melhor seria se esses políticos substituíssem os professores por robôs que poderiam, assim, transmitir o conteúdo para os alunos ou talvez simplificar tudo com uma simples consulta na internet. 
É bom lembrar que o referido programa ainda contraria a Constituição Federal, que prevê a liberdade de aprender, ensinar, pesquisar e divulgar o pensamento, a arte e o saber. A Contee tem reiteradamente apontado - incluindo na campanha nacional contra a Lei da Mordaça e na vitoriosa Ação Direta de Inconstitucionalidade (ADI) impetrada no Supremo Tribunal Federal - que a censura, a perseguição e a criminalização dos professores representam uma afronta à Constituição, à liberdade de aprender e ensinar e à concepção de uma educação crítica, democrática e cidadã.

No ano passado, a educação brasileira foi criticada pela Organização das Nações Unidas $(\mathrm{ONU})$ precisamente pela retirada dos termos "gênero" e "orientação sexual" do texto da Base Nacional Comum Curricular (BNCC).

A Lei da Mordaça afronta os principais tratados internacionais dos quais o Brasil é signatário, entre eles a Declaração Universal dos Direitos Humanos que, no seu artigo 18, destaca:

“Toda pessoa tem direito à liberdade de pensamento, de consciência e de religião; este direito implica a liberdade de mudar de religião ou de convicção, assim como a liberdade de manifestar a religião ou convicção, sozinho ou em comum, tanto em público como em privado, pelo ensino, pela prática, pelo culto e pelos ritos”.

E no artigo 19: “Todo o indivíduo tem direito à liberdade de opinião e de expressão, o que implica o direito de não ser inquietado pelas suas opiniões e o de procurar, receber e difundir, sem consideração de fronteiras, informações e ideias por qualquer meio de expressão...".

32.

DATA 11-06-2018

TíTULO DO ARTIGO: Educação deve ser arma contra o racismo

Autor: José de Ribamar Virgolino Barroso, coordenador da Secretaria de Finanças da Confederação Nacional dos Trabalhadores em Estabelecimentos de Ensino (Contee)

Tema: Preconceito, desigualdade e educação

ARGUMENTO CENTRAL: Uma educação de qualidade ensina a ética e o respeito às diferenças, busca a construção de uma sociedade sem preconceitos e sem violência 
Nomes dos atores citados:

Outras Informações importantes:

Resumo: Texto com dados e informações sobre a desigualdade nas escolas e universidades no Brasil. 


\section{APÊNDICE 4 - DADOS DA REVISTA FÓRUM}

1.

DATA 27-01-2016

TíTULO DO ARTIGO: Mulheres e LGBTs do PT repudiam declarações de exministro Luiz Marinho

Autor: Ivan Longo

Tema: Discussão de gênero nas escolas

ARGUMENTO CENTRAL:

Nomes dos atores citados: Luiz Marinho e setorial de Mulheres e LGBT do Partido dos Trabalhadores

Outras Informações importantes:

Resumo: O petista, que é prefeito de São Bernardo do Campo (SP), vem sendo alvo de críticas por, supostamente, ter cedido a setores conservadores ao se posicionar contra a inclusão do ensino de diversidade sexual nas escolas da cidade; em vídeo, Marinho procura desmentir boatos sobre a lei e defende a "família".

2.

DATA $17-01-2016$

TÍTULO DO ARTIGO: Bolsonaro grava vídeo sobe educação e revista especializada desmente frase por frase

Autor:

Tema:

ARGUMENTO CENTRAL:

Nomes dos atores citados:

Outras Informações importantes: 
Resumo: O deputado federal havia publicado em seu Facebook um vídeo em que criticava o material "Escola sem homofobia", que ele insiste em chamar de "kit gay" e que, ao contrário do que diz, está engavetado desde 2011; diante das mentiras, a revista Nova Escola, especializada em educação, corrigiu cada informação errada dita por Bolsonaro; “Quando o assunto é educação, pergunte a quem conhece”.

No último dia 10 de janeiro o deputado federal Jair Bolsonaro (PP-RJ) publicou em seu Facebook um vídeo em que se propõe falar sobre o tema 'educação'. Sua fala, no entanto, foi toda direcionada à críticas ao caderno do Governo Federal "Escola sem homofobia", material didático para escolas públicas sobre questões de gênero e sexualidade que, por pressão de frentes conservadoras, está engavetado desde 2011.

Bolsonaro, entre outras inverdades que diz ao longo de todo o vídeo, mostra livros que sequer são distribuídos nas escolas e ainda confunde a revista 'Nova Escola' também com um livro, afirmando que ela é distribuída para crianças em escolas públicas.

A publicação, então - que é especializada em educação -, resolveu produzir um outro vídeo em que desmente cada informação improcedente dita por Bolsonaro.

“Quando o assunto é educação, pergunte a quem conhece", escreveu a revista no final do vídeo que batizou de "Checagem de informações".

3.

DATA 02-06-2016

TÍTULO DO ARTIGO: Qual o partido da escola sem partido?

Autor: Fernando Nicolazzi, no $\underline{\text { Sul21 }}$

Tema: Escola sem Partido

ARGUMENTO CENTRAL: Como seria possível definir o projeto educacional de um país a partir da noção vaga e enganosa de "neutralidade"? A própria escolha pela educação já é uma opção política

Nomes dos atores citados: deputado federal Izalci Lucas Ferreira, deputado Erivelto Santana, vereador Valter Nagelstein e deputado estadual Marcel van Hattem

Outras Informações importantes: 
Resumo: No dia 24 de maio, a Câmara Municipal de Porto Alegre deu abertura ao processo referente ao PLL 124/2016, de autoria do vereador Valter Nagelstein. Segundo nos é informado no site da Câmara, tal projeto tem por objetivo instituir, "no âmbito da educação municipal, as diretrizes orientadoras ao comportamento aos estabelecimentos de ensino, funcionários, responsáveis e corpo docente, no ministério que envolve o ensino de questões sócio-políticas, preconizando a abstenção da emissão de opiniões de cunho pessoal que possam induzir ou angariar simpatia a determinada corrente políticopartidária-ideológica, desviando-se da neutralidade e do equilíbrio necessários à condução do aprendizado do corpo discente".

O fato traz para o contexto municipal uma situação mais abrangente que envolve projetos apresentados em outros âmbitos legislativos nacionais, como é o caso, para citar apenas dois exemplos, do PL 190/2015, protocolado na Assembleia Legislativa do Rio Grande do Sul pelo deputado estadual Marcel van Hattem, e do PL 867/2015, proposto à Câmara dos Deputados pelo deputado federal Izalci Lucas Ferreira. Em comum, todos incidem diretamente nas formas de atuação de professores e professoras em diferentes níveis de educação. Além disso, vinculam-se, em graus variados, ao programa defendido pelo movimento intitulado "Escola sem partido", cujo mote principal é "educação sem doutrinação", recentemente apresentado ao Ministro da Educação interino, Mendonça Filho, pelo ator Alexandre Frota e por representantes do grupo Revoltados Online.

Esta situação demanda uma reflexão sobre os sentidos e significados da educação para nossa sociedade e, de forma ainda mais relevante, sobre o papel da escola e dos profissionais da educação na construção e difusão dos princípios democráticos e dos valores de cidadania a eles atrelados. De modo geral, os textos destes projetos e suas respectivas justificativas invocam a neutralidade do Estado contra o que é definido como doutrinação ideológica, política e partidária, sem que uma definição mínima do que vem a ser tal doutrinação seja oferecida e justapondo de forma pouco precisa conceitos como ideologia política e ideologia partidária.

Um dos pontos mais controversos destes projetos reside na ideia de que os educadores e educadoras não devem discutir, nos espaços escolares, temas e conteúdos que possam contradizer as convicções morais dos pais e mães dos estudantes. Dependendo da turma, um professor estaria em uma situação de impasse ao tratar das origens da humanidade, pois não poderia discutir o evolucionismo diante de um aluno cuja crença familiar preconizasse o criacionismo. Da mesma forma, um adepto do liberalismo poderia ter sua moral familiar questionada em uma aula de história que discutisse as relações entre classes 
sociais e industrialização no século XIX, ou uma família socialista poderia acusar o professor do seu filho de ferir seus valores morais em uma aula sobre a ideologia liberal e a crença no livre mercado. E estes exemplos nem tocam ainda em outras questões tão ou mais sensíveis, como a educação sexual e o tema das relações de gênero.

4.

\begin{tabular}{l}
\hline DATA 04-06-2016 \\
\hline $\begin{array}{l}\text { TíTULO DO ARTIGO: O que fazia uma seita religiosa em uma escola } \\
\text { estadual paulista? }\end{array}$
\end{tabular}

Autor: Maria Izabel Azevedo Noronha presidente do Sindicato dos Professores do Ensino Oficial do Estado de São Paulo

Tema: Escola sem partido

ARGUMENTO CENTRAL: Conservadorismo nas escolas prejudica o ensino e os profissionais do ensino.

Nomes dos atores citados:

Outras Informações importantes:

Resumo: "Qual seria a finalidade desta visita? Estariam realizando doutrinação religiosa num espaço público de educação, sob responsabilidade do governo de São Paulo?". Em artigo, presidenta da Apeoesp denuncia a visita de integrantes de uma seita religiosa conservadora em uma escola pública.

A onda conservadora que estamos vivendo fez com que fossem retiradas de diversos planos estaduais e municipais de educação referências às questões de gênero, questões étnicas, referências a opções sexuais e outros assuntos incômodos aos conservadores. Também têm sido apresentados projetos de lei nas assembleias legislativas, câmaras municipais e no Congresso Nacional que preveem até mesmo penas de prisão a professores/as que tratem destes assuntos em sala de aula ou quaisquer outros espaços nas escolas.

Ao mesmo tempo em que são criminalizados os professores que ousam pensar e debater com os estudantes temas que contribuem para a sua formação integral como cidadãos e 
cidadãs conscientes, setores conservadores encastelados no Estado brasileiro acolhem e apoiam organizações conservadoras e seitas religiosas que nada têm a fazer no interior de uma escola pública. As imagens que encaminhamos anexo mostram integrantes da seita Arautos do Evangelho em visita à Escola Estadual Fernão Dias Paes, na tarde da quintafeira, 2 de junho.

5.

DATA16-06-2016

TíTULO DO ARTIGO: Clóvis Gruner: O excepcional normal

Autor: Clóvis Gruner

Tema: Educação e conservadorismo

ARGUMENTO CENTRAL: O conservadorismo gera violência.

Nomes dos atores citados:

Outras Informações importantes: Texto de opinião

Resumo: Aqui nossa esfera pública é atravessada pela vontade religiosa e privada: nas escolas, estamos proibidos de discutir gênero; psicologias cristãs defendem a “cura gay"; e o Estado ameaça com um Estatuto que não reconhece como família outra que não a formada pela união entre um homem e uma mulher.

A discriminação contra a comunidade LGBT, portanto, não se limita aos países e sociedades orientais nem, tampouco, tem matriz exclusivamente religiosa. Antes pelo contrário, estamos a falar de práticas que reverberam ao longo da história, inclusive nos limites do que se convencionou chamar "civilização Ocidental", e mesmo depois de consolidadas as democracias liberais, a laicidade do Estado e a cultura urbana e moderna. Saber disso é importante para não tomarmos como exceção o que, quase sempre, é parte da nossa normalidade cotidiana.

6.

DATA 08-07-2016 


\section{TíTULO DO ARTIGO: Deputada evangélica pede "providências legais" contra professor que debateu homofobia em sala de aula}

Autor:

Tema:

ARGUMENTO CENTRAL:

Nomes dos atores citados: Dep. Sandra Faraj (SD-DF)

Outras Informações importantes:

Resumo: A deputada do Distrito Federal, Sandra Faraj (SD), enviou um ofício a uma escola da cidade de Ceilândia cobrando explicações sobre um trabalho escolar que tratava de homofobia e outros temas que envolviam sexualidade. Entidades de educação e professores repudiaram a atitude da deputada.

No final do mês passado, um professor do segundo ano do ensino médio do Centro Educacional 6 de Ceilândia pediu um trabalho em grupo para os estudantes sobre os temas: homofobia, transexualidade, poliamor, pansexualidade e integração entre gêneros. Depois de ter recebido reclamações sobre esse debate em seu gabinete, Sandra Faraj decidiu encaminhar um ofício ao colégio cobrando "esclarecimentos" e "providências legais cabíveis".

A Secretaria de Educação do Distrito Federal disse que o debate sobre questões de gênero e sexualidade em sala de aula está previsto no Plano Distrital de Educação (PDE) e no Plano Nacional de Educação (PNE).

“Trabalhos de cunho pedagógico desenvolvidos por professores em sala de aula, que contemplem temáticas sociais, estão em conformidade com o Plano Nacional de Educação (PNE), previstos, inclusive, na discussão sobre cidadania e para os Direitos Humanos", afirmou em nota.

A deputada federal Erica Kokay (PT-DF) entregou na quinta-feira (7) uma representação por quebra de decoro parlamentar contra Sandra Faraj. O documento foi protocolado na Câmara Legislativa junto de representantes do Sindicato dos Professores, do Conselho de Direitos Humanos do DF e do Conselho Regional de Psicologia.

Em resposta, Sandra se disse vítima de uma perseguição e que as escolas só devem ensinar matérias como Matemática, Língua Portuguesa, Ciências, Física e Química. 
7.

DATA 12-07-2016

TÍTULO DO ARTIGO: Em algumas horas, MEC nomeia e exonera economista ligado ao "Escola Sem Partido"

Autor:

Tema: Escola sem Partido

ARGUMENTO CENTRAL:

Nomes dos atores citados:

Outras Informações importantes:

Resumo: Saiu no Diário Oficial da União da última segunda-feira (11) a nomeação de Adolfo Sachsida para o cargo de assessor especial do ministro da Educação Mendonça Filho. A nomeação, porém, foi cancelada na manhã desta terça-feira, (12).

Saschida é apoiador do "Escola sem Partido", um movimento que visa a "neutralidade do ensino", é contra a "doutrinação ideológica" nas escolas e tem ganhado força nos últimos meses. O ministro da Educação já afirmou ser contra o projeto. Apesar disso, uma professora de sociologia foi suspensa de uma escola depois que seus alunos fizeram uma paródia do funk "baile de favela" que abordava Karl Marx.

8.

DATA $14-07-2-16$

TÍTULO DO ARTIGO: Uma farsa chamada "Escola sem Partido"

Autor: Clóvis Gruner historiador e professor na Universidade Federal do Paraná

Tema: Escola sem Partido

ARGUMENTO CENTRAL:

Nomes dos atores citados:

Outras Informações importantes: 
Resumo: "A Escola sem Partido teme uma sociedade mais plural e sensível às diferenças e a diversidade, sejam elas étnicas, religiosas, de classe ou gênero, e sabe que uma escola e uma educação de qualidade são condições imprescindíveis para a construirmos"".

Hoje, projetos de lei que visam banir do ensino a "doutrinação ideológica" e instituir uma "escola sem partido" seguem em andamento em sete estados (RJ, GO, SP, ES, CE, RS, PA) e no DF. Em um, Alagoas, ele já foi aprovado pela Assembleia Legislativa. A inconsistência do projeto aparece já na argumentação que o justifica: o objetivo é "garantir a neutralidade política, religiosa e ideológica" e, ao mesmo tempo, "a pluralidade de ideias". Bom, ou bem se é neutro, ou bem se é plural: ser ao mesmo tempo duas coisas antagônicas e excludentes é bastante difícil. Mas a contradição não é o único nem o maior problema do projeto e da escola que ele pretende parir.

9.

DATA 16-10-2016

TíTULO DO ARTIGO: Sindicalistas, estudantes e pais lançam "Frente Escola sem Mordaça" no Rio de Janeiro

Autor: Do Brasil de Fato

Tema: Censura nas escolas

ARGUMENTO CENTRAL: Movimento contra o Escola sem Partido se organizam após consequências do projeto.

Nomes dos atores citados:

Outras Informações importantes:

Resumo: Neste sábado (15), quando se comemorou o Dia dos Professores, sindicalistas, docentes, estudantes, ativistas, mães, pais e responsáveis do Rio de Janeiro (RJ) lançaram a Frente Estadual Escola sem Mordaça, que se posiciona de forma contrária aos projetos de lei que instituem a programa Escola sem Partido, à reforma do ensino médio instituída via medida provisória pelo governo de Michel Temer e à PEC 241, que congela os gastos do governo por 20 anos - inclusive os da educação e da saúde. O ato 
aconteceu na orla da praia de Copacabana.

10.

DATA 05-09-2016

TíTULO DO ARTIGO: Prefeito que proibiu livros sobre união homossexual é obrigado a devolvê-los às escolas

Autor: Ivan Longo

Tema: Ideologia de Gênero

ARGUMENTO CENTRAL:

Nomes dos atores citados: prefeito de Ariquemes (RO), Thiago Flores (PMDB), deputado federal Jean Wyllys (PSOL-RJ), juíza federal Maria Lúcia Gomes de Souza

Outras Informações importantes:

Resumo: Thiago Flores (PMDB), prefeito de Ariquemes (RO), havia mandado retirar as páginas de um livro didático que apresenta diferentes formas de famílias e impediu que ele fosse distribuído nas escolas. Na época, o deputado Jean Wyllys entrou com uma representação contra a prefeitura e Flores chegou a zombar do parlamentar, mas Justiça concordou com Wyllys e livros devem ser distribuídos imediatamente.

11.

DATA06-09-2016

TÍTULO DO ARTIGO: Vereador chama Simone de Beauvoir de 'devassa' durante votação do 'Escola sem Partido'

Autor: Ivan Longo

Tema:

ARGUMENTO CENTRAL: 
Nomes dos atores citados: vereadores da cidade de Campinas, SP

Outras Informações importantes:

Resumo: A Câmara dos Vereadores de Campinas, cidade do interior de São Paulo, aprovou em primeiro turno de votações o projeto "Escola sem Partido", que impõe uma série de regras e restrições aos professores em sala de aula. A proposta foi apresentada pelo vereador Tenente Santini (PSD), que é ex-policial militar, e obteve 25 votos favoráveis contra cinco. Foram mais de três horas de discussões sobre o tema na noite de segunda-feira (4).

De acordo com o texto, os professores ficam proibidos de expressar opiniões e até mesmo de abordar certos temas. "Os viúvos da ditadura militar precisam entender que essa Constituição valoriza o estado democrático de direito", disse o vereador oposicionista Gustavo Petta (PCdoB).

Outro projeto, chamado de "Escola sem Censura", de autoria da vereadora Mariana Conti (Psol), chegou a ser discutido na pauta da Casa, entretanto, foi arquivado. A proposta antagônica, que pretendia "vedar qualquer tipo de censura de natureza política, ideológica, filosófica, artística, religiosa e cultural a estudantes e professores" não obteve parecer de legalidade da Comissão de Constituição e Justiça da Câmara, por "já existir matéria correlata", no caso o "Escola sem Partido".

12.

DATA 20-10-2017

TÍTULO DO ARTIGO: Aluna é suspensa depois de criticar escola que proibiu discutir sexo, gênero e religião

Autor:

Tema:

ARGUMENTO CENTRAL:

Nomes dos atores citados:

Outras Informações importantes: 
Resumo: Jovem de 17 anos resolveu rebater panfleto lançado pela escola Univest de Lages, em Santa Catarina, e recebeu punições; mãe estuda acionar a Justiça.

13.

DATA 29-10-2017

TÍTULO DO ARTIGO: Grupo fascista cria tumulto em debate sobre ideologia de gênero em Guarujá

Autor:

Tema: Religião e "ideologia de gênero"

ARGUMENTO CENTRAL: Durante uma discussão sobre gênero, um grupo de fanáticos neopentecostais invadiu a atividade e passou a ofender e ameaçar as pessoas presentes, além de tentar impedir o andamento da atividade.

Nomes dos atores citados:

Outras Informações importantes:

Resumo: Um show de intolerância, fascismo, falta de respeito e educação foi visto no evento Desafios de uma educação libertadora, que debateu questões relacionadas à ideologia de gênero e ao universo LGBT, realizado neste sábado (28), na Câmara Municipal de Guarujá, litoral de São Paulo. Durante os debates, um grupo de fanáticos neopentecostais invadiu a atividade, provocando tumulto, ofendendo e ameaçando as pessoas presentes, além de tentar impedir o andamento da atividade. A organização do encontro, democraticamente, concedeu o direito à fala aos fascistas, que se utilizaram do microfone para destilar o ódio peculiar, mas, em contrapartida, queriam impedir de se pronunciar quem tivesse ideias diferentes.

Os debatedores ressaltaram a importância de se respeitar as diferenças, em todos os níveis. No entanto, o grupo de extrema direita, por não conhecer essa linha de pensamento, grosseiramente, tentou estragar o evento.

14.

DATA $14-11-2017$ 
TÍTULO DO ARTIGO: Carlos Vereza vai pedir a Temer, "o comandante supremo", que combata ideologia de gênero

Autor: Julinho Bittencourt

Tema: Ideologia de Gênero

ARGUMENTO CENTRAL: Ator pede intolerância.

Nomes dos atores citados: Carlos Vereza e Michel Temer.

Outras Informações importantes:

Resumo: O ator Carlos Vereza foi ao gabinete em Brasília, nesta segunda-feira (13), pedir a Michel Temer que combata a ideologia de gênero.

De acordo com informações da coluna de Lauro Jardim, durante a reunião, o ator disse que esse debate está "erotizando e traumatizando as crianças".

E pediu ajuda de Temer, "como comandante supremo do país", para tomar uma medida para "parar com a solerte ideologia de gênero".

Segundo ele, professores "estão brincando de Deus e mudando toda a biologia".

15.

DATA 06-12-2017

TÍTULO DO ARTIGO: Temer exclui combate à discriminação de gênero na base curricular e inclui tema na área de Ensino Religioso

Autor: Ivan Longo

Tema: Base Nacional de Conteúdo Curricular

ARGUMENTO CENTRAL: Pela nova base curricular, as discussões de gênero e sexualidade nas escolas serão feitas apenas de acordo com as tradições religiosas.

Nomes dos atores citados:

Outras Informações importantes:

Resumo: A nova base curricular do Ministério da Educação, atendendo à pressão da 
bancada religiosa no Congresso, excluiu dezenas de menções ao combate à discriminação de gênero nas escolas e misturou o pouco que sobrou do tema com a área de Ensino Religioso. Ou seja, gênero e sexualidade serão discutidos de acordo com as tradições religiosas. A partir do ano que vem, as escolas devem discutir discriminação de gênero e sexualidade apenas dentro do âmbito do Ensino Religioso. A mudança foi apontada na nova versão Base Nacional Comum Curricular elaborada pelo Ministério da Educação. Na nova edição, foram excluídas dezenas de menções à discriminação de gênero e a temática foi incorporada à disciplina de Ensino Religioso. O documento deve ainda passar por modificações e uma aprovação final de um conselho ligado ao MEC.

16.

DATA10-12-2017

TÍTULO DO ARTIGO: Apesar de vetado pelo STF, municípios proíbem discussão de gênero nas escolas

Autor: Julinho Bittencourt

Tema: Ideologia de Gênero e Religião

ARGUMENTO CENTRAL:

Nomes dos atores citados:

Outras Informações importantes:

Resumo: Apesar da liminar do ministro do Supremo Tribunal Federal (STF) Luís Roberto Barroso que considerou inconstitucional uma lei estadual de Alagoas, já que cabe à União legislar sobre Educação, projetos de lei desse tipo se espalham pelo país. Em 14 municípios de nove estados do país já existem leis que proíbem — ou estão prestes a proibir - professores de discutir ou usar em sala de aula material didático que se refira a questões de gênero e religiões. Também há restrições a comentários políticos. No total, são afetados cerca de 270 mil alunos do ensino fundamental, com idade média entre 6 e 14 anos. 
DATA 24-05-2017

TÍTULO DO ARTIGO: Rio vota projeto que proíbe ensino sobre gênero e orientação sexual nas escolas

Autor: Felipe Martins

Tema: Educação e Ideologia de gênero

ARGUMENTO CENTRAL:

Nomes dos atores citados:

Outras Informações importantes:

Resumo: Os profissionais de educação das escolas públicas e privadas do Estado do Rio podem ser proibidos de ensinar sobre questões de gênero, orientação sexual e temas similares. Essa é a proposta do projeto de lei dos deputados Samuel Malafaia, Dr. Deodalto, Filipe Soares (todos do DEM), Tia Ju, Carlos Macedo (ambos do PRB), Flavio Bolsonaro (PSL), do deputado afastado Edson Albertassi e do ex-deputado Milton Rangel. O texto será votado na Assembleia Legislativa do Estado do Rio de Janeiro (Alerj) nesta quinta-feira (24), em primeira discussão.

O projeto também impede a utilização de qualquer meio pedagógico, como livros, cartilhas e panfletos, que aborde os assuntos. Segundo o texto, os Planos Municipais de Educação deverão adequar-se às exigências. "Especular a introdução na grade curricular de ensino o lecionamento da ideologia de gênero e congênere foge das atribuições do estado e invade o âmago das famílias", afirmam os autores. 


\section{ANEXO 1 - PROJETOS MODELOS PARA A IMPLEMENTAÇÃO DO \\ “ESCOLA SEM PARTIDO" EM ÂMBITO FEDERAL, ESTADUAL E MUNICIPAL.}

\section{ANTEPROJETO DE LEI FEDERAL}

Ementa: Institui o "Programa Escola sem Partido".

Art. $1^{\circ}$. Esta Lei institui, com fundamento nos artigos 23, inciso I, 24, XV, e $\S$ $1^{\text {}}$, e 227, caput, da Constituição Federal, o "Programa Escola sem Partido", aplicável aos sistemas de ensino da União, dos Estados, do Distrito Federal e dos Municípios, em consonância com os seguintes princípios:

I - dignidade da pessoa humana;

II - neutralidade política, ideológica e religiosa do Estado;

III - pluralismo de ideias e de concepções pedagógicas;

IV - liberdade de aprender, ensinar, pesquisar e divulgar o pensamento, a arte e o saber;

V - liberdade de consciência e de crença;

VI - direito à intimidade;

VII - proteção integral da criança e do adolescente;

VIII - direito do estudante de ser informado sobre os próprios direitos, visando ao exercício da cidadania;

IX - direito dos pais sobre a educação religiosa e moral dos seus filhos, assegurado pela Convenção Americana sobre Direitos Humanos.

Art. $2^{\circ}$. O Poder Público não se imiscuirá no processo de amadurecimento sexual dos alunos nem permitirá qualquer forma de dogmatismo ou proselitismo na abordagem das questões de gênero.

Art. $3^{\circ}$. É vedado o uso de técnicas de manipulação psicológica destinadas a promover o engajamento dos alunos em determinada causa.

Art. $4^{\circ}$. No exercício de suas funções, o professor:

I - não se aproveitará da audiência cativa dos alunos para promover os seus próprios interesses, opiniões, concepções ou preferências ideológicas, religiosas, morais, políticas e partidárias;

II - não favorecerá nem prejudicará ou constrangerá os alunos em razão de suas convicções políticas, ideológicas, morais ou religiosas, ou da falta delas; 
III - não fará propaganda político-partidária em sala de aula nem incitará seus alunos a participar de manifestações, atos públicos e passeatas;

IV - ao tratar de questões políticas, socioculturais e econômicas, apresentará aos alunos, de forma justa, as principais versões, teorias, opiniões e perspectivas concorrentes a respeito da matéria;

V - respeitará o direito dos pais dos alunos a que seus filhos recebam a educação religiosa e moral que esteja de acordo com as suas próprias convicções;

VI - não permitirá que os direitos assegurados nos itens anteriores sejam violados pela ação de estudantes ou terceiros, dentro da sala de aula.

Art. $5^{\circ}$. As instituições de educação básica afixarão nas salas de aula e nas salas dos professores cartazes com o conteúdo previsto no anexo desta Lei, com, no mínimo, 420 milímetros de largura por 594 milímetros de altura, e fonte com tamanho compatível com as dimensões adotadas.

Parágrafo único. Nas instituições de educação infantil, os cartazes referidos no caput serão afixados somente nas salas dos professores.

Art. $6^{\circ}$. As escolas particulares que atendem a orientação confessional e ideologia específicas poderão veicular e promover os conteúdos de cunho religioso, moral e ideológico autorizados contratualmente pelos pais ou responsáveis pelos estudantes, devendo ser respeitado, no tocante aos demais conteúdos, o direito dos alunos à educação, à liberdade de aprender e ao pluralismo de ideias.

Parágrafo único. Para os fins do disposto no caput deste artigo, as escolas deverão apresentar e entregar aos pais ou responsáveis pelos estudantes material informativo que possibilite o pleno conhecimento dos temas ministrados e dos enfoques adotados.

Art. $7^{\circ}$. Os alunos matriculados no ensino fundamental e no ensino médio serão informados e educados sobre o conteúdo desta Lei.

Art. $8^{\circ}$. O ministério e as secretarias de educação contarão com um canal de comunicação destinado ao recebimento de reclamações relacionadas ao descumprimento desta Lei, assegurado o anonimato.

Parágrafo único. As reclamações referidas no caput deste artigo deverão ser encaminhadas ao órgão do Ministério Público incumbido da defesa dos interesses da criança e do adolescente, sob pena de responsabilidade.

Art. $9^{\circ}$. O disposto nesta Lei aplica-se, no que couber:

I - às políticas e planos educacionais;

II - aos conteúdos curriculares; 
III - aos projetos pedagógicos das escolas;

IV - aos materiais didáticos e paradidáticos;

V - às avaliações para o ingresso no ensino superior;

VI - às provas de concurso para ingresso na carreira docente;

VII - às instituições de ensino superior, respeitado o disposto no art. 207 da Constituição Federal.

Art. 10. Configura ato de improbidade administrativa que atenta contra os princípios da administração pública o descumprimento do disposto no artigo $5^{\circ}$ desta Lei, bem como a remoção indevida ou a destruição total ou parcial dos cartazes ali referidos.

Art. 11. Esta Lei entra em vigor após decorridos 2 (dois) anos da data de sua publicação oficial.

Anteprojeto de Lei Estadual e minuta de justificativa

Ementa: Institui, no âmbito do sistema estadual de ensino, o "Programa Escola sem Partido"

Art. $1^{\circ}$. Esta Lei institui, no âmbito do sistema estadual de ensino, com fundamento nos artigos 23, inciso I, 24, inciso XV, e 227, caput, da Constituição Federal, o "Programa Escola sem Partido", em consonância com os seguintes princípios:

I - dignidade da pessoa humana;

II - neutralidade política, ideológica e religiosa do Estado;

III - pluralismo de ideias e de concepções pedagógicas;

IV - liberdade de aprender, ensinar, pesquisar e divulgar o pensamento, a arte e o saber;

V - liberdade de consciência e de crença;

VI - direito à intimidade;

VII - proteção integral da criança e do adolescente;

VIII - direito do estudante de ser informado sobre os próprios direitos, visando ao exercício da cidadania;

IX - direito dos pais sobre a educação religiosa e moral dos seus filhos, assegurado pela Convenção Americana sobre Direitos Humanos.

Art. $2^{\circ}$. O Poder Público não se imiscuirá no processo de amadurecimento sexual dos alunos nem permitirá qualquer forma de dogmatismo ou proselitismo na abordagem das questões de gênero.

Art. $3^{\circ}$. No exercício de suas funções, o professor: 
I - não se aproveitará da audiência cativa dos alunos para promover os seus próprios interesses, opiniões, concepções ou preferências ideológicas, religiosas, morais, políticas e partidárias;

II - não favorecerá nem prejudicará ou constrangerá os alunos em razão de suas convicções políticas, ideológicas, morais ou religiosas, ou da falta delas;

III - não fará propaganda político-partidária em sala de aula nem incitará seus alunos a participar de manifestações, atos públicos e passeatas;

IV - ao tratar de questões políticas, socioculturais e econômicas, apresentará aos alunos, de forma justa, as principais versões, teorias, opiniões e perspectivas concorrentes a respeito da matéria;

$\mathrm{V}$ - respeitará o direito dos pais dos alunos a que seus filhos recebam a educação religiosa e moral que esteja de acordo com as suas próprias convicções;

VI - não permitirá que os direitos assegurados nos itens anteriores sejam violados pela ação de estudantes ou terceiros, dentro da sala de aula.

Art. $4^{\circ}$. As instituições de educação básica afixarão nas salas de aula e nas salas dos professores cartazes com o conteúdo previsto no anexo desta Lei, com, no mínimo, 420 milímetros de largura por 594 milímetros de altura, e fonte com tamanho compatível com as dimensões adotadas.

Parágrafo único. Nas instituições de educação infantil, os cartazes referidos no caput deste artigo serão afixados somente nas salas dos professores.

Art. $5^{\circ}$. As escolas particulares que atendem a orientação confessional e ideologia específicas poderão veicular e promover os conteúdos de cunho religioso, moral e ideológico autorizados contratualmente pelos pais ou responsáveis pelos estudantes, devendo ser respeitado, no tocante aos demais conteúdos, o direito dos alunos à educação, à liberdade de aprender e ao pluralismo de ideias.

Art. $6^{\circ}$. O disposto nesta Lei aplica-se, no que couber:

I - às políticas e planos educacionais;

II - aos conteúdos curriculares;

III - aos projetos pedagógicos das escolas;

IV - aos materiais didáticos e paradidáticos;

$\mathrm{V}$ - às avaliações para o ingresso no ensino superior;

VI - às provas de concurso para o ingresso na carreira docente;

VII - às instituições de ensino superior, respeitado o disposto no art. 207 da Constituição Federal. 
Art. $7^{\circ}$. Esta Lei entra em vigor após decorrido 1 (um) ano da data de sua publicação oficial.

\section{DEVERES DO PROFESSOR}

1 - O Professor não se aproveitará da audiência cativa dos alunos para promover os seus próprios interesses, opiniões, concepções ou preferências ideológicas, religiosas, morais, políticas e partidárias.

2 - O Professor não favorecerá nem prejudicará ou constrangerá os alunos em razão de suas convicções políticas, ideológicas, morais ou religiosas, ou da falta delas.

3 - O Professor não fará propaganda político-partidária em sala de aula nem incitará seus alunos a participar de manifestações, atos públicos e passeatas.

4 - Ao tratar de questões políticas, socioculturais e econômicas, o professor apresentará aos alunos, de forma justa - isto é, com a mesma profundidade e seriedade -, as principais versões, teorias, opiniões e perspectivas concorrentes a respeito da matéria.

5 - O Professor respeitará o direito dos pais dos alunos a que seus filhos recebam a educação religiosa e moral que esteja de acordo com suas próprias convicções.

6 - O Professor não permitirá que os direitos assegurados nos itens anteriores sejam violados pela ação de estudantes ou terceiros, dentro da sala de aula.

\section{JUSTIFICATIVA}

É fato notório que professores e autores de livros didáticos vêm-se utilizando de suas aulas e de suas obras para tentar obter a adesão dos estudantes a determinadas correntes políticas e ideológicas; e para fazer com que eles adotem padrões de julgamento e de conduta moral - especialmente moral sexual - incompatíveis com os que lhes são ensinados por seus pais ou responsáveis.

Diante dessa realidade - conhecida por experiência direta de todos os que passaram pelo sistema de ensino nos últimos 20 ou 30 anos -, entendemos que é necessário e urgente adotar medidas eficazes para prevenir a prática da doutrinação política e ideológica nas escolas, e a usurpação do direito dos pais a que seus filhos recebam a educação moral que esteja de acordo com suas próprias convicções.

Trata-se, afinal, de práticas ilícitas, violadoras de direitos e liberdades fundamentais dos estudantes e de seus pais ou responsáveis, como se passa a demonstrar:

1 - A liberdade de consciência e de crença - assegurada pelo art. $5^{\circ}$, VI, da Constituição Federal - compreende o direito do estudante a que o seu conhecimento da 
realidade não seja manipulado, para fins políticos e ideológicos, pela ação dos seus professores;

2 - O caráter obrigatório do ensino não anula e não restringe essa liberdade. Por isso, o fato de o estudante ser obrigado a assistir às aulas de um professor implica para o professor o dever de não utilizar sua disciplina como instrumento de cooptação políticopartidária ou ideológica;

3 - Ora, é evidente que a liberdade de consciência e de crença dos estudantes restará violada se o professor puder se aproveitar de sua audiência cativa para promover em sala de aula suas próprias concepções políticas, ideológicas e morais;

4 - Liberdade de ensinar - assegurada pelo art. 206, II, da Constituição Federal - não se confunde com liberdade de expressão; não existe liberdade de expressão no exercício estrito da atividade docente, sob pena de ser anulada a liberdade de consciência e de crença dos estudantes, que formam, em sala de aula, uma audiência cativa;

5 - A liberdade de ensinar obviamente não confere ao professor o direito de se aproveitar do seu cargo e da audiência cativa dos alunos, para promover os seus próprios interesses, opiniões, concepções ou preferências ideológicas, religiosas, morais, políticas e partidárias; nem o direito de favorecer, prejudicar ou constranger os alunos em razão de suas convicções políticas, ideológicas, morais ou religiosas; nem o direito de fazer propaganda político-partidária em sala de aula e incitar seus alunos a participar de manifestações, atos públicos e passeatas; nem o direito de manipular o conteúdo da sua disciplina com o objetivo de obter a adesão dos alunos a determinada corrente política ou ideológica; nem, finalmente, o direito de dizer aos filhos dos outros o que é a verdade em matéria de religião ou moral;

6 - Além disso, a doutrinação política e ideológica em sala de aula compromete gravemente a liberdade política do estudante, na medida em que visa a induzilo a fazer determinadas escolhas políticas e ideológicas, que beneficiam, direta ou indiretamente as políticas, os movimentos, as organizações, os governos, os partidos e os candidatos que desfrutam da simpatia do professor;

7 - Sendo assim, não há dúvida de que os estudantes que se encontram em tal situação estão sendo manipulados e explorados politicamente, o que ofende o art. $5^{\circ}$ do Estatuto da Criança e do Adolescente (ECA), segundo o qual "nenhuma criança ou adolescente será objeto de qualquer forma de exploração";

8 - Ao estigmatizar determinadas perspectivas políticas e ideológicas, a doutrinação cria as condições para o bullying político e ideológico que é praticado pelos próprios estudantes contra seus colegas. Em certos ambientes, um aluno que assuma 
publicamente uma militância ou postura que não seja a da corrente dominante corre sério risco de ser isolado, hostilizado e até agredido fisicamente pelos colegas. E isso se deve, principalmente, ao ambiente de sectarismo criado pela doutrinação;

9 - A doutrinação infringe, também, o disposto no art. 53 do Estatuto da Criança e do Adolescente, que garante aos estudantes "o direito de ser respeitado por seus educadores". Com efeito, um professor que deseja transformar seus alunos em réplicas ideológicas de si mesmo evidentemente não os está respeitando;

10 - A prática da doutrinação política e ideológica nas escolas configura, ademais, uma clara violação ao próprio regime democrático, na medida em que ela instrumentaliza o sistema público de ensino com o objetivo de desequilibrar o jogo político em favor de determinados competidores;

11 - Por outro lado, é inegável que, como entidades pertencentes à Administração Pública, as escolas públicas estão sujeitas ao princípio constitucional da impessoalidade, e isto significa, nas palavras de Celso Antonio Bandeira de Mello (Curso de Direito Administrativo, Malheiros, $15^{\text {a }}$ ed., p. 104), que "nem favoritismo nem perseguições são toleráveis. Simpatias ou animosidades pessoais, políticas ou ideológicas não podem interferir na atuação administrativa e muito menos interesses sectários, de facções ou grupos de qualquer espécie.";

12 - E não é só. O uso da máquina do Estado - que compreende o sistema de ensino - para a difusão das concepções políticas ou ideológicas de seus agentes é incompatível com o princípio da neutralidade política e ideológica do Estado, com o princípio republicano, com o princípio da isonomia (igualdade de todos perante a lei) e com o princípio do pluralismo político e de ideias, todos previstos, explícita ou implicitamente, na Constituição Federal;

13 - Cabe recordar, a propósito, que o artigo 117, V, da Lei 8.112/91, reproduzindo norma tradicional no Direito Administrativo brasileiro, presente na legislação de diversos Estados e Municípios, estabelece que é vedado ao servidor público "promover manifestação de apreço ou desapreço no recinto da repartição";

14 - No que tange à educação religiosa e moral, a Convenção Americana sobre Direitos Humanos, vigente no Brasil, estabelece em seu art. 12 que "os pais têm direito a que seus filhos recebam a educação religiosa e moral que esteja de acordo com suas próprias convicções";

15 - Ora, se cabe aos pais decidir o que seus filhos devem aprender em matéria de moral, nem o governo, nem a escola, nem os professores têm o direito de usar a sala de 
aula para tratar de conteúdos morais que não tenham sido previamente aprovados pelos pais dos alunos;

16 - Finalmente, um Estado que se define como laico - e que, portanto deve manter uma posição de neutralidade em relação a todas as religiões - não pode usar o sistema de ensino para promover uma determinada moralidade, já que a moral é muitas vezes inseparável da religião;

17. Permitir que o governo de turno ou seus agentes utilizem o sistema de ensino para promover uma determinada moralidade é dar-lhes o direito de vilipendiar e destruir, indiretamente, a crença religiosa dos estudantes, o que ofende os artigos $5^{\circ}$, VI, e 19, I, da Constituição Federal.

Ante o exposto, entendemos que a melhor forma de combater o abuso da liberdade de ensinar é informar os estudantes sobre o direito que eles têm de não ser doutrinados por seus professores, a fim de que eles mesmos possam exercer a defesa desse direito, já que, dentro das salas de aula, ninguém mais poderá fazer isso por eles.

Nesse sentido, o projeto que ora se apresenta está em perfeita sintonia com o art. $2^{\circ}$ da Lei de Diretrizes e Bases da Educação Nacional, que prescreve, entre as finalidades da educação, o preparo do educando para o exercício da cidadania. Afinal, o direito de ser informado sobre os próprios direitos é uma questão de estrita cidadania.

Ao aprová-lo, esta Casa Legislativa estará atuando no sentido de "prevenir a ocorrência de ameaça ou violação dos direitos da criança e do adolescente", como determina o artigo 70 do Estatuto da Criança e do Adolescente.

Note-se por fim, que o projeto não deixa de atender à especificidade das instituições confessionais e particulares cujas práticas educativas sejam orientadas por concepções, princípios e valores morais, às quais reconhece expressamente o direito de veicular e promover os princípios, valores e concepções que as definem, exigindo-se, apenas, a ciência e o consentimento expressos por parte dos pais ou responsáveis pelos estudantes.

Anteprojeto de Lei Municipal e minuta de justificativa

Ementa: Institui, no âmbito do sistema municipal de ensino, o "Programa Escola sem Partido"

Art. $1^{\circ}$. Esta Lei institui, no âmbito do sistema municipal de ensino, com fundamento nos artigos 23, inciso I, 30, incisos I e II, e 227, caput, da Constituição Federal, o "Programa Escola sem Partido", em consonância com os seguintes princípios:

I - dignidade da pessoa humana;

II - neutralidade política, ideológica e religiosa do Estado; 
III - pluralismo de ideias e de concepções pedagógicas;

IV - liberdade de aprender, ensinar, pesquisar e divulgar o pensamento, a arte e o saber;

$\mathrm{V}$ - liberdade de consciência e de crença;

VI - direito à intimidade;

VII - proteção integral da criança e do adolescente;

VIII - direito do estudante de ser informado sobre os próprios direitos, visando ao exercício da cidadania;

IX - direito dos pais sobre a educação religiosa e moral dos seus filhos, assegurado pela Convenção Americana sobre Direitos Humanos.

Art. $2^{\circ}$. O Poder Público não se imiscuirá no processo de amadurecimento sexual dos alunos nem permitirá qualquer forma de dogmatismo ou proselitismo na abordagem das questões de gênero.

Art. $3^{\circ}$. No exercício de suas funções, o professor:

I - não se aproveitará da audiência cativa dos alunos para promover os seus próprios interesses, opiniões, concepções ou preferências ideológicas, religiosas, morais, políticas e partidárias;

II - não favorecerá nem prejudicará ou constrangerá os alunos em razão de suas convicções políticas, ideológicas, morais ou religiosas, ou da falta delas;

III - não fará propaganda político-partidária em sala de aula nem incitará seus alunos a participar de manifestações, atos públicos e passeatas;

IV - ao tratar de questões políticas, socioculturais e econômicas, apresentará aos alunos, de forma justa, as principais versões, teorias, opiniões e perspectivas concorrentes a respeito da matéria;

V - respeitará o direito dos pais dos alunos a que seus filhos recebam a educação religiosa e moral que esteja de acordo com as suas próprias convicções;

VI - não permitirá que os direitos assegurados nos itens anteriores sejam violados pela ação de estudantes ou terceiros, dentro da sala de aula.

Art. $4^{\circ}$. As instituições de educação básica afixarão nas salas de aula e nas salas dos professores cartazes com o conteúdo previsto no anexo desta Lei, com, no mínimo, 420 milímetros de largura por 594 milímetros de altura, e fonte com tamanho compatível com as dimensões adotadas.

Parágrafo único. Nas instituições de educação infantil, os cartazes referidos no caput deste artigo serão afixados somente nas salas dos professores. 
Art. $5^{\circ}$. As escolas particulares que atendem a orientação confessional e ideologia específicas poderão veicular e promover os conteúdos de cunho religioso, moral e ideológico autorizados contratualmente pelos pais ou responsáveis pelos estudantes, devendo ser respeitado, no tocante aos demais conteúdos, o direito dos alunos à educação, à liberdade de aprender e ao pluralismo de ideias.

Art. $6^{\circ}$. O disposto nesta Lei aplica-se, no que couber:

I - às políticas e planos educacionais;

II - aos conteúdos curriculares;

III - aos projetos pedagógicos das escolas;

IV - aos materiais didáticos e paradidáticos;

$\mathrm{V}$ - às provas de concurso para o ingresso na carreira docente.

Art. $7^{\circ}$. Esta Lei entra em vigor após decorrido 1 (um) ano da data de sua publicação oficial.

\section{DEVERES DO PROFESSOR}

1 - O Professor não se aproveitará da audiência cativa dos alunos para promover os seus próprios interesses, opiniões, concepções ou preferências ideológicas, religiosas, morais, políticas e partidárias.

2 - O Professor não favorecerá nem prejudicará ou constrangerá os alunos em razão de suas convicções políticas, ideológicas, morais ou religiosas, ou da falta delas.

3 - O Professor não fará propaganda político-partidária em sala de aula nem incitará seus alunos a participar de manifestações, atos públicos e passeatas.

4 - Ao tratar de questões políticas, socioculturais e econômicas, o professor apresentará aos alunos, de forma justa - isto é, com a mesma profundidade e seriedade -, as principais versões, teorias, opiniões e perspectivas concorrentes a respeito da matéria.

5 - O Professor respeitará o direito dos pais dos alunos a que seus filhos recebam a educação religiosa e moral que esteja de acordo com suas próprias convicções.

6 - O Professor não permitirá que os direitos assegurados nos itens anteriores sejam violados pela ação de estudantes ou terceiros, dentro da sala de aula.

\section{JUSTIFICATIVA}

É fato notório que professores e autores de livros didáticos vêm-se utilizando de suas aulas e de suas obras para tentar obter a adesão dos estudantes a determinadas 
correntes políticas e ideológicas; e para fazer com que eles adotem padrões de julgamento e de conduta moral - especialmente moral sexual - incompatíveis com os que lhes são ensinados por seus pais ou responsáveis.

Diante dessa realidade - conhecida por experiência direta de todos os que passaram pelo sistema de ensino nos últimos 20 ou 30 anos -, entendemos que é necessário e urgente adotar medidas eficazes para prevenir a prática da doutrinação política e ideológica nas escolas, e a usurpação do direito dos pais a que seus filhos recebam a educação moral que esteja de acordo com suas próprias convicções.

Trata-se, afinal, de práticas ilícitas, violadoras de direitos e liberdades fundamentais dos estudantes e de seus pais ou responsáveis, como se passa a demonstrar:

1 - A liberdade de consciência e de crença - assegurada pelo art. $5^{\circ}$, VI, da Constituição Federal - compreende o direito do estudante a que o seu conhecimento da realidade não seja manipulado, para fins políticos e ideológicos, pela ação dos seus professores;

2 - O caráter obrigatório do ensino não anula e não restringe essa liberdade. Por isso, o fato de o estudante ser obrigado a assistir às aulas de um professor implica para o professor o dever de não utilizar sua disciplina como instrumento de cooptação políticopartidária ou ideológica;

3 - Ora, é evidente que a liberdade de consciência e de crença dos estudantes restará violada se o professor puder se aproveitar de sua audiência cativa para promover em sala de aula suas próprias concepções políticas, ideológicas e morais;

4 - Liberdade de ensinar - assegurada pelo art. 206, II, da Constituição Federal - não se confunde com liberdade de expressão; não existe liberdade de expressão no exercício estrito da atividade docente, sob pena de ser anulada a liberdade de consciência e de crença dos estudantes, que formam, em sala de aula, uma audiência cativa;

5 - A liberdade de ensinar obviamente não confere ao professor o direito de se aproveitar do seu cargo e da audiência cativa dos alunos, para promover os seus próprios interesses, opiniões, concepções ou preferências ideológicas, religiosas, morais, políticas e partidárias; nem o direito de favorecer, prejudicar ou constranger os alunos em razão de suas convicções políticas, ideológicas, morais ou religiosas; nem o direito de fazer propaganda político-partidária em sala de aula e incitar seus alunos a participar de manifestações, atos públicos e passeatas; nem o direito de manipular o conteúdo da sua disciplina com o objetivo de obter a adesão dos alunos a determinada corrente política ou ideológica; nem, finalmente, o direito de dizer aos filhos dos outros o que é a verdade em matéria de religião ou moral; 
6 - Além disso, a doutrinação política e ideológica em sala de aula compromete gravemente a liberdade política do estudante, na medida em que visa a induzilo a fazer determinadas escolhas políticas e ideológicas, que beneficiam, direta ou indiretamente as políticas, os movimentos, as organizações, os governos, os partidos e os candidatos que desfrutam da simpatia do professor;

7 - Sendo assim, não há dúvida de que os estudantes que se encontram em tal situação estão sendo manipulados e explorados politicamente, o que ofende o art. $5^{\circ}$ do Estatuto da Criança e do Adolescente (ECA), segundo o qual "nenhuma criança ou adolescente será objeto de qualquer forma de exploração";

8 - Ao estigmatizar determinadas perspectivas políticas e ideológicas, a doutrinação cria as condições para o bullying político e ideológico que é praticado pelos próprios estudantes contra seus colegas. Em certos ambientes, um aluno que assuma publicamente uma militância ou postura que não seja a da corrente dominante corre sério risco de ser isolado, hostilizado e até agredido fisicamente pelos colegas. E isso se deve, principalmente, ao ambiente de sectarismo criado pela doutrinação;

9 - A doutrinação infringe, também, o disposto no art. 53 do Estatuto da Criança e do Adolescente, que garante aos estudantes "o direito de ser respeitado por seus educadores". Com efeito, um professor que deseja transformar seus alunos em réplicas ideológicas de si mesmo evidentemente não os está respeitando;

10 - A prática da doutrinação política e ideológica nas escolas configura, ademais, uma clara violação ao próprio regime democrático, na medida em que ela instrumentaliza o sistema público de ensino com o objetivo de desequilibrar o jogo político em favor de determinados competidores;

11 - Por outro lado, é inegável que, como entidades pertencentes à Administração Pública, as escolas públicas estão sujeitas ao princípio constitucional da impessoalidade, e isto significa, nas palavras de Celso Antonio Bandeira de Mello (Curso de Direito Administrativo, Malheiros, $15^{\mathrm{a}}$ ed., 104), que "nem favoritismo nem perseguições são toleráveis. Simpatias ou animosidades pessoais, políticas ou ideológicas não podem interferir na atuação administrativa e muito menos interesses sectários, de facções ou grupos de qualquer espécie.";

12 - E não é só. O uso da máquina do Estado - que compreende o sistema de ensino - para a difusão das concepções políticas ou ideológicas de seus agentes é incompatível com o princípio da neutralidade política e ideológica do Estado, com o princípio republicano, com o princípio da isonomia (igualdade de todos perante a lei) e 
com o princípio do pluralismo político e de ideias, todos previstos, explícita ou implicitamente, na Constituição Federal;

13 - Cabe recordar, a propósito, que o artigo 117, V, da Lei 8.112/91, reproduzindo norma tradicional no Direito Administrativo brasileiro, presente na legislação de diversos Estados e Municípios, estabelece que é vedado ao servidor público "promover manifestação de apreço ou desapreço no recinto da repartição";

14 - No que tange à educação religiosa e moral, a Convenção Americana sobre Direitos Humanos, vigente no Brasil, estabelece em seu art. 12 que "os pais têm direito a que seus filhos recebam a educação religiosa e moral que esteja de acordo com suas próprias convicções";

15 - Ora, se cabe aos pais decidir o que seus filhos devem aprender em matéria de moral, nem o governo, nem a escola, nem os professores têm o direito de usar a sala de aula para tratar de conteúdos morais que não tenham sido previamente aprovados pelos pais dos alunos;

16 - Finalmente, um Estado que se define como laico - e que, portanto deve manter uma posição de neutralidade em relação a todas as religiões - não pode usar o sistema de ensino para promover uma determinada moralidade, já que a moral é muitas vezes inseparável da religião;

17. Permitir que o governo de turno ou seus agentes utilizem o sistema de ensino para promover uma determinada moralidade é dar-lhes o direito de vilipendiar e destruir, indiretamente, a crença religiosa dos estudantes, o que ofende os artigos $5^{\circ}$, VI, e 19, I, da Constituição Federal.

Ante o exposto, entendemos que a melhor forma de combater o abuso da liberdade de ensinar é informar os estudantes sobre o direito que eles têm de não ser doutrinados por seus professores, a fim de que eles mesmos possam exercer a defesa desse direito, já que, dentro das salas de aula, ninguém mais poderá fazer isso por eles.

Nesse sentido, o projeto que ora se apresenta está em perfeita sintonia com o art. $2^{\circ}$ da Lei de Diretrizes e Bases da Educação Nacional, que prescreve, entre as finalidades da educação, o preparo do educando para o exercício da cidadania. Afinal, o direito de ser informado sobre os próprios direitos é uma questão de estrita cidadania.

Ao aprová-lo, esta Casa Legislativa estará atuando no sentido de "prevenir a ocorrência de ameaça ou violação dos direitos da criança e do adolescente", como determina o artigo 70 do Estatuto da Criança e do Adolescente.

Note-se por fim, que o projeto não deixa de atender à especificidade das instituições confessionais e particulares cujas práticas educativas sejam orientadas por 
concepções, princípios e valores morais, às quais reconhece expressamente o direito de veicular e promover os princípios, valores e concepções que as definem, exigindo-se, apenas, a ciência e o consentimento expressos por parte dos pais ou responsáveis pelos estudantes.

- Tendo em vista que o Programa Escola sem Partido não cria deveres que já não existem - exceto a obrigação de afixar os cartazes nas salas de aula -, nada impede que seja baixado por simples decreto do Poder Executivo, caso em que ele somente será obrigatório para as escolas públicas pertencentes ao sistema municipal de ensino. O mesmo vale para os Estados.

DECRETO No $\ldots$, DE $\ldots$

Determina a afixação de cartazes nas salas de aula das escolas pertencentes ao Município e dá outras providências.

(...), Prefeito do Município (...), no uso das atribuições que lhe são conferidas por lei,

CONSIDERANDO que é competência comum da União, dos Estados, do Distrito Federal e dos Municípios "zelar pela guarda da Constituição, das leis e das instituições democráticas" (CF, art. 23, I);

CONSIDERANDO o princípio constitucional da impessoalidade e da neutralidade política e ideológica do Estado $\left(\mathrm{CF}\right.$, arts. $1^{\circ}, \mathrm{V} ; 5^{\circ}$, caput; 17 , caput; 19 , III; 34, VII, 'a'; e 37, caput), que impede o uso da máquina pública para favorecer ou prejudicar indivíduos, grupos ou partidos que disputam o poder na sociedade;

CONSIDERANDO o princípio constitucional da laicidade do Estado (CF, art. 19, I), que impede o Poder Público de promover valores hostis à moralidade dessa ou daquela religião;

CONSIDERANDO o princípio do pluralismo de ideias (CF, art. 206, III), que impede o Poder Público de se comprometer oficialmente com determinada ideologia ou teoria científica;

CONSIDERANDO o princípio constitucional da dignidade da pessoa humana $\left(\mathrm{CF}\right.$, art. $\left.1^{\mathrm{o}}, \mathrm{III}\right)$, que assegura aos alunos o direito de não ser usados como "cobaias" em experimentos de engenharia social;

CONSIDERANDO o direito constitucional à intimidade $\left(\mathrm{CF}\right.$, art. $\left.5^{\circ}, \mathrm{X}\right)$, que impede o Poder Público de se imiscuir no processo de amadurecimento sexual dos alunos; 
CONSIDERANDO a garantia constitucional da liberdade de consciência e de crença $\left(\mathrm{CF}\right.$, art. $\left.5^{\circ}, \mathrm{VI}\right)$, que assegura aos estudantes o direito a que suas crenças e valores religiosos e morais não sejam desrespeitados ou manipulados pelo Poder Público e seus agentes;

CONSIDERANDO que ninguém será privado de direitos por motivo de crença religiosa ou de convicção filosófica ou política $\left(\mathrm{CF}\right.$, art. $\left.5^{\circ}, \mathrm{VIII}\right)$;

CONSIDERANDO a liberdade de aprender dos estudantes (CF, art. 206, II), que lhes assegura o direito a que o seu conhecimento da realidade não seja manipulado pela ação dos seus professores;

CONSIDERANDO que liberdade de ensinar (CF, art. 206, II) não se confunde com liberdade de expressão (CF, art. $\left.5^{\circ}, \mathrm{IV}\right)$;

CONSIDERANDO o princípio da proteção integral da criança e do adolescente $\left(\mathrm{CF}\right.$, art. 227, caput; ECA, arts. $3^{\circ}, 4^{\circ}$ e $\left.5^{\circ}\right)$

CONSIDERANDO o disposto no artigo 12, item 4, da Convenção Americana sobre Direitos Humanos, segundo o qual "os pais têm direito a que seus filhos recebam a educação religiosa e moral que esteja de acordo com suas próprias convicções";

CONSIDERANDO o disposto no parágrafo único do art. 22 do Estatuto da Criança e do Adolescente, segundo o qual "a mãe e o pai, ou os responsáveis, têm direitos iguais e deveres e responsabilidades compartilhados no cuidado e na educação da criança, devendo ser resguardado o direito de transmissão familiar de suas crenças e culturas, assegurados os direitos da criança estabelecidos nesta Lei";

CONSIDERANDO que o Poder Público tem o dever de agir preventivamente para impedir "a ocorrência de ameaça ou violação dos direitos da criança e do adolescente", conforme o disposto no art. 70 do Estatuto da Criança e do Adolescente;

CONSIDERANDO que todos os indivíduos têm direito de conhecer seus próprios direitos, visando ao exercício da cidadania,

\section{DECRETA:}

Art. $1^{\circ}$. A Secretaria de Educação providenciará a confecção e envio às escolas públicas pertencentes à rede municipal de ensino, de cartazes com o conteúdo previsto no Anexo deste Decreto, nas seguintes dimensões: " $x$ " centímetros de altura por " $y$ " centímetros de largura. 
Art. $2^{\circ}$. Os cartazes referidos no artigo anterior serão afixados em todas as salas de aulas e salas dos professores; ou, tratando-se de instituições de educação infantil, somente nas salas dos professores.

Art. $3^{\circ}$. O Poder Público não se imiscuirá na orientação sexual dos alunos nem permitirá qualquer forma de dogmatismo e proselitismo na abordagem das questões de gênero.

Art. $4^{\circ}$. É vedado nas escolas do Município o uso de técnicas de manipulação psicológica destinadas a obter a adesão dos alunos a determinada causa.

Art. $5^{\circ}$. Os professores e demais servidores da rede pública municipal de ensino respeitarão integralmente o que estabelece o art. 12, item 4, da Convenção Americana sobre Direitos Humanos.

Art. $6^{\circ}$. O disposto neste Decreto aplica-se, no que couber:

I - aos conteúdos curriculares;

II - aos projetos pedagógicos das escolas;

III - aos materiais didáticos e paradidáticos;

IV - às provas de concurso para ingresso no magistério.

Parágrafo único. Verificando a existência, no currículo, no projeto pedagógico ou no material didático, de conteúdos que estejam em conflito com os princípios constitucionais e legais em que se baseia o presente Decreto, o professor deverá abster-se de ministrá-los, comunicando o fato à Secretaria de Educação.

Art. $7^{\circ}$. A Secretaria de Educação promoverá, a partir da publicação deste Decreto, a realização de cursos com o objetivo de disseminar e aprofundar o conhecimento sobre os limites éticos e jurídicos da atividade docente.

Art. $8^{\circ}$. A Secretaria de Educação contará com um canal de comunicação destinado ao recebimento de reclamações relacionadas ao descumprimento desta Lei, assegurado o anonimato.

Art. $9^{\circ}$. A Secretaria de Educação enviará cópia deste Decreto a todos os professores da rede pública municipal de ensino, cientificando-os de que o Município não deixará de exercer o direito de regresso (art. $37, \S 6^{\circ}$, da Constituição Federal), caso venha a ser condenado a indenizar danos morais decorrentes do descumprimento dos deveres explicitados no presente Decreto.

Art. $10^{\circ}$. Ressalvado o disposto no artigo $7^{\circ}$, este Decreto entra em vigor 180 dias após a data de sua publicação oficial. 


\section{ANEXO 2 - QUESTIONÁRIO APLICADO AOS LÍDERES RELIGIOSOS}

4. ESTADO CIVIL:

5. NÚMERO DE FILHOS, SE HOUVER:

6. QUAL (OU QUAIS) FORMA (S) DE PARTICIPAÇÃO NA POLITICA QUE ESCOLHEU:

a) A SIMPLES PARTICIPAÇÃO EM ELEIÇÕES, VOTAÇÃO;

b) ESPÍRITO MILITANTE;

c) ALGUMA FILIAÇÃO PARTIDÁRIA? QUAL?

d) EXERCÍCIO DE CARGOS? QUAL? QUANDO?

$\checkmark$ MOTIVO DE PARTICIPAÇÃO NA POLITICA?

HÁ QUANTO TEMPO TEM ATIVIDADE POLÍTICA?

7. RELIGIÃO:

MOTIVO DE FAZER PARTE DA IGREA?
a) EDUCAÇÃO FAMILIAR;
b) CONVICÇÃO PESSOAL.
8. QUANTO TEMPO FAZ PARTE DA IGREJA?
9. ESTADO RELIGIOSO:
A) CRENTE: SIM( )/NÃO ( )

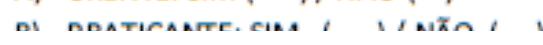


14. QUAL SUA PERCEPÇÃO DE FORÇA DO GRUPO RELIGIOSO QUE PERTENCE. V ACREDITA QUE SUA RELIGIÃO EM FORTALEZA é MUITO ... ALGUMA COISA ..., IMPORTÂNCIA?

15. NA SUA PERCEPÇÃO, QUAL A CONTRIBUIÇÃO SÓCIO-POLÍTICA MAIS IMPORTANTE SUA RELIGIÃO PARA OS FORTALEZENSES.

16. ENTENDE QUE EXISTE COMPATBILIDADE OU INCOMPATIBLIDADES ENTRE O EST/ LAICO E SUA CONDIÇÃ̃O DE CRISTÃO? QUAIS?

17. VOCÊ ACREDITA QUE SERIA MELHOR SE O ESTADO FOSSE CONFESSIONAL?

18. VOCÊ CONSIDERA QUE OS DIREITOS HUMANOS E AS CRENÇAS RELIGIOSAS COMPATIVEIS OU COMPLEMENTARES?

19. VOCÉ ACREDITA QUE OS DIREITOS HUMANOS SÃO MUITO ... POUCO ... ALGU COISA ... DE IMPORTANTE PARA AS PESSOAS E PAISES, OU SERIA MELHOR ESQU 
22. TENTE, POR FAVOR, UMA RÁPIDA DEFINIÇÃO DE "GÊNERO":

23. VOCÉ ACHA QUE O HOMEM É, POR NATUREZA, SUPERIOR OU IGUAL EM V CAPACIDADE EM RELAÇÃO AS MULHERES?

24. QUEM DEVE MANDAR EM CASA E SOBRE OS FILHOS:
A) HOMENS
B) MULHERES
C) OS DOIS

25. QUEM DEVE CUIDAR DELES FILHOS E DEPENDENTES
a) HOMENS
b) MULHERES
c) OS DOIS

26. OS HOMENS DEVEM OU NÃO COMPARTILHAR DO TRABALHO DOMÉSTICO EM COM AS MULHERES? 
29. ACREDITA OU NÃO, QUE HOMENS E MULHERES DEVEM TER DIREITOS IGUA AMBIENTE POLÍTICO?

30. AS MULHERES DEVEM EXERCER CARGOS POLITITICOS?

A) SIM, EM QUALQUER CASO;

B) SOMENTE SE ELAS FOREM SOLTEIRAS;

C) APENAS SE NÃO TIVEREM FILHOS PARA CUIDAR.

31. QUAL SUA OPINIÃO SOBRE A IMPORTÂNCIA QUE DEVE TER A ONU OU A COM INTERAMERICANA DE DIREITOS HUMANOS PARA O FUNCIONAMIENTO SOCIALE PO DO BRASIL?

31. QUAL SUA OPNIÃO DO DISCURSO DA ONU SOBRE DIREITOS HUMANOS?

32. DEVE O GOVERNO SE PREOCUPAR DE QUE SE ENSINEM NO SISTEMA FORM EDUCAÇÃO OS DERECHOS HUMANOS E VALORES DE IGUALDADE ENTRE HOM MULHERES AOS BRASILEIROS? 
35. SE CONHECE, QUAL SUA OPNIÃO DO DISCURSO DA ONU SOBRE O DIREITO A IGUALDADE DE GÊNERO?

36. VOCÊ JÁ OUVIU FALAR DA CONVENÇÃO SOBRE A ELIMINAÇÃO DE TODAS AS FOR DE DISCRIMINAÇÃO CONTRA AS MULHERES (CEDAW)? PARA VOCÉ, O QUE PARECI ESSA NORMATVA INTERNACIONAL?

37. VOCÊ ACHA QUE EXISTE ALGUMA RELAÇÃO ENTRE DIREITOS, DIREITOS HUMANOS MULHERES E MODALIDADE DE RELAÇÕES DE GÊNERO?

38. SE A LEI E RELIGIÃO DISCORDAM SOBRE OS PAPÉIS DE HOMENS E MULHERES, O DEVE FAZER O RELIGIOSO?
A) RESPEITAR A LEI;
B) NÃO CUMPRIR A LEI;
C) OUTRA.

39. CONHECE O DISCURSO DA ONU SOBRE OS DIREITOS E LIBERDADES SEXUA REPRODUTIVAS? 
42. SABE COMO SE DEFINE ESTA VIOLÊNCIA PELOS ORGANISMOS INTERNACIONA

43. VOCÊ ACREDITA OU NÃO QUE A VIOLÊNCIA BASEADA NO GÊNERO VIOLA OS HUMANOS, OUÉ OUTRA COISA?

44. QUANDO UM MARIDO EM CASA MALTRATA SUA ESPOSA, ACREDITA QUE ELA
A) DENUNCIAR E SEPARAR DO ABUSADOR;
B) RESIGNADAMENTE PENSAR DA UNIDADE FAMILIAR;
C) RECONCILIAR-SE COM O AGRESSOR;
D) OUTROS.

45. O QUE VOCÊ ACHA DE AÇÕES POSITIVAS EM FAVOR DAS MULHERES. TA QUOTAS PARA FORMAR LISTAS ELEITORAIS, PARA COMPOR GOVER TRIBUNAIS?

45. O QUÊ OPINA SOBRE MAJORAR OS TIPOS PENAIS HOJE EXISTENTES PARA C A VIOLENCIA EXERCIDA PELOS HOMENS CONTRA AS MULHERES E O FEMINIC 
47. DEVE, EM SUA OPINIÃO, SEREM FACILTTADO OU PROIBIDA AS UNIÕES HOMOSSEXUAIS?

48. VOCÉ ACHA QUE O ABORTO É INCOMPATÍVEL OU COMPATÍVEL COM OS DIREITOS HUMANOS?

49. SABE A POSIÇÃO DAS NAÇÕES UNIDAS SOBRE O ABORTO? O QUE VOCÉ ACHA?

50. TRABALHAM-SE DE ALGUMA FORMA OS DIREITOS HUMANOS E DIREITO À IGUALDADE DE GÊNERO NA SUA IGREAA? COMO? 


\section{ANEXO 3 - PARECER DO COMITÊ DE ÉTICA}

\section{DADOS DO PROJETO DE PESQUISA}

Titulo da Pesquisa: A PERCEPÇÃO DO DISCURSO INTERNACIONAL DOS DIREITOS HUMANOS E DA IGUALDADE DE GENERO PELOS LÍDERES CATOLICOS E EVANGÉLICOS EM FORTALEZA (CEARÁ).

Pesquisador: LARISSA MARIA DE QUEIROZ

Área Temática:

Versăo: 1

CAAE: 77713717.4 .0000 .8085

Instituiçăo Proponente:SOCIEDADE EDUCACIONAL EDICE PORTELA LTDA

Patrocinad or Principal: Financiamento Próprio

\section{DADOS DO PARECER}

Número do Parecer: 2.320 .950

Apresentaçăo do Projeto:

De acordo

Objetivo da Pesquisa:

De acordo

Avaliaçăo dos Riscos e Benefícios:

De acordo

Comentários e Considerações sobre a Pesquisa:

De acordo

Considerações sobre os Temmos de apresentaçăo obrigatória:

De acordo

Conclusōes ou Pendências e Lista de Inadequaçōes:

Projeto Aprovado pelo colegiado.

Consideraçōes Finais a critério do CEP:

Projeto Aprovado. 


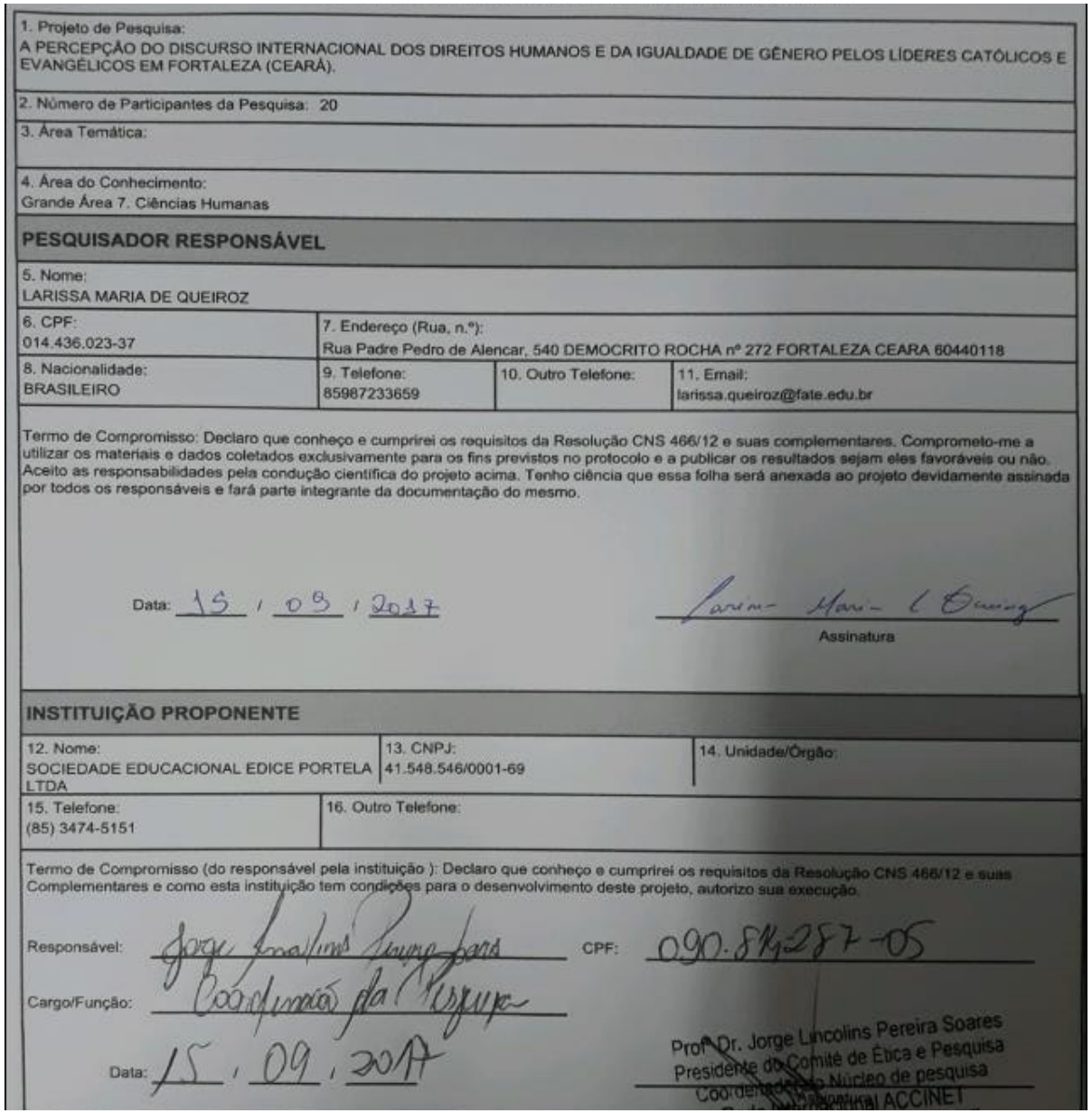

